\title{
MEDIEVAL LITURGICAL MUSIC OF ZAMORA
}

by

Kathleen E. Nelson, B. Mus. (Hons.), M. Mus.

A dissertation submitted in partial fulfilment of the requirements for the degree of Doctor of Philosophy in the Department of Music Studies at The University of Adelaide

October 1993 
To my parents 


\section{TABLE OF CONTENTS}

$\begin{array}{lr} & \text { Page } \\ \text { Abstract } & \text { vi } \\ \text { Preface } & \text { viii } \\ \text { Acknowledgements } & \text { x } \\ \text { Abbreviations } & \text { xii }\end{array}$

Part A: Introductory and Background Material

1. Introduction 2

2. Zamora in the Middle Ages: Aspects of Secular and Church History 24

Part B: Notation Studies

3. Plainchant Notation and Rhythm as Discussed by Spanish Musical Theorists to the Mid 16th Century $\quad 50$

4. Notation of the Plainchant Sources 94

5. The Plica in the Plainchant Sources 141

Part C: Repertory Studies

6. Chants for the Ordinary of Mass 164

7. Prosae and Responsory Prosae 192

$\begin{array}{ll}\text { 8. Hymns } & 210\end{array}$

9. The Prefaces and the Pater Noster for the Mass 232

$\begin{array}{ll}\text { 10. Polyphony } & 251\end{array}$

$\begin{array}{lr}\text { Conclusion } & 279\end{array}$ 


\section{Appendixes}

$\begin{array}{ll}\text { Appendix 1: Source Descriptions } & 288\end{array}$

Appendix 2: Numerical Table of Pergaminos Musicales 327

Appendix 3: Transcriptions 333

Chants for the Ordinary of Mass 335

Prosae and Responsory Prosae $\quad 346$

Hymns 355

$\begin{array}{ll}\text { Polyphony } & 371\end{array}$

Appendix 4: "Unknown Polyphony in a 14th Century Misal Votivo",

Miscellanea Musicologica: Adelaide Studies in Musicology

17 (1990): 1-12. 


\section{TABLE OF ILLUSTRATIONS}

Map 1: The Modern Province of Zamora Showing the Location of Population Centres and Monastic Establishments of Interest to this Study 22

Map 2: The Iberian Peninsula Showing Centre of Interest to this Study 23

Plate 1: $\quad$ Part of Z 196 (Book A) 108

$\begin{array}{lll}\text { Plate 2: } \quad \mathrm{Z} 184^{\mathrm{r}} & 258\end{array}$

Plate 3: $\quad \mathrm{Z} 184^{\mathrm{v}} \quad 259$

[Plate 4]: $\quad$ Misal votivo, fol. $49^{r} \quad 388$

[Plate 5]: Misal votivo, fol. 49v 389

[Plate 6]: Misal votivo, fol. $53^{\text {r }} \quad 390$ 


\section{ABSTRACT}

This dissertation presents a study of manuscript sources of liturgical music either located in Zamora or clearly connected with that town of western Spain. These sources date from as early as the 12 th century and as late as the end of the 15 th or the early 16 th century. They comprise a collection of fragments known as Pergaminos musicales held in the Archivo Histórico Provincial of Zamora, a 15th century Ritual (Zamora, Archivo Catedralicio, cód. 105), and a 14th to 15th century Misal votivo (Madrid, Biblioteca Lázaro Galdiano, Ms. 662). The sources predominantly contain plainchant with five polyphonic works also included.

An introductory section includes discussion of the history of medieval Zamora and the diocese. The second section focuses upon the notation of chant in the sources. Two principal types of notation are found, Aquitanian notation and square notation. These are examined in detail and different classes within the two types are established. Aspects of the Aquitanian notation studied in depth include the quilisma, the staff, and the semicircular virga. Square notation found in the sources is classified into three types on the basis of neumatic forms. The employment of the plica is analysed in depth and is examined for possible connections with liquescent practice and word accent. Mensurally influenced forms of chant notation are also identified and discussed. Examination of the writings on chant notation by Spanish theorists of the 15th and first half of the 16th centuries is included.

Selected genres of chant and the five polyphonic works found amongst the sources are studied. The genres of chant examined are Ordinary of Mass chants, prosae and responsory prosae, hymns, and Prefaces and prayers of the Mass. Two polyphonic works unknown outside the Zamoran sources have been discovered. The five polyphonic works are related to works in the polyphonic manuscript of Las Huelgas (Hu). Transcriptions of the polyphonic works, the Ordinary chants, the two types of prosae, and the hymns are presented. Appendixes list and describe the sources. 
This work contains no material which has been accepted for the award of any other degree or diploma in any university or other tertiary institution and, to the best of my knowledge and belief, contains no material previously published or written by another person, except where due reference has been made in the text.

I give consent to this copy of my thesis when deposited in the University Library being available for photocopying and loan.

SIGNED:.

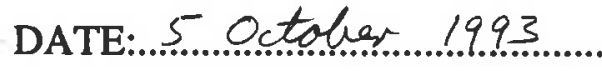




\section{PREFACE}

This dissertation presents a study of medieval sources of liturgical music connected with the town of Zamora in western Spain. Zamora lies beside the River Duero close to the border of Portugal and to the north of Salamanca. The town is now the capital of the province of the same name, one of the provinces of Castilla y León. The two main archives of the town are: 1. the Archivo Historico Provincial located in the Plaza de Claudio Moyano, and 2. the combined Archivo Historico Diocesano and Archivo Catedralicio of the Cathedral of Zamora. Both of these archives contain sources of central importance to this study. The monasteries of the town of Zamora and the surrounding region retain some liturgical manuscripts but amongst these it was only possible to locate one source likely to predate the mid 16th century. Many earlier sources must have been lost. A small number of sources known to be connected with Zamora are now found located outside of the town and one of these in particular is a central source for this study. Some conventions adopted in this dissertation for the treatment of source materials are described below.

The collection of fragments of liturgical manuscripts known as Pergaminos musicales and held by the Archivo Histórico Provincial of Zamora form a very important part of the source materials for this study. It is necessary to explain here the system of identification used in this dissertation when discussing the collection. Numbers were assigned to the Pergaminos musicales by the archive. In this dissertation, the letter $\mathrm{Z}$ (indicating Zamora) precedes each number, thus $\mathrm{Z} 35$ indicates Pergamino musical number 35 . While most of the fragments are no more than a single folio, some are bifolios; no modern foliation or pagination has been added by the archive. In instances where the position of a chant on a fragment is specified in the discussion, location on recto or verso is identified, and for those fragments which are bifolios, the two folios are designated " $a$ " and " $b$ ", the letters being placed in square brackets. The " $a$ " and " $b$ " identification is intended to indicate the first and second folios respectively, although for some of the fragments it has not yet been possible to establish with certainty which folio would have preceded the other in the original manuscript. In these doubtful cases the letters are nevertheless assigned, thus showing the presence of the bifolio and to distinguish one of its folios from the other. It 
has been possible to make tentative identification of fragments which originally may have formed part of a single manuscript. Such groupings of fragments are identified with the labels "Book" and "Group", the two terms being used to indicate respectively a greater and a lesser degree of similarity amongst the fragments of the groupings. These groupings are the work of this writer and are not employed by the Archivo Historico Provincial of Zamora.

A number of Spanish treatises from the 15th and 16th centuries have been studied in the course of the research for this dissertation. In most cases a facsimile edition or an original book was used for their study. When quoting from facsimiles or originals the following conventions of transcription have been followed: 1. punctuation and the use of capitals are modernized; 2 . original spelling is retained; and 3. abbreviations are filled out and only indicated (by square brackets) when doubtful.

Spanish names of people, places, and books are given modern Spanish spelling. Terms taken from treatises are, however, given the original spelling of the treatise rather than the modern Spanish spelling. Thus, for example, the term "compas" is used without the modern addition of a diacritical sign.

The method of musical transcription employed here in general follows commonly used principles. It is explained in detail at the beginning of Appendix 3 which contains the transcriptions of chant and polyphony. Transcription from the liturgical sources of underlaid text and rubrics retains original spelling and capitals are not added. 


\section{ACKNOWLEDGEMENTS}

I wish to thank all those people who advised, encouraged, or in some other way assisted me in the course of the preparation of this dissertation. They are so many that I am unable to name all.

In particular I owe many thanks to Andrew D. McCredie and David Swale, my supervisors at The University of Adelaide. I also owe special thanks to José López-Calo, Emeritus Professor of the University of Santiago de Compostela, whose advice and encouragement inspired me to go to Zamora and guided my introduction to Spanish liturgical sources and musical treatises. I wish to thank all those scholars who have kindly given of their time and advice answering my queries and making suggestions. Amongst these I especially wish to thank Jane Morlet Hardie of The University of Sydney and Robert J. Snow of The University of Texas at Austin.

My thanks are also due to the staff of the many libraries and archives in which I have worked in the course of this research. In particular thanks are due to the staff of the Archivo Histórico Provincial of Zamora, who helped me greatly and always with patience, and especially to the director of the archive who assisted me with information on sources and dating, Florián Ferrero Ferrero, and to the secretary María Jesús Revuelta Alonso. The former archivist at the Cathedral of Zamora, Ramón Fita Revert, gave me invaluable advice; to him, his assistants, and the Cabildo of the Cathedral, I also owe many thanks. In addition I wish to acknowledge the assistance of the library of the Fundación Lázaro Galdiano of Madrid, the Biblioteca Nacional of Madrid, the library of the Real Academia de la Historia of Madrid, and the Barr Smith Library and the Performing Arts Library of The University of Adelaide.

Special thanks are due to my husband, Alexander Newman, who spent many hours printing my photographs of sources, and to those who assisted me in the proof-reading of this work especially Reba Gohstand and W. P. Nelson.

I wish to acknowledge the financial assistance of the Australian Postgraduate Research Award scheme of the Commonwealth of Australia, The University of Adelaide, and the D. 
R. Stranks Travelling Fellowship scheme. Finally I wish to express my appreciation to Malcolm Gillies and the Department of Music at The University of Queensland for their support in the final stages of preparation of this dissertation. 


\section{ABBREVIATIONS}

$A H$

AHPZa

Apt 17

Apt 18

Barc 1

Besançon 76

Breviario

Burgos 61/2

$C A O$

DHEE

$\mathrm{Hu}$

Huesca

Huesca 4

Lo 23935

Ma 136

Ma 289

Ma 931

Ma 1361

Ma 1566

Ma 4404

Ma 19421

Ma 20324

Ma BRAH 18

Ma BRAH 51

Ma I 1137

Ma M 268
Analecta Hymnica Medii Aevi

Archivo Histórico Provincial de Zamora

Apt, Arch. Bas. Sainte-Anne, Ms. 17

Apt, Arch. Bas. Sainte-Anne, Ms. 18

Barcelona, Orfé Català, Ms. 1

Besançon Bibliotheque municipale, Ms. 76

Zamora, Archivo Catedralicio, cód. 104

Burgos, Archivo de la Catedral, Ms. 61/2

Corpus Antiphonalium Officii

Diccionario de historia eclesiástica de España

Burgos, Monasterio de las Huelgas, s.n.

Huesca, Archivo de la Catedral, Ms. 1 [hymnal of Huesca]

Huesca, Archivo de la Catedral, Ms. 4

London, British Library, Add. 23935

Madrid, Biblioteca Nacional, Mss. 136

Madrid, Biblioteca Nacional, Mss. 289

Madrid, Biblioteca Nacional, Mss. 931

Madrid, Biblioteca Nacional, Ms. M. 1361

Madrid, Biblioteca Nacional, Mss. 1566

Madrid, Biblioteca Nacional, M. 4404

Madrid, Biblioteca Nacional, Mss. 19421

Madrid, Biblioteca Nacional, Mss. 20324

Madrid, Biblioteca de la Real Academia de la Historia, Aemil., cód. 18

Madrid, Biblioteca de la Real Academia de la Historia, Aemil., cód. 51

Missale mixtum alme ecclesie toletane, Toledo, 1499. Madrid,

Biblioteca Nacional I 1137

Intonarium Toletanum. 1515. Madrid, Biblioteca Nacional, M 268 
Ma R 25990 Breviarium secundum morem et consuetudinem Zamoranae ecclesiae, n.d. Madrid, Biblioteca Nacional, R 25990

Ma V'19-7 Madrid, Biblioteca Nacional, Mss. Va 19-7

Misal votivo Madrid, Biblioteca Lázaro Galdiano, Ms. 662

MGG Die Musik in Geschichte und Gegenwart

Moissac Rome, Bibl. Apost. Vat., Rossi. 205 [hymnal of Moissac]

Mont 73 Montserrat, Biblioteca del Monasterio, Ms. 73

Mont 759 Montserrat, Biblioteca del Monasterio, Ms. 759

Mont 820 Montserrat, Biblioteca del Monasterio, Ms. 820

Mont 1042 Montserrat, Biblioteca del Monasterio, Ms. 1042 no. 25

Monte Cassino 339 Monte Cassino, Archivio della Badia, Ms. 339

Munich 11764 Munich, Staatsbibliothek, cod. lat. 11764

$N G$

The New Grove Dictionary of Music and Musicians

Pa 495 Paris, Bibliothèque nationale, n. a. lat. 495

$\mathrm{Pa} 778 \quad$ Paris, Bibliothèque nationale, lat. 778

$\mathrm{Pa} 887 \quad$ Paris, Bibliothèque nationale, lat 887

$\mathrm{Pa} 903 \quad$ Paris, Bibliothèque nationale, lat. 903

$\mathrm{Pa} 1084 \quad$ Paris, Bibliothèque nationale, lat. 1084

$\mathrm{Pa} 1139 \quad$ Paris, Bibliothèque nationale, lat. 1139

$\mathrm{Pa} 1177$ Paris, Bibliothèque nationale, n. a. lat. 1177

$\mathrm{Pa} 1235$ Bibliothèque nationale, n. a. lat. 1235

Pa $1339 \quad$ Paris, Bibliothèque nationale, lat. 1339

$\mathrm{Pa} 1871 \quad$ Paris, Bibliothèque nationale, n. a. lat. 1871

Pa 2194 Paris, Bibliothèque nationale, n. a. lat. 2194

$\mathrm{Pa} 3126 \quad$ Paris, Bibliothèque nationale, n. a. lat. 3126

Pa $3549 \quad$ Paris, Bibliothèque nationale, lat. 3549

Pa $3719 \quad$ Paris, Bibliothèque nationale, lat. 3719

Pa $14452 \quad$ Paris, Bibliothèque nationale, lat. 14452

Pa $15129 \quad$ Paris, Bibliothèque nationale, lat. 15129 (olim 812)

PM Paléographie musicale 
RISM Répertoire International des Sources Musicales

Ritual Zamora, Archivo Catedralicio, cód. 105

Rome 2048 Rome, Bibl. Vat. Reg. lat. 2048

TML

Thesaurus Musicarum Latinarum

Tol $35.10 \quad$ Toledo, Biblioteca Capitular, Ms. 35.10

Tol $35.11 \quad$ Toledo, Biblioteca Capitular, Ms. 35.11

Tol 44.1 Toledo, Biblioteca Capitular, Ms. 41.1

Tol 44.2 Toledo, Biblioteca Capitular, Ms. 41.2

Tortosa $133 \quad$ Tortosa, Archivo de la Catedral, Ms. 133

Tortosa 135 Tortosa, Archivo de la Catedral, Ms. 135

Vendôme 17E Vendôme, Chapter Library, Ms. 17E

Ver CVII Verona, Biblioteca Capitolare CVII

Vich 106 Vich, Museo episcopal, Ms. 106

W1 Wolfenbüttel, Herzog August-Bibliothek, Helmstedt 628

Wo 79 Wolfenbüttel, Herzog August-Bibliothek, Cod. Guelf. 79

Worcester 160 Worcester, Cathedral Chapter Library, F. 160 
PART A

INTRODUCTORY AND BACKGROUND MATERIALS 


\section{INTRODUCTION}

The primary sources studied in this dissertation are manuscripts containing liturgical music now located in the town of Zamora and one now located in Madrid but clearly associated with Zamora. The sources represent a wide period of time spanning from probably as early as the first half of the 12 th century to the late 15 th century or beginning of the 16th century. All belong to the Roman rite which was by the 12 th century established in the greater part of the Iberian Peninsula. The great majority of the music contained in the sources is chant, although five polyphonic works are also found.

With the exception of some brief cataloguing in which liturgical content is stressed, the sources have not been previously studied. It is therefore one of the objectives of this dissertation to provide an introduction to these Zamoran sources. A guide to a major collection of polyphonic sources from the 17th century onwards as well as chant books dating from the late 16th century onwards held in the Cathedral of Zamora is already available in a catalogue prepared by José López-Calo. ${ }^{1}$

Two principal directions are taken in the study of the source material. The first focuses on chant notation and the second on selected genres. With regard to the first direction, the main objectives are:

1. to classify the types of notation in use, identifying sub-groups through a study of note forms and their usage;

2. to elucidate the meaning and usage of selected signs.

In addition to facilitating understanding of the Zamoran sources, it is hoped that this study will make a useful contribution to knowledge of notation as it was used in Spain during the period, as well as to knowledge of performance practice. A study of chant treatises in which notational subjects are treated is included in order to provide background material for the investigation into the notation of the sources. That it is possible from a study of the Zamoran sources to draw general conclusions relevant to notation in Spain or at least in

${ }^{1}$ José López-Calo, La música en la catedral de Zamora. Vol. I. Catálogo del archivo de Música (Zamora: Diputación de Zamora, 1985). 
north-western Spain appears to be likely as observation of sources of other centres reveals similar notational types.

With regard to the second direction, the objective is the elucidation of the presence in the sources of each selected genre as a contribution to knowledge of their repertories in Spain. The selected genres are chants for the Ordinary of Mass, prosae, responsory prosae, and hymns, as well as prefaces and the Pater noster for Mass. Usage in Spain of these genres has yet to receive broad studies. The polyphonic works are treated as a further genre although, in fact, a variety of liturgical genres is represented amongst them. The method of study of the chant genres includes identification of each piece, text comparison as relevant with Analecta Hymnica or other sources, melody comparison with Spanish or other sources employing catalogues if available, and identification of special melodic features. A major difficulty encountered in these studies was the lack of readily available published Spanish material which could be used for comparison. In addition, the catalogues of melodies available for some of the genres are variable in their inclusion of Spanish sources; the catalogue of hymn melodies prepared by Bruno Stäblein ${ }^{2}$ excludes Spanish sources while two of the catalogues of Ordinary of Mass chants have an extremely sparse representation of Spanish sources. The fragmentary nature of some of the sources makes the identification of liturgical context difficult or impossible for some of the chants studied and has furthermore made tentative or impossible the identification of a few chants which otherwise would have been in the genre studies.

A similar method is employed in the study of the polyphonic works. For these concordances are identified and compared, and notation is examined. Identification and comparison is made easier for these works, owing to the ready availability of facsimiles, transcriptions, and studies of major sources of Spanish medieval polyphony.

${ }^{2}$ Bruno Stäblein, Hymnen (1). Die mittelalterlichen Hymnenmelodien des Abendlandes, Monumenta Monodica Medii Aevi, vol. 1 (Kassel: Bărenreiter, 1956). 


\section{SOURCES}

These comprise:

1. a selection of about 135 fragments from the collection of Pergaminos musicales held in the Archivo Histórico Provincial of Zamora (AHPZa);

2. Ritual de Sacramentos y Misal Propio de la Iglesia de Zamora, Zamora, Archivo Catedralicio, códice 105;

3. Misal votivo para uso de Zamora, Madrid, Biblioteca Lázaro Galdiano, ms. 662.

The second and third items, the Ritual and the Misal votivo, are manuscript books, the first dating from the 15 th century, and the second comprising two sections, one from the 15 th century and one from the 14 th century. ${ }^{3}$ (The two books will be referred to hereafter simply as Ritual and Misal votivo.). These sources are described briefly below and more detailed descriptions are to be found in Appendix 1.

The Ritual contains chants for the Wedding Mass, Mass of the Dead, prefaces, and the Pater noster. This manuscript was believed lost until recently found by the archivist of the Cathedral of Zamora, and is thought to be a book described as a 15 th-century missal by José Janini in his catalogue of liturgical manuscripts in Castilla and Navarra. ${ }^{4}$ It was clearly intended for Zamora as is evidenced by the calendar (fols. $1^{\mathrm{r}}-6^{\mathrm{v}}$ ), the penitential psalms for Zamora (fol. 49), and two Masses for one of the patron saints of Zamora, St. Ildefonsus (fols. $167^{r}-169^{\prime}$ ), one of which celebrates his Invention. The latter feast commemorates an event of local significance and is unique to the diocese of Zamora. ${ }^{5}$ Most of the book, however, gives only texts. Kept at the rear of the manuscript is a booklet of two bifolios with a further collection of prefaces. Although discovered by the archivist

${ }^{3}$ The dating of the Ritual is that given by the archive and the dating of the Misal votivo is that of José Janini, Manuscritos litúrgicos de las bibliotecas de España. Vol. I Castilla y Navarra (Burgos: Aldecoa, 1977), 198.

${ }^{4}$ Janini, Manuscritos, 327.

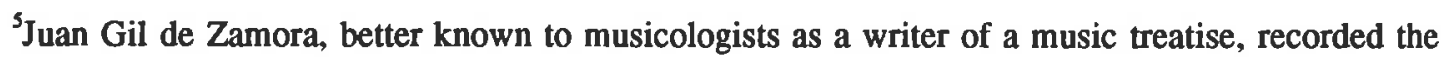
discovery, which occurred on 26 May 1260, of the remains of St. Ildefonsus in Zamora. See Vicente Bécares Botas, Los patronos de Zamora. San Ildefonso y San Atilano (Zamora: Archivo Histórico Diocesano, 1990), 25. It is this event which the May feast of Ildefonsus celebrates. For some more details on this event and on the feasts, see the present writer's article appended at the rear of this dissertation "Unknown Polyphony in a Fourteenth Century Spanish Misal votivo", 1-2. 
separate from the Ritual within the cathedral archive, it is now kept with the latter manuscript because of its similar size and appearance. It also is likely to date from the 15th century.

The first part of the Misal votivo, dating from the 15th century, contains chants for prefaces, the Pater noster, and the invitatory of the Office of the Dead. The second part of the same book, dating from the 14th century, contains vespers, matins, and lauds of the Office of the Dead, the Mass of the Dead, and two Masses for St. Ildefonsus. Finally, added at the end and written in late Aquitanian notation as opposed to the square notation of the earlier parts of the book, is the responsory Libera me domine de morte. Texts for which music is not required, such as the canon of the Mass, are also included. Identification of the book with the use of the Church of Zamora may be made from the inclusion of the two Masses for St. Ildefonsus including that for the invention. While only text incipits are given for these masses in the Ritual, in the Misal votivo the chants and full texts are given.

The AHPZa Pergaminos musicales, the first of the three source items listed above, require a more full discussion at this point than the two items already discussed. In addition, the Pergaminos musicales chosen for study are described in further detail in Appendix 1. Appendix 2 lists the Pergaminos musicales in numerical order with summary information. The choice of those to be studied was made from the full collection on the criteria of legibility and condition, size (some fragments are too small to be profitably studied unless there is clear indication of a particular value), and interest of content or notation. The Pergaminos musicales (these are generally referred to in the course of this work simply as fragments) represent a diverse collection with great variety in notation, size, content, date, and other aspects. It is amongst these fragments that the earliest and also the latest sources under study are found. A major problem associated with the fragmentary nature of the Pergaminos musicales is the lack of knowledge of the place of use of the larger manuscripts from which the fragments were probably taken. The only evidence for dating and place of copying is that which can be gleaned from features such as script, notation, and occasionally feast. There is no immediate evidence in any of the fragments to say that their liturgical content was for the use of the Church of Zamora or of monastic or other religious establishments within the region of Zamora. To establish some fragments which are indeed representative of the liturgy of Zamora would probably be possible 
through careful comparison with the two breviaries of that church; however, with only a few exceptions such investigations were not possible within the limitations of the present study. Such comparison would furthermore be complicated by the changes which are apparent between the two breviaries, one of which dates from the 14th century and the other from the first half of the 16th century, and the lack of a full missal for the church; another difficulty in such work is inherent in the nature of the fragments, as often the number of chants or other texts available for use in identification or comparison is too small to be of use. As a result of the difficulties of identifying origin, use, and date of the fragments, it is important to consider the history of the collection in order to establish parameters which might offer some guidance as to the origin of the fragments.

The fragments of the AHPZa Pergaminos musicales collection are all manuscript sources written on parchment. All were previously part of the binding of books held in the archive and dating from mainly the 16th and 17th centuries. The staff of the archive have formed the complete Pergaminos musicales collection of some 280 fragments by separating them from the books they served to bind, while noting the catalogue number of the books from which each fragment was taken, thus preserving important information concerning their history. A greater number of manuscript fragments in the archive still remain attached as binding to books and in this dissertation only fragments belonging to the collection already mentioned will be discussed, leaving many for possible future study.

As the principal historical archive of the province of Zamora, AHPZa has gathered together material previously housed in towns throughout the province thus providing a centralized point of collection and preservation. The manuscript fragments in the collection under study have been taken from books of protocols pertaining to the closely located towns of Zamora and Toro, as well as other usually smaller towns, most notably Vezdemarbán. (Map 1 at the end of this chapter shows the location of these centres.) During the 1930s, legislation in Spain established the gathering of all books of protocols over 100 years old into archives located in the capital cities of each province, ${ }^{6}$ AHPZa being one of these.

\footnotetext{
${ }^{6}$ María Jesús Alvarez-Coca González, "La fe pública en España. Registros y notarías", Boletin de la ANABAD 37, no. 1-2 (1987): 31 .
} 
The protocol books contain legal documents which the notaries (usually referred to as escribanos) of the towns were obliged by law to keep in their offices and to have available for anyone with a right to view them. When the position of a notary was transferred to another man, the documents, and therefore the books of protocols, had to be passed on to the new office holder. ${ }^{7}$ The protocol books of the major centres of Toro and Zamora would usually have been prepared by notaries resident in those cities; however, smaller places such as Vezdemarbán, are thought not usually to have had resident notaries but instead would have been visited by notaries from a major centre. ${ }^{8}$

From before 1503, few examples of such documents as contained in the protocol books remain in Castilla y León, but in that year, a new law clarified and made more strict the obligations of notaries, with the result that the great majority of protocols now in the archives date from the early 16th century onwards. ${ }^{9}$ That law, known as the Pragmática, required the binding of the books. ${ }^{10}$ The normal practice, as is observable in AHPZa, was for each notary to make a separate book for each year with the documents in chronological order. Although the documents contained in the protocol books from this period were written on paper, the material chosen for covering was parchment. Such parchment was either taken from liturgical books or was plain, perhaps new. On some books more than one piece of manuscript fragment is found, usually the pieces being sewn together. Large sheets of parchment were cut down or folded (or both) to fit protocol books. Information about a book was written on the parchment cover and included the name of the notary, the year, and a brief indication of the contents. Such information was sometimes written over the original text or musical notation, but in some instances appears to have been deliberately placed in margins.

Questions relating to the process of binding of the books and the method of acquisition of the parchment by those persons responsible for the binding need to be considered. Unfortunately it has not been possible to establish whether the binding of the protocol

\footnotetext{
${ }^{7}$ Alvarez-Coca González, "La fe pública”, 28-29.

${ }^{8}$ Verbal communication from the director of the AHPZa, Florián Ferrero Ferrero.

9Alvarez-Coca González, "La fe pública”, 29.

${ }^{10}$ Alvarez-Coca González, "La fe pública", 26.
} 
books would have taken place in the office of the notary or have been done by an outside worker, perhaps a professional binder. However, owing to costs of transport and the need to have documents available, it is likely that binding would not have been done at any great distance from the notary's office. The fact that within a series of protocols of a single notary there are often found folios which appear to have come from a single manuscript supports the idea that the binding would have taken place within the office of the notary who had written the document. Might an old book have been purchased from a church and kept in the office so that whenever a piece of parchment was needed for purposes such as binding it was readily available? On the other hand, pages apparently from the one book are to be found binding the work of different notaries. That different notaries apparently shared sources of manuscript used for binding suggests several explanations. Firstly, it may have been due to different notaries working within the one office and sharing such items as binding materials; secondly, the passing of the entire office including binding materials from one notary to another through means such as inheritance or sale; and thirdly, it may indicate that the binding of the work of various notaries was done by a binder working for some or all of the notaries in a town and using folios from one manuscript on the books of his various customers. Evidence supporting the second possibility occurring in Zamora is found in a document of the AHPZa which records the sale in 1657 of "el officio de escrivanía pública que usaron y ejercieron los dichos Diego Alvarez y Tomás Basurto, con todos sus papeles y protocolos y con lo demás que le perteneze". ${ }^{11}$ The examination of the lines of succession of the offices of the notaries and of the different scribes working contemporaneously within the single offices would give more evidence on which to base the grouping of the manuscript fragments but little study has so far been done by historians on this subject. Nevertheless, the knowledge that certain fragments came from the books of particular notaries has been helpful in confirming the grouping of fragments based on other criteria. Included in Appendix 1 is the name of the notary responsible for the protocol book to which each fragment was attached. ${ }^{12}$ The likelihood

\footnotetext{
${ }^{11}$ The quotation is taken from that cited by Alvarez-Coca González, "La fe pública", 23.

${ }^{12}$ Of course, the use of manuscript fragments in binding was by no means limited to Zamora or even Spain and must have been a widespread practice in Europe during the 16th century and later. An example for which some detailed information is available is that of the city of Oxford where liturgical manuscripts came
} 
of fragments having previously been part of a single manuscript is reflected in this dissertation by the use of groupings entitled "Book" and "Group". The terms reflect respectively a greater and lesser degree of similarity amongst the fragments grouped in this way. The fragments of each Group or Book are identified in Appendix 1 and also given there is further detail on the means of establishing each grouping.

With regard to the place of utilization of the manuscripts for their original liturgical purposes, it is probable that the manuscripts from which fragments were taken would have come from churches or monasteries not too far from the place of binding. For the fragments from protocols of Toro, the most likely of the town's churches is perhaps the Colegiata de Santa Marla la Mayor, the second most important of the churches in the bishopric of Zamora and the only collegiate church in the region. For those from protocols of Zamora, one may suggest the Cathedral of that town, the seat of the bishop of Zamora, a possibility supported by the remark of one scholar who has studied the Cathedral's history, that the majority of the "libros corales" were sold "casi como material de desecho"13 (unfortunately he gives no indication of when the sales took place). Others of the more wealthy churches in the town might similarly have had books to dispose of. The most important churches of the towns require consideration as possible sources for binders because of the likelihood that they would have had the means to have a collection of liturgical manuscripts and also to replace old and unused ones. Another possible source of supply must be the nearby monasteries, some of which were very powerful and important institutions in the Middle Ages. The giving of books by founding houses to their filial establishments may be the explanation of the arrival of some sources in the region. One small and damaged fragment in the AHPZa suggests a possible Cistercian connection. It contains liturgical polyphony which, as will be discussed in detail later, bears in various ways a close resemblance to the polyphonic manuscript $(\mathrm{Hu})$ of the Cistercian convent of Las Huelgas in Burgos. (Burgos

to be used by binders from about 1540 but diminished in use from about 1570 . See Rowan Watson, "Medieval Manuscript Fragments", Archives 13 (1977): 66. It is also worth noting that some studies of fragments in the United Kingdom have found that books were not always entirely destroyed by the removal of folios for use in binding, as for example in the case of fragments, now in several libraries, which have been identified as belonging to an incomplete manuscript in the National Library of Scotland (Watson, "Medieval Manuscript Fragments", 72). This type of identification has not been possible in the present study. 1982), 530.

${ }^{13}$ Guadalupe Ramos de Castro, La Catedral de Zamora (Zamora: Fundación Ramos de Castro, 
and other important population centres are shown in Map 2 at the end of this chapter.)

A question demanding consideration in the study of any manuscript fragments must be the reason for the discarding of the manuscripts which caused them to arrive in the hands of the binder who then took them apart. In discussing fragments used for binding in 15th-century and earlier medieval England, one writer has said "Only a general rationale can be discerned behind this process of discarding: the manuscripts evidently fell out of use as growing uniformity in the later Middle Ages in liturgy and in notation, as changes in vernacular languages and in literary tastes, made manuscripts of earlier times appear superfluous." ${ }^{14}$ For the fragments of the AHPZa, it is also not possible to give a definite answer to the question. Perhaps the discarded manuscripts were replaced by printed books or by updated manuscripts reflecting changed liturgical practices. With regard to those fragments using Aquitanian notation, perhaps they were replaced by books - either printed or manuscript - using the more modern square notation; perhaps the skill of reading Aquitanian notation had been lost. ${ }^{15}$ Records exist documenting the copying of chant books for the Cathedral of Zamora during the 16th century and for further purchases in the 17th century, ${ }^{16}$ suggesting that at that time at least, books may have been discarded and replaced by the new ones for which acquisition is documented.

It has been assumed here that whole books would have been discarded, yet the possibility exists that isolated folios may have been removed and used for binding even though the books may have remained in the possession of a church or monastery. In a study of one of the early chant books of the Roman liturgy to be copied in Spain (one belonging to the Cathedral of Calahorra and which is believed to have been copied between 1121 and $1125^{17}$ ), Andrés Araiz suggested that folios missing from the manuscript were

${ }^{14}$ Watson, "Medieval Manuscript Fragments", 65.

${ }^{15}$ Speaking generally and not with reference to any particular place or use, Huglo suggests two widely separated points in time, both connected with notational developments, at which chant books would have been dismantled. The first is "après l'invention de la portée (ca. 1030), qui rendait les livres neumés sans utilité pratique" and the second, "après l'invention d'un système d'impression de la notation musicale qui évitait la copie de la notation carrée sur portées imprimées." See Michel Huglo, Les livres de chant liturgique (Turnhout: Brepols, 1988), 85-86.

${ }^{16}$ Ramos de Castro, La Catedral de Zamora, 536 n. 46.

${ }^{17}$ Andrés Araiz, Historia de la música religiosa en España (Barcelona: Editorial Labor, 1942), 31. 
the result of their removal for binding purposes after the manuscript had been taken out of use in the cathedral during the 16 th century. ${ }^{18}$

The origin of manuscripts is further complicated by the fact that books may have been brought into the region but never actually employed there. The thoughts put forward here on the origin of the manuscripts must in the end be only tentative. Further information might be gleaned from detailed codicological, palaeographical and liturgical studies which unfortunately are beyond the scope of the present dissertation. It is to be hoped that as the study of Zamoran history and sources progresses, as it is certainly doing, the subjects of manuscript preparation and palaeography will receive more attention perhaps enabling more definitive statements to be made on the possible local origin of the fragments.

The remarks just made apply also to the issue of dating of the fragments. The scripts have been examined to identify characteristics of different periods; however, it was concluded that while such analysis could offer some clues it could not be precise because of such problems as local variation, the overall similarity of (especially later) Gothic scripts, and the possibility of a scribe copying not only the text but features of the handwriting. To be of real value, such a palaeographic study would have to incorporate the examination of sources other than those included in this collection in order to permit comparison and the establishment of regional characteristics, and must be a work requiring great expertise and lying outside the scope of this dissertation. It has therefore been decided to present in most cases only rough datings. For some of the fragments dating from after the late 13 th century, in particular, datings were decided in consultation with the director of the AHPZa. Prior to that period, palaeographic features characteristic of particular times are more readily identified; the palaeographic features of the early fragments are described in Appendix 1. ${ }^{19}$ Millares Carlo, in his highly respected study of Spanish scripts, Tratado de paleografia española, writes of the great difficulty involved in determining features which allow Gothic scripts from the 13th to the 16th centuries to be identified with particular places and even with Spain. He proposes:

\footnotetext{
${ }^{18}$ Araiz, Historia, 220.
}

${ }^{19}$ The following works provide material for such identification: Agustín Millares Carlo, Tratado de paleografla española, 3rd ed., 3 vols. (Madrid: Espasa-Calpe, 1983) and S. Harrison Thomson, Latin Bookhands of the Later Middle Ages 1100-1500 (Cambridge: Cambridge University Press, 1969). 
sólo un exhaustivo estudio de materiales fechados y localizados y la divulgación de buenos facsímiles de los mismos podría, con base en el examen de las abreviaturas y de otras peculiaridades, dar fecundos resultados en la solución del problema enunciado. ${ }^{20}$

This study does not pretend to be a complete guide to Zamoran sources from before the 16th century, but rather represents ones which seem to be of most significance and which are either located in Zamora or clearly associated with its Church. Other sources (all liturgical) include two manuscript books and some fragments held in the library of the Monastery of Montserrat near Barcelona which are thought to be associated with the region of Zamora; a late 14th- or 15th-century fragmentary and much altered manuscript in the convent of Clares of Villalobos in the region of Zamora; a small collection of fragments removed from bindings of books held in the cathedral archive of Zamora; and, similarly, a few fragments held in the Archivo Histórico Nacional in Madrid. All the sources just named have been examined by this writer. Further sources may, of course, exist in monasteries and convents of the region although in several visited by the writer in Zamora no material likely to date from before the 16 th century was found.

\section{LITURGICAL CHANT IN SPAIN}

In order to place the study of the Zamoran sources in a broader context, it is useful here to look briefly at the history of liturgical chant in Spain and some of the major historical events which were influential upon liturgical practices. It is notable that in some areas research has not yet proceeded sufficiently to allow a clear view of the consequences of historical events on the chant tradition.

Liturgical chant of the Roman rite is a subject not often figuring with prominence in the more general histories of music in Spain. In these, not surprisingly given the uniqueness of the topic, more information is likely to be found on Old-Hispanic (Mozarabic) chant, and also on polyphony in Spanish sources of the later Middle Ages. Authors whose work is of particular use for chant studies of the later Middle Ages on the Iberian Peninsula include Anglès, Corbin, Fernández de la Cuesta, Gümpel, Huglo, López-Calo, León-Tello,

\footnotetext{
${ }^{20}$ Millares Carlo, Tratado de paleografía española, 1: 86.
} 
Stevenson, and Suñol. ${ }^{21}$ Works by these writers and others will be referred to repeatedly in this and subsequent chapters. However, chant in later medieval Spain does in fact continue to be a field in which a great deal of research remains to be done.

\section{The Early Period}

Little is known about Christian liturgical chant on the Iberian Peninsula prior to the late 6th century, the time at which Arianism declined with the conversion of the Visigothic leaders to Catholicism. In Gallaecia, on the west of the peninsula, then under the rule of a Suevian king, the First Council of Braga (held in 561) adopted the Roman canon of the Mass for use throughout the kingdom. ${ }^{22}$ Such an influence is thought not to have extended to the music used in the liturgy; it would instead have been of Hispanic origin. ${ }^{23}$ In fact, on the origin of chant used prior to the late 7th century, José López-Calo has suggested that it grew from a base of chant introduced by the early Christians, new melodies being composed in the same style as the original material. ${ }^{24}$ From such writings as those of Isidore of Seville (d. 636) and Ildefonsus of Toledo (d. 667) as well as other sources of information we have considerable knowledge of the rite, and the composers and arrangers of chant from the later part of the 6th century and from the 7th century. Leander (bishop of Sevilla), Ildefonsus (bishop of Toledo), and Conancio (bishop of Palencia) amongst others were all recorded as having composed chants; and during this early period three main centres of liturgical music can be identified: Sevilla, Toledo, and Zaragoza. ${ }^{25}$ The Spanish church during this time had close connections with that of south-western Gaul owing to the political relationship which had seen the Visigoths ruling southern Gaul until their forced withdrawal to the region of Septimania during the 6th century. The Gallican and the

\footnotetext{
${ }^{21}$ Works by these authors are listed in the Bibliography of this dissertation.

${ }^{22}$ This adoption is discussed in José López-Calo, "Encuadratura del panorama global de la música en Braga", in IX Centenário de Dedicaçao da Sé de Braga. Congresso Internacional Actas, vol. 3 (Braga: Universidade Catolica Portuguesa, 1990), 130-33, and in the same volume, Miguel S. Gros I Pujol, "Las tradiciones litúrgicos medievales en el noroeste de la península", 104-5.
}

${ }^{20}$ López-Calo, "Encuadratura", 133.

${ }^{24}$ López-Calo, "Encuadratura", 138.

${ }^{25}$ Higini Anglès, "Hispanic Musical Culture from the 6th to the 14th Century", Musical Quarterly 26 (1940): 495-98; Ismael Fernández de la Cuesta, Historia de la música española. 1. Desde los orlgenes hasta el "ars nova", 2nd ed. (Madrid: Alianza Editorial, 1988), 187-92. 
Old-Hispanic liturgies were interconnected and an edict of the Fourth Council of Toledo (this council was led by Isidore of Seville) from the year 633 makes mention of "a single order of prayer and chanting for all of Spain and Gaul". ${ }^{26}$

The rite practised in Spain before the domination of the Roman rite has most commonly been known as the Mozarabic rite, but is also referred to as Visigothic or Hispanic. The most appropriate and least historically inaccurate seems to be the term "Old-Hispanic". 27 Notated manuscripts of the Old-Hispanic rite possibly dating from as early as the 9th century unfortunately use unreadable forms of notation which therefore limit the possibility of comprehension of the music. Interesting studies of this notation taking a semiological approach have recently been published by Herminio González Barrionuevo. ${ }^{28}$ Important musicological studies of the chant of the Old-Hispanic rite have been made especially by Don M. Randel ${ }^{29}$ and Clyde Waring Brockett. ${ }^{30}$

\section{Change of Rite: the 9th Century to the 12th Century}

As a consequence of Charlemagne's efforts to unify liturgical practice throughout his empire and the establishment of his authority in parts of north-eastern Spain, the Roman rite began to displace the local one in Cataluña during the 9 th century but it was not until the late 11 th century and the Council of Burgos of 1080 that the Old-Hispanic rite became officially suppressed in all of Christian Spain with the isolated exception of a small number of churches in Toledo. Some Old-Hispanic chants did continue in use, notably the preces. An attempt to revive the old rite during the 15 th century was promulgated by the famous

${ }^{26}$ Kenneth Levy, "Old-Hispanic Chant in its European Context", in España en la Música de Occidente, ed. Emilio Casares Rodicio, Ismael Fernández de la Cuesta, and José López-Calo, vol. 1 (Madrid: Instituto Nacional de las Artes Escénicas y de la Música, 1987), 12.

${ }^{27}$ The term is used by Kenneth Levy, "Old-Hispanic Chant", 3-14. Jose López-Calo in La música medieval en Galicia (La Coruna: Fundación "Pedro Barrie de la Maza, Conde Fenosa", 1982), 129 n. 9 , notes that the Spanish "hispánica antigua" would be a more appropriate description of the music commonly referred to as "mozárabe".

${ }^{28}$ See for example 'Dos grafías especiales del "scándicus" en la notación "Mozárabe" del norte de España', Revista de musicología 13 (1990): 11-79.

${ }^{29}$ See for example Don M. Randel, The Responsorial Psalm Tones for the Mozarabic Office (Princeton: Princeton University Press, 1969).

${ }^{30} \mathrm{Clyde}$ Waring Brockett, Antiphons, Responsories and other Chants of the Mozarabic Rite, Musicological Studies, vol. 15 (New York: Institute of Mediaeval Music, 1968). Brockett includes an informative chapter on historical background, pp. 69-90. 
Cardinal Cisneros but it seems that by then the original traditions had become altered as the books which he published do not correspond closely to the earlier ones.

The process of displacement of the Old-Hispanic rite by the Roman one must have been difficult and time-consuming. It is a topic of great importance for the history of chant in Spain with probable implications in relation to other schools of chant. Both Michel Huglo and Ismael Fernández de la Cuesta have taken up the subject in articles in volume nine of Revista de Musicología, ${ }^{31}$ and José López-Calo has provided an informative introduction to the historical background of the change in chapter two of his study on medieval music in Galicia. ${ }^{32}$ This remains however a complex area where much research is still to be done.

Fernández de la Cuesta has pointed to a number of questions which can be raised with regard to the changeover. For example, with the arrival of Cluniac reformers in monasteries in different parts of Spain during the 11th century prior to the Council of Burgos, did the rite change with the implantation of the new monastic rule or did the Old-Hispanic rite remain in use? Cuesta suggests that a possible answer to this question is that the offices when performed in the monasteries may have included a mixture of chants, some according to the Benedictine usage and others to the Old-Hispanic one, with the Mass celebrated in the Old-Hispanic style. ${ }^{33}$ A further issue which he raises is based upon the dating by Mundó of Old-Hispanic codices from centres other than Toledo which places the time of copying of these codices coincident with the implantation of the Roman rite rather than earlier. ${ }^{34}$ This then suggests that in some places the practice of the old rite may have continued (and without great opposition) for a longer period of time than is generally thought. The answer to this question, says Cuesta, lies in detailed studies of the scripts to determine whether or not the codices did in fact originate in the scriptoria of Castilla and León from which they are generally thought to come. ${ }^{35}$

${ }^{31}$ Michel Huglo, "La penétration des manuscrits aquitains en Espagne", Revista de Musicología 9 (1985): 249-56; Ismael Fernández de la Cuesta, "La imupción del canto gregoriano en España", Revista de Musicologla 9 (1985): 239-48.

${ }^{32}$ López-Calo, La música medieval en Galicia, 25-30.

${ }^{33}$ Fernández de la Cuesta, "La irrupción", 243-44.

${ }^{34}$ Fernández de la Cuesta, "La irrupción”, 245.

${ }^{35}$ Fernández de la Cuesta, "La irrupción", 246. 
The liturgical scholar, Miguel S. Gros I Pujol, has pointed to two closely connected problems which make difficult endeavours to establish the origin of liturgical books used at the time of the change of rite in Castilla-Leon. The first of these problems is the freedom which surrounded the copying of liturgical books, and the second is the lack of fixed liturgies in the churches and monasteries as late as the end of the 12 th century. ${ }^{36}$

The introduction of the new rite was largely the work of the French Cluniac monks and they would have been assisted by the importation of new books. An example of a manuscript which was very probably brought to Aragón for the purpose of establishing the new rite in the latter part of the 11th century is the hymnal of Huesca. This 11th-century manuscript which uses Aquitanian notation may have originated in the Benedictine monastery of Moissac or perhaps Cluny. ${ }^{37}$ Two important notated sources from this period held in Toledo (Tol 44.1 and Tol 44.2) show connections with south-western French sources. The second is thought to have been copied in Toledo but presents a Sanctorale suggesting south-western France and has been shown by Hesbert to transmit a Cluniac form of liturgy. ${ }^{38}$

The dominance of Cluny at the end of the 11 th century and the beginning of the 12th century in secular churches on the peninsula is demonstrated by the appointment in 1085 of the archbishop of Toledo following the reconquest of Toledo by Christian forces. He was the Cluniac Bernard de la Sauvetat who had previously been sent to Spain by Abbot Hugh of Cluny to take up the post of abbot of the monastery of Sahagún. Archbishop Bernard brought a number of clergy from France who were gradually placed as bishops around the peninsula. Among these were Bernard of Périgord who became bishop of Zamora. For the study of the transmission of liturgical chant, it is of interest that included among these French clergy were cantors such as Bernard of Agen who became bishop of Sigüenza and later Santiago de Compostela, ${ }^{39}$ and Gerald a Cluniac monk from Moissac who was made a

\footnotetext{
${ }^{36}$ Gros I Pujol, "Las tradiciones", 108-9.
}

${ }^{37}$ Antonio Durán Gudiol, Ramón Moragas, and Juan Villareal, eds., Hymnarium Oscense, vol. 2 (Zaragoza: Institución Fernando el Católico, 1987), 8. Carmen Julia Gutiérrez has noted, however, that writers dating upon palaeographic grounds tend to favour a later time c. 1100 , while those looking at musical notation tend to suggest the earlier dating of the 11th century; see Gutierrez, "El Himnario de Huesca: nueva aproximación", Anuario Musical 44 (1989): 31.

${ }^{38}$ Huglo, "La Pénétration", 251-52.

${ }^{39}$ Higinio Anglés, La música de las cantigas de Santa Marla del Rey Alfonso el Sabio, vol. 3 (Barcelona: Diputación Provincial de Barcelona, 1958), 430. 
cantor in Toledo before going to Braga as bishop. ${ }^{40}$ Other Cluniacs appointed as bishops around the turn of the century included Dalmacio in Santiago de Compostela and Gerald in Braga. ${ }^{41}$

Copies of books of the new rite were made with some at first using the local Visigothic script while the so-called Mozarabic notation ceased to be used in chant books, one of its replacements being Aquitanian notation. This development resulted in the production of manuscripts in which Aquitanian notation and Visigothic handwriting were combined. In Castilla-León this was largely a phenomenon of the early 12th century when the locally trained scribes apparently copied books using their own script. ${ }^{42}$ Important extant sources in this transitional style originated in the monastery of San Millán de la Cogolla. Further mention will be made concerning the combination of Visigothic script and Aquitanian notation in Chapter 4.

Manuscripts pertaining to the Roman rite were also to be found in Spain and especially in Cataluña prior to the formal implantation of the rite and as early as the 9th century. In the region of Cataluña a unique form of neumatic notation developed and was used in manuscripts of the Roman rite. Solange Corbin described the Catalan notation as "a mixture of very different trends - Aquitanian, Visigothic and even French" ${ }^{43}$ It is found in sources dating from the 10th century to the 12 th or 13 th century. This notation together with the other neumatic notations used in Spain was studied in some detail by Dom Grégoire Suñol in Introduction a la paléographie musicale grégorienne. ${ }^{44}$ 175.

${ }^{40}$ Archdale A. King, Liturgies of the Primatial Sees (London: Longmans, Green and Co., 1957),

${ }^{41}$ Paulino Iradiel, Salustiano Moreta and Esteban Sarasa, Historia medieval de la España cristiana (Madrid: Ediciones Cátedra, 1989), 136.

${ }^{42}$ In the words of Ismael Femández de la Cuesta (Historia, 226): "Los primeros testimonios de los códices musicales escritos por manos castellanas no aparecen hasta principios del siglo XII. Todavía en este momento los copistas no están acostumbrados a la letra carolina con que vienen los libros que sirven de modelo, y siguen escribiendo con la bella y armoniosa caligrafía visigotica." 13: 44 .

${ }^{43}$ Solange Corbin, "Neumatic Notations, §IV: Western Europe: Regional Forms of Notation", $N G$

${ }^{44}$ Dom Grégoire M. Suñol, Introduction à la paléographie musicale grégorienne (Paris: Desclée, 1935). For Catalan notation, see Suñol, Introduction, 353-82; detailed and more recent study is that of Josiane Mas, "La notation catalane", Revista de musicologia 11 (1988): 11-30. 
Anglès considered that the musical school of the monastery of Ripoll was the most prominent in the Iberian Peninsula during the 10th and 11 th centuries. ${ }^{45}$ The monastery had its own scriptorium and an outstanding library with a wide variety of works including scientific and philosophical ones from various parts of Europe. From Ripoll comes one of the two tonaries which Huglo has connected with the Aquitanian tradition of about the 11th century. ${ }^{46}$ A short tonary, it was written on the opening pages of a manuscript of the Etymologiae of St. Isidore in an 11th-century Catalan hand. Among the features that Huglo gives as showing a connection with the Aquitanian tonaries are the use of the word sonus instead of tonus, and the employment of the introit for the second Sunday of Lent, Domine dilexi decorem, a chant which is specific to sources from the south-west of France. ${ }^{47}$ The other tonary discussed by Huglo and connected by him with those of the Aquitanian tradition, is that from Silos in Castilla which occurs on the margins of the last pages of a monastic antiphoner. ${ }^{48}$ This tonary was written in an early 12 th-century hand at first in Visigothic script but changing to a cursive minuscule with an unusual notation about which Huglo says "nous ne sommes en présence ni de la notation à points superposés classique, ni de la notation wisigothique. Ces neumes rappelleraient plutôt par certains détails les notations de l'Italie du Nord. ${ }^{\star 49}$

The monastery of San Domingo de Silos, located in Castilla not very distant from Burgos, had during the 10 th and 11 th centuries an active and important scriptorium. With the arrival there of St. Domingo in 1041 came the influence of Cluny and from the same century are preserved several manuscripts transmitting the new liturgy but written with Mozarabic neumes. Following Hesbert, Huglo notes that two of these manuscripts demonstrate an order of chants similar to that of a breviary from Avignon, a centre in

\footnotetext{
1931), 18.

${ }^{45}$ Higini Anglès, El Codex Musical de Las Huelgas, vol. 1 (Barcelona: Institut d'Estudis Catalans,

${ }^{46}$ Michel Huglo, Les tonaires: inventaire, analyse, comparaison (Paris: Société Française de Musicologie, 1971), 160. The manuscript is Barcelona, Archivo de la Corona de Aragón, Ripoll 74.

${ }^{47}$ Huglo, Les tonaires, 160.

${ }^{48}$ Huglo, Les tonaires, 161. The manuscript is London, British Library, Add. Ms. 30850.

${ }^{49}$ Huglo, Les tonaires, 162.
} 
which French notation was employed. On the other hand, a 12th-century antiphoner of Silos is related to Cluniac sources. ${ }^{50}$

Of importance from the 12th century was the newly formed Cistercian order which after its founding in 1098 soon moved into the peninsula establishing houses there. Solange Corbin remarked on the large number of manuscripts in Portugal which are likely to be of Cistercian origin and some of which would have been associated with the monastery of Lorvão and the famous Alcobaça. ${ }^{51}$ Cistercian chant manuscripts in Spain have not yet received extensive study.

\section{Late Middle Ages}

The 13th and 14th centuries were a time of crisis for the peninsular church. The Castilian church suffered financial problems, pressures and control from the monarchy, and furthermore, levels of dedication, morality and education of the clergy were low. A letter to the pope told of parish churches not able to support the clergy who were forced as a result to find other ways of earning income. ${ }^{52}$ During the 14 th century the church was also vulnerable to attack and financial stress in the time of civil strife caused by fighting associated with royal minority. ${ }^{53}$ The problems were located not only in secular churches but also in monastic establishments, some of which became impoverished. The financial difficulties of the church continued even during the 15th century. The monasteries suffered from appointments of commendatory abbots who received funds from the monasteries without living within them or taking up the abbot's true role. ${ }^{54}$ Benedictine monasteries in particular declined, while the Cistercians succeeded in retaining somewhat higher standards although these were not consistent in all houses. (It is thought that the Cistercian monastery of Alcobaça in late 13th-century Portugal maintained a level of education and a scriptorium

${ }^{50}$ Huglo, "La pénétration", 255-56.

${ }^{51}$ Solange Corbin, Essai sur la musique religieuse portugaise au moyen age (1100-1385) (Paris: Société D’Édition «Les Belles Lettres», 1952), 242-43.

${ }^{52}$ Peter Linehan, "The Gravamina of the Castilian Church in 1262-3", in Spanish Church and Society 1150-1300 (London: Variorum Reprints, 1983), 731.

${ }^{53}$ Peter Linehan, "The Spanish Church Revisited: the Episcopal Gravamina of 1279", in Spanish Church and Society 1150-1300, 140.

${ }^{54}$ Joseph F. O'Callaghan, A History of Medieval Spain (Ithaca: Cornell University Press, 1975), 632. 
of the highest quality. ${ }^{55}$ ) It is to be expected that in this situation a decline would also have occurred in the level of knowledge and understanding of liturgical chant in association with a consequent fall in the standard of performance. In the previously active monastic scriptoria the production of new books diminished, ${ }^{56}$ and lack of money must have often affected the ability of churches to purchase liturgical books. ${ }^{57}$

In reaction to the decline of the church, reforms began to occur with varying degrees of success during the 14 th century and continued during the 15 th century. Unfortunately little is known about the effect of the reforms on liturgical chant. One may suppose that some improvement probably took place in standards of performance and understanding but that this improvement would probably have occurred unevenly and over a long period of time. At the ecclesiastical Council of Valladolid (1322) it was decided that all parish priests should be provided with catechisms that would give them guidance in matters of morality and faith. Given the lack of education of some of the clergy, catechisms had to be produced in Castilian. ${ }^{58}$ In one of these books Pedro de Cuellar, then bishop of Segovia, included instructions on the saying of the Mass and the hours, and also wrote briefly on the role of the chantre, thus giving an indication of the problems that were arising.

E el chantre peca que non sabe del canto nada, nin del ofiçio e déxase fazer chantre; e peca reçibiendo los que non convienen en coro e echar los ginos. Pecan en quebrantar las costumbres e los estableçimientos de la iglesia. ${ }^{59}$

Also often specifically intended for the clergy were the many treatises on the subject of plainchant during the later part of the 15 th century and continuing during the 16 th century. These can probably be viewed as reflecting the desire for reform and improvement.

${ }^{55}$ Wesley D. Jordan, "A Collection of Early Antiphoner Fragments from Portugal (Lisboa, Viseu, Ponte de Lima, and Guimarães): A Miscellany of Historical and Technical Observations", Gordon Athol Anderson (1929-1981) in Memoriam, Musicological Studies, vol. 49 (Henryville: Institute of Mediaeval Studies, 1984), 447.

${ }^{56} \mathrm{~J}$. Pérez de Urbel, "Monacato", Diccionario de historia eclesiástica de España, vol. 3 (Madrid: Instituto Enrique Florez, 1973), 1506.

${ }^{57}$ The Spanish music theorist Gonzalo Martinez de Bizcargui referred to this phenomenon during the first half of the 16th century. On his comment see page 72 of this dissertation.

${ }^{58}$ Iradiel, Moreta, and Sarasa, Historia, 568-69.

${ }^{59} \mathrm{José}-\mathrm{Luis}$ Martín and Antonio Linage Conde, Religion y sociedad medieval. El catecismo de Pedro de Cuéllar (1325) (Salamanca: Junta de Castilla y León, 1987), 251. Martín and Linage Conde in the commentary on this passage note that the meaning of the phrase "e echar los ginos" is not known (157 n. 337). 
Stimulus was given to monastic reform in late 14th-century Castilla by the monarch Juan I. In 1390 he founded the Benedictine monastery San Benito de Valladolid which became the spearhead of Benedictine reform in Castilla although its influence met with resistance until the late 15 th century. The great Benedictine monastery of earlier centuries, San Domingo de Silos, the scriptorium of which produced some still extant manuscripts of the Old-Hispanic liturgy, was one of those which had suffered decline. The influence of the Congregación of San Benito de Valladolid brought about change and renewal, with the latter's observance being adopted at Silos in 1502. During the 16th century a collection of choir books including both plainchant and polyphony was built at Silos so that a chronicler, P. Gaspar Ruiz de Montiano (d. 1639), was able to say that not even the collection of El Escorial was larger. ${ }^{60}$

The development of printing assisted churches, which previously relied on old and deteriorated manuscripts or on memory, to obtain new liturgical books. This change began to take place towards the end of the 15 th century and eventually had the further effect of allowing alterations to be made in the practices bringing them into line with then current reforms and ideas. The possibilities of the printing press were appreciated so quickly that during the period 1479-1490 almost half of the dioceses of Spain had printed liturgical books pertaining to their own liturgical use. ${ }^{61}$ Various monastic and other orders also had books printed, a Dominican processional of 1494 being an early example. ${ }^{62}$ The new books would not only have given the clerics up-to-date liturgical practices, but to those who may have had chant manuscripts with single line notation, new books would have given the opportunity to use the modern, very legible square notation. The acquisition of new books would have meant that old ones could be sold for the value of the parchment contained in them.

The Catholic kings encouraged church reform. During their reign Fray Francisco Jiménez de Cisneros, confessor to Isabel la Católica and later archbishop of Toledo, was a

\footnotetext{
${ }^{60}$ Ernesto Zaragoza Pascual, "Los cantorales de la abadía de Silos", Tesoro Sacro Musical 60, no. 2 (1977): 47.

${ }^{61}$ A. Odriozola, "Liturgia. D. Libros Litúrgicos Impresos", Diccionario de historia eclesiástica de España, vol. 2 (Madrid: Instituto Enrique Flórez, 1972), 1326-27.

${ }^{62}$ A. Odriozola, "Liturgia", 1328.
} 
significant figure in the carrying out of reforms in the later part of the century and also in encouraging the printing and wide dissemination of liturgical books. He also directed the assembling and printing of books for the Mozarabic community still in Toledo. The university at Alcala de Henares was founded in 1508 at the direction of Cisneros with the aim of better educating the clergy; it became an important centre of theology and permitted the introduction and diffusion of European humanist ideas.

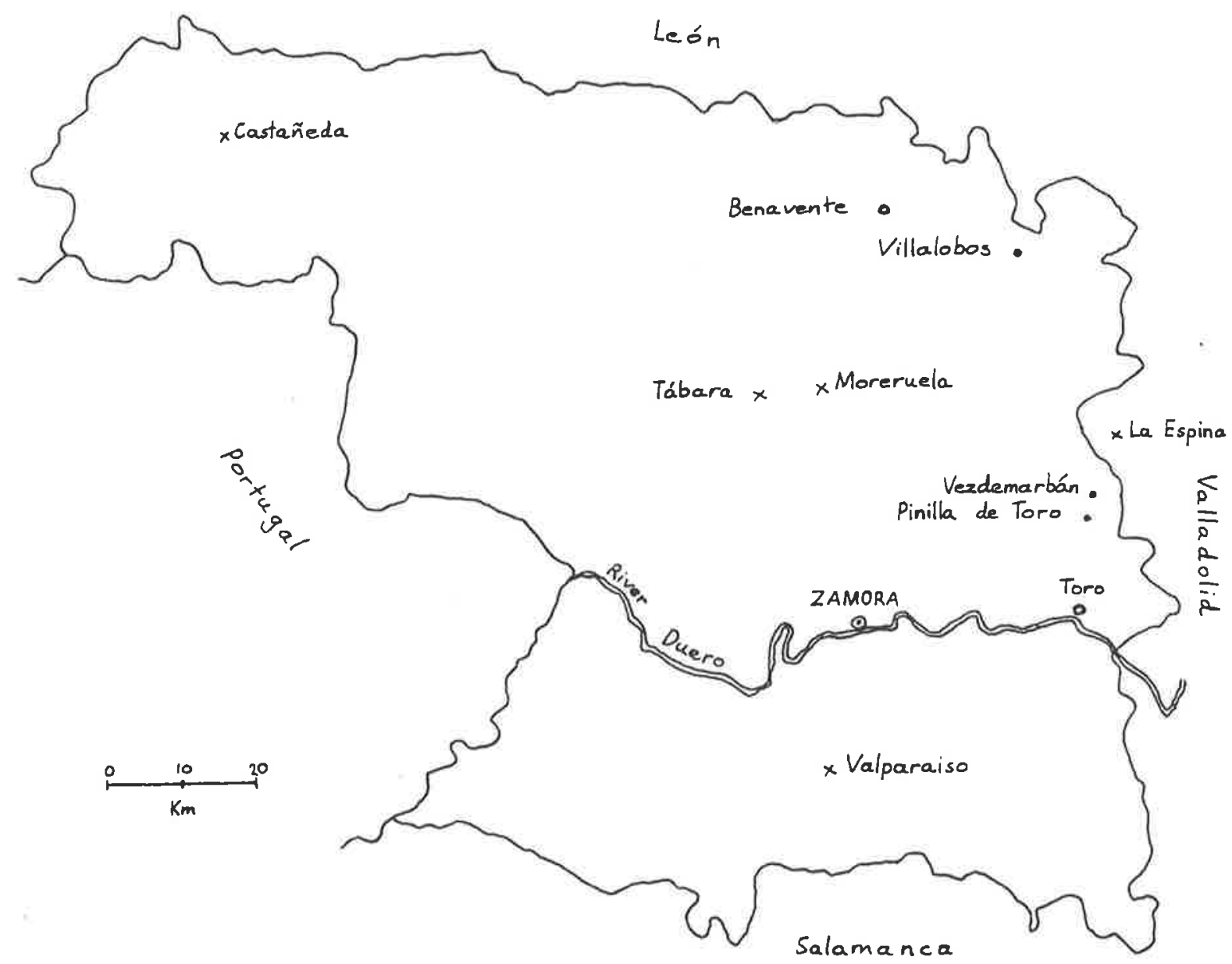

Map 1: The Modern Province of Zamora Showing the Location of Population Centres and Monastic Establishments of Interest to this Study ${ }^{63}$ Moreruela (1143-1300) (Zamora: Caja de Ahorros Provincial de Zamora, 1975), 88. 


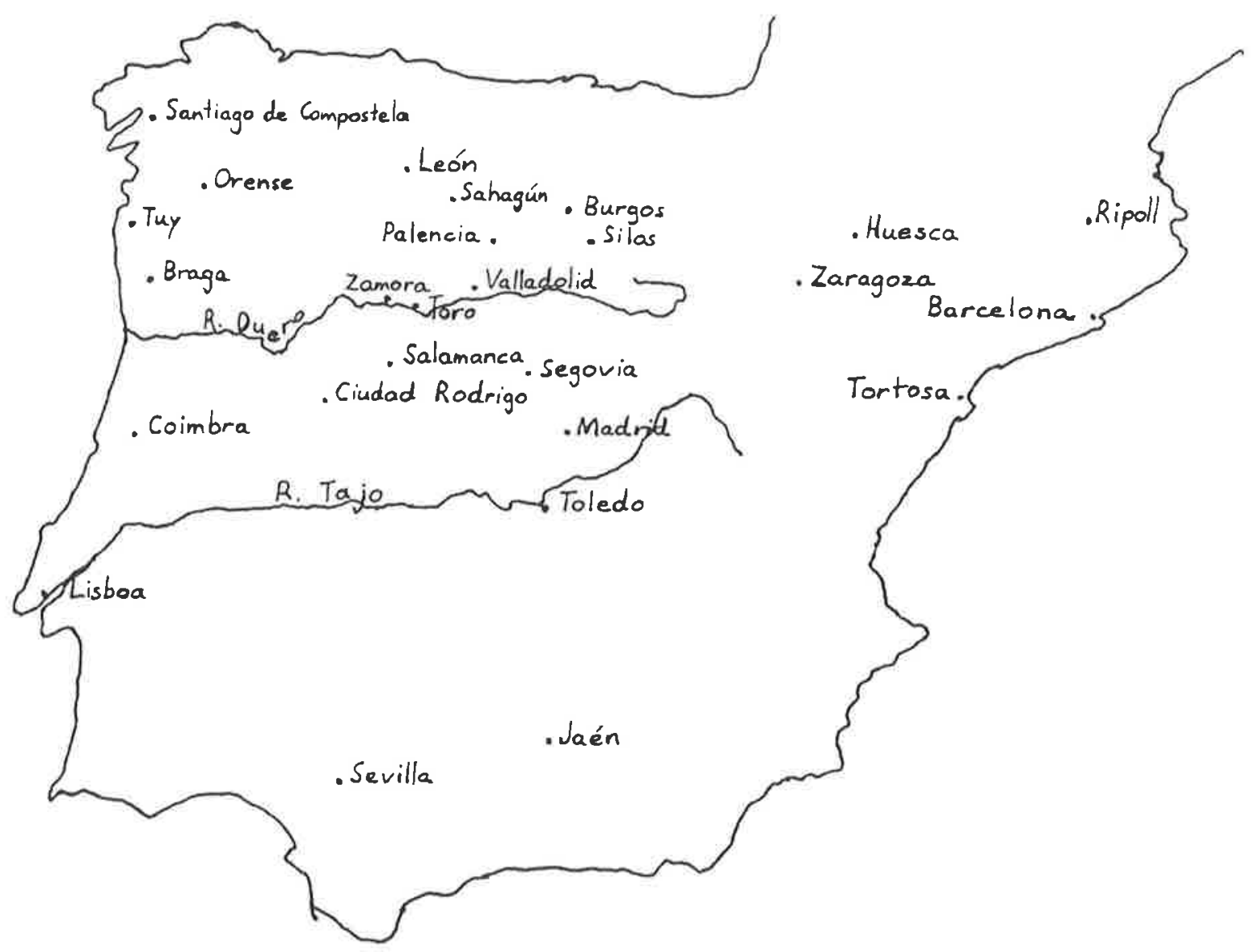

Map 2: The Iberian Peninsula Showing Centres of Interest to this Study 


\section{ZAMORA IN THE MIDDLE AGES: ASPECTS OF CHURCH AND SECULAR HISTORY}

\section{SECULAR HISTORY}

Following the Roman era, the region of Zamora was home to large landowners protecting themselves with private armies. These armies fell to the barbarian invasions and the western zone came in the 5th century to be dominated by the Sueves, who in their turn were defeated by the Visigoths. Churches, archaeological evidence, and place names such as Toro speak of the Visigothic presence in the region. There is, however, no mention of Zamora in the church councils of this period. ${ }^{1}$ The 8th century saw the Moslem invasion of the Visigothic kingdom and until the disintegration of the Cordoban caliphate in the first half of the 11 th century, the region of Zamora was racked by fighting and instability. Zamora was for a time part of a deliberately depopulated buffer zone between the Christian kingdom in the north and the Moslems to the south; no clearly defined frontier existed between the two groupings.

The late 11 th century, which witnessed the very major turning point within the history of the peninsular church of the change from the Old-Hispanic rite to the Roman rite, was also a crucial time of changing fortunes for the Zamoran region. Strategically located on the River Duero, Zamora had been a border town in early 11th-century Castilla-León, but later during the same century, with the movement of the frontier to the River Tajo, the town became more of an administrative and service centre to its region. It needs to be remembered that the period of development during which Zamora and other relatively small population centres such as Burgos and León became true towns only began in the latter part of the 11 th century and lasted until the middle of the 13 th century. ${ }^{2}$

Repopulation of the region was a high priority throughout the 11 th century with a notable influx of French migrants around the turn of the 12th century encouraged by Raymond of Burgundy. Raymond was the husband of Urraca, daughter of Alfonso VI, and

\footnotetext{
${ }^{1}$ E. Fernández Prieto, “Zamora, Diócesis de”, Diccionario de historia eclesiástica de España, vol. 4 (Madrid: Instituto Enrique Flórez, 1975), 2792.

${ }^{2}$ Iradiel, Moreta, and Sarasa, Historia, 112.
} 
was then administrator of Zamora as well as holding the rulership of Galicia. The arrival of French ecclesiastics was prominent in Zamora during the first quarter of the 12th century. French migrants are known to have come from such places as Gascony, Périgord, and Poitou, and it was not until the early 13 th century that the numbers coming to the region declined. $^{3}$

Not long after the death of Raymond of Burgundy in 1107, Zamora together with Salamanca fell into the hands of Count Henry of Portugal and his wife Teresa, and it seems that it was not until 1117 that Zamora was again united with Castilla-León under Urraca and her son. ${ }^{4}$ It was during this time that the diocese of Zamora was restored as had been other dioceses such as that of Braga. The 12th century saw the construction of the Cathedral of Zamora which like the restoration of the diocese will be discussed in more detail later in this chapter.

In relation to government, Zamora played its role in the cortes, hosting the assembly in 1427 . Economically the town was an important 13 th-century cloth manufacturing centre, but in general was based upon agriculture, the church being a prominent landowner. The textile industry remained important to Zamora and a recent study on the Zamoran economy in the 16 th century has shown its continuance and special place in the society at that time. During the early 14th century the region was not free from the social unrest affecting Castilla-León in general. It was a time of civil wars, epidemics, and economic difficulties, and that century saw the halting of the population growth which had been proceeding in Zamora since the efforts of repopulation. One result of this civil strife was that church officials felt the need to form brotherhoods for the protection of church property, such as the one formed in a meeting of ecclesiastics held in Zamora in $1311 .^{6}$

${ }^{3}$ Salustiano Moreta Velayos, "Repoblación" in Zamora en la edad media (Zamora: Caja de Zamora, 1988), 12; Amando Ripresa, "Genesis y evolución urbana de la Zamora medieval", Hispania 122 (1972): 528.

${ }^{4}$ Bernard F. Reilly, The Kingdom of Leon-Castilla under Queen Urraca 1109-1126 (Princeton: Princeton University Press, 1982), 320-21.

5José Carlos Rueda Fernández, "Introducción al estudio de la economía zamorana a mediados del siglo XVI: su estructura socio-profesional en 1561", Studia Historica 2, no. 3 (1984): 135.

${ }^{\circ}$ Martín and Linage Conde, Religion, 18. 
In addition to the town of Zamora two further population centres in the region need to be mentioned here as significant numbers of the manuscript fragments studied in this dissertation are associated with them. These centres are Toro and Vezdemarbán. Vezdemarbán is a small town situated to the north of Toro; very little information is available on its history. It is known to have been populated before 1000 A.D. and during the Middle Ages had established in it seven parish churches, ${ }^{7}$ a number suggesting a township of some importance. The much more significant centre of Toro is situated about twenty kilometres to the east of Zamora and shares with the latter a similar history. It is also built on the banks of the river Duero and was of similar strategic importance in the period of reconquest. The lovely collegiate church, second only in importance within the region to the Cathedral of Zamora, stands on a high point at the edge of the town where the land drops steeply to the river, thus occupying an excellent viewpoint over the plain. The bishops of Zamora appear to have included Toro in their see at least from 1147 at which time the title "Episcopus Bernardus in Zamora et in Tauro" was used in a document. ${ }^{8}$ A synodal meeting is known to have been held in Toro in the 13 th century under the direction of the bishop, Suero Pérez. ${ }^{9}$ As a wealthy town, 13th-century Toro was a keen supporter of the monarchy against the noble class and on occasion played an influential political role during that century and later, with various monarchs taking temporary residence in the town. A number of meetings of the cortes were held there including those of 1371,1426 , and 1505. The decline of Toro as an important centre coincided with the position it held against the power of the monarchy from about 1521 .

\section{ESTABLISHMENT OF THE EPISCOPACY}

Although recent years have seen an important growth in studies of the episcopacy and diocese of Zamora, in attempting this study here, a problem is still encountered in the lack of secondary studies directly pertinent to the topic. Such difficulties are not limited to

7osé Navarro Talegón, Catálogo monumental de Toro y su alfoz (Zamora: Caja de Ahorros Provincial de Zamora, 1980), 392.

\$Navarro Talegón, Catálogo, 10 n. 9.

${ }^{9}$ Antonio Linage Conde, review of Synodicum hispanum, edited by Antonio García y García, Scriptorium 42 (1988): 239. 
Zamora; referring to the 13th-century church in Spain, Peter Linehan lamented in an article of 1968 the lack of fundamental studies and especially monographs concerning the episcopacy. ${ }^{10}$ In particular, the early history of the episcopacy of Zamora is confused. According to Bernard F. Reilly, a scholar who has made detailed studies of Spanish medieval history, the see of Zamora was not established until 1120 or 1121 when Archbishop Bernard of Toledo appointed Bernard of Périgord to the new see of Zamora. Of the situation of the Church of Zamora before 1120 , Reilly says:

There was no such see in antiquity. Its early medieval status is still open to dispute but there is no doubt that it was treated as a possession of the church of Salamanca in the first decade of the 12th century. Apparently there was a sufficient tradition, however, to suggest to Archbishop Bernard that he could convincingly erect it into an independent see. ${ }^{11}$

On the other hand, St. Atilano is frequently cited as the first bishop of Zamora as for example is done in the Diccionario de historia eclesiástica de España. ${ }^{12}$ He held the position at the beginning of the 10th century. Others are listed for that century, but during the 11 th century and until 1121 , Zamora seems to have been without its own bishop. Similarly the historian Salustiano Moreta Velayos mentions the date of the foundation of the episcopacy in Zamora as 901, during a period in which the Christians were establishing strongholds against the Moslems in the region. ${ }^{13}$ It has been suggested that during the 11th century, Zamora belonged to the see of Astorga. ${ }^{14}$

It is not clear how or when the first impact of the decrees of the 1080 Council of Burgos concerning the change of rite was felt in Zamora, and it may have taken the arrival of French clergy to enable a more or less thorough implementation. Of great importance, then, must have been the arrival of Jerónimo bishop of Valencia, who was sent to the regions of Salamanca and Zamora following the fall to Moslems of Valencia in 1102. Jerónimo was a Cluniac and a Frenchman from Périgord. He took up the bishopric of

\footnotetext{
${ }^{10}$ Peter Linehan, "La carrera del obispo Abril de Urgel: la Iglesia española en el siglo XIII", in Spanish Church and Society 1150-1300, 143.

${ }^{11}$ Reilly, León-Castilla under Queen Urraca, 245.

${ }^{12}$ Fermández Prieto, “Zamora, Diócesis de", 2799.

${ }^{13}$ Moreta Velayos, "Repoblación”, 11.

${ }^{14}$ María Luisa Bueno Domínguez, Historia de Zamora: Zamora de los siglos XI-XIII (Zamora: Fundación Ramos de Castro, 1988), 20.
} 
Salamanca and incorporated within it was that of Zamora. ${ }^{15}$ Reilly has suggested that Jerónimo may in fact have governed his diocese from the more established town of Zamora rather than Salamanca which was still very important militarily with regard to the Moslem frontier and which would still have had only a small constant population. ${ }^{16}$ Salamanca lay in the zone of repopulation south of Zamora which during the late 11 th century and the 12th century was given particular attention by the rulers as part of the effort of reconquest. Bishop Jerónimo died in 1120 , at about the time of the appointment of Bernard, ${ }^{17}$ another Cluniac from Périgord, as bishop of Zamora. Bernard, prior to his appointment in Zamora, had held the post of archdeacon in Toledo. ${ }^{18}$ The important role of Cluny in Zamora at this time reflects the general importance of representatives of the Cluniac tradition in the implantation of the Roman rite on the Iberian Peninsula and also the influence of the archbishop of Toledo. Also in relation to Cluny, it should be mentioned that the area not far from Zamora known now as the Tierra de Campos, including Palencia and Valladolid, (in the Middle Ages known as the Campi Gothicorum, then forming the border country between Castilla and León) became during the 11th and 12th centuries according to the historian C. J. Bishko "the true center of all Cluny's trans-Pyrenean expansion". ${ }^{19}$

It may be postulated that the Cluniac bishops Jerónimo and Bernard might have obtained from France liturgical books of the Roman rite for use in the Church of Zamora, although there is as yet no unequivocal evidence for such an occurrence. It may also be expected that in the form of the Roman rite in use in the Church of Zamora, just as elsewhere on the peninsula, French and Cluniac customs would be found. An example of the entry of French features into a peninsular rite has been documented for the rite of Braga in northern Portugal where it is known that "Within the framework of the Roman rite, secondary prayers and ceremonies have been taken from various sources, for the most part

${ }^{15}$ Iradiel, Moreta, and Sarasa, Historia, 134.

${ }^{16}$ Bernard F. Reilly, The Kingdom of Leon-Castilla under King Alfonso VI, 1065-1109 (Princeton: Princeton University Press, 1988), 308, 320-21.

${ }^{17}$ Reilly, Leon-Castilla under Queen Urraca, 245 n. 67.

${ }^{18}$ Reilly, León-Castilla under Queen Urraca, 245.

${ }^{19}$ Charles Julian Bishko, "Fernando I and the Origins of the Leonese-Castilian Alliance with Cluny", in Studies in Medieval Spanish Frontier History (London: Variorum Reprints, 1980), 15. This article is important for its recognition of the powerful role played by Cluny, together with its detailed discussion of the period c. 1020 to 1150. 
French." ${ }^{, 20}$ Detailed studies of the liturgy of Zamora remain to be undertaken by liturgical scholars.

How long the Cluniac or Benedictine influences continued in the Church of Zamora is difficult to ascertain. Bishop Bernard's successor, Stephen, may also have been a foreigner, his name being characteristic of southern France rather than Castilla-León. ${ }^{21}$ Reilly has found that the custom of choosing former members of monastic houses to fill the office of bishop in many peninsular sees during the late 11th and early 12 th century had come to an end by the second quarter of the latter century, at which time bishops were often chosen from cathedral chapters and furthermore were not always natives of CastillaLeón. ${ }^{22}$ Problems arose during the 12th century in relation to the suffraganship and the independence of the see of Zamora. With the appointment in 1120 or 1121 of Bishop Bernard by the archbishop of Toledo, the see of Zamora was a suffragan of Toledo; however, the bishop of Astorga disputed the right of Zamora to be an independent see as he considered it part of his territory. This difficulty was not without a political component as Astorga was a suffragan see of Braga in Portugal. ${ }^{23}$ In 1150 Bishop Stephen was appointed by the archbishop of Toledo as successor to Bernard in Zamora, continuing the allegiance of Zamora to Toledo; his appointment thus disregarded a papal decree that Zamora should go to the see of Astorga following Bernard's death. Peter Linehan shows the continuing problem in a discussion of disputes over ecclesiastical boundaries and suffraganship, choosing Zamora as an example:

The evidence submitted in 1198-9 by the archbishops of Braga and Compostela for control of the church of Zamora aptly illustrated the political dimension of ecclesiastical divisions. One witness recalled how Fernando II of León had sought to draw the suffragans of Braga from obedience to their archbishop because the latter intended to excommunicate him; another remembered Fernando's pressure on the bishop of Zamora, politically his subject, to defect from Braga to Compostela ${ }^{24}$

${ }^{20}$ King, Liturgies of the Primatial Sees, 191.

${ }^{21}$ Bernard F. Reilly, 'On Getting to Be a Bishop in Leon-Castile: The "Emperor" Alfonso VII and the Post-Gregorian Church', Studies in Medieval and Renaissance History 1 (1978): 40, 42.

${ }^{2}$ Reilly, "On Getting to Be a Bishop", 67, 40ff.

${ }^{23}$ Reilly, León-Castilla under Queen Urraca, 183-84.

${ }^{24}$ Peter Linehan, "Religion, Nationalism and National Identity in Medieval Spain and Portugal", in Spanish Church and Society 1150-1300, 186. 
The dispute was finally resolved so that by the beginning of the 13th century Zamora was within the ecclesiastical province of Santiago de Compostela. ${ }^{25}$

The 13th century seems to have been something of a golden period for the Church of Zamora despite the financial pressures put upon the churches of Castilla-León by the monarchy and other problems. It was favoured by the Spanish cardinal, Gil Torres, a native of Zamora to whom the pope referred problems of peninsular churches. He appears to have given preference to Zamora over Salamanca, even going against the constitutions that he himself had established. Following Gil Torres' death in 1254, some Spanish bishops turned for assistance to Cardinal Stephanus, bishop of Palestrina and a Hungarian, who followed Gil's example in interesting himself in Zamora. ${ }^{26}$ Peter Linehan's description of events favouring Zamora follows:

En diciembre de 1253 había asegurado la reserva de tres beneficios vacantes, y de ello se aprovecharon los clérigos de su Zamora natal: en julio de 1254 se ordenó al deán de Salamanca que proporcionase una canonjía a Elias, alumpnus de Zamora, a petición del obispo y capítulo de Zamora. En enero de 1264 las constituciones del cardenal fueron anuladas expresamente hac vice en favor del magister scolarum de Zamora - un pariente del cardenal - a quien se proporcionó una canonjía en Salamanca. ${ }^{27}$

One of the bishops of Zamora, Suero Pérez, was a royal notary at the court of Alfonso X. He was a strong bishop who seems to have wielded much influence in the town, holding office from $1254-86 .^{28}$ The Cathedral of Zamora now holds a greater quantity of documentation produced there during the 13th century than from either the 12th or the two following centuries. ${ }^{29}$ This fact must reflect the activity of the 13th century, and in relation to musical sources, one may ask whether this period particularly may not also have seen the

${ }^{25}$ José Sánchez Herrero, Las Diócesis del reino de León. Siglos XIV y XV (León: Centro de Estudios e Investigación "San Isidoro", 1978), 41.

${ }^{26}$ Peter Linehan, "La carrera del obispo Abril de Urgel: la Iglesia española en el siglo XIII", in Spanish Church and Society 1150-1300, 160-62.

${ }^{27}$ Peter Linehan, "La carrera del obispo Abril de Urgel: la Iglesia española en el siglo XIII", in Spanish Church and Society 1150-1300, 157-58.

${ }^{28}$ On Bishop Suero see Marciano Sánchez Rodríguez, "La Diócesis de Zamora en la segunda mitad del siglo XIII", in Primer congreso de historia de Zamora, vol. 3 (Zamora: Instituto de Estudios Zamoranos "Florián de Ocampo", 1991), 147-71.

${ }^{29}$ José Carlos de Lera Maillo, "La documentación medieval del Archivo Catedral de Zamora: fuentes para la historia de Zamora", in Fuentes y Métodos de la Historia Local. Actas (Zamora: Instituto de Estudios Zamoranos, Diputación de Zamora, 1991), 69. 
production of books containing notated chants. Unfortunately no clear evidence for such production has yet been found.

An inventory dating from the late 13th century contains names of the manuscripts of the cathedral chapter of Zamora. Among those listed are some which are thought to have contained chants. These are identified with the terms "Prosaria" or "Prosarium" and "Officiaria" or "Officiarium". ${ }^{30}$ Again it is not possible to ascertain whether these were copied in Zamora. The manuscripts are no longer found in the cathedral, no doubt at least in part as a result of a fire in the late 16th century which destroyed the library. ${ }^{31}$ One wonders whether some, however, may be represented amongst the fragments studied in this dissertation.

\section{The Cathedral of Zamora and the Colegiata de Santa Maria la Mayor of Toro}

These two buildings together with the Old Cathedral of Salamanca share similar architectural characteristics, the most notable being the domes. All were built at about the same time. The construction of the Cathedral of Zamora had begun by 1139 and was completed or largely completed by $1174 .^{32}$ It was built on the site of an earlier church on the highest point of the town overlooking the plain and above the River Duero. The austere style of the building has frequently brought about the suggestion that it was influenced by Cistercian ideals. ${ }^{33}$ A sculpture of Mary with the child Christ is thought representative of a style developed in France and seen first in Chartres. ${ }^{34}$

The dome of the cathedral is the outstanding feature of the building. One writer, Madrazo, has seen it and those of Toro and Salamanca as Byzantine in style and as a theme

${ }^{30} \mathrm{M}$. Luisa Guadalupe, "El tesoro del cabildo zamorano: aproximación a una biblioteca del siglo XIII", Studia Historica 1, no. 2 (1983): 178-79.

${ }^{31}$ Clyde Waring Brockett mentions that a collection of Mozarabic manuscripts may have been lost in this fire (Brockett, Antiphons , 73). This supposition has not yet been proven; however, according to Guadalupe, one of the books in the inventory has been identified as likely to have belonged to the Old-Hispanic (Mozarabic) liturgy; see Guadalupe, "El tesoro", 169.

${ }^{32}$ Ramos de Castro, La Catedral de Zamora, 24.

${ }^{33}$ The suggestion is found in Navarro Talegón, Catálogo, 98; and Ricardo Abrontes, "Arquitectura medieval", in Zamora en la edad media (Zamora: Caja de Zamora, 1988), 26.

${ }^{34}$ Ana Isabel Fernández Salmador, "Escultura medieval", in Zamora en la edad media (Zamora: Caja de Zamora, 1988), 33. 
introduced by the southern French churchmen who came to the region. ${ }^{35}$ The idea of Byzantine stylistic origin is supported by the fact that the technique of construction of these domes has precedents in the domes of Saint Mark's in Venice and the earlier Saint-Sophia in Constantinople. ${ }^{36}$ Furthermore, in the French region of Périgord, various churches with domes of the same type are to be found, the best known being the church of Saint-Front in Périguax with five domes. ${ }^{37}$ The relationship between the church in Prriguax and those of Zamora, Toro, and Salamanca raises the interesting possibility that the construction of this particular type of dome may have been another result of the influx into the region of French churchmen, as well as migrants belonging to other callings and in particular those from Périgord. Madrazo saw Bishop Jerónimo as the most influential in bringing the style to Spain and the Cathedral of Zamora and also as the initiator of construction.

Que éste [Jerónimo] quiso perpetuar en Salamanca y Zamora el recuerdo de la arquitectura religiosa de su país natal, y del santo patrono á quien estaba consagraba la famosa abadía bajo cuyas bóvedas transcurrieron quizá los años floridos de su juventud, claramente atestiguaban de la Catedral vieja [Salamanca], donde fué inhumado, y el arrabal de San Frontis que levantó enfrente de Zamora en la orilla opuesta de Duero, en cuya iglesia yacen sepultadas algunas compatriotas del buen obispo que con él vinieron a España. ${ }^{38}$

Although later writers have not pursued the idea of Jerónimo's influence, nor is the Byzantine design always spoken of, these ideas do seem worthy of mention in view of the added association it suggests with southern France. The fact that the church of Saint-Front in Periguaxx is thought to have been built only in about $1120^{39}$ makes a connection between Périgord and the Cathedral of Zamora and the Colegiata of Toro stemming from Bishop Jerónimo dubious; nevertheless, there remains the fact that Bernard, the first appointed bishop of Zamora in the 12th century, was also from the region of Périgord. Bernard was bishop in Zamora from about 1121 until 1147, during which time the construction of the Cathedral of Zamora was taking place. A further tie with Périgord lies with the saint, St. Fronto (Front or Frontis), who was especially associated with the town of Périgueux. A 438.

\footnotetext{
${ }^{35}$ Pedro de Madrazo, “La Colegiata de Toro", Boletln de la Real Academia de la Historia 20 (1892):
}

\footnotetext{
${ }^{36}$ Friedrich Rahlves, Cathedrals and Monasteries of Spain (London: Nicholas Kaye, 1966), 173.

${ }^{37}$ Oliver E. Bodington, Romance Churches of France (London: Grant Richards, 1925), 52.

${ }^{38}$ Madrazo, "La Colegiata de Toro", 439.

${ }^{39}$ James Snyder, Medieval Art (New York: Henry N. Adams, 1989), 307.
} 
suburb close to the Cathedral of Zamora (mentioned in the above quotation) was named after St. Fronto; his feast is found in the Calendar of Zamora on the 25th of October. Another cited Byzantine feature is found in aspects of the design of the cathedral's sculpture of Mary, although the scholar who discusses this relates it to the arrival in Zamora of Byzantine ideas through general contacts with other parts of Europe such as Italy, France, or Germany, rather than to any specific person or place. ${ }^{40}$

The date and circumstances of the foundation of the Colegiata de Santa Maria la Mayor of Toro are uncertain, but it is thought that the construction would have begun after the middle of the 12th century and finished in the 13th century during the reign of Fernando III. ${ }^{41}$ More ornamentation is found in this church than in the Cathedral of Zamora. French influence in the Gothic style is seen in some of the decoration. ${ }^{42}$ Interesting are two doorways displaying figures playing musical instruments, the earlier of the two having been completed only about twenty years after the completion of the magnificent Pórtico de la Gloria of the Cathedral of Santiago de Compostela and the design of which may have been founded to some extent on that of the Pórtico de la Gloria. ${ }^{43}$ The church is known to have had collegiate status in $1332^{44}$ and this position may date from an earlier time. It was a wealthy church and therefore would probably have had a valuable collection of liturgical books in the late Middle Ages although this has not yet been documented.

\section{Cantor, Subcantor, and Magister Scolarum}

Prior to the 16th century little information concerning musical matters can be gleaned from the records pertaining to the Church of Zamora which this writer has been able to study ${ }^{45}$ Documents usually relate to topics such as: gifts to the cathedral wills, tithes,

\footnotetext{
${ }^{40}$ Ramos de Castro, La Catedral de Zamora, 54-55.

${ }^{41}$ Navarro Talegón, Catálogo, 91, 13.

${ }^{42}$ Navarro Talegón, Catálogo, 109.

${ }^{43}$ López-Calo, La música medieval en Galicia, 120.

${ }^{44}$ Navarro Talegón, Catálogo monumental, 91.
}

${ }^{45} \mathrm{~A}$ very useful collection of documents has been published by Jose-Luis Martín under the title Documentos Zamoranos I. Documentos del Archivo Catedralicio del Zamora. Primera parte (1182-1261) (Salamanca: Ediciones Universidad de Salamanca, 1982). Other secondary sources in which documents, either in part or in full, are published have also been of assistance and are referred to below. In addition to these, I have been able to study a small number of original documents in the Archivo Diocesano of Zamora 
sales, and purchases; or agreements between ecclesiastics, churches, monasteries, or religious orders. Holders of the offices of cantor, subcantor and magister scolarum are on occasion named as witnesses, beneficiaries of wills, etc. From this information we know that the offices did exist and have some of the names of the people who filled them, but little else can be discovered.

Evidence exists from as early as 1168 of the position of magister scolarum in the Cathedral of Zamora and the possibility that it existed earlier cannot be precluded. This office had begun to appear in Spanish cathedrals in the late 11th century, the occupant having responsibility for the cathedral school in which would have been taught the subjects of the trivium and the quadrivium. It is known that on some occasions during the 12 th and 13th centuries, the magister scolarum had to be brought from outside the peninsula to fill the position. ${ }^{46}$ Unfortunately such details on the occupants of the position in Zamora during this period have not yet been found.

Below are listed the names of holders of the position of cantor or chantre, subcantor or sochantre, and magister scolarum which it has so far been possible to find. Although the lists are incomplete, it is hoped that they may form a useful reference for future musicological research concerning the region of Zamora. Work currently underway on the preparation of a catalogue (in the form of a computerized database) of the medieval documents held in the cathedral archive of Zamora may make available data to fill some of the lacunae in the information presented here. ${ }^{47}$ The holdings of the cathedral include not only documentation pertinent to that church but also to other churches of the region such as the Colegiata of Toro. It may thus be possible in the future to construct similar lists for that town.

The dates in the lists indicate the date of the document in which each name was found. Names are given in the form in which they appear in the documents. ${ }^{48}$

and the Archivo Historico Provincial of Zamora.

${ }^{46}$ Javier Fernández Conde, "La renovación de los estudios eclesiásticos", in Historia de la Iglesia en España, ed. Javier Fernández Conde, vol. 2, pt. 2 (Madrid: Biblioteca de Autores Cristianos, 1982), 180-181.

${ }^{47}$ A description of this project is given in Lera Maillo, "La documentación medieval".

${ }^{48}$ The main source of information for this listing is José-Luis Martín, Documentos Zamoranos. Other sources are Antonio Matilla Tascón, Gula-inventario de los archivos de Zamora y su provincia (Madrid: Dirección General de Archivos y Bibliotecas y Diputación Provincial de Zamora, 1964); José Luis Rodríguez 


\section{Cantor of Zamora}

1103 Don Ovieio Sanchez

1197? E. cantor

1210 Egee (Egas)

1219 Egas

1221 el cantor Gil

1234 G. cantor

1251 Garsias Pelagii (don García Peláez)

1252 D. Pedro

1255 magister Egidius (Gil)

1258 mestre Gil

1259 Mestre Gil, chantre de la eglisia de Çamora

1285 Pedro Benítez

1389 Gómez Martínez

\section{Subcantor of Zamora}

1200 Stephanus subcantor

1219 Stefanus

1250 don Estevan

1251 don Gil

1259 don Gil

\section{Magister scolarum of Zamora}

1168 magister del scola [no name]

1180 magisterscola de Zamora Albergante

1187 Alberganti, maestrescuela

1200 Iohanes capellanus magister scolarum

de Diego, "Documentación medieval del Archivo Histórico Provincial de Zamora" Studia Historica 1, no. 2 (1983): 181-202; Linehan, "La iglesia de León a mediados del siglo XIII", in Spanish Church and Society (1150-1300), 72; and Peter Linehan, The Spanish Church and the Papacy in the Thirteenth Century (Cambridge: Cambridge University Press, 1971), 295. 
1268 Petro Benedicti magistro scolarum zamorensi

1357 Juan Pérez de Villaquirán

\section{MONASTERIES}

During the 11th century the great monastery of Sahagún not very distant from León and north of Zamora came under the strong influence of Cluny. The monasteries of Zamora through their close connection with Sahagún and the cathedral of León ${ }^{49}$ may also have received some of the Cluniac reforms. Monasticism, however, had been established in the region of Zamora well prior to this period; for example, the monastery of San Martín de Casteñeda was established during the Visigothic era. ${ }^{50}$ Also in the region of Zamora, the monastery of Tábara had, during the 10th century, a fine scriptorium which produced illuminated manuscripts. ${ }^{51}$ The 12 th century saw the rise of the Cistercian monasteries which were to play an important role in the development of the Zamoran region with regard to the continuing process of repopulation and to economic factors. The rise of the Cistercians in 12th-century Castilla-León was assisted by the interest in them of Sancha, the sister of Alfonso VII and also by the gradual decline of Cluny.

For the period of Benedictine domination of the monastic life little is known of the Zamoran monasteries ${ }^{52}$ but more information is available for the Cistercian period which dates from the mid 12th century. The records of the Middle Ages from the monasteries near Zamora which have been studied by modern historians rarely include information on the musical or even the liturgical practices. A writer of a monograph on Cistercians in Castilla and León says "Pocas cosas se pueden estudiar, a decir verdad, de la vida interna de estas comunidades a partir de la documentación disponible, casi todo de tipo económico."\$3

${ }^{49}$ Isabel Alfonso, "El monacato", in Zamora en la edad media, 21.

${ }^{50}$ For a listing of early monasteries as well as a map of their locations, see Antonino González Blanco, "La cristianización de Zamora", in Primer Congreso de historia de Zamora, vol. 2 (Zamora: Instituto de Estudios Zamoranos "Florián de Ocampo" 1990), 291, 298.

${ }^{51}$ Agustín Millares Carlo, Manuscritos visigóticos (Madrid: Instituto P. Enrique Flórez, 1963), 25 , 46.

${ }^{52}$ Isabel Alfonso, "El monacato", 21.

${ }^{53}$ Javier Pérez-Embid Wamba, El Cister en Castilla y León: Monacato y dominios rurales (Siglos XII-XV) (Salamanca: Junta de Castilla y León, 1986), 220. 
Perhaps the most outstanding of the Cistercian monasteries in the region of Zamora was Moreruela. Formerly Benedictine, the origin of Moreruela came about when the community of the monastery of Tábara moved to the present site probably in the late 10th century, the location being not very distant to the north of the town of Zamora. ${ }^{54}$ In the mid 12th century with the expansion of the new Cistercian order in Spain, Moreruela became a Cistercian house, changing its dedication from St. James to the Virgin Mary thus becoming known as Santa María de Moreruela. It soon developed into a powerful and wealthy landowner receiving favour and support from monarchs and the Zamoran nobles. The conversion of Moreruela into a Cistercian house may have been promoted by Alfonso VII in order to gain himself the support or approval of the Cistercian leader, Bernard of Clairvaux. ${ }^{55}$ A wealthy monastery during the 13th century, Moreruela had among its monks those with titles such as cantor and magister novitorum ${ }^{56}$ both of which are indicative of the recognition of the need for leadership and training in the singing of liturgical chant. It is likely that such a monastery would have had a good supply of liturgical books. ${ }^{57}$ The monastery had connections with the Church of Zamora although these were not always without problems. Interestingly, a chantre of Zamora, Don Pedro, donated land to the monastery in 1252. Moreruela in the 14th and 15th centuries suffered a period of decline, reviving in the 16 th century.

Two other Cistercian monasteries were located near the town of Zamora. These were the early established San Martín de Casteñeda and Nuestra Señora del Valparaíso. Valparaíso was founded to the south of Zamora in the mid 12th century and had the support of Alfonso VII. It quickly saw not only economic success but became a cultural centre as well. ${ }^{58}$ Casteñeda to the north-west of Zamora had previously been a Benedictine monastery but changed to the Cistercian rule in 1245 . Located in the region of Valladolid immediately

${ }^{54}$ Bueno Domínguez, El monasterio, 32.

${ }^{55}$ Bueno Domínguez, El monasterio, 40-41.

${ }^{56}$ Bueno Domínguez, El monasterio, 83.

${ }^{57}$ On the location of the library, see Manuel de la Granja Alonso, Estudio historico, artistico, religioso, agricola y humano del Real Monasterio de Santa Marla de Moreruela de la Orden Cisterciense (Zamora: Diputación de Zamora, 1990), 77, 163.

${ }^{38}$ Florián Ferrero Ferrero, El imperial monasterio de Nuestra Señora de Valparaiso (Zamora: Archivo Histórico Provincial de Zamora and Caja de Zamora, 1986), 3-5. 
to the west of Zamora was another important Cistercian monastery, Santa María de la Espina, which is mentioned here because it had property holdings in Vezdemarbán, Toro, and Zamora ${ }^{59}$ (as did the monastery of Moreruela). Monks from Claraval were brought by Sancha, sister of Alfonso VII to La Espina. ${ }^{60}$

The Franciscans and Dominicans established a number of houses in the region of Zamora in the 13th century. The Franciscan house in the town of Zamora appears to date from the first half of the century before $1246 .{ }^{61}$ The scholar and writer on music Juan Gil de Zamora belonged to the monastery which is thought to have had a good library. ${ }^{62}$ At least five houses of Clares were founded in the region during the 13th century, that of Toro being founded by Berenguela, daughter of Alfonso X. ${ }^{63}$ The establishment of the Dominicans in Zamora began early, with the visit to the town of their founder Domingo de Guzmán in 1219, at which time a house was donated to him. ${ }^{64}$ The Real Monasterio de San Ildefonso was an important Dominican house founded in Toro in 1275 and there in 1405 the future king Juan II was born. ${ }^{65}$ Two houses of Dominican nuns founded in the 14th century had considerable royal patronage in Toro as did the 13th century established house in Zamora. ${ }^{66}$ The importance which the two mendicant orders must have held in Zamora is reflected in the number of their saints found in the calendar of the 14th-century Breviario de Zamora as will be shown later in this chapter. ${ }^{67}$ (This manuscript is referred to hereafter as Breviario.) Other orders were also present in the region as were various military orders. ${ }^{68}$

${ }^{59}$ José Luis Rodríguez de Diego, El tumbo del monasterio cisterciense de la Espina (Valladolid: Universidad de Valladolid, 1982), 131, 153, 164, 183.

${ }^{60}$ Pérez de Urbel, "Monacato", 1506.

${ }^{61}$ Manuel de Castro, La provincia franciscana de Santiago. Ocho siglos de historia (Santiago de Compostela: Ediciones Monte Casino, 1984), 118.

${ }^{62}$ Castro, La provincia, 118.

${ }^{63}$ Fernández Prieto, “Zamora, Diócesis de”, 2797.

${ }^{64}$ Ursicino Alvarez Martínez, Historia general civil y eclesiástica de la provincia de Zamora (1899; reprint, Madrid: Editorial Revista de Derecho Privado, 1965), 182.

${ }^{65}$ Navarro Talegón, Catálogo, 278.

${ }^{66}$ On current female monastic houses of the region, see Manuel Espías Sánchez, Monasterios de clausura en Zamora (Zamora: Ediciones Monte Casino, 1980).

${ }^{67}$ Breviario de Zamora, Zamora, Archivo Catedralicio, códice 104. This manuscript, as its name suggests, is not notated.

${ }^{68}$ For a listing of monastic houses in the region, together with some details of their history, see Fermández Prieto, “Zamora, Diócesis de”, 2796-98. 
Fires and floods are known to have occurred throughout the centuries affecting the monasteries as well as the cathedral and have contributed to the loss of manuscripts. Much material that would undoubtedly have been of value in a study such as the present one must have been lost during the 1830s when monasteries throughout Spain were secularized and their wealth and libraries taken over by the state or destroyed. Buildings were eventually sold or destroyed. Monasteries in the region of Zamora dismantled in this movement included Moreruela, San Francisco, San Domingo, San Martín de Casteñeda, and Valparaíso. ${ }^{69}$ One is left to conclude that, as with the lost church libraries, some of the fragments of liturgical books now extant owing to their use as binding material may have once been part of the libraries of the monastic houses of the region.

\section{JUAN GIL DE ZAMORA}

A Franciscan monk, Juan Gil de Zamora is known to musicologists as the writer of the most important extant music treatise from 13th-century Spain. As a native of Zamora ${ }^{70}$ his inclusion here is essential, although his work does not have any direct bearing on the sources studied in this dissertation. The Ars musica is only one of his treatises, the others belonging to such disciplines as history, theology, and natural sciences. Among his works are studies concerned directly with Zamora. In addition he wrote Latin poetry. ${ }^{71}$

Very few facts are known about his life and as a result some controversy has arisen over certain issues, notably the date of writing of the Ars musica and the identity of its dedicatee. Gil dedicated the work to a Iohannes, minister general of the Franciscan order, without giving a date. The dedicatee had ordered the writing of the work. There were two ministers general with the name Iohannes during the lifetime of Gil. The case for the

${ }^{69}$ Alvarez Martínez, Historia, 372.

${ }^{70}$ The evidence for this fact was given by Gil himself, see Rafael Mota Murillo, "El Ars musica de Juan Gil de Zamora. El ms. H/29 del Archivio Capitolare Vaticano", Archivo Ibero-Americano 42 (1982): 656.

${ }^{71}$ On the writings of Gil de Zamora see Cesáreo Femández Duro, Coleccion Bibliografica-Biografica de noticias referentes a la provincia de Zamora (Madrid: Imprenta Manuel Tello, 1891), 418-20; and Manuel de Castro, "Gil de Zamora, Juan", Diccionario de historia eclesiástica de España, vol. 2 (Madrid: Instituto Enrique Flórez, 1972), 1022. Specifically conceming Gil de Zamora's poetry, see Marcelino Menéndez Pelayo, Obras completas. Antologia de poetas liricos castellanos, vol. 1 (Madrid: Consejo Superior de Investigaciones Científicas, 1944), 63. 
earlier, John of Parma, has been supported by Robert Stevenson and places the composition of the treatise prior to 1257 , making it an early work of the author. ${ }^{72}$ The second Iohannes, Giovanni Mincio de Murrovalle, is the more usual to be seen in the role and has been accepted by the two recent editors of the Ars musica. As his minister generalship was around the turn of the century the Ars musica would therefore be a very late work of Gil coming well after most of his works were written. ${ }^{73}$

One writer puts forward the following as the only certain facts concerning Gil's life: that his place of birth was the town of Zamora, that he was living there in 1278 in the Franciscan monastery, and that he was closely associated with the court of Alfonso X. ${ }^{74}$ The date of his birth is placed variously from 1230 to $1241^{75}$ and his death after $1318 .^{76}$ He is believed to have had a period of study in Paris but again the dates are unknown. Also unknown is the date of his entry into the Franciscan order; Gil identified himself as "frater" in the opening of the Ars musica. ${ }^{77}$ In the later part of his life, Gil is thought to have filled the important positions of provincial vicar and later (c. 1300) provincial minister of the Franciscan province of Santiago. ${ }^{78}$

The Ars musica is devoted to the discussion of chant. Having begun with such themes as the invention, divisions and usefulness of music, Gil moved to practical aspects, such as solmization, the gamut, intervals, church modes, and instruments. It does not pretend to be a largely original work, but rather compiles information from earlier writers. Gil's notice concerning the use of the organ in church however is important and seems to be original. "Et hoc solo musico instrumento utitur Ecclesia in diversis cantibus et prosis, in sequentiis et in hymnis, propter abusum histrionum, eiectis aliis communiter

${ }^{72}$ Robert Stevenson, "Spanish Musical Impact beyond the Pyrenees (1250-1500)", in España en la Música de Occidente, ed. Emilio Casares Rodicio, Ismael Fernández de la Cuesta, and José López-Calo, vol. 1 (Madrid: Instituto Nacional de las Artes Escénicas y de la Música, 1987), 120-23.

${ }^{73}$ Michel Robert-Tissot, ed., Johannes Aegidius de Zamora. Ars musica, Corpus Scriptorum de Musica, vol. 20 (American Institute of Musicology, 1974), 8-13; Mota Murillo, "El Ars musica", 659-62.

${ }^{74}$ Mota Murillo, "El Ars musica ", 656.

${ }^{75}$ Stevenson, "Spanish Musical Impact", 121; Mota Murillo, "El Ars musica ", 657.

${ }^{76}$ Castro, "Gil de Zamora, Juan", 1022; Mota Murillo, "El Ars musica ", 657.

${ }^{n}$ Mota Murillo, "El Ars musica ", 677.

${ }^{78}$ Mota Murillo, "El Ars musica ", 656.

${ }^{79}$ Don M. Randel, "La teoría musical en la época de Alfonso X el Sabio", in Symposium Alfonso X el Sabio y la música (Madrid: Sociedad Española de Musicología, 1987), 45. 
instrumentis". ${ }^{80}$ Contemporary theory in relation to polyphony does not have a place in the treatise. In fact polyphony is not discussed at all, and neither is rhythm. The treatise, written at the direction of the minister general of the order and - as Gil stated - written in a simple manner, may well have been intended for the instruction of members of the Franciscan order. That no mention of polyphonic practices is made may well be a reflection of such an intention. Given the link of Gil with the court of Alfonso X and also his interest in Marian worship, it is perhaps surprising that there is no reference in the Ars musica to the Cantigas de Santa Maria. This omission also may be explained by the purpose of the treatise having been confined to use within the order. Don M. Randel's interpretation of the Ars musica supports such an intent for the treatise. He understands Gil's view as having been focused on music as a path to God, unlike the 13th-century mensural theorists who were principally concerned with practical problems and the new style of music. ${ }^{81}$

Attempts have been made to link Gil's treatise with the University of Salamanca where the new position of maestro en organo was established in 1254. In Music in the Medieval and Renaissance Universities, Nan Cooke Carpenter tried to connect Juan Gil with that University because of the short distance between Zamora and Salamanca, and the format of the treatise being "definitely of the type generally springing from university studies". 82 Despite such suggestions, the proposal that the treatise was written for use within the Franciscan order remains more convincing. ${ }^{83}$ Furthermore there does not appear to be definitive evidence that Gil taught in the University of Salamanca.

\section{THE USE OF THE CHURCH OF ZAMORA}

As was normal throughout the western church of the Middle Ages, the diocese of Zamora had its own characteristic use. This use is identified in the statement found in the 14th-century Breviario of Zamora "ordo briviarii secundum consuetudinem ecclesie zamorensis". 84 A

${ }^{80}$ Mota Murillo, "El Ars musica ", 696.

${ }^{81}$ Randel, "La teoría musical", 42-43; Stevenson, "Spanish Musical Impact", 120, 124.

${ }^{82}$ Nan Cooke Carpenter, Music in the Medieval and Renaissance Universities (Norman: University of Oklahoma Press, 1958), 94.

${ }^{83}$ Randel, "La teoría musical", 50-51.

${ }^{84}$ Breviario, fol. $1^{x}$. 
thorough study of the liturgy of Zamora remains to be made and so far only limited explorations have been carried out, the most notable being that of Pedro Romano Rocha within the context of his study of the church of Braga. This latter work will be referred to in some detail later in this chapter.

In order to establish characteristic features of a local use various methods may be employed including studies of the calendar, the sanctorale, the litany, and the Office of the Dead. ${ }^{85}$ While a full study of this topic is outside of the scope of the present work, it is possible to give here a survey of the features of the calendar of Zamora. Following this a summary of the findings of Rocha will be presented.

The church calendar of the early and medieval periods of Christianity was not a fixed entity. The early church saw the introduction of local martyrs and other saints into the calendars in a process which continued throughout the Middle Ages. While at first tending to remain localized, the celebration of some feasts such as that of St. Lawrence of Rome gradually began to spread while others continued with only a narrow local recognition or were limited to certain regions. Later, in the face of a great diversity of calendars and practices, some of the great orders attempted to introduce uniformity into the worship, this being visible in the 13th-century reforms of the Cistercians, the Dominicans, and the Franciscans. At the same time there developed a drive for greater homogeneity in the practices of the churches of a diocese. ${ }^{86}$ The Franciscans, in particular, assisted in the spread of a more homogeneous calendar following their adoption and modification of the papal court liturgy and the carrying of their books and practices throughout many parts of Europe. ${ }^{87}$ It was, however, only with reforms following from the Council of Trent and with the assistance of the earlier development of printing, that a high degree of uniformity and regulation of the calendar entered into the Catholic Church, although a number of local

${ }^{85}$ For a recent study and critique of means of identifying a use, see John Plummer, "Use" and "Beyond Use", in The Book of Hours in Medieval Art and Life, ed. Roger S. Wieck (London: Sotheby's Publications, 1988).

${ }^{86}$ Gregory Dix, The Shape of the Liturgy (Westminster: Dacre Press, 1945), 588.

${ }^{87}$ On the Franciscan role see Theodor Klauser, A Short History of the Western Liturgy (London: Oxford University Press, 1969), 95; and Archdale A. King, Liturgy of the Roman Church (London: Longmans, Green and Co., 1957), 37. On the Franciscan adoption of the papal court liturgy, see S. J. P. van Dijk, Sources of the Modern Roman Liturgy, vol. 1 (Leiden: E. J. Brill, 1963), 40-41. 
rites able to prove a tradition of at least two hundred years were permitted to continue (two examples being the rite of Lyons and the rite of Braga).

\section{The Calendar of Zamora}

Two examples of the calendar of the Church of Zamora have been examined. These are found at the front of the 14th-century Breviario and the 15th-century Ritual held in the cathedral archive of Zamora. ${ }^{88}$ The two calendars are very similar especially with regard to the more important feasts, but are not identical. In the following survey, local feasts are identified. The more universally celebrated feasts were identified through comparisons with the Franciscan influenced 1260 papal court calendar ${ }^{89}$ and the feasts of the Carolingian sanctorale as listed by Leroquais. ${ }^{90}$ These more universal feasts will not be detailed in this discussion but various groupings of those remaining will be explored.

As was the common practice, red ink was used in both the calendars to indicate the most solemn feasts. The less universal feasts marked in red are: Ildefonsus - 23 January, Isidore Transitus - 5 April, Ildefonsus Inventio - 26 May, Transfiguration - 6 August, Dedication of the Church - 15 September (not in red in the Breviario), Eugenius - 15 November, Conception of BVM - 8 December, BVM Festivitas - 18 December. The three saints in this list - Ildefonsus, Isidore, and Eugenius - were all important figures during the development of the church in late 6th- and 7th-century Spain following the conversion from Arianism of the Visigoth rulers. Eugenius and Ildefonsus were both archbishops of Toledo and demonstrate Zamora's connection with the Church of Toledo. Ildefonsus was of special importance to Zamora as his remains had been brought there from Toledo; he is a patron saint of Zamora. The first of the two dates relating to him in the calendar, the 23rd of January, is his principal feast. It was celebrated widely in Spain and was found in calendars of the Old-Hispanic rite. ${ }^{91}$ The second, however, relates to the

${ }^{88}$ Breviario, unnumbered folios; Ritual, fols. $1^{\mathrm{r}}-6^{\mathrm{v}}$.

${ }^{89}$ S. J. P. van Dijk has published this Franciscan influenced calendar which he compiled and which is representative of that of the papal court in 1260. See van Dijk, Sources, 2: 363-76.

${ }^{90}$ Victor Leroquais, Les Bréviaires Manuscrits des Bibliotheques Publiques de France, vol. I (Paris: Lefever, 1934), cxxx-cxxxii.

${ }^{91}$ Carmen García Rodríguez, El culto de los santos en la España romana y visigoda (Madrid: Consejo Superior de Investigaciones Científicas, 1966), 344. 
rediscovery of his remains in Zamora and is thus a feast of local significance to the town. ${ }^{92}$ This feast, which has already been referred to in chapter 1, appears to have been celebrated only in Zamora. ${ }^{93}$ The inclusion of the Transfiguration as a red-letter feast is likely to be due to its significance to the Cathedral of Zamora which was dedicated to that event in the life of Christ ${ }^{94}$ although it is known simply as San Salvador. The two Marian feasts given in red but not widely celebrated seem to require no further explanation of their distinction as all other major Marian feasts in the calendar of Zamora are in red.

Also of local significance are the feasts of St. Atilano (5 October), the first recorded bishop of Zamora and a patron of the diocese, and of St. Froilán (3 October) a contemporary of Atilano's with whom he is believed to have been instrumental in the founding of monasteries in the region of Zamora. ${ }^{95}$ City ordinances of the mid 16th century list the feasts which had to be observed in Zamora. These were: all Sundays, all the principal feasts of the Lord and of the Virgin Mary, the Apostles and the two patrons, St. Ildefonsus and St. Atilano. 96

The calendar shows a good representation of saints of wider peninsular importance such as Leander of Sevilla (27 February), Victor of Braga (12 April), Torquatus (1 May), Leocadia (9 December), and Dominic of Silos (20 December). Also noticeable are feasts of the eastern church not universally celebrated at least by the mid 13th century but which were contained in Old-Hispanic sanctorales, for example Saints Julian and Basilissa (7 January), and St. Thyrsus (28 January).

A large group of feasts in the calendar of Zamora comprises those of French derivation with saints from all parts of France. Among this latter group are a number of saints who were very probably introduced by the Cluniacs, including Gerald of Aurillac (13 October), Majolus (11 May), Consortia (22 June), and Philibert (20 August). St. Martin of Tours has

${ }^{92}$ For more detail concerning St. Ildefonsus and Zamora, see the present writer's article appended at the rear of this dissertation, $1 \mathrm{ff}$.

${ }^{93}$ It is not found in any of the calendars examined in the course of this research including those of Salamanca, Segovia, and Toledo.

${ }^{94}$ Alvarez Martinez, Historia, 175.

${ }^{95}$ Alfonso, "El monacato", 20.

${ }^{96}$ Equipo Jupiter 81-82, "Ordenanzas de la ciudad de Zamora, siglos XV-XVI", Studia Zamorensis 3 (1982): 16. 
the distinction of appearing three times in the calendar - his principal feast (11 November) and its octave, as well as his translation. Of these only that of 11 November was included in the 1260 papal court calendar. ${ }^{97}$ Alfonso III had connections with the church of St. Martin of Tours in the see of Tours which may have led to that church being a source of manuscripts for use on the peninsula following the change of rite ${ }^{98}$ and may have encouraged the celebration of the feasts of the saint.

Veneration of the Virgin Mary is shown at a high level in the calendar of Zamora. Seven Marian feasts are included together with a further three octaves and the feast of Anne, mother of Mary. The six major feasts (Purification, Annunciation, Assumption, Nativity, Conception, and the Hispanic Annunciation on December 18) are all red letter feasts. Our Lady of the Snows is not given the distinction of being a red letter day.

Given the number of important Cistercian monasteries in the region, it is surprising to find no sign of special acknowledgement of their saints in the calendar of Zamora. Bernard of Clairvaux (20 August) is present but his feast was widely celebrated and found in the 1260 Papal Court calendar. ${ }^{99}$

The Franciscans had an early presence in Zamora and given also their importance in the development of the liturgy and calendar of the western church in general, it is of interest to look at the presence of Franciscan feasts in the calendar of Zamora. Four major Franciscan saints are included in the Zamoran calendar and these occur on the dates which they are allotted in the 1260 papal court calendar. These are: St. Francis (0ctober 4), St. Anthony of Padua (June 13), and St. Clare (August 12) and St. Elisabeth of Hungary (November 19). The feast of St. Elisabeth of Hungary was not in the original forms of the two Zamoran calendars and is a later addition to that of the Breviario. Two further Franciscan feasts in the calendar of Zamora but not in that of the 1260 papal court are St. Louis, bishop of Toulouse, and St. Bernardine of Siena. St. Louis of Toulouse was translated to Marseilles and then to Valencia, thus giving him a special importance to Spain. St. Bernardine of Siena was a later addition in both calendars not surprisingly as his canonization

\footnotetext{
${ }^{97}$ Van Dijk, Sources, 374.

${ }^{98} \mathrm{King}$, Liturgies of the Primatial Sees, 193

${ }^{99}$ Van Dijk, Sources, 372.
} 
took place in 1450 following his death in $1445 .^{100}$ He was a propagator of reform in the order and new Observant houses were often dedicated to him.

Feasts of the Dominican order are well represented with three saints: St. Dominic (August 5), St. Peter Martyr of Verona (April 29), and St. Thomas Aquinas (March 7). A further feast of importance to the Dominicans appears: the Crown of the Lord (May 4). The calendar of Zamora does not include the translation of St. Dominic. Of the Dominican feasts in the Zamoran calendar only that of St. Dominic is found in the 1260 papal court calendar.

Dating of the Zamoran calendars can be made roughly according to the presence and absence of various feasts. The inclusion of St. Thomas Aquinas in the earlier calendar indicates that it was copied after 1323, the year of his canonization. The addition of the feast of St. Bernardine of Siena by a later hand to both calendars suggests the possibility that both were copied before that saint's canonization in 1450 .

\section{The Liturgy}

As already mentioned a thorough study of the liturgy of the Church of Zamora has not yet been undertaken. The most useful comments on the topic are those of Pedro Romano Rocha included in his L'office divin au moyen âge dans l'église de Braga ${ }^{101}$ in which the Breviario of Zamora was studied as one of a number of manuscripts compared with the Bragan breviary. Rocha chose to study the series of responsories from the Sundays of Advent and from the triduum sacrum. His comparisons (based on text alone) were made with breviaries of the 12th to the 16th centuries from Moissac, Aquitaine (Tol 44.2), Zamora, Toledo, Salamanca, Santiago de Compostela, Orense, Tuy, and Coimbra.

With regard to the responsories of Advent, Rocha concluded that of all those compared, Zamora was the closest to Braga and in fact he sees Zamora as following Braga: "Zamora, qu'on peut réduire à Braga". Toledo was found to be close to Braga (and therefore

\footnotetext{
${ }^{100}$ D. Pacetti, "Bernardine of Siena, St.", New Catholic Encyclopedia, vol. 2 (New York: McGraw-Hill, 1967), 345-46.

${ }^{101}$ Pedro Romano Rocha, L'office divin au moyen âge dans l'église de Braga (Paris: Fundaçao Calouste Gulbenkian, 1980).
} 
Zamora) but closer to Aquitaine. ${ }^{102}$ With regard to the responsories of the triduum sacrum, Zamora was again found to be very like Braga, although showing a greater degree of independence (as was normal at least for the series of Good Friday). Rocha notes the absence of the responsory Caligaverunt from Moissac, Braga, and Zamora, a point which he emphasizes as it was almost universal but not used in sources of Cistercians, Cluniacs, Braga, Évora, and Zamora. ${ }^{103}$ Another point of coincidence between Moissac, Braga, and Zamora in which these centres diverge from the other peninsular sources (except for Tuy) listed earlier (Toledo, Salamanca, etc.) and that of Aquitaine, is the placing of the responsory Velum templi in the second position of the Good Friday series. Rocha observes that this placing tends to occur elsewhere, mainly in northern and Italian sources.

Rocha's work on the responsories shows that Braga had a close affinity with both Cluniac and Aquitanian traditions, and that the affinities with the Cluniac tradition are sometimes not represented by the practices of Moissac but are closer to those of other houses. Given the similarities he finds between Braga and Zamora it seems reasonable to accept Rocha's conclusions on this part of the Bragan liturgy as largely applicable to Zamora, at least until a more thorough study of the Zamoran liturgy has been undertaken. A different picture emerges from Rocha's examination of the lectionary which shows that in this subject the neighbouring dioceses diverged markedly from the Bragan practice at least as represented in the Bragan Breviary of Soeiro. ${ }^{104}$ From his analyses of other sources it is clear that in this area many local variations could occur. Zamora often uses the same material as other peninsular churches but elsewhere demonstrates its own idiosyncrasies; ${ }^{105}$ there is no marked affinity with Braga as was the case with the responsories.

Comparison of the calendar of the Breviary of Soeiro ${ }^{106}$ with that of Zamora shows considerable variation which is not limited to local saints, but rather there are changes in dates as well as non-Hispanic saints present in one and not the other. An example of the

\footnotetext{
${ }^{102}$ Rocha, L'office divin , 438.

${ }^{103}$ Rocha, L'office divin , 430.

${ }^{104}$ Rocha, L'office divin , 470-71.

${ }^{105}$ Rocha, L'office divin , 447-69.

${ }^{106}$ This calendar is given by Rocha, L'office divin, 67-89.
} 
variation occurs with the date of celebration of St. Martial of Limoges, the proper date being June 30. In some sources, both French and Iberian, it is celebrated in early July with July 7 appearing to be the usual date. The calendar of Braga gives the July 7 celebration while Zamora has July 2. 
PART B

NOTATION STUDIES 


\section{PLAINCHANT NOTATION AND RHYTHM AS DISCUSSED BY SPANISH MUSICAL THEORISTS TO THE MID 16TH CENTURY}

This chapter is intended to provide background and reference material for the following chapters which discuss the notation of plainchant in the Zamoran sources. Comments by Spanish music theorists concerning the notation of plainchant as well as the rhythmic interpretation of plainchant will be discussed. Aspects included are note forms, staff, and virgulas ("bar-lines") in square notation written on a five-line staff, and details of the late Aquitanian one-line notation which continued to be used in Spain into the 16th century. Broader studies of the theoretical works mentioned here and others omitted are to be found in the important work of Francisco José León Tello. ${ }^{1}$ Discussions of Spanish theorists of the 16th century and earlier are also found in studies by Mary Duncan, Ismael Fernández de la Cuesta, Karl-Werner Gümpel, and Robert Stevenson. These and other authors will be referred to below.

The present study is very largely limited to discussion of treatises from the 15 th century and the first half of the 16 th century. This restriction is largely dictated by two factors. Firstly, very few music treatises of Spanish origin are extant from prior to the 15 th century. Secondly, prior to the late 15 th century, treatises dealing with chant very rarely discuss either notation (other than features such as clefs) or rhythmic interpretation. From about 1480 , no doubt with the assistance of printing developments, the numbers of extant treatises increased extraordinarily. ${ }^{2}$ Anglès however speculated that the current paucity of earlier works is not representative of the original situation:

the scriptoria of those monasteries that were centers of liturgical music in Spain must have produced an abundance of treatises, and it is inconceivable

${ }^{1}$ Francisco José León Tello, Estudios de historia de la teoría musical, 2nd ed. (Madrid: Consejo Superior de Investigaciones Científicas, 1991). Later treatises were covered by León Tello in La teorla española de la música en los siglos XVII y XVIII (Madrid: Consejo Superior de Investigaciones Científicas, 1974).

${ }^{2}$ This abundant music theoretical production was commented on by Menéndez y Pelayo who is quoted together with further discussion of the phenomenon in Miguel Alonso, Cuatro tratados de principios de canto llano: los de Espinosa, Aguilar, Escobar y el Anónimo, Viejos Libros de Música J/M (Madrid: Joyas Bibliográficas, 1983), 17. 
that the schools of Ripoll in Catalonia, of San Juan de la Penya in Aragon, of San Millan de la Cogolla, of Silos and Cardeña in Burgos, of Távara and Liébana in León, and of Toledo - the cultural center of Castile - did not have more or less scientific manuals of music. ${ }^{3}$

Since Anglès wrote these words, few discoveries have been made in the field of medieval music theory in Spain. ${ }^{4}$ The single important Spanish collection of music theory dating from the period of the peninsular establishment of the Roman rite (11th century), and until the 13 th century, remains Codex 42 of the monastery of Ripoll. This codex contains the work of a monk of Ripoll, Oliva, as well as an important collection of early music theory including such works as the Musica Enchiriadis and the Commemoratio brevis. ${ }^{5}$ The Breviarium de musica by Oliva is largely based on Boethian theory and deals with the monochord, intervals, tetrachords, and the eight ecclesiastical modes. ${ }^{6}$

The major music treatise of 13th-century Spain is the Ars musica of Juan Gil de Zamora. As his name suggests, Juan Gil was a native of the town of Zamora; his work has already been discussed in Chapter 2. The treatise does not discuss the notation of chant, other than describing the placement of the various pitches on the staff, nor rhythmic interpretation of chant. ${ }^{7}$ In 1960 Stevenson surmised a "tradition of theoretical studies" in Zamora, older than that of Salamanca, on the basis of Gil's scholarly work. He saw this as possibly supported by the connection with Zamora of Bartolomé Escobedo 'one of the most "learned" of Spanish Renaissance composers'. ${ }^{8}$ Further evidence of such a school has not yet arisen.

${ }^{3}$ Higini Anglès, "Hispanic Musical Culture", 506.

4The publication of the RISM volume devoted to Iberian sources will be very helpful in allowing the formation of a full view of the currently known, extant theoretical sources of the peninsula.

${ }^{5}$ Details of the contents of the codex are given by Karl-Werner Gümpel, "Musica cum rhetorica: Ms Ripoll 42", in Essays on the Music of J. S. Bach and Other Divers Subjects: A Tribute to Gerhard Herz, ed. R. L. Weaver (Louisville: University of Louisville Press, 1981), 117-44.

${ }^{6} \mathrm{An}$ introduction and transcription of the Breviarium de musica is found in Kristine T. Utterback, “"Cum multimodi curiositatis": A Musical Treatise from Eleventh-Century Catalonia', Speculum 54 (1979): 283-96.

${ }^{7}$ Editions of this treatise are named in Chapter 2.

${ }^{8}$ Robert Stevenson, Spanish Music in the Age of Columbus (1960; reprint, The Hague: Martinus Nijhoff, 1964), 48. 
From about the second quarter of the 14th-century is an anonymous treatise from Cataluña, De cantu organico, which deals with mensural notation. ${ }^{9}$ In addition, three further short works on mensural notation and counterpoint from the late 14th century are connected with Cataluña. ${ }^{10}$

\section{MUSIC TREATISES OF SPANISH ORIGIN FROM THE 15TH CENTURY TO THE MID 16TH CENTURY}

The extant treatises of this period which treat plainchant are either focused on that topic or are part of broader studies dealing also with polyphony and mensural notation. The plainchant studies, both those which are independent and those which form part of more comprehensive works, are an important source for the understanding of late medieval and renaissance plainchant interpretation and theory. They cover subjects such as solmization, hexachords, modes, accidentals, intervals, clefs, note forms, notation on a single line, the qualities of good singing, and the tasks of the cantor. Much of the material however is based on that included in earlier chant manuals. Fernández de la Cuesta has pointed out that the plainchant treatises of the 15 th century had their origins in the earlier tonaries used as manuals in major churches. ${ }^{11}$ Similarly León Tello remarked:

Completamente formados y estructurados los temas correspondientes que integraban tradicionalmente los tratados de canto llano, pocas novedades podía ofrecer un teórico de los siglos XV y XVI. ${ }^{12}$

Gümpel has shown a tradition of chant theory in peninsular treatises of the 15th century through a comparative study of four sources, one of which is the treatise from 1410 by Fernand Estevan. Gümpel proposed an earlier archetypal text for the four treatises, the subject matter and form of which can to some extent be deduced from the existing sources.

${ }^{9}$ Edition and commentary in Higinio Anglès, "De cantu organico. Tratado de un autor catalán del siglo XIV", Anuario Musical 13 (1958): 3-24.

${ }^{10}$ On these see María Carmen Gómez Muntané, "De arte cantus de Johannes Pipudi, sus Regulae contrapunctus y los apuntes de teoría de un estudiante catalán del siglo XIV", Anuario Musical 31-32 (1976-77): 37-49; and María Carmen Gómez Muntané, "Prehistoria de la enseñanza musical en las universidades españolas", De Musica Hispana et Aliis. Miscelánea en honor al Prof. Dr. José López-Calo, S. J., co-ordinated by Emilio Casares and Carlos Villanueva, vol. 1 (Santiago de Compostela: Universidade de Santiago de Compostela, 1990), 77-89.

"Ismael Fernández de la Cuesta, Los tratados de canto llano de Spañon, Martinez de Bizcargui y Molina, Viejos Libros de Música G/I (Madrid: Joyas Bibliográficas, 1978), 24.

${ }^{12}$ León Tello, Estudios, 197. 
The tradition may date back to the late 14 th century. ${ }^{13}$ Traces of the proposed archetype may be found recurring in treatises dating from the late 15 th century and continuing into the 17 th century. ${ }^{14}$ Some of these treatises are among those to be discussed below and include the two chant treatises by Domingo Marcos Durán which will be examined first. For Gümpel two of the earlier treatises, that of Estevan and that known as Anonymous Seville, "represent a new type of treatise characterized by an emphasis on fifteenth-century Spanish Chant practices." 15 An important feature of both treatises is their treatment of musica ficta and in this area they are important representatives of Spanish practices. ${ }^{16}$

In the area of notation and durational interpretation some novelties emerge from 15th- and early 16th-century treatises. For León Tello, the writers of particular interest with regard to the notation of rhythm in plainchant were Podio (also known as Puig), Aguilar, Durán, and Ferrer. He saw the renaissance interest in classical metrics as having influenced ideas on the rhythm of chant such as those evident in the work of Podio. ${ }^{17}$

Not all of the Spanish music treatises of the era included plainchant note forms and rhythm in their discussions; among theorists who excluded the topics were Fernand Estevan, whose treatise of 1410 is notable for having been written in Castilian instead of Latin, and the radical Bartolomé Ramos de Pareja. ${ }^{18}$ Estevan and others limited their discussion of notation principally to clefs and accidentals with occasional reference to the staff.

The theorists of most interest for this study are treated separately below. Others are mentioned in passing, while yet others who are not relevant here are discussed in works by authors mentioned previously such as those of León Tello. It is unfortunate that the 1504 plainchant treatise by Alonso del Castillo is lost as he had a direct connection with Zamora.

${ }^{13}$ Karl-Werner Gümpel, "Zur Frühgeschichte der vulgärsprachlichen spanischen und katalanischen Musiktheorie”, Gesammelte Aufsätze zur Kulturgeschichte Spaniens 24 (1968): 259-60. Some reference to this tradition is found also in Karl-Wemer Gümpel, "Gregorian Chant and Musica Ficta. New Observations from Spanish Theory of the Renaissance”, Recerca Musicoldgica 6-7 (1986-87): 6.

${ }^{14}$ Gümpel has listed treatises belonging to the tradition ("Zur Frühgeschichte", 330).

${ }^{15}$ Gümpel, "Gregorian Chant", 12-13.

${ }^{16}$ Gümpel, "Gregorian Chant", 6-7, 13.

${ }^{17}$ León Tello, Estudios, 402.

${ }^{18}$ For an edition and commentary of Estevan's treatise see Fernand Estevan, Reglas de canto plano e de contrapunto e de canto de organo, ed. M.! Pilar Escudero García (Madrid: Editorial Alpuerto, 1984); and for a facsimile edition of Ramos de Pareja's treatise, Bartolomeo Ramis de Pareja, Musica Practica (Bologna: Forni, 1969). 
He held the position of chapel master in Zamora and had the degree of doctor from Salamanca. ${ }^{19}$

Two groups may be observed among the music theorists who discussed note forms and the rhythmic interpretation of plainchant. The first group is here termed the "equalist" school as perhaps its most important member advocates the performance of all notes of plainchant with equal durational value. The group has in common a concentration on particular features of plainchant notation as will be seen in the discussion and with the possible exception of one theorist, the quality of equal duration may have been assumed. The second group represents a "non-equalist" school which advocated varied duration of notes and consistently named the signs of mensural notation for use in plainchant. The theorists to be discussed have been placed in one of these two categories with the exception of Juan Bermudo who will be discussed last.

\section{1. "Equalists"}

\section{Domingo Marcos Durán}

Durán is the earliest of the theorists to warrant substantial discussion in the present context. His work is important for the understanding of duration in chant as related to notation and for knowledge of the employment of certain notational features and one-line notation. Durán's contribution will be discussed at length here. (During the subsequent discussion of later theorists, repetitions of material presented by Durán will not be detailed again.) Robert Stevenson compares Durán's work with that of non-Spanish theorists and shows some of the remarkable contributions which were made by Durán in Spanish Music in the Age of Columbus. ${ }^{20}$

The three treatises by Durán are written in Castilian. The earliest and shortest, a plainchant manual, Lux bella, was printed first in 1492 in Sevilla and is thus the first extant music treatise to be printed in Spain. ${ }^{21}$ The second half of the work consists of an

\footnotetext{
${ }^{19}$ Henri Collet, "Contribution à l'étude des théoriciens espagnols de la musique au XVI' siècle", L'Année Musicale (1912): 19.

${ }^{20}$ Stevenson, Spanish Music, 63-73.

${ }^{21}$ Carlos Romero de Lecea in José Subirá, Los tres tratados musicales de Domingo Marcos Durán, Viejos Libros de Música A/C (Madrid: Joyas Bibliográficas, 1977), 97.
} 
intonarium. In addition, Durán published a second plainchant manual enlarging on the first in Salamanca in 1498, Comento sobre Lux bella. This is an important and influential work giving detailed explanations of many aspects of plainchant. It was described by León Tello as "una obra fundamental en su género dentro de esta época". ${ }^{22}$ His third treatise is the Súmula de canto de órgano, contrapunto y composición vocal y instrumental, práctica y especulativa. Although this last work is principally about polyphonic music, it contains some useful references to plainchant. It makes an important contribution to theoretical studies of polyphony and is believed to have been published in about $1502 .^{23}$

Despite the great interest of Durán's work, León Tello sees his knowledge of the theoretical works he cited as poor ${ }^{24}$ and his involvement in theoretical problems as marginal. ${ }^{25}$ In fact, for the purposes of the present work, these criticisms represent no difficulties. It is the simplicity and sincerity of Durán's approach which identifies much of the usefulness of his work, his treatises probably having been intended primarily as teaching vehicles or practical handbooks rather than as original theoretical or speculative expositions.

Born in the region of Cáceres in western Spain in about 1460, Durán studied at the University of Salamanca. His death occurred some time before the fifth of September 1529 in Santiago de Compostela where he held the position of choirmaster in the cathedral. ${ }^{26}$ The Comento and the Súmula are thought to have been dedicated to Alfonso III de Fonseca who was archbishop of Santiago de Compostela during the period 1506-24. ${ }^{27}$ Little more is known about Durán's life but this information identifies a strong association with northwestern Spain, in which area Zamora is located. It may therefore be hypothesized that the practices discussed by Durán are applicable to the Zamoran sources of the era.

It is very clear from the work of Durán that he understood plainchant (canto llano) as belonging to the category of mensurable music and that he expected it to be performed according to a compas (measure). The types of mensurable music are enumerated in both

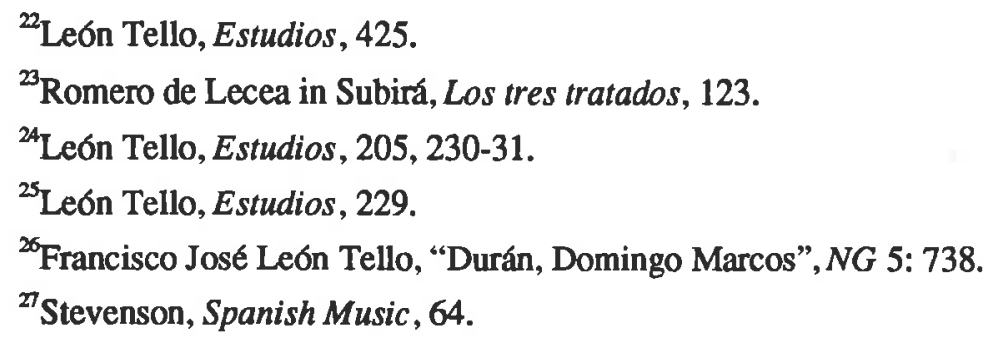


the Comento and the Súmula with reference to earlier authorities. In the following quotation from the Comento, he continues with a list of non-mensurable sounds and explains that which makes music mensurable or non-mensurable including the concept of the compas:

Ioannes de Mures y el maestro Durando de Paris con otros peruectos la diuiden [musica] en mensurable e immensurable. Musica mensurable llamaron al canto llano, contrapunto y canto de organo que se mensura y canta por numeros y compasses en deuida proporcion. Immensurable llamaron al sonido que fazen los animales brutos assi como las aues, peces cantantes, serenas marinas, perros, cauallos, etc, cuyo sonido es por instinto natural careciendo de razon y arte no sabiendo el como nin porque, e por esto le llamaron immensurable que va sin orden y medida y numero y compas fuera de deuida porporcion. ${ }^{28}$

There is in fact no explicit inclusion of a music created by humanity which is non-mensurable.

As the compas is integral to Durán's concept of plainchant as mensurable music, the meaning of the term needs to be examined. Durán offers the reader definitions of the term compas in both the Comento and the Súmula. The latter work, although primarily a study of polyphonic music, gives in a chapter concerning the compas (chapter nineteen) a clear definition of the term which makes reference to plainchant:

Compas es la tardança que ay de vn punto de canto llano a otro, o de su valor. O es la tardança que ay de vna cayda del golpe que damos con la mano a otra, o compas es ygual quantidad de tiempo de cayda a cayda yendo cantando, fasta en fin del canto. ${ }^{29}$

A similar definition appears in the plainchant treatise, the Comento:

el compas es la tardança que ay de vn punto de canto llano a otro, en manera que vn tiempo y vn compas y vn punto de canto llano vna mesma cosa significan, e comiença el compas quando cae la mano y da el golpe, ${ }^{30}$

From these quotations one learns that one note (punto) in plainchant has the durational value of one compas, and that the compas may be marked by the beat of the hand. Furthermore, the compas has equal duration from one beat of the hand to the next. In both the Comento and the Súmula, Durán stresses the importance of the compas making use of a Latin phrase, in the Súmula reading "el compas est maximus certificator vniversalis in tota

\footnotetext{
${ }^{28}$ Domingo Marcos Durán, Comento sobre Lux bella, Viejos Libros de Música 2 (Madrid: Joyas Bibliográficas, 1976), fol. [ c7]" (facsimile edition).

${ }^{29}$ Domingo Marcos Durán, Súmula de canto de organo, contrapunto y composición vocal y instrumental, práctica y especulativa, Viejos Libros de Música 3 (Madrid: Joyas Bibliográficas, 1976), fol. [a8] (facsimile edition).

${ }^{30}$ Durán, Comento, fol. diiii".
} 
musica mensurabili". He continues by likening the compas to a brake (in the sense of something which restrains or checks motion) and to blood. ${ }^{31}$

Samuel Rubio has made an analysis of the different types of compas used in mensural music and described by Durán, concluding that the meaning of the term compas as used by the Spanish theorists was different from that of the tactus of other theorists. The term tactus was not used by the Spanish theorists. ${ }^{32}$ The concept of compas is still deserving of fuller investigation with regard to the emergence of the term and also its relationship to the concepts of tactus and plausus. Such investigation would be of interest especially given the fact that it was in the 1490 treatise of Adam von Fulda that tactus first received detailed discussion ${ }^{33}$ and that Durán first mentioned compas in 1492.

With the concept of the compas, the issue of the durational value of each note of plainchant has already been introduced. As one compas is equal to the duration of each note and the compas always has the same duration, then it follows that all notes of chant must be of equal value. The following quotation from the Comento states the durational equality of each note in different terms:

Item porque llamamos llano al canto llano, este vocablo llano quiere dezir ygual quantidad de tardança de tiempo en cada figura, $s$ [cilicet] que no tardemos mas en vn punto que en otro saluo que todos se canten por vna ygual medida de tiempo. ${ }^{34}$

While at first sight it seems that Durán unambiguously intended to teach that all notes receive equal duration, problems nevertheless arise. The first of these is the variety of terms used to refer to notes. It must be asked whether or not these are synonymous. This question however was answered by Durán: "Item punto figura nota, grado/indiuiduo/y tono simple: son synonomos en significar vna mesma cosa que es qualquier figura de punto". ${ }^{35}$ Less clear is whether each note of a two or more note neume is covered by these terms or whether they only apply to isolated single notes. However, the term punto is employed in reference to the individual notes of ligated neumes and melismas in the work

${ }^{31}$ Durán, Súmula, fol. $\mathbf{b}^{\mathrm{r}}$.

${ }^{32}$ Samuel Rubio, Libro de música práctica de Francisco Tovar, Viejos Libros de Música F (Madrid: Joyas Bibliográficas, 1978), 93-99.

${ }^{33}$ Howard Mayer Brown, "Tactus", NG 18: 518.

${ }^{34}$ Durán, Comento, fol. diiii.

${ }^{35}$ Durán, Comento, fol. [d6]'. 
of Durán. ${ }^{36}$ From this it may be inferred that a punto in a compound neume should have the same durational value as an isolated punto.

With regard to notation, Duran introduced some notational signs and some rules in the Lux bella. Accidental and clef signs are illustrated under the name of claves, claves speciales referring to accidentals and claves generales referring to clefs. Four of each are given. ${ }^{37}$ He spoke of two types of staff, that with five lines and that with one line. The five-line staff is used in the examples and the tonary. A list of names of note forms is presented but without descriptions: "tenemos punto quadrado, alphado, semidoblado, o triangular". ${ }^{38}$ Alphas dobles are illustrated in five-line notation. It appears that these may refer to either the form of a porrectus $N$ or to the torculus form alphas dobles is reminiscent of the mention in the treatise known as Anonymous Seville (1480) to the "punto doblado que es llamado alpha duplex intensum et remissum tonicum" during discussion of conjuntas. ${ }^{40}$ A similar reference is found in the treatise, Esta es una introducción muy breve de canto llano, by Cristóbal de Escobar which dates from 1490 or 1491 and is thought to have been printed in Salamanca. ${ }^{41}$ Escobar refers to "alpha, duplex intensum, remisum tonicum, o puntos doblados" during a discussion on the use of square b. ${ }^{42}$ Punto doblado and alpha duplex or alpha doble are therefore all terms which appear to refer to the same type of sign. ${ }^{43}$

${ }^{36}$ Domingo Marcos Durán, Lux bella, Viejos Libros de Música 1 (Madrid: Joyas Bibliográficas, 1976), fols. [a2] and [a 5]' (facsimile edition).

${ }^{37}$ Durán, Lux bella, fol. [a3]".

${ }^{38}$ Durán, Lux bella, fol. [a3] ${ }^{\text {. }}$

${ }^{39}$ Durán, Lux bella, fol. [a3] ${ }^{\vee}$.

${ }^{40}$ Anonymous Seville is quoted in Gümpel, "Gregorian Chant", 21-23. For a recent edition of the treatise which presents only text without musical illustrations, see Alan D. Hastings, ed., Text and Concordances of the Tratado de la música MS. c..III.23, Biblioteca del Escorial (Madison: The Hispanic Seminary of Medieval Studies, 1989). Mentions of the alpha duplex may be found in this edition on pages 24, 33, and 34.

${ }^{41}$ Carlos Romero de Lecea in Alonso, Cuatro tratados, 215.

${ }^{42}$ Alonso, Cuatro tratados, 162.

${ }^{43}$ Confirmation of the synonymous meanings of alpha doble and punto doblado will be found later in this chapter with the discussion of the work of the theorist Gonzalo Martinez de Bizcargui. Doblado later came to be regularly used for signs in which two notes occur together at the same pitch as in the bistropha. An example of this usage occurs in Pedro Cerone, El Melopeo y Maestro. Tractado de musica theorica y practica (Bologna: Fomi, 1969), 412 (facsimile edition). As a result of these findings, the definition of punto doblado given by José Subira in his glossary of terms found in the treatises of Durán therefore seems more appropriate for the later usage. The definition reads: "Nota musical cuyo signo presenta dos notas juntas." 
Also in the Lux bella, brief explanations are given of virgula, plica, and ligadura under the heading "Reglas para ordenar la letra". The first two of these are the most interesting.

Tenemos virgula, plica, e ligadura. Virgula es linea suelta que diuide las partes. Plica es linea que depende de vn punto y no toca en otro e acompaña a la nota. Item punto con dos plicas: vale dos compases sin spresar cantando el segundo. Ligadura es linea que toca dos puntos y no entra letra saluo en el primero. $^{44}$

In the Comento sobre Lux bella the material on notation is amplified. Clefs, accidentals, and direct (guion) are discussed in the Comento. "Todo canto se rije por claue y guion" says Durán. He describes the function of the direct as indicating the pitch of the first note of the next staff. ${ }^{45}$ The form of direct used in the musical examples is $\sqrt{ }{ }^{46}$ The shapes of the punto quadrado, the alfado [sic], and the punto semitonado or triangular are described but are not illustrated in the facsimile edition studied, although spaces were left blank. ${ }^{47}$ Punto quadrado refers to the square note $\mathbf{a}$; alfado refers to the slanting beam which he said could rise or fall (surprising in the context of chant notation); and semitonado appears to refer to the lozenge-shaped note $\bullet$, while triangular seems to have been an alternative form of the semitonado with the same meaning ${ }^{48}$ (a shape given in white notation in the Súmula fits the description of the Comento $\triangleleft))^{49}$ The meaning of the semidoblado mentioned in Lux bella is not explained and in fact does not appear to occur in the Comento at all; however it seems likely that it had the same meaning as semitonado.

On the semitonado, Durán finished "dize semitonado, porque es meytad de vn punto quadrado."50 This ambiguous comment becomes clear when compared with the discussion on an earlier folio where it is clear that he viewed the lozenge and the triangular form as being about half the shape of a square note. In the same place he continued to explain that

(Subirá, Los tres tratados, 58).

\footnotetext{
${ }^{44}$ Durán, Lux bella, fol. [a5]".

${ }^{45}$ Durán, Comento, fol. [d6]".

${ }^{46}$ See for example, Durán, Comento, fol. $b^{r}$.

${ }^{47}$ Durán, Comento, fol. [d6] ${ }^{\mathrm{r}}$.

${ }^{48}$ Durán, Comento, fol. [d6] $]^{\mathrm{r}}$.

${ }^{49}$ Durán, Súmula, fol. aiii ${ }^{\mathrm{r}}$.

${ }^{50}$ Durán, Comento, fol. [d6] ${ }^{\mathrm{r}}$.
} 
the puntos semitonados were previously sung two in the time of one compas, a fact which he must have seen as producing a profound result because he added: "de ally començaron a constituir el canto de organo."

In connection with the punto semitonado, Durán mentioned the tonicus. This term appears to refer to a three-note melisma in the pattern of c-d-c or d-c-d in which the notes are always a whole tone apart. Durán defined it in the following manner: "Tonicus es diminutiuo de tono". This statement may refer to the idea of the breaking of a tone into the three part pattern already named, which Durán may have seen as a form of diminution analogous to the use of a portion of the full form of a square note to create a lozenge-shaped note. ${ }^{52}$ The concept of the tonicus may be connected with that of melodic ornamentation and the note form called tocus referred to by other Spanish theorists and which will be discussed later in this chapter.

The heading, already seen in Lux bella, "Reglas para ordenar la letra" occurs again in the Comento. Durán refers back to the opening sentence of the corresponding chapter in Lux bella by beginning with the words "Tenemos virgula etc." He then elaborates on the virgula, the plica, and the ligadura. ${ }^{53}$ These three items are discussed below.

Virgula. It is clear from Durán's description that this term refers to the vertical lines or "bar-lines" found frequently in many chant manuscripts and which are used principally to separate words or sections. He comments that virgulas do not touch notes and that they are used with both the one-line staff and the five-line staff. ${ }^{54}$ (One-line staff notation will be discussed below.)

Plica. From the brief definition in Lux bella we are able to gather two important facts about the plica. Firstly, the plica is another type of line which is attached to a note. It is therefore the stem of a note. Secondly, a note with two plicas should be held for the duration of two compases. (In order to distinguish this usage of the term plica from that of its better known usage as a full note form, the term is placed in italics here when used in

\footnotetext{
${ }^{51}$ Durán, Comento, fol. $\mathrm{d}^{\mathrm{v}}$.

${ }^{52}$ Durán, Comento, fol. d $\mathrm{d}^{\mathrm{v}}$, also fol. cii'.

${ }^{53}$ Durán, Comento, fol. [e4]".

${ }^{54}$ Durán, Comento, fol. [e4] $]^{\mathrm{v}}$.
} 
the Spanish sense of the stem of a note or ligature.) The Comento offers a substantial amount of further information which is of considerable interest to the interpreter and student of plainchant. Listed below are the first points Durán makes about the plica. ${ }^{55}$

1. Plica, trato, cauda, and virgula pendens are synonymns.

2. The plica may ascend or descend.

3. The plica adorns a note. Durán evidently means that a plica has no other function or meaning.

4. In the past plicas were only placed on notes above accented vowels.

en tiempo antiguo no se ponian estas plicas saluo al punto que estaua sobre la vocal en que se fazia el acento, rnas ya no se guarda. ${ }^{56}$

The modern reader interested in notation inevitably wishes Durán had explained the last point further. He appears to be describing the long as opposed to the stemless breve, saying that the long was only used with accented text syllables. In his previous points, Durán had only mentioned the plica as being attached to "un punto" leaving doubtful the issue of the stem of a ligature. On the other hand, Durán talks of the individual puntos of ligatures and may well have seen no ambiguity in referring to "un punto" which could be either part of a ligature or an isolated note. ${ }^{57}$ It is interesting to observe that he attributes no special meaning to an isolated note with a single stem as opposed to one without it, and his discussion certainly leaves open the possibility of both stemmed and stemless isolated notes. ${ }^{58}$ When the fourth point is understood as referring to isolated single stemmed notes, knowledge of mensural notation suggests that Durán is speaking of the limitation of the use of notes of long duration (longs) to accented syllables in the context of plainchant during a prior period.

\footnotetext{
${ }^{55}$ Durán, Comento, fol. [e4] $]^{\mathrm{v}}$.
}

${ }^{56}$ Durán, Comento, fol. [e4]". In his glossary of terms used by Durán, José Subirá includes "composición antigua" defining it as "Aquella de Boecio y de sus tratadistas contemporáneos." (Subirá, Los tres tratados, 53). Durán himself defines "composicion antigua" in this way: "Composicion antigua es la musica del boecio y de sus contemporaneos y antecessores" (Comento, fol. [b5]"). Durán did however make reference to later theorists including those from the 13th and 14th centuries such as Franco of Cologne and Marchetto da Padova, and it may be that he was referring in the discussion of the plica to such a more recent period. (Durán gives a list of theorists in the Comento, fol. [e5] ${ }^{\mathrm{v}}$ and refers to various ones throughout the treatise).

\footnotetext{
${ }^{57}$ Durán, Comento, fol. [e5]'; Lux bella, fol. [a5]?.

${ }^{58}$ The intonarium of the Lux bella contains no examples of isolated notes with a single stem.
} 
Following the fourth point, Durán begins a new item in which he elaborates on the punto con dos plicas (note with two stems). The punto con dos plicas was introduced also in Lux bella where its meaning of a note held for the duration of two compases was given. Although not illustrated, one might expect the phrase punto con dos plicas to refer to the signs $1 \mathrm{~W}$ which may be found in sources of the era. ${ }^{59}$ The discussion may be summarized in the following points:

1. Each plica represents the value of one compas, therefore two plicas represent the value of two compases. (Each plica of the punto con dos plicas is seen as denoting one point; the note with two stems is therefore like two notes joined together.)

2. The plicas point upwards when the melody is rising and downwards when the melody is falling. They may point in either direction when the melody is at the unison.

3. A tongue-like (lengueta) sign in the middle of the punto con dos plicas, he seems to think of as an indicator of the two notes represented by the two plicas. This description probably refers to the sign which is found in the intonarium of the Lux bella and sources of the era. ${ }^{60}$ Durán makes no mention of a form of the sign without the tongue.

4. The term punto cargado is then introduced as a name for the punto con dos plicas. It may be asked whether this name refers specifically to the sign with the tongue. The use of the term is explained as follows:

llamanle punto cargado porque tanto tardamos en el como en dos puntos que son dos compases de los quales el segundo no hemos de pronunciar con la spressiva yendo cantando saluo contarlo en el compas. ${ }^{61}$

5. The second half of the above quotation refers back to the point made in the Lux bella that the two parts of the punto con dos plicas are to be held without separation, with the added proviso that the compas continues to be counted.

\footnotetext{
${ }^{59}$ Examples occur in the 15th-century Zamoran Ritual and in many of the fragments employing square notation in the AHPZa collection.

${ }^{60}$ For example, Durán, Lux bella, fol. $\mathrm{b}^{\mathrm{v}}$, second staff, and fol. biiir, first staff. The protruding short lines at the top corners of the sign are commonly found in the examples of the treatises discussed in this chapter. This sign (not always with protruding short lines) is found in some of the Zamoran sources of square notation including the 15th-century section of the Misal votivo as well as fragments Z 148 and Z 260.

${ }^{61}$ Durán, Comento, fol. [e4]".
} 
The most problematic issue raised in the five points above is the question of the shape of the punto con dos plicas. The initial impression a modern reader receives from the description of a note with two stems is of the form $\Pi$, however it may have been that Durán was more accustomed to the form with the tongue and would have associated the latter with such a description. We are left with the question: does the plain form without the tongue have the same significance as that with the tongue? Without further evidence it will be hypothesized that the two do have the same significance, and therefore the tongueless form should be viewed as being sung with the duration of two single notes just as the form with tongue.

Ligadura. This term refers to the joining of one note to another so that puntos ligados are sung to only one syllable. The information given concerning text placement and ligatures was of importance for a singer's or a scribe's understanding but need not be described further here. ${ }^{62}$

Still under the heading of "Reglas para ordenar la letra", Durán finishes by describing the varied durational values which were formerly given to different figures. The first note of the alpha took the value of one and a half compases while the second took half a compas. The square note had the value of one compas and was therefore unchanged in Durán's time. The former value of lozenge-shaped notes, two per compas, had been mentioned earlier in the treatise (see above) but is now reiterated. Durán closes the chapter with his favoured device of introducing a Latin phrase which one assumes is to give more authority to his text.

Item en las alphas se tenia este modo al cantar, que en el primer punto fazian compas y medio, e en el segundo [punto fazian] otro medio [compas] que eran dos compasses e a vn punto quadrado dauan vn compas. E dos puntos semitonados, o semibreues passauan en otro compas. Sed iam recessit ab vsu hec consuetudo ${ }^{63}$

${ }^{62}$ Durán, Comento, fol. [e4] $]^{\mathrm{v}}-[\mathrm{e} 5]^{\mathrm{r}}$.

${ }^{63}$ Duran, Comento, fol. [e5] ${ }^{\mathrm{T}}$. The interpretation of this quotation offered here differs from that given by Mary Duncan who appears to have understood it as referring to current practice rather than former practice. See Mary Elizabeth Duncan, “A Sixteenth-Century Mexican Chant Book: Pedro Ocharte's Psalterium, an[t]iphonarium sanctorale cum psalmis \& hymnis" (Ph.D. diss., University of Washington, 1975), 71-72. 
The final topic from Durán's work which needs to be discussed here is one-line notation. Notational figures belonging to this type of notation are listed as well as illustrated in the Comento. The names of figures reflect the fact that the fundamental shapes of the one-line notation illustrated are also those of notation on a five-line staff. Found in the one-line notation are squares, oblique descending beams, and lozenge-like shapes. The illustrations are not labelled, and the names of the figures are not explained nor are they accurately identifiable with the illustrations. The names appear to apply to figures which are able to either stand alone as complete note forms or as parts of larger neumes. Some are recognizable and understandable from Durán's use of them elsewhere; these are puntos perfectos o quadrados (the square punctum), puntos semitonados o triangulares (the lozenge-shaped and triangular notes), and puntos traçtraua, o ligados (ligatures). The term alphas dobles probably refers to the signs which resemble the porrectus of square notation. This seems to be represented in the illustration by the shape $M$. A similar sign in the context of five-line notation with the same name was illustrated in Lux bella. ${ }^{64}$ The phrase puntos doblados, o detenidos, o cargados sobientes $y$ decendientes brings to mind the punto cargado of five-line notation (a note with two ascending or descending stems). On the other hand, as has already been mentioned, punto doblado is elsewhere found with the same meaning as alpha doble. Furthermore, a sign in one-line notation like a porrectus occurs illustrated with the name punto doblado in a later treatise to be discussed below. The most obscure of the names is puntos cabeçudos y rabudos. The term punto cabeçudo occurs also in a later treatise by Gonzalo Martínez de Bizcargui (discussed below) as a figure of one-line notation. There it refers to a sign like the virga of Aquitanian notation. The word rabudo means a long tail which is characteristic of the sign shown in Durán's illustration which resembles an epiphonus with its small lozenge and which has the form $\int{ }^{65}$ It is however impossible to determine finally which signs Durán may have associated with these two names.

At the beginning of the list of figures used in one-line notation is the phrase mis y fas señalados. Is this a reference to a differentiation in note shape for semitones, or did he

\footnotetext{
${ }^{64}$ See page 58 .

${ }^{65}$ The illustrations and the names are given in Durán, Comento, fol. $c^{r}$.
} 
mean that $m i$ and $f a$ (and therefore the placing of semitones) are indicated through the use of sharp and flat signs? The latter possibility seems the most likely. This is because later in his discussion of mode recognition in one-line notation he said "Item mis y fas tenemos por claues", and more explicitly, that F, C and G clefs are used for five-line notation just as the mis and fas are the clefs of one-line notation. ${ }^{66}$ The signs for $b$ quadrado and $b[b \mathrm{~mol}]$ which indicate $m i$ and $f a$ respectively are called claves speciales. ${ }^{67}$ The claves speciales are illustrated in Lux bella and Comento with the usual signs (there are two forms for each):

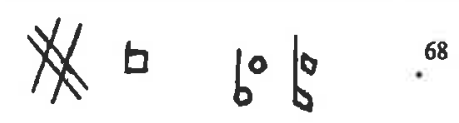

Durán also gave instructions in Lux bella and Comento for the recognition of the modes of chants when written in one-line notation. These are similar to those found in other Spanish treatises such as those of Fernand Estevan and Cristóbal de Escobar. ${ }^{69}$ The fundamental rule is that for authentic modes the line takes the pitch of the third above the final, and that for plagal modes the line takes the pitch of the final. Durán gave a detailed discussion of the topic including placement of semitones. He points out that in mode four the line can be on either F or E but says that F is used "algunas vezes" thus suggesting the $\mathrm{F}$ as being more usual. ${ }^{70}$

\section{Bartolomé Molina}

Molina was a member of the Franciscan order and like Durán was associated with the west of Spain. His treatise Arte de canto llano llamado Lux videntis was intended for instruction in the diocese of Lugo. ${ }^{71}$ It was printed in Valladolid in $1504 .^{72}$

\footnotetext{
${ }^{66}$ Durán, Comento, fol. $\mathrm{c}^{\mathrm{v}}$ - ciir.
}

${ }^{6}$ Durán, Comento, fol. [b5]".

${ }^{68}$ Durán, Lux bella, fol. [a3]"; Comento, fol. [a5]".

${ }^{69}$ Estevan, fol. 16. For Escobar, see the edition of his treatise in Alonso, Cuatro tratados, 166-67.

${ }^{70}$ Durán, Comento, fols. $c^{r}$-ciiiir. Gümpel ("Zur Frühgeschichte", 274) has drawn attention to the point made by Estevan that in mode four the note $\mathrm{F}$ is placed on the line "por uso" but $\mathrm{E}$ is used "por arte". For a summary of the theorists' writing on mode recognition in one-line notation see M." Pilar Sauco Escudero in Serrano Velasco et al., Estudios sobre los teóricos españoles de canto gregoriano de los siglos XV al XVIII (Madrid: Sociedad Espańola de Musicología, 1980), 106-10.

${ }^{71}$ Stevenson, Spanish Music, 87-88.

${ }^{72}$ León Tello, Estudios, 439. 
The treatise was written with much attention to minutiae and made good use of examples to illustrate the instructions. The use of a four-line staff, both in the tonary included with the treatise and in some examples accompanying the text, differentiates Molina's treatise from those of Durán.

Like Durán, Molina discussed the plica, the virgula and the ligadura. ${ }^{73}$ His approach was however a different one. In relation to the plica (stem) he did not mention durational value, instead concentrating on the correct placing of stems on ligatures. His examples show correct placement on falling and rising binary ligatures and on an alpha. ${ }^{74}$ His placement of stems follows the usual well known practices of square chant notation such as the use of a descending stem on the far left of a clivis but on the far right of a pes 7 . (In another example the alternative pes form is used in which the upper note is set directly above the lower one. $)^{75}$

The instructions for the use of the virgula are more precise than those so far discussed. There are two types. The first consists of double lines the full height of the staff and has two uses, being placed either at the end of a chant, or after the first word or expression at the beginning of a gradual, an alleluia or an offertory indicating the point of entry of the choir following the soloist (cantor). The second type of virgula is the single line which only covers two or three lines of the staff and occurs after each dicion. Molina's meaning is slightly ambiguous here as the word dicion can mean either a word or a phrase; nevertheless, the short example shows a virgula after each word, two of which are monosyllables. ${ }^{76}$

The definition of the ligadura given by Molina "un ayuntamiento de dos o tres o mas puntos" is amplified by examples, one of which is a tristropha and another a climacus. It is therefore evident that a ligadura was not only a group of notes attached to one another as

${ }^{73}$ On similarities between Lux bella and Lux videntis, see also Leon Tello, Estudios, 438-39. The passage on plica, virgula, and ligadura is quoted in Duncan, "Mexican Chant Book", 73-74.

${ }^{74}$ Bartolomé Molina, Arte de canto llano llamado Lux videntis, Viejos Libros de Música 9 (Madrid: Joyas Bibliograficas, 1977), fol. [a6] ${ }^{\vee}$ (facsimile edition). Illustrations and quotations from the treatise are given in Serrano Velasco et al., Estudios, 235-36.

${ }^{75}$ Molina, Lux videntis, fol. [a6] .

${ }^{76}$ Molina, Lux videntis, fol. [a6 $]^{\text {. }}$. 
Durán indicated, but also an unattached group; both types being sung to only one syllable. ${ }^{77}$ Relevant to the topic of note forms and their names is the observation that Molina used the term triangulares for the lozenges. ${ }^{78}$

Molina introduces a unique term for the note form with two descending stems and a tongue-like sign which is illustrated in the treatise with the form $\%$. He calls it punto silabico and states that it has a longer duration than any other note without giving a precise length. "El punto silabico ... es mayor in cantidad que ninguno de los otros puntos."79 The form without tongue but with ascending stems is also found in the treatise. ${ }^{80}$

On the tonico, Molina says: "El tonico es suspensivo que se retiene o engrandesce a si mesmo e quita a su compañero aquello que demas tomo para si". ${ }^{81}$ This description seems to indicate two notes, the one longer than the other, and recalls the obsolete interpretation of the alpha given by Durán which would in modern notation be transcribed as a dotted crotchet followed by a quaver. Molina gives three illustrations, which perhaps illustrate the different ligatures in which this interpretation should take place: two share the movement of the tonicus or tonico described by Durán as they appear to fall by a step and then return to the original tone. Molina's avoidance of clearly determined durational values for the punto silabico and the tonico is not characteristic of the "equalist" group of theorists with which he has been grouped here. His subject matter and avoidance of mensural terms however has caused his classification with the group rather than with the "non-equalists".

\footnotetext{
${ }^{\pi}$ Molina, Lux videntis, fol. [a6]".

${ }^{78}$ Molina, Lux videntis, fol. [a6]"

${ }^{79}$ Molina, Lux videntis, fol. [a6]"

${ }^{80}$ Molina, Lux videntis, fol. [b4] ${ }^{\mathrm{r}}$.

"Molina, Lux videntis, fol. [a6]".

${ }^{82}$ Molina, Lux videntis, fol. [a6]"
} 


\section{Alonso Spañon}

Little is known about the life of Spañon but Stevenson has proposed that he "enjoyed some dignity in Cordova cathedral". 83 The Introducción muy útil e breve de canto llano of Spañon cannot be dated precisely but is thought to have been printed in 1504 in Sevilla. ${ }^{84}$ The treatise illustrates note forms used in plainchant notation with their names, but does not explain their interpretation. ${ }^{85}$ Spañon also mentions briefly the direct and the virgula but adds no new information to that already known from Durán. ${ }^{86}$ The note forms are given as follows:

$\begin{array}{llll}\text { quadrado } & \mathbf{n} & \text { tonito } & \mathbf{7} \\ \text { alphado } & \mathbf{n} & \text { unisonantes } & \mathbf{0} \\ \text { intenso } & \mathbf{0} & \text { ligados } & \mathbf{4} \\ \text { remiso } & \mathbf{n} & \text { duples } & \mathbf{0}\end{array}$

Five terms in the above list require discussion: these are intenso, remiso, tonito, duples, and unisonantes.

Intenso and remiso are terms which have not yet been encountered in this chapter. No explanation was given of the terms or the meaning of the note forms by Spañon and so their usage elsewhere must be examined. The terms, intenso and remiso, are derived from Latin words with the meanings of rising and falling, or tension and relaxation. The Latin terms, in the sense of ascent and descent, may be found in the Practica musicae of Franchinus Gaffurius, especially during discussions concerning mutation in Book One and consonance in counterpoint in Book Three. ${ }^{87}$ Durán used remiso and intenso in the context of discussions concerning modes, claves speciales, and semitones. ${ }^{88}$ In the discussion of claves speciales (square b and soft b), Durán says that with the square b "hemos de dezir mi, o fazer el punto intenso rezio" and that with the round $b$ "hemos de dezir fa, o fazer el punto remisso

${ }^{83}$ Stevenson, Spanish Music, 85.

${ }^{84}$ Carlos Romero de Lecea in Femández de la Cuesta, Los tratados, 73.

${ }^{85}$ Alfonso Spañon, Introduccion de canto llano, Viejos Libros de Música 7 (Madrid: Joyas Bibliográficas, 1976), fol. av (facsimile edition).

${ }^{86}$ Spañon, Introduccion, fol. av.

${ }^{87}$ See for example fols. aviir and ddii' in Practica Musice Franchini Gafori Laudensis (New York: Broude Bros., 1979); TML files GAFPM1 and GAFPM3.

${ }^{88}$ For example, Durán, Comento, fols. bii and [d8] ${ }^{\mathrm{T}}$. 
lasso y muy blando." 89 In later Spanish treatises, the terms appear with respect to clausulas. Luis de Villafranca (Breve instrucción del Canto llano, 1565) explains that intenso refers to the rise of a tone or the fall of a semitone and remiso to the rise of a semitone and the fall of a tone. Two later theorists, Monserrate and Roxas y Montes, as well as the anonymous author of the Ritual Carmelitano, all refer to three-note clausulas which always move in the same rising and falling patterns by either a whole tone or a semitone, such as f-e-f (intensa) and e-f-e (remisa). In the manner of Villafranca, both Roxas y Montes (Promptuario armónico y conferencias teóricas y prácticas de Canto llano, 1760) and the anonymous Ritual Carmelitano (1789) used the terms intensa and remisa in reference to classifications of clausulas, with the exception that the falling remisa was not mentioned. ${ }^{90}$ However, it is in the 1555 Declaración by Juan Bermudo that the most helpful information regarding the intenso and remiso is found. Bermudo gave both discussion and illustration of the signs. His illustrations are similar to those found in Spañon's Introducción. There we learn that the intenso signifies the raising of the given pitch by a semitone and the remiso signifies the lowering of the pitch by a semitone. Given the similarity of the illustrations, this meaning seems most likely to have been that understood by Spañon.

The tonito has the same form as the third of the illustrations of the tonico in the treatise by Molina. Given the similarity of the two terms, tonico and tonito, as well as the coincidence of the illustrated form, one is inclined to hypothesize that the two terms refer to the same concept. However, with the evidence of Spañon's illustration, it must be asked whether in fact he might have intended to indicate the lozenge by the term tonito. Such a supposition is give some support by the fact that Durán had referred to the tonico or tonicus (he used both these forms of the word) in association with the semitonado or lozenge. The presence of the stemmed square note to the left of the lozenge in the example in Spañon's treatise does not necessarily overthrow this argument as it may have been included because lozenges were not used in isolation in chant notation.

\footnotetext{
${ }^{89}$ Durán, Comento, fol. [b5]
}

${ }^{90}$ Villafranca, Monserrate, and Roxas y Montes are discussed and quoted by M. ${ }^{4}$ Pilar Sauco Escudero in Serrano Velasco et al., Estudios, 120. For Roxas y Montes see León Tello, La teoria, 501. For the Ritual Carmelitano see Gümpel, "Gregorian Chant", 21 n. 40. 
The illustration of the duples is puzzling, as a similar sign appears in the musical examples of the treatise but with a descending stem on the right side of the second square note. One must ask whether there was any difference in meaning between the two signs, and if so, why did he not show the stemmed form in the list of illustrations? Concerning the duples, Spañon only says that this is the exception to the rule that isolated puntos always receive the text. By this statement he is likely to refer to the second of the puntos of the sign, the first receiving the text syllable as does the beginning of a ligature. ${ }^{1}$ Pedro Cerone in his El melopeo of 1613 illustrates two types of doblado, 1 and ar for which he gives different meanings in the context of plainchant performed with varying durations; the first form to be performed as if the text syllable was repeated under each note, the second form apparently without that repetition but the sound held for the duration of two compases. $^{92}$ As the interpretation of the second of Cerone's signs is closer to that of Spañon's, the hypothesis that there was no difference in the two signs given in the latter's treatise gains some strength although remaining in question. In addition, one needs to ask in what way the performance of the duples would differ from that of the unisonantes. As the unisonantes are not specified in the discussion of text placement, perhaps it should be assumed he is there illustrating no more than the fact that unison refers to notes repeated at the same pitch.

\section{Gonzalo Martínez de Bizcargui}

Arte de canto llano e contrapunto e canto de órgano con proporciones e modos by Bizcargui was published first in 1508 in Zaragoza. ${ }^{93}$ It presented some controversial ideas, particularly concerning semitone theory, which caused his name to be spoken of with derision by contemporaries and later writers. ${ }^{94}$ Nevertheless, the work was very popular

\footnotetext{
${ }^{91}$ Spañon, Introduccion, fol. a ${ }^{v}$.
}

${ }^{92}$ Cerone, Melopeo, 378.

${ }^{93}$ The 1511 edition is published in facsimile as Gonzalo Martínez de Bizcargui, Arte de canto llano y contrapunto y canto de órgano con proporciones y modos, Viejos Libros de Música 8 (Madrid: Joyas Bibliográficas, 1976).

${ }^{94}$ In particular, Bizcargui was attacked by the Spanish music theorist Juan de Espinosa in a 1514 publication (Stevenson, Spanish Music, 92; Carlos Romero de Lecea in Alonso, Cuatro tratados, 191). Karol Berger includes Bizcargui in his study of musica ficta, Musica Ficta: Theories of Accidental Inflections in 
and was reprinted numerous times in Zaragoza and Burgos until $1550 .^{95}$ The various editions have been divided into two groups by Albert Seay, those of the second group being substantially enlarged from the earlier versions and first appearing in $1515 .^{96}$ Stevenson has named the Arte de canto llano "the most successful plainsong instructor published in sixteenth-century Spain". ${ }^{97}$ In the Cathedral of Burgos, Bizcargui held the post of maestro de capilla and is known to have died shortly after the year $1538 .^{98}$ Two bishops of Burgos were the dedicatees of the treatise. ${ }^{99}$ The theorist Guillermo de Podio was frequently cited by Bizcargui, but in addition, there are some close resemblances to work of Durán in Bizcargui's treatise.

Bizcargui's brief comments on the figures of plainchant notation written on a five-line staff are familiar. A striking resemblance to Durán's Lux bella occurs in his descriptions of the virgula, the plica, and to a lesser extent the ligadura. The similarity to Lux bella is so great that one must surmise that Bizcargui either quoted Durán or that both authors followed the same as yet unidentified source. On duration of the notes of plainchant, Bizcargui gives only the dictum "punto con dos plicas vale dos compasses". ${ }^{100}$ In his separately printed tonary, the punto con dos plicas may be found with the simple form $\Pi .{ }^{101}$

Of particular interest are Bizcargui's discussions of chant written on a single line. His contribution on this topic is an unusual and valuable feature of the treatise and goes beyond the guidelines given for reading one-line notation with regard to mode and semitone placement which were common in Spanish treatises. Of the other theorists, only Durán

Vocal Poyphony from Marchetto da Padova to Gioseffo Zarlino (Cambridge: Cambridge University Press, 1987).

${ }^{95}$ León Tello, Estudios, 367.

${ }^{96}$ Albert Seay, ed., Arte de canto llano, by Gonçalo Martinez de Biscargui (Colorado Springs: Colorado College Music Press, 1979), i.

${ }^{97}$ Stevenson, Spanish Music, 88.

${ }^{98}$ Francisco José León Tello, “Martínez de Bizcargui, Gonzalo”, NG 11: 722.

${ }^{99}$ Seay, ed., Arte de canto llano, i.

${ }^{100}$ Bizcargui, Arte de canto llano, 1511, fol. [b6]"; 1528 edition: Madrid, Biblioteca Nacional R 9405 , fol. dii". The 1528 edition of the Arte de canto llano is referred to here as it was available to the writer for close study. A brief examination of the 1515 edition in Oxford (Bodleian, Tenbury e. 15) suggests that there are only very minor differences between it and the 1528 edition. This conclusion is supported by Albert Seay's observations on the editions and revisions (Seay, ed., Arte de canto llano, i).

${ }^{101}$ Gonzalo Martínez de Bizcargui, Intonaciones nuevamente corregidas según uso de los modernos que hoy cantan y entonan en la Iglesia Romana, Viejos Libros de Música 15 (Madrid: Joyas Bibliograficas, 1980) fols. aiiii", [a5] $]^{\mathrm{r}}$, etc. 
appears to have attempted the study of the note forms used in this style of notation but does not approach the detail and clarity of Bizcargui on this topic. In the 1528 edition of his treatise, Bizcargui expands his earlier work on the use of one-line notation, saying for example, that once it has been studied by a singer that person can then easily use five-line notation but not vice versa. One-line notation was more difficult to learn to read than five-line notation. Moreover, books using one-line notation continued to be found throughout Spain, those with five-lines found only "en las yglesias cathedrales y en algunas colegiales, y por marauilla en algunas parrochiales". ${ }^{102}$ The poverty of churches, "specialmente en este obispado de Burgos", prevented them from replacing old books in one-line notation with new ones in five-line notation. ${ }^{103}$

In both the 1511 and 1528 editions Bizcargui gives instructions for the understanding of the mode of chants written in one-line notation. Each mode could be identified by the placing of the final and signs which indicated the lower note of semitones and the solmization syllable $f a .^{104}$ These signs will be discussed further below. Escobar (1490/1491) had previously mentioned puntos fas and the semitone among the means of recognizing the mode of chants written on the one-line staff. ${ }^{105}$

In 1528 Bizcargui added two further points of instruction for one-line notation. The first concerns changing between authentic (maestro) and plagal (discipulo) modes. To do this a direct was needed because each has its own relationship with the staff line. Bizcargui gives an example to illustrate this practice involving two directs. ${ }^{106}$ The second point is on the recognition of eight types of seculorum for antiphons when written on one-line notation. For these Bizcargui gives rules concerning melodic motion, final notes, and note forms. In the last category he says that the second seculorum may be differentiated from the sixth because the second has a "punto con rasgo que se dize tono simple". ${ }^{107}$ The tono simple

${ }^{102}$ Bizcargui, Arte de canto llano, 1528, fol. diiir.

${ }^{103}$ Bizcargui, Arte de canto llano, 1528, fol. diiiv. Robert Stevenson has drawn attention to Bizcargui's discussion of notation on a one-line staff and gave a summary in English of the chapter in which the value of its study and its use in books all over Spain is described (Stevenson, Spanish Music, 89-90).

${ }^{104}$ Bizcargui, Arte de canto llano, 1511, fol. [a5] ${ }^{\mathrm{v}}$-[a6] ${ }^{\mathrm{r}}$; 1528, fol. [a7] ${ }^{\mathrm{v}}$ - [a8] ${ }^{\mathrm{v}}$.

${ }^{105}$ Alonso, Cuatro tratados, 167.

${ }^{106}$ Bizcargui, Arte de canto llano, 1528, fol. diii". Here the direct has the same effect as a change of clef in other types of notation.

${ }^{107}$ Bizcargui, Arte de canto llano, 1528 , fol. diii". 
was illustrated earlier in the treatise and is shown in Table 1 below. This usage of the note form correlates with the punto con dos plicas commonly observed in the seculorum formulas of Spanish renaissance manuscripts in five-line notation.

In both the editions studied, the note forms used in notation on one line are presented. There are however two different classifications, a fact to which Bizcargui himself refers in the later edition saying that the new method was more readily understood. ${ }^{108}$ The 1511 treatise presents three classes - percutiens, percussum, and medium percutiendi - while the 1528 version presents similar groupings of note forms but with two classes according to whether or not the note forms receive letra 'text' and a further two unclassified signs. ${ }^{109}$ All but one of the note forms are named in both editions, the exception occurring in the 1528 edition as one of the unclassified signs. The names vary only in spelling and in Table 1 below that of 1528 has been used. The note forms are as shown in Table 1 .

The first four note forms are all given the term tono by Bizcargui. ${ }^{110}$ These are signs which may stand in isolation over a syllable as he indicates through his description of them as having the letra. It may be proposed that these signs are the equivalents of the earlier Aquitanian punctum (1), epiphonus (2), clivis or climacus (3), and cephalicus (4). ${ }^{111}$

Signs five to eight are all termed punto. These, it seems from the description, were signs which occurred only after another note that had already taken the beginning of the text syllable and therefore in neumes of more than one note or in melismas. Relating these to the earlier notation presents difficulties but comparison with later forms of Aquitanian notation gives clarification. The sixth resembles the porrectus praepunctis, and the eighth may be derived from a clivis form also found as part of a torculus. ${ }^{112}$ Study of late Aquitanian notation in the Zamoran sources confirms that the sixth sign is a porrectus in the form which it takes when in composition rather than isolated. ${ }^{113}$ This sign, called punto

${ }^{108}$ Bizcargui, Arte de canto llano, 1528, fol. $\mathrm{d}^{\mathrm{v}}$.

${ }^{109}$ Bizcargui, Arte de canto llano, 1511, fol. [b6]; 1528, fol. d.

${ }^{110}$ Tono simple, tono general, and tono compuesto are terms which were also used by Durán. He employed them in discussions of intervals and modes (Durán, Lux bella, fol. a').

${ }^{111} \mathrm{~A}$ comprehensive table of Aquitanian neumes from the 11th-century $\mathrm{Pa} 903$ is given in Paleographie musicale, vol. 13, Le codex 903 de la Bibliotheque Nationale de Paris (XIe siecle): Graduel de Saint-Yrieix (1925; reprint, Berne: Herbert Lang, 1971), 154-59 (hereafter cited as PM 13).

${ }^{112} P M$ 13: 154-55.

${ }^{113}$ Late forms of Aquitanian notation as they occur in the Zamoran sources are studied in Chapter 4. 
doblado, shares its name with the note form used on the five-line staff also known as alpha duplex or alpha doble (the equivalent of a porrectus) and which it also resembles in shape. ${ }^{114}$ The seventh term, punto subjetado, may in fact refer to the lozenges of the illustrated sign, a conclusion suggested by the use of the same term in the treatise by Aguilar to be discussed below. The entire form of the sign is suggestive of a climacus which is preceded by at least one note below its uppermost pitch and over the same syllable. It is the topmost lozenge with its tail descending on the left which suggests this likelihood, as it is similar to the Aquitanian virga often found in the topmost position in rising Aquitanian neumes. The eighth sign, punto compressa, is like that commonly found as part of a torculus form in late Aquitanian notation. ${ }^{115}$ The ninth sign, punto cabeçudo, takes the late form of the Aquitanian virga. The tenth is likely to be the equivalent of the bistropha and is the same as a version of the sign used in contemporary and earlier square plainchant notation.

Not yet discussed is the fifth sign, the punto de semitono. The form is an unusual one with no immediately apparent precedent in earlier Aquitanian notation. Wider comparison suggests that the sign is in fact part of the quilisma group and it will be discussed in further detail in Chapter 4. The punto de semitono was used to indicate the lower note of a semitone, a fact which may be deduced from Bizcargui's discussion. In the rules for the eight modes in one-line notation, the positions of the puntos de semitono are given. ${ }^{116}$ The punto cabeçudo may have been associated with the indication of the solmization syllable $f a$ and may be another name for the nota de fa of which Bizcargui spoke. This however is unclear. $^{117}$

\footnotetext{
${ }^{114}$ See page 58.

${ }^{115}$ Forms of the torculus are discussed in Chapter 4.

${ }^{116}$ Bizcargui, Arte de canto llano, 1528, fols. [a7]"-[a8]".

${ }^{117}$ On the punto cabeçudo and its role in relation to conjuncta, see Bizcargui, Arte de canto llano,
} 1511, fol. biiiir and 1528, fol. [c5]. 
Table 1: Note Forms of One-line Notation as Given by Bizcargui

1511

percutiens

1. tono propio

2. tono simple

3. tono compuesto

4. tono general

5. punto de semitono

6. punto doblado

7. punto subjetado

8. punto compressa

9.

10.

\section{Gaspar de Aguilar}

Another treatise on plainchant is the Arte de principios de canto llano by Gaspar de Aguilar, published c. 1530 and probably in Toledo. ${ }^{118}$ Included in this work is a section on

\footnotetext{
${ }^{118}$ Carlos Romero de Lecea in Miguel Alonso, Cuatro tratados, 203-7.
}

1528

se mete letra

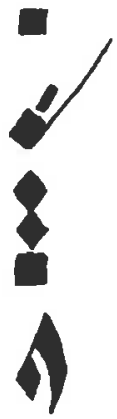

no se mete letra

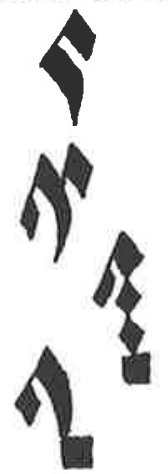

punto cabecudo

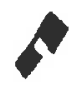

an

\section{medium percutiens

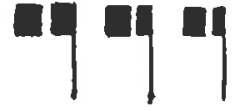


notation in the tradition of Durán but offering some different information. As will be shown below there are some notable similarities between the work of Aguilar and Durán, and it may also be said that Aguilar's prose is clearer to understand than Durán's. On the other hand, it is Franchinus Gaffurius who is acknowledged by Aguilar at the end of his introductory sentence in the chapter on notation. The acknowledgement is by means of Gaffurius' first name, his full name having been given in the form of Franquino Gafori previously in the treatise. ${ }^{119}$

Para meter la letra se requiere tener conoscimiento de siete cosas, conuiene a saber, de punto simple y ligado, y subjetado, y virgula y plica, y de vocal simple et dicthongada. Fra[n]quino. ${ }^{120}$

In particular, Aguilar follows Gaffurius in the employment of three categories of notes for which he gives explanations and examples. The names of the categories and the illustrations from Aguilar's treatise are shown below.

1. punto simple (a square, unligated note)

2. punto ligado (a note ligated to another with two varieties)

\section{i. ligadura recta in}

\section{ii. ligadura oblica}

3. punto subjetado $\quad$ (may not be used singly). ${ }^{121}$

Gaffurius' three categories of notes as given in the Practica Musicae (Milan, 1496) are simplex, composita, and mediocris. ${ }^{122}$ These correspond respectively to the first, second, and third categories of Aguilar. Aguilar imitates Gaffurius in his descriptions of the note forms although without the detail of the earlier writer. For example, concerning the punto subjetado, Aguilar says "paresce en algo al oblico . . y no puede venir vno solo" while

${ }^{119}$ Gaspar de Aguilar, Arte de principios de canto llano, Viejos Libros de Música 11 (Madrid: Joyas Bibliográficas, 1977), fol. b iiii" (facsimile edition).

${ }^{120}$ Aguilar, Arte de principios, fol. [ b7] .

${ }^{121}$ Aguilar, Arte de principios, fol. [b7].

${ }^{122}$ Practica Musice Franchini Gafori, fol. aiii"; TML file GAFPM1. English translation by Irwin Young, The Practica musicae of Franchinus Gafurius (Madison: University of Wisconsin Press, 1969), 18-19. 
Gaffurius had similarly stated "in sui simplicitate obliquo corpori certa similitudine comparatur neque sola describitur". ${ }^{123}$

The ligadura oblica is that form which was termed alpha in other treatises. The punto subjetado or lozenge-shaped note was termed semitonado, triangular, and possibly tonito in treatises discussed already; Bizcargui also had used the term punto subjetado evidently with the same meaning although in the context of one-line notation.

Aguilar's discussions of plica and virgula are like those of Durán rather than Gaffurius. Gaffurius details correct stem placements for ligatures, but using the term virgula to mean stem instead of plica. ${ }^{124}$ For Aguilar, like Durán, the plica signifies a stem attached to a note; in fact, the definitions of the two writers are almost identical suggesting that Aguilar may have borrowed his from Durán or that both may have followed an earlier work. Aguilar also (again like Durán) explains the duration of a note (punto simple) with two stems as being two compases as well as the rules for positioning the stems upwards or downwards according to the rise or fall of a melody. Significantly the note with two stems is illustrated in Aguilar's treatise where it appears in the simple form without a tongue-like sign П. Aguilar treated the virgula somewhat differently from Durán but with much the same meaning. ${ }^{125}$

By way of comparison with the Spanish writers already examined, the discussion of plainchant notation by the Italian music theorist, Franchinus Gaffurius, is summarized below. His highly influential treatise Practica musicae was printed first in Milan in 1496. It is therefore contemporary with the two treatises of Durán. Practica musicae is known to have had wide circulation beyond Italy. In addition to writing his varous treatises on music, Gaffurius was music director at the Ambrosian cathedral in Milan, taught at the University of Pavia, and composed. Book One of the Practica musicae is devoted to plainchant. $^{126}$ GAFPM1.

${ }^{123}$ Aguilar, Arte de principios, fol. [b7]". Practica Musice Franchini Gafori, fol. aiiiir; TML file ${ }^{124}$ Practica Musice Franchini Gafori, fols. aiii ${ }^{\mathrm{x}}$-aiiiir; TML file GAFPM1.

${ }^{125}$ Aguilar, Arte de principios, fol. [b7]".

${ }^{126}$ Young, Practica musicae, xv-xvii. 
From Gaffurius we learn that all notes are to be sung with equal duration, so that each note had the value of one breve. ${ }^{127}$ He divides the notes of plainchant notation into three categories as discussed above and describes the forms very clearly as to the manner in which they were to be written including the placing of stems. ${ }^{128} \mathrm{He}$ mentions that the simple square note is sometimes written with a stem on the right "in the manner of a mensurable long". ${ }^{29}$ The fact that he observes its likeness to a mensurable sign yet emphasizes elsewhere in the chapter that all notes were performed with equal duration, and given his clear interest in accuracy and clarity of explanation, points to the possibility that Gaffurius saw these two ways of writing a single note of plainchant as interchangeable and not indicating any durational differentiation. Gaffurius is very specific with regard to the duration of the individual notes of ligatures. All such notes are to receive the same duration as the normal plainchant note no matter what their form. ${ }^{130}$ With the term mediocris, Gaffurius refers to the lozenge-shaped note which he says cannot be written on its own. Although he calls it a semibreve, he explains that the lozenge-shaped note has the same duration as other notes of plainchant. Furthermore, he observes that those singers who give the lozenges a rendering of twice the usual speed act according to their own whims. ${ }^{131}$

In his discussion of ligatures, Gaffurius illustrates the two forms of the pes both correct and without offering any differentiation in meaning. Both styles are able to be used at the end of a ligature and receive the title of "perfection". ${ }^{132}$ This is a detail not to be found in the Spanish treatises. The two styles of pes are apparently interchangeable; again it seems likely that Gaffurius' inclination to accuracy would have caused him to explain if indeed the two forms required differing interpretations. Gaffurius accepts the isolated falling two-note oblique ligature but he does not permit it in a rising form nor its occurrence at the end of ligatures. ${ }^{133}$

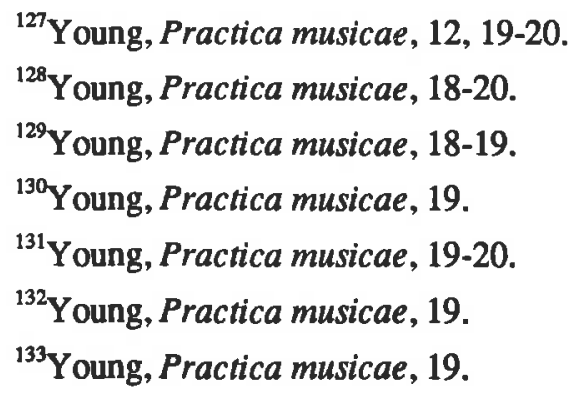


Having insisted on the equal duration of the notes of plainchant, the final comment made by Gaffurius in the chapter on notation relates to mensural performance of chant. Some people sing certain types of chant with the differentiated durations of longs, breves, and semibreves: "vt constat in Symbolo cardineo, et nonnullis prosis atque hymnis". Furthermore, the mensural style of performance is used by the French for ornamentation. ${ }^{134}$ A reference to a mensural Credo (Symbolum was the term for Credo in the Ambrosian tradition) is later made by Gioseffo Zarlino who calls it Credo Cardinalesco. ${ }^{135}$ This Credo has been equated with the modern Vatican Credo IV. ${ }^{136}$ The allusion made by Gaffurius to the French performance style brings to mind the advice of Jerome of Moravia in chapter twenty-five of his Tractatus de musica on the varied duration of notes used in the singing of chant and suggests that Jerome's discussion reflected a regional practice. ${ }^{137}$ A comparable admission of different types of interpretation (equal duration and varied duration) suitable for different types of chant does not occur amongst the work of the Spanish music theorists until the mid 16th century.

\section{2. "Non-equalists"}

The treatises in this group all give note forms for use in chant notation otherwise better known for their place in mensural notation. Two are anonymous and of uncertain dating.

\footnotetext{
${ }^{134}$ Practica musice, fol. aiiií; TML file GAFPM1; Young, Practica musicae, 20.
}

${ }^{135}$ Young, Practica musicae, 20. Zarlino's remark on this Credo and mensural performance reads: "in plainsong ... a syllable is assigned to each square note, except sometimes for the middle notes of a ligature, which are performed like minims and also like semiminims, as seen in many chants, especially in the Credo in unum deum called the Cardinal Credo." Gioseffo Zarlino, On the Modes, Part Four of Le Istitutioni harmoniche, 1558, trans. Vered Cohen, ed. Claude V. Palisca (New Haven: Yale University Press, 1983), 98. For some further discussion of Gaffurius' treatment of the issues of duration in chant and his ideas in relation to the comments of a few of his contemporaries, see Clement A. Miller, "Gaffurius's Practica Musicae: Origin and Contents", Musica Disciplina 22 (1968): 111-13.

${ }^{136}$ Zarlino, On the Modes, ed. Palisca, 98 n. 2.

${ }^{137}$ Part of chapter twenty-five of the Tractatus de musica is translated into English in Carol MacClintock, Readings in the History of Music in Performance (Bloomington: Indiana University Press, 1979), 3-7. 
Anonymous. Barcelona, Biblioteca de Catalunya, Ms. 1327

This anonymous manuscript music treatise is written in Catalan. It has been dated by Gümpel as "vielleicht noch vor Ende des 15. Jahrhunderts" and its provenance is a Convent of Clares in Valencia. ${ }^{138}$ Gümpel has shown that it belongs to the tradition of treatises based upon a probable archetypal compendium and which includes those of Estevan and Durán. The note forms named, however, are not a usual part of this tradition.

Five note forms are given, the first three well known from mensural notation: "longua, breu, semibreu, vncus et tocus". The performance of the two unusual note forms, the uncus and the tocus, is described. The description is ambiguous but appears to indicate that each note form is to be sung with two pitches, the melodic motion rising in one and falling in the other. The forms of the uncus and the tocus are similar to the punto con dos plicas but it is notable that the note-heads are curved rather than square. The illustrations are written on a four-line stave and are not labelled. The first three signs can be identified easily as their forms are well known and are illustrated in the same order as they are named. It then follows that the uncus and the tocus should similarly be illustrated in the order that they are named. This is not the case as is seen when the two treatises to be discussed next are examined. The illustration of each is as follows: ${ }^{139}$

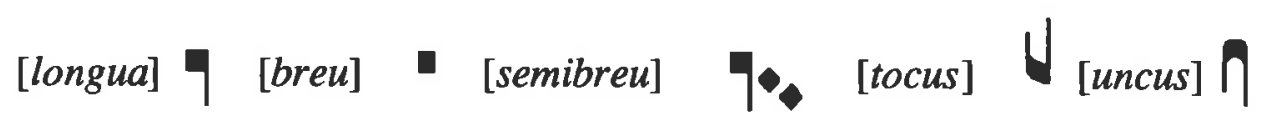

\section{Guillermo de Podio}

The second of the treatises belonging to this tradition is that of Guillermo de Podio. Podio was also known as Despuig or de Puig, but very little information is available about his life. He lived during the latter half of the 15th century and his major work, the Ars musicorum (written in Latin), was printed in Valencia in $1495 .{ }^{140}$ A shorter undated

\footnotetext{
${ }^{138}$ Gümpel, "Zur Frühgeschichte”, 278.

${ }^{139}$ Gümpel, "Zur Frühgeschichte", 323.

${ }^{140}$ Francisco José León Tello, "Podio [Puig], Guillermo de", NG 15: 17. For further on his biography
} see Stevenson, Spanish Music, 73-74. 
manuscript treatise In enchiridion is thought to have possibly been written for students in Bologna. $^{141}$

Podio was frequently cited in music treatises of the 16 th century and continued to receive mention into the 18 th century. Ramos de Pareja, despite his fame outside of Italy and his radical ideas, had less influence on Spanish music theorists as is attested by the lack of reference to his work. ${ }^{142}$ It would seem that the Spanish music theorists preferred Podio's more conservative approach based in Boethian and Guidonian methods. For example, unlike Ramos, Podio accepted the old Guidonian system of solmization. ${ }^{143}$ Albert Seay has compared Podio to the more conservative Italian theorists such as Franchinus Gaffurius and Nicolaus Burtius. ${ }^{144}$ Apparently well versed in humanism, he was concerned with the importance of taking the text into consideration when writing new liturgical melodies advising, for example, that the melody rise or fall if such is suggested by the text. ${ }^{145}$

Durán taught that all notes of plainchant should have equal duration. This idea was however rejected by Podio as is seen in the following quotations referring to plainchant from Book Five of the Ars musicorum, chapter thirty-six, entitled "De figurarum in cantu plano pronunciatione et eius nominis causa."

veruntamen non certo et determinato temporis spacio limitatim vt in mensurabili cantu, sicut ex huius nomine aperte colligitur, inde enim hic cantus ideo planus dictus est.

Qua de re qui equali temporis spacio siue vniformitur predictas pronunciant figuras contra omnem rationem agere videntur. ${ }^{146}$

From the first of the above quotations we learn not only that all notes are not to be of equal duration, as is emphasized in the second, but also that the duration is not fixed. Podio requires that notes in plainchant be of varying durations and he expected that the notation,

${ }^{141}$ Stevenson, Spanish Music, 74. For an edition see Karl-Werner Gümpel, "Das Enchiridion de principiis musice discipline des Guillermus de Podio", Gesammelte Aufsätze zur Kulturgeschichte Spaniens, 1st ser., 27 (1973): 359-96.

${ }^{142}$ Podio's influence on Spanish writers as well as the innovations and influence of Ramos are discussed in Robert Stevenson, "Spanish Musical Impact", 125-35. On Podio's influence and work, also, Stevenson, Spanish Music, 73-82.

${ }^{143}$ Francisco José León Tello, "Podio [Puig], Guillermo de", 17.

${ }^{144}$ Albert Seay, ed., Guillermus de Podio, Ars musicorum Libri VI et VIII (Colorado Springs: Colorado College Music Press, 1978), iii.

${ }^{145}$ León Tello, Estudios, 424.

${ }^{146}$ Guillermo de Podio, Ars musicorum, Viejos Libros de Música 4 (Madrid: Joyas Bibliográficas, 1976), fol. XXXXVI" (facsimile edition). 
which he describes as using note forms such as the long, the breve and the alpha, would be a guide to this. ${ }^{147}$ These note forms however were not to be strictly measured as was the case in mensural music, flexibility was essential. As León Tello comments, Podio held a concept of duration in chant "opuesto al isosilabismo". ${ }^{148}$

In a short work written in Spanish on mensural notation and which is closely related to the two last books of the Ars musicorum, Podio makes a brief mention of pausas or rests in plainchant: "En canto llano, la dicha pausa no es determinada por alguna quantidad de tiempo". ${ }^{149}$ This freedom in the duration of a pause reflects Podio's teaching of the need to avoid fixed time values in the performance of plainchant. However, the indication of pauses in plainchant is a subject not discussed by the theorists examined here. The earliest mention of pauses indicated in notation which it has been possible to find is that of Luis de Villafranca in his Breve introducción de Canto llano of 1565 . He says that virgulas can be used either to separate sections of a piece or to mark pauses. ${ }^{150}$

Podio names eight types of note forms for use in plainchant: "maxima, longa, breuis, semibreuis, alpha, tocus, vncus et finis". ${ }^{151}$ The first four are the same figures which he lists for mensural notation in chapter one of Book Seven. ${ }^{152}$ Five are listed in the anonymous Catalan treatise already discussed. Just as lozenges are not to be written singly according to other theorists, Podio says that a single semibreve may not occur alone. ${ }^{153}$ The finis is the same as the maxima but lacks or almost entirely lacks a stem. ${ }^{154}$ No illustrations are given.

Like the punto con dos plicas described in other Spanish music treatises, Podio says that the tocus and the uncus each have two stems, ascending in the case of the tocus and descending in the case of the uncus. Podio uses the terms tractus and linea to refer to the

${ }^{147}$ Podio, Ars musicorum, fol. XXXXV'-XXXXVI".

${ }^{148}$ León Tello, Estudios, 423.

${ }^{149}$ Higinio Anglés, "La notación musical española de la segunda mitad del siglo XV", Anuario Musical 2 (1947): 170. The article contains a transcription and an introduction to this short treatise by Podio.

${ }^{150}$ Duncan, "Mexican Chant Book", 120.

${ }^{151}$ Podio, Ars musicorum, fol. XXXXV".

${ }^{152}$ Podio, Ars musicorum, fol. XXXXIX ${ }^{\text {. }}$.

${ }^{153}$ Podio, Ars musicorum, fol. XXXXVI'.

${ }^{154}$ Podio, Ars musicorum, fol. $X_{X X X V}$. Leon Tello interprets Podio as meaning that the finis has no stem (Estudios, 423). 
stems of note forms including the tocus and the uncus: "tocus et vncus propter eorum binos tractus omni carent ligatura". He also gives the term plica as a synonym of tractus. ${ }^{155}$ From the descriptions it appears that the tocus and the uncus may both have had curved heads perhaps like those shown in the anonymous Catalan treatise already discussed. The tocus is described as a Greek pot or shell (grece teste) but also as having the body of a brevis. ${ }^{156}$ The uncus, however, is a curved brevis, and Podio notes that "vncus enim curuum significat". ${ }^{157}$ The curved shapes differentiate the forms from the punto con dos plicas but bring to mind the intenso and the remisso named by Bermudo and Spañon. On the other hand, the very short stems of the latter two note forms distinguish them from the tocus and the uncus. In the previous discussion of the anonymous Catalan treatise it was observed that the order of illustrations and the order of names of note forms suggested that the uncus had ascending stems and the tocus descending stems; however, in Podio's treatise it is clear that in fact the reverse is true. The third treatise in this tradition also leaves no doubt that it was the uncus which had descending stems, and the tocus which had ascending stems. It will be assumed in this dissertation that this is the correct naming of the two signs.

The interpretation of the tocus and the uncus is not made explicit by Podio. However, it appears that they are to be sung as two (or perhaps three) pitches with the pitch of the body of the sign sung with full value while the sounds represented by the stems are sung rapidly. The tocus probably moves upwards away from the pitch of the main body of the note in the direction of its stems, while the uncus moves downwards also in the stem direction. (The correlation of stem direction and melodic direction is made explicit in the next treatise to be discussed.) Interestingly the two signs are associated with diphthongs by Podio. ${ }^{158}$ With the tocus and the uncus, Podio therefore appears to be following in the tradition of liquescence in both the association with diphthongs and the singing of more than one pitch for the single sign. He also notes that the tocus and the uncus (like the finis)

\footnotetext{
${ }^{155}$ Podio, Ars musicorum, fols. XXXXV'-XXXXVI'.

${ }^{156}$ Podio, Ars musicorum, fols. $\mathrm{XXXXV}^{\mathrm{r}}-\mathrm{XXXXV}^{\mathrm{v}}$.

${ }^{157}$ Podio, Ars musicorum, fol. XXXXV".

${ }^{158}$ Podio, Ars musicorum, fols. $\mathrm{XXXXV}^{*}$. On rapid execution in the tocus and the uncus, see also
} León Tello, Estudios, 423. 
are now rarely observed. ${ }^{159}$ Podio thus shows his knowledge of earlier practices, while acknowledging the contemporary lack of understanding.

\section{Anonymous. Arte de melodia sobre canto lano y canto d'organo}

This anonymous manuscript treatise written in Spanish, like the anonymous Catalan treatise discussed previously, is held in Barcelona. ${ }^{160}$ It dates from the beginning of the 16th century and makes use of some Catalan expressions and makes occasional reference to Toledo. ${ }^{161}$

Eight note forms are named as the principal ones used in plainchant; they are those listed in the Ars musicorum: "Máxima, longo, breue, semibreue, alfa, tocus, vncus, finalis."162 Each one is illustrated and its function explained. The link between the note forms and long and short syllables is made clear, so we learn that both the maxima and the longo are given to long syllables, while the breve is given to short syllables. The semibreve, alfa, tocus, uncus, and finalis are discussed in other terms, without mention of association with syllable types. It is noteworthy that two forms are given for the semibreve, the first the typically mensural form 4 and the second the lozenge. The term plica is used for the stems of the tocus and the uncus, and as Podio had done, the body of the note is described as a brevis or breve and the stem direction is specified. The illustration however does not show the body of the notes as curved. Once again the stems of the tocus are said to ascend, while those of the uncus descend. The motion of the voice indicated by the two signs is described, that for the tocus is as follows: "senyal de repelar la vos aza riba y tornar al mesmo puncto en lugar de melodía." The motion of the uncus takes the opposite direction, moving down rather than up. From the descriptions we learn that the signs represent a

\footnotetext{
${ }^{159}$ Podio, Ars musicorum, fol. XXXXV; León Tello, Estudios, 424.

${ }^{160}$ Barcelona, Biblioteca de Catalunya, Ms. 1325. For an edition see Karl-Werner Gümpel, "El canto melodico de Toledo: algunas reflexiones sobre su origen y estilo", Recerca Musicoldgica 8 (1988): 38-45.

${ }^{161}$ Gümpel, "El canto melódico", 29.

${ }^{162}$ Gümpel, "El canto melódico", 39.
} 
three-note melodic figure in which the first and third pitches are the same. The anonymous author adds that, in Toledo, the tocus and the uncus are called estrunto. ${ }^{163}$

The description of the tocus as being used instead of melodía refers the reader to the main topic of the treatise. The art of melodia meant the addition of ornament to plainchant for the purpose of beautification. The practice has been examined by Gümpel and appears to have been particularly associated with the church of Toledo. ${ }^{164}$ The treatise classifies and describes different types of ornament giving their names and melodic examples. As an orally transmitted art, the ornaments of melodia were not usually notated. The tocus and the uncus therefore are exceptional note forms in their representation of an ornamental melodic motion.

The reference to the use of the two signs instead of melodía allows a further hypothesis to be made as to their performance. From the description already quoted of the performance of the tocus we know that a three-note melodic figure was indicated with the first and third notes at the same pitch. As the examples of ornaments move always in conjunct motion, it may be proposed that the motion of the tocus and the uncus was also conjunct; an example of the tocus would therefore be d-e-d and the uncus d-c-d. To this then may be added Podio's mention of rapid execution. Again the examples of ornamentation in the Arte de melodia are of assistance. A graph-like representation of an ornament called onda shows two examples; in the first the rise in pitch occurs shortly after the beginning and in the second shortly before the end. As Gümpel has pointed out, the onda "puede ser ejecutado tanto al principio como al final de la nota."165 This type of quick motion either at the beginning or at the end of a note may then have been the interpretation to which Podio was referring. ${ }^{166}$

\footnotetext{
${ }^{163}$ Gümpel, "El canto melódico", 39.

${ }^{164}$ Gümpel, "El canto melodico", 25-34.

${ }^{165}$ Gümpel, "El canto melódico", 35.
}

${ }^{166}$ For the sake of comparison, one much later treatise may be referred to in reference to the tocus and the uncus. The Fragmentos músicos (Barcelona, 1739) by Bernardo Comes y Puig names only the uncus but describes stems which either ascend or descend. For Comes y Puig, the sign indicated two pitches which moved up or down according to the stem direction (Serrano Velasco et al., Estudios, 217.) A simplification of the ornamental practice may have occurred during the more than two hundred year period. 
In conclusion, the interpretation of the tocus and the uncus is clearly different from that of the punto con dos plicas of the "equalist" treatises; however, the forms of the signs are less clearly differentiated. This is because the Arte de melodia presents the tocus and the uncus without the curved shapes of the other two treatises in the "non-equalist" tradition. The curved shape otherwise differentiates the tocus and the uncus from the punto con dos plicas. Among the "equalist" treatises, the punto con dos plicas sometimes occurs with a small tongue between the stems, a characteristic which may perhaps be seen as distinguishing it from the tocus and the uncus. However, the punto con dos plicas is not always described or illustrated with the tongue, and the plain forms $1 \mathrm{U}$ are indistinguishable from the illustrations of tocus and uncus in Arte de melodía.

\section{Pedro Ferrer}

Intonario general para todas las iglesias de España by Pedro Ferrer was printed in Zaragoza in 1548. Ferrer, a Zaragozan priest, is thought to have been interested in the reform of liturgical music and may have represented the views of the more educated and modern churchmen. ${ }^{167}$ In the Intonario, the use is advocated of note forms such as long, breve, semibreve, and oblique ligature. ${ }^{168}$

Ferrer speaks only of a note being longer than another and does not give definite durations, for example, "en los longos con alguna detención más que en los breves”. ${ }^{169}$ The avoidance of exact durational values resembles Podio's advice. In a comment on the performance of the prefaces of the Mass, Ferrer says that by differentiating between the different note forms (long, breve, and semibreve) the accent will be kept. ${ }^{170}$ A similar idea has been seen in the Arte de melodia where note forms are said to have been invented for use with long and short syllables. With regard to the semibreve, Ferrer limits it to generally non-syllabic usage but says that it is used independently in certain syllabic chants including

\footnotetext{
${ }^{167}$ León Tello, Estudios, 283-85.

${ }^{168}$ Francisco José León Tello, "Ferrer, Pedro", NG 6: 496; León Tello, Estudios, 461.

${ }^{169}$ León Tello, Estudios, 462.

${ }^{170}$ Duncan, "Mexican Chant Book", 67.
} 
"la Gloria de nueve liciones y en el Credo romano"."171

\section{Juan Bermudo}

The Declaración de instrumentos musicales was published in 1555 in Osuna in southern Spain. It is a wide-ranging, comprehensive treatise covering plainchant and polyphony as well as including sections on instruments. Bermudo's Arte Tripharia (1550) summarizes much of the material from the Declaración and an earlier treatise (1549) included most of Book One. ${ }^{172}$ Bermudo has gained respect for the fact that his work reflected the current musical practices of his day. In the words of León Tello:

El maestro franciscano es el gran observador de la música de su tiempo, que expone en sus tratados no las reglas comunes tantas veces repetidas, que respondían a un arte anterior, sino los procedimientos que advierte en los compositores de su época. ${ }^{173}$

Composition is the topic of Book Five of the Declaración and it is there that Bermudo gives a detailed commentary on notational aspects of plainchant in the chapter entitled "Que cosas se requieren para puntar canto llano". The six partes which he says are needed for plain chant are "regla, claue, punto, plica, virgula, y guion". ${ }^{174}$ In Book Two he had already given a brief exposition on the subject in which he had named the same six signs but instead of the plica included the signs for $b$ quadrado and $b \mathrm{~mol}$. In the same chapter he made explicit the fact that all notes have the same durational value with the exception of the single note with two plicas which has the value of two compases. "Aunque con diuersas figuras en canto llano sean señalados, todos tienen vn mesmo valor, excepto el que tiene dos plicas, que vale dos compases." ${ }^{\text {"175 }}$ The illustration of the various signs given in Book Five is in white notation so for example the punto has the form: 日. The advice given by Bermudo on regla (staff), punto, plica, and virgula is summarized below.

${ }^{171}$ León Tello, Estudios, 462.

${ }^{172}$ Samuel Rubio, Historia de la música española 2. Desde el "ars nova" hasta 1600 (Madrid: Alianza Música, 1983), 256. Robert Stevenson, "Bermudo, Juan", NG 2: 611.

${ }^{173}$ León Tello, Estudios, 380.

${ }^{174}$ Fray Juan Bermudo, Declaración de instrumentos musicales, ed. Macario Santiago Kastner, Documenta Musicologica, vol. 11 (Kassel: Bărenreiter, 1957), fol. cxxv".

${ }^{175}$ Bermudo, Declaración, fol. xxi ${ }^{\text {. }}$. 
Regla. Bermudo recommends the use of a five-line staff (cinco reglas), which he says is now common in Spain although a one-line staff is still employed "en muchas partes de ytalia, y en algunas de España". He noted that one-line notation was used formerly in the times of St. Gregory and St. Ambrose. ${ }^{176}$

Punto. Bermudo names four types of punto: suelto, ligado, intenso, and remisso. Punto suelto seems to refer to any isolated single note on which the text syllable is sounded. In addition, he appears to use the same term to refer to the note at the beginning of a ligature or melisma which receives the text syllable. Punto ligado seems to refer to any note of a ligature or melisma following the note which receives the text syllable. ${ }^{177}$

The brief mention of intensos and remissos used by the diligent (curiosos) makes clear the form of these signs which is confirmed by the illustration: $\boldsymbol{M}$. "El punto intenso, a la parte superior quadrado, y a la inferior estaua en medio circulo: y el punto remisso, al contrario del intenso." 178 In Book Three of the treatise, in a section on mensural music, Bermudo gives an analysis of the function of the signs in sharpening and flattening pitch. The intenso raises the pitch of a note by a semitone and the remisso lowers the pitch of a note by a semitone. ${ }^{179}$

With regard to ligatures, Bermudo distinguishes two types, mayor and menor. His description of the correct forms which these must take illustrates the conscious regularity with which plainchant notation was approached. The ligadura mayor comprised squareshaped notes or alphados (two notes joined in an oblique form). The use of the alphado was restricted; it was to be used in three-note ligatures (or at the end of longer ligatures) in which the first and last notes were of the same pitch with the alphado placed on two falling notes, either first and second notes or second and third notes, and was usually only used if the falling interval was a second. The ligadura menor used lozenges, described as "puntos a manera de semibreves", and could only occur when there were more than two notes

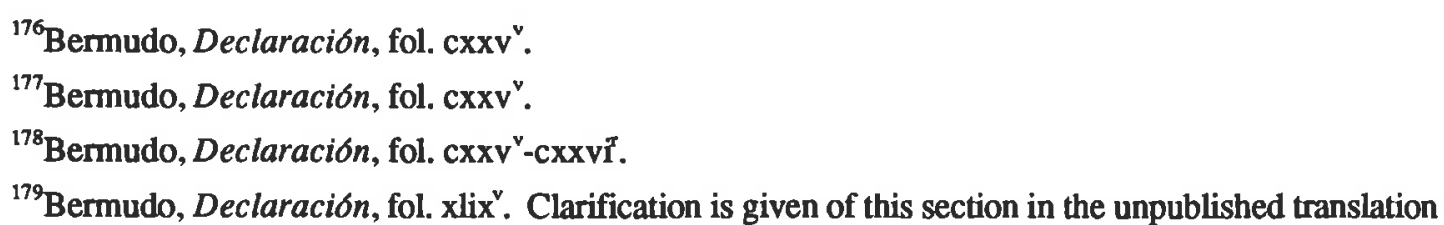
by Gordon J. Kinney of the Declaracion "Exposition of Musical Instruments" (M. I. King Library, University of Kentucky, Lexington, 1976), 244-45. Also on intenso and remisso, Robert Stevenson, Juan Bermudo (The Hague: Martinus Nijhoff, 1960), 64. 
falling, the first note always in the form of a square. He explains how the ligadura menor could be used in a longer ligature which rises and then falls, and that in this situation also there had to be more than two falling notes. The final instruction on the ligadura menor details the restrictions on placing lozenges at the end of a staff. For example, if only two falling notes of a ligadura menor could be fitted at the end of a line they were both to be written as squares. ${ }^{180}$ As Durán has told us elsewhere that all notes have the same durational value, ${ }^{181}$ it may be assumed that there is no durational difference between the two types of ligature.

Plica. The plica could have either of two functions: "vnas vezes por hermosear lo puntado, y otras vezes por necessidad". In the following quotation Bermudo gives instructions on the location of plicas attached to ligatures, all of which as he says have a plica. He continues with a reference to the punto con dos plicas.

Toda ligadura tiene vna plica. Si abaxa, la terna el punto primero, y si sube, el vltimo. Quando la ligadura es de puntos quadrados, abaxando terna la plica el punto primero a la mano yzquierda, y si fuere ligadura menor, terna el dicho punto primero la plica a la mano derecha. Si fuere ligadura mista, que primero abaxa, y despues sube, terna la tal ligadura dos plicas, vna en el punto primero a la mano yzquierda y otra en el vltimo a la mano derecha. Nunca en vn punto solo se ponga plica, sino fuere en el que dixe valer dos compases. Algunos de los cantores modernos (porque este punto de dos plicas no se vsa, a lo menos no es de todos entendido, pues no le dan su valor) en su lugar ponen dos puntos, el segundo un poco menor, y con vna plica a la mano derecha. En canto llano, todas las plicas son hazia baxo. ${ }^{182}$

Bermudo had already mentioned the punto con dos plicas earlier in the same chapter. There he says "Algunas vezes el punto suelto tiene dos plicas hazia baxo, y vale dos compases en canto llano". This is interesting as it is only the punto suelto which can have the two plicas; such a note could therefore only occur as an isolated note or - if the interpretation given above of punto suelto is correct - as the first note of a ligature or melisma. ${ }^{183}$

Bermudo repeatedly says that the punto con dos plicas is now rarely kept or understood. In the lengthy quotation above he describes an alternative form of the sign sometimes used

\footnotetext{
${ }^{180}$ Bermudo, Declaración, fol. $\mathrm{cxxv}^{\mathrm{v}}$.

${ }^{181}$ See pages $56-58$.

${ }^{182}$ Bermudo, Declaración, fol. cxxv ${ }^{v}$.

${ }^{183}$ Bermudo, Declaración, fol. cxxv".
} 
instead of it and consisting of two puntos, the second punto with a stem and smaller than the first. This is similar to the sign called duples in the treatise by Spañon and doblado in the early 17 th-century treatise by Cerone. ${ }^{184}$ Ferrer also referred to the stemless form using the terms doblado and punto detenido. ${ }^{185}$ The illustration of the punto con dos plicas takes the form $\bigcap$, and it is followed in the example of the treatise by another sign very likely to be the alternative form ${ }_{0}^{186}$ There is no mention of the tongue-like sign between the stems of the punto con dos plicas found in earlier treatises, nor is there any illustration of it in the Declaración. This then adds confirmation to the likelihood that there was no difference between the meaning of the puntos con dos plicas with and without the tongue.

Virgula. "El officio destas es diuidir las partes." A short line which usually only occupies two spaces of the staff is placed between one diction and another, no matter how few syllables each consists of ${ }^{187}$ A longer line covering the whole staff is placed at the ends of chants and at the point of repetition in alleluias. Double virgulas are used by the diligent to mark the place in a chant where the choir takes over from the soloist. ${ }^{188}$

In chapter eighteen of Book One of the Declaración, Bermudo gives advice on the use of compas in plainchant. He explains three different styles of rhythmic practice used in chant. The section is worth quoting at length:

Tres compases ay en el canto llano. Vno sirue para la psalmodia, otro para hymnos particulares, y el tercero para todo lo demas puntado. El compas de los psalmos no mira hazer todos los puntos yguales, sino va midiendo todas las sylabas breues y longas, segun las reglas grammaticales. Deforma, que tanto tiempo gasta en vna sylaba longa, como en dos breues. El que en la psalmodia vuiere de lleuar compas, no tan solamente ha de ser buen cantor, sino tambien buen grammatico. Entiendo lo sobredicho de compas ygual en tiempo, y los puntos desiguales. Vna vez entran en vn compas dos puntos, y otra vez tres. Ay algunos que lleuando el compas en la psalmodia, tantas vezes baxan la mano, quantas sylabas pronuncian. En todo y por todo se deue guardar el accento en la psalmodia, especialmente en la mediacion de los versos, y en la sequencia. Los principiantes esten en esto muy auisados, porque algunos descuydandose, hazen grandes yerros, quebrantando los

\footnotetext{
${ }^{184}$ See pages 68 and 70.

${ }^{185}$ Duncan, “Mexican Chant Book", 133.

${ }^{186}$ Bermudo, Declaracion, fol. cxxvi .

${ }^{187}$ The same ambiguity of meaning arises here as was noted with regard to Molina's description of the employment of virgulas in that diction may refer to either a phrase or a word.

${ }^{188}$ Bermudo, Declaracion, fols. cxxv"-cxxvir.
} 
accentos. El compas de algunos hymnos es a proporcion de sesquialtera, que entran tres semibreues en un compas. Los tales hymnos en pocas partes estan bien puntados, porque tienen todos los puntos quadrados. Los hymnos que se cantan al compas ternario, o de sesquialtera son los siguientes. El del aduiento que dize Conditor alme, de la resurrection Ad cenam agni, Rex eterne, y Aurora lucis, del sacramento Pange lingua gloriosi, Sacris solemniis, y otros semejantes. Otros hymnos se cantan en tiempo de por medio, que ya se dize vn punto en vn compas, ya dos, ya tres, los quales son Aures ad nostras de quaresma, Pange lingua, .... . Todos los otros hymnos lleuan el compas del otro canto, el qual en cada vno de los puntos, se gasto un compas. Aunque en el canto llano aya puntos de figura de semibreues, todos son de ygual valor. Vnos puntos ay con dos plicas en el canto llano, y apenas les dan su valor que es dos compases. ${ }^{189}$

To summarize, plainchant may be classified into three groups. These are:

1. Psalmodia. Note duration varies according to syllable length so that long syllables receive long notes and short syllables receive short notes. Equal compas is maintained. Accent must be kept. ${ }^{190}$

2. Particular hymns. These are further subdivided into sesquialtera which has three semibreves in a compas, and por medio which has one, two or three notes per compas.

3. All others. Each note has the duration of one compas with the exception of the punto con dos plicas which has the duration of two compases. ${ }^{191}$

Later theorists continued to discuss different styles of rhythmic interpretation and the correlation with various types of chant. Pedro Cerone followed Bermudo's thinking reusing the section quoted above and making additions. ${ }^{192}$ Pablo Nassarre in his Escuela Musica, published between 1723 and 1724 in Zaragoza, speaks of canto llano and canto mixto. By canto llano he meant the usual interpretation of equal duration as one note per compas. The term Canto mixto, on the other hand, points to its meaning - a mixture of aspects of canto llano and of canto de organo. From the latter, canto mixto takes the employment of varying durations according to the note forms so that all notes do not have the same

\footnotetext{
${ }^{189}$ Bermudo, Declaración, fol. xvii" .
}

${ }^{190}$ Duncan considers that the term psalmody as used in Spanish treatises referred to "a type of chant in which the durational value of the notes was determined by the textual accents" and so included chants other than psalm settings (Duncan, "Mexican Chant Book", 64-65). Her view will be referred to again in Chapter 4.

${ }^{191}$ This section of Bermudo's work has also been discussed in Stevenson, Juan Bermudo, 39-40.

${ }^{192}$ Cerone, Melopeo, 414-15. 
duration. ${ }^{193}$ The ecclesiastical chants which he says belong to the category of canto mixto are psalmody, hymns, Glorias, Credos and the solo Epistles, Gospels, Collects, etc. Nassarre says that the hymns of San Pedro and San Pablo as well as a few others belong to the category of canto llano while all the rest are Canto de organo (apparently using the term here synonymously with canto mixto). ${ }^{194}$

The opposing views of the two groups of theorists, the "equalists" and the "nonequalists", are to some extent resolved in the work of Juan Bermudo. He shows that different rhythmic interpretations are appropriate for different classes of plainchant. However, the problem remains that while the "equalists" did not provide for the possibility of varied duration other than that provided by the punto con dos plicas, the "non-equalists" appeared to expect that all plainchant would be notated in the note forms of mensural notation and be sung accordingly with varied duration of notes. Two of the "non-equalists" also observed that duration in chant should not be precisely measured, thus emphasizing the gap between the two types of interpretation, the one equally measured, and the other only loosely measured. The views of the non-equalists may have been representative of a reformist tradition which wished to see the performance of chant maintaining the correct Latin accent. It may not be coincidental that it was not until the mid 16th century that theorists began to differentiate between various classes of chant to be performed with or without varied durations. By that time the reformers' views may have become partially absorbed into the performance of particular chants which were by then accepted as requiring varying durations sometimes according to text accent. Further clarification of the situation may be gained from the work of Cerone although his treatise dates from the beginning of the 17th century. He spoke of the singing of chant with different durational values as a practice of "algunos modernos" whereas the singing of equal durational values for all notes "guardara

\footnotetext{
${ }^{193}$ Pablo Nassarre, Escuela Música según la practica moderna, introduction by Lothar Siemens (Zaragoza: Institución “Femando el Católico", 1980), 194-95 (facsimile edition).

${ }^{194}$ Nassarre, Escuela Música, 195-96.
} 
la orden de los antiguos". Both methods it seems were correct. His discussion also shows that notes were not to be strictly measured as occurred in "Canto de Organo". 195

The writings of the two groups suggest two clearly different chant schools in Spain during the late 15 th and early 16 th centuries. Given the connection of the first three non-equalist treatises discussed above with Cataluña, one may postulate that the different styles may have had a regional basis. A regional classification, however, is complicated by other factors such as the connection which one of the three treatises (Arte de melodia) appears to have had with the church of Toledo. The solution may lie in the existence of reformers and traditionalists who were perhaps only partially separable on regional or diocesan grounds.

${ }^{195}$ Cerone, Melopeo, 412-15, 377. 


\section{NOTATION OF THE PLAINCHANT SOURCES}

In this chapter different types of notation used in the Zamoran sources are examined. The two principal types are Aquitanian notation and square notation. Variants of these forms will be discussed, notably the late form of Aquitanian notation, as well as mensurally influenced notations. Aquitanian notation is given a more detailed wide-ranging discussion than square notation in this chapter because of the greater complexity of its diversity, while one aspect of square notation is given special discussion and analysis presented in Chapter 5. The notation of the polyphonic works will not be discussed here but in Chapter 10 .

\section{AQUITANIAN NOTATION}

Aquitanian notation is common amongst the fragments of AHPZa dating from the 12th century to probably the 15 th century. It is also present in the booklet of the Ritual and at the end of the Misal votivo.

This style of notation takes its name from the region of its origin, although it came to spread further afield through the southern part of France with centres such as Cluny, Lyon, Poitiers and Nevers lying not far to the north of the limits of its extension. Included in its sphere were the Cluniac houses of Saint-Martial, Moissac, and Saint-Yrieix. The city of Périgueux,mentioned in Chapter 2 as the home town of Zamora's first bishop (a Cluniac) who was appointed following the establishment of the Roman rite, lay well within the zone of use of Aquitanian notation. (Books from Cluny itself, however, are written in French neumatic notation. $)^{1}$ From the south of France, Aquitanian notation moved into the Iberian Peninsula and also to Naples. ${ }^{2}$

Thanks largely to the part played by Cluniac monks in the establishment of the Roman rite in Castilla-León and other parts of the peninsula, books utilizing Aquitanian notation and brought from southern France came to be used as models for peninsular

\footnotetext{
${ }^{1}$ The extent of Aquitanian notation is shown on the maps in Solange Corbin "Neumatic notations, §IV, 5: Western Europe - Aquitaine", NG 13: 138-39; and Corbin, Essai, 239.

${ }^{2}$ Suñol, Introduction, 121, 229.
} 
scribes copying the books of the Roman rite. Early important sources in Aquitanian notation were produced in San Millán de la Cogolla (Rioja) and San Juan de la Peña (Aragón).

The combination of Visigothic script with Aquitanian notation, seen in two of the AHPZa fragments ( $\mathrm{Z} 15$ and $\mathrm{Z} 202$ ), is unique to Iberian sources and dates from the period of the general spreading of the Roman rite into the central and western parts of the peninsula. It occurs in manuscripts (often fragmentary) now located in various places including Santiago de Compostela, Braga, Lisboa, and Madrid. In her study of Portuguese medieval sacred music, Solange Corbin discusses a few such fragments found in Portugal which pertain to the Roman rite and date from the 11 th and 12 th centuries. ${ }^{3}$ While the Visigothic script is known to have virtually ceased to be used in the scriptorium of the important monastery of Sahagún in León by about $1125,{ }^{4}$ elsewhere it continued to be written - although with diminishing frequency - during the 12th century, with its replacement by gothic script becoming general in the second half of that century. ${ }^{5}$ A very important large manuscript of this type is the Misal plenario from San Millán de la Cogolla (Ma BRAH 18) which is dated to the end of the 11 th century and contains liturgy of the Roman rite. ${ }^{6}$

Aquitanian notation in Spain was employed not only in its original form but also came to be modified as was pointed out by Bruno Stäblein. ${ }^{7}$ Corbin found Aquitanian notation serving as a model until the 15 th century in Portugal, ${ }^{8}$ and the situation was similar in Spain where manuscripts with Aquitanian notation continued in use into the 16th century as is evident from the work of music theorist, Gonzalo Martínez de Bizcargui, discussed in the previous chapter. In fact, copying of manuscripts in Aquitanian notation

${ }^{3}$ Corbin, Essai, 249-50, 281-82.

"Barbara A. Shiloah, "The Scriptorium of San Sahagún: A Period of Transition", in Santiago, Saint-Denis, and Saint Peter, ed. Bernard F. Reilly (New York: Fordham University Press, 1985), 44.

${ }^{5}$ J. Janini, "Liturgia Romana", Diccionario de historia eclesiástica de España, vol. 2 (Madrid: Instituto Enrique Florez, 1972), 1322. Millares Carlo mentions that the Visigothic script was used in the 12th century in Asturias, Leon, Toledo, and Portugal. See Agustín Millares Carlo, Tratado de paleografla española, 1: 179.

${ }^{6}$ Description and contents listed in Janini, Manuscritos,150-53.

${ }^{7}$ Bruno Stăblein, Schriftbild der einstimmigen Musik, Musikgeschichte in Bildern, vol. 3, pt. 4 (Leipzig: VEB Deutscher Verlag für Musik, 1975), 34.

${ }^{8}$ Corbin, Essai, 235. 
on a one-line staff is thought to have continued to be more frequent on the peninsula than copying in square notation on a five-line (or four-line) staff until the 15 th century; Corbin has given c. 1450 as the date when one-line notation began to be less common in Portugal. ${ }^{9}$ The persistence of Aquitanian notation is confirmed by chant books and numerous fragments extant in Spanish libraries, including examples found in the Zamoran sources under study here.

The widespread usage of Aquitanian notation through southern France and the Iberian Peninsula suggests to the researcher the possibility of discovering features which might be characteristic of the notation of different localities and times. However, on the comparative study of types of earlier forms of Aquitanian notation, Huglo has commented:

Les différentiations [sic] de la notation aquitaine d'un manuscrit à un autre sont assez difficiles à observer puisque les neumes se réduissent [sic] à des groupements de points. Les observations se réduisent donc à l'étude du quilisma et du guidon en fin de ligne: mais les différenciations rencontrées des deux côtés des Pyrénées sont très minimes. ${ }^{10}$

Accordingly the forms of quilisma and direct in the AHPZa fragments will be discussed in this chapter.

The presence of one or more coloured staff lines may also be of assistance in the identification of region and date. The earliest manuscripts of Aquitanian notation to use a staff utilized the dry-point lines also employed for the text. By the 12th century a coloured line came to be used quite frequently (having been used only occasionally in the 11 th century ${ }^{11}$ ), perhaps in response to the system of coloured lines promoted by Guido of Arezzo. Sources in Aquitanian notation associated with the Iberian Peninsula show a similar general pattern of line use as may be seen from the following details compiled through a study of Fernández de la Cuesta's catalogue of sources from the Middle Ages located in Spanish libraries and of sources of Spanish origin now in London and Paris. ${ }^{12}$ Amongst the small number of sources from the 11th century listed in the catalogue as using Aquitanian notation, most have a dry-point line and there are none named as having a

'Ismael Fernández de la Cuesta, Manuscritos y fuentes musicales en España. Edad media (Madrid: Editorial Alpuerto, 1980), 11; Corbin, Essai, 259.

${ }^{10}$ Huglo, "La pénétration", Revista de Musicología 9 (1985): 256.

${ }^{11}$ David Hiley, "Notation, §III, 1: Western, plainchant" NG 13: 350.

${ }^{12}$ Fernández de la Cuesta, Manuscritos. 
coloured line. The majority of those from the 12 th century also have a dry-point line, a smaller group are without line, a still smaller group (all from the north-east of the peninsula) use a red line, and one has a charcoal line. In the sources of the 13th century, a change is found with the coloured line outnumbering the dry-point line. Most examples of the coloured line from that period are red, with a few sources mentioned as having a yellow, green, black, or charcoal line. By the 14th century, the proportion of sources using Aquitanian notation is much lower and amongst these the dry-point line is still found although outnumbered by the red line; for the period, the only other colour named is black but this is very infrequent. Sources with both a red and a yellow line are found in the north-eastern part of the peninsula from mainly the 13 th century.

Even by the time a line had come into regular use for orientation of neumes in Aquitanian notation (this had occurred by the middle of the 11 th century), identification of pitch and mode continued to be complicated by the fact that clefs were not frequently used and by the varying pitch of the line. As clefs are not found in any of the Zamoran sources in Aquitanian notation, the issue of pitch identification needs to be treated in some detail here. The initial guide to pitch determination comes from the placing of the final of a chant in relation to the staff. The third degree of an authentic mode and the final of a plagal mode were usually placed on the one-line staff, the main exception to this rule being the fourth mode for which the second degree might be placed on the line instead of the final. ${ }^{13}$ The mode-line relationship for Stäblein was a feature of the "classic stage" of Aquitanian notation (well exemplified by the early 11 th-century $\mathrm{Pa} 903$ ) and is to be found employed in numerous sources. ${ }^{14}$ To fix the mode and pitch of chants more precisely, it is necessary to use information such as that identifiable from psalm tone endings (differentiae) and verse tones. Certain note forms (such as the quilisma) usually associated with particular intervals, are sometimes helpful in establishing pitch. It may also be necessary to make

${ }^{13}$ Stäblein, Schriftbild der einstimmigen Musik, 41, 56. On the significance of the staff line in $\mathrm{Pa}$ 903, see $P M$ 13: 160-61. An example of a manuscript found to use the $\mathrm{E}$ line for the fourth mode is Tol 44.2 . See Ronald Thomas Olexy, "The Responsories in the 11th Century Aquitanian Antiphonal Toledo, Bibl. cap. 44.2", (Ph.D. diss., Catholic University of America, 1980), 41. Another exception has been shown by Leo Treitler. He found that in the 11th- and 12th-century Aquitanian repertory of versus the fourth degree was placed on the line in the G mode. See Leo Treitler, "The Aquitanian Repertories of Sacred Monody in the Eleventh and Twelfth Centuries", (Ph.D. diss., Princeton University, 1967), 71.

${ }^{14}$ Stăblein, Schriftbild der einstimmigen Musik, 41 n. 372 lists examples of manuscripts. 
reference to other sources with a clef or to a tonary in which the mode is indicated. In sources where the typical mode-line relationship is not present, a further complication may arise in the changing of the pitch associated with the line within single pieces which may or may not be marked by the use of a direct or other sign; an example of such a source in Aquitanian notation is the hymnal of Moissac (Rome, Bibl. Apost. Vat., Rossi. 205). ${ }^{15}$

The continued use of Aquitanian notation in Spain until the 16th century has already been mentioned briefly. The modifications which appeared in the form of the notation mean that it is useful to employ the phrase "late Aquitanian notation" to designate the altered style. ${ }^{16}$ From the 13th century onwards, the traditional style of Aquitanian notation of earlier centuries was altered in varying degrees more or less significant. To some extent this type of notation demonstrates a transitional stage between "classic" Aquitanian notation ${ }^{17}$ and square notation, but as it was coexistent with square notation and appears to have taken over a few of the latter's features it can also be seen as a contact notation. Late Aquitanian notation was by no means uniform and is found with a number of variants, some of which will be discussed here.

Little research has been focused on the later modifications of Aquitanian notation and the comments made by Bruno Stäblein in his Schriftbild der einstimmigen Musik remain of major significance for this area. The first characteristic of the changes which he pointed to was the growing tendency to the use of square note forms observable from as early as the 11 th century in for example $\mathrm{Pa} 903 .^{18}$ This tendency while still sporadic during the 12th century became marked in late Aquitanian notation after c. 1200. Stäblein put forward three classes into which the various types of Aquitanian notation from 1200 may be placed. His classification follows:

\footnotetext{
${ }^{15}$ Stäblein, Hymnen, 523.
}

${ }^{16}$ The Spanish music theorists who discussed notation on one line never employed the term "Aquitanian" to describe it. The term is used here, however, because of the continued presence in the examples studied of the note forms (although modified to varying degrees) of Aquitanian notation.

${ }^{17}$ Stäblein, Schriftbild der einstimmigen Musik, 41. A fundamental style of the "classic stage" is illustrated by Stäblein in the "Neumentabelle" opposite p. 33.

${ }^{18}$ Stablein, Schriftbild der einstimmigen Musik, 66. 
(a) almost unchanged with the exception of the squaring of the punctum;

(b) modified Aquitanian notation of two styles, northern and southern;

(c) square notation with traces of Aquitanian. ${ }^{19}$

Class (b) was further elaborated by Stäblein. The northern style he identified as showing affinity with the French square notation; the southern style he identified as remaining closer to the older Aquitanian note forms and was found especially on the Iberian Peninsula. ${ }^{20}$ The example of the northern style given by Stäblein does not use lozenges and sometimes ligates puncta occurring in two-note or larger neumes. The pes is unusual also in its resemblance to a pair of ligated puncta having a square-shaped upper head instead of the usual downwards pointing, lozenge-like upper head of the typical Aquitanian pes form which continued to be used in the southern style of the developed notation. The kinship of this northern style of notation to the Aquitanian is however notable in the use of the opposed heads of the pes. The northern style of clivis illustrated by Stäblein parallels that of the northern pes with its two ligated puncta, while the southern style of clivis is similar to the classic Aquitanian form with a lozenge-shaped upper note which has, unusually, a tail descending at an angle from the left. ${ }^{21}$

In late Aquitanian notation the use of a multi-lined staff can sometimes be observed, a development which may reflect the effect of contact with square notation. Extra lines may also have been necessary for accurately aligning larger notation less easy to judge by eye alone. Such lines are often only lightly drawn with one or more inked in red or yellow. ${ }^{22}$

Corbin also discussed late Aquitanian notation which she called "notation aquitaine évoluée" or "notation aquitaine décadente". ${ }^{23}$ She saw it as differing from the standard

\footnotetext{
${ }^{19}$ Stäblein, Schriftbild der einstimmigen Musik, 66-67.
}

${ }^{20}$ Stäblein, Schriftbild der einstimmigen Musik, 66.

${ }^{21}$ Plates 43a-c and 44 in Stäblein, Schriftbild der einstimmigen Musik illustrate these styles. Further examples of late Aquitanian notation dating from the 13th or 14th century are found in Paleographie musicale, vol. 2, Le répons-graduel Justus ut palma, reproduit en fac-similé d'après plus de deux cents antiphonaires manuscrits d'origines divérses du IXe au XVIIe siècle (1891; reprint, Berne: Herbert Lang, 1974), plates 104-7.

${ }^{22}$ Examples are found among the Zamoran sources and will be mentioned later. See also $P M$ 2: plate 107 and Stäblein, Schriftbild der einstimmigen Musik, plates 36-38.

${ }^{23}$ Corbin, Essai, 248, 250. 
Aquitanian notation in a loss of the usual neume groups, and an increase in the size of the notes which became square shaped. ${ }^{24}$ In Portuguese manuscripts the lowest note of a semitone appears occasionally as a lozenge or "virgule". 25

In addition, she described a form which she called "notation portugaise" and which she viewed as a direct growth from Aquitanian notation that emerged at the end of the 12th century. Portuguese notation continued in use into the 15 th century. It was a diastematic notation using one red line, its notes being larger and more angular than those of Aquitanian. The distinctive characteristic of this notation was the frequent use of a lozenge as the lower note of a semitone. ${ }^{26}$ Amongst the Zamoran sources such a use of the lozenge is not found. The facsimiles given by Corbin as examples of Portuguese notation show the preponderance of square-shaped notes and the use of a stemmed square head instead of a lozenge-like head for the pes, these being characteristics also seen in late Aquitanian notation. ${ }^{27}$

The forms of Aquitanian and late Aquitanian notation used in the Zamoran fragments will be studied here in order to highlight features which may serve to assist in future identification of the provenance of the fragments and also to add to the sparse information available with regard to the notation as it was used in Spain. Reference will be made to the discussions of the Spanish music theorists Durán and Bizcargui about one-line notation.

\section{Zamoran Sources}

The Zamoran sources of Aquitanian and late Aquitanian notation may be divided into two classes. Class 1 may be said to use Aquitanian notation similar but not identical to Stäblein's classic form; it contains AHPZa fragments from the 12th to the mid 13th century. The class may be further subdivided into two groups, the first, 1a, containing most of the earliest fragments, all dating from the 12th century. Class $1 \mathrm{a}$ is characterized by the avoidance of the lozenge-shaped punctum, a rounded or more or less square point being used instead. (This feature will be discussed further below.) The second group, 1b,

${ }^{24}$ Corbin, Essai, 250.

${ }^{25}$ Corbin, Essai, 250-51. Other means of semitone indication in Aquitanian notation will be discussed later in this chapter.

${ }^{26}$ Corbin, Essai, 251.

${ }^{27}$ Corbin; Essai, plates 7-9. 
includes further 12th-century fragments as well as fragments believed to date from the first half or middle of the 13th century; in these the lozenge-shaped punctum is employed as well as the more or less square one. Class 2 contains the sources of late Aquitanian notation, all dating from probably the late 13 th, the 14 th, and the 15 th centuries. Stäblein's three classes of modified Aquitanian notation are observable within the present class 2 which contains a considerable variety of styles. These sources may also be said to align with his idea of a southern style in late Aquitanian notation. Corbin's observation of the loss of the usual Aquitanian neumes groups is not generally applicable to the sources studied here and it may be hypothesized that this characteristic was more dominant in Portuguese forms. The two classes are illustrated in Table 1 later in this chapter; this table also gives the sources pertaining to each.

As the two classes have much in common including similar variations found in each, aspects of both as they occur in the Zamoran sources will be discussed together. These aspects are those in which major variations occur or which are of interest for other reasons such as their discussion by Spanish music theorists. The aspects include size and general shape, lozenge use, staff, direct, virga, quilisma, liquescent neumes, torculus and porrectus; each will be discussed separately below.

Size and general shape. In general it may be said that the size of the neumes increases from the early to the late sources. The size increase results in the need for a greater amount of space dedicated to notation and is reflected in the measurements of distance between staffs given in the source descriptions of Appendix 1. In class 1 (12th and 13th century) fragments, the distance between staffs ranges from approximately $13 \mathrm{~mm}$ to $22 \mathrm{~mm}$, but in the late Aquitanian sources the corresponding measurements range from $15 \mathrm{~mm}$ to $75 \mathrm{~mm}$. In the sources with large notation more space is devoted to notation in relation to text than in sources with smaller notation. Thus, five text lines are occupied by

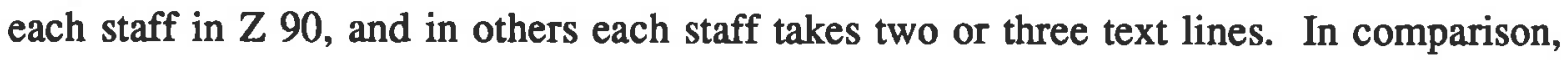
smaller notation, found in usually earlier sources takes only one text line, so that alternate lines may be used for text and music. 
Similarly between early and late sources there is a change in the shapes of the various components of Aquitanian neumes. The somewhat rounded and imprecise shapes of most of the earliest sources are replaced by characteristically square, angular and often precise shapes in later sources. These more angular shapes give late Aquitanian notation an appearance resembling that of square plainchant notation. The puncta generally become square with precise, angular corners, and lozenges also become more carefully formed with angular, precise shapes. In addition to their use in descending neumes or in descending parts of longer neumes, marked lozenge-shaped strokes of different sizes are sometimes used in late sources as both the upper and lower heads of virgae (Z 90, Book I, Misal votivo) or as only the lower head of virgae ( $\mathrm{Z} 269$ ). The lozenge shapes of virgae are often set at a different angle from the individual lozenges of the typical clivis or climacus (see Table 1 for the clivis). A small lozenge is also used in the epiphonus and like the lozenge forms of other neumes becomes more precisely formed in late sources. A comparison of forms shows increasingly angular shapes in both punctum and virga. In addition, such a comparison shows the replacement in some late sources of the lozenge-shaped upper head of the virga by a more or less square head. It also shows another feature of some sources of the late notation: the marked contrast between hairline stems and thick note-heads or other strokes not evident in the smaller, earlier notations. This may be seen in Table 1.

The axis of the notation in the Zamoran sources is for the great majority the usual one of Aquitanian notation in which ascending series slope to the right and descending series are placed more or less vertically. ${ }^{28}$ The two exceptions are Z 100 and the Misal votivo; these will be returned to below.

Lozenge. The individual lozenge of Aquitanian notation which represents a single pitch is regarded as a form of punctum. ${ }^{29}$ It may be found in some examples of "classic" Aquitanian notation such as $\mathrm{Pa} 903$. With only one exception the lozenge is not used in isolation in the Zamoran sources, but rather forms part of descending groups. The exception is $\mathrm{Z} 219$ in which lozenge-shaped puncta are regularly used in isolation together with

\footnotetext{
${ }^{28}$ The Aquitanian axis is shown in Solange Corbin, "Neumatic notations, §II: Central and western Europe", $N G$ 13: 131.

${ }^{29} P M$ 13: 171.
} 
occasional rhomboidal puncta in isolation. In that source lozenges are found in place of the usual more or less square puncta in neumes such as the pes and scandicus, and also at the bottom of descending series of pitches such as occur in the clivis and climacus. There are also occasional instances in which the difference between a lozenge and a more or less square punctum is not clearly defined and a punctum placed at an angle thus resembling a lozenge may be found in isolation.

The absence of the lozenge from neumes such as the clivis and the climacus is a feature of the class 1a fragments. These fragments, most of the 12th-century Zamoran sources, do not use the lozenge, simply using instead the ordinary punctum. ${ }^{30}$ Another of the 12 th-century fragments, $\mathrm{Z} 268$, is ambiguous in its use of lozenge and punctum as the two there appear to be interchangeable at times. Amongst the 13th-century Zamoran sources, the lozenge is used consistently and continues as a component of the notation in most later sources with the only exceptions being the fragments of Book G (14th or 15th century). In the sources without the lozenge, the puncta of descending passages are no different from isolated or rising puncta. The use of the lozenge is shown in the illustrations of the clivis in Table 1.

Staff. The Zamoran sources may be observed to have used a staff in the great majority of cases. With only very few exceptions, lines ruled in manuscript preparation which might be used for text or music have been utilized. Such lines were often coloured for use as a staff. In the few examples where no line is apparent, a dry-point text line may well have been used for alignment during copying but has become invisible. Diastematy is in general good, and is weakest in some of the class 1 fragments especially those of class 1a such as $Z 15, Z 202$, and $Z 218$.

The staff types in sources of Aquitanian notation connected with Spain have already been discussed. The Zamoran sources show a similar picture to these. The earliest, those believed to be from the 12 th century, mainly use a dry-point line as is the case with the Spanish sources generally. Two have a yellow line and one a red line while no line is visible in a further one. The yellow line was not found in the Spanish sources of this

\footnotetext{
${ }^{30}$ The sources are $Z 15, Z 202, Z$ 218, and the Book A fragments.
} 
century listed by Fernández de la Cuesta, an observation which suggests two alternative conclusions: firstly, the dating of the two fragments, Z 197 and Z 268, on palaeographic grounds may be too early, and secondly, the use of the yellow line began in sources perhaps those in use in western Spain - earlier than has previously appeared to be the case in Spain. Class 1a is consistently without a coloured line. The 13th-century Zamoran sources, as with the general results, mainly use a coloured line; however, the preferred colour here is yellow rather than red. This variety in line is reflected in class $1 \mathrm{~b}$ with its 12 th and 13 th-century sources. Class 2 sources mainly use a single red line, but a yellow staff line is found in the 14 th-century $Z$ 219. The dry-point line ceases to be used as the staff line in the Zamoran sources after the 13th century. The use of a coloured staff line (red, yellow, or black) is characteristic of class 2. The preference for a red line in the later period is also shown in the general Spanish sources. Five late sources take text lines as further guides for the notation in addition to the coloured line which forms the principal single line of the staff. In these cases the manner in which the extra text lines are employed varies: they may be used with or without precision in their guidance of placing notes in spaces or on lines. There are no cases of two coloured lines in a staff in the Zamoran sources. Furthermore, there is no evidence of the colour of the line being related to specific pitches or modes.

The lack of clef signs in the Zamoran sources has necessitated employment of the means already outlined in this chapter for determining pitch. This has been successful for the majority of the sources and their chants, the exceptions mostly being due to poor legibility. The usual mode-line relationship has been maintained in the great majority of the sources. ${ }^{31}$ The only mode which usually shows variation in pitch of line is number four; in the early Zamoran sources this is found to be the case. The two fragments with Visigothic script and Aquitanian notation, Z 15 and Z 202, both take E as the line pitch of mode four; all other sources in which it has been possible to determine the pitch take $F$ as the line pitch in the same mode. Only one other exception to the usual mode-line relationship is found. This occurs in the section in Aquitanian notation at the back of the Misal votivo

\footnotetext{
${ }^{31}$ Mode one - line F, mode two - line D, mode three - line G, mode four - line F, mode five - line A, mode six - line F, mode seven - line B, mode eight - line G.
} 
where the Office of the Dead responsory Libera me domine de morte occurs. The usual mode of the chant is one and its occurrence earlier in the Misal votivo has the usual final of $\mathrm{D}$ as well as beginning on that note. ${ }^{32}$ The line might therefore be expected to have the pitch $\mathrm{F}$, but instead it takes the pitch of the final.

The subject of pitch in one-line notation was discussed by various Spanish music theorists of the 15th and 16th centuries as has already been discussed in the previous chapter. They, of course, did not use the term Aquitanian notation but simply referred to the use of one line (e.g. "canto llano de vna regla"33). It is especially the work of Bizcargui that identifies this one-line notation as Aquitanian because of his inclusion of clear illustrations very like its well known forms. The standard mode-line relationship found in the Zamoran sources is identical with that taught by the theorists. With regard to the variable line pitch of mode four, the theorists acknowledge the two possibilities, E and F. Estevan and Duran both recognized $\mathrm{F}$ as the more usual line pitch for mode four. ${ }^{34}$

In the hymn Eterna xpisti found in Z 3, an example appears to occur of a change in the pitch of a one-line staff without any indication by means of direct, letters, or other method. In this case the line changes from the initial $F$ to $G$ and back to $F$. A very similar change occurs in the Moissac hymnal within the same melody. ${ }^{35}$

Direct. A greater variety of forms was used for the direct than for the note shapes of Aquitanian notation. Study of published facsimile examples and manuscripts available to this writer suggests that the forms of direct in Aquitanian sources may be largely grouped into two broad types. In both types, the direct has a more or less straight line usually tilted to the left. Attached to this line is a head which in the first type is on the right of the line, e.g. $F$, and in the second type on the left, e.g. $\quad$. The head occurs in varying positions on the line or stem and is used to indicate the pitch. The first type with dextral head is found principally in French sources: e.g. Pa 903 and $\mathrm{Pa} 778 .^{36}$ The second type

\footnotetext{
${ }^{32}$ The Liber Usualis with Introduction and Rubrics in English (Tournai: Desclee, 1963), 1798-1799; Walter Howard Frere, Antiphonale Sarisburiense, vol. 1 (1901-24; reprint, Farnborough: Gregg Press, 1966), 99; Misal votivo fol. $31^{\text {r. }}$.

${ }^{33}$ Bizcargui, 1528, fol. $\mathrm{d}^{\mathrm{r}}$.

${ }^{34}$ See page 65, n. 70.

${ }^{35}$ This example is further discussed in Chapter 8.

${ }^{36} \mathrm{~A}$ facsimile example of the first manuscript is found in $P M 2$, plate 97 and of the second in
} 
with sinistral head is found principally in sources of the Iberian peninsula: e.g. Ma BRAH 51, and Toledo, Biblioteca Capitular Ms. 39.12. ${ }^{37}$ There is evidence to suggest that the sinistral head came to be preferred more widely in the 13th and 14th centuries ${ }^{38}$ and may have been in response to the practice of using a direct with sinistral head in square notation. Both the possible regional and chronological associations of the types of direct need, however, to be further investigated.

The different forms of direct in the Zamoran sources are illustrated in Table 1. There is a clear predominance of the sinistral head, thus lending support to the suggestion of Iberian preference for this class of direct. The most frequently found direct is the simple one in which the sinistral head is placed at the top of the stem. It is found in fragments from the 12 th century to the 15 th century and is associated particularly with notation classes $1 \mathrm{~b}$ and 2. An unusual direct is that found in Group $\mathrm{H}$; in these fragments an Aquitanian epiphonus is utilized. In Book I a sign with the form of a plica is employed as direct. The direct is completely absent from only a small number of sources including the early Z 202. In a few other sources, especially earlier ones, the direct occurs irregularly. The absence or irregular use of the direct is mainly found in notation class 1a fragments.

Bizcargui discussed and illustrated the change of line pitch within a single chant by means of the direct. Only one example of the practice has been found amongst the Zamoran sources examined in detail, this being in $\mathrm{Z} 68$ (Book $\mathrm{C}$ ) where a direct is given to indicate a change of pitch in the middle of the staff line. There the mode one Kyrie Clemens rector initially takes the expected $\mathrm{F}$ as the pitch of the line, this being changed to B by a direct. The return to the opening line pitch is not marked by a direct or any other sign but may be established by reference to other sources. ${ }^{39}$

Virga. Amongst the Zamoran sources the virga usually forms a part of neumes such as the pes and the torculus, occurring where two or more notes ascend over a single

Stäblein, Schriftbild der einstimmigen Musik, plate 36.

${ }^{37} \mathrm{~A}$ facsimile example of the Toledo manuscript is found in $P M 2$, plate 103.

${ }^{38}$ See for example $P M 2$, plates 104 and 105.

${ }^{39}$ In fact, the line is almost invisible and the pitch placement is therefore not certain. The Kyrie is discussed again in Chapter 6. 
syllable, the top note being written as a virga. It is not used in isolation. Such use of the virga is typical of later forms of Aquitanian notation in general. ${ }^{40}$

The typical Aquitanian virga, with its two heads at top and bottom, is employed in most of the Zamoran sources. Amongst the 12th-and 13th-century fragments in which the notation is generally small and employing less square forms, the virgae tend to vary in the placing of the lower head. In general, it is placed to the right of the base of the stem, at other times occurring centrally or to the left. (See Table 1.) There appears to be no significance in this variation. Amongst the 13th-century fragments with more square forms as well as the later Zamoran sources, there is a tendency to reduce the size of the lower head so that it sometimes disappears altogether. Moreover, in the later sources, greater consistency is found in the placement of the lower head at the right of the stem base. In some fragments the lower head in places disappears altogether while being clearly formed in other examples of the same fragments. Z 100 is an example of this practice. ${ }^{41}$ Marked diminution of the lower head is however by no means universal in the later sources as may be seen, for example, in Book $I$.

Of the two special forms of virga which have been identified in Aquitanian notation, the semicircular virga and the horned virga, ${ }^{42}$ only the first occurs amongst the Zamoran sources. The semicircular virga is present in the 12th-century fragments of Book A in addition to the standard virga. It has the form $\bullet$. (The sign is visible in Plate 1 in the top left line of music above the second syllable of the word "impleuit".) Like the standard virga it does not occur in isolation and is found at the topmost point of rising passages at the end of neumes with two or more notes. The semicircular virga is used in a similar manner in $\mathrm{Pa} 903$ but there is not limited to being the final note of neumes. ${ }^{43}$ Its use as the highest note of a scandicus has been said to be very rare and it does occur in such a position in the Book A fragments. ${ }^{44}$ In $\mathrm{Pa} 903$ the semicircular virga was used to indicate

\footnotetext{
${ }^{40} \mathrm{~A}$ virga could be used in isolation over a syllable with a higher pitch in the earlier Aquitanian notation; it is sometimes used in this manner in Pa 903 (PM 13: 166).

${ }^{41}$ There is no reason to assume changing notators to be the cause of this variance.

${ }^{42}$ The two forms are discussed in detail in $P M$ 13: 166-70; they are discussed briefly by Corbin in "Neumatic notations, §IV, 5: Western Europe - Aquitaine", NG 13: 141.

${ }^{43} P M$ 13: $157,166$.

${ }^{44} P M$ 13: 166.
} 
the upper note of a semitone and thus would occur, for example, in a pes in which the interval spanned is a minor second. On the other hand, in $\mathrm{Pa} 903$ the horned virga was found to be used with the interval of a major second and always took the top note of that interval. In that manuscript, the horned virga was only used for the pitches e natural and $b$ natural, as well as very occasionally for $a^{45}$

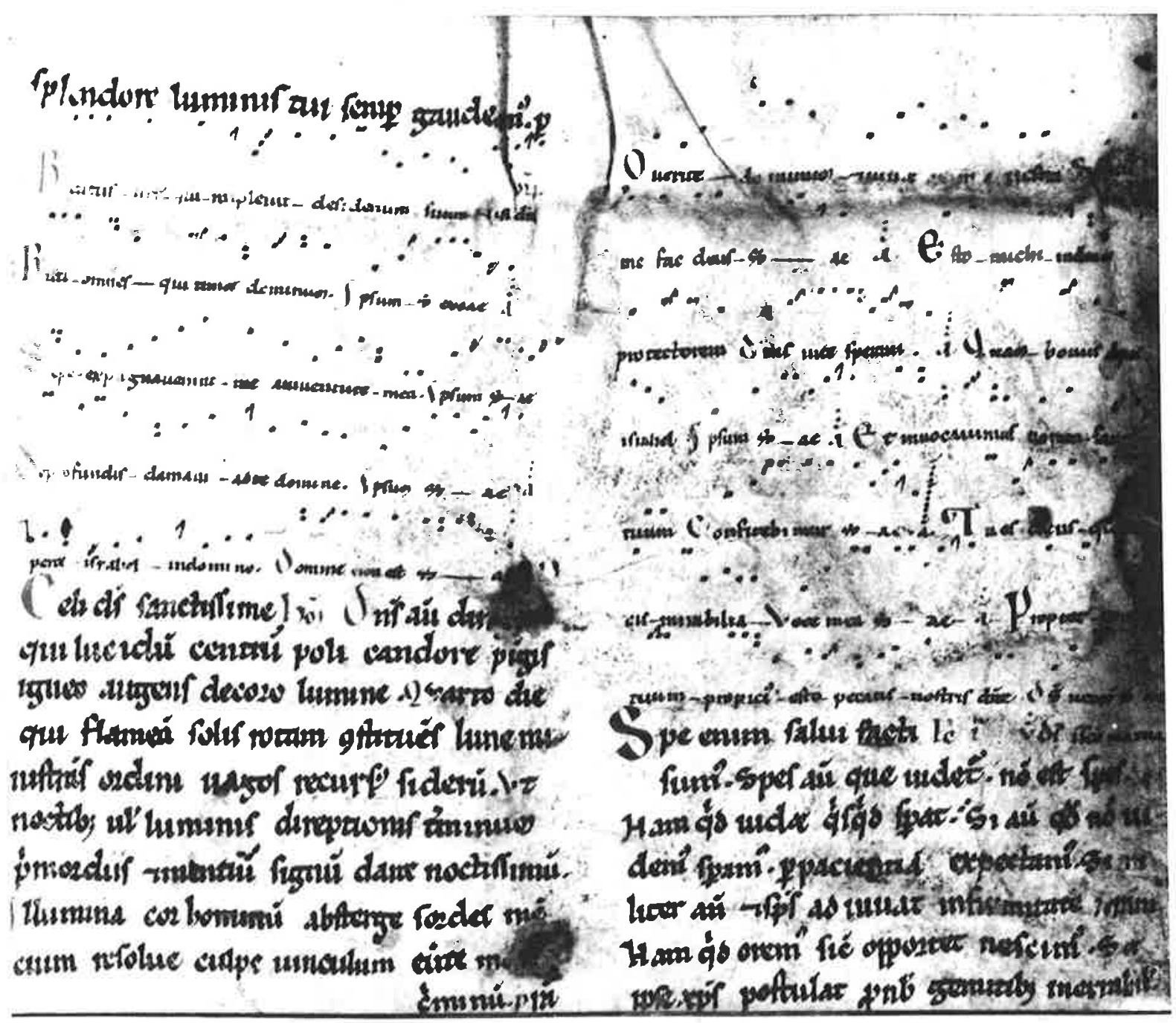

Plate 1: Part of Z 196 (Book A)

${ }^{45} P M$ 13: $169-70,173-74$. 
Although pitch is sometimes difficult or impossible to determine in Book A, identification has been possible for sufficient numbers of chants to say tentatively that the semicircular virga in these fragments is used only for $\mathrm{b}$ natural and e natural. (The means by which the pitch has been established is discussed above.) This then suggests that the usage in these sources was not that of the semicircular virga in Pa 903 but rather that of the horned virga. In Book A the semicircular virga always forms the upper note of a major second, but its use always as the final note of a neume differentiates it from the horned virga of $\mathrm{Pa}$ 903. In Book $\mathrm{A}$, this virga is used principally as the second element of examples of the pes, and secondly as the third element of examples of the scandicus.

Quilisma. The quilisma occurs in both early and late Zamoran sources of Aquitanian notation. This is of particular interest as it was not used in contemporary square notation. It is a sign which never occurs in isolation. It is always followed by a virga and is usually preceded by a lower note so as to form a quilisma group. ${ }^{46}$ In the Zamoran sources the quilisma is always part of such a group and the quilisma itself is never found at the beginning of a new syllable.

Two principal types of the quilisma group have been identified in the sources and a variety of styles of each type is also observable. The first type is represented by the form $\boldsymbol{r}$. It is characterized by the straight or almost straight line which may be drawn from the left side of the head of the upper virga along the right side of the quilisma to the right of the low punctum. The body of the quilisma itself is therefore entirely to the left of that line. The low punctum is placed below the quilisma. The top of the quilisma is usually lower than the head of the virga and may have a fine line descending from its lower left corner. The second type of quilisma group is exemplified by the form. . In this type a line drawn between the left of the upper virga head and the low punctum would cut through the body of the quilisma. The head of the virga is usually attached towards the left side of the quilisma although there are some late sources in which it is attached at the far right. The punctum is placed to the side of the lower part of the quilisma rather than below as is the

${ }^{46}$ The "quilismatic group" as well as derivation from a grammatical sign are discussed by Eugène Cardine, Gregorian Semiology, trans. Robert M. Fowels (Solesmes, 1982), 199. On the quilisma as a virga see $P M$ 13: 175. 
case in the first type. Table 1 shows the two types of quilisma group and the variety in the forms may be observed there. The distinction between the two types is indefinite only rarely. Within the large majority of sources the same type is used consistently. The first type is found in most early sources while the second type is predominant in later sources. While the quilisma itself has a curved form in most of the sources, some from the late 13th or 14th century and later show a square or rhomboidal form amongst both types 1 and 2 . That of the 12th-century Z 218 is particularly unusual in the placing of the virga head considerably above the curve of the quilisma. Also notable in the same source is the hook-like appearance of the quilisma.

The first type of quilisma group occurs in all notation class 1a fragments as well as in some class $1 \mathrm{~b}$ and class 2 sources including 14th-century sources. The second type occurs in the 12th-century fragments of class $1 \mathrm{~b}$ as well as later class $1 \mathrm{~b}$ and class 2 sources but is found principally in the later sources in large notation.

The association of the quilisma group with the interval of a minor third in which a semitone occurs between the quilisma and the virga above is well known in Aquitanian notation. ${ }^{47}$ As far as it has been possible to ascertain this rule is followed strictly in all the Zamoran sources and there are no instances of a quilisma group covering an interval greater than a third. The quilisma is almost entirely present as the central note of the melodic patterns a-b-c or d-e-f. Some exceptions have been identified which take the pattern g-a-b-flat in fragments from the 12th to 14th centuries. These are in Z 197, Z 59, Z 53, and Z 219 and are found in a single mode one chant, three mode five chants, and two mode six chants. The b-flats of the first three fragments are indicated in other sources. ${ }^{48}$ B-flats have been found shown in other sources of two of the three chants with this quilisma in $\mathrm{Z} 219 .{ }^{49}$ These chants are in modes 5 and 6. A fourth chant has several instances of the g-a-b-flat quilisma which is followed by the descending notes a-g as part of

${ }^{47} P M$ 13: 176. Cardine, Gregorian Semiology, 200.

${ }^{48}$ Mode one responsory, Peccata mea, in Paléographie musicale, vol. 12, Antiphonaire monastique XIIIe siecle codex F. 160 de la bibliothèque de la cathédrale de Worcester (1922; reprint, Berne: Herbert Lany, 1971), 62; Mode five gradual, Domine dominus noster, in Graduale Sarisburiense, 150; mode five responsory, Vidisti domine, in Worcester 160 (PM 12: 275).

${ }^{49}$ Graduale Sarisburiense 315, 331; Worcester 160 (PM 12: 173, 184-85). 
a longer melisma. This is the responsory Libera me domine de morte from the end of the 14th-century section of the Misal votivo. It has not been possible to find verse tones which match those of the Zamoran source, but the chant does use b-flats in other sources ${ }^{50}$ and is usually in mode one as has already been mentioned above.

The theorists Durán and Bizcargui who both discussed pitch and one-line notation also identified the placing of semitones in such notation. In the case of Duran, the location of the solmization syllable $m i$ or of semitones (i.e. the lower note of semitones) and the solmization syllable $f a$ was discussed. It has already been proposed that he thought of these as signalled in the notation by accidental signs. ${ }^{51}$ Only one instance of the use of an accidental in the fragments has been observed. It occurs in Z 226 and indicates the use of b-flat in the hymn Magne dies. Bizcargui, on the other hand, referred to the location of the puntos de semitono, by which he meant mi, and also to the location of notas de fas. From his illustrations of the signs of one-line notation, we know the form of the punto de semitono, ${ }^{52}$ and from comparison with the Zamoran sources it is apparent that the lower curve of Bizcargui's punto de semitono in fact represents the quilisma and its upper curve represents the top note of a quilisma group. The significance of the punto de semitono as $m i$ is in accordance with the finding of the pitch of the quilisma in the Zamoran sources which could also be said to represent mi, the lower note of a semitone. Bizcargui's reference to the location of notas de fas cannot be associated with another note form and so it may be hypothesized that these were represented by the upper curve of the punto de semitono (i.e. the top note of the quilisma group). Whether or not the figure named as the punto cabeçudo by Bizcargui is also associated with $f a$ as was considered in Chapter 3 remains unclear.

The illustrations of the punto de semitono in the two versions of Bizcargui's treatise studied in Chapter 3 are not identical, that of 1511 having the closer resemblance to the forms of the quilisma group of the Zamoran sources. Both forms belong to type 2. A

\footnotetext{
${ }^{50}$ Antiphonale Sarisburiense, 584; Liber Usualis, 1798.

${ }^{51}$ See page 65.

${ }^{52}$ see page 75.
} 
figure illustrated but unidentified by Durán is like the type 1 quilisma and may be seen below in Table 2 .

In their discussions of pitch and the one-line staff, both Durán and Bizcargui mention the possible use of b-flat in mode five, and Durán also mentions its possible use in mode two. ${ }^{53}$ It is apparent, however, that b-flat could also be used with other modes; perhaps the specification of mode five as possibly using b-flat by both theorists is indicative of that being the mode in which they knew it to be most commonly employed. This hypothesis receives some confirmation from the observation that in the Zamoran sources mode five chants most commonly use the g-a-b-flat quilisma group.

Liquescent neumes. Liquescent neumes are found throughout the range of the Zamoran sources in Aquitanian notation. The signs maintain their usual frequent association with potentially liquescent syllables throughout the sources with only one exception. ${ }^{54}$ That exception is the booklet at the rear of the Ritual; there, the cephalicus is used principally in association with accent. 55

The two liquescent signs occurring most frequently are the epiphonus and the cephalicus. These are shown in Table 1. They are principally used in isolation. More rarely, a probably liquescent indicator is added to the final virga of a pes, to a punctum, to a strophic sign, and to other neumes. ${ }^{56}$ Examples of these are found in Z 239.4 , Z 59 .4 , Book C $y$, and Book D y . In some sources, a cephalicus or epiphonus is found as part of a neume of two or more notes.

The ascending stem slanting to the right is characteristic of the epiphonus of Aquitanian notation. ${ }^{57}$ Variation is observable in Table 1 in the shape and the angle at which the lower head of the epiphonus is set. The earlier sources prefer a lozenge shape for this head from which the stem may form a continuation upwards from the lower right side. While the same style is also preferred in the later sources, a few replace the lozenge-shaped head with a more or less square or rhomboidal head placed parallel to the staff (Group F, Book G, and

\footnotetext{
${ }^{53}$ Durán, Comento, fols. cii" ${ }^{\mathrm{v}}$-ciiir; Bizcargui, 1528, fol. a $[8]^{x}$.

${ }^{54}$ The method of determining potential liquescence of text syllables is discussed in Chapter 5.

${ }^{55}$ This use of the cephalicus will be treated in detail in Chapter 5.

${ }^{56} \mathrm{~A}$ wide variety of liquescent neumes used in Pa 903 are set out in $P M$ 13: 158-59.

${ }^{77}$ It may be seen in the forms of the epiphonus in $\mathrm{Pa} 903$ and $P M$ 2, plates $84,85,86,88$, etc.
} 
Group H) and Z 226. The same sources which prefer the last type of epiphonus also prefer a virga in which the upper head is more or less square and placed parallel to the staff.

The form of the cephalicus is more variable than that of the epiphonus as may be seen in Table 1. In most it takes a form of the typical cephalicus with its curved form $\uparrow$; this is also found in $\mathrm{Pa} 903$. The small head at the base of the virga-like sinistral stem may be placed towards the right or the left. Later sources show a preference for this head to be set clearly at the left of the stem. In some sources the left stem is replaced by a lozenge, such as occurs in the Misal votivo and Z 202, the neume as a result having an appearance quite unlike that of the typical cephalicus illustrated above. That such signs are indeed cephalici is confirmed by comparison with other sources in which a known cephalicus form is sometimes found in corresponding positions. ${ }^{58}$ Furthermore, these sources contain no other form suggestive of the cephalicus but do contain the epiphonus.

None of the Spanish theorists identified a particular performance method with liquescent signs in their discussions of one-line notation nor is there any reason given to speculate that for them such signs held a special significance of any sort. Both the epiphonus and cephalicus are illustrated by Bizcargui although without these names. Durán presents the epiphonus as well as a sign similar to the cephalicus of some late Aquitanian sources which adopts the form 11.59

Torculus and Porrectus. Amongst the early Zamoran sources, the torculus takes the usual two or three-part Aquitanian forms which are found in $\mathrm{Pa} 903 .^{60}$ The three-part form consists of a punctum plus a virga and finally another punctum, while in the two-part form the virga and the final punctum are joined. The two-part form is preferred for isolated positions; the two-part form is shown in Table 1. In the later Zamoran sources greater variation is found in the torculus forms. The lower head of the central virga is less

${ }^{58}$ Sources used for comparison with the Misal votivo: Worcester 160 (PM 12: 438); Paléographie musicale, vol. 9, Antiphonaire monastique XIIe siècle codex 601 de la Bibliothèque capitulaire de Lucques (1906; reprint, Berne: Herbert Lang, 1974), 497; Antiphonale Sarisburiense, 583. Sources used for Z 202: Ma BRAH 18 fol. 73; Graduale Triplex(Solesmes: Desclée, 1979), 89 and 273; and Graduale Sarisburiense, 26-27.

${ }^{59}$ Bizcargui, 1528, fol. d; Durán, Comento, fol. $c^{r}$.

${ }^{60} P M$ 13: 155 . (Form 7a in $P M 13$ has an exaggeratedly curved central shape; the facsimile of the manuscript shows this to be in fact more pointed at the peak, as is the case in most of the Zamoran early sources.) 
frequently used in the two-part form of the later sources than it was in the earlier sources; it instead may have a simple stem as is shown in Table 1. In some later sources the lower head of the virga is retained thus maintaining the characteristic earlier notational style. The lower head may be on either the left or the right side of the stem in the later sources, a surprising observation as in the same sources this head when part of rising neumes such as the pes is placed on the right side of the stem. The form of the central part of the torculus of $\mathrm{Z} 218$ and Book $\mathrm{G}$ is distinguished by its rounded shape from the pointed peak of the usual torculus. Another form presents the three notes of the neume joined so as to form an accent-neume and is found in Book E, Group F, and Z 219. This last form may be very like that of square notation. ${ }^{61}$

The porrectus of Aquitanian notation may sometimes be differentiated according to whether it is used in isolation or in composition. ${ }^{62}$ This is also the case in the Zamoran sources. The isolated porrectus consists of three discrete elements, usually a lozenge followed by a punctum and a virga $\because f$. In composition, although the porrectus just described continues to be employed, in most sources an alternative form is present as well. This latter form appears to derive from the second and third notes of the two-part torculus with an added virga at the end and joins the three pitches, forming a one-piece accent-neume. ${ }^{63}$ The form is shown in Table 1, see for example Book C and Z 219. It is not used in isolation. Sources from the late 13 th century or the 14th century and later which have the two-part torculus without lower virga head also drop the lower head at the beginning of the one-piece porrectus if that form is used. Those sources in which the one-piece torculus is present also do not utilize the low initial virga head on the porrectus with the exception of $\mathrm{Z}$ 219. In other late sources, however, the low initial head is retained. (Some sources use the porrectus both with and without the low head.) The one-piece Aquitanian porrectus has a marked resemblance to the porrectus of square notation with its oblique beam

${ }^{61}$ An exceptional pes also occurs Group F but only occurs once. It is shown in the table. The two notes are joined together as if to form the first two notes of a torculus, resulting in a form also found in square notation.

\footnotetext{
${ }^{62}$ The two forms are shown in PM 13: 154-55.
}

${ }^{63}$ The parts of this neume are identified as a clivis followed by a virga in PM 13: 175. 
representing the two falling notes; however, in square notation the final head may be on the left instead of the right and the initial head is absent.

The one-piece porrectus is found only very infrequently in the early Zamoran sources and is particularly rare in the 12th-century fragments where the porrectus of discrete points is preferred. The later sources may use both forms of porrectus or, more rarely, may avoid the one-piece porrectus altogether.

Reference has already been made in this chapter to the discussions of the theorists, Durán and Bizcargui, about one-line notation. Some further comments on this topic remain to be made as part of the conclusion of the discussion of Aquitanian notation in the Zamoran sources.

Amongst the Zamoran collection the neumes most like Durán's illustrations in the Comento are those of the 14th-century Misal votivo and the 14 th/15th-century Z 100 . In Table 2 some of the neumes are compared. The punctum of the Comento often has short stems ascending and/or descending from the corners; Durán's illustrations are inconsistent in this feature. Short stems may be observed descending from puncta of the Misal votivo,while in Z 100 fine short stems ascend and/or descend from puncta. Another unusual feature of the two sources and Durán's illustrations is the manner of writing neumes with series of rising notes. The notes of the ascending series with the exception of the topmost are placed more or less vertically one above the other, unlike the other Zamoran sources studied in which the standard Aquitanian neumatic slope is used placing the rising notes at a more or less $45^{\circ}$ angle to the staff. As with other sources descending series are placed almost vertically. The virga at the topmost point is placed to the right of the vertically rising series but that of the Comento takes a non-standard form in comparison with later Zamoran sources: unlike those of the Misal votivo and $\mathrm{Z} 100$ a lower head is placed to the left of the stem. Durán's use of the left lower head in the virga component of the two-part torculus is less unusual and is seen also in the Misal votivo. The one-piece porrectus of the Comento also has the left placed lower head. 
Bizcargui's illustrated forms of one-line notation have been shown in Chapter 3. His neumes are neatly shaped, using square puncta and more precisely formed lozenges than those of Durán. He does not use short lines ascending and descending from corners of puncta as did Durán. Nearly vertical placing of the notes of descending forms is found when these consist of lozenges and puncta at the base, however in Bizcargui's two examples of music written on one line, descending passages are also notated as series of square puncta which descend at an angle rather than vertically. None of the Zamoran sources have notation resembling the series of attached puncta given by Bizcargui in these two examples. ${ }^{64}$ The forms as given in his illustrations of individual neumes are, however, like those of the late Aquitanian forms in most of the Zamoran sources, with the most unusual being the porrectus (in his words punto doblado) with its pronounced curved form and his medium percutiens which is so like the bistropha of square notation. A form similar to Bizcargui's medium percutiens occurs in Z 64 (Group H).

The most distinctive of the notation classes identified above is class 1a. The following features may be named as belonging to it: type 1 quilisma, no lozenges, irregular application of direct, and preference for the porrectus of discrete points. One of the exceptional fragments of the Zamoran collection and of class 1a is Z 218. It differs from the other fragments in its class in the use of larger and longer puncta, the rounded curves of the torculus and cephalicus; and an overall appearance of elongation which results partly from the use of fine lines. Z 218 bears some resemblance to a 12 th-century source from Alcobaça in Portugal. ${ }^{65}$ Notably different in the Alcobaça source, however, is the use of a red staff line and occasional lozenges. Another exceptional fragment, Z 219, is placed in class 2 . It differs from the common style of the class in a number of ways including its use of lozenge-shaped puncta in isolation, a yellow staff, and a one-piece torculus. Characteristics generally found in late Aquitanian notation of the collection, some of which are also features of the earlier styles, may be summarized in the following list:

1. notes are larger in size than in earlier notation;

2. square or rhomboidal, angular, precise shapes;

\footnotetext{
${ }^{64}$ Bizcargui, 1528, fol. diii"-diiiir.

${ }^{65}$ Corbin, Essai, plate 3.
} 
3. use of lozenges in descending parts of neumes but not in isolation;

4. one red staff line;

5. absence of clef but usual Aquitanian association of mode and line;

6. use of direct with sinistral head placed at or near top of stem;

7. occasional loss of lower head of virga;

8. placing of lower head on left side of left "stem" of cephalicus ;

9. employment of quilisma (quilisma group covering the interval of a minor third);

10. one-piece forms of torculus and porrectus similar to those of square notation.

In order to be able to establish conclusive evidence for the identification of local, regional or other styles of copying, more studies will be needed on Aquitanian notation, especially in sources for which provenance and dating is known. ${ }^{66}$ In addition, the fragmentary nature of the Zamoran sources means that observations such as the finding of the absence of a particular type of neume cannot be taken as sufficient evidence for its total avoidance by a particular scribe or its exclusion from the original, lost manuscripts. The study presented here is therefore viewed as offering preliminary material for other studies of the Zamoran sources as well as some comparative material for future research into the use of Aquitanian notation on the Iberian Peninsula. A wider study would take into account other signs not discussed here, such as the oriscus and apostropha. The oriscus in fact is used very rarely and only in early Zamoran sources. A particularly significant feature which is worthy of further investigation is the semicircular virga found in Book A. Further research on this sign would include study of sources in which it is used, located both in and out of Spain. The usage of the sign may assist in location of a place or a region of origin for the fragments as well as providing another aspect for use in dating. It is particularly of interest as both the form and the meaning of the sign are distinctive.

${ }^{66}$ María Carmen Gómez has commented on the use of Aquitanian notation in Catalan manuscripts. Alterations, such as increasingly lozenge or square forms, are noticeable among these between early and late sources, but as Gómez notes the small number of sources prevents the establishment of conclusions. "Quelques remarques sur le répertoire polyphonique antérieur à l'Ars nova provenant de l'ancien royaume d'Aragon" Cahiers de Civilisation Médievale 31 (1988): 102-3. 
Table 1: Selected Neumes and the Direct of Aquitanian and Late Aquitanian Notation in Zamoran Sources

Key: 1 - pes; 2 - clivis; 3 - porrectus; 4 - torculus; 5 - quilisma group 1; 6 - quilisma group 2; 7 - epiphonus; 8 - cephalicus; 9 - direct.

(Real sizes are not shown although reflected. The sources are arranged according to the dates which have been assigned to each source and are shown in Appendix 1.)
1
23
4
5
6
$\begin{array}{ll}7 & 8\end{array}$
9

Class 1a

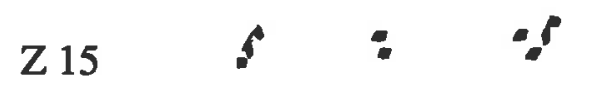

Z 202

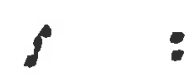

.1

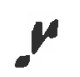

7

Book A \& : : it

Z 218

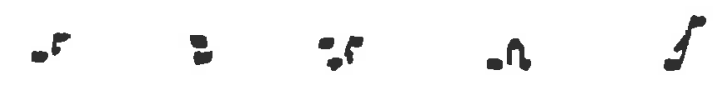

1

ข

1

1

Class 1b

Z 171

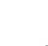

(n)

$+$

:

$: 2.1$

d 1

())

Z 197

\&

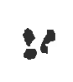

.1

1

Z 239

$f$

?

8

.6

s

9

1

Z 268

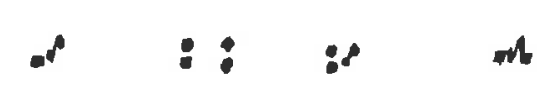

Z 58

s

if N A

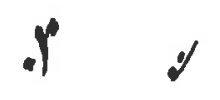

Z 59

. $\quad$ in $\mu$

Z 123

$\therefore$

8

$-1$

.9

1


Table 1 continued

$\begin{array}{lllllllll}1 & 2 & 3 & 4 & 5 & 6 & 7 & 8 & 9\end{array}$

\begin{tabular}{|c|c|c|c|c|c|c|c|}
\hline Book B & .1 & . & 8 & $A$ & $\mu$ & 2 & 1 \\
\hline Z 9 & $f$ & : & 8 & $\Lambda$ & $\mu$ & $d$ & A \\
\hline
\end{tabular}

Book C \& $\&$ \& $\&$ \& 1

\section{Class 2}

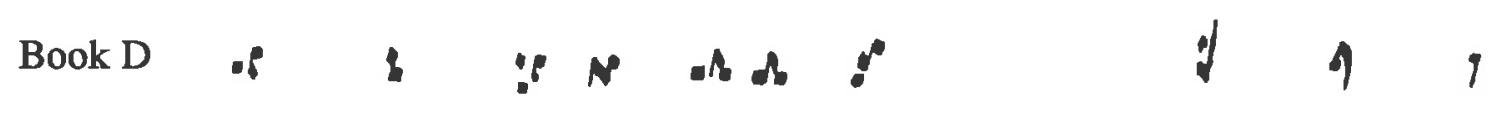

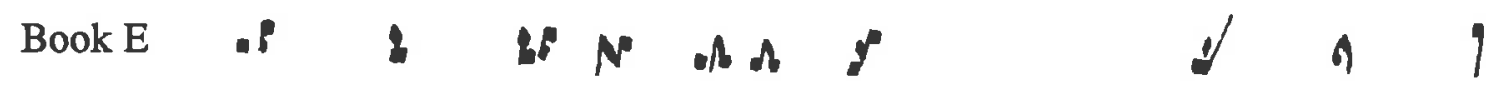

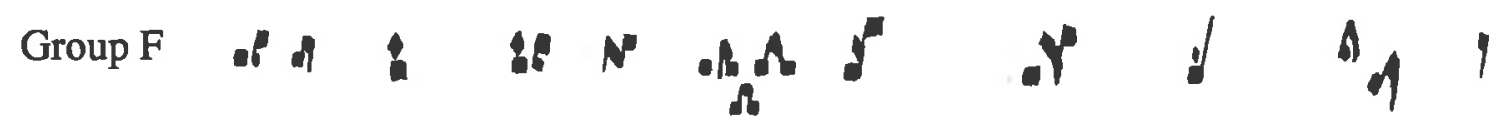

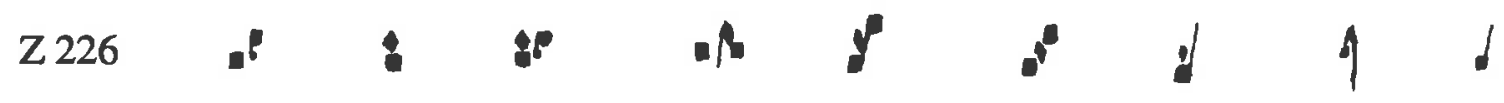

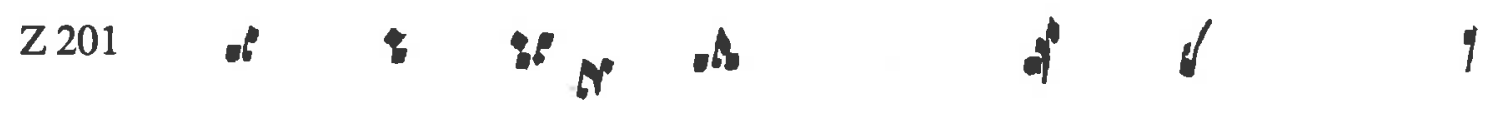

$\mathrm{Z} 219+8 \%$ \& $\$$

Book G of $\quad$ a $\quad$ of $\quad$ of $d d$

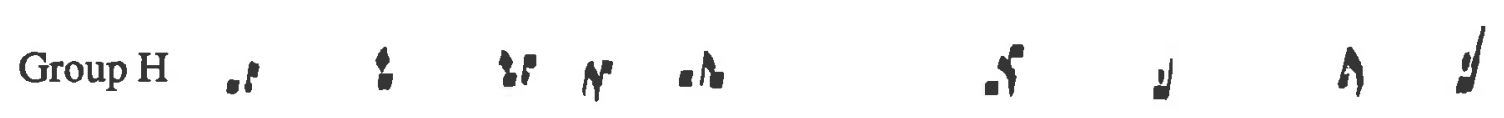

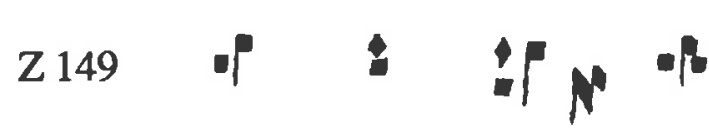

4

Z 269 of

9

$\mathrm{Z} 272$ of 8 of

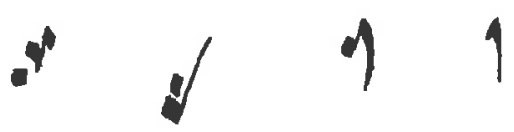


Table 1 continued

Misal votivo at

Table 2: Comparison of Neumes from the Comento, $\mathrm{Z} 100$, and the Misal votivo

Key : 1 - punctum; 2 - torculus; 3 - porrectus; 4 - quilisma group 1; 5 - ascending series (with descending series in the Comento).

Durán,Comento




\section{SQUARE NOTATION}

Square notation is found in many of the AHPZa fragments, the earliest being the single fragment which contains polyphony, and extending through to fragments dating from the late 15 th or early 16 th century. The Ritual and the Misal votivo also use square notation. Notation styles with marked mensural influence as well as fully mensural notation are also found amongst the sources and will be discussed later in this chapter. The term "square notation" is used here to refer to the standard forms of chant notation with very little or no influence from mensural notation. The terms "semi-mensural" and "pseudo-mensural", 67 as well as the phrase "mensurally influenced notation" identify chant notations which show distinct non-standard variations to square notation, those variations having the appearance and sometimes the significance of characteristically mensural signs.

Square notation came to prominence during the 13th century. The dissemination of the new notation must have been assisted by the Franciscans' adoption of it during the mid 13th century. Both the Franciscans and Dominicans wished for clearer, more easily readable manuscripts and accordingly set out rules to achieve this end. ${ }^{68}$ They required the use of square notation written on a staff of four lines, which could be either red or black according to the more detailed Franciscan rules, and the text was to be written clearly and separated sufficiently so that the notes would not be squeezed together. The rules also required that text and notes together with ligatures and pausas or virgulae pausarum be preserved with care and not changed. Additionally prescribed in the Dominican rules was the use of the direct or custos, yet another feature able to contribute to greater efficiency in the use of a manuscript. Given the interest of these two orders in this type of notation, one may ask whether they may have been associated with the production of some of the Zamoran sources which use square notation, especially those of the 14th century. ${ }^{69}$ A notable

${ }^{67}$ I am grateful to Dr. Hendrik van der Werf for suggesting the use of the term "pseudo-mensural ".

${ }^{68}$ See the statutes quoted by Michel Huglo in "Règlement du XIIr siècle pour la transcription des livres notés", Festschrift Bruno Stäblein zum 70. Geburtstag (Kassel: Bărenreiter, 1967), 124-25, as well as substantial discussion of them in the same article. These rules are also discussed in S. J. P. van Dijk, "An Advertisement Sheet of an Early Fourteenth-Century Writing Master at Oxford", Scriptorium 10 (1956): 47-64; and S. J. P. van Dijk and J. Hazelden Walker, The Origins of the Modern Roman Liturgy (London: Dartmann, Longman \& Todd, 1960), 329-32.

${ }^{69} 13$ th-century manuscripts in Spain known to have been associated with other orders are also written in square notation, for example, those of the Cistercian monastery of Las Huelgas. 
similarity of notational style exists between the 14th-century Zamoran Book 1 and the 15th-century Antiphonarium, Montserrat, Biblioteca del Monasterio, Ms. 759. The provenance of the latter source may be the Dominican monastery, Santa María de los Caballeros, in Toro. ${ }^{70}$ The fragments of Book 1, like many of the AHPZa fragments, were bound to protocol books of Toro.

The four-line staff was the standard for chant written in square notation. ${ }^{71}$ This rule did not, however, apply to Spain where the five-line staff seems to have been most frequent, with other parts of Western Europe generally preferring four lines. ${ }^{72}$

\section{Zamoran Sources}

Square notation found in the Zamoran sources may be divided into three classes based principally on the form of pes in use. These classes may be named class 3 , class 4 , and class 5 in order to distinguish them from the Aquitanian notation classes. The pes of class 3 is $\mathbf{W}$, and that of class 4 is 7 . Class 5 uses both forms of pes.

Dating of most of the sources is problematic; however, use of the approximate datings which have been made shows that the classes are associated with different periods of time. Sources of class 3 notation include the earliest ones using square notation from the mid to late 13th century and the 14th century, as well as some from the 15th century. The 14th-century section of the Misal votivo, the Ritual, the large fragment group identified as Book 1, and a small number of other fragments all fall into this class. ${ }^{73}$ Class 4 includes sources of the 15 th century up to the late 15 th or early 16 th century. It contains a greater

\footnotetext{
${ }^{70}$ Alexandre Olivar, Cataleg dels manuscrits de la biblioteca del Monestir de Montserrat, Scripta et Documenta, vol. 25 (Monestir de Montserrat, 1977), 55-56.

${ }^{71}$ All the examples in square notation in the following two facsimile sources employ the four-line staff: $P M 2$, plates 50-79, and Jacques Hourlier, La notation musicale des chants liturgiques latins (Cenomani: Solesmes, 1960), plates 26-29.

${ }^{72}$ Early printed books produced in Spain show frequent employment of the four-line staff. Out of eleven dating from 1485 to 1500 described by Stevenson, only two use a five-line staff (Stevenson, Spanish Music, 102-11). Could this variation from common Spanish manuscript practice have been associated with the fact that many printers working in Spain were of German origin and thus may have introduced a practice familiar to them instead of the usual Spanish one?

${ }^{73}$ This section of the Misal votivo very occasionally uses a stemless form of oblique pes. Owing to the differentiation from the usual oblique pes form, it has been decided that the class 3 classification is the most appropriate.
} 
number of the fragments than class 3 and includes the other large fragment group, Book 8 , as well as the 15th-century section of the Misal votivo. Class 5 sources date from the late 14 th or 15 th centuries and comprise a smaller number than the other two classes. The notation class of each source studied is identified in Appendix 1.

The characteristics of the three classes of square notation are given below. (The English equivalent of the Spanish virgula, "virgule", is used here and in the remainder of the dissertation for the vertical lines or "bar-lines" of the manuscripts. Similarly the term "plica" is used to mean the square note with two stems referred to in the previous chapter as punto con dos plicas rather than with the Spanish meaning of a stem.)

\section{$\underline{\text { Class } 3}$}

1. vertical pes form

2. varying types of porrectus of which the two main ones are $M$ and $M$

3. scandicus forms are principally $\$$ and

4. the punctum is either plain $\square$ or has a short stem $\square^{4}$

5. virgules are used for separating either phrases, words, syllables or melisma sections.

\section{Class 4}

1. oblique pes form

2. porrectus form $N$

3. scandicus form

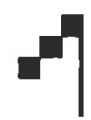

4. plain punctum $\square$ or with short stems

${ }^{74}$ Such short stems appear to have no significance with regard to interpretation. This is also the case with the stems of class 4 puncta. 
5. virgules are used principally to separate each word of a chant although monosyllables are sometimes not separated from the following word.

\section{Class 5}

In this class the characteristics listed for classes 3 and 4 are mixed. Each of the sources contains both forms of the pes; each may contain the porrectus of both classes, the scandicus of class 4 and one or both forms of class 3 , either of the punctum forms of class 3 , and the virgule use of class 3 or 4 .

The five-line staff is commonly used in all the Zamoran square notation sources with the only exceptions being Book 1 (class 3) and Z 203 (class 5), both of which have a four-line staff. There are no exceptions in the class 4 sources. The five-line staff, as opposed to the four-line staff, was clearly regarded as the norm by theorists; it was mentioned by Durán, Bizcargui, and Bermudo. The direct is used in all the sources of square notation, the most common form in the three classes being $\sqrt{ }{ }^{75}$ This form is employed frequently in the illustrations of treatises such as those by Durán, Spañon, and Bermudo.

The employment of the oblique pes form is matched in class 4 notation by the use of the oblique scandicus and the porrectus in which the final head is placed in an oblique relation to the central note. Similarly the vertical pes is matched in class 3 notation by the scandicus in which two of the three notes are placed vertically, and at times by the use of the porrectus in which the final note is placed vertically above the central one.

The frequent references by the Spanish theorists to the slanting beam known as alpha or alphado (also spelt with $f$ instead of $p h$ ) seem to indicate their interest in this neume component well known for its appearance in the porrectus. The theorists' comments, however, are not wholly reflected in the sources. One such comment is Durán's instruction that the alpha may either descend or ascend, but rising beams are extremely rare in the

\footnotetext{
${ }^{75}$ Research into the use of the direct in English Sarum sources is of interest although the Zamoran sources cannot be dated with the precision of the English ones: "the general adoption of the custos in the Sarum manuscripts must be dated to the third or fourth quarter of the fourteenth century"; see Dianne Lynne Droste, "The Musical Notation and Transmission of the Music of the Sarum Use, 1225-1500" (Ph.D. diss., University of Toronto, 1983), 80. The presence of the direct is therefore a useful indicator of date in Sarum manuscripts (Droste, "The Musical Notation", 141-42).
} 
sources. In fact, Durán's acceptance of the rising alpha was unusual; Bermudo specified the employment of the beam only for descending notes, whilst others of the Spanish theorists illustrated only the falling alpha. Other limitations named by Bermudo, and which have been discussed in Chapter 3, are not observable in the sources. The alpha is found used throughout the three classes of notation without variation in manner of employment. The characteristics of its employment are: firstly, it may be used in ligatures of three or more notes; secondly, the two descending notes which it represents are either a second or a third apart; thirdly, the note preceding or following the alpha within the ligature is not always of the same pitch as the first note of the beam; and fourthly, as already noted, the alpha, with very few exceptions, descends.

The plica is used in all classes but with a variety of forms. In some of the sources of classes 3 and 5 there is a tendency to set the heads of plicas at a slant, as is shown at number 1 in Example 1 below. Exclusive to a single fragment of class 5, Z 10, is the form given as number 2. Number 3 gives the most common form of plica with the simple square shape; it is found in all three classes. Number 4 is also found in the three classes but principally in class 4 ; it is the form described by Durán as having a tongue-like sign between the stems. Among the Zamoran sources, the last type of plica appears only in some from 15 th- or early 16 th-century sources. It has not been found by this writer in any non-Spanish sources, this fact suggesting the hypothesis that it could be a feature of Spanish square notation. ${ }^{76}$

\section{Example 1}
1.
2.
3.
4. 17

Forms 1, 3, and 4 all occur with ascending stems instead of descending stems. Number 1 usually takes the form when inverted. Ascending or descending stems appear to have

\footnotetext{
${ }^{76}$ It is not found, for example, in any of the examples of square notation in $P M 2$, plates 50-79, or Hourlier, La notation musicale, plates 26-29.
} 
been very largely determined by the direction of melodic movement so that if the note following the plica is higher the stems ascend, but if the next note is lower the stems descend.

Repercussive neumes are also found in a variety of forms. Most of these are given in Example 2.

Example 2
1.97
2.
3. 94
4. 1

The form given as number 1 is the most common and is found in all classes but is especially characteristic of class 4 . Number 2 represents the form employed in the class 3 fragments of Book 1 and occasionally in the class 3 (14th-century) section of the Misal votivo. Both form numbers 3 and 4 are rare. As a connection between the plica and the first of the forms was indicated by Bermudo, the latter is discussed further in Chapter 5. For purposes of discussion, form number 1 will be referred to as a "double" and form number 2 as a "plica double".

A particularly interesting usage of the double is found in a hymn, Iesus ab ore, in fragments Z 206 and Z 207. In these probably late 15th-century or early 16th-century fragments, performance according to the dictum of one note per compas would result in each double having a total duration of two compases; Bermudo's comment of the double being used in place of the plica ${ }^{77}$ confirms this durational interpretation. In lesus ab ore the double is used so regularly that the sign is able to take the role of establishing meter and the notation may be viewed as a simple form of measured notation. (A transcription of Iesus $a b$ ore is given at the rear of this dissertation.)

The intenso and the remisso, a pair of signs mentioned by various theorists and discussed in Chapter 3, have proved impossible to identify. Their function of sharpening and flattening seems to be taken instead by the use of accidentals, although these were not

\footnotetext{
${ }^{n}$ See pages 89-90.
} 
employed regularly in many sources. The triangular form of semibreve is another sign mentioned by the theorists which is not found amongst the Zamoran sources.

The differentiation in usage of virgules between classes 3 and 4 is worthy of comment. The usage of class 4 is founded on the simple approach of separation of neumes belonging to individual words. The exceptions are monosyllables which may be grouped with another word, and melismatically set words in some sources for which virgules mark individual syllables. A perhaps more sophisticated basis for virgule placement appears to have been operative for some class 3 sources, in which greater discretion was apparently employed. The meaning of class 3 virgules seems to be associated with phrasing in such sources. Placing of virgules within melismas as well as within melismatically set words occurs especially in Book 1 fragments (class 3 notation). The breaking of melismas is particularly intriguing and deserves wider investigation than is possible in the present study. The placement of virgules within words in an early Dominican manuscript is also remarked upon briefly in the dissertation by Haller. ${ }^{78}$ On the subject of function of virgules or in his term "bars" he makes the interesting comment: "It is the present author's contention that their principal use may be to allow the eye to focus on easily recognizable note groupings in order to facilitate reading of the chant or the correction of other manuscripts" and later adds "the bars certainly do not seem to have had rhythmic value." Sample comparisons of Book 1 chants very similar to those in non-Zamoran sources show that the placing of bars is not duplicated, an observation which is given more significance by Haller's reference to work carried out by Bonhomme in comparing recurrences of the same chants within the Dominican manuscript. Bonhomme showed that even in such situations virgule placement was not duplicated. ${ }^{80}$

The simple use of virgules to mark the neumes for each word (with the occasional exception of monosyllables) is also found in late Aquitanian (class 2) notation of the Zamoran sources, although amongst those there are also some which either do not use

${ }^{78}$ Robert B. Haller, "Early Dominican Mass Chants: A Witness to Thirteeenth-Century Chant Style" (Ph.D. diss., Catholic University of America, 1986), 45.

${ }^{79}$ Haller, "Early Dominican Mass Chant", 45.

${ }^{80}$ Haller, "Early Dominican Mass Chant", 45. 
virgules or use them irregularly. The earlier Aquitanian sources, those of class 1, employ virgules infrequently and their function is apparently to clarify the alignment of notation and text. Amongst the class 1 sources, frequent use is limited to a single responsory in $\mathrm{Z}$ 218 in which the scribe clearly met considerable difficulty in fitting melismatic passages over the text. ${ }^{81}$

The virgules just discussed are those used singly. In the Zamoran square notation sources, double or triple vertical lines are also found marking the ending of chants and frequently preceding psalm incipits. Very rare, however, is their employment to separate solo and chorus sections.

Mont 759 , referred to above as being similar in notational style to Book 1 , makes use of the class 3 manner of notation. As in Book 1, virgules are placed within melismas although comparison of chants shows that positioning may vary. The melodies also show some variations between the two sources as do the chants and chant order employed. Other notational similarities include the four-line staff, the form of the direct, and the regular use of accidentals. The probably late 14 th- or early 15 th-century antiphoner belonging to the Convento de Santa Clara in Villalobos in the region of Zamora (founded $1386^{82}$ ) also shows some notable similarities to Book 1 . These are principally in the areas of notational style which is that of class 3, as well as script and initial style. Virgules are used to separate words or phrases but not to break melismas as is a feature of Book 1 and Mont 759. The Villalobos antiphoner, however, uses a five-line staff. Comparison of chants with Book 1 shows that, amongst those examined, while melodies are in general similar they are by no means identical, and neither is the order of chants nor all the chants employed the same. The study of the antiphoners of Montserrat and Villalobos suggest that an identifiable school of manuscript copying may have been located in or may have supplied the region of Zamora, resulting in some homogeneity of notational style but responding to

${ }^{81}$ A similar observation is made about "vertical lines" in Aquitanian versaria by James Grier who examined their occurrence in both monophony and polyphony. "These lines were added to give clearer visual information about the alignment of text and music, either to scribes who might copy from these manuscripts or to performers." (James Grier, "Scribal Practices in the Aquitanian Versaria of the Twelfth Century: Towards a Typology of Error and Variant", Journal of the American Musicological Society 45 (1992): 381.

${ }^{82}$ Espías Sánchez, Monasterios de clausura en Zamora, 101. 
different liturgical needs. This is a topic which cannot be pursued further here but is one which might be worthy of further investigation along paleographical and codicological lines.

The choice of pes form as the principal criterion for the establishment of the three classes of notation discussed in this section was made because this is the most prominent and regular difference observable amongst the sources. The two forms were not discussed by the Spanish 15th- and 16th-century theorists although they were given by the Italian Gaffurius ${ }^{83}$ Nevertheless from the illustrations of the treatises, the oblique pes form seems undoubtedly to have been the preferred form of the Spanish writers, although the vertical form does appear very occasionally in examples. Their preference confirms the observation that the vertical pes tended to be replaced by the oblique one during the later period. There is no reason to believe that the two forms may have indicated differing performance methods. Further research into a broader range of Spanish square notation sources as well as sources from outside of Spain would be of interest to examine further the usage of the two forms of pes and to compare the results of the findings from the Zamoran sources.

\section{MENSURAL NOTATION}

The association of liturgical chant and mensural notation can be observed occasionally from the 13th century onwards. While the complete notating of chants in mensural signs was rare, more common was the influence of mensural notation observable in the employment of various signs usually characteristic of the mensural system. Such signs, however, seem not always to have brought with them any mensural significance. ${ }^{84}$

Mensural or mensurally influenced notation came to be employed increasingly during the latter part of the Middle Ages as was stated by Stäblein: "Bereits Ende des 13. Jahrhunderts beginnen unter dem Einfluß der mehrstimmigen Musik mensurale Elemente in die Quadratschrift einzudringen, was bis zum Ende des Mittelalters bei Neukompositionen fast

\footnotetext{
${ }^{83}$ See page 78.
}

${ }^{84}$ Stäblein found that stemmed notes placed at ends of words sometimes were not meaningful. He gave two Catalonian manuscripts held in Lérida as examples. See Stäblein, Schriftbild der einstimmigen Musik, 69 n. 696. 
die Regel wird." 85 David Hiley has commented that mensurally notated chants "are almost exclusively chants with texts in regular accentual verse" 986 and Stäblein noted the appearance of mensural elements in the notation of such genres as hymns, sequences, and chants of the Ordinary. ${ }^{87}$ Of the Ordinary chants, it was especially newly composed ones (predominantly Credo settings) that received mensural treatment. ${ }^{88}$

The mensural notation of hymns in Spanish sources of the 14th and 15th centuries has been commented upon by various writers including Stäblein and Anglès. ${ }^{89}$ An early 15th-century mensural hymnal is currently being studied by M. Bernadó of Barcelona. His study promises to be of importance in regard to both the use of mensural notation in Spanish chant sources of the period and the repertory of hymns employed..$^{90}$

The convent of Las Huelgas houses two manuscripts of interest for their use of mensural notation. The first is the well known largely polyphonic codex Hu which includes some mensurally notated monophonic chants which have been transcribed by Anglès and Anderson. ${ }^{91}$ The second manuscript, number 8 of the Huelgas collection, is a 14th-century Cistercian antiphoner using square notation in which long notes are distinguished from short notes by the addition of stems and are employed for long syllables. ${ }^{92}$

Early examples of printed liturgical books from Spain are sometimes found to show mensural elements in the notation. Concerning these sources Stevenson has observed that "where diamond-shaped notes (not in descending series), single square notes with two

${ }^{85}$ Stäblein, Schriftbild der einstimmigen Musik, 176.

${ }^{86}$ David Hiley, "Chant", in Performance Practice. Music before 1600, ed. Howard Mayer Brown and Stanley Sadie, 37-54 (London: Macmillan, 1989), 48. On pages 48 to 49, Hiley presents a useful, brief coverage of mensural chant notation and also of chant performance following the Council of Trent.

${ }^{87}$ Stäblein, Schriftbild der einstimmigen Musik, 69.

${ }^{88}$ Stäblein, Schriftbild der einstimmigen Musik, 69, 176. Other mentions of mensural notation of the Credo are found in Franz Tack, Gregorian Chant (Cologne: Amo Volk Gerlag, 1960), 19 (facsimile, 50); and Hiley, "Chant", 49. Reference to the comments of Gaffurius and Zarlino with regard to the mensural Credo has already been made on page 79 .

${ }^{89}$ Stäblein, Schriftbild der einstimmigen Musik, 69; Higinio Anglés, "Early Spanish Music Culture and Cardinal Cisneros's Hymnal of 1515", in Aspects of Medieval and Renaissance Music, ed. Jan LaRue (London: Oxford University Press, 1967), 8-16.

${ }^{90} \mathrm{M}$. Bernardo, "Sobre el origen y la procedencia de la tradición himnódica hispánica a fines de la Edad Media", paper delivered at the 15th Congress of the International Musicological Society, Madrid, 1992.

${ }^{91}$ Anglès, Huelgas; Gordon A. Anderson, The Las Huelgas Manuscript, Corpus Mensurabilis Musicae 79, 2 vols. (Neuhausen-Stuttgart: American Institute of Musicology, 1982).

${ }^{92}$ Fernández de la Cuesta, Manuscritos, 107. 
stems, and single squares with right-hand descenders combine to make rhythmic patterns as in the Toledo books - measured chant rather than plainsong in free rhythm must have been sung." ${ }^{93}$ An example of an incunable employing mensurally influenced notation is the 1499 Missale Toletanum of Cisneros. ${ }^{94}$ Mensural notation for hymns is employed in another of the Cisneros books, the early 16th-century Intonarium Toletanum. ${ }^{95}$ Overall, it may be observed that mensural notation of chant became increasingly common during the 16th century in Spanish sources. ${ }^{96}$

\section{Zamoran Sources}

Different styles of mensurally influenced notation are found amongst these sources. Although it is not always possible to establish with certainty the significance of the mensural signs in the Zamoran sources, three types of notation seem to emerge. These may be named pseudo-mensural, semi-mensural, and mensural; each will be discussed below with some examples given.

In fact, the use of mensurally influenced chant notations amongst the Zamoran sources is very rare and is found in only seven AHPZa fragments and the Misal votivo. The fragments, which date from the 15 th century or early 16 th century, are all those of Group 2 ( $Z$ 85, Z 105, and Z 145); two from Book 5a ( $\mathrm{Z} 167$ and Z 174); one from Book 6 ( $Z$ 151); as well as Z 115. While all the chants of Group 2 and Z 115 use mensurally influenced notation, Books 5a and 6, as well as the Misal votivo, juxtapose chants in square notation with chants in varying degrees of mensurally influenced notation.

${ }^{93}$ Stevenson, Spanish Music, 103.

${ }^{94}$ Stevenson, Spanish Music, 108.

${ }^{95}$ Ma M 268. For discussion of this source, see Anglés, "Early Spanish Music Culture”, 8-16.

${ }^{96}$ Spanish practices were also reflected in books produced in Mexico during the second half of the 16th century. The notation of one of these, printed in Mexico in 1584, is studied in depth by Duncan. Mensural notation was used in that book for a large proportion of hymns and some Office of the Dead chants while square notation was the standard employed for the source. See Duncan, "Mexican Chant Book", 14; for the study of the mensurally notated hymns see Chapter 9 of her work. 


\section{Pseudo-mensural notation}

Pseudo-mensural notation refers to that in which mensural signs are present but seem to be without their durational significance. Such seemingly mensural signs occur occasionally throughout the 14th-century section of the Misal votivo, becoming more frequent in a few chants such as Conditor kyrie omnium, fol. 46. Two instances of apparently mensural notation in this chant are discussed immediately below.

Signs with the appearance of longs are employed over the syllable "ley" in the word "eleyson" on three occasions in which the melody falls by a step to the final syllable, both syllables receiving only a single note. The significance of these single-stemmed notes is made increasingly puzzling by the signs employed in the same position and with the same melodic motion in other instances of the word: a plain punctum without stem occurs once, and a double also occurs once. (Two further instances of "eleyson" have an ascending step to the final syllable. One of these has a single-stemmed note on the final, while both have unstemmed notes on the penultimate syllables.) Another 14th-century Spanish square notation source studied employs plica doubles on the syllable "ley" of "eleyson" in the same work. ${ }^{97}$ Given that the syllable is one on which liquescent treatment was appropriate, could the single-stemmed isolated notes in this chant of the Misal votivo have been intended to represent plicas? The apparent long might therefore be sung with two notes; however, this question must remain unanswered at the present time. The opening of Conditor kyrie omnium is given with the transcriptions at the rear of this dissertation. The syllable "ley" in this segment of the chant is that notated with a plain punctum.

Also having the appearance of a sign suited to mensural notation in Conditor kyrie

omnium is 1 . (Its placement may be seen in the transcription of the opening of the chant.) Such a sign in a mensural context would probably be interpreted as indicating a plicated ligature to be sung with an additional rising note at the end of the three falling notes. However, in chant notation a final plica would not usually be indicated in this manner. Comparison with other sources of the chant show that an added rising note at this

\footnotetext{
${ }^{97}$ Ma 1361 , fols. $182^{\mathrm{v}}-183^{\mathrm{r}}$.
} 
point is not to be found. The evidence of $\mathrm{Hu}$ is curious as it uses the very similar sign in the corresponding cantus position of a two-voice setting of the chant. ${ }^{98}$ This observation raises the difficult question of whether the chant of the Misal votivo might have been copied from a mensural manuscript connected with $\mathrm{Hu}$ or a tradition to which $\mathrm{Hu}$ belonged.

The fragments of Group 2 all seem to show pseudo-mensural notation. The two features of these fragments suggestive of mensural influence are the use of apparently cum opposita proprietate ligatures and of single-stemmed notes. The fact that the rising stem at the beginning of ligatures characteristic of cum opposita proprietate is used only when the following note of the ligature is higher than the first, suggests that the usual mensural interpretation may not be valid. Ligatures in which the second note is lower than the first never use an opening ascending stem in these fragments. The rising stem as an indicator of the semibreve interpretation expected from cum opposita proprietate ligatures and as indicated by one of the anonymous Spanish theorists ${ }^{99}$ therefore seems placed in doubt. Such ligatures in which the pitch of the second note is higher than the first occur occasionally in the Misal votivo and for these also there is no reason to suspect a durational significance. ${ }^{100}$ The second of the possibly mensural features in the Group 2 fragments is the employment of single-stemmed notes which appear to be longs. The irregularity of their occurrence suggests that they are without durational significance. Nevertheless, it must be admitted that another viewpoint might prefer to give these a lengthened duration and therefore see the notation as semi-mensural (this style of notation is discussed below). The issue of the significance of such signs arises again in Chapter 10 in association with notation of polyphony in the Misal votivo.

\section{Semi-mensural notation}

In semi-mensural notation, mensural signs are mixed with standard, non-mensural signs. Amongst the Zamoran sources this type of notation is found in three fragments: two

\footnotetext{
${ }^{98}$ Facsimile: Anglè, Huelgas 2, fol. $2^{r}$.

${ }^{99}$ See page 84 .

${ }^{100}$ For example, fols. $21^{\mathrm{x}}, 28^{\mathrm{r}}$, and $30^{\mathrm{v}}$.
} 
from Book 5a ( $Z 167$ and $Z$ 174) and $Z$ 115. The mensural signs of these sources appear to require mensural interpretation, while the remaining signs evidently should be treated as they would in non-mensural square chant notation. The mensural approach is especially noticeable in words of two or more syllables set syllabically; longs and breves, or sometimes breves and semibreves, may be observed in such words, often, but by no means always, reflecting syllable accent. Non-mensural signs are represented by the regular ligature forms characteristic of square notation. Apart from the few exceptions outlined below, the ligature forms of mensural notation are absent.

The two fragments of Book 5a already mentioned contain part of the chants of the Lamentations for use in Holy Week. These are given in semi-mensural notation, while a responsory also found in $\mathrm{Z} 174$ is in square notation without mensural influence. The third fragment of Book 5a, Z 175, contains part of the antiphons and responsories of Good Friday matins and is in square notation again without mensural influence. The differentiation in these fragments of the treatment of genres is noteworthy. The tendency to employ mensurally influenced notation for certain genres such as the Credo is already well known, but the case of the Lamentations represents a practice which appears to have been little documented and is certainly worthy of further investigation. ${ }^{101}$

The mensural features of the notation of $\mathrm{Z} 167$ and $\mathrm{Z} 175$ are:

1. the employment of semibreves, breves, and longs in isolation;

2. the occasional ligature with an opening upward left-hand stem occurring either at the beginning or within a melisma;

3. the occasional employment of a lozenge in a rising position within ligatures.

$\mathrm{Z} 115$, also classified here as semi-mensural, makes use of longs and breves for syllabically set words, although the great majority are longs. In this fragment, such differentiation in duration reflects word accent to at least some degree. An example is found in the setting of the word "opera" in which the first and third syllables are given longs while the second receives a breve.

\footnotetext{
${ }^{101}$ Samuel Rubio reported "reminiscencias de mensuralismo" in some genres of chant including the Lamentations found in late 16th-century manuscripts of the Escorial. Samuel Rubio, "Las melodias de los «libros corales» del Escorial”, La Ciudad de Dios 182 (1969): 351.
} 


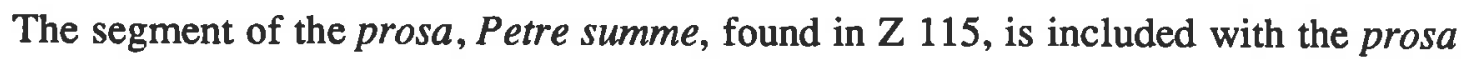
transcriptions at the rear of this dissertation. The transcription is given in modern measured notation in order to show the durational variety which, although not great, seems to be indicated. A difficulty for transcription is presented by the employment of the binaria 1", while the more common double 1 is not found. It has been assumed here that the former sign has the same meaning as the latter and so it is transcribed with the duration of twice that of the prevailing note value, the long. (Bermudo's instruction on the meaning of the double was that it was the same as the plica and therefore should take the value of two compases.) This binaria is found on accented syllables, a positioning appropriate to its proposed duration. Furthermore, it occurs on the stressed and penultimate syllable of all but one of the five versicles of the prosa found in the fragment. Also problematic in the same chant are the two instances of a pes. As the sign cannot be understood as giving a particular durational direction, the two occurrences of the sign have been interpreted differently in accordance with melodic and accentual factors.

Study of these sources of pseudo-mensural and semi-mensural notation leads to the conclusion that it is not possible to formulate general rules for the interpretation of such notations. Instead, each source must be assessed individually. If a notation is judged to be semi-mensural, performance must be based upon the interpreter's judgment guided more or less loosely by the notation.

The following guidelines may be of assistance as starting points for interpretation of semi-mensural chant notation in Spanish sources of the 15th century and first half of the 16th century. In making these suggestions, it is recognized that much further investigation remains to be carried out on this topic and that these guidelines can only be tentative. They are derived both from the theoretical writings discussed in the previous chapter and from study of the Zamoran sources.

1. Longs, breves, and semibreves in isolation should usually be respected and followed. However, if these move against the word accent it may perhaps be justifiable to disregard their potential durational significance.

2. Each note of a ligature may normally be sung as a breve (or as a long if that is the prevailing note value) with the following exceptions: 
(a) an ascending stem at the beginning of a ligature is likely to signify a cum opposita proprietate interpretation;

(b) a rising lozenge suggests the duration of a semibreve, or one or two downward stems suggest a long;

(c) especially in earlier sources, alphas with descending sinistral stems might be sung with longer duration on the first note than on the second;

(d) in a situation in which the word accent would be altered in such a way as to be out of keeping with text treatment generally in a work, a differing interpretation might be preferable.

3. Plicas may have two possible interpretations. One is that belonging to the tocus and the uncus which means the singing of two (or possibly three) notes, rising or descending according to stem direction, the other interpretation is that of the note of double duration. In a context where varying degrees of duration is already indicated by means of signs such as the breve and the long, the former interpretation of the plica seems more appropriate.

The concept of semi-mensural notation presented above is similar to that of "psalmodic notation" presented by Mary Duncan in her dissertation. ${ }^{102}$ Duncan's ideas are based upon the discussion of notation by late 15 th-century and 16th-century Spanish theorists and especially Bermudo who spoke of psalmodia. She concludes that psalmodia referred to "a type of chant in which the durational value of the notes was determined by the textual accents" 103 and seems to include any genre of chant treated in this way. In her view, psalmodic notation makes use of some signs of mensural notation together with their usual meaning (long, breve, and isolated semibreve), while each note of a binary ligature she sees "interpreted as consisting of two equal breves". ${ }^{104}$ The plica as a note indicating double duration (referred to by Duncan as the punto cargado) is seen as a sign belonging primarily to psalmodic notation. In the opinion of the present writer however, the plica (punto

\footnotetext{
${ }^{102}$ This is discussed by Duncan, "Mexican Chant Book", particularly 64-74.

${ }^{103}$ Duncan, "Mexican Chant Book", 64.

${ }^{104}$ Duncan, "Mexican Chant Book", 77. Other ligatures were rarely employed in this type of notation
} (Duncan, "Mexican Chant Book", 67). 
cargado or punto con dos plicas) is better viewed as integral to non-mensural square notation of Spanish chant sources of at least the 15 th century and early 16 th century.

\section{Mensural notation}

Z 151 from Book 6 is the only fragment which emerges unequivocally as presenting a chant notated in fully mensural notation. It contains part of a Credo, the Credo being the item of the Mass Ordinary most frequently notated mensurally. The other fragment of Book 6, Z 153, contains sections of two Glorias, both of which are written non-mensurally in square notation. The consistent use of mensural notation in the Credo may reflect the syllabic nature of the chant as opposed to the more melismatic nature of the Lamentation melodies of the Book 5a fragments. The features of the notation are:

1. breves and semibreves in isolation;

2. two forms of two-note ligature ( $\mid 7$ and $)$, both of which might be interpreted as indicating semibreves in the light of theorists' instructions. ${ }^{105}$ No other ligatures are found.

A transcription following the mensural indication of the notation is given at the rear of this dissertation together with the transcriptions of Mass Ordinary chants.

The final chant which needs to be discussed in this section is the Sanctus on folio $50^{v}$ of the Misal votivo. The first impression on finding this chant in a manuscript written predominantly in regular square notation and with some pseudo-mensural elements, is that it is undoubtedly in mensural notation. This impression is created initially by the frequent use of apparent longs or single-stemmed notes which in this source are extraordinary because the unstemmed puncta is the usual form of isolated note. Other apparently mensural features are: a cum opposita proprietate ligature, rising (but not isolated) semibreves, and the separation of notes which are normally ligated in chant notation. In fact, the notation might well be described as Franconian-like. Transcription according to Franconian principles

\footnotetext{
${ }^{105} \mathrm{~A}$ ligature like the first shown represents semibreves in the Anonymous Arte de melodia sobre canto lano y canto d'organo (see page 84 above). Podio in his teaching on mensural notation of polyphony says that the second of the ligatures, an alfa, indicates two semibreves (Ars musicorum, fol. LIII').
} 
is, however, unsatisfactory and is complicated by the erasures which have been made to the original notation in various parts of the chant. It is not possible to determine readily whether the erasures were made during the original copying or afterwards. Altered ligatures are left in an ambiguous state with regard to any intended mensural significance, as is found over the first syllable of the second setting of the word "Sanctus" where the left hand descending stem of a binaria remains although the second note has been erased $\Gamma$. In studying this notation, one wonders whether this chant was copied from a mensural version or even the mensurally notated cantus of a polyphonic setting of the chant. ${ }^{106} \mathrm{~A}$ similar question has already arisen with regard to Conditor kyrie omnium which, moreover, occurs in the same Mass as the Sanctus. In copying the notation of the proposed exemplar the notator of the Misal votivo may have made changes which have resulted in difficulties for the modern reader. Problematic use of a single rising stem on the right of single notes and ligatures leads to the suspicion of a decorative rather a significant function. Although a mensural transcription of the Sanctus might be justified, in view of the difficulties discussed, it has been decided to present only a non-mensural version with the transcriptions at the rear of this dissertation.

An important issue for performance which remains unanswered is that emerging from the previous chapter, that of precise measurement of duration. From the findings made there, two possible approaches to the interpretation of semi-mensural and mensural chant notation must be posited. In the case of semi-mensural notation, either of these approaches could be used in conjunction with the guidelines given earlier. The first approach is that expressed by two of the "non-equalist" theorists (Podio and Ferrer). This approach takes the position that notes of different duration are not strictly measured and therefore do not employ strict proportions of time value. The second approach is similar to that of the "equalist" theorists and was expressed by Bermudo. In this case, strictly measured notes of different duration would be employed, so for example, a breve would have half the time value of a long. These two approaches may have had some regional

\footnotetext{
${ }^{106}$ The melody is known in two-voice settings in $\mathrm{W} 1$ and $\mathrm{Pa} 15129$. These are transcribed by Max Lütolf, Die mehrstimmigen Ordinarium Missae-Sätze vom ausgehenden 11. bis zur Wende des 13. zum 14. Jahrhundert, vol. 2 (Bem: Kommissionsverlag Paul Haupt, 1970), 96-98, 139-40.
} 
association given the fact that the "non-equalist" theorists were connected with north-eastern parts of Spain, while the "equalist" theorists mainly have connections with western or central Spain, and in the case of Bermudo with southern Spain. On this geographical basis, it is proposed here that the strictly measured interpretation be preferred for the semi-mensural and mensural chants of the Zamoran sources.

The interpretation of the plica in semi-mensural notation was discussed above. In mensural notation it may again be suggested that as signs for representing long duration are available, the plica should be understood as representing two (or possibly three) notes. In other words, it takes the role of the tocus and the uncus discussed by "non-equalist" theorists. The difficulty with this proposal is that such an interpretation was not broadly discussed by theorists even though a plica-shaped sign was mentioned with some frequency. Podio's remark that the tocus and the uncus were rarely observed suggests that such a meaning may have been unknown to many musicians by at least the late 15 th century. ${ }^{107}$ It cannot, therefore, be definitely proposed that the plica in the context of mensural or semimensural notation in the Zamoran sources should take either of the two interpretations. The issue must be left to an interpreter's discretion and the particular evidence of each source.

In conclusion, it needs to be said that this brief examination of the mensurally influenced notations of the Zamoran sources leaves many unsolved problems. Some if not many of the conventions known to singers of chant in Spain during the late Middle Ages have been lost. Such conventions might have made clear problems such as the interpretation of ligatures in semi-mensural and mensural notation. The question can also be raised as to whether a mensural performance may have been commonly used for chants belonging to the genres in which mensural notation is most frequently found (such as the Credo) even when the notation is not mensural. Another problem encountered in the study of mensurally notated chant in Spain is the variety of methods which were employed. It is interesting to speculate that different centres might have had characteristic procedures. Future research

\footnotetext{
${ }^{107}$ See page $83-84$.
} 
may clarify this possibility perhaps producing some more substantial evidence of different local performing practices. ${ }^{108}$

${ }^{108}$ Robert Stevenson has already remarked on the latter idea: "Were it possible to give an interpretation of the semimensural notation on which all scholars would agree, the comparison of local variants could be pushed much further." Spanish Music, 112. 


\section{THE PLICA IN THE PLAINCHANT SOURCES}

The presence and manner of employment of the note form commonly known as a plica in plainchant sources using square notation in the Zamoran collection as well as the discussion of the sign in the Spanish musical treatises of the late 15th and the 16th centuries occasion the need here for a discussion of its interpretation and usage. The note form is one which continues to present modern musicology with problems of interpretation not only for its usage in plainchant, but also in polyphony and non-liturgical monody. This chapter emphasizes the meanings of the term and the sign, as well as the criteria which may have determined the usage of the sign in the sources of Zamora. ${ }^{1}$

The plica developed from liquescent signs of earlier neumatic notations, the epiphonus and the cephalicus. In plainchant sources using square notation it generally came to take

the forms: $\$. These might be more rounded in shape, especially in earlier sources, and show varying stem lengths.

The name is a descriptive one referring to the folded shape of the sign, "plica" being a Latin word meaning "fold". The term "plica" appears to have been first used by musical theorists during the 13th century. The earliest known usage of the term occurs in the work of Johannes de Garlandia, ${ }^{2}$ c. $1240,{ }^{3}$ where it was used in the context of mensural notation. The first appearance of the term in relation to plainchant seems to be that in the Tractatus de musica by Jerome of Moravia, which dates from the second half of the 13th century. ${ }^{4}$ The term may in fact have been taken over to plainchant terminology from the

'A very useful introduction to the plica is found in the article by David Hiley, "Plica", NG 15: 12-13. An important, earlier study but one focused upon the usage of the plica in polyphonic sources and secular monodic sources is that by Higini Angles, "Die Bedeutung der Plika in der mittelalterlichen Musik", in Festschrift Karl Gustav Fellerer zum 60. Geburtstag, ed. Heinrich Hüschen (Regensburg: Bosse, 1962), 28-39. Another important, yet earlier discussion of the plica in polyphony is that by Hans Tischler, "Ligatures, Plicae and Vertical Bars in Premensural Notation", Revue belge de musicologie 11 (1957): 83-92.

${ }^{2}$ David Hiley, "The Plica and Liquescence”, Gordon Athol Anderson (1929-1981) in Memoriam, Musicological Studies, vol. 49 (Henryville: Institute of Medieval Music, 1984): 380.

${ }^{3}$ Gordon A. Anderson, "Johannes de Garlandia", NG 9: 662.

${ }^{4} \mathrm{It}$ has been dated to between 1272 and 1304 by Huglo in Les Tonaires, 335. Various datings of the treatise are discussed by Robert B. Haller. See Haller, "Early Dominican Mass Chant", 106. 
mensural usage. ${ }^{5}$

Among 13th-century music treatises, the term plica referred to types of notes which were distinguished in notation by particular usages of note stems indicating the division of one note into two. As in the treatise of Johannes de Garlandia, the term plica could be used in association with another note name, for example, plica longa. Garlandia's definition of the plica longa reads "A plica longa is that <note> which has two strokes, namely, the one on the right side longer than that on the left; there are two kinds one ascending and the other descending". 6 The modification indicated by the use of the term plica was represented in the notation by the addition of one or two stems of particular lengths. The term was also used in reference to the final note of a ligature where a stem could be used to give that final note the same meaning as an isolated plica, that is division into two sounds. Garlandia thus began the discussion of such ligatures with the words "For each figure with a plica. . .." The St. Emmeram anonymous De musica mensurata also saw the plica as identified by the presence of a stem or two stems: "The representation or form of a plica occurs sometimes by means of one line, sometimes by means of two, and especially in single figures." In this excerpt the anonymous writer used the word tractum to refer to the stem or line representing the plica. ${ }^{8}$ Tractus and cauda were in general the preferred terms for the stems of note forms. The word plica for these writers did not signify a stem but the whole concept through which stems were added in such a way as to indicate a special interpretation involving the division of the note into two sounds. Its use by Spanish theorists of the late 15 th and 16th centuries to signify a stem attached to a single note or a ligature has been discussed in Chapter 3. No concept of a further meaning such as division into two or liquescence was included in the meaning of the term for these writers. The term plica is used here, as is generally done in modern English language usage, to refer to the note form

${ }^{5}$ Michael Bernhard, "Das musikalische Fachschrifttum im lateinischen Mittelalter", in Rezeption des antiken Fachs im Mittelalter,Geschichte der Musiktheorie, vol. 3 (Darmstadt: Wissenschaftliche Buchgesellschaft, 1990), 84.

"Translation from Gordon A. Anderson, "The Notation of the Bamberg and Las Huelgas Manuscripts", Musica Disciplina 32 (1978): 20-21.

${ }^{7}$ Anderson, "Notation", 22.

${ }^{8}$ Translation from Jeremy Yudkin, De Musica Mensurata. The Anonymous of St. Emmeram (Bloomington: Indiana University Press, 1990), 92-93. 
consisting of a more or less square punctum with two descending stems or with two (occasionally only one) ascending stems.

Two important aspects of the plica as it was used in the 13th and 14th centuries were its division into two pitches and its likely liquescent mode of performance. The division into two sounds together with measured interpretation of the sign was discussed repeatedly in the 13 th-century treatises concerned with mensural notation. ${ }^{9}$ Liquescence was referred to less frequently in connection with the plica and remains an area of uncertainty for the modern interpreter. ${ }^{10}$ David Hiley's work on the topic has begun to unravel the questions of liquescence and the plica. In his article for The New Grove Dictionary of Music and Musicians, Hiley began with a definition of the term: "The name used in the 13th and 14th centuries for liquescent neumes". 11 He found that "The plica retained its basic function of indicating liquescence in all plainchant manuscripts, in most manuscripts containing nonmensural secular monophony and in most manuscripts containing polyphony until the 14th century." In his later article, "The Plica and Liquescence", Hiley explored the connection between the plica and liquescence in 13th-century polyphony in further detail. In doing so he examined two 13th-century chant manuscripts in square notation and presented figures which show that in these the plica is mainly used in those situations usually expected to take liquescence, for example, where the consonant $r$ is followed by another consonant. ${ }^{13}$

The performance of the plica in chant notation as two notes is generally accepted. The validity of this interpretation was demonstrated for the plica-like cephalicus and epiphonus in the square notation of the Sarum rite books (1225 to 1500) by Diane Lynne Droste. She was able to make a comparative investigation of the sources, examining variations in the

'For Garlandia's comments in De mensurabili musica, see Anderson, "Notation", 20-23. The interpretation of the plica was clarified by the work of Magister Lambertus, c. 1275 (Anderson, "Notation", 33). Two further treatises covering this topic are those by Franco of Cologne and Anonymous IV.

${ }^{10}$ Two references from medieval theorists are those of firstly, Magister Lambertus who in his treatise concerning mensural music gave a description of the voice production used in the performance of the plica which may reflect liquescent treatment, see Willi Apel, The Notation of Polyphonic Music 900-1600, 5th ed. (Cambridge, Mass.: The Medieval Academy of America, 1961), 226-27; and secondly, Jerome of Moravia who associated the "plica longa vel brevis" with the liquescent concept in relation to chant, see E. de Coussemaker, Scriptorum de musica Medii Aevi, vol. 1 (1864-76; reprint, Hildesheim: Georg Olms, 1963), 87.

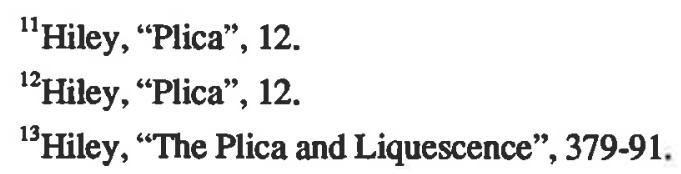


notation of the same chants found in different sources. Through study of liquescent neumes which were replaced by non-liquescent neumes in corresponding positions of other sources, Droste came to the conclusion that:

the ordinary plica or cephalicus is the liquescent equivalent of the flexa, and that it should be sung as two distinct pitches. Because it generally stands in the place of two ordinary notes, the second pitch should usually be considered an essential melody note, rather than an ornament, although this is not always true. ${ }^{14}$

The epiphonus was found similarly to be related to the pes. ${ }^{15}$

The late 15th-century and early 16th-century Spanish theorists who wrote on plainchant demonstrate varying interpretations of the plica. Two groups may be identified amongst these theorists, the grouping being almost identical to that already established in Chapter 3. The first group includes the earliest Spanish music theorist known to have written on the plica (which he described as "punto con dos plicas"), Domingo Marcos Durán; no other appears to have mentioned it previously even in studies of polyphonic notation. ${ }^{16}$ Also in the first group are others of the "equalists" - Molina, Bizcargui, and Aguilar - and in this context Bermudo must be included. The second group includes most of the "non-equalist" works discussed in Chapter 3: the work of Podio and the two anonymous treatises. Although the treatises of these two groups have already been considered in Chapter 3, their ideas on the plica need to be summarized as part of the discussion below.

For these theorists, the term plica was a general one denoting a line or stem attached to a single note or a ligature and was distinguished from the virgula which was an unattached line. Durán gave alternative names for the plica - trato, cauda, and virgula pendens - the first two of which are well known from non-Spanish mensural treatises. Such stems or plicas were seen as adorning notational figures by being attached to ligatures in the traditional positions required by square plainchant notation. Duran's comment that notes with stems were used only on accented syllables in former times but are no longer observed is unique and puzzling. ${ }^{17}$ Some Spanish sources dating from the time Durán was writing do make

\footnotetext{
${ }^{14}$ Droste, "The Musical Notation", 280.

${ }^{15}$ Droste, "The Musical Notation", 281.

${ }^{16}$ The term - in the sense of a stem only - had been mentioned earlier (for example Anonymous Seville of 1480, see Hastings, ed., Text and Concordances, fol. $47^{\mathrm{r}}$ etc.) but the well known sign had not.

${ }^{17}$ Durán, Comento, fol. [e4] .
} 
use of single stemmed notes on accented syllables, especially in recitative style chants such as those for the prefaces. This may be seen, for example, in the prefaces of the Missale mixtum alme ecclesie toletane, $1499 .^{18}$

It is clear that by the time during which these theorists were writing, a shift had taken place in the meaning of the word plica which thus, unequivocally, came to denote a note stem rather than the formerly denoted note form. The same meaning was also used in the context of mensural notation of polyphony by theorists of the two groups who wrote on that topic. Bermudo not only used the word plica to refer to the stems of note forms and ligatures in mensural notation but also explained how the plica (i.e. stem) affected durational significance. ${ }^{19}$ Other terms were also used to denote the stem in the mensural context: for example, Bizcargui preferred trato or rasgo. ${ }^{20}$ Among contemporary non-Spaniards, Tinctoris referred to the stem of single notes and ligatures in mensural notation with the term cauda and he appears to have reserved the term tractus for the lines which represent pauses. $^{21}$

Like Durán, the three writers Aguilar, Bizcargui, and Bermudo all described a sign used in plainchant notation formed from a single punctum with two stems attached, one on either side. Rather than calling this sign a plica, they referred to it as a "punto con dos plicas". The same writers all gave instructions on the interpretation of the punto con dos plicas found in plainchant notation. It was to be sung as one pitch and held for the duration of two single notes or two compases; one single note (punto) having the value of one compas. ${ }^{22}$ For the modern reader the question inevitably arises of the relation of the note form discussed by these theorists to the plica found in earlier sources of chant and polyphony. In particular, it may be asked whether its use was connected with liquescent practices in their understanding. In answer to this question, it may be observed firstly that from the discussions of the plica as stem and of the punto con dos plicas, it may be inferred that the

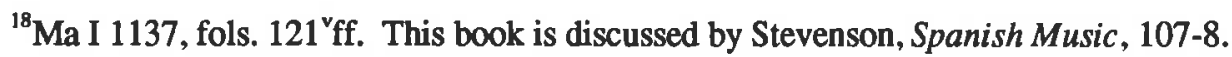

${ }^{19}$ Bermudo, fol. $x^{x} v^{x}$ and fols. xlviii ${ }^{v}$-xlix ${ }^{\mathrm{x}}$.

${ }^{20}$ Bizcargui, 1511, fol. $\mathrm{c}^{\mathrm{r}}$.

${ }^{21}$ See Tractatus de notis et pausis, in Coussemaker, Scriptorum de Musica Medii Aevi 4: 42-45.

${ }^{22}$ The fifth member of this group of theorists, Molina, did not specify the duration precisely, saying simply that it should be longer than that of any other note. See Molina, fol. [a6]".
} 
plica was no longer associated with a liquescent style of performance; and secondly that in fact no criteria are given by these theorists for determining the placement of the punto con dos plicas within chants. Durán's reference to the association in former times of stemmed notes with accented syllables may have had some application to the punto con dos plicas although the reference precedes discussion of the latter sign. That it did have application is suggested by the use of the punto con dos plicas in the Zamoran Ritual. The possible association of this sign and accent will be discussed further later in this chapter. The performance of the sign as two pitches advocated by 13 th-century mensural theorists is never alluded to by these Spanish writers. From their descriptions one concludes that the sign represented a single pitch only, that pitch having the value of two compases.

These theorists' understanding of the note with two stems as signifying a note with the duration twice that of a single punctum finds a parallel in an English work. In The Booke of Common Praier Noted by John Merbecke and dating from 1550, the sign was called a strene note. ${ }^{23}$ He used it as part of his system of measured notation for liturgical music, either composed or adapted by himself, and contained in the book. Merbecke defined the strene note as a breve, whereas he defined the plain punctum without stems as a semy breve. ${ }^{24}$ A strene therefore had the duration twice that of a punctum. In addition to Merbecke's use of the strene, it is found in English sources of polyphonic vocal music which date from the late 15 th century and the early 16th century. ${ }^{25}$ Margaret Bent has referred to measured notation in which strenes, breves, and ligatures are employed as "strene notation". ${ }^{26}$ An interesting difference is to be found between the English strene and the Spanish punto con dos plicas: while both the ascending and descending stem forms are regarded by the first group of Spanish theorists as single notes of double duration, the English ascending stem form seems not to have been a note of double duration but one

${ }^{23}$ Another reference to the note is found in a 14th-century Middle English text written by a monk. He refers to "a streinant with two long tails" but it is not clear whether the sign was used in chant or polyphony. See Francis Lee Utley, “The Choristers' Lament”, Speculum 16 (1946): 195-202.

${ }^{24}$ Judith Blezzard, "Merbecke, John", NG 12: 169.

${ }^{25}$ Margaret Bent, "New and Little-known Fragments of English Medieval Polyphony", Journal of the American Musicological Society 21 (1968): 150-51.

${ }^{26}$ Bent, "New and Little-known Fragments", 149. 
representing two rising notes. ${ }^{27}$

The second view of the meaning of the note with two stems in the work of Spanish chant theorists has been seen in three treatises of the "non-equalists". Here, in the context of chant notated in signs of mensural notation, the note with two stems takes on a different meaning and new names. Two terms are used to refer to the note form. These are tocus and uncus, the first being used when the stems ascend from the note-head, and the second when they descend. Plica was one of several words used by Podio to mean a note stem. ${ }^{28}$ The same meaning is again found in the Anonymous Arte de melodia sobre canto lano $y$ canto d'organo where it is used in reference to the stems of the tocus and the uncus. ${ }^{29}$

As has been described in Chapter 3, Podio gives the most detailed discussion of the tocus and the uncus. From him we learn that they were to be performed as two rising notes (tocus) or two falling notes (uncus), the second note being short; that they were associated with diphthongs; and that they were no longer well understood. The description of the tocus and the uncus in the Anonymous Catalan treatise, Barcelona, Biblioteca de Catalunya, Ms. 1327, seems to indicate the method of performance described by Podio, but that in the Anonymous Arte de melodia sobre canto lano y canto d'organo seems to indicate a three note performance, the voice rising and then falling to the first pitch in the tocus and vice versa for the uncus. Neither of the anonymous treatises mention diphthongs. Podio's comment that the signs were rarely observed suggests an explanation for the fact that neither the terms nor the changing pitch interpretation were given widely in the Spanish treatises. A further explanation may lie in the existence of a second tradition of chant singing proposed in Chapter 3 and identified as "non-equalist". This tradition, characterized by unequal duration of notes, may have included the moving pitch interpretations of the tocus and the uncus. Such an interpretation of signs with the form of plicas would be in accord with their traditional significance in mensural notation.

Returning to the question of criteria for the employment of notes with two stems, it

\footnotetext{
${ }^{27}$ I am indebted to Dr. John Caldwell of Oxford University for communicating this information on the English note forms to me.

${ }^{28}$ Podio, Ars musicorum, fols. $\mathrm{XXXXV}^{\mathrm{v}}$.

${ }^{29} \mathrm{Gümpel}$, "El canto melodico", 39.
} 
may be observed that two possibilities have been found. Both are connected with former or by then rarely observed practices. The first is the association of stemmed notes with accented syllables mentioned by Duran, problematic for its indirect relation with the single note with two stems; the second is the association of notes with two stems with diphthongs mentioned by Podio and suggestive of liquescence. In some cases the reason for use of the plica may be simply that it continued to be copied from earlier manuscripts in which liquescence had been intended by the sign but with little or no understanding of that original significance.

In the following section a study of the usage of the note form in the Zamoran sources will be presented, with an analysis of its use on accented syllables and positions of potential liquescence including diphthongs. Only the use of the isolated plica will be discussed, as opposed to the plica placed at ligature ends. (It might be argued that the supposition of association of liquescence and the plica on the grounds of Podio's comments is applicable only to the notation of chant in mensural signs, nevertheless, this limitation has not been adopted here in view of the known liquescent association of the plica in earlier chant sources written in square notation.) In accordance with English language usage the note form will be referred to simply as a plica despite the inaccuracy of the usage with regard to the Spanish theorists.

\section{ZAMORAN SOURCES}

For the first part of this section, the principal focus is the tones for the prefaces and the Pater noster in the Ritual. These were chosen for special study because of their surprisingly frequent and unusual usage of the plica. By way of comparison, the 15 th-century portion of the Misal votivo is used as it also includes preface and Pater noster tones. These tones are not found in any other of the Zamoran sources. Included here also are two settings of the invitatory psalm as one of these occurs in the 15th-century portion of the Misal votivo. The second part of the section includes chants belonging to the more freely composed classes such as responsories, antiphons, and introits, as well as including the more elaborate tones. The sources for the second part embrace the legible fragments or legible portions of fragments using square notation from the AHPZa collection included for study in this 
dissertation, as well as the Misal votivo and Ritual. Psalm, canticle and other incipits have been excluded as well as abbreviated repeated sections. Chants written in mensural notation are not included. Polyphonic works are also not included.

\section{Liturgical Recitative}

\section{Ritual}

The main body of the Ritual contains fourteen prefaces. In the loose booklet kept at the back of the Ritual are a further five prefaces (not all complete), written in late Aquitanian notation. The latter group will be discussed at the end of this section.

The tones of the prefaces and the prayers of the main body of the Ritual exhibit the usual structure of reciting notes and various inflections. Their structure and melodies are discussed in detail in Chapter 9. Particularly interesting is the use of the plica on the principal reciting note (F) of the preface and the festive Pater noster tones. Not only is the plica used quite frequently but analysis shows that it mainly falls on accented syllables of the Latin texts. The analysis is shown in Table $1 .^{30}$ Introductory sections to the tones are not included. Reference to accented syllables in this and the following tables refers to accented syllables found in words of two or more syllables.

Table 1: Plicas on the Principal Reciting Note of Prefaces and Festive Pater Noster Tones in the Ritual

Total number of plicas 146

Number of plicas on monosyllabic words

Percentage of plicas on accented syllables or monosyllabic words $95.2 \%$

Percentage of plicas in two or more syllable words on accented syllables $94.6 \%$ Percentage of plicas on positions of potential liquescence ${ }^{31}$

${ }^{30}$ No figures are given for the use of the plica throughout the preface and Pater noster tones, as opposed to the $\mathrm{F}$ reciting note passages. This is because the usage of the sign for durational melodic balancing adds a factor which would confuse the picture presented by the tables.

${ }^{31}$ Positions of potential liquescence have been identified in this study by application of the principles delineated by Mocquereau. The figure therefore represents the number of plicas associated with consonantal and vowel combinations found by Mocquereau to be associated with liquescent neumes. See PM 2: 38-57; summarized in Eugène Cardine, Gregorian Semiology, trans. Robert M. Fowels (Solesmes, 1982), 215-16. It was decided for the purposes of this study to use the theory of liquescence established by Mocquereau rather 
The great frequency of the plica on accented syllables and monosyllabic words suggests that the presence of the accent was the determining factor in the placing of the sign. If the interpretation of the plica taught by Durán and other theorists as signifying a note of double duration is applied to the interpretation of these chants, the result is a lengthening of many of the accented syllables sung to the reciting note. The very few cases (7 out of 130) in which the plica is placed on an unaccented syllable of a word of two or more syllables may result from factors such as scribal error, differing accent placing, the desire to stress a secondary accent, or response to a following inflection. ${ }^{32}$ No other means of indicating stress or lengthening are employed in the $\mathrm{F}$ reciting note passages of these tones.

Analysis of the use of the plica in other parts of the same tones produces a varied picture. In the mediations and endings of the ferial forms, accented syllables receive all of the occasionally occurring plicas. These mainly fall on the final accented syllables of texts set to the ferial tone ending formula. In fact, a plica is always used in this position in these tones; this is true also for the ferial Pater noster tone.

In the endings of the festive preface and Pater noster tones, the principle of concurrent plica and accent no longer operates, while in the mediations of festive tones, plicas are never used. The mediation and ending formulas of the festive tones make much use of two-note neumes which give lengthening to accented and unaccented syllables. A plica is invariably employed in the festive ending formula on the syllable which immediately precedes the final accented syllable. This usage suggests that the plica indicates lengthening of the syllable in order to provide balance for the two-note neumes which come before and after it. If Durán's instructions are followed in performance each note of a two-note neume would receive the same duration, that of one compas, which is also the duration of a stemless punctum. An instance of the festive ending formula is shown in Example 1. (In

than that of Freistedt largely as a result of Cardine's support of the former. Leo Treitler discusses the differences between the two theories in "Reading and Singing: On the Genesis of Occidental Music-Writing", Early Music History 4 (1984): 164-68.

${ }^{32}$ The plica is used on the first syllable of "Eterna" in two ferial versions of the preface with a similar treatment also occurring in the booklet. The resulting lengthening of an unaccented syllable may have been in response to the following inflection. Differing accentuation of a Latin word is suggested by the placing of the accent on the third syllable of "sempitemeque" instead of on the usual penultimate syllable. 
all the following examples, the transcriptions give no rhythmic indication but the plica is indicated by a hollow note-head which tends to suggest to a modern reader a note of longer duration than the surrounding black note-heads.)

Example 1: Ending Formula (from common preface, festive tone, Ritual, fol. $75^{\mathrm{x}}$ )

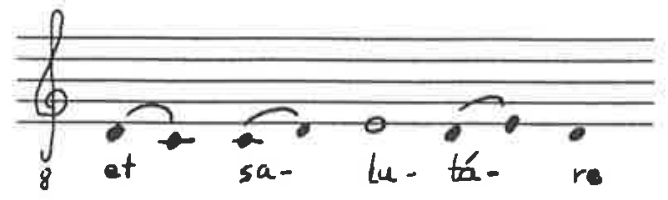

The secondary reciting note $\mathrm{E}$ is employed less and without the frequent unbroken repetition of the pitch that characterizes the principal reciting note $F$. It is frequently used in conjunction with ornamental melodic movement, sometimes with three-note neumes in festive forms of the tones. Similarly to the plica of Example 1, in these sections plicas falling on $\mathrm{E}$ or on an ornamenting note often appear to have been chosen in response to needs other than the textually based one of stressing accented syllables. The proportion of E reciting notes with plicas falling on either accented syllables or monosyllables is only slightly larger than that falling on unaccented syllables, a situation very unlike that of the F reciting note. If interpreted as a note of double duration the plica of these sections may be seen to fill a melodic need providing balance to the two-note and three-note neumes occurring on single syllables. Plicas on the E reciting note sometimes appear to form secondary accents, the resulting lengthening having the effect of balancing the use of two-note neumes in following ending formulas. An example occurs in the Christmas preface where a plica on the reciting note $E$ falls on the first syllable of a closing phrase "claritatis infulsit". The phrase continues so as to conclude with the ending formula. This is shown in Example 2. As can be seen the principal accent of "claritatis" falls on the penultimate syllable at which point the first two-note neume of the formula begins. The second plica in the example is an invariable part of the festive ending formula. 
Example 2: (from Christmas preface, Ritual, fols. 91 ${ }^{\mathrm{v}}-92$ )

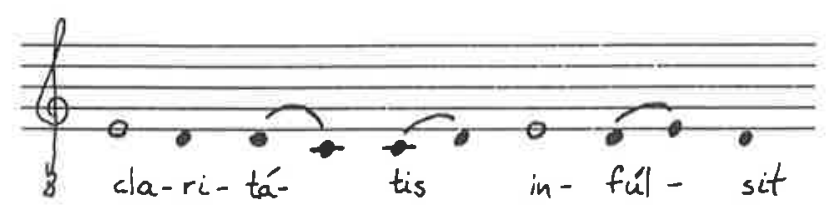

The ferial Pater noster tone has been mentioned only in passing so far. This is because it uses a different fundamental tone from the festive and ferial prefaces as well as the festive Pater noster which in fact are all variations on a second fundamental tone. The tones are discussed in detail in Chapter 9. The usage of the plica, however, follows that already seen. It occurs only on accented syllables of words of two or more syllables except for one monosyllabic word. Most occurrences are in the endings where the plica is employed on the last accented syllable.

The introductions of the prefaces and the Pater noster tones as well as the closures of the latter show a preference for placing the plica on accented syllables or else as part of formulas. The usage in the Pax domini is similar.

With regard to the question of association of the plica and liquescence, liquescence appears not to have been the criterion for the usage of the sign, those criteria already discussed being more likely, i.e., the stressing of accent, and durational balancing of melodic movement. This conclusion is drawn primarily because of the greater frequency of association of accent with the plica than with potential liquescence resulting from certain consonant and vowel combinations. It is drawn secondarily because of the constant formulaic occurrence of the plica in identical positions in endings and in other positions requiring lengthening.

A sample study of the Ritual preface texts was made which counted the number of accented syllables in words of two or more syllables and of monosyllabic words which show possible liquescence as a result of particular letter combinations. This study was made without reference to the musical setting and its notation. The finding was that $48.4 \%$ of the 223 words show potential liquescence on the accented syllable or are monosyllabic words, the formation or following context of which shows potential liquescence. The number of plicas in such potentially liquescent positions is only a little lower (39.7\%) and 
so suggests that the number of plicas falling in positions of potential liquescence may be a result of the character of the language. A more complete study of liquescence might indicate more reliably the usual frequency of such situations in Latin chant texts. In conclusion, it seems that the usage of the plica in the tones of the Ritual is based not upon liquescence but upon requirements of accent and durational melodic balance. For both types of usage, the application of the meaning of double duration of the plica is appropriate and produces satisfactory results.

\section{Booklet}

Instead of the usual form of the plica, the booklet uses a late Aquitanian cephalicus. ${ }^{33}$ It is employed in a manner very similar to the plica in the Ritual prefaces. Cephalici are found in the F reciting note passages, where only three instances out of thirty are not on accented syllables. (There are no occurrences on monosyllabic words in the reciting note passages.) As may be seen in Table 2, the percentage on positions of potential liquescence is low. Aside from the reciting note passages, the cephalicus continues to be used mainly on accented notes, with the number occurring on potential liquescent positions continuing to be low. In particular, it forms an invariable part of the ending formula of the booklet in the same way as the plica was seen in the ending formula of the ferial prefaces. ${ }^{34}$ The cephalicus in this source has clearly altered its character from liquescence to association with accent. It therefore was probably performed in the same way as the plica of the Ritual, very probably as a note of doubled duration in relation to the surrounding puncta.

\section{Table 2: Cephalici in F Reciting Note Passages of the Booklet}

Total number of cephalici

Number of cephalici on monosyllabic words

Percentage of cephalici in two or more syllable words on accented syllables $\quad 90 \%$ Percentage of cephalici on positions of potential liquescence stems.

${ }^{33}$ There is also one occurrence of a plica in the standard form of square head and two descending

${ }^{34}$ Figures for use of the cephalicus apart from the F reciting note are not given in Table 2 in order to facilitate comparison with Table 1. 


\section{Misal votivo (15th-century section) and Z 246}

Different practices must to some extent have determined the choice of placement of plicas in the 15th-century section of the Misal votivo. Here, unlike the Ritual, the plica is not employed on the reciting notes of the preface and Pater noster tones. Neither does it appear in the mediations and endings as it had done in the Ritual tones. In the Misal votivo tones, there are only five instances of plicas and they are only found in introductory dialogues and concluding sections. All five plicas fall on either accented positions in words of two or more syllables at phrase closes or on monosyllabic words at the opening of phrases. Three are in positions of potential liquescence. This preference for placing the plica in accented positions is continued in the invitatory psalm of the 15 th-century portion of the source. The coincidence of plicas and potential liquescence is low in the invitatory tone. The figures for plica use in the tones of the preface, the Pater noster and the invitatory psalm are presented in Table 3. From these it can be seen that the preference for use of the plica on accented syllables or on monosyllabic words is unequivocal and is found in addition in $\mathrm{Z} 246$. Z 246 (15th century) contains the sole other example in the Zamoran sources of the invitatory psalm with plicas employed. The Misal votivo has another invitatory psalm setting in the 14th-century portion of the source. That setting, however, does not make use of plicas.

Table 3: Plicas in Liturgical Recitative in the 15th-century Section of the Misal votivo and Z 246

Misal votivo $\underline{\mathrm{Z} 246}$

Total number of plicas

Number of plicas on monosyllabic words

Percentage of plicas on accented syllables or monosyllabic words

Percentage of plicas in two or more syllable words on accented syllables $\quad 100 \% \quad 100 \%$

Percentage of plicas on positions of potential liquescence 21

2 2 $100 \% \quad 100 \%$ $52.4 \% \quad 50.0 \%$ 
In the Misal votivo invitatory psalm, the accented syllables with the plica are mainly those in medial closures. There the use of the plica is influenced by word structure. Plicas are only used in the closures when the final word is a paroxytone and only occur on the accented syllables. It is never employed with the few proparoxytones. Two types of medial closure are found and in the first of these every instance of a final paroxytone carries a plica. Replacement of the plica in final paroxytones of the second medial closure by a torculus confirms the likelihood that the plica indicated lengthening. This is because the torculus, when sung with each of its notes receiving a duration the same as a single punctum, has the effect of lengthening the accented syllable as does the plica with the duration of two puncta. All of the second type of medial closures ending in paroxytones have lengthening on the final accented syllable by means of either a plica or a torculus. The proparoxytones do not employ lengthening on the final accented syllables. In an exceptional case, lengthening by means of a torculus is found on the penultimate syllable of one proparoxytone ending. Example 3 gives the standard paroxytone and proparoxytone forms of the two types of medial closure.

Example 3: (Misal votivo, fols. 11'-13')

Type one medial closure

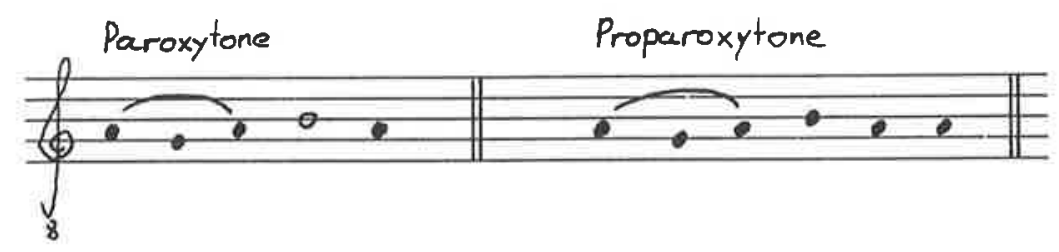

Type two medial closure

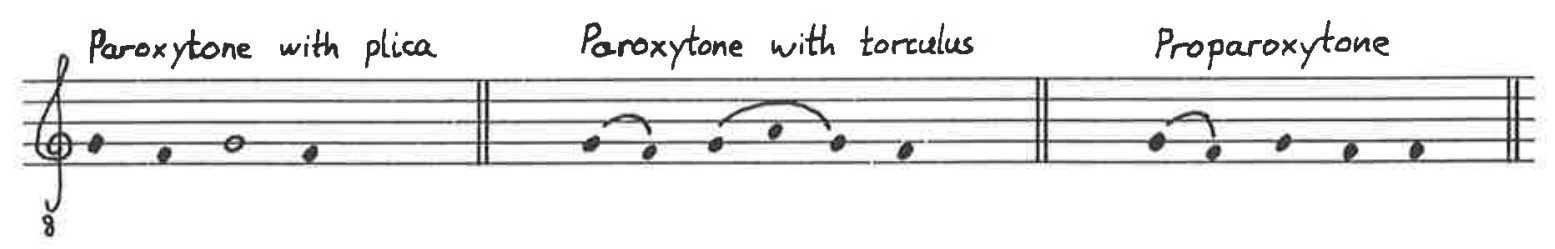

Returning to the question of liquescence with regard to the.Misal votivo, it is notable that all three plicas in the invitatory tone which fall outside of the closures occur on 
positions of potential liquescence. ${ }^{35}$ The invitatory antiphon employs much the same melodic material as the tone with which it is coupled. The use of plicas in the antiphon is similar to that of the tone, but has not been included in the figures of Table 3 . One plica is found at a phrase end with the first type of medial closure, and, as in the tone, the plica is on the accented syllable of a paroxytone. On the other hand, another plica occurs in the expected melodic position in the second type of medial closure but is not associated with an accented syllable. This suggests that the psalm melody was adapted to the antiphon rather than the other way round. The third and last plica of the antiphon occurs on a potentially liquescent position and accented syllable outside of the melodic closure formulas.

\section{Freely Composed Chants and Elaborate Tones}

The following section focuses upon the plica as used in all chants other than those already discussed but not including incipits. Polyphonic settings are not included. The sources embrace all those in the studied collection of AHPZa fragments written in square chant notation, apart from that fully studied in the preceding section, Z 246. Also included are chants from the Ritual and the Misal votivo. The booklet does not need to be examined again as it has already been fully covered. The chants notated in the mensural, semi-mensural, and pseudo-mensural notations discussed in Chapter 4 are not included.

Tables 4 and 5 give the results of the analysis of plica usage in these chants. Table 4 includes only 14th-century sources: the 14th-century portion of the Misal votivo and the group of sixteen fragments identified as Book 1. (With the exception of the polyphony containing $\mathrm{Z} 184$, none of the fragments in square notation has been dated to the 13 th century.) Table 5 gives results for Books 4, 6, 7, 8, 9, and 10, as well as the isolated fragments Z 101, Z 104, Z 148, Z 154, Z 203, Z 234, and Z 260. The fragments of Table 5 are believed to date mainly from the 15 th century, although some may have originated during the late 14 th century or the early 16 th century. ${ }^{36}$

\footnotetext{
${ }^{35}$ These plicas fall on the first syllables of "magnus", "autem", and "dominus".

${ }^{36}$ There are further fragments in square notation from the 15 th to early 16 th centuries which do not employ the plica and which therefore have not been included here.
} 
Table 4: Plicas in Sources of the 14th Century

\section{Book 1 Misal votive}

Total number of plicas

Number of plicas on monosyllabic words

Percentage of plicas on accented syllables or monosyllabic words

$73.6 \% \quad 69.2 \%$

Percentage of plicas in two or more syllable words on accented syllables $65.9 \%$ $52.9 \%$

Percentage of plicas on positions of potential liquescence

$94.3 \%$

$92.3 \%$

Table 5: Plicas in Sources of the Late 14th to Early 16th Centuries

\section{Fragments Ritual}

Total number of plicas 70 16

Number of plicas on monosyllabic words 15 2

Percentage of plicas on accented syllables or monosyllabic words $80.0 \% \quad 87.5 \%$

Percentage of plicas in two or more syllable words on accented syllables

$74.5 \%$

$85.7 \%$

Percentage of plicas on positions of potential liquescence

$74.3 \% \quad 31.3 \%$

From these two tables it emerges that a change occurred over the period embraced. The figures of Table 4 suggest that liquescence was a factor behind the use of the plica in the two 14th-century sources, with accented syllables and monosyllabic words being clearly secondary. Table 5 shows the rise of accented syllables and monosyllabic words, with a drop in potential liquescence which is especially marked in the Ritual. A reinterpretation of the material represented in Tables 4 and 5 according to the notation classes identified in Chapter 4 shows no differentiation along such lines. Table 4 includes only class 3 sources while Table 5 includes sources of each class with the majority belonging to class 4 . The high proportion of association of the plica with potential liquescence shown in Table 4 is not continued in the class 3 sources of Table 5.

The higher proportion of plicas in positions of potential liquescence shown in Table 5 for the fragments as compared with the Ritual might be explained by a high degree of retention in the fragments of liquescence indicating signs occurring in the manuscripts from which they were copied. Whether or not it was understood by the compilers or users of the 
sources, liquescence could therefore have served indirectly as a factor determining employment of the plica although playing a less important role than in earlier sources. (That the actual practice of liquescence was widespread by the 15 th century seems unlikely given the scarcity of theoretical reference.) Brief study shows plicas in chants of Zamoran sources which correspond to liquescent neumes in the same chants occurring in the gradual of Saint-Yrieix ( $\mathrm{Pa} 903$ ), the antiphoner Worcester $160,{ }^{37}$ and in the Graduale Triplex. These examples do in fact suggest that the tradition of copying of liquescent neumes as plicas was continued in some Zamoran sources from the 14 th to early 16 th centuries. The Ritual seems to have been an exception. ${ }^{38}$ In the Ritual, the plica occurs on potentially liquescent positions no more frequently than might probably be expected given the level of frequency of such positions occurring by nature of the language. ${ }^{39}$

The double is employed quite extensively in the fragments of the late 14th to early 16th centuries and in the Ritual. ${ }^{40}$ We know from Bermudo that this sign was used instead of the plica and with the same meaning of double duration, the plica by his time having fallen into disuse. ${ }^{41}$ In order to compare the usage of the double and the plica, study has been made of the sources used for Table 5, together with some additional fragments in which the plica does not occur. ${ }^{42}$ The Ritual, like some of the fragments, makes use of both signs. (There are also fragments used for Table 5 in which the double does not occur.) The results given in Table 6 show the same pattern as that of Table 5, with isolated doubles being used mainly on accented syllables and monosyllabic words, and a smaller number appearing in positions of potential liquescence. Once again, there is no distinction to be

${ }^{37} P M 13$ and $P M 12$.

${ }^{38} \mathrm{~A}$ thorough study of this issue has not been made here. This is due to the difficulties of obtaining sufficient and suitable comparative materials which would be necessary for a systematic investigation.

${ }^{39}$ The plica use of the Ritual demonstrates a coincidence with potentially liquescent positions close to the percentage (38\%) found in a sample study. This number was arrived at by counting all liquescent and non-liquescent syllables in the notated chants of the office In Nativitate Domini as given in the Antiphonale Monasticum (Paris: Desclée, 1963), 236-37. The total of syllables counted was 927. The sample study of liquescent formations in the prefaces limited to accented syllables and monosyllabic words already referred to, found a higher proportion, i.e. $48 \%$.

40."Double" and "plica double" are defined in Chapter 4, page 126.

${ }^{41}$ See pages 89-90.

${ }^{42}$ Fragments used for Table 6: Groups 3 and 3a, Books 4, 5, 6, 8, and 10, as well as $\mathrm{Z} 35, \mathrm{Z} 111, \mathrm{Z}$ $165, \mathrm{Z} 168$, and Z 260. 
made along the lines of notation class, both class 3 and and class 4 being represented. Doubles are not used in the tones of the Ritual or Misal votivo.

Table 6: Doubles in Fragments of the Late 14th to Early 16th Centuries and the Ritual Total number of doubles 62

Number of doubles on monosyllabic words 8

Percentage of doubles on accented syllables or monosyllabic words $75.8 \%$

Percentage of doubles in two or more syllable words on accented syllables $72.2 \%$ Percentage of doubles on positions of potential liquescence

The two 14th-century sources, Book 1 and the second portion of the Misal votivo, sometimes use the plica double. As in Table 6, these signs, as well as the doubles of the Misal votivo, are often found with accented syllables or monosyllabic words. They are found with less frequency in positions of potential liquescence.

The results of the study of the plica in Zamoran sources may be summarized as follows:

1. Three criteria for plica usage have emerged: accentuation, durational balancing, and liquescence.

2. The principle criterion of 14th-century plica usage is liquescence. It is less important in the later sources.

3. The criteria of accentuation and durational balancing are of importance in the later sources, and especially prominent in the Ritual.

The first and third criteria named in point 1 are those which emerged from study of the theorists' work. Moreover, the first and second criteria may be seen as connected with the interpretation of the plica as a note of double duration as taught by the "equalists" and Juan Bermudo, while the third relates to the teaching of Guillermus de Podio, of the "non-equalists". The views of the "non-equalists" on the plica, however, are not directly relevant to the notation considered in this chapter as they discussed the plica in the context of chant notation employing mensural signs. 
The apparent change over time in importance of criteria seems to have been paralleled by, and perhaps closely associated with, change in the meaning of the plica in the context of square chant notation from performance as two (or perhaps three) notes to performance as one long note. As a note of double duration and as such the only sign to indicate a non-standard duration in square chant notation in Spain during at least the 15th century and the first half of the 16th century, the plica may have been found to fulfil a perhaps newly perceived need for indication of lengthening of certain notes according to word accent.

Musicians may have acted in response to the need expressed by the influential grammarian, Antonio de Nebrija, who, in late 15th-century Spain, promoted the correct pronunciation of Latin. ${ }^{43}$ Nebrija spoke of the lengthening of long syllables so as to give them twice the duration of short syllables. Referring to Latin syllables, Nebrija in his Gramatica Castellana said:

Tiene ... la silaba longura de tiempo por que unas son cortas i otras luengas ... i llaman silabas cortas i breves alas que gastan un tiempo en su pronunciacion, luengas alas que gastan dos tiempos: como diziendo corpora, la primera silaba es luenga, las dos siguientes breves, assi que tanto tiempo se gasta en pronunciar la primera silaba como las dos siguientes.

Bermudo's wording, when speaking about half a century later on the topic of maintaining the accent, reminds the reader of that of Nebrija in the quotation above:

va midiendo todas las sylabas breues y longas, segun las reglas grammaticales. Deforma, que tanto tiempo gasta en vna sylaba longa, como en dos breues. ${ }^{45}$

The confusion which may seem to arise here between Latin quantity and accent finds resolution in recent research by Don Harrán. Harrán has observed that music theorists when speaking of long and short syllables usually "appear to refer, obliquely, to the musical results of setting accented and unaccented syllables in postclassical Latin: long notes or several notes on accented syllables, short notes on unaccented ones. ${ }^{946}$ This may well

${ }^{43}$ Antonio de Nebrija, Gramatica Castellana, ed. Pascual Galindo Romeo and Luis Ortiz Mufioz, (Madrid: Silvero Aquirre, 1946), xxix. Nebrija taught at the University of Salamanca and was a contemporary of Durán.

${ }^{44}$ Nebrija, Gramatica Castellana, 37.

${ }^{45}$ Bermudo, Declaracion, fol. xvii". A longer quotation of which this is a part is given in Chapter 3.

${ }^{46}$ Don Harrán, Word-Tone Relations in Musical Thought, Musicological Studies and Documents 40 , (Neuhausen-Stuttgart: American Institute of Musicology, 1986), 116. Harrán includes a study of the Italian theorist, Blasius Rossetti, who dealt with the issues of Latin pronunciation, accent, and music in his Libellus de rudimentibus musicae of 1529. 
have been the case with Bermudo and the practice of lengthening accented syllables is certainly the one observed in the tones of the Ritual.

The Ritual gives a demonstration of the plica employed in the 15th century to indicate the lengthening of accented notes in recitative passages of preface and Pater noster tones. It is therefore an early example of an attempt to maintain text accent, a practice which came to be more important in such chants during the following century. The cephalicus of the late Aquitanian notation of the booklet, takes the lengthening role of the plica, and in doing so presents a further and very interesting example of alteration in the meaning of a sign, that alteration being from its well known one of liquescence to lengthening.

Before concluding, results of a brief study of the notation of the prefaces of the Missale mixtum alme ecclesie toletane of 1499 may be remarked upon. ${ }^{47}$ In these prefaces, the plica of the Zamoran Ritual is replaced by a long, both on accented syllables of reciting note passages and in endings. The Missale mixtum is one of the chant books which was prepared under the direction of Cardinal Cisneros and is notated in mensural signs. Longs, breves, alphas, plicas, and three-note neumes with a rising stem on the left are used. That the long occurs in positions filled by the plica in the Ritual serves to confirm the function of the plica as a note signifying long duration. (No other Spanish noted missals from before the 16th century looked at in the course of this investigation make regular use of plicas or longs on the reciting notes of preface or Pater noster tones. ${ }^{48}$ ) The plica in the prefaces of the 1499 Missale mixtum appears, at least at times, to signify two notes. This is identifiable in the mediations of the festive preface tones which in many other sources consist of three two-note neumes. In the Missale mixtum, one of these, a clivis, is regularly replaced by a plica with two descending stems. ${ }^{49}$ This meaning of the plica is in keeping with the interpretation taught by the Spanish "non-equalist" theorists. The possibility of the plica as an abbreviation of the clivis and perhaps also the pes is an important one which

${ }^{47} \mathrm{Ma}$ I 1137 , fols. $121^{\mathrm{v}} \mathrm{ff}$.

${ }^{48}$ These include Ma 931 (14th or 15th century); Santiago de Compostela, Archivo de la Catedral, frag. 9 (14th or 15th century); Missal de Santa Eulalia de la seu de Barcelona, Barcelona, Archivo de la Catedral, cod. 116 (15th century); and Missale Giennense, printed in Sevilla, 1499.

${ }^{49}$ For example, fol. 122. Robert Stevenson, however, mentions the meaning of the "punctum with two stems" in the Missale mixtum as being double duration (see Spanish Music, 108). 
appears to have been the case at times in square chant notation of sources outside of Spain. ${ }^{50}$ However, the Zamoran sources studied here show no reason to believe that amongst them, the plica was ever intended primarily as an abbreviation replacing a clivis or pes. ${ }^{51}$

In conclusion, the meaning of the plica appears to have varied according to the type of notation in which it was employed in Spain during the 15th and first half of the 16th centuries: in unmeasured notation the plica indicated a single long note, and in measured notation it indicated two (or even three) notes of different pitch. Modern performance could therefore follow this pattern. In the 14th century the continuing association of the plica with liquescence suggests that a liquescent meaning of the plica may still have been known and the sign performed accordingly. Modern performance of such sources might therefore give two notes to the plica, the second note perhaps with the diminished sound quality which seems to be appropriate for the singing of liquescence. It is to be hoped that further research will eventually shed more light on this difficult aspect of chant performance and notational practice. ${ }^{52}$

${ }^{50}$ I am grateful to John Stinson of La Trobe University, Melbourne, for informing me that he has found the plica acting as an abbreviation of the clivis in Italian 14th-century chant manuscripts.

${ }^{51}$ Samuel Rubio noted that chant books of the Escorial from the second half of the 16th century frequently used a plica in the place of a clivis found in modem editions. See Samuel Rubio, "Las melodias de los «libros corales» del Escorial", La Ciudad de Dios 182 (1969): 349.

${ }^{52} \mathrm{~A}$ further refinement of the type of study carried out in this chapter could explore implications of Dom Eugène Cardine's division of augmentative and diminutive liquescence for the plica and its possible meanings in sources such as those studied in this chapter (Cardine, Gregorian Semiology, 217-20). Such investigation would require extensive comparative studies with earlier sources. 
PART C

REPERTORY STUDIES 


\section{CHANTS FOR THE ORDINARY OF MASS}

Examples of each of the five principal chants of the Ordinary of Mass are found in the sources under study. Among these are troped Kyrie chants and a fragment of the troped Gloria, Gloria. Spiritus et alme. The former group of tropes will be discussed in this chapter, but the latter work, a three-voice setting, will be discussed as part of Chapter 10 on polyphony. In addition one example of a troped Ite missa est is also found amongst the sources. As it is paired with a two-voice troped setting of the Deo gratias, the troped Ite missa est will also be discussed in Chapter 10 rather than in the present chapter.

The studies of the Ordinary chants by Margareta Melnicki, Detlev Bosse, Peter Josef Thannabaur, and Martin Schildbach have facilitated the identification of the melodies discussed in this chapter. ${ }^{1}$ As part of their studies all four authors produced catalogues of the melodies which form an indispensable tool for the study of these chants. Those melodies which were able to be identified are referred to here by the numbering of these catalogues, with the author's name (or its abbreviation) preceding the number. The disadvantage of the four catalogues is that Spanish sources are not strongly represented. This deficiency is most noticeable in those of Melnicki and Bosse (for example, only 2 out of the 493 sources used by Melnicki are from Spain²). In order to supplement the Ordinary catalogues, that of Fernández de la Cuesta was used for the two troped Kyries, and some Spanish and French manuscripts were consulted. The recent catalogue compiled by David Hiley of English, northern French, and Sicilian Ordinary chants is referred to as well during the discussion. ${ }^{3}$ As there is no catalogue devoted to Credo melodies yet

${ }^{1}$ Margareta Melnicki, Das einstimmige Kyrie des lateinischen Mittelalters, Forschungsbeiträge zur Musikwissenschaft, vol. 1 (Regensburg: Gustav Bosse Verlag, 1955); Detlev Bosse, Untersuchung einstimmiger mittelalterlicher Melodien zum "Gloria in excelsis deo", Forschungsbeiträge zur Musikwissenschaft, vol. 2 (Regensburg: Gustav Bosse Verlag, 1955); Peter Josef Thannabaur, Das einstimmige Sanctus der römischen Messe in der handschriftlichen Überlieferung des 11. bis 16. Jahrhunderts, Erlanger Arbeiten zur Musikwissenschaft, vol. 1 (Munich: Walter Ricke, 1962); Martin Schildbach, "Das einstimmige Agnus Dei und seine handschriftliche Überlieferung vom 10. bis zum 16. Jahrhundert" (Ph.D. diss. Friedrich-AlexanderUniversităt, Erlangen-Nümberg, 1967).

${ }^{2}$ Melnicki, Kyrie, 138.

${ }^{3}$ David Hiley, "Ordinary of Mass Chants in English, North French and Sicilian Manuscripts", Journal of the Plainsong and Medieval Music Society 9 (1986) (complete two part volume). 
available, these were compared with those in the modern Vatican books and the index of Bryden and Hughes. ${ }^{4}$

At the beginning of each of the sections in this chapter pertaining to the five items of the Ordinary is a table listing each chant to be discussed, giving the source in which it is found in the collection, melody identification, dating of the source, notation, and in the case of tropes, the number from Chevalier's Repertorium Hymnologicum. The column labelled "Context" indicates context within the liturgical year, but this is only given for a few of the works, as most of the sources are without such indication.

A catalogue of the openings of each chant is given at the rear of this dissertation in the section devoted to transcriptions. These openings are sometimes longer than is usual in a catalogue of incipits in order to show more of the material described in the discussion presented in this chapter than would otherwise be possible. For those chants for which the opening is missing in the fragments, the catalogue entry begins with the first remaining and legible note. A few of the most interesting chants are transcribed in full immediately following the catalogue.

\section{CHANTS OF THE KYRIE}

Table 1: Chants of the Kyrie in the Sources of Zamora
Source Melody
Dating
Notation Context
Chevalier
1. $\mathrm{Z} 68[\mathrm{a}]^{\mathrm{v}}$
Mel. 102
13 th $\mathrm{c}$
Aquitanian
3393
(Vat. ad lib. I)

2. Misal votivo, fol. $36^{\prime}$

14th c. Square

Requiem

3. Misal votivo, fol. 46 Mel. 70

14th c. Square

St. Ildefonsus 3737

(Vat. ad lib. V)

January

${ }^{4}$ John R. Bryden and David G. Hughes, An Index of Gregorian Chant (Cambridge, Mass.: Harvard University Press, 1969). 


\section{Z 68[a]": Clemens rector eterne}

On fragment $\mathrm{Z} 68$ of Book $\mathrm{C}$ is found the annotation "Incipiunt kyrri" suggesting the beginning of a group of Kyries or perhaps even of a kyriale. The chant immediately following this rubric is the texted Kyrie Clemens rector, Melnicki 102. It frequently occurs in this position or as the second chant in Kyrie collections of Aquitanian origin. ${ }^{5}$ As is usual with Aquitanian sources, Clemens rector is not associated in $\mathrm{Z} 68$ with any particular feast. $^{6}$ It has been found with varying usages, as may be seen for example in sources from Nevers where it occurs in the feast of St. Stephen Protomartyr following Christmas day, and in two sources from Apt where it is found in the feast of Ascension in one and Easter Sunday in another. ${ }^{7}$ Chevalier cites Christmas Day as the feast to which Clemens rector pertains. $^{8}$

Clemens rector belongs to the class of the "syllabically texted Latin Kyrie" which, as David A. Bjork has demonstrated, can be seen as distinct from the so-called Kyrie trope. ${ }^{9}$ The two forms are distinguished by their use of melody: the Kyrie trope adds a different melody in addition to text while the texted Kyrie simply adds text to the melody of the Kyrie resulting in a largely syllabic setting. In $\mathrm{Z} 68$ the chant begins with the verse "Clemens rector eterne pastor inmense eleyson" which is followed by the Ordinary text "Kyrie leyson" (sic) using the same melody. This procedure continues until the end of the fragment, each single acclamation of the Ordinary being preceded by a Latin verse to its melody. The fragment thus conforms to that which is thought to be the usual practice of the texted Kyrie. ${ }^{10}$

${ }^{5}$ John Boe, ed., Beneventanum Troporum Corpus II. Ordinary Chants and Tropes for the Mass from Southern Italy, A.D. 1000-1250, Recent Researches in the Music of the Middle Ages and Early Renaissance vol. 19 (Madison: A-R Editions, 1989), 25-26.

${ }^{6}$ Gunilla Björkvall, ed., Corpus Troporum V, Les deux tropaires d'Apt, mss. 17 et 18 (Stockholm: Almquist \& Wiksell, 1986), 229 n. 5.

${ }^{7}$ Nancy van Deusen, Music at Nevers Cathedral, Musicological Studies 30, vol. 1 (Henryville: Institute of Mediaeval Music, 1980), 11; Björkvall, ed., Corpus Troporum V, 218-19.

${ }^{8}$ Ulysse Chevalier, Repertorium Hymnologicum. Catalogue des chants, hymnes, proses, séquences, tropes en usage dans l'église latine depuis les origines jusqu'à nos jours, vol. 1 (Louvain, 1892-1921), 224.

'David A. Bjork, "The Kyrie Trope", Journal of the American Musicological Society 33 (1980): 3.

${ }^{10}$ Bjork, "The Kyrie Trope", 3. 
This Kyrie occurs in many widespread sources, those of French provenance being especially numerous. ${ }^{11}$ It was thought by Blume possibly to have originated at St. Martial of Limoges and in a more recent study Bjork has similarly proposed origin in Aquitaine. ${ }^{12}$ It belonged to the early repertory of Aquitanian Kyrie melodies and is known from the 10th century. ${ }^{13}$ A southern French source Ma 136 from Toulouse will be used for the comparative study given below. (It was not included by Melnicki in her survey.) Ma 136 is dated variously to the 14 th century ${ }^{14}$ and to the first half of the 13 th century, ${ }^{15}$ the latter a dating which seems very credible given the appearance of the notation.

Two Spanish sources of Clemens rector other than $\mathrm{Z} 68$ have been identified ${ }^{16}$ and will be used for comparison. These are the fine Ma BRAH 51 of 11 th-century San Millán de la Cogolla, and Ma 1361 which is thought to be of 14 th-century Catalonian origin. ${ }^{17}$

As Clemens rector is not given in its entirety in $\mathrm{Z} 68$ due to the continuation having been on another now lost folio, its study is necessarily limited. The fragment ends with the first word of the second verse of the text added to the Christe. Despite this limitation some interesting features may be observed. The trope text of $\mathrm{Z} 68$ contains one significant variant from the form given in $A H$ which is of particular interest as it is not found in any of the variants listed by Blume from sources dating from the 10 th to the 14 th centuries. ${ }^{18}$ It occurs at the opening of the phrase which in the usual form begins "Aether stellifer noster", but which in Z 68 reads "Sother salvator noster". Could this be a local or regional variant?

${ }^{11} A H$ 47: 57; Melnicki, Kyrie, 105; Hiley, "Ordinary of Mass", 69. Its presence in Beneventan sources to which it came from the Norman repertory is discussed together with a useful summary of the history and structure of this Kyrie trope by Boe in Beneventanum Troporum Corpus II/, vol. 19: xxix, 24-26. English and Sicilian sources as well French sources are listed by Hiley, Ordinary of Mass, 69-70.

${ }^{12}$ AH 47: 58; David A. Bjork, "Early Repertories of the Kyrie eleison", Kirchenmusikalisches Jahrbuch 63 (1979): 25.

${ }^{13}$ Bjork, "Early Repertories", 24.

${ }^{14}$ Higinio Anglés and José Subirá, Catálogo Musical de la Biblioteca Nacional de Madrid, vol. 1 (Barcelona: Consejo Superior de Investigaciones Cientifícas, 1946), 94-95.

${ }^{15}$ Anscari Mund6, "El proser-troper Montserrat 73", Liturgia 3 (1966): 107.

${ }^{16}$ Some assistance in identification was gained from Fernández de la Cuesta, Manuscritos, 325.

${ }^{17}$ Angles and Subira, Catálogo, 99.

${ }^{18} \mathrm{AH}$ 47: 56-58. 
In fact, this text variant also occurs in Ma BRAH 51 suggesting that this might be a regional variant. Unfortunately the probably Catalonian Ma 1361 and the southern French Ma 136, do not give the full trope texts.

The melody, a variant of Melnicki 102 (Vatican ad lib. I), ${ }^{19}$ is a very attractive one. Comparison of the melody of $\mathrm{Z} 68$ with the incipit given by Melnicki shows the Zamoran version to have one significant variant which it also has in comparison with the Melnicki 102 melodies given in David Hiley's catalogue. ${ }^{20}$ Instead of rising by conjunct motion from the opening note to the fourth above it, Z 68 rises only to the third. See Example 1. Ma BRAH 51, Ma 1361, and Ma 136 also rise only to the third, suggesting that this may have been characteristic of a particular tradition of the melody, one perhaps favoured in Spain. $^{21}$ The finding of further examples of this melody in Spanish sources would be of interest in order to discover whether this version is more widespread, and whether it may truly be seen as representing another tradition to those of Melnicki and Hiley. The form of the chant in $\mathrm{Z} 68$ for the first set of Kyries is $a b a$ which is as given by Melnicki for the melody (the repeats of each section caused by the singing of the added text are not included in this summary of the form). A full transcription of the chant from $\mathrm{Z} 68$ is found at the rear of this dissertation.

\section{Example 1}

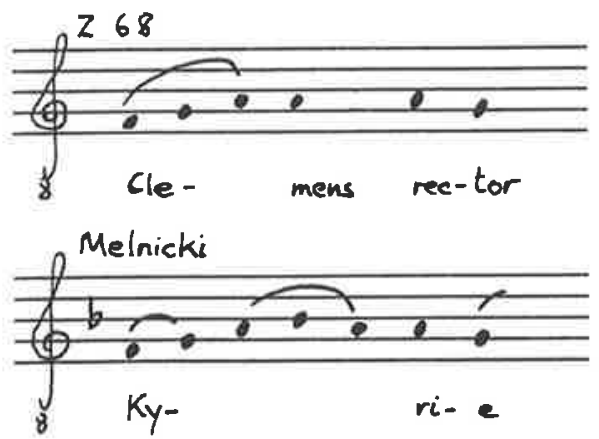

\footnotetext{
${ }^{19}$ Melnicki, Kyrie, 105; Graduale Triplex, 785.

${ }^{20}$ Hiley, "Ordinary of Mass", 69-70.

${ }^{21} \mathrm{Ma} \mathrm{1361}$, fol. 179'; Ma 136, fol. 76 .
} 
The notation in Aquitanian neumes without a clef has been transcribed here with D as the final, this being consistent with the mode in other sources as found by Melnicki ${ }^{22}$ and with that of Ma 1361. Although the staff-line is scarcely visible for this chant, it seems to take the third degree above the final at the opening; this is the standard line pitch for mode one in Aquitanian notation. The pitch of the line then changes in the middle of the second stave and at the beginning of the verse which opens "Nostrus nec ne". Here the line placement is difficult to determine but it is probably B given the indication of the direct. The following trope verse sees the return of $\mathrm{F}$ as the pitch of the line but is without a direct. In both Ma BRAH 51 and Ma 136 the notation is also Aquitanian and without clefs. The changes of pitch placement just described occur also in these other sources but without directs. Ma 136 does however give the mode in a rubric together with the first word of the added text "Clemens p[rim]i toni". 23 A further change of pitch placement occurs in Z 68 for the opening of the last verse in the fragment and for which only the word "Trine" is found in the source. Once again the pitch of the line is probably B.

\section{Misal votivo, fol. $36^{v}$}

This melody occurs in the Requiem Mass of the Misal votivo but it has not been possible to identify it in the catalogues of Melnicki or Hiley, nor has it been found in any of the Spanish manuscript sources studied during the course of this research including $\mathrm{Ma}$ 1361 and Mont $73 .^{24}$ The chant displays the following carefully structured form: $a b a c b^{l} c$ $a^{l} b^{l} a^{2}$. This may be seen as a variant of one of the common Kyrie forms identified by Melnicki in which the relationship of the three sections of the whole may be summarized as $A B A .^{25}$ The rising fourth G-a-c is prominent throughout the whole, occurring at the beginning of each repeat of $a$. The settings of "eleyson" in $a$ and $c$ are similar, moving within the same fourth as the opening of $a$; again the same rise G-a-c is incorporated

\footnotetext{
${ }^{22}$ Melnicki, Kyrie, 36.
}

${ }^{23}$ Ma 136, fol. $75^{\mathrm{r}}$.

${ }^{24}$ It would be particularly interesting to search for this melody in the Palencia manuscript which contains the the Sanctus and Agnus Dei from the Requiem Mass of the Misal votivo and which is included in the catalogues of Thannabaur and Schildbach. The manuscript will be referred to in more detail later in this chapter.

${ }^{25}$ Melnicki, Kyrie, 64. 
although altered, with more emphasis placed on the a at the beginning of the syllable "ley". Modally ambiguous, the whole closes on $\mathrm{E}$, with section closures on $\mathrm{b}$ and $\mathrm{G}, \mathrm{G}$ being the opening pitch of phrases $a$ and $c$; the overall ambitus is the octave D-d. The opening rising fourth suggests a $G$ mode as the majority of melodies in Melnicki's catalogue with this opening are in that mode. Comparison of the closing notes and mode with Melnicki's study stresses the unusual qualities of this Kyrie. ${ }^{26}$

\section{Misal votivo, fol. 46: Conditor kyrie omnium}

The melody for this Kyrie is Melnicki 70 (Vatican ad lib. V), one, which while not commonly occurring, is found in widespread sources and using various added texts. ${ }^{27}$ Only the first verse of the trope text is given in the Misal votivo and this is the same as that in $A H .^{28}$ Bjork sees Melnicki 70 as possibly of Aquitanian origin, but unlike Melnicki 102 possibly of a "second generation" and with a much smaller frequency of occurrence. ${ }^{29}$ The earliest source of the melody is the 10 th or 11 th century ${ }^{30} \mathrm{~Pa} 887$ from southern France. With the text Conditor kyrie omnium, the melody seems to have occurred mainly in English sources. ${ }^{31}$ The only sources of Spanish provenance named for the text by Fernández de la Cuesta are Ma 1361 and $\mathrm{Hu}^{32}$ In both cases Melnicki 70 is used but that in $\mathrm{Hu}$ is a two-voice setting. ${ }^{33}$ The melody is also employed in Huesca 4 from San Juan de la Peña, ${ }^{34}$ but not in the Spanish source Ma BRAH 51 nor the southern French Ma 136 named for Clemens rector.

${ }^{26}$ Melnicki, Kyrie, 34-48.

${ }^{27}$ Melnicki, Kyrie, 100; Hiley, “Ordinary of Mass”, 67.

${ }^{28} \mathrm{AH}$ 47: 77-78.

${ }^{29}$ Bjork, "Early Repertories", 27 and 24.

${ }^{30}$ Björkvall, ed., Corpus Troporum V, 422.

${ }^{31}$ Melnicki, Kyrie, 100; Hiley, "Ordinary of Mass", 67. The text is listed in $A H$ as occurring especially in English sources, with a small representation in French sources ( $A H 47$ : 77-78).

${ }^{32}$ Fernández de la Cuesta, Manuscritos, 325, 352. Chevalier includes no Spanish sources for this text (Repertorium Hymnologicum 1: 224, 5: 99).

${ }^{33} \mathrm{Ma} 1361$, fol. $182^{\mathrm{v}}-183^{\mathrm{r}}$; Hu facsimile: Anglès, Huelgas 2, fol. $1^{\mathrm{v}}-2^{\mathrm{v}}$.

${ }^{34}$ Bjork, "Early repertories", 36. 
Comparison of the version in the Misal votivo with the incipits of Melnicki and Hiley, and the complete melodies of Vatican ad lib. $\mathrm{V}^{35}$ and $\mathrm{Ma} 1361$, shows many variants but no patterns of variation. The ambitus is interesting as that of the Misal votivo is a tenth from $\mathrm{D}$ to $\mathrm{f}$, the same as the Vatican melody, but Ma 1361 makes use of one tone higher, D-g. Hu, which contains the only known Spanish polyphonic setting of the melody, also rises to the $\mathrm{G}$. The form and the mode (seven) in the Misal votivo correspond to those features as described by Melnicki. ${ }^{36}$

\section{CHANTS OF THE GLORIA}

Table 2: Chants of the Gloria in the Sources of Zamora

\begin{tabular}{|c|c|c|c|c|}
\hline Source & Melody & Dating & Notation & Context \\
\hline 1. $\mathrm{Z} 68[\mathrm{~b}]^{\mathrm{r}}$ & Bo. 51 (Vat. XI) & 13th c. & Aquitanian & 一 \\
\hline 2. $\mathrm{Z} 68[\mathrm{~b}]$ & Bo. 11 (Vat. XIV) & 13th c. & Aquitanian & - \\
\hline 3. $\mathrm{Z} 68[\mathrm{~b}]^{\mathrm{v}}-\mathrm{Z} 67^{\mathrm{r}}$ & Bo. 43 (Vat. XV) & 13th c. & Aquitanian & - \\
\hline 4. $\mathrm{Z} 67^{\mathrm{r}}$ & Bo. 20 (Vat. III) & 13th c. & Aquitanian & - \\
\hline 5. Misal votivo, ff. $46^{v}-47^{v}$ & Bo. 20 (Vat. III) & 14 th c. & square & $\begin{array}{l}\text { St. Ildefonsus, } \\
\text { January }\end{array}$ \\
\hline 6. Misal votivo, fol. $2^{r}$ & Bo. 56 (Vat. IV) & 15 th/16th $\mathrm{c}$ & square & - \\
\hline 7. $\mathrm{Z} 153^{\mathrm{r}}$ & Bo. 43 (Vat. XV)? & 15th/16th $\mathrm{c}$ & square & - \\
\hline 8. Z 153 & Bo. 38 (Vat. VIII) & 15 th $\mathrm{c}$. & square & $\begin{array}{l}\text { in honore } \\
\text { angelorum }\end{array}$ \\
\hline
\end{tabular}

\section{Z $68[b]^{r}$}

This fragment has already been discussed as it contains the Kyrie Clemens rector. $\mathrm{Z}$ 68 , and the following $\mathrm{Z} 67$ which also contains melodies for the Gloria, both belong to Book C. The opening of this Gloria has been lost, thus making identification tentative. It does however appear to be Bosse 51 (Vatican XI), a melody found in numerous widespread

\footnotetext{
${ }^{35}$ Graduale Triplex , 711-12.

${ }^{36}$ Melnicki, Kyrie, 67, 41.
} 
sources and known from the early Gloria containing manuscripts of the late 10th and 11th centuries. ${ }^{37}$ The loss of the opening phrases means that confusion with the closely related Bosse 2 is possible as the latter differs from Bosse 51 principally in the opening two phrases. ${ }^{38}$ The more widespread use of the melody beginning with the phrases of Bosse 51 and the use of that opening in two Spanish manuscripts suggests that the melody of $\mathrm{Z} 68$ may be classified as number 51. Bosse found melody 51 principally in sources of French and Italian provenance, while Hiley's listing shows it also in a large number of English sources. The absence of any Spanish sources in the list given by Bosse must be due to his inclusion of only one Spanish manuscript in his study. The three Spanish sources of the melody which have, however, been found in addition to $\mathrm{Z} 68$ will be cited in the discussion below.

Z 68 differs significantly from Vatican XI and although the loss of the first third of the chant makes comparison uncertain, the repetitive form of the melody which sees the reiteration of the opening phrase throughout allows the opening of the $\mathrm{Z} 68$ version to be assumed and thus it can be proposed to differ from the opening incipits given by Bosse and Hiley. ${ }^{39}$ The repeated opening phrase which in Z 68 is EGGF-E or EGF-E is in Bosse 51 DG-FE. Another recurring difference is a cadential pattern making use of the subtonium in $\mathrm{Z} 68$, FE-CD-D, while that in the Vatican version is FE-D-D. In addition to these differences, it may be said that in general the Zamoran melody is somewhat more ornamented than the Vatican version. Comparison of $\mathrm{Z} 68$ with the versions of the melody in Mont 73 (thought to be from 12th-century Urgell ${ }^{40}$ ) and $\mathrm{Ma} 1361$ shows that the three peninsular sources share these differences from the Vatican edition. All three use the E opening and the subtonium cadence. ${ }^{41}$ Another Spanish source, Ma BRAH 51, also shares these features, although with the addition of repeated notes in the cadence. ${ }^{42}$ Bosse identifies differences

${ }^{37}$ Bosse, Gloria, 28 (dating), 87-88 (sources); Hiley, "Ordinary of Mass", 88.

${ }^{38}$ The similarity between the two melodies is discussed by John Boe who uses the description Bosse 51=2, Beneventanum Troporum Corpus II, vol. 22: 37 .

${ }^{39}$ Graduale Triplex, 749-50; Bosse, Gloria, 99, Hiley, "Ordinary of Mass", 88.

${ }^{40}$ Mund6, "El proser-troper Montserrat 73", 105, 130-31.

${ }^{41}$ Mont 73, fols. $16^{\mathrm{r}}-17^{\mathrm{r}}$; Ma 1361, fol. 185.

${ }^{42}$ Ma BRAH, fols. $240^{\mathrm{v}}-241^{\mathrm{x}}$. 
of the ambitus in the melody in French, German, and Italian sources. ${ }^{43}$ That of French sources, $\mathrm{C}-\mathrm{a}$, is the one used in $\mathrm{Z} 68$ as far as can be said in view of the fragmentary nature of the example.

The melody is transcribed with the final of $\mathrm{D}$, the usual one for the melody. ${ }^{44}$ The placing of the final on the line suggests a plagal mode which is in accord with the modal classification given by the Graduale Triplex. ${ }^{45}$

\section{2. $\mathrm{Z} 68[b]$}

This melody is Bosse 11 (Vatican XIV). It is complete in the fragment except for a small segment lost as a result of damage to one corner. Like Bosse 51 it occurs in numerous and widespread sources from as early as the 10 th or 11 th centuries. ${ }^{46}$ Again Bosse gives no sources in Spain but three in addition to $\mathrm{Z} 68$ have been located.

Bosse 11 follows immediately in $\mathrm{Z} 68$ after the Gloria described above. The same sequence of melodies occurs in Ma 1361 and Ma BRAH 51, although the chants show some variation. (Ma BRAH 51 gives tropes with both melodies.) Bosse 11 also occurs in Mont 73. Comparisons between $\mathrm{Z} 68$ and the Spanish sources as well as the Vatican version and the incipits of the two catalogues, show that the version of $\mathrm{Z} 68$ differs from all, but is closest to the Spanish sources. ${ }^{47}$ One feature of $\mathrm{Z} 68$ which is found in only two of these other versions, Ma 1361 and Ma BRAH 51, is the reuse later in the melody of the repeated $\mathrm{c}$ which initially occurs on the first syllable of the opening word "Gloria". The repeated c recurs in $\mathrm{Z} 68$ at the beginning of three further phrases which all begin cc-a-G or cc-aa-G. In both Ma 1361 and Ma BRAH 51 it is used in two phrases in addition to the opening. The setting of the "Amen" in Mont 73 and Ma BRAH 51 is the same as that in Z 68, while that of $\mathrm{Ma} 1361$ has been changed from its original copying but may well previously have been identical.

\footnotetext{
${ }^{43}$ Bosse, Gloria, 33.

${ }^{44}$ Bosse, Gloria, 33.

${ }^{45}$ Graduale Triplex, 749.

${ }^{46}$ Bosse, Gloria, 87-88, Hiley, "Ordinary of Mass", 83-84

${ }^{47}$ Ma 1361, fols. 185 $5^{\mathrm{v}}-186^{\mathrm{r}}$; Mont 73, fols. $14^{\mathrm{v}}-15^{\mathrm{v}}$; Ma BRAH 51, fols. $241^{\mathrm{r}}-242^{\mathrm{r}}$; Graduale Triplex, 757-58; Bosse, Gloria, 87; Hiley, "Ordinary of Mass", 83.
} 
Both Ma 1361 and Mont 73 use the word "Quia" instead of "Quoniam" at the beginning of the verse which usually reads "Quoniam tu solus sanctus". ${ }^{48}$ This is not the case in $\mathrm{Z}$ 68. An error appears to have been made, however, in the same verse during the writing of the text of $\mathrm{Z} 68$ as the word "sanctus" is repeated; notation does not seem to have been written above the repeated word although the poor condition of the fragment makes it impossible to be certain of this.

The transcription begins on $\mathrm{c}$ as is usual with this melody in the third mode. The line therefore takes the pitch $\mathrm{G}$, suitable to the authentic form of the $\mathrm{E}$ mode which generally takes the third degree as the pitch of the line.

\section{3. $Z 68[b]^{v}-Z^{2} 67^{r}$}

This melody is Bosse 43 (Vatican XV). It begins on the same folio as the Gloria just discussed and a small segment is missing due to the lost corner. The last phrase is also missing as a result of damage possibly caused by water. Bosse 43 is another Gloria melody found in early sources and of widespread and frequent occurrence. ${ }^{49}$ Again it is contained in Ma 1361 where it follows immediately from Bosse 11 continuing the sequence of Glorias already remarked upon. It is not used in Mont 73 nor in Ma BRAH 51.

The $\mathrm{Z} 68$ version follows the usual psalmodic, very simple style of the melody. It maintains the usual ambitus of a fifth and the cadential pattern of a falling third. A strophic neume occurs on the penultimate syllable of most of the verse closures and is a feature of the version not found in Vatican XV nor in the incipits of Bosse or Hiley. ${ }^{50}$ The version of Ma 1361 is a simpler one but also frequently uses a bistropha on the penultimate syllable of closures.

The transcription uses $\mathrm{E}$ as the final as is normal for the melody, ${ }^{51}$ the line taking the second degree F. The placement on the line of the second degree is characteristic of the

${ }^{48}$ This change is thought possibly to be due to the derivation of Bosse 11 from a melody set to a Greek text as discovered by Michel Huglo. See Boe, Beneventanum Troporum Corpus II, vol. 22: 42.

${ }^{49}$ Bosse, Gloria, 22; Hiley, "Ordinary of Mass", 87.

${ }^{50}$ Graduale Triplex, 760-62; Bosse, Gloria, 96; Hiley, “Ordinary of Mass”, 87.

${ }^{51}$ Bosse, Gloria, 32. 
fourth mode as has been discussed in Chapter 4 .

\section{4. $\mathrm{Z} 67^{\mathrm{r}}$}

Following directly from the Gloria just discussed, the beginning of this melody is illegible as a result of damage to the fragment. It nevertheless may be identified as a version of Vatican III, which was given the melody number 20 by Bosse. Bosse's information shows melody 20 occurring very much less frequently than the Gloria melodies already discussed and only in sources of France (one of those from southern France) and England. ${ }^{52}$ The sources of melody 21, with which Bosse equates 20, are also not numerous but are more widespread; English sources are outstanding in Hiley's catalogue. ${ }^{53}$ Early sources of Bosse 21 are dated from the 10 th to 11 th centuries. ${ }^{54}$

The equating of melody 20 with his number 21 by Bosse causes some confusion, and the comment made by John Boe that 20 should have been labelled as a variant of 21 is apposite. ${ }^{55}$ The present example has been labelled as Bosse 20 rather than 21 because the remaining notes of the opening match that of 20 more closely. The only other Spanish source which has so far been found is the Zamoran Misal votivo (see the next Gloria discussed in this section).

Unlike the Vatican III version, that of $\mathrm{Z} 67$ has quite lengthy melismas added to the four acclamations which end with the word "te"; the first cannot be seen clearly but may be surmised as a result of space allocated to "te" and some very faint remains of the notation. Among other variations from the Vatican version is the ending on the second above the final on the last syllable of "Dei patris" immediately preceding the closing "Amen". In Vatican III this closure ends with the final G. ${ }^{56}$ Bosse found the closure on the final at this point to be the usual practice in Gloria melodies. ${ }^{57}$ The transcription also takes $\mathrm{G}$ as the

${ }^{52}$ Bosse, Gloria, 21. (The sources of 20 were named by Bosse together with those of 21 , but the table on p. 21 gives geographic distribution.)

${ }^{53}$ Bosse, Gloria, 21, 90-91; Hiley, "Ordinary of Mass", 85.

${ }^{54}$ Bosse, Gloria, 27.

${ }^{55}$ Boe, Beneventanum Troporum Corpus II, vol. 22: 8.

${ }^{56}$ Graduale Triplex, 719-20.

${ }^{57}$ Bosse, Gloria, 37. Two out of three southern Italian examples given by Boe (Beneventanum Troporum Corpus II, vol. 23-24: 31) show the same variation with "patris" ending on a and "Amen" on G. 
final, that representing the most common mode of the melody; the final is placed upon the line.

\section{Misal votivo, fols. $46^{\circ}-47^{\circ}$}

This is another example of Bosse 20 (Vatican III) but now found in a 14th-century source and fully legible. Overall it is very like the version in the 13 th-century $\mathrm{Z} 67$, sharing the differences in comparison to Vatican III already described. Again Bosse 20 has been chosen as opposed to 21 because the opening phrases of the Misal votivo version are more like those of Bosse 20.

The versions of the Misal votivo and $\mathrm{Z} 67$ use similar melodic phrases at the opening of the verses beginning with the word "Domine". These phrases are different from that of Vatican III and also from southern Italian examples. ${ }^{58}$ Further research would be of interest to see whether these similar phrases are localized to Spanish sources. Example 2 shows the versions of the phrase found in the Zamoran sources and the Graduale Triplex. Similarly, the melismas added to the four acclamations might be researched further. These are reminiscent of the trope added to this Gloria melody in southern Italian sources. The added melismas of both Zamoran versions are very similar, the greatest difference being the use of a longer one at the end of the fourth acclamation in the Misal votivo. Example 3 shows the fourth acclamation of both Zamoran sources.

\section{Example 2}

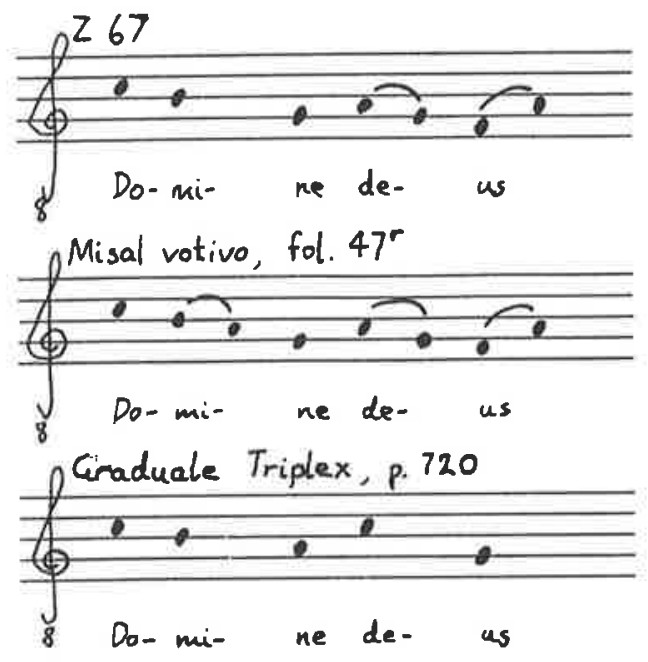

${ }^{58}$ For southem Italian examples, see Boe, Beneventanum Troporum Corpus II, vol. 23-34: 20-22. 


\section{Example 3}
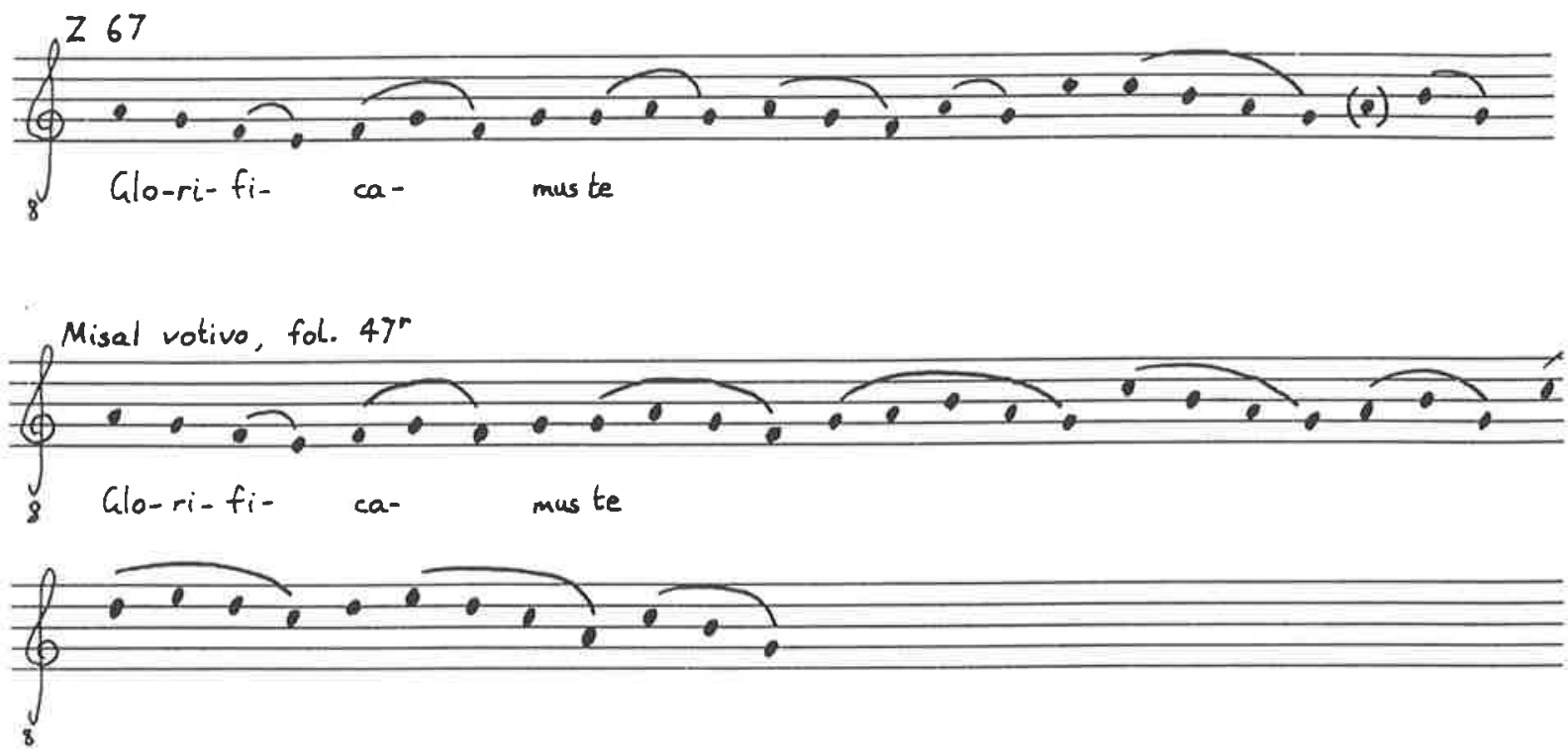

\section{Misal votivo, fol. $2^{\mathrm{r}}$}

Only the incipit of this Gloria is given; it is found together with an incipit for a Credo prior to the full statement of the common prefaces for festive and ferial use. It occurs at the beginning of the Misal votivo in the 15th-century section which precedes the earlier part in which the next Gloria to be discussed is located.

The incipit matches that of Bosse 56 (Vatican IV). This was a much used Gloria and is found in numerous and widespread manuscripts including early sources of the Gloria dating back as far as the 10th and 11th centuries. ${ }^{59}$ The Spanish manuscripts Mont 73 and Ma 1361 include the melody. The example in the Misal votivo uses the customary pitch and begins on $\mathrm{C}$.

\section{7. $\mathrm{Z} 153^{r}$}

Only the end of this Gloria is contained on the fragment and as a result the melody identification cannot be made with certainty. It does however appear to be Vatican XV (Bosse 43) in a version more like that of Z 68-Z 67 than that of the Vatican. The bistropha

\footnotetext{
${ }^{59}$ Bosse, Gloria, 22, 28, 100-1; Hiley, "Ordinary of Mass", 89.
} 
which is used on the penultimate syllable of closures in the other Zamoran source is replaced here by the plica which in a late source such as this should probably be interpreted as a single pitch with double duration. The final is $\mathrm{E}$, as is believed to be that of the previously discussed version.

\section{Z 153}

The second Gloria on this fragment following immediately after the first is a version of Bosse 38 (Vatican VIII). The opening is preceded by the rubric "in honore angelorum". The melody is a late one, the earliest of the eight sources listed by Bosse being from the 15th century, with all but one (a French source) being Italian. ${ }^{60}$ Bosse 38 is not included in Hiley's catalogue of manuscripts from England, northern France, and Sicily, thus emphasizing its limited distribution.

The opening "Gloria in excelsis deo" is not the same as that given by Bosse or the still different one of the Vatican version; ${ }^{61}$ however, like the openings of these other two versions, that of Z 153 is melodically related to later sections of the chant. The melodic material of this Gloria is in fact restricted with much repetition throughout. The F mode of $\mathrm{Z} 153$ corresponds to the usual one for the melody as does the ambitus F-f. ${ }^{62}$ This mode was found by Bosse to be mainly used in Italian Gloria melodies ${ }^{63}$ and its use may therefore be suggestive of Italian origin as may also be surmised from the predominance of Italian sources. On the other hand, new melodies using the $\mathrm{F}$ mode increased in number generally after 1100 and it therefore can be seen as a characteristic of later medieval composition. $^{64}$

The clef appears to have been placed one line too high on the sixth and seventh staffs of the recto of the fragment (these carry the chant from "terra pax" to "Laudamus te"). The discrepancy is made clear by the placing of the direct at the end of the previous staff as

\footnotetext{
${ }^{60}$ Bosse, Gloria, 28, 95.

${ }^{61}$ Bosse, Gloria, 95; Graduale Triplex, 738.

${ }^{62}$ Bosse, Gloria, 32.

${ }^{63}$ Bosse, Gloria, 33.

${ }^{64}$ Karlheinz Schlager, "Regionaltradition und Modalităt in der liturgischen Monodie des Mittelalters",
} Studia Musicologica 27 (1985): 121. 
well as through the divergence from the usual melody of the section which would otherwise be followed exactly. The loss of the top staff on the verso makes it impossible to see where the scribe rectified the apparent error, but it may be seen from the first remaining staff that the clef has been positioned differently and the melody now reads at the usual pitch. The error has been corrected in the transcription.

\section{CHANTS OF THE CREDO}

Table 3: Chants of the Credo in the Sources of Zamora

\begin{tabular}{lllll}
\multicolumn{1}{l}{ Source } & Melody & Dating & Notation & Context \\
1. Misal votivo, fol. $2^{\mathrm{r}}$ & - & 15 th c. & square & - \\
2. Z 151 & Vatican IV? & 15th/16th c. & mensural & -
\end{tabular}

\section{Misal votivo, fol. $2^{r}$}

The opening incipit of a Credo is given in this source with only the first verse "Credo in unum deum". It is not one of the six Vatican melodies for the Credo ${ }^{65}$ and is in fact that of the immediately preceding Gloria incipit. The Gloria incipit is that of Bosse 56 (Vatican IV) and small changes make the melodic phrase suitable to the shorter opening verse of the Credo. As the incipit matches the beginning of a Credo given in the 1734 revised edition of the 1598 treatise by Francisco Montanos, Arte de Canto Llano con entonaciones comunes de coro y altar, further investigation of late chant sources might reveal more information on the employment of this melody for the Credo. ${ }^{66}$

\section{Z 151}

Although only fragmentary sections remain in $\mathrm{Z} 151$, sufficient similarities may be seen between this Credo and the Vatican Credo IV to suggest that this may be a version of the latter melody. ${ }^{67}$ A complete transcription of the Credo from Z 151 is given at the rear

\footnotetext{
${ }^{65}$ Graduale Triplex, 769-84.

${ }^{66} \mathrm{Joseph}$ de Torres, Arte de Canto Llano (Madrid, 1734), 97.

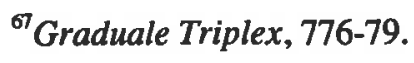


of this dissertation. Boxed segments in the transcription mark those parts which are identical in pitch to the Vatican Credo IV. Those marked with broken line boxes are without clef but have identical intervallic movement to the Vatican melody.

The notation of this Credo is mensural. As was mentioned in Chapter 4, Credo melodies, especially newly composed ones, appear to have been notated mensurally more frequently during the late Middle Ages than other chants. The Vatican Credo IV must have been regularly interpreted and notated in a mensural manner. It was mentioned in this context by Zarlino and Gaffurius (as has been noted in Chapter 3) and is known in mensural notation in early printed sources. ${ }^{68}$ A search for its appearance in further Spanish sources would be of interest and might provide fruitful comparative material for a larger study of this widespread melody.

\section{CHANTS OF THE SANCTUS}

Table 4: Chants of the Sanctus in the Sources of Zamora

\begin{tabular}{|c|c|c|c|c|}
\hline Source & Melody & Dating & Notation & Context \\
\hline 1. Misal votivo, fol. 41 & Th. 223 (Vat. XV) & 14th c. & square & Requiem \\
\hline 2. Misal votivo, fol. $50^{v}$ & Th. 116 (Vat. VIII) & 14th $c$. & square & $\begin{array}{l}\text { St. Ildefonsus, } \\
\text { January }\end{array}$ \\
\hline 3. Misal votivo, fol. $4^{\mathrm{r}}$ & Th. 116 (Vat. VIII)? & 15th c. & square & 一 \\
\hline 4. Z 245[a] & Th. 49 (Vat. IV) & 15 th/16th $c$. & square & 一 \\
\hline 5. Z 245[b] & Th. 32 (Vat. XVII) & 15 th/16th c. & square & - \\
\hline
\end{tabular}

\section{Misal votivo, fol. 41}

This melody occurs in the Requiem Mass found in the 14th-century section of the Misal votivo. It is a version of Thannabaur 223 (Vatican XV), a melody which occurs in very many, widespread sources dating from as early as the 11 th century. ${ }^{69}$ Thannabaur

\footnotetext{
${ }^{68}$ See for example that reproduced in Francis Tack, Gregorian Chant, 50. That version differs both in melodic detail and notation from the Credo of Z 151.

${ }^{69}$ Thannabaur, Sanctus, 205-8; Hiley, "Ordinary of Mass", 109.
} 
lists four non-monastic Spanish sources including Ma 1361 and one from Braga. Two monastic sources are listed as belonging to Spanish houses while a further three now located in Spain or Portugal are also named. ${ }^{70}$ One of the Spanish monastic sources is Cistercian (Poblet, Biblioteca del Monasterio, s.n.) and is from San Andrés de Arroyo in Palencia, to the north-east of Zamora on the route to Burgos. ${ }^{71}$ This source, written in square notation, and dating from the 13 th or 14 th and 15 th centuries, ${ }^{72}$ also contains two of the Agnus Dei melodies in the Misal votivo. Although Thannabaur does not mention whether this melody occurs in the Requiem Mass in the Palencia manuscript, an Agnus Dei occurring on the following folio is identified by Schildbach's catalogue as intended for the Requiem Mass. ${ }^{73}$ It is therefore likely that the Sanctus was part of a Requiem Mass in this source also.

The opening two repetitions of the word "Sanctus" are fully syllabic unlike those of the versions in the catalogues. ${ }^{74}$ Other variants in the Zamoran version recognized on comparison with Vatican XV include a five-note melisma on the second syllable of "excelsis" in both its occurrences, as well as differing closures. ${ }^{75}$ All the closures in the version of the Misal votivo, with one exception, use a subtonium to final movement. In the single exception at the end of the verse "Pleni sunt celi", the second degree is added as the penultimate pitch so that the closure falls by a second to the final. Comparison with $\mathrm{Ma}$ 1361 also reveals a number of differences with the Zamoran version. ${ }^{76}$ There, for example, plicas are found in the opening two acclamations and the consistent closure pattern is not found. The D mode of the Misal votivo is the usual one for the melody. ${ }^{77}$

${ }^{70}$ Thannabaur, Sanctus, 207.

${ }^{71}$ Thannabaur, Sanctus, 229.

${ }^{72}$ Thannabaur, Sanctus, 229.

${ }^{73}$ Schildbach, “Agnus Dei", 144.

${ }^{74}$ Syllabic setting of the word "Sanctus" is unusual throughout the corpus of Sanctus melodies. On this subject see Thannabaur, Sanctus, 53-54.

${ }^{75}$ Graduale Triplex, 740.

${ }^{76} \mathrm{Ma} 1361$, fol.190'.

nThannabaur, Sanctus, 205. 


\section{Misal votivo, fol. $\mathbf{5 0}{ }^{\mathrm{v}}$}

Another Sanctus occurring in the 14th-century section of the Misal votivo, this melody is a version of Thannabaur 116 (Vatican VIII). The notation is an interesting feature of this Sanctus as it displays apparently mensural characteristics which have already been discussed in Chapter 4.

Thannabaur 116 occurs in widespread sources, although not as frequently as Thannabaur 223, with the earliest dating from the 12 th century. ${ }^{78}$ Seven non-monastic Spanish sources are listed; Ma 1361 does not contain the melody. The present version uses a final of c, a fifth higher than that of its standard form. This variant is known in other sources, ${ }^{79}$ but not in any of the Spanish sources listed by Thannabaur. This chant is transcribed in full at the rear of this dissertation.

A b-flat is placed at the beginning of each staff which is surprising given that it lowers the subtonal degree to a whole-tone below the final while the standard version of the melody has a semitone rise to the final. In the standard form with the F final, b-flat accidentals are employed in the melody to lower the fourth degree. However, the removal through erasure of all usage of the subtonium until the penultimate syllable, largely negates the effect of the b-flat in the Misal votivo.

Erasures may clearly be seen to have been made to the original notation in various parts of the chant, some of them affecting the use of b-flat as has just been mentioned. The overall effect of the erasures is to make the melody more like the standard version as represented by the melodies given by Thannabaur and the modern Vatican books. ${ }^{80}$ The erased notes were taken from short melismas of generally more than two notes, some representing passing notes, others a larger ornamenting of the melody. If, in fact, the erased notes represent an earlier version which was later brought more into line with the standard version of a well known melody, then the proposed earlier version would present

\footnotetext{
${ }^{78}$ Thannabaur, Sanctus, 165-66; Hiley, "Ordinary of Mass", 103.

${ }^{79}$ Hiley gives the melody opening on c rather than on F. See Hiley, "Ordinary of Mass", 103.

${ }^{80}$ Graduale Triplex, 740 .
} 
an interesting divergence from the tradition. ${ }^{81}$ Example 4 shows the opening acclamations with the erased notes placed in boxes. The erased notes are not shown in the transcription at the rear of this dissertation.

The form of the melody is the usual one for Thannabaur 116. Melodic material is reused throughout, most notably that of the third setting of the word "Sanctus" and the opening c-e-g of the next phrase (although without the plica added to the e of the first appearance of the motive). Also similar to the standard melody are the closures which occur at the end of each of the five main phrases, all falling to the final by a tone with the exception of one which closes on the fifth degree.

\section{Example 4}
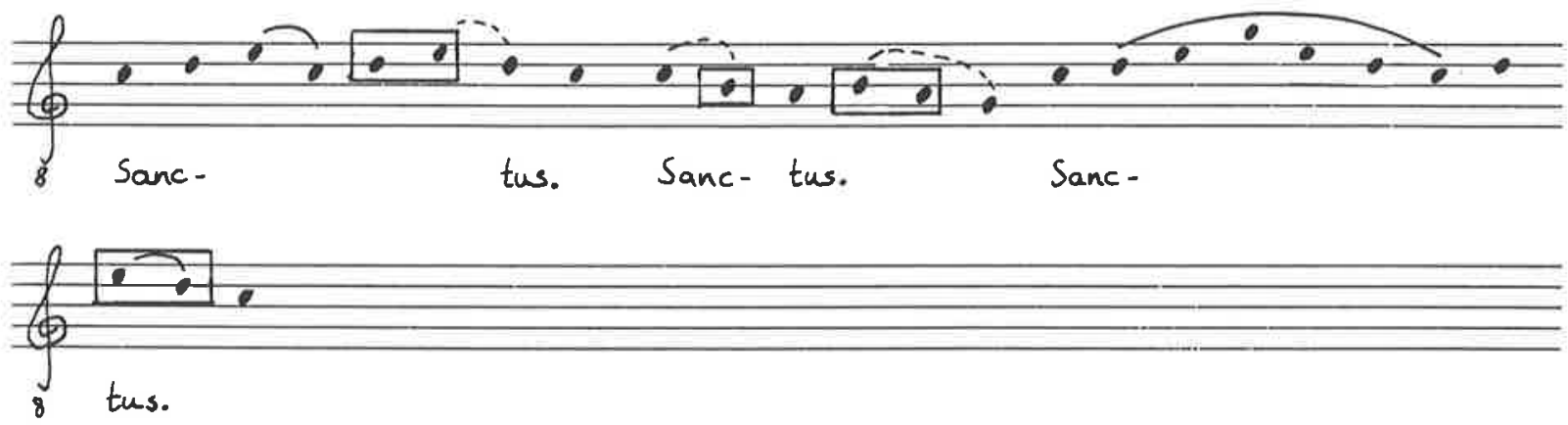

\section{Misal votivo, fol. $4^{\mathrm{r}}$}

No more than an incipit is found here in the 15th-century section of the Misal votivo. Only the first word ("Sanctus") is given, and, as a result, it is not possible to identify the melody with certainty. Thannabaur gives several melodies with this opening but none begin on a nor have transpositions beginning on a. Furthermore, none have the minor third movement of the first three notes of the Misal votivo incipit. If in fact this is a variant of one of Thannabaur's listing, it is most likely to be of Thannabaur $116,{ }^{82}$ the melody which has just been discussed as occurring on folio $50^{v}$ of the Misal votivo. This would then be

${ }^{81}$ The presence of mensurally influenced notation suggested that comparison with polyphonic settings might be useful with regard to the notation and the erasures. Accordingly, the versions of this Sanctus in W1 and $\mathrm{Pa} 15129$ were examined. This comparison, however, did not prove helpful. Transcriptions of these two polyphonic works are in Lütolf, Die mehrstimmigen 2: 96-98, 139-40.

${ }^{82}$ Thannabaur, Sanctus, 165; Hiley, "Ordinary of Mass", 103. 
another variant of Thannabaur 116 beginning on a instead of the usual $F$ or the less common c.

\section{Z 245[a]}

The fragment contains only that part of the melody from "terra gloria" to "Benedicta qui venit" and the closing "[do]mini osanna in excelsis". From these remaining sections, the melody appears to be a version of Vatican IV (Thannabaur 49). This is another very widely used melody which occurs in numerous sources dating from as early as the 11thcentury; Thannabaur lists twelve non-monastic Spanish sources and one from Braga, some with multiple occurrences of troped versions of the melody. ${ }^{83}$ The Spanish sources include Ma 1361 and Ma BRAH 51, both with tropes to the melody. A number of variants occur between the versions in Z 245, Ma 1361, Ma BRAH 51 and the Graduale Triplex. ${ }^{84}$ The most notable occurs in the setting of "excelsis" at the end of the first "Osanna" which in Z 245 is quite unlike that of the other three sources, however, part of this segment is repeated at the beginning of the next occurrence of the word "Osanna" where the same notes are also used in other sources. The complex variations occurring between the sources compared reveals no pattern. The $\mathrm{G}$ mode used in $\mathrm{Z} 245$ is the usual one for the melody.

\section{Z 245[b]}

Like the previous Sanctus only the closing parts of this example remain in the fragment, in this case beginning from the first "Osanna". The melody, nevertheless, may be identified as Thannabaur 32 (Vatican XVII), another Sanctus to have had wide usage and which is found in numerous sources, the earliest dating from the 11 th century. ${ }^{85}$ It occurs in twelve non-monastic Spanish sources named by Thannabaur as well as one from Braga; all but one of these sources also contains Thannabaur 49. Amongst the Spanish manuscripts are Ma 1361 and Ma BRAH 51, both of which carry tropes for the melody.

\footnotetext{
${ }^{83}$ Thannabaur, Sanctus, 135-40; Hiley, "Ordinary of Mass", 99.

${ }^{84}$ Ma 1361, fols. 192-193; Ma BRAH 51, fol. 244; Graduale Triplex, 727.

${ }^{85}$ Thannabaur, Sanctus, 122-25; Hiley, "Ordinary of Mass”, 97.
} 
The presence of the two melodies in so many Spanish sources suggests that they may be viewed as having had a regular place in a peninsular repertory of Sanctus melodies.

The F mode used in Z 245 is the usual one for the melody. An error appears to have been made in the placement of the clef for the section of the first "Osanna in excelsis" contained in the fragment. As the use of the same melodic material in both settings of "Osanna in excelsis" is a feature of this Sanctus, it seems that the clef placement should be corrected so as to maintain their identity. This correction has been made in the transcription. Comparison of the melody in Z 245, Ma 1361, Ma BRAH 51, and the Graduale Triplex reveals many small variations with no consistent pattern. ${ }^{86}$ Two of the more prominent points of variation occur in the closures. The first of these is the setting of the word "excelsis" which, on the two occasions it occurs in Z 245, uses two three-note melismas on its first two syllables, but in the other sources one of these is replaced by a two-note melisma. The second occurs at the end of "in nomine domini" for which Z 245, Ma 1361, and Ma BRAH 51 all use a rising second, but in the Vatican version a falling second is employed.

\section{CHANTS OF THE AGNUS DEI}

Table 5: Chants of the Agnus Dei in the Sources of Zamora

\begin{tabular}{|c|c|c|c|c|c|}
\hline & Source & Melody & Dating & Notation & Context \\
\hline 1. & Misal votivo, fol. $41^{v}$ & Sch. 209 (Vat. XV) & 14th c. & square & Requiem \\
\hline \multirow[t]{2}{*}{2.} & Misal votivo, ff. $50^{\mathrm{v}}-51^{\mathrm{r}}$ & Sch. 115 & 14th c. & square & St. Ildefonsus \\
\hline & & & & & January \\
\hline 3. & $\mathrm{Z} 245[\mathrm{a}]^{\mathrm{v}}$ & Sch. 136 (Vat. IV) & 15th/16th c. & square & 一 \\
\hline 4. & $\mathrm{Z} 245[\mathrm{~b}]^{\mathrm{v}}$ & Sch. 226 (Vat. II) & 15th/16th c. & square & - \\
\hline
\end{tabular}

${ }^{86} \mathrm{Ma} 1361$, fols. $191^{\mathrm{v}}-192^{\mathrm{r}}$; Ma BRAH 51, fol. 243"; Graduale Triplex, 765-66. 


\section{Misal votivo, fol. $41^{v}$}

This Agnus Dei, used here for the Requiem Mass, is based upon Schildbach 209 (Vatican XV). The melody is found widely and in many sources as can be seen from the listings given by Schildbach and also by Hiley ${ }^{87}$ It occurs in sources from as early as the 11 th century. Schildbach names seven non-monastic sources of Spain or Portugal, plus additional monastic sources. The use of this melody for the Requiem Mass is not unique to the Misal votivo; Schildbach cites two 14th-century English sources and a Cistercian source from Spain as using Schildbach 209 in this context. The Spanish source (Poblet, Biblioteca del Monasterio, s.n.) is of particular interest as it is the manuscript from Palencia which contains the Sanctus for the Requiem Mass of the Misal votivo. ${ }^{88}$

The usual Agnus Dei text is replaced here by that for the Requiem Mass, with "dona nobis pacem" replaced by "dona eis requiem". The final word "sempiternam" of the text of the third Agnus Dei acclamation as given in the Vatican version is not used. ${ }^{89}$ Even without "sempiternam" this text includes an extra syllable in comparison to the usual one, necessitating the adjustment of the melody normally found with the standard text.

Some significant variations between Vatican $\mathrm{XV}$ and that of the Zamoran source may be observed. ${ }^{90}$ Firstly, while the first part of the tripartite chant is very close to that of Vatican XV, the Misal votivo repeats this section in the second instead of the third part of the chant. (The repeat of $A$ is not written out in full in the source.) The form of the Misal votivo chant is as a result $A A B$ while that of Vatican $\mathrm{XV}$ is $A B A$. Secondly, the $B$ melody of the Misal votivo is not the same as that of the Vatican chant although an emphasis on a, the fifth above the final is noticeable in both. Thirdly, the cadences at the end of each of the three parts in the Misal votivo rise to the final from the subtonium unlike those of Vatican XV, although the overall cadential movement is otherwise similar, FD-C-D or FED-C-D in the Misal votivo, and FD-D in Vatican XV. Both versions are in the first mode. The extra subtonium in the Misal votivo may represent an addition made to

\footnotetext{
${ }^{87}$ Schildbach, "Agnus Dei”, 142-44; Hiley, "Ordinary of Mass", 119.

${ }^{88}$ Schildbach, "Agnus Dei”, 184.

${ }^{89}$ Liber Usualis, 1815.

${ }^{90}$ Graduale Triplex, 762.
} 
accommodate the extra syllable of the final word of the Requiem text, the melisma on the third last syllables of $A$ and $B$ matching the melismas on the penultimate syllables of $A$ and $B$ of Vatican XV. The melody from the Misal votivo is transcribed in full at the rear of this dissertation.

A version of Schildbach melody 209 is included in Ma 1361 (a source included by Schildbach in his study). ${ }^{91}$ The chant in Ma 1361 and that in the Misal votivo share the same form (AAB), ambitus (C-b), and section closing pitch (D). These versions are very similar throughout. However, Ma 1361 does not use the subtonium in cadences and is not named as being for use in the Requiem Mass. Example 5 shows the opening and close of section $A$ as it is given in the Misal votivo, Ma 1361, and the Graduale Triplex. Variation may be observed on the first syllable of "ṕeccata" and at the close.

\section{Example 5}
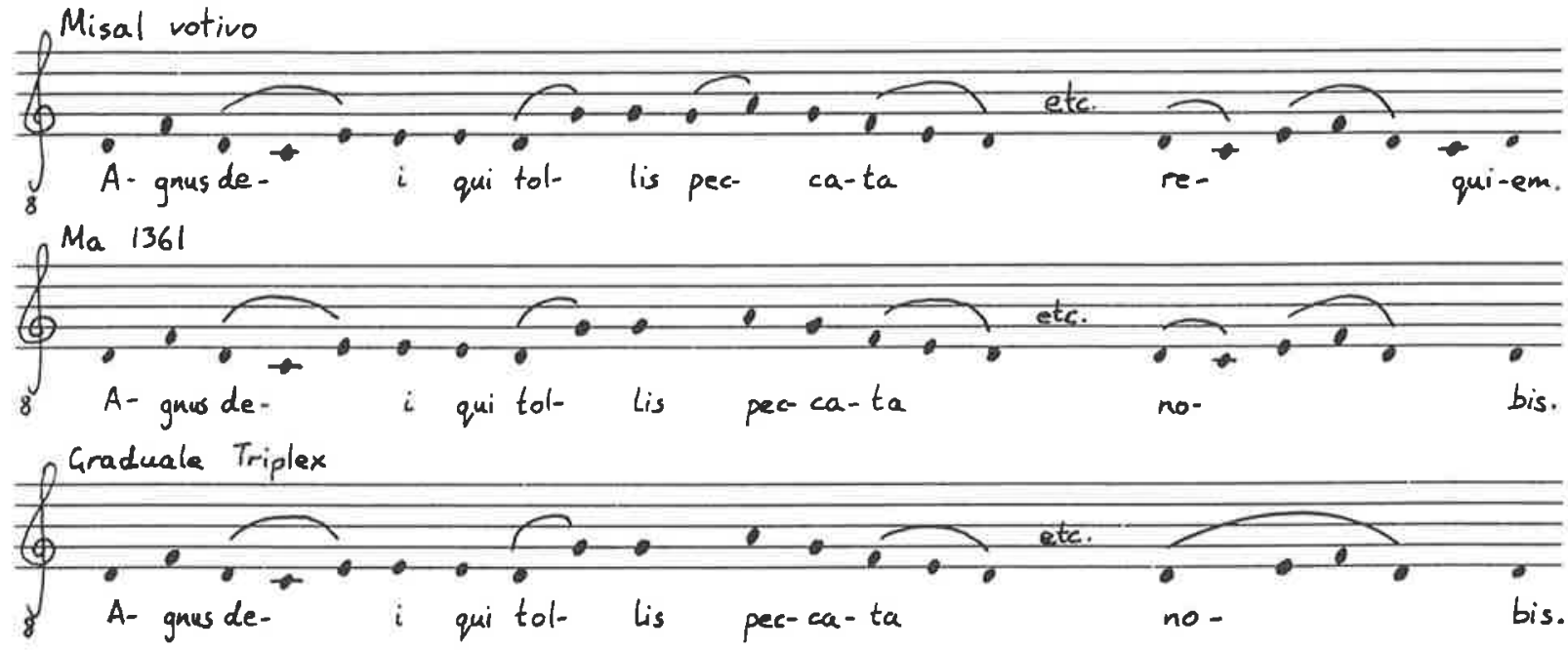

Section $B$ in Ma 1361, so similar to section $B$ in the Misal votivo, is also employed in the two preceding Agnus Dei chants of Ma 1361 for their closing sections. It also seems likely that the Palencia manuscript also has the $B$ section in third position. ${ }^{92}$ It is therefore likely that the chant in the source from Palencia is very similar to those of the Misal votivo and Ma 1361, the third sections of which might also be said to correspond to Vatican

${ }^{91}$ Ma 1361, fol. 196 .

${ }^{92}$ This assumption is made on the basis of Schildbach's remark on the correspondence between the third part of Schildbach 209 in the Palencia manuscript and Agnus Dei Vatican XVIII (Schildbach, "Agnus Dei”, 144). 
XVIII. Given the results of these comparisons, it may be asked whether future study of the Agnus Dei melodies in Spanish manuscripts might uncover a special tradition of construction involving the section $B$ melody discussed here, and a greater frequency than is common of the form $A A B$ which Schildbach found to be infrequently used. ${ }^{93}$

\section{Misal votivo, fols. $50^{\mathrm{v}}-51^{\mathrm{r}}$}

This melody is unusual in its use of a sweeping rise to an octave above the opening $F$ on the first syllable. This rise is repeated later, both within the first acclamation and after. Such a movement is characteristic of the late style of chant composition and similar to some Kyrie melodies. ${ }^{94}$ Although not identical, the melody corresponds to Schildbach 115 , variant 1 , for which only one source is cited by Schildbach, that from Palencia also found as a concordance of the Agnus Dei for the Requiem Mass. ${ }^{95}$ Like its variant, Schildbach 115 has only one occurrence, this being in a 14th-century gradual of Rouen. ${ }^{96}$

The ambitus given by Schildbach for melody 115 , variant 1 , is the same as that used in the Misal votivo, as are the closing notes of each part, the mode (three), and the form $\left(A A A^{l}\right)$. The b-flat of the Misal votivo is evidently not used in the Palencia source. The melody of each acclamation may be subdivided into two, the second being a variation of the first without the distinctive octave rise of the latter. The incipits from the two sources are given in Example 6. It may be observed that the incipit of the Palencia manuscript is more melismatic than the Misal votivo but follows the same outlines, in places corresponding exactly.

\footnotetext{
${ }^{93}$ Schildbach, “Agnus Dei”, 34.

${ }^{94}$ Apel, Gregorian Chant, 407-8.

${ }^{95}$ Schildbach, "Agnus Dei", 111. Mass", 115.

${ }^{96}$ Schildbach, "Agnus Dei", 111. Hiley gives the same source for the melody, Hiley, "Ordinary of
} 
Example 6

Misal votivo

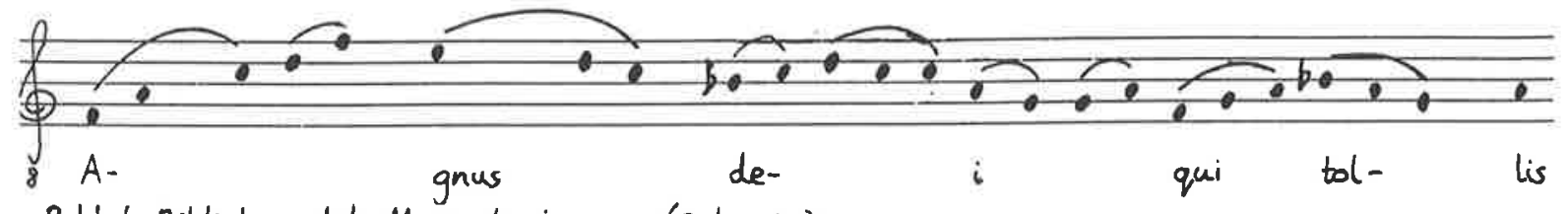
Poblet, Biblioteca del Monasterio, s.n. (Palencia)

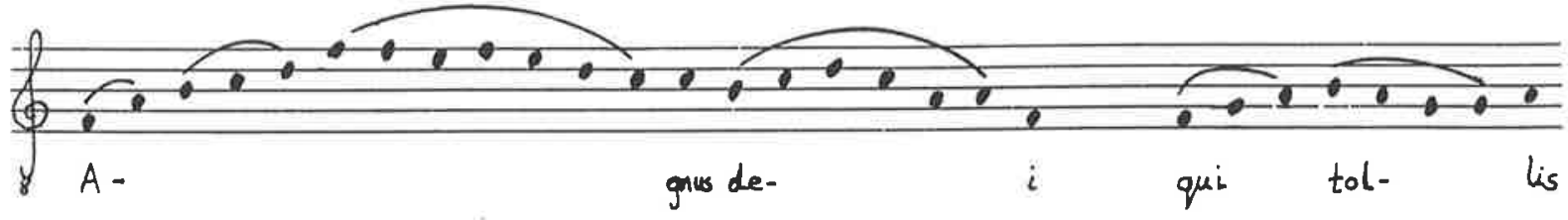

\section{Z 245[a] $]^{v}$}

This melody, of which only a part of the first acclamation remains, is identifiable as Schildbach 136 (Vatican IV). This melody was widespread and occurs in many sources especially from Germany and France, but also from England, Italy, and Spain; the earliest dates from the 11 th century. Schildbach names nine non-monastic Spanish sources, one of which is Ma $1361 .^{97}$

$\mathrm{F}$ is regarded as the main final, although a transposition to a $\mathrm{G}$ final is also frequently found. In Spanish sources the G final is more common. ${ }^{98}$ The $G$ final seems the most probable for Z 245. Ma 1361 uses the G final for Schildbach 136, but like the incipit given in Schildbach's catalogue, it displays differences in comparison to Z 245 . $^{99}$ The incipit of Ma 1361 is in fact almost identical with that given in Schildbach's catalogue.

\section{Z 245[b]}

Like the previous chant, only a part of the first acclamation remains, and from this the first syllable is lost. The melody cannot be identified with confidence but may be a variant of Schildbach 226 (Vatican II). Schildbach 226 is another very commonly found and widespread Agnus Dei melody first known in 11th-century sources. Six non-monastic Spanish sources are listed in Schildbach's catalogue, including Ma 1361. ${ }^{100}$ Schildbach

\footnotetext{
${ }^{97}$ Schildbach, "Agnus Dei", 117-19; Hiley, "Ordinary of Mass", 116-17.

${ }^{98}$ Schildbach, “Agnus Dei”, 118-19.

${ }^{99} \mathrm{Ma}$ 1361, fol. 196; ; Schildbach, "Agnus Dei”, 99.

${ }^{100}$ Schildbach, "Agnus Dei", 117-19; Hiley, "Ordinary of Mass”, 116-17.
} 
gives the usual final as $D$ with two transpositions to finals of $G$ and a. The melody of $Z$ 245 does not correspond exactly with any of the incipits in the catalogues or with Ma 1361, furthermore, it appears to take $\mathrm{F}$ as the final, unlike any of those listed.

The majority of the Ordinary of Mass melodies of the Zamoran sources have been shown here to occur in widespread sources from outside of Spain, many occurring as early as the 11 th century. They are only infrequently unknown, rare, or of likely late composition; in fact, only one is completely unknown. Many are found in other Spanish sources. It has been possible in a number of cases to identify notable variants in the melodies from the versions given in the Ordinary catalogues and the modern Vatican books, and, for some, comparison with Spanish sources has suggested that there may be evidence of a peninsular tradition to be found in such variants. The limited sources available for detailed comparison, however, have made it impossible to establish here whether or not such melodic variants are in fact of a regional character. Furthermore, if a regional tradition is involved, it is not yet possible to establish its extent. The Zamoran version of the Kyrie Clemens rector has been found to be similar to that in a southern French source as well as Spanish sources, this example suggesting not solely a peninsular tradition, but one involving both the Iberian peninsula and southern France. Although the repertory found in the present survey of Zamoran sources suggests that many of the melodies employed were those in wide use, there can be little doubt that a large study of Ordinary chants in Iberian sources, initially involving their identification and cataloguing, would be of interest, especially in view of the regional melodic variants which might then be identified.

The most marked pointer to a regional tradition which has been found amongst the Ordinary chants is that associated with the Cistercian manuscript from Palencia. Two Agnus Dei melodies and one Sanctus melody found in the Misal votivo are also found in the Palencia manuscript. The connections between the melodies of the two sources need not be repeated here, but it may be added that further comparison of the two manuscripts would be of interest and might cast some light onto the associations of Zamora with other traditions. 
Pairs and cycles of Ordinary chants have not yet been remarked upon. These are observable in two of the sources, Z 245 and the Misal votivo. In the Book C fragments (Z 67 and $Z$ 68) and $Z 153$, on the other hand, the Gloria chants are presented in groups; in fact, Book C seems to have contained a kyriale in which the Kyrie melodies were followed by the Gloria melodies. In the late fragment, Z 245, two Sanctus and Agnus Dei pairs are found. These pairings are known elsewhere. The first is that of Vatican Mass IV, a cycle known in medieval sources from as early as the 13 th century ${ }^{101}$ and which, by the early 14 th century, was in use in Paris for "Easter and Pentecost and on all annual and duplex feasts whatsoever." 102 The second pair, Thannabaur 32 and Schildbach 226, was used in Paris also by the early 14th century as part of two mass cycles, one for the second day of certain octaves and for semiduplex feasts, the other for Saturday Marian celebrations. ${ }^{103}$

Two cycles of Ordinary chants are found in the 14th-century section of the Misal votivo. The first is that found in the Requiem Mass; the Sanctus and Agnus Dei melodies are those of the Vatican Mass XV, a cycle which apart from its Kyrie is known, for example, in a 13th-century source. ${ }^{104}$ The Sanctus and Agnus Dei from Vatican Mass XV were employed in three mass cycles in Parisian usage. ${ }^{105}$ The second Misal votivo cycle is that for the Mass of St. Ildefonsus. The four melodies have not yet been found occurring as a cycle elsewhere.

Only two troped chants were found, both examples of the Kyrie. This is initially surprising given the frequency with which troped Ordinary chants occur in other Spanish sources such as Ma BRAH 51; however, their lack may be a reflection particularly of the occurrence of Sanctus and Agnus Dei melodies only in later sources. A former continuation of the Book C kyriale may have contained such tropes.

\footnotetext{
${ }^{101}$ Apel, Gregorian Chant, 420.

${ }^{102}$ Craig Wright, Music and Ceremony at Notre Dame at Paris, 500-1550 (Cambridge: Cambridge Univerrsity Press, 1982), 83.

${ }^{103}$ Wright, Music and Ceremony, 84, 87.

${ }^{104}$ Apel, Gregorian Chant, 420.

${ }^{105}$ Wright, Music and Ceremony, 85-86, 88.
} 


\section{PROSAE AND RESPONSORY PROSAE}

Prosae (or sequences) and responsory prosae are studied in this chapter although the two represent different applications of the troping principle. The two genres are discussed separately beginning with the former. The term prosa is preferred here instead of sequence as the former is the term which occurs in the various AHPZa fragments and also in the Misal votivo. ${ }^{1}$

\section{PROSAE}

The Spanish repertory of prosae has not yet been comprehensively examined although beginnings have been made, notably by Anglès in his study of $\mathrm{Hu}^{2}$ Further studies are warranted and for these one such as that Lance W. Brunner made of the Italian repertory ${ }^{3}$ would provide a helpful foundation. Of use would be classification of prosae according to region of sources, period of origin, and liturgical placing, as well as identification of any particularly Spanish traits of compositional style or transmission. The forthcoming catalogue of sequences by Nancy van Deusen will undoubtedly be of great assistance; her 1982 article in the Journal of the Plainsong and Medieval Music Society has already begun to tackle the question of Spanish stylistic traits. ${ }^{4}$ Fernández de la Cuesta's catalogue of Latin monody and polyphony gives researchers a valuable guide to the textual content of the sources in the repertory. ${ }^{5}$

Six prosae have been identified in the AHPZa collection and are listed in Table 1 below. The table gives the text incipit, Zamoran source, dating and notation of the source, the melody name if available, and Chevalier's numbering of the text from Repertorium

${ }^{1}$ See for example, Misal votivo, fol. $49^{x}$. Richard Crocker remarks: "German scholars tend to use Sequenz as a categorical term, the French, Prose; in English, mostly from habit, we use 'sequence'." See Richard Crocker, "Medieval Chant" in The Early Middle Ages to 1300, ed. Richard L. Crocker and David Hiley (Oxford: Oxford University Press, 1990), 257.

${ }^{2}$ Higini Anglès, Huelgas, vol. 1.

${ }^{3}$ Lance W. Brunner, "The Sequences of Verona, Biblioteca Capitolare CVII and the Italian Sequence Tradition" (Ph.D. diss., University of North Carolina at Chapel Hill, 1977).

"Nancy van Deusen, "Style, Nationality and the Sequence in the Middle Ages", Journal of the Plainsong and Mediaeval Music Society 5 (1982): 46-49.

'Fernández de la Cuesta, Manuscritos. 
Hymnologicum. The last prosa in the list is for two voices and will not be discussed in this chapter but instead in Chapter 10 with other polyphonic works.

Table 1: Prosae in the Sources of Zamora

\begin{tabular}{|c|c|c|c|c|c|}
\hline Incipit & $\underline{\text { Source }}$ & Melody & Date & $\underline{\text { Notation }}$ & Chevalier \\
\hline 1. Nato canunt & $\mathrm{Z} 67^{v}$ & Multifarie & 13 th $c$ & Aquitanian & 11890 \\
\hline 2. [Adest precelsa] & $\mathrm{Z} 52^{\mathrm{r}}$ & Adest una & 13th c. & Aquitanian & {$[423 / 436 /$} \\
\hline & & & & & 2253] \\
\hline 3. Celeste organum & $\mathrm{Z} 52$ & 一 & 13th c. & Aquitanian & 3413 \\
\hline 4. Gaude roma & $\mathrm{Z} 203^{\mathrm{v}}$ & - & 14th c. & square & 6928 \\
\hline 5. Petre summe & $\mathrm{Z} 115[\mathrm{~b}]^{\mathrm{v}}$ & Concordia & 15 th c. & semi-mensural & 14871 \\
\hline $\begin{array}{l}\text { 6. Conlaudemus } \\
\text { omnes pie }\end{array}$ & $\begin{array}{l}\text { Misal votivo } \\
\text { fol. } 49\end{array}$ & , - & 14th c. & square & 一 \\
\hline
\end{tabular}

The first three prosae of the list above are found in fragments $\mathrm{Z} 67$ and $\mathrm{Z} 52$. Both these fragments belong to the group labelled in this dissertation Book C. Of the two fragments $Z 67$ would probably have preceded $Z 52$. Z 67 may have occurred in a former book at the point at which a section of Gloria (and perhaps also Kyrie) chants ended and a section of prosae began. On the recto of the fragment is the end of a Gloria while on the verso is the prosa. The use of a large initial for the opening word of the prosa of $\mathrm{Z} 67$ suggests the beginning of a prosa section. ${ }^{6}$

\section{Nato canunt (Z 67)}

This is a first epoch prosa which had extensive usage and continued to be sung over a long period of time, eventually appearing in printed books. Nato canunt is a Christmas prosa and is given in Z 67 with the rubric "De gallicantu. prosa in nathale domini". Christmas Day was the usual placement for the work, although the mass was variable.

\footnotetext{
'The initial takes up the space of two staves and has a flourish extending through a third. On the other hand, the initial of $\mathrm{Z} 52$ takes up only one staff.

${ }^{7} A H$ 7: 49; Chevalier, Repertorium Hymnologicum 2: 129. In a Spanish source discussed below, Mont 73, Nato canunt was used for the fifth day of Christmas.
} 
The text is listed in $A H$ as occurring in numerous and widespread French sources, and also in English, Germanic, Italian, and two Spanish sources. Amplification of the listing has been given by David Hiley especially with regard to English sources. ${ }^{8}$ The prosa is well represented in southern French sources; amongst those from the library of St. Martial it is found in thirteen of the sixteen listed in $A H$ vol. 7.9 The earliest source found for Nato canunt is $\mathrm{Pa} 1240$ from 923-934. ${ }^{10}$ It occurs there in a supplement "apparently added by the original hand during the composition of the manuscript". 11

The Spanish sources given in $A H$ are a 12th-century proser-troper in Huesca and the 13th-century Tol 35.10. ${ }^{12}$ In addition to these two, Nato canunt is found in the 12 th-century Catalonian proser Mont 73 from Urgell. ${ }^{13}$ Chevalier names books from Spain of the late 15 th and first half of 16 th centuries which contain Nato canunt. These are a missal of Zaragoza of 1485 , and various 16 th-century missals from Sevilla. ${ }^{14}$

The comparison of the text in the Zamoran fragment with that given in $A H$ vol. 53 reveals a number of variants. Two of the three manuscripts with which the most variants are shared are from southern France; they are $\mathrm{Pa} 778$ from Narbonne and $\mathrm{Pa} 1871$ from Moissac. In general variants are shared mainly with French sources (most are southern French from the 10th or 11 th centuries) and secondly with British sources. ${ }^{15}$ One variant, the use of the word "De" at the beginning of the second half of the second versicle pair "De nocte precelsa", is without concordance in $A H$. Unfortunately the two Spanish sources were not included among the sources for which text variants were listed in $A H$. Comparison with Mont 73 (not included in $A H$ ) shows that version to share a number of the variants of

${ }^{8} A H$ 7: 52; $A H$ 54: 3-5; David Hiley, "The Liturgical Music of Norman Sicily: a Study Centred on Manuscripts 288, 289, 19421 and Vitrina 20-4 of the Biblioteca Nacional, Madrid" (Ph.D. diss., University of London, 1981), 545.

${ }^{9} \mathrm{AH}$ 7: 50.

${ }^{10}$ The dating is taken from John A. Emerson, "Sources", NG 17: 612.

${ }^{11}$ Richard L. Crocker, "The Repertory of Proses at Saint Martial de Limoges in the 10th Century", Journal of the American Musicological Society 11 (1958): 156.

${ }^{12} \mathrm{AH}$ 53: $42-43$.

${ }^{13}$ For an important study of Mont 73 (although with only brief reference to music) see Mund6, "El proser-troper Montserrat 73"; for dating and place of origin see 105, 130-31.

${ }^{14}$ Chevalier, Repertorium Hymnologicum 2: 129; 5: 263-64.

${ }^{15} A H$ 53: 41-43. Provenance and dating is taken from sources additional to $A H$, namely Bjorkvall, ed. Corpus Troporum V, 421-23; Le Graduel Romain. II Les Sources (Solesmes: 1957); and Alejandro Enrique Planchart, "St Martial", NG 16: 396. 
$\mathrm{Z} 67$ in a way similar to $\mathrm{Pa} 1871$ and $\mathrm{Pa} 778$, but again without the unique word change at the beginning of the second half of the second versicle pair.

The melody of Nato canunt is that known as Multifarie. The melody of Nato canunt in the Zamoran fragment was compared with versions of the same prosa in $\mathrm{Ma} 289, \mathrm{~Pa}$ 1139, $\mathrm{Pa} 1235$, and Mont $73 .^{16}$ The results of the comparison are inconclusive. It was found that variants exist between $\mathrm{Z} 67$ and all four other versions. Disregarding the frequent use of liquescent signs in $\mathrm{Z} 67$, that version seems to have most in common with $\mathrm{Pa} 1139$ and Mont 73. On the other hand, the source from Nevers, $\mathrm{Pa} 1235$, and the Norman-Sicilian, Ma 289, make more use of liquescent signs than Pa 1139 and Mont 73. The frequency of liquescent signs in $\mathrm{Z} 67$ is very much greater than in the other sources of the prosa studied. The use of the epiphonus at the beginning of most of the versicles in $\mathrm{Z}$ 67 is remarkable. This is important as it is a feature not shared by any of the other sources of this chant which have been examined. ${ }^{17}$ The majority of the two types of liquescent signs employed, the epiphonus and the cephalicus, are used in conjunction with potentially liquescent letter combinations in the text.

The transcription takes the usual pitch of this work which has a final of $G$. The line takes the pitch of the final until the fifth versicle pair where the pitch of the line apparently changes so as to place the final a third below the line and $b$ on the line. There is no clear indicator of this change which takes place at the beginning of a new staff; however, a now illegible direct may have indicated the alteration. The pitch may be deduced from the placement of the last note at the end of the versicles and the pitch in other sources. A very similar change of line pitch occurs in Mont 73 near the beginning of the same versicle pair. It is clearly marked by a direct. The similar locations of the change of line pitch suggest two possibly associated explanations. Firstly, the change may have been found necessary by the notators of both manuscripts at that point owing to the rise of the predominant pitch; in fact the melody moves up to an octave above the final, the previous highest note having been a fifth above the final. The second explanation is that Mont 73 and Z 67 were copied

\footnotetext{
${ }^{16} \mathrm{Ma} 289$, fol. $37^{\mathrm{v}}-38^{\mathrm{r}}$; Pa 1139, fol. 80; Mont 73, fol. $21^{\mathrm{r}}-22^{\mathrm{r}}$; and for the melody of $\mathrm{Pa} 1235$, the transcription by Nancy van Deusen was employed, Music at Nevers Cathedral 2: 27-28.

${ }^{17}$ In addition to those listed above is the version of Ma 19421, fol. $37^{\mathrm{\nu}}-38^{\mathrm{r}}$.
} 
from related manuscripts in which a tradition of changing the line pitch in this versicle had been transmitted.

A text incipit for the prosa, Nato canunt, is found in a fragment belonging to Group $\mathrm{F}, \mathrm{Z} 217$. That fragment is from an office book, the prosa preceding the magnificat antiphon Hodie xpistus natus est, the service being second vespers for Christmas Day.

\section{2. [Adest precelsa] (Z 52')}

The prosa is incomplete in the fragment with only the last sections being contained on the recto of $\mathrm{Z} 52$; it has however been possible to identify the work from these later sections. With various openings, Adest precelsa is included in $A H$ vol. 7 and $A H$ vol. $53 .^{18}$ In $\mathrm{Pa} 495$ from Gerona, the words "summa atque" are inserted between "Adest" and "precelsa". 19 The incipit used here, Adest precelsa, is therefore uncertain. The prosa is for use on Christmas Day or its octave, ${ }^{20}$ and in some sources the mass is specified as "missa majori". ${ }^{21}$ This is another first epoch prosa.

In $A H$ vol. 7 the prosa is listed as occurring in nine sources all of which are southern French. The earliest of these manuscripts dates from the late 10th century. Further sources, of which four out of the total five are Spanish, are named in $A H$ vol. 53. These are Pa 495, Vich 106, Huesca 4 from San Juan de la Peña, and Tol 35.10. The fifth and non-Spanish source is $\mathrm{Pa} 1871$ from Moissac and therefore another of southern French provenance. Although not mentioned in AH, Adest una (an alternative opening of Adest precelsa) is also found in the two tropers Apt 17 and Apt 18 which date from the 11th to early 12 th centuries, and which originate from Apt or the surrounding region. ${ }^{22}$ The spread of the prosa is therefore limited to the southern half of France and Spain.

No conclusive information arises from comparison of the text with the versions of the prosa in $A H$ vol. 7 and $A H$ vol. 53. A number of variants exist in common with various manuscripts but no pattern emerges from these. It is unfortunate that variants of

\footnotetext{
${ }^{18} A H$ 7: 35-6; $A H$ 53: 35-37.

${ }^{19} \mathrm{AH}$ 53: 36 .

${ }^{20}$ AH 53: 37; Chevalier, Repertorium Hymnologicum 1: 26-27.

${ }^{21}$ AH 7: 35; Chevalier, Repertorium Hymnologicum 5: 13.

${ }^{2}$ Bjorkvall, ed. Corpus Troporum $V, 58$ and 65.
} 
two of the Spanish sources named in $A H$ vol. 53 were not able to be given by the editors of the volume.

The melody as found in the fragment is the last part of that titled "Adest una" by Hughes. ${ }^{23}$ Comparison of the version of $\mathrm{Z} 52$ with that given for the prosa in $\mathrm{Pa} 495^{24}$ shows significant differences which fall into two classes. The first class is associated with the differences between the texts of the two sources. The versicles of $\mathrm{Pa} 495$ are in most cases longer than those of $\mathrm{Z} 52$ : a larger number of notes is employed to set the larger number of syllables. The second class of difference is found in the frequent use of liquescent neumes (especially the cephalicus) and bistrophae. The custom of opening versicles with a liquescent sign is found in the two halves of one of the pairs. The majority of the liquescent neumes are found in potentially liquescent text positions. The transcription takes the pitch as given in $\mathrm{Pa} 495$ and also by Hughes. The final is therefore $\mathrm{G}$ and occurs on the line.

\section{Celeste organum (Z 52)}

This prosa begins at the bottom of the recto of $\mathrm{Z} 52$, immediately following the end of Adest precelsa. As has already been indicated above, it is likely that the two fragments $Z 67$ and $Z 52$ were taken from the proser of a manuscript book in which $Z 52$ would have followed $\mathrm{Z}$ 67. It would seem, therefore, that the first three works of that proser would have been the three prosae found in the two fragments and that a lost folio would have occurred between $\mathrm{Z} 67$ and Z 52. That lost folio would have contained the end of Nato canunt as well as the beginning and large part of Adest precelsa. As all three are Christmas prosae, it may further be hypothesized that they were to be used in the first, second, and third Masses of Christmas Day respectively. The particular mass is not specified on Z 52 with the rubric for Celeste organum saying only "Alia prosa in natale domini".

Celeste organum is found in mainly French and English sources. ${ }^{25}$ It is included in

${ }^{23}$ Anselm Hughes, Anglo-French Sequelae (Nashdom Abbey: The Plainsong and Mediaeval Music Society, 1934), 22.

${ }^{24} \mathrm{~Pa} 495$, fols. $62^{\mathrm{v}}-63^{\mathrm{v}}$.

${ }^{25} A H$ 7: 52; $A H$ 54: 3-5. Hiley, "The Liturgical Music", 545; David Hiley, "Rouen, Bibliothèque Municipale, MS 249 (A.280) and the Early Paris Repertory of Ordinary of Mass Chants and Sequences", 
southern French sources from the late 11th century. Two manuscripts listed in $A H$ vol. 54 are located in Spain; these are from the 12th and 12th or 13th centuries and are located in Huesca and Toledo (Tol 35.10). ${ }^{26}$ Celeste organum is also included in the 12th-century proser Mont $73 .{ }^{27}$ Chevalier cites a late 15 th-century and three 16 th-century missals from Spain that include the prosa. The first is from Zaragoza (1485) and the others from Sevilla (c. $1500,1534,1537) .^{28}$ All the Spanish sources named here as sources of Celeste organum are also sources of Nato canunt. The sources of Huesca and Toledo also contain versions of Adest precelsa.

Unlike Z 52, $A H$ vol. 7 gives the first Mass of Christmas Day as the liturgical placing of Celeste organum ${ }^{29}$; in Mont 73 it has the assignment "in gallicantu". ${ }^{30}$ On the other hand and as seems to have been closer to the situation in $\mathrm{Z} 52$, in northern French and English sources studied by Hiley, Celeste organum is cited for the second and third Masses of Christmas Day and occasionally for use in the octave. ${ }^{31}$

Notable word variants occur in the Zamoran fragment in comparison with the text given in $A H .^{32}$ Study of the $\mathrm{Z} 52$ text in comparison with the information given in $A H$ provides no indication of other sources sharing similar variants. Comparison with the texts of two further sources, Mont 73 and $\mathrm{Pa} 3126,{ }^{33}$ reveals no new information with regard to text variants, only showing once again the notable number of differences in Z 52 .

Study of the melody of Celeste organum in Z 52 shows a similar picture to study of the text. Again there are notable features not found in the sources with which it was compared and it is not possible to point to a particular likeness to any source or sources. The sources used for comparison were Mont 73, $\mathrm{Pa} 1139,{ }^{34}$ and $\mathrm{Pa} 3126$. The frequent

Music and Letters 70 (1989): 475.

${ }^{26} \mathrm{AH} 54: 4$.

${ }^{27}$ This is the only reference given for the prosa by Fernández de la Cuesta, Manuscritos, 323.

${ }^{28}$ Chevalier, Repertorium Hymnologicum 5: 90.

${ }^{29} \mathrm{AH} 7: 51$.

${ }^{30}$ Mont 73, fol. $17^{\mathrm{r}}$.

${ }^{31}$ Hiley, "The Liturgical Music", 545.

${ }^{32}$ AH 54: 3-5.

${ }^{33}$ Mont 73, fol. 17; Pa 3126, fol. 8.

${ }^{34} \mathrm{~Pa} 1139$, fol. 151. 
employment of liquescent signs contributes a prominent feature to the melody and one not found in those other versions examined. Also remarkable is the use of the bistropha, although it occurs less frequently than the liquescent signs. Examples of both the cephalicus and the epiphonus make up the twenty-six liquescent signs employed in the prosa and all except one are employed in positions where are to be found the usual combinations of letters which are understood to be associated with the practice of liquescence. Moreover, the technique of employing liquescent signs on the first syllable of verses is to be observed but again not in such positions in the other sources studied. It must be of particular interest that the three prosae of $\mathrm{Z} 67$ and $\mathrm{Z} 52$ share an unusually frequent use of liquescent neumes and bistrophae, as well as the notable occurrence of liquescent signs on opening syllables. These are features that further research might reveal to be of importance as part of a particular regional or other style.

The pitch of the transcription takes that of the source $\mathrm{Pa} 3126$ in which a clef is used on a five-line staff. This means that the line on the recto of $\mathrm{Z} 52$ is read as $F$, the second degree above the final $\mathrm{E}$. There is no visible line on the verso, a fact which caused difficulties with transcription. This problem together with the poor condition of the verso meant that to make the transcription some reference to the three sources used for text and melody comparison had to be made. ${ }^{35}$ In addition, careful judgements based on the pitch of the closing note of each versicle were made to determine pitch. The transcription is thus somewhat conjectural, although care has been taken to provide the best possible reading.

\section{Gaude roma ( $\mathrm{Z}$ 203)}

$\mathrm{Z} 203$ appears to contain parts of two prosae. The beginning of that found on the recto side of the fragment is lost and efforts to identify the work from the remaining text and melody have proved fruitless. The couplet structure of a prosa is however visible. The rubric "Prosa. cathedre sci. petri" introduces the prosa on the verso, the well known Gaude roma. Feasts of St. Peter the Apostle are the normal usage of this text. ${ }^{36}$ The fragment

\footnotetext{
${ }^{35} \mathrm{~Pa} 1139$ and Mont 73 also presented some problems as these sources (especially Pa 1139) are not completely diastematic.
}

${ }^{36}$ AH 55: 313; Chevalier, Repertorium Hymnologicum 1: 495. 
contains only the first two versicle pairs and the beginning of the third.

Gaude roma is a late prosa (from the 12th century) believed to be of Parisian origin. ${ }^{37}$ The sources given in $A H$ range from the 12 th to the 15 th century and are mainly French, a number being from the Parisian Abbey of St. Victor. The prosa is also found in the Aquitanian sources, $\mathrm{Pa} 778$ from 12th-century Narbonne and $\mathrm{Pa} 1139$ from Limoges. ${ }^{38}$ No Spanish sources are cited in $A H$ but Chevalier names a 1485 missal of Zaragoza. ${ }^{39}$ The absence of the prosa from earlier Spanish sources is highlighted by the fact that there is no entry for it in Fernández de la Cuesta's catalogue.

Only one text variant is found in Z 203 in comparison with that of $A H$ : the word "Et" is replaced by "Ut" in the Zamoran source at the beginning of the fifth versicle. The variant is not recorded in $A H$.

Various melodies are known for Gaude roma. ${ }^{40}$ One of the melodies is that used for the important prosa of the Parisian repertory, Salve mater salvatoris. ${ }^{41}$ Heinrich Husmann has pointed to a connection between the Salve mater salvatoris melody and those employed for various prosae including Prunis datum, Roma petro and Gaude syon et letare, but unfortunately he gives only incipits in his article. ${ }^{42}$ Fassler discusses a melody for Prunis datum with the same incipit as given by Husmann from the 13th-century source of the Parisian Abbey of St. Victor Pa 14452. Apart from small variations, this latter melody is that employed for Gaude roma in Z 203 as far as may be judged from the small part of the prosa found in $\mathrm{Z} 203$. Fassler shows that the melody is related to that of Laudes crucis. ${ }^{43}$ She calls this melody "uniquely Victorine". 4

\footnotetext{
${ }^{37}$ For reference to Gaude roma, its melody, and its place in the Parisian repertories, see Heinrich Husmann, "Notre-Dame und Saint-Victor", Acta Musicologica 36 (1964) especially 119, 195-96, 215-17; and Margot Fassler, "Who Was Adam of St. Victor? The Evidence of the Sequence Manuscripts", Journal of the American Musicological Society 37 (1984): 246, 253.

${ }^{38}$ AH 55: 314-15.

${ }^{39}$ Chevalier, Repertorium Hymnologicum 5: 166.

${ }^{40}$ Husmann, "Notre-Dame und Saint-Victor", 196-207.

${ }^{41}$ For this prosa see Rene-Jean Hesbert, ed., Le prosaire de la Sainte-Chapelle, Monumenta Musicae Sacrae 1 (Macon: Protat Frères, 1952), 93-94. Hesbert gives most of the first verse of Gaude roma on p. 80.

${ }^{42}$ Husmann, "Notre-Dame und Saint-Victor", 216-17.

${ }^{43}$ Fassler, "Who Was Adam", 259-60.

${ }^{44}$ Fassler, "Who Was Adam", 252.
} 
The variants between the melodies of $\mathrm{Pa} 14452$ and $\mathrm{Z} 203$ occur mainly in the use of two and three-note melismas. Both sources make use of these but in different places and patterns as is shown in Example 1. Both use G as the final. ( 203 uses square notation with a clef and so the pitch of the final is unequivocal.) The fragment of Gaude roma shows the beginning of the double versicle structure well known in prosae - $A A B B$; the Prunis datum setting also uses this form. Line ends within the versicles occur at the same points in the melody in both prosae, the two texts using rhyme at the end of each line. Another difference apart from the use of the melismas already mentioned is found as a result of an irregular line length in $\mathrm{Z} 203$. This occurs in the second versicle of the first pair where the middle line has only seven syllables instead of the eight syllables of the middle line in the other versicles of Gaude roma and in Prunis datum.

Example 1: Versicles 1 and 3 of Gaude roma (Z 203) and Prunis datum (Pa 14452) ${ }^{45}$

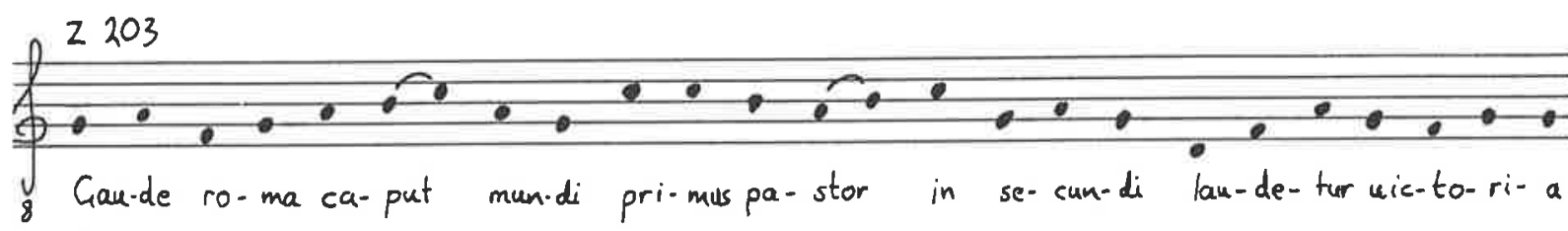

$\int_{8}$ Pru-nis de-tum ad-imi- re-mur. Lau-re-a-tum ve-ne-re-mur Lau-di- bus Lau-ren-ti-um $\int_{8} \mathrm{Pe}$-trussa-cri fax a- mo-ris lux doctri- ne sal du-co-ris pe-trusmewiu-sti-ci-e $\mathrm{Pa} 14452$

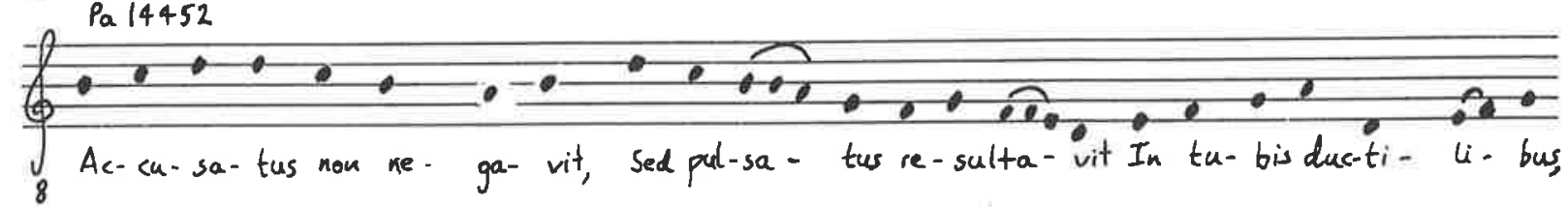

With regard to notation, Z 203 is an atypical fragment among the Zamoran sources studied here. This is because of its use of a four-line staff and consistently stemmed

${ }^{45}$ The transcription from $\mathrm{Pa} 14452$ is that by Fassler, "Who Was Adam", 259. 
puncta, two characteristics suggestive of a non-Spanish origin. This feature together with Margot Fassler's observations and the absence of the prosa from medieval Spanish sources suggests that in a future study it would be of interest to investigate the melodies of Gaude roma in French sources of the late 13th to 15th centuries (such as the Franciscan $\mathrm{Pa}$ $1339)^{46}$ in order to trace the usage of the melody found there and its appearance with the text Gaude roma. Such a study might throw some light on the probable origin of Z 203.

\section{Petre summe (Z 115[b])}

This is a first epoch prosa and the only prosa by Notker of St. Gall to have been identified in the collection. ${ }^{47}$ The prosa is found on the verso of the second half of the bifolio which makes up this fragment; only five versicles are present. The rubric "prosa apostolorum petri et pauli" found in the fragment indicates the usual liturgical assignment to the feast of St. Peter and St. Paul. ${ }^{48}$ The beginnings of versicles are marked by the letter $v$. The fragment is the latest in the Zamoran collection to contain a prosa and dates from the 15 th century. The notation is also unusual and shows the influence of mensural notation as has been discussed in Chapter 4.

Petre summe was one of the prosae of the East Frankish repertory and is found in numerous sources of eastern origin, those given in $A H$ dating from the 10th to the early 16th century. $A H$ also shows it occurring in a few more western and also Italian sources. ${ }^{49}$ Another prosa, Laude iucunda, was generally used in France, England and Spain instead of Petre summe. ${ }^{50}$ The presence of Petre summe in Spanish sources has not previously been recorded apart from its occurrence in the Norman-Sicilian source held in Madrid, Ma $19421 .^{51}$

\footnotetext{
${ }^{46}$ The entry of prosae into Franciscan practices under the influence of the Victorine tradition is discussed in S. J. P. van Dijk and J. Hazelden Walker, Origins, 395-96.

${ }^{47}$ On Notker, Petre summe, and related texts, see Richard L. Crocker, The Early Medieval Sequence (Berkeley: University of Califomia Press, 1977), 75-93.

${ }^{48} \mathrm{AH}$ 53: 336.

${ }^{49} A H$ 53: 337-38. No Spanish sources are cited in Chevalier, Repertorium Hymnologicum.

${ }^{\text {so }} \mathrm{AH}$ 53: 339.

${ }^{51}$ Fernández de la Cuesta, Manuscritos, 336.
} 
A number of differences exist between the text of Petre summe as given in $A H$ and in $\mathrm{Z}$ 115. The major difference lies in the absence from $\mathrm{Z} 115$ of the versicle which normally forms the second half of the second versicle pair. This variant is not recorded in $A H$ and neither are three further variants which consist of single words. Two of the latter variants result in changes of syllable numbers. The first of these produces an irregular couplet as a result of the addition of the word "omnium" to the third versicle. Three variants which are recorded in $A H$ are of interest as they are found mainly in north Italian sources. Although the north Italian sources date from the 11 th and 12 th centuries, ${ }^{52}$ the similarities between their texts and that of Z 115 suggest an Italian connection for the Zamoran source.

The melody, Concordia (also frequently known as Epiphaniam), is the usual one associated with the text. ${ }^{53}$ Comparison of the melody in Z 115 with that given by Crocker ${ }^{54}$ for Petre summe suggests that it has remained largely the same through the long period of time. Two further sources used for comparison, Ma 19421 and Ver CVII, confirm this observation, although in these versions there are notable differences particularly in the first two versicles. ${ }^{55}$ The main variations in $\mathrm{Z} 115$ are the use of bistrophae ( 1 ) and plicas not found in the other sources, occasional pitch changes notably in the cadential approach of the first and second versicles, and the extra word of versicle three. The last variation required additional pitches, those added simply forming a sequential pattern with the previous notes of the versicle.

Bistrophae are used in both Ma 19421 and Z 115 on the penultimate syllable of versicles. Only one versicle is without a bistropha in this position in $\mathrm{Z} 115$, while the corresponding versicles of Ma 19421 use it consistently. The plicas of Z 115 find no correspondence in liquescent and two-note neumes of the other sources. They are without

\footnotetext{
${ }^{52}$ AH 53: 338.
}

${ }^{53}$ Anselm Hughes included Concordia under the title Chorus in his study Anglo-French Sequelae, 29-30. Although having much in common with the melodies of Petre summe seen by this writer, the version he gave is significantly different, and is closer to the melodies for the prosa, Epiphaniam, as found in French sources including $\mathrm{Pa} 1139$ and $\mathrm{Pa} 1177$. Bruno Stäblein discussed Concordia and the texts associated with it in "Die Sequenzmelodie «Concordia» und ihr geschichtlicher Hintergrund", Festschrift Hans Engel zum siebzigsten Geburtstag, ed. Horst Heussner (Kassel: Bärenreiter, 1964), 364-92.

${ }^{54}$ Crocker, Early Medieval Sequence, 91. 2: 38 .

${ }^{55} \mathrm{Ma} 19421$, fols. $65^{\mathrm{v}}-66^{\mathrm{z}}$. A transcription from Ver CVII is found in Brunner, Sequences of Verona 
exception associated with potentially liquescent syllables. In the transcription, which is presented in modern measured notation, plicas are transcribed as two pitches but without definite durational indication. The two pitch interpretation of the plica seems in keeping with their use on potentially liquescent syllables and the interpretation of the bistropha as a note of double duration similar to Bermudo's double. ${ }^{56}$ The duration of the two notes of the plica is left open as this aspect seems best left to the performer's judgement until further evidence is found for this aspect of interpretation.

The cadential approaches of the first two versicles show a definite variation in the fragment from the melodies of the two other sources. Instead of descent by step to the final through the last five syllables in $\mathrm{Z} 115$, both the other sources use falling intervals of a third or a fourth between two of the syllables and repetition of pitches before arriving at the same final as $Z 115$. The final of $G$ as employed in $Z 115$ is the usual one for the melody.

The first three prosae to be discussed were all found to occur in other Spanish manuscripts dating from as early as the 12th century, as well as in southern French sources. It may therefore be postulated that these were part of an early repertory of prosae used on the Iberian Peninsula probably transmitted from southern French centres such as Moissac and Limoges. The Zamoran sources suggest a wider spread for the three prosae than previously known. The other two prosae, however, appear to have a different history. Petre summe appears to have been a late introduction to the Spanish repertory, the only other Spanish source so far found to include it dating from the late 15 th century. The later prosa, Gaude roma, has not yet been identified in any other Spanish source and the fragment is one which suggests a non-Spanish origin. The two-voice prosa to be discussed in Chapter 10 has only Spanish musical concordances and a unique text.

When viewed as a whole neither textual nor melodic comparisons appear to produce any significant information which might relate the works to any line of transmission more particular than that already observed. Nevertheless, the finding of the unusual recurrent use of liquescent neumes and bistrophae in the fragments notated in Aquitanian notation as

${ }^{56}$ The interpretation of the bistropha in $\mathrm{Z} 115$ and other aspects of the notation of the source are discussed in Chapter 4, pages 134-35. 
well as the probably corresponding plicas and bistrophae of Z 115 is of great interest. This may well represent a stylistic feature which may have particular regional or other type of affiliation. The liquescent neumes, if sung as two notes moving in step (as certainly seems appropriate for most if not all of them), often fill in steps of a third in the melodies. Their use is reminiscent of one of the "features characteristic of 'Spanish' melodic style" identified by van Deusen from her studies of Spanish sequence sources. ${ }^{57}$ The feature referred to is the employment of short melismas moving in steps. ${ }^{58}$ The use of liquescent neumes at the beginning of versicles in the first three prosae deserves to be mentioned again, as it is another stylistic feature which may prove of interest in identification of a particular regional or other type of style. This feature will be found again during the next chapter on hymns in the Zamoran sources. Plicas and bistrophae are not a feature of the possibly non-Spanish fragment, Z 203.

Before proceeding to the next section a remark may be made concerning mode. All but one of the prosae which have been studied were found to have a $G$ final, the exception being Celeste organum. ${ }^{59}$ The situation is different in the following responsory prosae as both are understood as having a c final.

\section{RESPONSORY PROSAE}

Two prosae to responsories have been identified in the Zamoran sources, both in AHPZa fragments. Although they represent a different genre of trope to the works already discussed in this chapter, it has been decided to include examination of these prosae here because of the interest of the two items. ${ }^{60}$ They are identified in the table below. The 14th-century unnoted Breviario of the Church of Zamora includes occasional responsory prosae; however, the two found in the fragments are not found in the Breviario.

${ }^{57}$ Van Deusen, "Style, Nationality", 46.

${ }^{58}$ Van Deusen, "Style, Nationality", 46-49.

${ }^{59}$ Crocker found D and G as the most common finals of sequences (Crocker, Early Medieval Sequence, 25).

${ }^{60}$ Significant studies of the responsory prosae are those of Thomas Forrest Kelly and Helma HofmannBrandt. See Kelly's "Responsory Tropes" (Ph.D. diss., Harvard University, 1973), and "New Music from Old: The Structuring of Responsory Prosas", Journal of the American Musicological Society 30 (1977): 366-90. The work of Hofmann-Brandt is Die Tropen zu den Responsorien des Officiums, 2 vols. (Kassel: Bärenreiter, 1973). Hofmann-Brandt includes specific reference to Spanish sources (see for example vol. 1, 32-35). 
Table 2: Responsory Prosae

\begin{tabular}{lllll}
\multicolumn{1}{c}{ Text incipit } & Source & Date & Notation & Chevalier \\
1. Inviolata maria intacta & $\mathrm{Z} 123^{\vee}$ & 13th c. & Aquitanian & 9096 \\
2. Velut in & $\mathrm{Z} \mathrm{224}$ & 13th/14th c. & Aquitanian & 21143
\end{tabular}

\section{Inviolata maria intacta (Z 123)}

Prosa is the rubric given in the fragment for this chant. It occurs in the context of matins, probably for the Purification of the BVM. The prosa lies on the verso side of the fragment. The section of chant at the top of the verso and immediately preceding Inviolata maria intacta begins "fortissime rex sanctorum qui" and must be the continuation of the barely legible verse Gloria virtus et gratia which begins on the recto. That verse is preceded by another verse Gabrielem archangelum and the largely obscured responsory, Gaude maria virgo. The responsory is thus followed by two verses and a prosa. The melodies for the responsory and the first verse are, as far as can be determined as a result of the bad condition of the recto, the standard ones. ${ }^{61}$ Immediately following the prosa in $\mathrm{Z}$ 123 are a further three responsories and then the lauds antiphons. The prosa is given in complete form in this fragment.

Sources of the prosa, Inviolata maria intacta, have been listed by Hofmann-Brandt and Chevalier ${ }^{62}$ and include two polyphonic settings. With the exception of one, all earlier sources as listed by Hofmann-Brandt are from southern France and include some of those from the environs of Limoges. The exception is from Huesca in Cataluña and is the 12thor 13th-century Huesca $9 .{ }^{63}$ No other Spanish sources have been found. Comparison of

\footnotetext{
${ }^{61}$ See for example Antiphonale Monasticum (Paris: Desclée, 1963), 1195-1196.

${ }^{62}$ Hofmann-Brandt, Die Tropen 1: 140; 2: 71. Chevalier, Repertorium Hymnologicum 1: 545; 5 :
} 204. The texts of the prosa in $\mathrm{Pa} 1084$ and Wo 79 are given and discussed in Olof Marcusson, ed., Corpus Troporum II: Prosules de la messe I: Tropes de l'alleluia (Stockholm: Almquist \& Wiksell, 1976), 121-26; and Eva Odelman, ed., Corpus Troporum VI: Prosules de la messe 2: Les prosules limousines de Wolfenbüttel (Stockholm: Almquist \& Wiksell, 1986), 9, 85-86. Thomas Forrest Kelly in "Responsory Tropes" gives a list of thirty sources all of which contain prosae to the responsory Gaude maria virgo. Three different incipits are given for the prosae of that responsory, Inviolata integra, Inviolata intacta, and Inviolata nos tua. Inviolata maria is not included ("Responsory Tropes", 265-66). Inviolata maria is also not found in AH nor in Fernández de la Cuesta, Manuscritos.

\footnotetext{
${ }^{63}$ Hofmann-Brandt, Die Tropen 2: 172.
} 
the text of the prosa with versions in some earlier manuscripts ${ }^{64}$ shows that the Zamoran fragment has two unique features amongst this group of sources. These divergences are the addition of "et" in versicle five and the use of "pre clara" instead of "beata" in versicle seven.

The beginning of the melody for Inviolata maria intacta in Z 123 is like the openings of the prosa in other sources including $\mathrm{Pa} 1139$ and $\mathrm{Pa} 3719 .{ }^{65}$ This similarity, however, does not continue throughout. The second, third, and fourth versicle pairs as found, for example, in $\mathrm{Pa} 1139$ and $\mathrm{Pa} 3719$ are markedly different from the corresponding ones of $\mathrm{Z}$ 123. Moreover, couplet form is not clearly present throughout the $\mathrm{Z} 123$ setting. Whereas Hofmann-Brandt gave the form of melody as $A A B B C D C D E$, for $\mathrm{Z} 123$ the form might be better described as $A A^{l} B C D E F F G$ (each occurrence of a letter represents one versicle). Segments $A, F$, and $G$ of $\mathrm{Z} 123$ are all closely related and linked to the responsory Gaude maria. A similar relationship is found in the melody in other sources and may be expressed in the form as laid out by Hofmann-Brandt as existing between segments $A, C$, $D$, and $E$. Returning to $\mathrm{Z} 123$, sufficient similarity is observable between the central segments of the melody (versicles three to six) and the outer ones to allow the suggestion that the complete melody derives from the material of the responsory used in the opening and closing versicles of the prosa. The melismatic ending of the $\mathrm{Z} 123$ prosa appears to be identical to the legible parts of the Z 123 responsory ending with the text "inviolata permansisti". The closures at versicle ends in Z 123 are mainly on the third degree, e, with the exception of the fourth versicle on $d$ and the last on the final, $c$. This is at variance with $\mathrm{Pa} 1139$ and $\mathrm{Pa} 3719$ where internal closures are found on the final and third degree as well as on the second degree in $\mathrm{Pa} 1139$. Versions of Inviolata maria intacta are known with either the final of $\mathrm{c}$ or of $\mathrm{F}$. For the transcription $\mathrm{c}$ has been chosen as the final, the same pitch as found in the monophonic source in Aquitanian notation, $\mathrm{Pa} 1139$, for which a clef

${ }^{64} \mathrm{~Pa} 1139$, fol. 142; Pa 3549 (facsimile given by Hofmann-Brandt, Die Tropen 1: 142); Pa 3719, see Sarah Fuller "Aquitanian Polyphony of the Eleventh and Twelfth Centuries", vol. 3 (Ph.D. diss., University of Califomia, Berkeley, 1969), 175-79; Pa 1084 and Wo 79 (see footnote 62 above).

${ }^{65}$ The melodies of the last two sources are closely connected with melodies for Inviolata integra and Inviolata intacta found in sources such as $\mathrm{Ma} 1566$, Mont 759, and Antiphonale Sarisburiense. The cantus from Fuller's transcription of the two-voice Inviolata maria intacta in Pa 3719 has been utilized for the comparison. See Fuller, “Aquitanian Polyphony" 3: 175-79. 
is employed. ${ }^{66}$ This pitch also allows for the interpretation of quilisma groups in the responsory and verses as d-e-f rather than the less common g-a-b[flat]. The final is placed on the line.

\section{Velut in (Z 224)}

This prosa follows the responsory Benigno favore and the verse Hinc fugantur. Benigno favore is, in this context, probably the last responsory of the second nocturn of the office (the following rubric appears to be for the third nocturn but is partially obscured and therefore uncertain). The prosa is complete in $\mathrm{Z} 224$, beginning on the recto and continuing on the verso.

The only concordances of the prosa which it has been possible to locate are in central-northern French sources from Angers and Vendôme. ${ }^{67}$ In all these sources (dating from the 12th, 13th, and 16th centuries) Velut in occurs with the responsory Benigno favore and is part of the office for St. Katherine. No source located in Spain has been recorded in Fernández de la Cuesta nor has any further source been found by this writer.

Comparison of the text of Velut in as it appears in Z 224 with that of the mid 13th-century Vendôme source, Vendôme 17E, shows some small differences including at least one word change. ${ }^{68}$ Unfortunately, the poor condition of Z 224 precludes certainty on at least one other point of text comparison.

The melodic settings in both sources are syllabic, with that of Z 224 using occasional liquescent neumes not employed in Vendôme 17E. ${ }^{69}$ The not always precise diastematy of Z 224 leads to some ambiguity in pitch. Nevertheless, it is clear that each versicle pair has its own melodic material, and within each pair variations appear to be limited to the use of liquescence. The melody of Vendôme $17 \mathrm{E}$ is related to that of $\mathrm{Z} 224$ but with some notable differences. In Z 224 and Vendôme 17E the same melody is used for the first two

\footnotetext{
${ }^{66} \mathrm{~Pa} 1139$, fol. 142.
}

${ }^{67}$ Chevalier, Repertorium Hymnologicum 2: 709; Kelly, "Responsory Tropes", 308-9; HofmannBrandt, Die Tropen 2: 141. The text is not recorded in $A H$.

${ }^{68}$ The text and melody is given in Kelly, "Responsory Tropes", 449.

${ }^{69}$ It has not been possible to see the manuscript of Vendome 17E but the comparison makes use of Kelly's transcription in which neumes are transcribed diplomatically. 
versicles. However, the remainder of the prosa is divided differently in $\mathrm{Z} 224$ with two short versicle pairs used instead of the single undivided versicles of Vendôme 17E. Two couplets are therefore formed in Z 224 whereas the couplet structure in Vendôme 17E does not extend past the first two versicles. The form of $\mathrm{Z} 224$ could be described as $A A B B C C$ and that of Vendôme 17E as $A A B C$. The melody of the last couplet of $Z 224$ is the same as that at the end of Vendôme 17E. Another similarity is found in the structure of closures. The closures of Z 224 coinciding with the vowel $a$ at the end of each versicle are on F, all but one moving E-F-F. The same closing figure E-F-F is also preferred in Vendôme 17E. A notable difference between the two versions is the use of motives in Vendôme 17E incorporating a skip of a third and a fourth such as F-G-b[flat]-F. In Z 224 the third is replaced by a second and the following skip down therefore becomes a third.

Vendôme 17E takes $\mathrm{c}$ as the final, the melody beginning on the fifth degree $\mathrm{g}$. The same pitch has been taken for the transcription of $Z 224$; the notation of the fragment does not use a clef and places the final on the line. Such a reading of the pitch of the line produces a standard meaning (d-e-f) for the quilisma groups of Benigno favore and its verse.

In conclusion, it is interesting to note the significant melodic differences of the Zamoran examples from the French ones with which they were compared. In particular, it is remarkable that Inviolata maria should diverge from the more or less standard form of what must have been a well known melody. The version of Inviolata maria intacta found in $\mathrm{Z} 123$ is unusual both in its melody and text with no other sources having been found to show the same notable differences from the usual form of the work. Further research into Inviolata maria intacta would therefore be of interest in order to investigate whether or not these divergences are indeed unique or whether they are also found in other perhaps Spanish sources. As a whole, the area of responsory prosae in Spanish sources awaits attention. 


\section{HYMNS}

This study of the hymns found in the Zamoran sources can only be regarded as a beginning due to the complexity and breadth of the field. Studies of medieval hymns have mainly concentrated on the texts, with Bruno Stäblein's very distinguished work being the most detailed examination of the melodies. ${ }^{1}$ With regard to Spanish sources containing notated hymns, two important studies of the hymnal of Huesca (Hymnarium Oscense) have been published, one with an edition of text and music, and the other by Gutiérrez with only brief references to the melodies. ${ }^{2}$ Thorough comparative studies of the melodies of Huesca remain to be published. Also to have received attention, although limited, is the hymnal of Cisneros. ${ }^{3}$ A useful list of Spanish sources in major libraries which include hymns is given by Gutiérrez, but unfortuately she does not identify those with musical notation. In her 1989 article she mentions that she is in the process of cataloguing hymns contained in uncatalogued fragments in Spanish libraries. When this latter work is published it will provide very useful comparative material for the repertory under study in this dissertation.

Only a small number of hymns with musical notation are found in the sources of Zamora. All occur in the collection of fragments of AHPZa. Table 1 lists the hymns together with their fragment number. ${ }^{4}$ The fragments represented range from among the earliest ( $\mathrm{Z} 199$, mid to late 12th century) to the latest ( $\mathrm{Z} 206$, c. 1500), and most use Aquitanian (sometimes late Aquitanian) notation. As far as possible the hymn melodies have been identified in Bruno Stäblein's study Hymnen, some remaining unmatched with that work and other sources. The matches are indicated in Table 1 with the number assigned to each melody by Stäblein and the added prefix "ST". The table also indicates the type of notation used and the number of the text in Chevalier's Repertorium Hymnologicum.

${ }^{1}$ Stăblein, Hymnen.

${ }^{2}$ Durán Gudiol, Moragas, Villareal, Hymnarium Oscense; Gutiérrez, "El Himnario de Huesca".

${ }^{3}$ Higinio Anglés, "Early Spanish Musical Culture".

${ }^{4}$ The identification of recto and verso has been omitted for some of these fragments as it is uncertain.

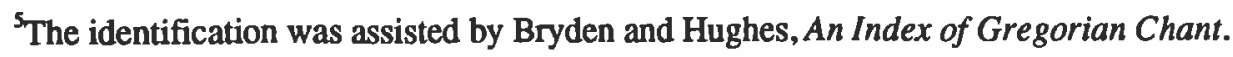


$\underline{\text { Table } 1}$

Incipit

1. A solis ortu

2. Conditor alme siderum

3. Eterna xpisti muneral apostolorum

4. Exultet celum laudibus

5. Huius obtentu

6. Iam xpiste sol iusticie.

7. Iesus ab ore

8. Inmense celi conditor

9. Laudis ergo preconium

10. Magne dies leticie

11. O gloriosa domina

12. O lux beata

13. Pange lingua gloriosil corporis

14. Sacris sollempniis

15. Te lucis ante terminum

16. Ternis ter horis

17. Xpiste qui lux
Source Melody Date $\underline{\text { Notation Chevalier }}$

Z 217[a] ${ }^{v}$ ST71 13th/14th c. Aquitanian 26

Z 119[a] ${ }^{v} \quad$ ST19 15th/16th c. square 3734

$Z^{r} \quad$ ST115 13th c. Aquitanian 590

Z 122 ST231 15th/16th c. square

5832

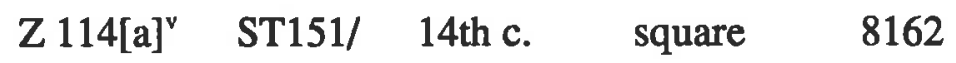

ST266

Z 197[a] ${ }^{v}$ ST148 12th c. Aquitanian 9205

Z 206 $-207^{\mathrm{r}}-15$ th/16th square 9724

$\mathrm{Z} 171[\mathrm{~b}]^{\mathrm{r}} \quad \mathrm{ST} 145 \quad$ 12th c. Aquitanian 8453

$\mathrm{Z}^{\mathrm{r}} \quad \mathrm{ST71}$ 13th c. Aquitanian -

Z 226[a] ${ }^{v} \quad$ ST188 13th/14th c. Aquitanian 10942

Z 239 ST16 12th c. Aquitanian 13042

$\mathrm{Z} 199[\mathrm{a}]^{\mathrm{v}} \quad$ - $\quad$ 12th c. Aquitanian 13150

Z 272 ST56 14th/15th c. Aquitanian 14467

Z $272 \quad-\quad$ 14th/15th c. Aquitanian 17713

Z 120[a $]^{\mathrm{r}} \quad$ ST19 15th/16th c. square 20138

$\mathrm{Z} 197[\mathrm{~b}]^{\mathrm{r}} \quad$ - $\quad$ 12th c. Aquitanian 20356

$\mathrm{Z} 197[\mathrm{~b}]^{\mathrm{r}} \quad$ - $\quad$ 12th c. Aquitanian 2934

Comparative studies have been made by this writer of the melodies and texts of these hymns in order to investigate any connections between the Zamoran sources and those of other regions. The principal material employed for melodic comparison was Stäblein's Hymnen and for textual analysis the relevant volumes of Analecta Hymnica. These publications were chosen for their availability and for their wide coverage of a diverse range of sources. One major drawback in the use of this material is the poor representation of Spanish sources which are entirely absent from Hymnen, and in $A H$, Spanish sources are 
in general less well represented than those of other regions, with only a small number of sources up to the 12th century provided as well as the limited but useful volume 16 with its inclusion of hymns of Spanish origin from later medieval sources. The results of this comparative study have proved largely inconclusive probably due to two principal factors: firstly, the wide time span covered by the fragments, and secondly the great diversity and variation which is constantly found to be characteristic of medieval chant and its usage from one time to another or one place to another. Nevertheless interesting data have emerged, particularly in relation to the widespread or otherwise use of melodies and texts, and to possible connections with certain traditions. One apparently unknown text is found in the sources and five melodies were not identified in Hymnen. These findings will be discussed in more detail below, and comments based on the comparative studies are given for each hymn.

One Iberian source with notation available to the writer for use in comparison of melodies was a Cistercian Temporale probably of Las Huelgas, c. $1225 .^{6}$ However only four of the texts from the Zamoran collection are found in the hymnal at the end of the manuscript. They are A solis ortu cardine, Conditor alme siderum, Te lucis ante terminum, and Xpiste qui lux. ${ }^{7}$ None of these use the same melodies as the sources under study here.

Table 2 gives the results of comparison of text incipits of the Zamoran hymns with sources of the Old-Hispanic rite $(\mathrm{O}-\mathrm{H})$, and the following manuscripts of the Roman liturgy all associated with the Cluniac rite and dating from the late 11th century to around 1100: the Antiphoner of Silos, London, British Library, Add. 30850 (S); the hymnal of Huesca, Huesca, Archivo de la Catedral, Ms. $1(\mathrm{H})$; and the hymnal of Moissac, Rome, Bibl. Apost. Vat., Rossi. 205 (M). ${ }^{8}$ The Huesca hymnal is thought to have been taken from France to Spain soon after its copying for a Benedictine monastery. ${ }^{9}$ It is not possible to localize it

${ }^{6}$ Dating and provenance were given to the writer by Wesley D. Jordan. I am grateful to Dr. Jordan for allowing me to study his copy of this manuscript. The manuscript is believed to have been copied in Las Huelgas and taken to Portugal where it is now located in Arouca, Arquivo do Mosteiro de Santa Maria, s.n.

${ }^{7}$ Arouca, Arquivo do Mosteiro de Santa Maria, s.n., fols. $197^{\vee}, 198^{\vee}, 200^{7}$.

${ }^{8}$ The sources used in the preparation of this list are: for O-H, $A H 27$ and $A H$ 51; for S, Ismael Fernández de la Cuesta, ed., Antiphonale Silense, British Library Mss. Add. 30.850, (Madrid: Sociedad Española de Musicología, 1985), XXXIII; for H, Gutiérrez, "El Himnario de Huesca", 49-50; for M, $A H 2$, $A H 51$ and Gutiérrez, "El Himnario de Huesca", 49-50.

9Durán Gudiol, Moragas, Villareal, Hymnarium Oscense 2: 7-8. 
as having been destined for a particular place, but the monastery of San Juan de la Peña is thought to be the most likely candidate. ${ }^{10}$ By 1130 it was in the cathedral of Huesca. Both Huesca and Moissac use Aquitanian notation. The last column indicates whether further Spanish sources other than Old-Hispanic sources are cited by Chevalier in Repertorium Hymnologicum, details of which are found in the study of each hymn or in footnotes below. Most of these sources are from the late 15th and 16th centuries and include a Mozarabic source of this period. From the list of hymns in Table 2 have been removed those known, or very likely, to have been composed too late for inclusion in the earlier manuscripts used. These are Iesus ab ore, Laudis ergo preconium, Magne dies leticie, Pange lingua gloriosi/corporis, and Sacris sollempniis. Also not included is Huius obtentu which only came into use as an independent hymn in late sources, as is discussed below. Chevalier cites Spanish sources for those in this group with the exceptions of Laudis ergo preconium and Magne dies leticie. Presence of a hymn in the sources is indicated by a plus sign in the table, while a hyphen indicates absence.

From Table 2 seven of the eleven hymns are seen to be included in all three specified manuscripts of the Roman rite, with three of the remainder included in at least one of the same three sources. Iam xpiste sol iusticie is a late 12 th- or early 13 th-century addition to the Huesca hymnal which would have been made after its arrival in Spain before $1130 .^{11}$ Gutiérrez suggests that $O$ gloriosa domina, the hymn included in none of the early manuscripts of the table, would probably have been in the lost conclusion of Huesca. ${ }^{12}$ Although further research is needed to give conclusive comment on this repertory of earlier hymns, it can be suggested that the Zamoran collection largely reflects the tradition of the Roman rite as it was transmitted from France in the late years of the 11th century and the early 12th century by the Cluniac monks. There is less in common with the hymns of the Old-Hispanic rite.

\footnotetext{
${ }^{10}$ Gutiérrez, "El Himnario de Huesca", 32.

"Gutiérrez, "El Himnario de Huesca", 31-32.

${ }^{12}$ Gutiêrrez, "El Himnario de Huesca", 33.
} 
Table 2

Hymn incipit

A solis ortu

Conditor alme siderum

Eterna xpisti

Exultet celum laudibus

Iam xpiste sol iusticie

Inmense celi conditor

O gloriosa domina

O lux beata trinitas

Te lucis ante terminum

Ternis ter horis

Xpiste qui lux

\section{$\underline{\mathrm{O}-\mathrm{H}}$}

$\underline{\mathbf{S}}$

$\underline{\mathrm{H}}$

M Chevalier

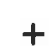

$+$

$+$

$+$

$+$

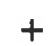

$+$

$+$

$+$

$+\quad+\quad+$

- $+\quad+$

$+\quad+$

$-\quad-13$

$+\quad+$

$+$

$-$

\section{A solis ortu cardine (Z 217[a]')}

The text of this hymn is the widely used 5th-century one by Sedulius, the first seven strophes of which were used in the Christmas celebration whilst the following four beginning Hostis herodes were used at Epiphany. ${ }^{14}$ Z 217 presents only the first seven strophes and these are for use in the context of Christmas Day at lauds.

Unfortunately the partial illegibility of the fragment makes it impossible to present a sure transcription of this hymn in both melody and text. It is however possible to see that the melody bears some resemblance to the widespread ST53 often employed for the text. ${ }^{15}$ The rising fifth of the opening, although occurring with a skip of a third in the Z 217 melody and by step in ST 53, produces an immediate impression of similarity. Another feature of both is the beginning of the melody on the note one step lower than the final. Further investigation reveals that the melody used in Z 217 is in fact ST71, one which is not listed by Stäblein for this text. The opening of ST71 is like that of ST53, as is the use

${ }^{13} \mathrm{O}$ gloriosa femina is found in the Silos manuscript.

${ }^{14}$ A. S. Walpole, Early Latin Hymns (1922; reprint, Hildesheim: Georg Olms, 1966), 150.

${ }^{15}$ Stablein, Hymnen, 516. 
of a repeat of the first line for the fourth. ST71 also begins with the tone one step below the final. The form of ST71 is either $A B C A$ or $A B C A^{1}$, that of $\mathrm{Z} 217$ being the latter, while that of ST53 is $A B B^{l} A^{l}$.

Of the versions of ST71 given by Stäblein, the closest to that of Zamora seem to be those of Moissac and the 12th- to 13th-century Cistercian hymnal of Heiligenkreuz. ${ }^{16}$ The connection with Moissac is made stronger by the closeness of the texts, Moissac being the most like the text of $\mathrm{Z} 217$ among the sources of $A H .{ }^{17}$ Also like $\mathrm{Z} 217$ but with evidently more variation than Moissac are two further French sources from Fleury and Troyes.

On the basis of the similarities between the ST71 and the melody of Z 217, the transcription takes the opening pitch of ST71 which is constant in all versions of the melody in Hymnen. A single quilisma group employed in the notation of the melody has, therefore, one of the two most common pitch placements of the group reading a-b-c.

\section{Conditor alme siderum (Z 119[a]')}

$\mathrm{Z} 119$ is one of the later dated fragments and is most probably from the late 15 th or early 16 th century. This must cast some doubt over the discussion below as the sources for comparison are all earlier. The information is however given as it remains of some interest and possible use in commencing further studies. The text is a widespread and frequently occurring one for use in Advent at vespers. ${ }^{18}$ The placement of the hymn in $\mathrm{Z} 119$ is probably that of the first Sunday of Advent at vespers.

The melody is ST1, one of eleven given by Stäblein for the text. It is not a generally spread melody but one found in France, Germany, and Italy. ${ }^{19}$ Of the three versions in Hymnen that of Nevers ${ }^{20}$ is closest to that of Zamora. Two Italian sources have a range of

${ }^{16}$ Stăblein, Hymnen, 63, 43.

${ }^{17} A H$ 2: 36-37; $A H$ 27: 117-118; $A H$ 50: 58-60. Chevalier cites as sources of the text, breviaries of Burgos (12th century), Tarragona (1483-84), Plasencia (1503), and Valladolid (1598) (Chevalier, Repertorium Hymnologicum 1: 3 and 5: 2).

${ }^{18} A H$ 51: 46. Chevalier, Repertorium Hymnologicum 5: 16, cites a breviary of Tarragona (1483-84) as containing the hymn.

${ }^{19}$ Stäblein, Hymnen, 529.

${ }^{20}$ Stäblein, Hymnen, 70. 
a seventh for the melody whereas those of Zamora and Nevers have an octave. Other differences are also present.

With regard to the text comparison with $A H$, only three variants were noted. ${ }^{21}$ The first of these is the absence of a strophe from the Zamoran version, one which occurs in many sources between the fourth and fifth strophes of $\mathrm{Z} 119$. Blume notes that this extra strophe has been erased in the Moissac hymnal and was not included in two Cistercian breviaries from Germanic regions of the 14th and 15th centuries. ${ }^{22}$ A second variant is interesting as it is listed for only one of the over twenty sources for which variants are given by Blume, that being an 11th-century source described as from Rheinau or possibly St. Gall. ${ }^{23}$ Both these variants, and a third more common one, are also found in the Cistercian Temporale probably from Las Huelgas. ${ }^{24}$ It would be interesting to make further studies of early and late sources of this hymn in Spain in order to further examine the text variants identified. ${ }^{25}$ It should also be noted that despite the similarity in texts, the melody given for the hymn in the Temporale is not the same; however, to the last statement needs to be appended the information that in that source the melody is given in black measured notation and has been added to the manuscript at a late date, perhaps in the 15th century, probably replacing an earlier form of the melody.

\section{Eterna xpisti munera / apostolorum (Z 35)}

This quite commonly found hymn text is based upon the martyrs' hymn with the same opening line of probably the 5 th century. ${ }^{26}$ It was adapted to become a hymn for celebrations of the apostles and is known from the 10 th century ${ }^{27}$ the adaptation was made

${ }^{21}$ AH 51: 46-47.

${ }^{22} A H$ 51: 47.

${ }^{23}$ AH 51: 47.

${ }^{24}$ Arouca, Arquivo do Mosteiro de Santa Maria, s.n., fols. $198^{\mathrm{v}}-199^{*}$.

${ }^{25}$ Chevalier, Repertorium Hymnologicum 1: 224 and 5: 98-99, cites breviaries of Burgos (12th century), "Hispanicum" (11/12th century), Tarragona (1483), and Valladolid (1598).

${ }^{26}$ John Julian, A Dictionary of Hymnology, 2nd ed. (1907; reprint, New York: Dover Publications, 1957), 24.

${ }^{27}$ Walpole, Early Latin Hymns, 105. 
by the substitution of the word "apostolorum" for "martyrum". In Z 3 the hymn is given for use at matins in the feasts of Apostles.

Among the versions included in $A H$, that for the apostles is only given as occurring in the Moissac hymnal. ${ }^{28}$ The two instances in which the word "apostolorum" replaces "martyrum" in Moissac both cause alteration in syllable number, producing irregularities in the standard pattern of eight syllables per line. This problem is not evident in $\mathbf{Z} 3$ as a result of the omission of the word "et" in strophe one, line two and the substitution of the four syllable "istorum" for the five syllable "apostolorum" in strophe five, line two. ${ }^{29}$

Many melodies are given by Stäblein for the text. ST115, with which the present one has been identified, occurs in widespread sources. ${ }^{30}$ The versions of the melody in Hymnen and that of Zamora are all very similiar, with the greatest similarity to $\mathrm{Z} 3$ occurring in the three French versions (two from the Moissac hymnal, one from Nevers) and that from Worcester. $^{31}$

The fragment is one of those using Aquitanian notation, and, as is normal in the collection, no clef is employed. The usual pitch of the melody with a final of $\mathrm{E}$ was therefore adopted, the line taking F (that being the usual pitch of the line for the fourth mode). After transcribing the melody of $Z 3$ and comparing the result with the melodies of Hymnen, a lowering of the pitch by a second was observed from the beginning of the word "munera" until the middle of the last line. It seems appropriate to assume that a change has occurred in the relationship of pitch and staff-line which has not been indicated by the scribe. This is most interesting in light of Stäblein's observation that a similar change occurs in the first line of ST115 set to the same text in the Moissac hymnal. There, a staff-line with the pitch of $\mathrm{F}$ is used in the first line, but in following lines changes to the pitch of $\mathrm{G}^{32}$ In the transcription, asterisks mark the points at which the pitch-line relationship appears to have changed in $\mathrm{Z} 3$. Only two music lines were needed for the copying of the

${ }^{28} A H$ 50: 19 and $A H$ 2: 74-75. Chevalier, Repertorium Hymnologicum 5: 16 cites a late 15th-century Spanish breviary containing the text from Tarragona (1483-84) together with other non-Spanish sources.

${ }^{29}$ Walpole, Early Latin Hymns, 105, gives instead of "istorum", the word "ipsorum".

${ }^{30}$ Stäblein, Hymnen, 529.

${ }^{31}$ Stăblein, Hymnen, 60, 63, 101, 195.

${ }^{32}$ Stäblein, Hymnen, 526. 
hymn in the fragment, and, as the points of probable change of line pitch do not occur at their endings, the direct placed at the end of the first line is of no assistance in identifying the change of pitch. An alternative approach to the melody of $\mathrm{Z} 3$ would be to see it as representing a variant from the usual form of ST115. In this variant the range of the melody would be D to b as opposed to the usual range of D to c. Such an interpretation, however, does not affect the interest inherent in the similarity of the two sources, $\mathrm{Z} 3$ and the Moissac hymnal, with regard to this feature. This further similarity with Moissac suggests that further research into the origins and use of $\mathrm{Z} 3$ might profitably be undertaken to investigate whether a closer connection existed between the liturgical practices of the monastery and those represented in the fragment.

\section{Exultet celum laudibus (Z 122)}

Another late fragment, Z 122 consists of a folio from which the lower quarter has been cut off and a section of another folio sewn onto the lower edge. As a result the text of the hymn is lost from the middle of the word "gloria" in the third line, although part of the last line of the melody can be seen as the cut was made more or less along the second line of the staff. In the transcription the usual text of the fourth line of the strophe is added in brackets, with spaces left for the lost notes. The melody resembles ST231, one of those which Stäblein lists for the widely used text Exultet celum laudibus. This melody he describes as a variant of the more commonly used and widespread ST114, the "root-melody" (Stammelodie) of the text Exultet celum laudibus. ${ }^{33}$ ST114 is found with the text in, for example, the hymnal of Moissac. ${ }^{34}$ His single example of ST231 is from an early 12 th-century French source originating in Laon, Laon, Bibl. publ. 263, fol. $169^{v} .^{35}$

The brevity of the text in the fragment makes comparison with $A H$ not useful. The opening given here is identical to that in $A H$ and no variants are given there for this part of

\footnotetext{
${ }^{33}$ Stäblein, Hymnen, 556, 574.

${ }^{34}$ Stäblein, Hymnen, 59-60 (transcription).

${ }^{35}$ Stäblein, Hymnen, 144-45.
} 
the hymn. ${ }^{36}$ The liturgical context of the hymn in Z 122 is probably the usual one, that being the feasts of Apostles at vespers. ${ }^{37}$

\section{Huius obtentu (Z 114[a]')}

Only the incipit of this hymn is given in $\mathrm{Z} 114$. It matches the beginnings of the widespread ST151 and the unique ST266 (ST266 is written a fifth higher than ST151 and the Zamoran example). ${ }^{38}$ While that of Z 114 is very similar to the openings of these two melodies in Hymnen, it is not identical to any. With regard to the texts, none of Stäblein's examples of these melodies use the text Huius obtentu, but both are listed for the text Virginis proles which is the beginning of a hymn in which a strophe beginning Huius obtentu is found.

Virginis proles was a very widely used hymn for feasts of virgins. The strophe beginning Huius obtentu is the last of four in the version given in $A H^{39}$ Blume notes that the fourth strophe together with the doxology were used in 15th- and 16th-century breviaries as an independent hymn for Holy Women who were neither virgins nor martyrs. ${ }^{40}$ This finding is in keeping with its apparent use for the feast of Mary Magdalene who is viewed as neither virgin nor martyr. The liturgical context of the hymn in Z 114 is probably the feast of Mary Magdalene, matins.

\section{Iam xpiste sol ( $\mathrm{Z} 197[\mathrm{a}]$ )}

The melody in the Zamoran fragment is ST148, of which there are only two examples in Hymnen. It was widely used but not known to Stäblein in English sources. ${ }^{41}$ The text is also a widely used one and may date from as early as the 6 th century. ${ }^{42}$ The liturgical

${ }^{36} A H$ 51: 125-26. Chevalier, Repertorium Hymnologicum 5: 145, cites an 11 th-century hymnal of Silos containing the hymn.

${ }^{37} A H$ 51: 125.

${ }^{38}$ Stäblein, Hymnen, 529 (for ST151) and 558 (for ST266).

${ }^{39} \mathrm{AH}$ 51: 137. Chevalier, Repertorium Hymnologicum 5: 189 , cites the text occurring in a 1484 breviary of Tarragona.

${ }^{40} \mathrm{AH}$ 51: 138.

${ }^{41}$ Stăblein, Hymnen, 529.

${ }^{42}$ Walpole, Early Latin Hymns, 326. 
context of the hymn in Z 197 appears to be lauds on the first Sunday of Lent, either lauds or matins on that day being usual placements. ${ }^{43}$

The melody and text in Z 197 are not fully legible and as a result transcription and comparison are difficult. Nevertheless, as the fragment is an early one in the collection, probably from the second half of the 12th century, comparison with the sources for the text and melody in $A H$ and Hymnen, which are all from the 12th century or earlier, is of particular interest. Of two versions given by Stäblein, the melody appears to be closer to the French version from Nevers, as the other, from Verona, uses more frequent short melismas than were probably found in the Zamoran source. ${ }^{44}$ On the other hand, while the text variants show an inclination towards greater convergence with French sources in general than with sources of other regions, the variants in common with the Veronese source are more numerous than those with any other single source. ${ }^{45}$ Blume in $A H$ and Stäblein both used the same source from Verona - Verona, Bibl. Capitol. CIX (102). The pitch of the transcription is that of the melody in Hymnen for which the final is G. The staff-line takes the $\mathrm{G}$.

\section{Iesus $a b$ ore $\left(\mathrm{Z} 206^{\mathrm{v}}-207^{\mathrm{r}}\right)$}

This is the only hymn in the collection to be unique to Spanish sources with regard to both text and melody. The text is included in $A H$ vol. 16 which is devoted to Spanish medieval hymns. ${ }^{46}$ It is noted there as occurring in two breviaries of Zamora (firstly, a 15th-century manuscript, perhaps the Breviario now in the Cathedral of Zamora, and secondly a printed source from the 16th century which is probably that in the Biblioteca Nacional of Madrid - R 25990), two of Plasencia (1503 and 1555), one each of Santiago de Compostela (1497), Sevilla (1521), Jaén (1528), Ciudad Rodrigo (1555), and a military order (the last printed in León in 1532). As may be seen, all date from the 15th or 16th centuries and all

\footnotetext{
${ }^{43}$ Walpole, Early Latin Hymns, 326; Chevalier, Repertorium Hymnologicum 1: 552.
}

${ }^{44}$ Stăblein, Hymnen, 89, 380.

${ }^{45}$ AH 51: 59-60. Chevalier, Repertorium Hymnologicum 1: 552, cites the text occurring in breviaries of Tarragona (1484) and Valladolid (1598), although without specifiying between variants in the second line.

${ }^{46} A H$ 16: 283. Chevalier, Repertorium Hymnologicum 1: 587 and 5: 218 (Chevalier lists the text but cites no further sources). 
are from western and south-western to south-central Spain. The liturgical context of the hymn as specified in the fragment and $A H$ is vespers in the feast of Continentium.

The text shows one variant from that given in $A H$ vol. 16. This is the lack of the word "jam" from the fourth line of the third strophe. Dreves notes this word as missing from the Breviary of Plasencia printed in Venice in $1503 .^{47}$ This coincidence suggests a connection between the Plasencia breviary and the Zamoran manuscript fragment which may date from the 15 th or early 16 th century and it might therefore be illuminating to compare the two sources further.

It has not been possible to identify the melody in Hymnen. It is a simple melody, with a clear tonal centre of $G$ and each line of verse ending with the falling second a to $G$. Like many hymns, it makes use of repetition, in this case using an only slightly altered repeat of the first line for the fourth line of the text, and with the second and third lines opening in the same manner. The climax occurs as is usual in the third line, where the melody rises to its highest point and finishes with a closing short melisma on the last syllable of the line, features found in several other melodies in this collection as well as being known in other sources. ${ }^{48}$ The notation of this late fragment is interesting in its transmission of a measured interpretation of the melody. ${ }^{49}$ This results in a continual flow of triple meter, which, with the exception of the end of the third line, is in the ratio of 1:2. (See the transcription at the rear of this dissertation in which is seen alternation between single and repeated notes.) The iambic movement of the music does not closely reflect the syllable accent of the text, however the consistently proparoxytone line endings are always set so that the stressed syllable of the last word is placed on a long note. Such constant rhythmic movement is reminiscent of an example given by Stäblein from a 13th-century French manuscript in which the same constant rhythmic flow is maintained but resulting from the use of two notes per syllable alternating with one note per syllable. In this example also, the lengthening of syllables does not always coincide with syllable accent. ${ }^{50}$

${ }^{47} \mathrm{AH}$ 16: 283.

${ }^{48}$ On melodic style in hymns and the findings of Stäblein, see the article by Ruth Steiner, "Hymn, §II: Monophonic Latin", NG 8: 838-41.

${ }^{49}$ The notation has been discussed in Chapter 4.

${ }^{50}$ Bruno Stäblein, "Hymnus, B. Der lateinische Hymnus" MGG 6: 999, example 5. 


\section{Inmense celi conditor $\left(\mathrm{Z} 171[\mathrm{~b}]^{\mathrm{r}}\right)$}

With the exception of one note the music of this hymn is entirely legible, on the other hand, the text is difficult to read. The melody, ST145, was a widespread one for use with this text. ${ }^{51}$ Stäblein's examples include English, French (not Moissac), Italian, and Germanic region sources. Very close to that of $Z 171$ is the melody from the 14 th-century manuscript of the Klosterneuberg house of Regular Canonesses. ${ }^{52}$ Although the Klosterneuberg melody uses one two-note melisma, the Zamoran version is syllabic throughout. No staff is visible in $\mathrm{Z} 171$ nor is any other help available in the source for determining the opening pitch. Stäblein's examples all have the same final (D) and that pitch has therefore been employed for the transcription.

Few variants are listed for the section of text included in $\mathrm{Z} 171$, the single one in the Zamoran version not being listed in $A H^{53}$ The text had widespread usage. The usual liturgical context is Monday, vespers; ${ }^{54}$ in $\mathrm{Z} 171$ the placement is undoubtedly for vespers and is probably for use on Monday.

\section{Laudis ergo preconium ( $\left.\mathrm{Z} \mathrm{1}^{\mathrm{r}}\right)$}

This text does not occur in Repertorium Hymnologicum of Chevalier, AH, nor in Stäblein's list of texts in Hymnen. The use of rhyme throughout suggests composition during the later centuries of the Middle Ages, as the technique was a late development. ${ }^{55}$ The last two syllables of each line are rhymed. Three other chants surrounding the hymn show that it is part of a rhymed office for lauds on the feast of St. Thomas of Canterbury, bishop and martyr (see Appendix 1, Book B). Unfortunately only a short section of the office is contained in the fragment. An examination of the St. Thomas office in the Breviario of Zamora showed that most of it had been cut out so that it is impossible to know whether this hymn was included.

${ }^{51}$ Stäblein, Hymnen, 541.

${ }^{52}$ Stăblein, Hymnen, 213.

${ }^{53} \mathrm{AH}$ 51: 35-36. No Spanish sources are given by Chevalier.

${ }^{54} A H$ 51: 35.

${ }^{55}$ Paired rhyming lines, although not necessarily applied throughout a poem, are observable by the early 11 th century. See E. A. Curtius, European Literature and the Latin Middle Ages (London: Routledge \& Kegan Paul, 1979), 389. 
Only the first half of the melody is given, but it is recognizable as ST71, that used in the Zamoran collection for $A$ solis ortu. The melody of $Z 1$ is very like the versions given in Hymnen from Moissac, Heiligenkreuz, and Gaeta in Italy, athough it is a somewhat more ornamented form. ${ }^{56}$ It is interesting to find that in the two appearances of ST71 in Zamora, there is one three-note melisma not found in any of the versions of Hymnen, and one quilisma which is noted as occurring in only one of Stäblein's nine versions. Unusual amongst the Zamoran collection of hymns is the use in $\mathrm{Z} 1$ of two liquescent neumes and a quilisma in a very short section of melody. The rising liquescent on the opening syllable is a feature of three of the hymn melodies in the Zamoran fragments and is not found in any of the versions of the same melodies in Hymnen. The features in common with the two Zamoran usages of this melody and the opening liquescent, possibly characteristic of hymn melodies in the region, suggest that further study of examples of ST71 from western Spain would be fruitful.

This widely used melody is found in medieval sources with finals of either G or D. ${ }^{57}$ $\mathrm{Z} 1$ has no clef indication and has been transcribed assuming $\mathrm{F}$ as the pitch of the line, resulting in the version on D as is used for Moissac and Heiligenkreuz. This is the same pitch as that used for $A$ solis ortu and offers a suitable placement to the quilisma group which therefore reads a-b-c.

\section{Magne dies leticie (Z 226[a] $\left.]^{\mathrm{v}}\right)$}

This is one of the later hymns in the collection. The melody, ST188 is described by Stäblein as the "root melody" of the mid 13th-century hymns composed for the canonisation of St. Peter the Martyr. ${ }^{58}$ The usual usage of the hymn is in vespers as is the case with $\mathrm{Z}$ $226^{59}$

Only one appearance of the hymn occurs in Hymnen, this being taken from the Dominican Archetype of c. $1255 .^{60}$ The versions from the latter source and Z 226 are alike

\footnotetext{
${ }^{56}$ Stăblein, Hymnen, 64, 43, 409.

${ }^{5}$ Stäblein, Hymnen, 521, 529.

${ }^{58}$ Stäblein Hymnen, 553.

${ }^{59} \mathrm{AH}$ 52: 283.

${ }^{60}$ Rome, Santa Sabina, Biblioteca del Curia generalizia dei Dominicana, XIV, lit. 1; Stäblein, Hymnen,
} 
with only minor changes. A text variant revealed by $A H$ is found in the same manuscript of c. 1255 as that from which Stäblein's version of the melody was taken, as well as three further sources from the 14 th and 15 th centuries. ${ }^{61}$ The pitch used for the transcription is that given by Stäblein and allows the flat sign indicated in the fragment to fall on $b$. The line is read as $\mathrm{F}$.

\section{O gloriosa domina (Z 239)}

This hymn is given with music and text in Z 239, while in Z 123 the text is given alone thus allowing textual comparison to be made within the fragment collection. Both sources use Aquitanian notation and are amongst the fragments dating from the second half of the 12 th century and the 13 th century. The texts in both appear to be identical, although some doubt must be given to the reading of $\mathrm{Z} 239$ as it is very badly preserved. In $A H$ the text is given only as the last three strophes of the widely used Marian hymn text by Fortunatus Quem terra, pontus, aethera, ${ }^{62}$ but $O$ gloriosa domina is recorded independently by Chevalier. ${ }^{63}$ It is possible that the earlier strophes of Quem terra would have occurred in the original sources from which the two fragments were taken in preceding parts of the same feasts in which the text $O$ gloriosa was included. The usual liturgical contexts of Quem terra are the feasts of Purification or Annunciation of the Virgin Mary, ${ }^{64}$ while $O$ gloriosa domina is also used in feasts of the Virgin Mary with Chevalier specifying the office principally as lauds (also matins, vespers and compline). ${ }^{65}$ In both Z 239 and Z 123 , O gloriosa domina is for use at lauds, probably in the feast of the Purification of the Virgin Mary.

122-23 (melody), 552-53 and 697 (source).

${ }^{61} A H$ 52: 283-84. Chevalier (Repertorium Hymnologicum 2: 66, 5: 247) has no citations for this hymn in Spanish sources.

${ }^{62} \mathrm{AH}$ 50: 87.

${ }^{63}$ Chevalier, Repertorium Hymnologicum 1: 197. Spanish sources are a breviary of Lérida (1451), Tarragona (1484), and Plasencia (1503) (Chevalier, Repertorium Hymnologicum 5: 198).

${ }^{64} \mathrm{AH}$ 50: 86, 88.

${ }^{65}$ Chevalier, Repertorium Hymnologicum 1: 197. 
With regard to text variants, the most important in the context of Quem terra, pontus, aethera in $A H$, concerns the word "domina" from the line "O gloriosa domina". In $A H$ "domina" is replaced by "femina", without "domina" being recorded as a variant.

The melody, ST16, is that commonly associated with Quem terra, pontus, aethera in sources other than Milanese ones and had widespread usage. ${ }^{66}$ The Zamoran version of ST16 uses a final melisma at the end of the third line, a feature it shares with most of the examples in Hymnen. The version to which Z 239 appears to be the most similar is that of the Cistercian hymnal of Heiligenkreuz, although the latter does not use the just mentioned melisma. ${ }^{67}$ The melody uses a repetition of the second line for the fourth, a feature which in the Zamoran source is more markedly disguised by omamentation in the repeat than in most of the Hymnen versions.

Stäblein's examples in Hymnen show the melody with three finals - G, D (or d) and a - thus presenting a problem for transcription; however a quilisma occurring on the second degree above the line offers some restriction in the choice of line pitch. As the final is placed on the staff (indicating a plagal mode) and as the three-note quilisma group is more likely to begin on $D$ or a rather than $G$, the choice may be limited initially to the first two. Of these, $\mathrm{D}$ has been chosen for the transcription as the other, $\mathrm{a}$, is less frequent in Stäblein's examples.

\section{O lux beata (Z 199[a] $\left.]^{v}\right)$}

$\mathrm{Z} 199$ is one of the 12 th-century Book A fragments. The hymn is distinguished from the surrounding chants by the use of red ink which has fortunately remained legible. Part of the first strophe cannot be read after the opening three words but most of the following strophes are legible. Comparison with the version of the hymn in $A H$ vol. 51 shows only one variant in the first two strophes. ${ }^{68}$ This variant is not listed as occurring in any other sources. The third strophe (doxology) is very difficult to read but can be seen to be different from that in the Moissac hymnal but like that of the Verona hymnal and two

\footnotetext{
${ }^{66}$ Stăblein, Hymnen, 507, 529.

${ }^{6}$ Stăblein, Hymnen, 39.

${ }^{68} \mathrm{AH}$ 51: 38-39.
} 
manuscripts possibly both from St Gall. ${ }^{69}$ While the usual usage of this hymn places it on Saturday at vespers, ${ }^{70}$ it has not been possible to identify the context of its presence in $\mathrm{Z}$ 199 other than to say that it may be the first Sunday after Epiphany.

Stäblein comments that this text is only rarely not associated with the melody ST22, ${ }^{71}$ and it is therefore interesting to find that the melody in $\mathrm{Z} 199$ cannot be identified in Hymnen. Neither does the Zamoran melody have the highly repetitive form characteristic of ST22 in which the opening melodic line is repeated in the third and fourth lines; Z 199 uses only a partial repeat of the first line in the fourth. A short melisma on the first syllable is reminiscent of the opening rising liquescents of other hymns in the Zamoran collection. In this case the neume consists of two puncta on the same pitch followed by a virga one step above.

The notation used in this fragment is Aquitanian, and two problems are encountered in transcription which result in some inevitable uncertainties. These are the identication of the pitch of the dry-point line without clef and the inconsistency of neume spacing with regard to the line. The mode can been taken as plagal as the final is placed on the line, with the music seeming to extend a fourth above and below the line. A semicircular virga is employed at one point and seems to be placed a second below the line. As it has earlier been proposed that this sign is only used for $\mathrm{b}$ natural or $\mathrm{E}$ natural preceded by a major second, the pitch of the line may tentatively be limited to either $\mathrm{c}$ or $\mathrm{F}^{72}$ A quilisma group occurring above the line is problematic as its placement relative to the staff is unclear; nevertheless, it seems best understood as beginning a second above the line, a reading in keeping with either of the proposed line pitches. Although the use of $\mathrm{c}$ as the pitch of the line has not yet been ruled out, $\mathrm{F}$ has been employed for the transcription.

${ }^{69} A H$ 51: 39. A Spanish source, the Mozarabic breviary of 1502 , is cited by Chevalier, Repertorium Hymnologicum 5: 280 .

${ }^{70} \mathrm{AH}$ 51: 38; Julian, A Dictionary of Hymnology, 842.

${ }^{71}$ Stäblein, Hymnen, 509.

${ }^{72}$ For discussion of pitch and the semicircular virga of Book A see Chapter 4, page 109. 


\section{Pange lingua gloriosi / corporis misterium (Z 272)}

The melody used here is ST56, but it is not given in its entirety. According to Stäblein this generally widespread melody ${ }^{73}$ was one of the most used for the family of texts beginning with the words "Pange lingua". ${ }^{4}$ Of Stäblein's five versions from diverse regions the closest to the Zamoran one are those from Worcester and Einsiedeln. None however use the opening liquescent neume found in Z 272 which causes the chant to begin from the tone below the final. The staff-line has been read as F for the transcription which is in accord with the $\mathrm{E}$ as final. $\mathrm{E}$ is a common opening note as well as final for the melody, ${ }^{75}$ this version therefore being unusual in its choice of opening pitch. Also unusual in the Z 272 melody are the repeated notes (bistrophae) of the third syllable of the first line, a feature not found in any of the Hymnen versions.

Only the first strophe of the text is given in the fragment and as it is in very poor condition much cannot be read. This is unfortunate as the legible parts suggest that it is not identical with the standard text as given in $A H .^{76}$ The usual liturgical context for the hymn is vespers on the feast of Corpus Christi. ${ }^{77}$ This appears to be the case for its occurrence in Z 272.

\section{Sacris sollempniis iuncta (Z 272)}

This melody has not been identified in Stäblein's collection. Like that of Pange lingua in the same fragment, it is not given in its entirety, no music being given for the fourth line. The melody has a short melisma at the opening which is repeated when the music of the first line is reused for the third.

${ }^{73}$ Stablein, Hymnen, 529.

${ }^{74}$ Stăblein, Hymnen, 516.

${ }^{75}$ See for example Stäblein, Hymnen, 33, 90, 286-87.

${ }^{76} A H$ 50: 586-87. Chevalier, Repertorium Hymnologicum 2: 287 and 5: 301-2, cites the text as contained in the following Spanish breviaries: Tarragona (1484) and Valladolid (1598).

${ }^{\pi} A H$ 50: 586. 
The first strophe of the text, which is by St. Thomas Aquinas, is given in the fragment without variant from that in $A H$ apart from the spelling of the second word which is usually "sollemniis". 78 The three abbreviations marked are not indicated in the fragment but have been presumed to be such in accord with the standard text. The liturgical context may be the usual one of matins on the feast of Corpus Christi, ${ }^{79}$ or on the other hand it may be the octave of the same feast.

The pitch of the line is difficult to establish; the only pointers found in the Aquitanian notation of the fragment being one quilisma group based on the line and the probable final also occurring on the line. D and a are the most common base notes for quilisma groups and as D is more frequently used as a final it has been chosen as the pitch of the line.

\section{Te lucis ante terminum (Z 120[a] $\left.]^{r}\right)$}

The melody used in Z 120 is ST19, the same as is employed for Conditor alme siderum in $\mathrm{Z} 119$. In fact, the two fragments appear likely to have been taken from the same late 15 th-century or early 16 th-century manuscript and are placed in Group 3a. It is surprising that ST19 is not included among the forty-nine melodies given by Stäblein for Te lucis ante terminum. On the other hand, in the Antiphonale Monasticum ST19 is found with this text for use during compline in Advent, ${ }^{80}$ as also appears to be the context of the Zamoran example. The widely used text occurs in the fragment in full and is without any variants in comparison with $A H^{81}$

\section{Ternis ter horis (Z 197[b] )}

This text was in widespread use. The hour of none on Sundays during Lent is the usual context; ${ }^{82}$ however, in Z 197 the hour is unclear and may be either sext or none. One Spanish source from the 12 th century is included amongst the sources named in $A H$ but

${ }^{78}$ AH 50: 587-88. Chevalier, Repertorium Hymnologicum 1: 492, cites the Spanish breviaries from Tarragona (1484), and Valladolid (1598) as containing the text.

${ }^{79}$ AH 50: 587.

${ }^{80}$ Antiphonale Monasticum, 183.

${ }^{81}$ AH 51: 42-43; Chevalier, Repertorium Hymnologicum 2: 646-47 and 5: 383-84, cites two 9th/10thcentury manuscripts of Toledo as containing the texts.

${ }^{82} A H$ 51: 66. 
unfortunately variants for it are not listed there. A number of variants occur, however, between the text of $\mathrm{Z} 197$ and that given in $A H$, the variants of the Zamoran text showing convergence with those of Italy and southern France, rather than other regions. ${ }^{83}$

No match was found with Hymnen, but it can be observed that the melodies given by Stäblein for this text share with that of Z 197 the use of repeated notes of the same pitch at the beginning of the melody. Stäblein's melodies continue in a simple style tending to repetition throughout and maintenance of a narrow range. The transcription of Ternis ter horis from Z 197 shows a range of a seventh, while the five melodies given in Hymnen have a range of a third, fourth or a fifth.

Although this 12th-century fragment is written in Aquitanian notation, the pitch of the melody is not difficult to identify. This is because the final is placed one step below the staff-line, a placement which is characteristic of only one mode, the fourth. The line may therefore be read as $\mathrm{F}$.

\section{Xpiste qui lux (Z 197[b])}

The text is a widely used one, the usual context of which is compline during Lent. ${ }^{84}$ This liturgical placement seems to be maintained in the fragment. Comparison with $A H$ shows that this version makes use of a very frequent variant which Blume believed to be an alteration from the original version. Interestingly, two Old-Hispanic sources of the 10th and 11 th centuries have yet another version in the same position (strophe one, line three). A further two variants are also common to many of the sources for which variants are listed. $^{85}$

Despite the poor legiblility of the fragment and the resultant uncertainties and gaps in the transcription, the melody of the fragment can be regarded as different from the single melody (ST9) which Stäblein found for this widely used hymn dating from the 6th century. ${ }^{86}$

${ }^{83} \mathrm{AH}$ 51: 66-67. Chevalier, Repertorium Hymnologicum 1: 661, gives the Spanish breviaries of Burgos (12th century), "Hispanicum" (11th/12th century), Valladolid (1598) as containing the text.

${ }^{84} \mathrm{AH}$ 51: 21.

${ }^{85}$ AH 51: 21-23. Chevalier, Repertorium Hymnologicum 1: 173, cites the Spanish breviary, Palencia $(1545 / 1546)$, as containing the text.

${ }^{86}$ Stăblein, Hymnen, 506. 
Amongst the various differences between the melodies, a formal one stands out; ST9 uses the same or only slightly varied music for the first and last lines, a feature not found in the melody of Z 197. The Z 197 melody appears to be through-composed. (Poor legibility makes it impossible to study the form of this melody accurately). Given the fact that Stäblein knew of only one melody for Xpiste qui lux, it would be of great interest to look for further settings of the text in Spanish sources to find whether that of Z 197 is repeated elsewhere. No help is gained for the determination of the pitch from the notation, and so for the purposes of initial transcription only, the staff-line has been read as D.

From the comparisons with Hymnen and $A H$ some pointers have emerged to connections between Zamoran sources and the c. 1000 hymnal of the Cluniac monastery of Moissac and to some Cistercian traditions. These connections cannot be seen as applying generally to the whole Zamoran hymn collection but rather should be viewed as relevant to individual sources and hymns.

Of the five melodies which have not been identified in Hymnen, it is interesting to observe that three are in early sources, while one other is from a late source and is connected with a text unknown outside Spanish sources. The presence of three unknown melodies in early sources raises the question as to whether there may have been a greater variety of hymn melodies in use in Spain during the early period represented in the collection (12th and 13th centuries). Furthermore, could a melodic tradition have been carried over from the Old-Hispanic rite? That five out of a total of only sixteen melodies, almost one-third, should be unknown to Hymnen does suggest the likelihood of a regional tradition. Also to be noted in the context of a regional or local tradition is the combination of a text with a melody other than those with which it is usually associated. Issues such as those raised in this paragraph would have to be tested in a larger and more detailed investigation, unfortunately beyond the scope of the present study.

A further item concerning the unidentified melodies may be added as a result of brief examination of the melodies of the Huesca hymnal; this is the fact that the unidentified 
melody for $O$ lux beata occurs in a varied form in Huesca with a different hymn text. ${ }^{87}$ The text $O$ lux beata also occurs in the manuscript and may also take the same melody. ${ }^{88}$ Two of the other hymn texts of the Zamoran collection with unidentified melodies occur in the Huesca hymnal but different melodies are employed there. In summary, and taking other hymns into account, the Huesca source appears to have no more, and perhaps less, in common with the Zamoran collection than the hymnal of Moissac.

The opening rising liquescent neumes found in three of the hymns need to be remarked upon. These are reminiscent of the similar phenomenon found in the prosae discussed in Chapter 7. The hymns in which they are found are Pange lingua gloriosi / corporis, Laudis ergo preconium and Magne dies leticie. Such opening liquescents are not found for the same melodies in Hymnen. The three note figure of ST71 as found in both A solis ortu and Laudis ergo preconium is also of interest and brings to mind van Deusen's observation on short melismas moving by steps which has already been referred to in Chapter 7. From the observations of the two instances of ST71 occurring in two different sources of the Zamoran collection, it is possible to hope that this melody would present a particularly interesting further case study if more examples of it were found in Spanish sources, one which might provide information relevant to a local or regional melodic style.

A final comment may be made with regard to modaliy. The D mode is found to be the most commonly used in the hymns of the Zamoran collection and Stäblein shows this to be the most common mode for hymns in French and Cistercian sources. ${ }^{89}$ Given the strong likelihood of transmission of French and Cistercian repertories into western Spain, such a parallel finding is not surprising.

\footnotetext{
${ }^{87}$ Durán Gudiol, Moragas, Villareal, Hymnarium Oscense 2: 107.

${ }^{88}$ Facsimile in Durán Gudiol, Moragas, Villareal, Hymnarium Oscense 1: viii ${ }^{v}$. (This photograph is difficult to read.)

${ }^{89}$ Stäblein, "Hymnus", 1009.
} 


\section{THE PREFACES AND THE PATER NOSTER FOR THE MASS}

As is the case with the genres discussed in the previous three chapters, little investigation has been made in Spanish sources of the prefaces or prayers such as the Pater noster. For the study of the tones used for the prefaces and the Pater noster, Bruno Stäblein's work is once again outstanding and includes reference to Spanish sources of the Pater noster. ${ }^{1}$ The only Zamoran sources relevant to this chapter are the Misal votivo, the Ritual, and the loose booklet of the Ritual. Neither prefaces nor the Pater noster are found in any of fragments of the AHPZa. The inclusion of a study of these tones in this dissertation is motivated in part by the interesting usage of the plica found in their notation within the Ritual. This has already been referred to in detail in Chapter 5 and so will only be mentioned in passing in the present chapter.

\section{PREFACES}

The preface is that part of Mass which introduces the Sanctus and begins with the words "Vere dignum". Although the opening words are invariable, it may be classified as part of the Proper of the Mass as it has a variety of texts and melodies, the number of which in use has varied over the centuries. That known as the "Common Preface" is found in the Liber Usualis as part of the Mass Ordinary, while special texts for various feasts are given in the Liber Usualis under the title of "Proper Prefaces". In the Zamoran sources under study, prefaces are found in the Ritual of Zamora, the loose booklet at the back of the Ritual, and the Misal votivo. The various prefaces are listed together with their folio numbers in Appendix 1 of this dissertation. From the texts of the prefaces which form the entire contents of the booklet, it is clear that part of the booklet has been lost, only two bifolios remaining from what must have been at least three bifolios. In the Misal votivo, the prefaces occur in the first part which dates from the 15th century; the Ritual and the

'Bruno Stăblein, "Präfation”, MGG 10 (Kassel: Bărenreiter, 1949-86), 1535-1537; Stäblein, "Pater noster", $M G G$ 10: 943-50.

${ }^{2}$ Liber Usualis, 3-4, 8-10. 
booklet are also dated to the 15 th century. Tones for the prefaces to be used in both festive and ferial celebrations are given in these sources.

Also found in the Ritual and the Misal votivo are settings of the introductory dialogue which precedes the preface. It begins "Per omnia secula seculorum. Amen" and concludes "Dignum et iustum est". This dialogue is sometimes included under the title of preface as for example in the Liber Usualis. ${ }^{3}$ The musical settings of the dialogue will be referred to only briefly.

The prefaces represent a topic which in general has not been extensively studied, the two most useful studies known to the writer being those of Wagner and Stäblein, that of Wagner being the most comprehensive. ${ }^{4}$ In addition a brief analysis of the structure of the preface tone by Crocker is of interest. ${ }^{5}$ It has not been possible to find any studies of the prefaces in Spanish sources.

\section{Order of the Prefaces}

The different prefaces to be used during the year were commonly placed together in missals and usually in association with the text for the canon of the Mass. The Ritual of Zamora follows this pattern and presents a group of thirteen prefaces in this part of the manuscript. (Reference to the Ritual is always to the main body of the book rather than to the loose booklet which will be specified when discussed.) The first two prefaces use the common text, the first being the more solemn with the rubric "prephatio cum suo cantu in omnibus festivis", while the second is for ferial use "Cantus iste dicitur ferialis". After these is the text for the canon of the Mass, as well as the tones for the Pater noster and the Pax domini sit. This ordering is not an unvarying one. Following the completion of the Mass text are the prefaces for special feasts beginning with that for Christmas. In several non-Spanish manuscripts observed by the writer, including the c. 1260 to 14th-century Dominican Lo 23935, a 15th-century missal of Rouen, and a 15th-century missal of Besançon

\footnotetext{
${ }^{3}$ Liber Usualis, 3-4.
}

${ }^{4}$ Peter Wagner, Einführung in die gregorianischen Melodien, vol. 3 (1921; reprint, Hildesheim: Georg Olms, 1962), 69-80; Bruno Stäblein, "Präfation".

'Richard Crocker, A History of Musical Style (New York: McGraw-Hill, 1966), 8-9. 
(Besançon 76), the prefaces for the special feasts precede the common ones. ${ }^{6}$ Ma 931 , a Spanish manuscript of the 14th or 15 th century, begins with the common prefaces, those for special feasts following. Ma 931 contains twelve out of the thirteen prefaces found in the Ritual, although there is some variation in the order of the proper prefaces; furthermore, in Ma 931 the canon of the Mass and the Pater noster are placed after the proper prefaces, unlike the Ritual. One further proper preface is included in the Ritual in addition to the group of thirteen: it occurs as part of the Wedding Mass.

A full comparison of the prefaces in the Ritual and in the booklet inserted at the back of the manuscript is made impossible by the incomplete nature of the latter group; however, those present in the booklet give the same order as that in the Ritual although no prefaces are found between those for Epiphany and Resurrection.

The Misal votivo contains only the two common prefaces which are located at the beginning of the manuscript with the festive one as usual placed first. Interestingly, the incipit of the Sanctus is given and notated immediately before the text of the canon of the Mass which begins with the words "Te igitur clementissime". As in the Ritual, the tones for the Pater noster and Pax domini sit are also given.

\section{The Tones}

Two tones (festive and ferial) are used in the Zamoran sources for the prefaces. These are used not only for the common texts but also for the proper texts. Among the group of thirteen prefaces found in the Ritual $^{7}$ only two use the ferial tone: the common ferial preface and the preface for Quadragesima. The remainder all use the festive tone, as does the preface for the Wedding Mass. ${ }^{8}$ The employment of the ferial tone for Quadragesima is not an unusual practice.

Similarly to the various classes of psalm tones, a number of structural components may be identified in preface tones in general. These components are the reciting note, and

'Lo 23935, fols. $496^{\mathrm{r}}-497^{\mathrm{v}}$; Rouen, Bibliothèque municipale ms. $260 \mathrm{y} .1$, fols. $131^{\mathrm{v}}-143^{\mathrm{r}}$. (Folio numbers for Besançon 76 were not available to this writer.)

${ }^{7}$ Ritual, fols. $74^{\mathrm{x}}-101^{\mathrm{v}}$.

${ }^{8}$ Ritual, fol. 25. 
formulas for intonation, mediation, and ending. They are altered in order to fit the different texts by means of addition and deletion of notes, while maintaining the fundamental structure of the tones (the intonation is not always used). Also as is general with psalm tones, they follow a bipartite structure of two elements which may be identified in preface tones by the occurrence of the mediation and ending formulas as well as through the changing reciting note. 9 The mediation and ending formulas provide the closures for the two elements, the first characteristically rising to its closing pitch, and the second falling to its closing pitch. ${ }^{10}$

The ferial and festive preface tones of the Zamoran sources follow the pattern just described. The festive tone is less syllabic than the ferial version resulting in a more ornamented effect. Examples 1 and 2 show the two elements of the festive and ferial tones respectively as found throughout the Ritual. The sections marked element 1 and element 2 in both examples represent the most usual form of each with brackets to indicate notes not used in all repetitions of an element. The mediation and ending formulas are marked. Important variants are shown as $1 \mathrm{a}$ and $2 \mathrm{a}$. When the text segment beginning with the words "Et ideo" is included in the prefaces (it is not part of the common preface) the setting of the two opening words forms part of the intonation in the first element. This is included in 1a of Example 1. "Et ideo" is not found in the Quadragesima preface and as that and the common preface are the only ones with the ferial tone in the Ritual no setting for the phrase is given in Example 2. A further form of the second element of the festive tone (2a of Example 1) is found as well as the principal form of element 2 in the prefaces for Wedding, Trinity, Marian, and Resurrection Masses, with an abbreviated version of the same in the Ascension preface. The scandicus at the beginning of element 2 of the festive tone can be regarded as an ornamentation of the reciting note, which in $2 \mathrm{a}$ is spread over three syllables. Element 2 is also found without ornamentation and sometimes without the reciting note as well, thus commencing with the ending formula. In the ferial tone also, element 2 is found shortened and commencing at the ending formula. An abbreviated form of element 1 is used on one occasion in the ferial tone for the Quadragesima preface; it is shown in 1a of

${ }^{9}$ On the two elements of the preface tones see Wagner, Einführung, especially 71-72.

${ }^{10}$ This pattern of closures may be observed in the examples given by Wagner (Einführung 3: 71-78) and Stăblein ("Präfation", 1535-1536). The latter writer also comments upon the phenomenon ("Praffation", 1536). 
Example 2. In this variant the first note of the mediation formula is omitted, and it is in fact the only occasion on which the first note (bracketed in Example 2, element 1) of the formula is not used. The reciting note in both festive and ferial tones of element 1 is $\mathrm{F}$ and that of element 2 is E. (Earlier preface tones generally made use of $c$ and $b$ as reciting notes. ${ }^{11}$ ) As will become clear later in this chapter, in general the Zamoran tones are very like those of other sources from diverse places and much of the above description would in fact apply to many other examples.

\section{Key to Examples in this Chapter}

ㅂ. $=\mathrm{A}$ pitch which may or may not be repeated. It is either the reciting note or the principal pitch of the intonation.

( )

A ○
$=$ Note or notes which are not always present.

$=$ Placing of the final accented syllable within formulas.

= Plica.

\section{Example 1: Festive tone, Ritual}

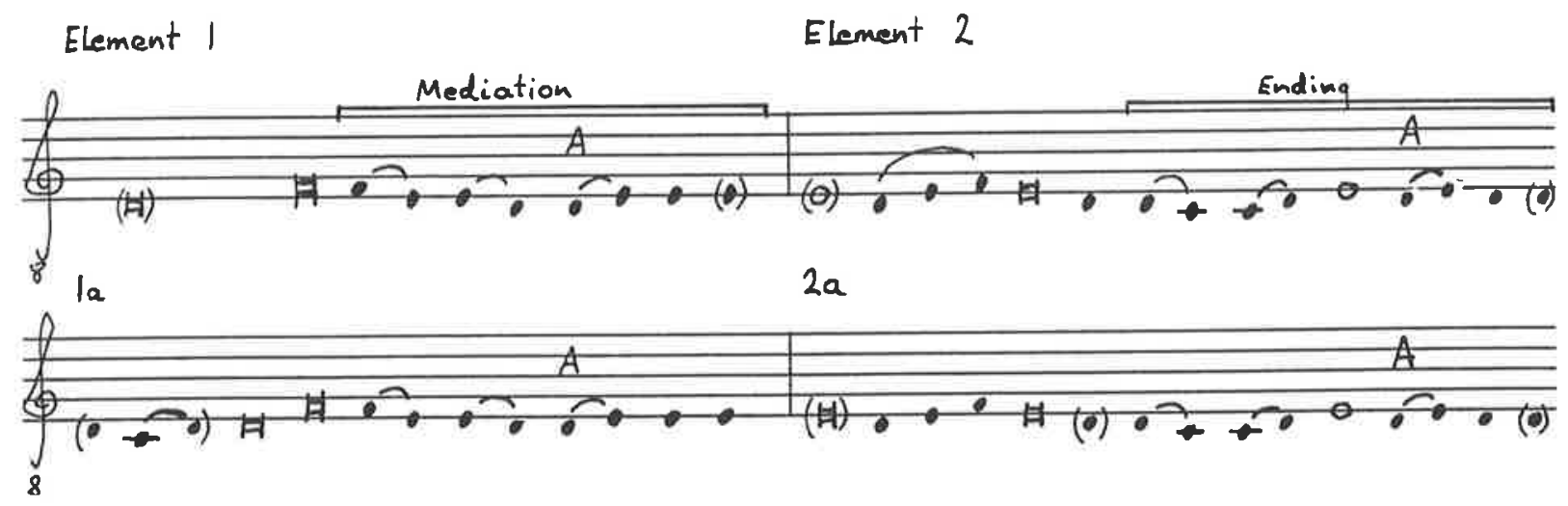


Example 2: Ferial tone, Ritual

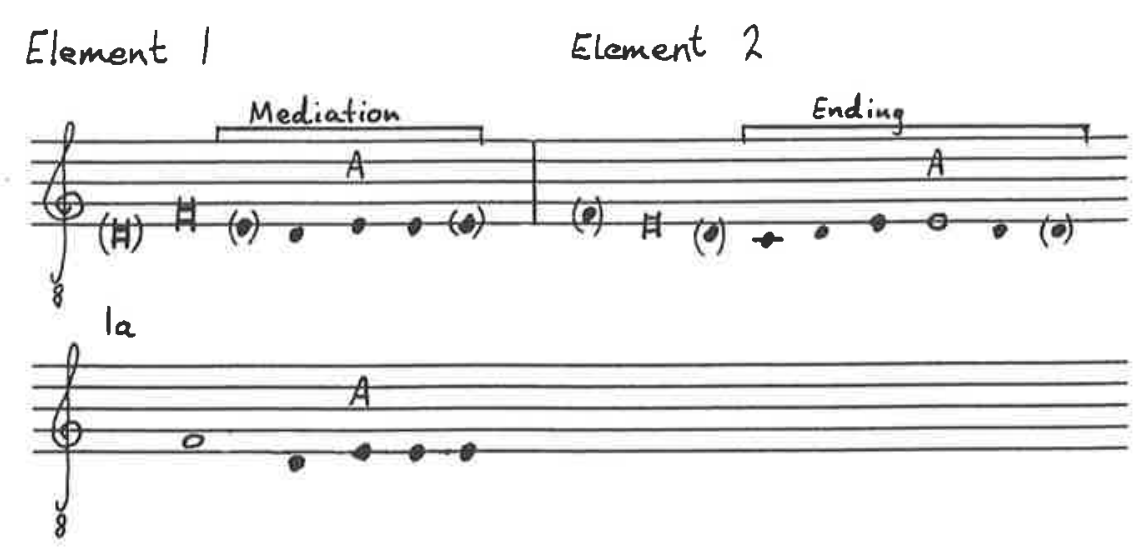

Very minor differences only are found between the tones for the common preface of the Ritual and the Misal votivo. (Only the common preface is contained in the latter manuscript.) The differences in the festive tone found in the Misal votivo are one occurrence of the mediation formula with only two two-note neumes instead of the three characteristic of the Ritual, the repetition of one note (perhaps an error), and the omission of all plicas. Similarly in the ferial tone of the Misal votivo all plicas are omitted and one mediation is altered.

Wagner gives festive and ferial tones for the Resurrection preface from a 14th-century Franciscan missal (Rome 2048) which are very similar to the two tones as used for the different preface texts in the Zamoran sources and of other sources with which it has been possible to make comparison. The explanation for the similarity between the preface tones of these sources very probably lies in the point made by Wagner with regard to the tones from Rome 2048. His view was that these versions were disseminated over time through the churches using the Roman liturgy with only slight alterations. ${ }^{12}$

Three of the sources mentioned in relation to the order of the prefaces contain very similar tones to the Zamoran ones; these are Lo 23935, Besançon 76, and Ma 931. It may be observed that of these sources, that with the festive tone for the common preface most similar to the Zamoran sources is the only Spanish one of the group, Ma 931. Example 3 shows the two elements from the festive tones for the common preface of each of the three sources and those of the Ritual. Abbreviated forms of the second element consisting

\footnotetext{
${ }^{12}$ Wagner, Einführung, 74.
} 
largely of the ending formula are not included except for one case from Besançon 76 in which the formula is altered. The elements of Ma 931 may be observed to be very like the Zamoran ones with the major difference being in the absence of plicas. The only other divergences are both found in the first sentence beginning "Vere dignum". The first of these divergences is the replacement of the first two-note neume of the mediation with the single note $\mathrm{E}$, as also occurs in the Misal votivo. The second is an additional repetition of the reciting note of element 2 , evidently as a result of the word "equum" being assigned three syllables. A notable variant is observable in Lo 23935 in the non-employment of the scandicus ornamenting the reciting note in element 2 . This scandicus is found in the other sources shown in Example 3 and in Rome 2048. Besançon 76 is remarkable for the

Example 3: Festive tone - common preface
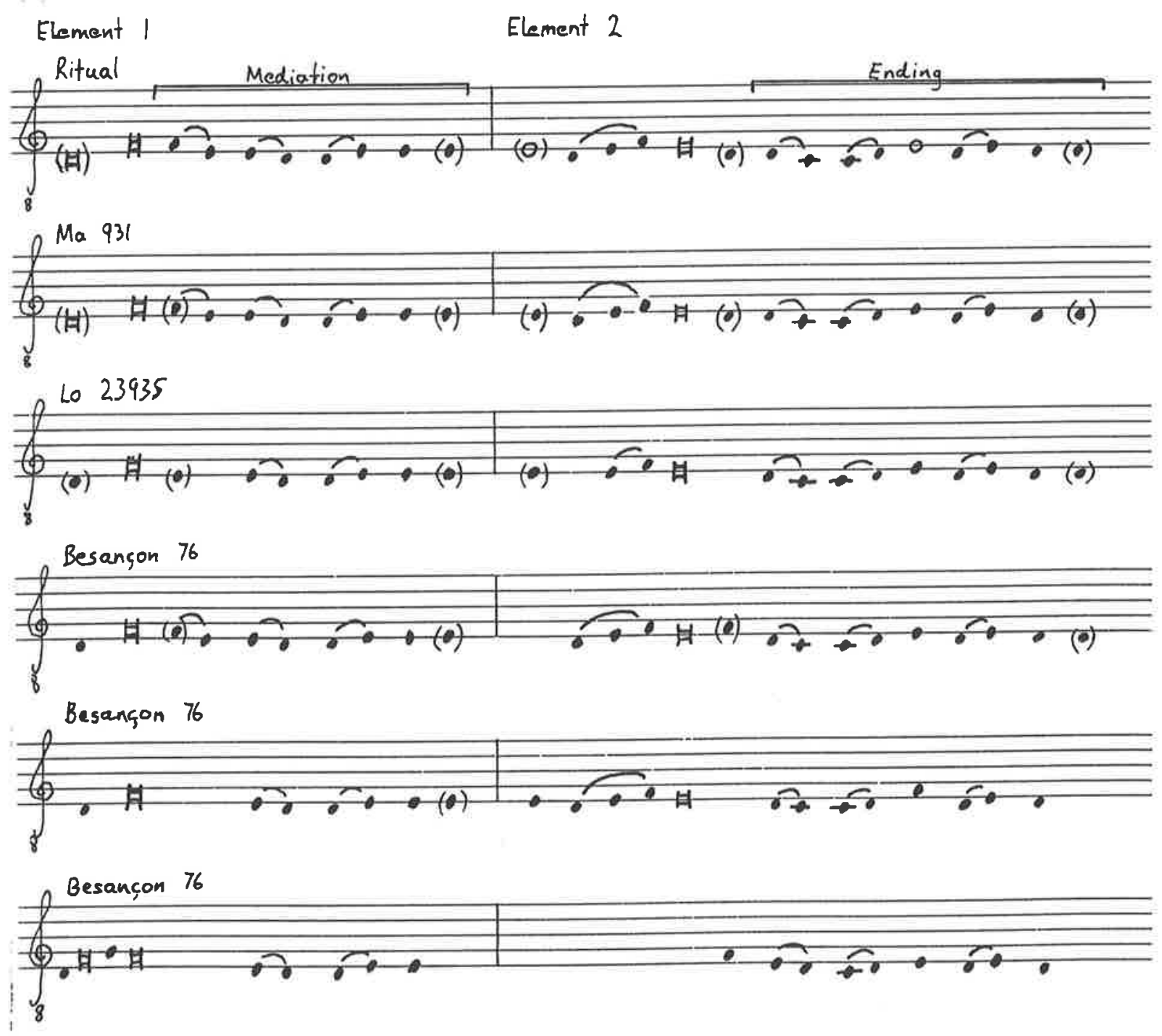
employment of a greater variation within elements but maintains a surprisingly rigid use of the intonation tone $D$ of the first element which in that source always occurs in each appearance of that element and is never repeated as it is in the Ritual and Ma 931. Among the common prefaces of the non-Spanish sources, all but two phrases are formed from equivalent although internally varying elements, the text divisions occurring at the same points.

The Ritual makes invariable use of three two-note neumes in the mediation throughout all prefaces employing the festive tone, a feature the rigidity of which is unusual with regard to the other three sources discussed in the last paragraph. Ma 931 and Besançon 76 use either two or three two-note neumes in the mediation, the first of the group of three being the variable one. In Ma 931 the first two-note neume is at times replaced by a single note $\mathrm{E}$, and in Besançon 76 the same occurs or it is replaced by the reciting note $\mathrm{F}$. Lo 23935 consistently uses only two two-note neumes in its mediations, the note preceding them being either F or E. Comparison of the preface for the Nativity of Christ as presented in the same group of sources reveals that in all three non-Zamoran sources, the alternative mediation in which the first two-note neume is replaced by the single note $\mathrm{E}$, occurs in each in the same positions with regard to text. In the Ritual the mediation always has three two-note neumes. It is not apparent what factors would have determined the choice of placement of the different mediations in the non-Zamoran sources and an explanation for their absence from the Ritual is also not evident. Could it be that the clergy of Zamora or the compilers of the Ritual (or another tradition to which they subscribed) favoured an approach to the prefaces dominated by uniformity thus preferring not to use the different alternative mediation formula? On the other hand, the tradition of variation of the mediation in the festive tone may have been unknown to the compilers of the Ritual, a possibility which seems unlikely in view of other features which the tones of the Ritual share with other sources.

Indication of a possible regional pattern in mediation types is gained from the examination of the prefaces in a further five sources from various parts of Spain as both forms of mediation are present within each source. The earliest of these sources dates from the 14th or 15 th centuries and is located in Santiago de Compostela. The remainder all date 
from the 15 th century, two being printed sources of 1499. The Santiago de Compostela source shows a marked preference for the three binaria mediation with only one or possibly two instances of the two binaria mediation occurring amongst five prefaces. The mediations of the Christmas preface in the same source may consist entirely of three binaria mediations; the one possible exception is located at a damaged part of the manuscript and cannot be substantiated. ${ }^{13}$ Another of the sources shows the consistent employment of three two-note neumes in the mediations of the Christmas preface but has a greater proportion of two two-note neume mediations in other prefaces. ${ }^{14}$ The tentative conclusion can be drawn that the preference for the three binaria mediation seen in the Zamoran Ritual may be part of a regional preference reflected also in the Santiago de Compostela source. This conclusion must, however, be tested further before it can be asserted with confidence.

Extension of the earlier comparisons of the Ritual with non-Spanish sources and $\mathrm{Ma}$ 931 to take in both elements of all the festive preface tones shows that Ma 931 continues to have the most in common with the Ritual. The variations which nevertheless exist between the two sources can be further illustrated from the preface for the feast of the Holy Cross. ${ }^{15}$ There, one phrase has a more extended use of the $\mathrm{D}$ in the intonation of element 1 in $\mathrm{Ma}$ 931 than in the Ritual, and in one instance of element 2 the familiar scandicus is replaced in Ma 931 by a single note in a simpler version of the same element. Again in Ma 931, the mediation formula with two two-note neumes is employed. Only the first appearance of element 1 (beginning "Eterne deus") makes use of the three two-note neumes, the form of mediation used in all examples of that element in the Ritual. (The same prefaces in Lo 23935 and Besançon 76 also employ the two two-note neume mediation in the same places as $\mathrm{Ma}$ 931.)

From the findings of the comparisons one may surmise that the festive preface tones of the Zamoran manuscripts exemplify a regional or local version of the common model as identified by Wagner. However, to establish whether or not this is true would require a

\footnotetext{
${ }^{13}$ Santiago de Compostela, Archivo de la Catedral, frag. 9, fol. $1^{v}$.

${ }^{14}$ Huesca, Archivo de la Catedral, cod. 20 (3). The other three sources looked at are from Jaén, Toledo, and Barcelona.

${ }^{15}$ Ritual, fols. $93^{\mathrm{v}}-94^{\mathrm{r}}$; Ma 931 , fol. $183^{\mathrm{v}}$.
} 
broad comparison using a large number of sources from inside and outside Spain representative of different monastic and secular traditions. In this dissertation comparison is of necessity very limited and the results must therefore be tentative.

The ferial tones of the same group of non-Zamoran sources show a remarkable similarity of element structure to those of Zamora. Occasional differences may be found in placing of elements with regard to text. All are characterized by continual syllabic motion. Most interesting and most varied among the prefaces in the Zamoran sources to use the ferial tone are those of the booklet found with the Ritual.

One point of variation in the ferial settings of the common preface found among the Zamoran sources and those used for comparison may be remarked upon. The two Zamoran sources, the Ritual and the Misal votivo, as well as Ma 931 have in common the treatment of two sentences in a manner unlike the non-Spanish Lo 23935 (the common preface with the ferial tone is not found in the booklet nor in Besançon 76). Lo 23935 maintains the reciting note where the other sources introduce the mediation formula. As the same choice and placing of elements occurs for these sentences in the festive versions of the Zamoran sources and Ma 931, it might be proposed that this is a characteristic of Spanish usage. This view, however, is complicated by the observation that the Santiago de Compostela source mentioned earlier treats the first of the sentences in the ferial tone in the same manner as Lo 23935. Considerable further comparison would be needed to clarify this point of variation amongst preface tones. Example 4a gives the ferial setting of the first of these sentences in the two Zamoran sources and Ma 931. Example 4b gives the corresponding setting of Lo 23935.

Example 4a: Ritual, fol. 77r; Misal votivo, fol. $3^{\mathrm{v}}$; Ma 931 fol. $171^{\mathrm{v}}$

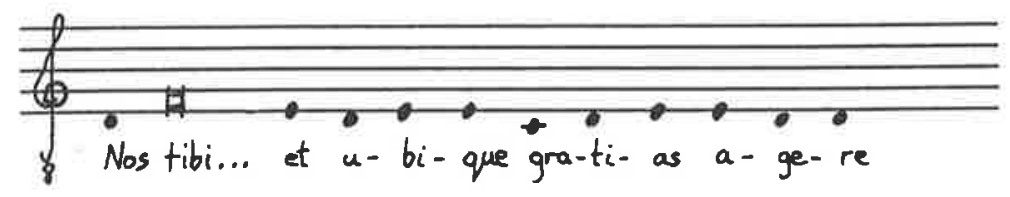


Example 4b: Lo 23935, fol. 497"

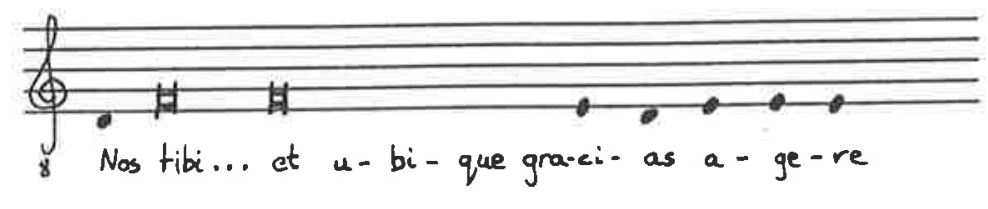

The booklet contains prefaces for the feasts of Christmas, Epiphany, Resurrection, the Virgin Mary, and the Apostles, with only the first and last being complete due to the loss of one or more bifolios. The use of versions of the ferial tone combined with proper texts and the appearance of the term "simplex" in the rubrics suggests that these may have been intended for use during the octaves of the feasts specified. ${ }^{16}$ As the notation of the booklet is late Aquitanian written on a one-line staff, without a clef or other indication of pitch, it has been assumed that the pitch is that of the preface tones in the other Zamoran sources and Ma 931. The pitch of the line is therefore read as D. Three different approaches to the ornamentation of the reciting note in the second element are found, none of which occur in the ferial preface tones of the Ritual. Comparison of the preface for the Resurrection given by Wagner from Rome 2048 with that of the booklet shows that in both versions an identical variation of element 2 is found with the same text phrase. Different, however, is the choice of element for the opening phrase. ${ }^{17}$ (The same element is used in the Resurrection preface of both the Ritual and the booklet in this position.) Further research into non-Spanish and Spanish sources is needed to reveal the frequency and manner of employment of variations in the second element of ferial preface tones.

Comparison of the preface texts of the Zamoran sources with Ma 931 and Lo 23935 reveals variants with all in such a way that no conclusive result may be drawn and thus no further light can be thrown on the comparisons already made with regard to the tones. The common preface text of the Ritual and the Misal votivo is identical with that of Ma 931 and Lo 23935. Two significant points of variation among the proper texts involve a noun (Epiphany preface) and a final sentence (Mary). In the first of these, the Ritual and booklet

\footnotetext{
${ }^{16}$ For this suggestion I am indebted to the liturgical scholar, Father Kieran Adams, of the Dominican Fathers in Prospect, South Australia.

${ }^{17}$ Wagner, Einführung, 74-75.
} 
share one version while Ma 931 and Lo 23935 share another version. In the second, different pairs share versions: the Ritual and Lo 23935, Ma 931 and the booklet. It is impossible to conclude that either the Ritual or the booklet is in a closer relationship with any one or other of the sources.

During the preceding discussion of the tones reference has been made to the employment of plicas. The Ritual is outstanding in the use of this note form, firstly with respect to the greater frequency of its occurrence in comparison to the other sources studied and secondly in the pronounced concurrence of the note form with accented syllables especially in those sections outside the formulas and in association with the reciting note $F$. The use of plicas in the Ritual has already been discussed in detail in Chapter 5. If the performance of these signs as notes of double duration as proposed there is applied to the Ritual prefaces, the resulting musical accentuation will coincide with the normal Latin word accent of words sung to the reciting note. The booklet is notable for concurrence of cephalici with accented syllables and, as was also discussed in Chapter 5, the cephalici of this source should probably be sung as notes of double duration. The placing of cephalici and plicas on the reciting notes in the booklet and the Ritual often occurs on the same words. The durational differentiation observed in these prefaces is in keeping with the advice of two 16th-century Spanish theorists referred to in Chapter 3, Ferrer and Bermudo. Ferrer advocated the preservation of word accent in the prefaces and Bermudo advocated the same for psalmody.

Respect for word accent is not limited to reciting note passages but is also evident in the formulas. All the formulas are tonic and therefore are placed according to the final accented syllable of a phrase. Thus, when the final word is a proparoxytone, the closure of the formula becomes dactylic through the repetition of the last pitch. In Examples 1 and 2 the placing of the final accents in the formulas is marked with the letter " $\mathrm{A}$ ". The use of tonic closures in the prefaces appears to be characteristic of the genre generally in both festive and ferial tones. ${ }^{18}$ Another means by which accent is stressed in the Ritual is

\footnotetext{
${ }^{18}$ This may be observed in all the sources mentioned in this chapter, and in the ferial and solemn tones given by Stałblein, "Präfation", 1535-1536.
} 
observable in the use of the intonation of element 1 . The intonation always moves from $D$ to $F$ in such a way that the second note of the interval of the third always falls on either an accented syllable of a word with more than one syllable or on a single syllable word.

Brief mention of the musical settings of the dialogue which immediately precedes the preface should be made before proceeding to the next section. The preface tone is not used for the dialogue although some material is generally found in both, as may be observed for example in Wagner's example from Rome 2048. ${ }^{19}$ Immediately noticeable is the scandicus which occurs in element 2 of the festive preface tone in that and other sources. Comparison of the festive versions of the dialogues of the common text in the Zamoran sources reveals a marked difference in the settings of the words "Gratias agamus domino". ${ }^{20}$ The setting of the Misal votivo brings the mediation formula with three two-note neumes characteristic of the preface tone into the dialogue for the first two of these words instead of the partial form of the ending formula which occurs in the Ritual. As this is immediately followed by element 2 of the preface tone including the ornamenting scandicus (not found at the same place in the Ritual), the link with the preface is made very strong. That such a marked difference should occur between the two Zamoran sources is all the more notable for the fact that other divergences are minor throughout the dialogue and the preface and mostly concern the absence of plicas from the Misal votivo. The version of the Ritual appears to be the more usual as it resembles more closely that in Ma 931, Lo 23935, and Besançon 76.

\section{PATER NOSTER}

The tones of the Pater noster for inclusion in the Mass following the canon are found, like the settings of the prefaces, in the Ritual and the first part of the Misal votivo, both from the 15th century. (The booklet contains only prefaces.) The text of the prayer in both sources is the standard one, the Pater noster belonging to the Ordinary of Mass.

\footnotetext{
${ }^{19}$ Wagner, Einfïhrung, 74.

${ }^{20}$ Ritual, fol. 74; Misal votivo, fol. 2 .
} 
Studies of the musical settings of the Pater noster are greatly assisted by the work of Wagner and Stäblein and especially that of the latter presented in $M G G .^{21}$ Stäblein was able to group tones and identify developments and different versions; furthermore, some of the sources which he used are Spanish. In addition to the principal tones, he pointed to two special ones, one of which he identified as a Spanish-French tone. ${ }^{22}$ The following discussion of the Pater noster tones in the Zamoran sources takes its starting point from Stäblein.

\section{The Tones}

Two tones for the Pater noster are given in both the Ritual and the Misal votivo, one for festive use and the other for ferial use. ${ }^{23}$ Differences between the two sources are small. The Pater noster is preceded by an introduction "Per omnia secula ...", the setting of which varies from that of the Pater noster itself until the part beginning "et divina institutione" in the ferial tone and "Preceptis salutaribus" in the festive. As with the prefaces, the main part of the Pater noster is set to tones which divide into two elements, the first closing with a mediation formula and the second with an ending formula. The final section of the festive tone from "Et ne nos inducas" deviates from the preceding pattern, as does the final section of the ferial tone although the alteration begins earlier with "debitoribus nostris". Such a structure is not unusual for Pater noster tones. ${ }^{24}$ Example 5 gives the festive tone from the Ritual. Brackets mark those notes not used in all repetitions of each element. One further abbreviation of element 2 which begins with the ending formula is not included. Example 6 gives the two elements of the ferial tone from the Ritual as they occur at the beginning of the prayer set to the text: "Pater noster qui es in celis sanctificetur nomen tuum". One variation of the second element marked " $2 a$ " is given in order to show the alteration of the ending formula to accommodate a proparoxytone at

\footnotetext{
${ }^{21}$ Wagner, Einführung, 58-69; Stäblein, "Pater noster".

${ }^{22}$ Stäblein, "Pater noster", 950.

${ }^{23}$ Ritual, fols. $85^{\mathrm{v}}-88^{\mathrm{v}}$; Misal votivo, fols. $7^{\mathrm{x}}-8^{\mathrm{v}}$.

${ }^{24}$ Johannes de Grocheo in De musica referred to the structure of the Pater noster, identifying the beginning of a second section at "Panem nostrum" and the ending of the same section at "Et ne nos". See Johannes de Grocheo, Concerning Music (De Musica), trans. Albert Seay, (Colorado Springs: Colorado College Music Press, 1974), 42. The Zamoran versions may be viewed in the same way.
} 
the closure. Although the mediation and the reciting note pitches are not altered, there is in fact a remarkable degree of variation in the occurrences of each element in the ferial tone.

Example 5: Pater noster festive tone, Ritual, fols. $86^{\mathrm{N}}-87^{\mathrm{r}}$

Element 1

Element 2

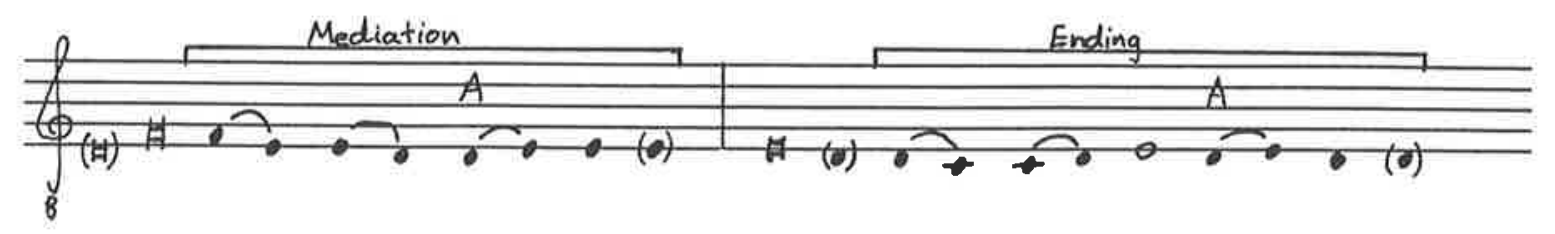

Example 6: Pater noster ferial tone, Ritual, fols. $87^{\mathrm{v}}-88^{\mathrm{v}}$

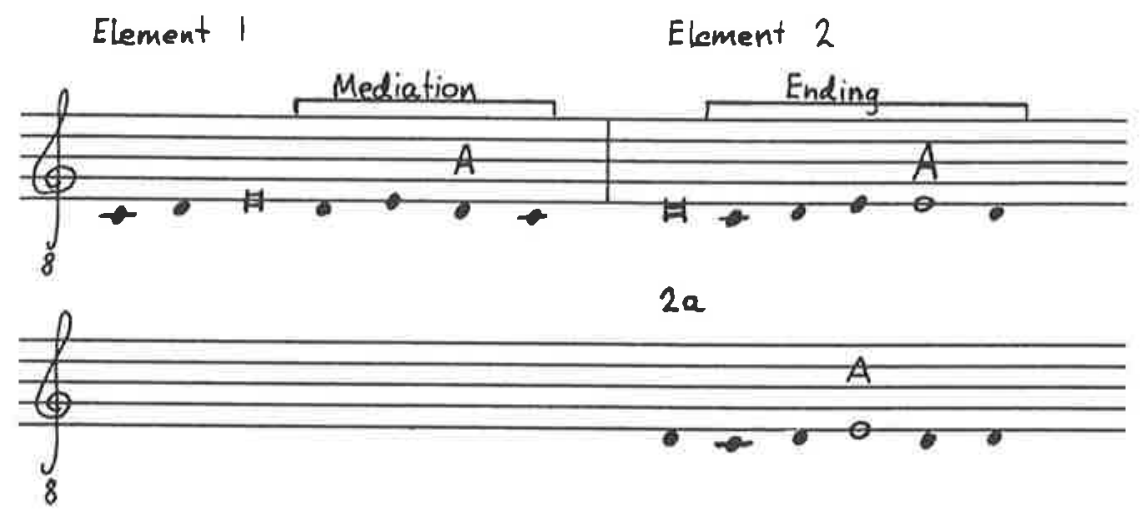

The concurrence in the Ritual prefaces of the plica with accented syllables outside the mediation and ending formulas is observable in the Pater noster festive tone of the Ritual; the sign is not employed on the reciting notes of the ferial tone. The response to a final proparoxytone (Example 6, 2a) as opposed to a paroxytone in the closure of the ferial ending formula is surprising in its deletion of the repeated E. As occurs in both tones of the prefaces, the closure of the ending formula of the festive tone simply adds a second D at the end without removing another note from the formula. While the mediation formula of the festive tone is also adapted in the latter manner to a final proparoxytone, all mediations in the ferial version close with paroxytones as a result of the differing element distribution.

Although the ferial settings in the two Zamoran sources are not identical, they are both versions of the tone for festive use found in the earliest Roman liturgical sources such 
as the 11 th-century sacramentary, Monte Cassino 339 , cited by Wagner and Stäblein. ${ }^{25}$ This tone came to be used widely not only for solemn occasions but in a simplified form for ferial use. It was spread by the Franciscans and Dominicans and became part of the standard usage of the Roman rite. ${ }^{26}$ It will be referred to in the following discussion as tone $A{ }^{27}$ Not surprisingly many small variants occur between the versions of the tone. The major difference between the examples of tone A given by Wagner and Stäblein and that of the Zamoran sources is the pitch which is a fifth lower in the latter sources and uses the reciting notes of $E$ and $D$ instead of $b$ and $a$. The division into elements 1 and 2 takes place at the same points in the Zamoran and non-Zamoran examples with only one exception. The mediation and ending formulas of the two elements follow the usual patterns of tone A as given by Wagner and Stäblein (small variations are found among their examples). Intonations and ornamentations of the reciting notes vary also in all these sources. The concluding sections are similarly variable although conforming to an overall pattern. There is no local characteristic observable in the two Zamoran versions of the ferial tone.

The festive Pater noster of the Zamoran sources uses the tone employed for the festive prefaces of the same sources. This tone will be referred to here as tone B. The ferial and festive preface tones are in fact both versions of tone B. Stäblein noted the use of this tone for the Pater noster, although without relating it to the prefaces. This is the tone referred to in the introduction to this section as being described by Stäblein as SpanishFrench. $^{28}$ He found it used for ferial masses in two Spanish sources, Tol 35.11 and Ma 931, as opposed to the festive usage of Zamora. In his musical example 9, Stäblein gives versions of the tone (tone B) from Tol 35.11 and $\mathrm{Ma} \mathrm{V}^{\mathrm{a}} 19-7 .^{29}$ The first of Stäblein's examples is almost identical with the version of tone $B$ for the ferial preface given in Example 2 above, while the second is close to the version for the festive preface seen in Examples 1 and 3 above. As may be expected, tone B when used in the festive Pater four).

${ }^{25}$ Wagner, Einführung, 62; Stăblein, "Pater noster", 945-46, musical example 2 (upper group of

${ }^{26}$ Stăblein, "Pater noster", 946-47; Ruth Steiner, "Lord's Prayer", NG 11: 229.

${ }^{27}$ The terms "tone A" and later "tone B" are introduced by the writer to identify the two (related) families of tones and have no further significance.

${ }^{28}$ Stăblein, "Pater noster", 949.

${ }^{29}$ Stăblein, "Pater noster", 949. 
noster in the two Zamoran sources makes use of the characteristic three two-note neumes in the mediation as found in the corresponding prefaces of the same sources. Only one difference exists between the Zamoran festive Pater noster as found in the Ritual and that in the Misal votivo. This difference occurs in one instance of the ending formula in which the first two-note neume (a clivis) is replaced by a three-note neume (a climacus) in the Misal votivo. ${ }^{30}$ Unlike the preface settings, no ornamentation of the reciting note is employed in the second element.

Two major differences between tones A and B for the Pater noster of the Zamoran sources are: firstly, the reciting notes of $F$ and $E$ in tone $B$ and $E$ and D in tone $A$; and secondly, the choice of element in two sections (for example, "Adveniat ... tuum" uses element 1 in the tone A setting and element 2 in the tone B setting). ${ }^{31}$ It is notable that the ending formulas of both tones are constructed on the same basis despite the different reciting notes; the festive ending is an ornamented rendering of the ferial. The ending formulas of both tones therefore belong to the same tradition. As in the ferial preface tone of the Zamoran sources, the final accented syllable of the text of element 2 in the ferial Pater noster is always set to the note E. In the Ritual, again as occurs in the ferial preface of the source, this note is invariably given a plica and is therefore a note of long duration.

The two non-Spanish sources used for comparison with the prefaces reveal a picture of greater divergence from the Zamoran sources when the Pater noster settings are compared than was the case with the prefaces. Lo 23935 presents Pater noster tone A for both ferial and festive versions with the reciting notes of $\mathrm{E}$ and $\mathrm{D} \cdot{ }^{32}$ Besançon 76 includes only one setting, which is in the festive style of tone A but uses F and D reciting notes. The third source used for comparison with the prefaces, the Spanish Ma 931, was included by Stäblein in his study and has already been referred to briefly. It makes use of the same tones as do the Zamoran sources but reverses their application. The ferial tone of Zamora (tone A) appears in the festive context in Ma 931 with a more ornamented ending formula;

\footnotetext{
${ }^{30}$ Misal votivo, fol. $7^{\mathrm{v}}$.

${ }^{31}$ These differences correspond to those between the Spanish-French setting and the usual tradition cited by Stäblein, "Pater noster", 949.

${ }^{32}$ Lo 23935 , fol. 498.
} 
the first element is the same in both sources. The festive tone of Zamora (tone B) uses more ornamentation in the form of two-note neumes in its ferial context of $\mathrm{Ma} 931 .^{33} \mathrm{~A}$ further complication emerges from a study of a 1572 printed Missale romanum of Jaén Cathedral which, although modelled on the missal of Pius V, introduces Spanish variants. ${ }^{34}$ In it there are four versions of the Pater noster. ${ }^{35}$ The first of these, the most solemn, and the fourth, the ferial setting, use tone B in ornamented and simple forms respectively. The mediation formulas of the first use both the form with three two-note neumes, and that in which the first two-note neume is replaced by the single note E. For use in the feasts in between these two extremes are the second and third versions, both of which use tone $A$, the second with an ending employing two-note neumes and the third with a syllabic ending formula. Brief examination of a further three Spanish sources of the 15 th century from Huesca, Barcelona, and Toledo shows different employment of the two tones in each. One, that of Toledo dating from 1499, is similar to the Jaén missal just discussed in employing tone B for the most solemn tone and for the ferial tone. The other two sources employ tone A for the festive or solemn tone.

In this chapter it has been possible to identify a number of topics which might profitably be investigated during further research into preface and Pater noster tones. These include such features as the employment of notes indicating long duration on accented syllables of reciting note passages, mediation formulas in festive preface tones, and the so-called "Spanish-French" tone of the Pater noster and its relation to preface tones.

The findings of this chapter show that the Zamoran preface and Pater noster tones in general follow well known traditions. Certain aspects, however, have been found to be unique in the Ritual and suggest the possibility of a local tradition. The two unique aspects of the preface and Pater noster tones of the Ritual are: firstly, the use of plicas with regard

\footnotetext{
${ }^{33}$ Ma 931, fols. $186^{\mathrm{r}}-187^{\mathrm{r}}$.

${ }^{34} \mathrm{I}$ am indebted to Dr. Robert J. Snow for his discussions with me concerning this source.

${ }^{35} \mathrm{Jaén}$, Catedral, Missale romanum (1572), pp. 310-15.
} 
to their frequency and association with accented syllables; and secondly, the uniformity of the mediation formula in festive tones. Another feature which may be indicative of a local or regional tradition is the ordering of the texts of the prefaces.

The use of the "Spanish-French" tone (tone B) for the Pater noster also needs further investigation to clarify the contexts of its usage, and its pairing with the traditional tone $\mathrm{A}$. Further research in Spanish and French sources of the 15th and 16th century would probably produce a fascinating and complex picture of the Pater noster tones which might assist in understanding connections between different centres and traditions. 


\section{POLYPHONY}

Although the medieval Zamoran sources contain very little polyphony, that which does occur is of considerable interest not only musically but for the evidence it gives of the existence of a more widespread polyphonic performance tradition in Spain than is usually considered. Outside of Catalonia, the location of the major Spanish sources of polyphony in a few important centres tends to suggest the view that polyphony was concentrated in these places, notably Santiago de Compostela, Toledo, and Las Huelgas (Burgos). ${ }^{1}$ While not controverting this view, the polyphonic material to be discussed here, at least some of which is undoubtedly closely connected with the region of Zamora, suggests that although probably not comprising a major centre of polyphonic performance, the region should be seen as another place in which polyphony was known and practised during the Middle Ages. The significance of the region during the Middle Ages makes such a supposition not surprising and raises the likelihood of its presence in other centres such as León. As the materials of Spanish archives are increasingly studied, it is to be expected that polyphonic sources will continue to be discovered in more diverse places.

Three sources related to the region of Zamora, all from the 13th and 14th centuries, contain polyphony. The first two sources have been recently found to contain polyphony by the present writer and thus are new additions to the corpus of polyphonic sources from Spain. The three sources are Z 184, the Misal votivo, and Mont 1042 no. 25. The third source consists of a bifolio from which a large section has been cut and is included in the catalogue of the manuscripts of the library of the monastery of Montserrat, as well as Fernández de la Cuesta's catalogue of medieval sources in Spain. ${ }^{2}$ Mont 1042 no. 25 is thought to have come from a polyphonic proser of the 13 th or 14 th century. The connection

'The problem of whether these places may legitimately be called "centres" of polyphonic music is discussed by Max Lütolf, "Fünf Punkte zur Mehrstimmigkeit in Spanien vor 1320/1330", in Symposium Alfonso X el Sabio y la música (Madrid: Sociedad Española de Musicología, 1987), 62-63. Medieval polyphony in Spain has been studied by a number of other authors including Gordon A. Anderson, Higini Anglès, María Carmen Gómez Muntané, and José López-Calo. Work by most of these writers is referred to in this chapter. In particular, the manuscript Hu has received considerable attention, although a number of issues remain to be studied with regard to it.

${ }^{2}$ Alexandre Olivar, Els manuscrits litúrgics de la Biblioteca de Montserrat, Scripta et Documenta, vol. 18 (Monestir de Montserrat, 1969), 124-5; Fernández de la Cuesta, Manuscritos, 146. 
of the source to the region of Zamora derives from its use as folio reinforcing material in a 15th-century Dominican antiphoner Mont 759. The presence of a document attached to the inside cover of the manuscript suggests that the antiphoner may have belonged to a Dominican convent in Toro to which the document relates (the convent is described as Santa María de los Caballeros). ${ }^{3}$ The square notation of Mont 1042 no. 25 shows traces of Aquitanian style especially in the use of a diamond for the upper note of a clivis 1 and is written on red five-line staffs in score notation. Unfortunately the mutilation caused to the fragment largely by the removal of the large section already referred to, makes more detailed study very difficult and none of the works have yet been identified. Its overall appearance bears no relation to any of the other Zamoran sources seen by this writer. This source will not be discussed further here.

The polyphony of Z 184 and the Misal votivo will be discussed in detail below and transcriptions given. Plates showing the two sides of $\mathrm{Z} 184$ are included later in this chapter. Transcription of parts of the verso of $\mathrm{Z} 184$ was possible only with the aid of special lighting. Plates of the polyphony of the Misal votivo are found in the appended article. The works are all for use in the Mass, and it is notable that all are in discant style as opposed to the melismatic organum characteristic of the sources related to the Notre Dame school known in Castilla. Each work is listed in Table 1 below.

Table 1: Polyphony in the Sources of Zamora

Incipit

1. Gloria. Spiritus et alme

2. Benedicta. Virgo dei genitrix

3. Alleluya. [Que est ista tam formosa]

4. Conlaudemus omnes pie

5. Deo nos agentes $\underline{\text { Source }}$

Z $184^{r}$

Z 184

$\mathrm{Z} 184^{\mathrm{v}}$

Misal votivo, fol. 49

Misal votivo, fol. $53^{\text {r }}$

\section{Date}

13th c.

13th c.

13 th c.

14th c.

14th c.

3“"Crònica del Santuari”, Analecta Montserratensia 2 (1918): 406; Olivar, Els manuscrits, 55. Mont 759 has been discussed in Chapter 4 of this dissertation. 


\section{Z 184}

This fragment is of particular significance as a previously unknown source of liturgical polyphony related to the very important polyphonic manuscript of Las Huelgas $(\mathrm{Hu})$ from c. $1300 .{ }^{4}$ The fragment contains sections of three works all of which are represented in the first part of Hu although not in identical versions. The three fragmentary works are in order of appearance the troped Gloria, Gloria. Spiritus et alme, the gradual and verse Benedicta. Virgo dei genitrix, and an alleluia, the verse of which is missing. Despite the fact that none of the works are complete, this fragment makes available some interesting new information relevant to the study of medieval polyphony in Spain, and suggests a few new possibilities in the development of a more complete view of the tradition which is principally represented by $\mathrm{Hu}$.

The fragment is likely to date from the mid 13 th century or later but is probably earlier than the Las Huelgas manuscript. ${ }^{5}$ Where it was copied is impossible to know, although the likenesses to Hu suggest some place connected with that monastery. Its use as part of the binding material of a protocol book from Toro brings the supposition that it may have come from a manuscript used in that town, perhaps in the Colegiata de Santa María.

The fragment has been cut from a single folio which must have been about $380 \mathrm{~mm}$ high if not greater. ${ }^{6}$ The large size is surprising in view of the smaller $\mathrm{Hu}$ and the usually small size of polyphonic manuscripts of the period such as those of the Notre Dame school. ${ }^{7}$ The polyphony is set out in score notation on red five-line staffs and written in apparently Franconian-like mensural notation similar to that of $\mathrm{Hu}$. On the recto side are seven red five-line staffs, while the verso has six. It is likely that the uncut folio would have contained nine staffs on the recto and eight on the verso, the lost staffs having been above those remaining. The variance between the staff numbers of the two sides seems to be explained by the requirement of an extra single staff for a section of monophonic chant 656.

${ }^{4}$ Dating by Luther Dittmer cited in Ernest H. Sanders, "Sources, MS, §V. Early motet”, NG 17:

SFor advice on the dating of $\mathrm{Z} 184$, I am grateful to Florián Ferrero Ferrero, director of AHPZa, and Dr. Wesley D. Jordan.

${ }^{6}$ Further description of the fragment is given in Appendix 1.

${ }^{7}$ The height of Hu is $26 \mathrm{~cm}$ (Fernández de la Cuesta, Mansucritos, 106). 
on the recto, while on the verso all staffs are required for two-voice polyphony. The recto staffs must have been divided into two systems of three staffs and one system of two staffs with the ninth staff on the bottom of the page for monophony. The monophonic chant was also placed on the staffs employed for the short polyphonic trope segments. The diagram below shows the layout of the text on the recto side of the fragment with the trope segments beginning with large initials and the gradual commencing with "Enedicta" from which the large initial "B" has been lost. The vertical lines represent long red lines found on the fragment separating polyphony from monophony.

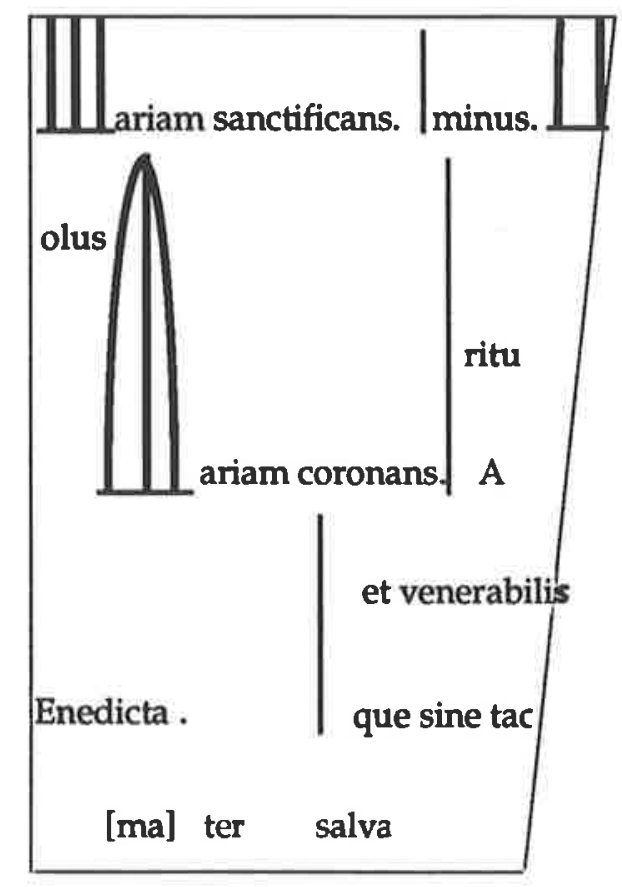

The first two works (the Gloria trope and the gradual and verse) use well known texts and are for Marian usage; both are found in sources outside Spain in monophonic and polyphonic settings. They occur consecutively and in the same order as monophonic settings in some chant sources from eastern Spain: Barc 1 (fols. $1^{\mathrm{r}}-2$ ); Madrid, Biblioteca Nacional M. 4404 (fols. 58r-62'); Gerona, Museo Diocesano Ms. 4 (fols. 168-70); and Mont 820 (fols. $88^{v}-90^{v}$ ). The datings of these sources range from c. 1300 (Barc 1) to probably the 16th century (Mont 820). ${ }^{8}$ The gradual and the verse are found in Marian Masses of the Ritual of Zamora ${ }^{9}$ but the troped Gloria is not.

${ }^{8}$ Fernández de la Cuesta, Manuscritos, 77, 96, and 143. For Barc 1 see Gilbert Reaney, ed., Manuscripts of Polyphonic Music. 11th - Early 14th Century, RISM BIV ${ }^{1}$ (Munich-Duisburg: G. Henle Verlag, 1966), 207-9, and for Mont 820 see Olivar, Els manuscrits, 89-90.

'For example, fol. $111^{\text {. }}$. 
Gloria. Spiritus et alme and Benedicta. Virgo dei genitrix also occur consecutively in $\mathrm{Hu}$, this being the only polyphonic source known until the finding of $\mathrm{Z} 184$ in which they are placed together. The alleluia may be tentatively identified as Alleluya. Que est ista tam formosa which is unknown outside Spain. In that country it is found only in one chant source again from eastern Spain, Tortosa $135,{ }^{10}$ and one polyphonic source, $\mathrm{Hu}$. In $\mathrm{Hu}$ this alleluia is separated from the Benedicta. Virgo dei genitrix by one work, another alleluia. The similarity of the ordering of the works between $\mathrm{Z} 184$ and Hu immediately suggests a connection between the two sources. The polyphonic concordances of the three works are listed in Table 2.

\section{Table 2: Polyphonic Concordances}

\section{Gloria. Spiritus et alme}

Three voices: $\mathrm{Hu}$, fols. $4^{\mathrm{v}}-5^{\mathrm{v} 11}$

Three voices: Burgos, Archivo de la Catedral, Ms. 61/2

Two voices: Ma 20324, fol. ccxxii.c ${ }^{\mathrm{v13}}$

\section{Benedicta. Virgo dei genitrix}

Two voices: $\mathrm{Hu}$, fols. $5^{\mathrm{v}}-6^{\mathrm{rl}}$

Two-voice motet Virgo virginum: Hu, fols. $109^{\mathrm{v}}-110^{\mathrm{r} 15}$

\section{Alleluya. Que est ista tam formosa}

Two voices: $\mathrm{Hu}$, fol. $7^{\text {rl6 }}$

${ }^{10}$ Karlheinz Schlager, Alleluia-Melodien II ab 1100, Monumenta Monodica Medii Aevi, vol. 8 (Kassel: Bărenreiter, 1987), 409, 755.

${ }^{11}$ Facsimile: Anglès, Huelgas 2: $4^{\mathrm{v}}-5^{\mathrm{v}}$. Transcriptions: Anglès, Huelgas 3: 11-12; Anderson, Huelgas 1: 10-11; Lütolf, Die mehrstimmigen 2: 85-86

${ }^{12}$ Facsimiles: Anglès, Huelgas 1: 89; Lütolf, Die Mehrstimmigen 1: plate 4. Transcriptions: Lütolf, Die Mehrstimmigen 2: 69-70; Andrés Araiz, Historia, 46-48.

${ }^{13}$ Transcription: Lütolf, Mehrstimmigen 2: 77.

${ }^{14}$ Facsimile: Anglès, Huelgas 2, fols. 5 ${ }^{\mathrm{N}}-\mathrm{6}^{\mathrm{r}}$. Transcriptions: Anglès, Huelgas 3: 13-14; Anderson, Huelgas 1: 47-48.

${ }^{15}$ Facsimile: Anglès, Huelgas 2, fols. 109"-110. Transcriptions: Anglès, Huelgas 3: 211-12; Anderson, Huelgas 2: 59.

${ }^{16}$ Facsimile: Anglès, Huelgas 2, fol. 7. Transcriptions: Anglès, Huelgas 3: 16; Anderson, Huelgas 1: 52 . 
The practice, seen for example in Notre Dame polyphony, of setting those sections of a chant normally sung by a soloist in polyphony and retaining the monophonic chant for those normally given to the chorus is reflected in $\mathrm{Z} 184$, at least as far as can be seen given the fragmentary nature of the source. Thus, of the gradual, only the first word of the respond, Benedicta, is set polyphonically with the immediately following text and the remainder of what can be seen of the section being monophonic, while all that remains in the fragment of the verse is polyphonic. ${ }^{17}$ Similarly, the polyphonic opening of the alleluia is in keeping with the responsorial practices which gave the opening to the soloist. ${ }^{18}$ The inclusion in the fragment of the chant melodies sung between the polyphonic sections of the texts is a feature little shared with Hu. There, in the three pieces under consideration, the monophonic settings are given only for the beginning of the Gloria text and its ending from "Ihesu xpiste". The appearance of parts of the chants in the Zamoran fragment may be of assistance in determining monophonic interpolations for performance of the $\mathrm{Hu}$ works. It is notable that the chant version given by Gordon A. Anderson with his transcription of the gradual and verse are different from those found in $\mathrm{Z} 184$.

The notation is similar to that of the older sections of $\mathrm{Hu}$ and like the notation of that source appears to be mensural. It is able to be interpreted according to Franconian rules with only occasional deviations, a few of which might be resolvable from context if more of the fragment were extant. Table 3 shows ligatures occurring at points in the two sources which are melodically the same. These show sometimes different, sometimes the same ligatures being used. The number 3 ligatures of the table occur in these forms in their respective sources on three occasions suggesting a real difference in scribal technique. Other ligatures also occur in Z 184 that are not listed for it in Table 3.

${ }^{17}$ This then follows the practice which had been introduced by at least the 12th century of beginning the respond of the gradual with the soloist and then changing to the chorus, the soloist then taking over in the verse. (Apel, Gregorian Chant, 196-97.)

${ }^{18}$ Apel, Gregorian Chant, 197. 
$\underline{\text { Table } 3}$

Z 184

1.

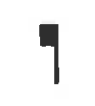

2.

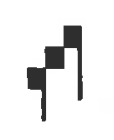

3.

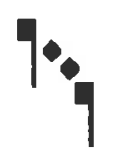

4.

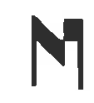

5.

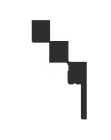

6.

$$
\text { Y }
$$

7.

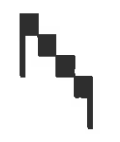

$\mathrm{Hu}$
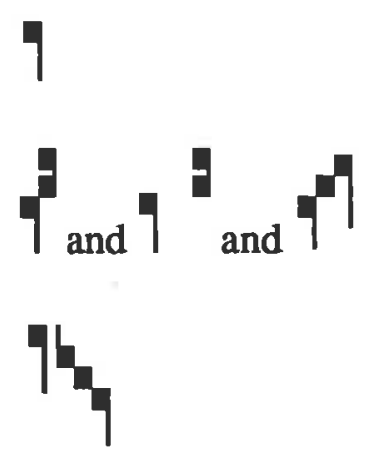

N

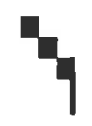

4

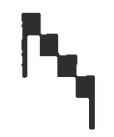

It may be kept in mind that despite the mensural appearance of the notation, a mensural reading of the source may not have been originally expected. Until a new method is found, however, perhaps as a result of more discoveries, the Franconian influenced transcription seems to remain a useful solution to the problem. Difficulties for the modern transcriber may arise from a medieval attitude to notation described by Wulf Arlt as "pragmatic" and "empirical"19 which may have allowed a notator considerable latitude in the use of signs. The same idea is useful also as a possible explanation for the presence of a variety of ligatures which seem to have the same meaning, ${ }^{20}$ a practice found in this fragment and to a great extent in $\mathrm{Hu}$.

${ }^{19}$ Wulf Arlt, "À propos de notations pragmatiques: le cas du codex Las Huelgas", Revista de Musicologla 13 (1990): 401-19.

${ }^{20}$ Arlt, “À propos”, 411, gives examples of such. 


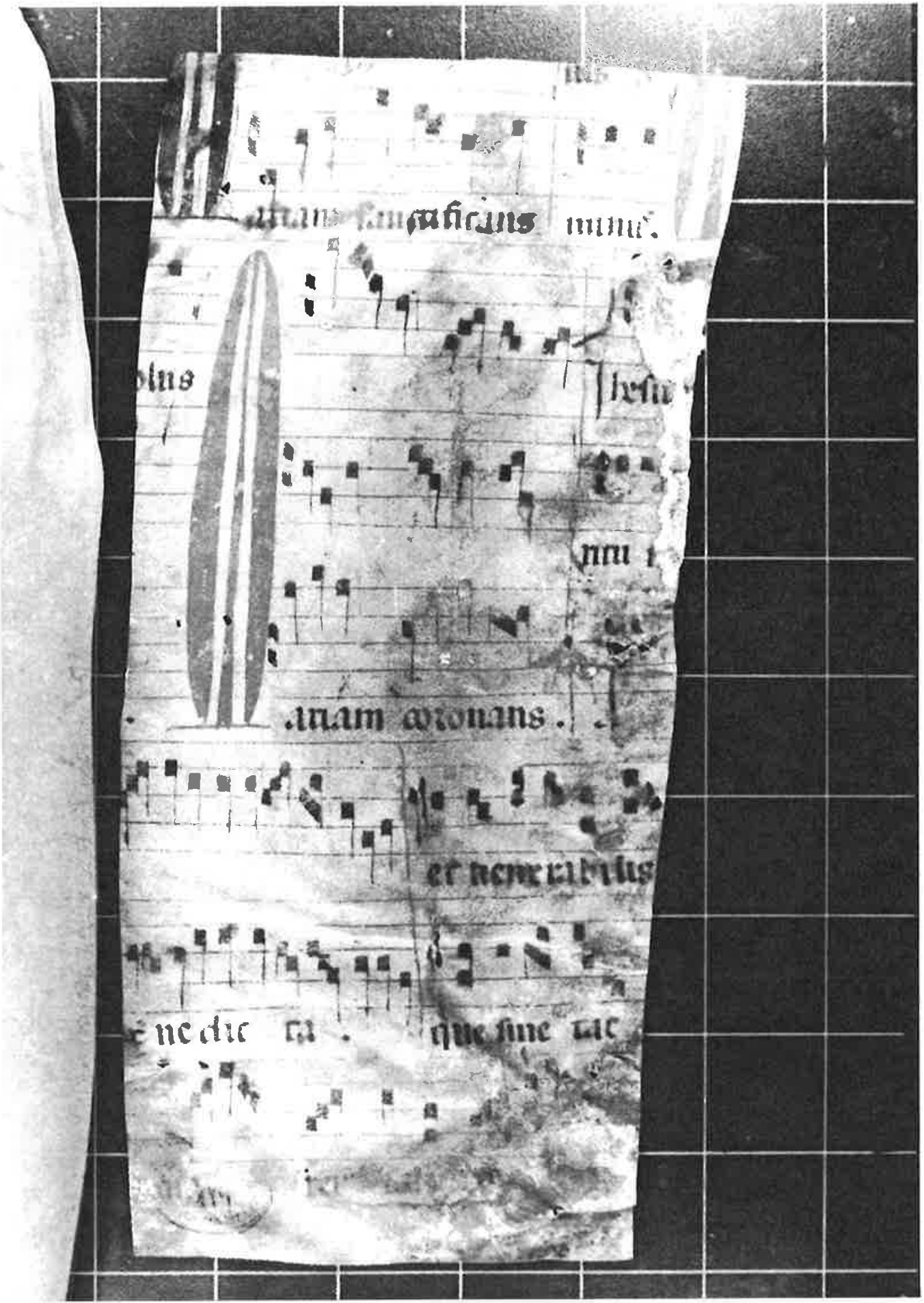

Plate 2: $\mathrm{Z} 184^{\mathrm{r}}$ 


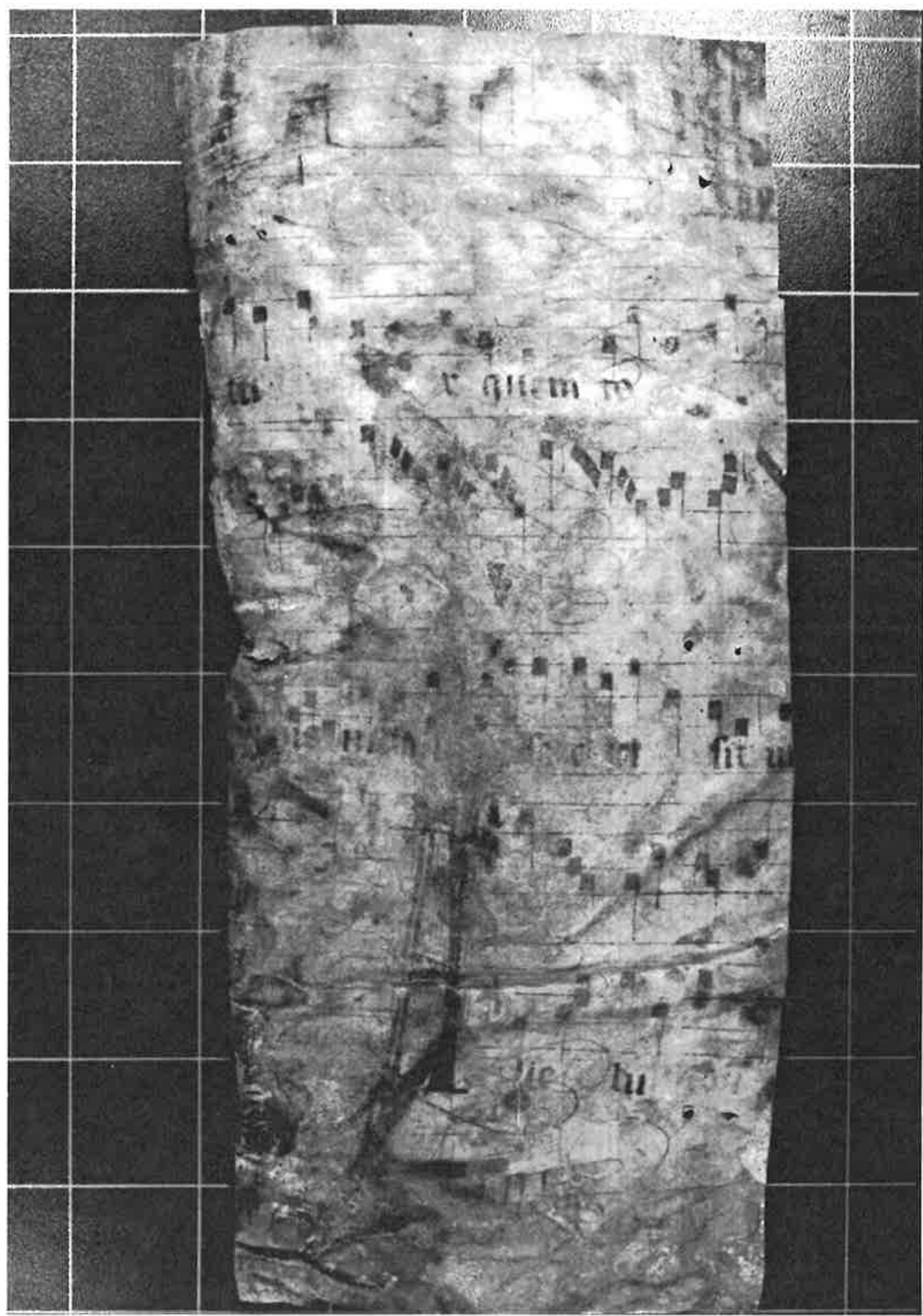

Plate 3: Z $184^{v}$ 


\section{Gloria. Spiritus et alme}

This evidently popular trope is known in many sources from all over Europe and has been the subject of a monograph by Bernhold Schmid. ${ }^{21}$ The earliest known example of a monophonic setting of the work is one from Jumièges in northern France, c. 1100, while the first known polyphonic setting also comes from northern France and dates from the late 12th century. ${ }^{22}$ In Spain the monophonic version is found in several 13th-century manuscripts, two from eastern Spain, Tortosa 135 and Barc 1, and one from Silos, Pa 2194. ${ }^{23}$ The two earliest polyphonic settings from Spain are in two 13th-century sources both of which are shown in the list of concordances given earlier: Madrid 20324 and Burgos 61/2. Some later manuscripts with the monophonic version have been mentioned previously.

Occurring on the recto side of the fragment, only small sections of the work remain. At the top of the fragment is what is probably the lowest voice of a three-voice setting of the phrase "Mariam sanctificans". Below it is the complete three-voice setting of the final phrase of the trope, "Mariam coronans". Also visible are short bits of the Gloria text interspersed between the polyphonic trope phrases, as well as part of the initial $M$ which must have begun a polyphonic setting of the phrase "Mariam gubernans", part of the usual trope text at this point. From these fragments of the work, one may surmise that a three-voice setting of the well known trope text was performed in alternation with the monophonic Gloria as was practised elsewhere although not always notated. ${ }^{24}$ The setting of the trope which can be seen is almost identical to that of $\mathrm{Hu}$. Among the three voices, the only melodic differences lie in the occurrence of plicated notes. Notable variation is found in the ligature forms which are often, however, simply different ways of expressing the same durational pattern. An ambiguity which arises in a mensural interpretation of $\mathrm{Z}$ 184 is resolved through comparison with $\mathrm{Hu}$; the final ligature 7 in the top voice over the final syllable of coronans would normally be interpreted as breve-long. This appears wrong in relation to the ligatures of the lower voices which require interpretation with a

\footnotetext{
${ }^{21}$ Schmid, Gloria-Tropus.

${ }^{22}$ Schmid, Gloria-Tropus, 13-14, 29.

${ }^{23}$ Schmid, Gloria-Tropus, 15.

${ }^{24}$ Schmid, Gloria-Tropus, 29.
} 
duration of two longs. Comparison reveals that the $\mathrm{Hu}$ version has two longs notated in this position.

A theory concerning the relationship of the three polyphonic settings given above as concordances of the Z 184 example of Gloria. Spiritus et alme has been proposed by Max Lütolf. He suggested that a now lost two-voice composition may have provided the basis for both the extant two-voice version in Madrid and the three-voice version in Aquitanian notation in the archive of Burgos cathedral, with the latter work possibly acting as the model for $\mathrm{Hu}^{25}$ Bernhold Schmid has proposed on the other hand that an unwritten tradition of polyphonic singing forms the background of the three concordances. Closest to that unwritten form would be the two-voice Madrid setting, while the third voices of Burgos and Las Huelgas require written transmission. ${ }^{26}$ The Zamora fragment adds a further example to this group of concordances, one which must be placed together with that of Hu due to the close similarity of the two settings.

\section{Benedicta. Virgo dei genitrix}

This chant received various polyphonic settings outside of Spain. ${ }^{27}$ Of these, those which this writer has been able to examine are not similar to the settings of $\mathrm{Hu}$ and $\mathrm{Z} 184$. The two concordances in Spain are those listed previously and both are found in $\mathrm{Hu}$, one of the two being a motet Virgo virginum based on the verse of the gradual. Only sections of Benedicta. Virgo dei genitrix remain in Z 184; these include the opening "Benedicta", part of the following gradual chant in monophony, two fragments of the polyphonic section of the verse, and fragments of the monophonic verse ending. The loss of the opening large initial $B$ presents no difficulties as the text and melody are readily identifiable without it.

Unlike the Gloria. Spiritus et alme, this work uses only two voices as do the concordances in $\mathrm{Hu}$. Further similarities between the gradual and verse in the two sources include: firstly, the application of polyphony to the same sections as far as can be judged

${ }^{25}$ Lütolf, Die mehrstimmigen, 219-20, 309.

${ }^{26}$ Schmid, Gloria-Tropus, 120-21, 127.

${ }^{27}$ Anderson, Huelgas 1: xxx. Reaney, RISM BIV' and Gilbert Reaney, ed., Manuscripts of Polyphonic Music (c. 1320-1400), RISM BIV² (Munich-Duisburg: G. Henle Verlag, 1969). 
from the fragmentary nature of $\mathrm{Z} 184$; secondly, voice ranges and the avoidance of voicecrossing, the tenor in Z 184 remaining consistently below the added voice or occasionally meeting it at the unison (voice-crossing occurs now and then in $\mathrm{Hu}$ ); and thirdly, the prevalence of longs in the notation of the tenor and the therefore possible fifth mode interpretation. Greater divergence exists between the upper voices of $\mathrm{Hu}$ and the Zamoran version than is found in the Gloria trope section already discussed. The opening "Benedicta" in Z 184 maintains note-against-note counterpoint almost entirely in contrary motion, while the duplum of Hu uses two or more notes for every single note of the tenor. The movement of the duplum becomes more like that of $\mathrm{Hu}$ in the verse fragments. With regard to the tenor, minor variations occur between the versions of the melody of "Benedicta" while a greater degree of variation may be observed over that which remains of the $Z 184$ setting of the word "orbis". Some of the differences in both voices however may be explained by the fact that examination of the facsimile edition of Hu shows that alterations have been made to the original copying of parts of the verse.

The motet Virgo virginum reveals further information with regard to the variants between the verse settings in $\mathrm{Hu}$ and $\mathrm{Z}$ 184. The two-voice motet makes use of both voices of the gradual verse and follows the two-voice chant setting in Hu closely through much of the work. There are however some marked differences especially in the duplum. Comparison of the $\mathrm{Hu}$ motet and the two fragments of the verse legible in $\mathrm{Z} 184$ reveal a closer degree of similarity than exists between these sections of the motet and the verse in $\mathrm{Hu}$. Although it is not entirely possible to reconstruct the erased sections from the faint remnants of the earlier notation, it appears that they may have been closer to the corresponding parts of $\mathrm{Z}$ 184 and the motet than the present version. This observation leads to the hypothesis that the similar versions of the verse in the newly discovered source and the motet are earlier than that of the $\mathrm{Hu}$ verse. This is supported by the earlier dating of $\mathrm{Z} 184$ in relation to $\mathrm{Hu}$.

Example 1 shows most of the second fragment of the verse from $\mathrm{Z} 184$ together with the corresponding sections of the motet and the Hu verse. At the beginning marked " $A$ " is a section of the tenor which varies in each version and which has been found to be variable in other sources of the chant consulted. Alterations are visible in the facsimile at this point in the verse of $\mathrm{Hu}$. The duplum sections " $B$ " are those in which the Hu verse differs 
significantly from Z 184 and the motet. Again in the first of these, alterations are visible in the Hu verse. The transcriptions from Hu follow Anderson ${ }^{28}$ except for the omission of rests and bar-lines and the replacement of the first tenor note of the motet with the pitch shown in the facsimile (D) ${ }^{29}$ The motet text has been omitted for the sake of clarity.

\section{Example 1}
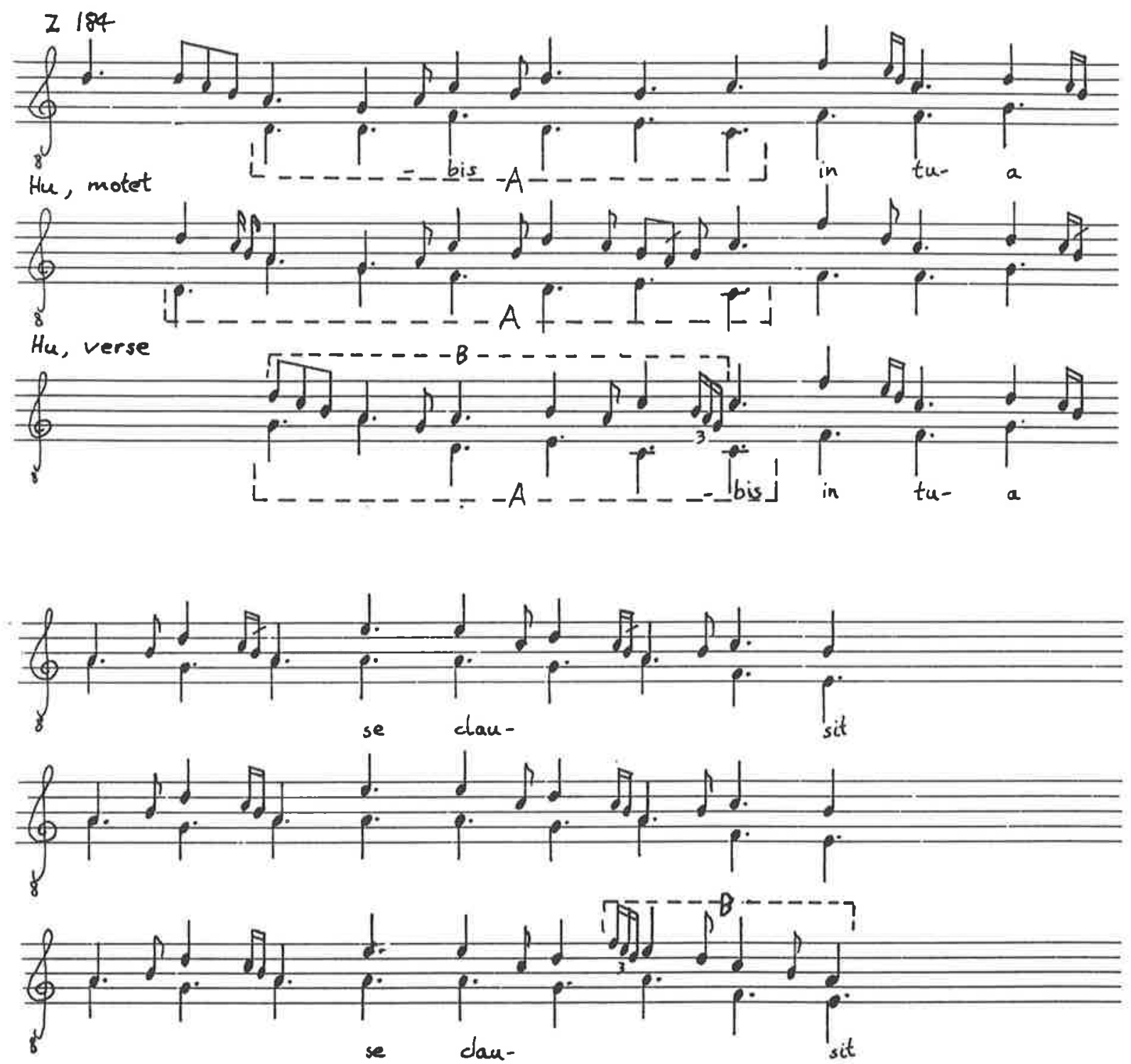

Study of the motet is also of use in the interpretation of the ligatures of $Z 184$. The notation of the motet duplum is clear, often alternating longs and breves, and thus is able to

${ }^{29}$ Anderson notes this alteration in his commentary Huelgas 2: xxxviii. 
confirm the mensural interpretation of the ligatures of $\mathrm{Z} 184$. In addition the motet assists confirmation of the transcription of the nearly illegible segments which were transcribed initially without reference to Hu or any other source prior to identification of the work.

The loss of all clefs belonging to the polyphonic segments of this work has necessitated that their probable placement in both voices be ascertained from the concordances or evidence internal to $\mathrm{Z} 184$. The pitch of the tenor chosen for the transcription is that used in $\mathrm{Hu}$ and commonly employed for the melody in chant sources including Barc 1 and Graduale Triplex. ${ }^{30}$ The duplum pitch for the two fragments of the verse may easily be taken from the same voice in the motet and the verse of $\mathrm{Hu}$. That for the opening "Benedicta" which is quite different from $\mathrm{Hu}$, has been decided with the assistance of other factors. On the basis of medieval consonance usage and common pitch relationships of voices, the two most likely opening pitches for the duplum at this point are $F$ at the unison with the tenor and $c$ at the fifth above the tenor. Of these, that beginning on $\mathrm{c}$ has been chosen because it produces a style of counterpoint more like that of the two verse fragments. ${ }^{31}$ The use of $\mathrm{F}$ would result in features not found in the two later sections: voice-crossing, separation of the voices never greater than a fourth, and a voice range of a sixth from $\mathrm{C}$ to a. The range of the duplum in the two later sections is a seventh from $g$ to $f$ and that of the tenor a sixth from $\mathrm{C}$ to a. Also probably undesirable as a result of an opening on $\mathrm{F}$ would be some prominent fourths.

\section{Alleluya. [Que est ista tam formosa]}

The third work in the fragment is cut off even before the end of its first word "Alleluya", the final syllable thus being lost. ${ }^{32}$ It has however been possible to give it a tentative identification as the Alleluya. Que est ista tam formosa which occurs in Hu. Several features suggest this hypothesis: firstly, the tenor melodies of the Zamoran fragment and the Hu alleluia which vary in pitch only as the result of the use of plicas (these plicas

\footnotetext{
${ }^{30}$ Barc 1, fol. 2 ; Graduale Triplex, 407-8.
}

${ }^{31}$ I am grateful to the audience and chairperson Dr. Marie Louise Gollner who listened to my paper on Z 184 at the XIV Conference of the Musicological Society of Australia (1991) and for comments on the choice of $\mathrm{c}$ as opening pitch.

${ }^{32}$ The spelling "ya" of the final syllable is taken from Hu. 
are discussed further below); secondly, the ordering of the works in relation to that of $\mathrm{Hu}$ although another alleluia is placed between this one and the Benedicta. Virgo dei genitrix; and thirdly, while very similar melodic incipits of the alleluia are shared by two others, Alleluia. Per te dei genitrix and Alleluia. Benedictus es domine, current indexes give no indication of these texts in Spanish sources, whereas the Alleluya. Que est ista tam formosa occurs only in Spanish sources. ${ }^{33}$ Both Anderson and Anglès found the polyphonic setting in $\mathrm{Hu}$ to be a unicum. ${ }^{34}$

The melodic movement of the duplum is similar but not identical to $\mathrm{Hu}$. It commences on the $\mathrm{d}$ one octave above the tenor whereas that of $\mathrm{Hu}$ begins on the fifth. $\mathrm{Z} 184$ retains a higher range in the duplum without voice-crossing throughout the section, ${ }^{35}$ while in $\mathrm{Hu}$ the voices share an almost identical range, the tenor for much of the time moving above the duplum. The notation of the two sources is divergent, that of Hu when interpreted mensurally producing a quicker moving section than that of $\mathrm{Z} 184$. With regard to the tenor, in the latter source two of the ligatures of $\mathrm{Hu}$ are broken into single notes and binariae. The plica on the first note of the tenor in $\mathrm{Hu}$ is not seen in $\mathrm{Z} \mathrm{184}$, however its presence there may not be precluded due to the poor legibility of the source at this point. The final tenor ligature 7 in $\mathrm{Z} 184$ is one of those in which the right-hand stem may or may not be interpreted as a plica. In the transcription the stem is treated as a plica in accordance with the final duplum ligature which ends with an unequivocal plica. The penultimate ligature of the alleluia in $\mathrm{Hu}$ finishes with the same two tenor notes as the problematic $\mathrm{Z} 184$ ligature. It also has a similarly ambiguous final stem; the duplum however offers no reason for interpreting

${ }^{33}$ Melodies of the Alleluias, Per te dei genitrix and Benedictus es domine are given in Karlheinz Schlager, Alleluia-Melodien I ab 1100, Monumenta Monodica Medii Aevi, vol. 7 (Kassel: Bärenreiter, 1968), 51, 380, 583. For the source and melody of Alleluia. Que est ista tam formosa, Schlager, Alleluia-Melodien II ab 1100, 409, 755. Fernández de la Cuesta, Manuscritos was also consulted.

${ }^{34}$ Anderson, Huelgas 1: xxx; Angles, Huelgas 2: xxiv.

${ }^{35}$ The differing voice ranges and lack of voice-crossing in the two two-voice works of $\mathrm{Z} 184$ is reminiscent of Fuller's observations with regard to 11th- and 12th-century Aquitanian two-voice settings of liturgical chants. She found that in such works in which a voice of lower range takes the liturgical melody, voice-crossing is rarely evident. See Fuller, “Aquitanian Polyphony", 272-74. 
that stem as a plica. Neither Anglès nor Anderson did so in their Hu editions. ${ }^{36}$

\section{MISAL VOTIVO PARA USO DE ZAMORA (MISAL VOTIVO)}

Although the source is included in a catalogue by Janini, the two two-voice works contained in the Misal votivo have evidently not previously been recognized as polyphonic, the first publication to mention them being this writer's article appended to the end of this dissertation. The two works are found in the Masses for St. Ildefonsus which lie in the 14th-century section of the manuscript. The first work, the prosa Conlaudemus omnes pie, occurs in the Mass for the saint's main feast which takes place in January and the second, a troped setting of the Deo gratias, occurs at the end of the Mass for his Invention in May, the latter feast being of local significance to Zamora. The two feasts are found in the calendar of Zamora. ${ }^{37}$ Both works are related to pieces elsewhere associated with Marian celebrations as will be mentioned during the discussion below. That a Marian connection should be found for music used in the feasts of St. Ildefonsus is initially surprising but an explanation can be proposed in the commitment of Ildefonsus to the Virgin Mary which is known through his writings and through miracle stories.

The two works may be seen as belonging to a tradition parallel to that in Italian sources of the 14th to early 16th centuries known as cantus planus binatim although in its strict sense the latter term refers only to music using a liturgical tenor. ${ }^{38}$ While many of the Italian sources are linked with a particular religious order, the following description of those which are not seems apt with regard to that of the Misal votivo:

a considerable number of sources, particularly of the earlier period, are also linked to the musical usage of the secular clergy active in the cathedrals of small towns. Manuscripts which reveal this provenance are mostly graduals or antiphonaries, or in any case official books for use during the divine service, into which the two-voice intonations are consequently inserted in their correct liturgical order. $^{39}$

\footnotetext{
${ }^{36}$ Anderson discussed this type of ambiguous ligature in "Notation", 61. He additionally gave there the guidelines employed for their resolution in the preparation of his Hu edition.

${ }^{37}$ The feasts of St. Ildefonsus are discussed in Chapters 1 and 2, as well as pages 1-2 of the writer's article appended at the rear of this dissertation.

${ }^{38}$ The subject receives important discussion and the sources are listed in F. Alberto Gallo, "The Practice of Cantus Planus Binatim in Italy from the Beginning of the 14th Century to the Beginning of the 16th Century", in Le polifonie primitive in Friuli e in Europa (Rome: Edizioni Torre d'Orfeo, 1989), 13-30. On cantus planus binatim in the strict sense, see Margaret Bent, "The Definition of Simple Polyphony. Some
} 
The occurrence of such works in the Italian sources is very infrequent in comparison to the presence of monophonic chant and is usually intended for special feasts. ${ }^{40}$ The same appears to be true for Spanish sources.

Unlike the homogeneous style of notation in $\mathrm{Z} 184$, the two polyphonic works in the Misal votivo employ different methods, the first appearing to be non-mensural (although with some pseudo-mensural elements) and the second semi-mensural. In addition, the second work appears to have been added, perhaps as an afterthought, after completion of the copying of the Ildefonsus Masses. The layout of the staffs is different and one must ask whether the two works were notated by different scribes. ${ }^{41}$

\section{Conlaudemus omnes pie}

No textual concordances have been found for this two-voice prosa which is not found in $A H$ or in Chevalier's Repertorium Hymnologicum. Neither it nor the second two-voice piece in the Misal votivo are mentioned in the text of the Masses for St. Ildefonsus in the Ritual of the Cathedral of Zamora. As for musical concordances, the prosa Promereris summe laudis found in $\mathrm{Hu}, \mathrm{Barc} 1$, and Tortosa 133 may be named. ${ }^{42}$ The latter work is for use in Marian feasts as is made clear by the rubric on folio $19^{r}$ of Barc 1. The form of the text of Conlaudemus is discussed on page four of the article appended to the end of this dissertation. Promereris and Conlaudemus both use pairs of versicles set to the same music. As in $\mathrm{Hu}$ the music for each versicle pair in the Misal votivo is written out only once with the texts written one below the other. Barc 1, on the other hand, rewrites the music for each versicle and minor changes may be found in the settings.

An example of simple polyphony with non-mensural notation, the two voices of Conlaudemus share a very similar range both covering an eleventh, the lower voice being

Questions", in Le polifonie primitive in Friuli e in Europa (Rome: Edizioni Torre d'Orfeo, 1989), 37-38.

${ }^{39}$ Gallo, Cantus Planus Binatim, 23.

${ }^{40}$ Kurt von Fischer, "The Sacred Polyphony of the Italian Trecento", Proceedings of the Royal Musical Association 100 (1973-4): 145.

${ }^{41}$ For more on the layout of the works, see appended article, p. 4.

${ }^{42} \mathrm{Hu}$ facsimile: Anglès, Huelgas 2, fol. 33; transcriptions: Anglès, Huelgas 3: 70, Anderson, Huelgas 1: 84-85. Barc 1, fol. 19; transcription: María Carmen Gómez Muntané, "El Ars Antiqua en Cataluña", Revista de Musicología 2 (1979): 233-34. Tortosa 133, fol. $1^{\mathrm{v}}$. No facsimile or transcription of the Tortosa 133 example is available but it "is identical with $\mathrm{Hu}$ 50" (RISM BIV", 258); it is, however, notated in 
one tone lower. Voice-crossing is used frequently and contrary motion predominates. Perfect fifths, unisons, and octaves are the most commonly used intervals at the beginning of syllables. A description of the differences between Promereris in $\mathrm{Hu}$ and Conlaudemus has been given in the appended article. In summary, it may be said that Conlaudemus transposes the voice parts of $\mathrm{Hu}$ and Barc 1 in most of the second and all of the fourth versicle pairs. The tenor rather than the duplum of Conlaudemus is closer to that of the corresponding voice of Promereris in the transposed sections. The versions of $\mathrm{Hu}$ and Barc 1 are very alike (the greatest difference being in the notation) and share more similarities together than with Conlaudemus. In addition to the changes of the second and fourth versicle pairs, the third varies markedly in the duplum of Conlaudemus. The closing third on $g$ at the end of the second versicle pair is out of character with the work as a whole; the three other versicle pairs end with unison or a fifth on g. In Promereris, intermediate and final cadences close with the intervals of unison, fifth, or octave only. Also unusual in the second versicle pair is the opening farth an interval not usually given such a prominent position; however, an example does occur among the proses of $\mathrm{Hu}$ at the beginning of the third versicle pair of Salve sancta christi parens. This has been changed by Anderson in his transcription to a third, which interval is again used at the beginning of the next versicle pair instead of the notated unison. ${ }^{43}$ The endings of the two prosae show an interesting variation as that of Conlaudemus has been contracted from that of Promereris. ${ }^{44}$

Although durational differentiation is suggested by the appearance of isolated notes with and without a single descending stem and the occasional sign not frequently found in square notation of chant, the notation cannot be interpreted as mensural. As has been discussed in Chapter 4, such signs are occasionally found in the monophonic chant of the manuscript but there appear to have no durational significance. In Conlaudemus isolated notes with stems are always accompanied by a single note without a stem in the other voice, a phenomenon similar to that occurring in the next polyphonic work to be discussed. There seems no reason to regard such stemmed notes as anything other than a scribal

\section{Aquitanian notation.}

${ }^{43}$ Facsimile: Angles, Huelgas 2, fols. $35^{\mathrm{V}}-36^{\mathrm{r}}$. Anderson, Huelgas 1: 88-89.

${ }^{44}$ See appended article, p. 5. 
idiosyncrasy, perhaps in imitation of mensural notation and having no significance with regard to performance.

The transcription proposed here takes an isosyllabic approach as its foundation. The choice of this method was influenced by the fact that the tradition of syllable-counting verse appears to have been associated with an approximate equality of duration for each syllable. ${ }^{45}$ To this basis is added a ternary meter and a rendering of binariae according to the first mode. Non-isochronous, modal interpretation following poetic meter as used for polyphonic prosae by Bryan Gillingham was rejected, largely because in Conlaudemus syllabic note-groups would fall frequently on the unaccented and therefore shortened text syllables. ${ }^{46}$ The proposed transcription is similar to that of Promereris in Anderson's edition of $\mathrm{Hu}$, apart from the change to the first mode and without the use of semiquaver pairs. The transcription of Promereris from Barc 1 by María Carmen Gómez Muntané is rhythmically very like that given here, also avoiding semiquaver pairs and employing the first mode as opposed to the second. Such an interpretation is very similar to the method followed by Max Lütolf in his transcriptions of non-mensurally notated Mass Ordinary movements from Barc $1 .^{47}$

\section{Deo nos agentes}

This two-voice work, a trope of the Deo gratias, appears to be a unicum; it is not mentioned in RISM, nor in Fernández de la Cuesta's catalogue of medieval Spanish sources, nor is it included in $A H$ or Chevalier's Repertorium Hymnologicum. A few polyphonic settings of the Deo gratias (but not with this trope) are known, although no other example appears to have been recorded as extant in Spain. Closely related settings of other texts including one in $\mathrm{Hu}$ will however be discussed below. 1986), 421.

${ }^{45}$ John Stevens, Words and Music in the Middle Ages (Cambridge: Cambridge University Press,

${ }^{46}$ Bryan Gillingham, "Atavism and Innovation in a Late Medieval Proser", Studies in Music from the University of Western Ontario 10 (1985): 79-103. Apel, Notation, 265-66, discusses the problems with this type of modal interpretation with regard to conductus.

${ }^{47}$ See for example Sanctus. Sospitati dedit mundum and Sanctus. Ad honorem virginis, Lütolf, Die mehrstimmigen 1, plates 16-19 (facsimiles) and 2: 125-30 (transcriptions). 
Deo nos agentes is preceded in the Misal votivo by a monophonic troped Ite missa est, the incipit of which is Ite vos deum. The melody of Ite vos deum reappears as the tenor in Deo nos agentes. The text, Ite vos deum, is not listed in AH or Repertorium Hymnologicum. A connection with Marian celebrations is brought to the Ite and Deo gratias tropes by the rubric "De sancta maria" given for the sole known concordance of Ite vos deum. The source of the concordance is a manuscript of Spanish provenance, Ma 931, which is dated to the 14th or 15th century and is from the convent of Velés. ${ }^{48}$ In that manuscript, Ite vos deum occurs towards the end of the kyriale and precedes the Benedicamus trope Verbum patris hodie. ${ }^{49}$

The melody of Ite vos deum and of the tenor in Deo nos agentes is that of the Vatican Kyrie II, number 48 in the catalogue of Melnicki. ${ }^{50}$ The use of a Kyrie melody for the Ite missa est appears to have been a regular practice. ${ }^{51}$ Another Spanish source to show this practice is Ma 1361 (also a 14th-century manuscript) which employs Melnicki 18 for one of eleven occurrences of the Ite missa est. ${ }^{52}$

Melnicki gives eleven different Kyrie trope texts for the melody. ${ }^{53}$ The best known of the texts is Kyrie fons bonitatis. The catalogues of Melnicki and Hiley show the use of the melody to have been very widespread, occurring in sources of France, England, Germany, Austria, and Italy as well as various monastic ones, with the earliest belonging to late 10th-century England. ${ }^{54}$ The absence of Spain from this list is due to the very slight representation of sources from that country in Melnicki's catalogue, only two being listed

${ }^{48} 14$ th century, Fernández de la Cuesta, Manuscritos, 100; 15th century, Anglés and Subirá, Catálogo, 117. Both books give the same provenance; unfortunately, nothing further can be gleaned concerning the use of Ma 931 from the catalogues consulted.

${ }^{49} \mathrm{Ma} 931$, fol. $188^{\mathrm{v}}$.

${ }^{\text {so }}$ Melnicki, Kyrie, 95.

${ }^{51}$ Melnicki includes discussion of this usage of Kyrie melodies, Melnicki, Kyrie, 73-74. It also receives mention in Apel, Gregorian Chant, 420-21. More recently Anne Walters Robertson has shown the employment of Kyrie melodies for the Benedicamus domino, and in particular that of the Kyrie, Clemens rector, for both Benedicamus domino and Ite missa est, see Anne Walters Robertson, "Benedicamus Domino: the Unwritten Tradition", Journal of the American Musicological Society 41 (1988): 40.

${ }^{52} \mathrm{Ma} 1361$, fol. $197^{\mathrm{r}}$.

${ }^{53}$ Melnicki, Kyrie, 95-96.

${ }^{54}$ Melnicki, Kyrie, 15, 21; Hiley, "Ordinary of Mass", 62, and for information on the earliest source, 4. 
among 493 manuscripts. ${ }^{55}$ It is in fact found in Spanish manuscripts, for example, Ma 1361 , fol. $182^{r}$. A two-voice setting of the melody to the text Kirie fons bonitatis is found in $\mathrm{Hu}$, fols. $2^{\mathrm{v}}-3^{\mathrm{v}}$. Melnicki cites another thirteen polyphonic settings in sources of the 14 th to 16 th centuries all from outside Spain. ${ }^{56}$ The only differences between the incipit given by Melnicki and the melody of Ite vos deum in the Misal votivo are the result of plicas. Comparison with Melnicki 48 of Ma 1361 and Ma 931 shows that plicas also produce the only differences present apart from the setting of the last two syllables. The penultimate syllable of the Misal votivo melody has a four-note melisma while the last syllable receives two notes, both being longer settings than the corresponding syllables in the two other Spanish versions studied and the Vatican version. ${ }^{57}$ In changing from its monophonic usage to employment as the tenor of the polyphonic setting, Melnicki 48 is unaltered but for the use of plicas and doubles, and stems on isolated notes.

Deo nos agentes is in discant style and may be described as simple polyphony. ${ }^{58}$ The two voices move within the same ambitus with the tenor in the upper position for much of the time. Both contrary and parallel movement are used with the voices never being more than a fifth apart. The many fifths are noticeable at the beginning of syllables and in parallel motion. As comparison the polyphonic Kirie fons bonitatis of $\mathrm{Hu}$ may be examined. Also for two voices, it shares the features just described as belonging to Deo nos agentes, although in $\mathrm{Hu}$ the fifths are less common and at one point an interval of an octave occurs. The placing of short melismas and other simple ornamentation often coincides. Given these similarities and the fact that in places the added voice of $\mathrm{Hu}$ is similar or identical to that of the Misal votivo, it appears that these are likely to be two versions of a single tradition of two-voice performance of the tenor melody; however, the two works have different endings. Reminiscent of the relationship between the endings of Conlaudemus omnes pie and Promereris summe laudis (but reversed) are the last six notes of the added voice in both the Hu Kirie and Deo nos agentes. These notes are identical in both works

\footnotetext{
${ }^{55}$ Melnicki, Kyrie, 138.

${ }^{56}$ Melnicki, Kyrie, 77-78.

${ }^{57}$ Graduale Triplex, 715.

${ }^{58}$ On simple polyphony see Bent, "The Definition".
} 
but are spread over three and four syllables respectively; this is shown in Example 2. ${ }^{59}$ The two endings reflect the use of only three syllables in setting the word "eleyson" in $\mathrm{Hu}$, with the Misal votivo work retaining the number of syllables found in other versions of the Kyrie trope which use the four syllable interpretation of the word "eleyson".

\section{Example 2}

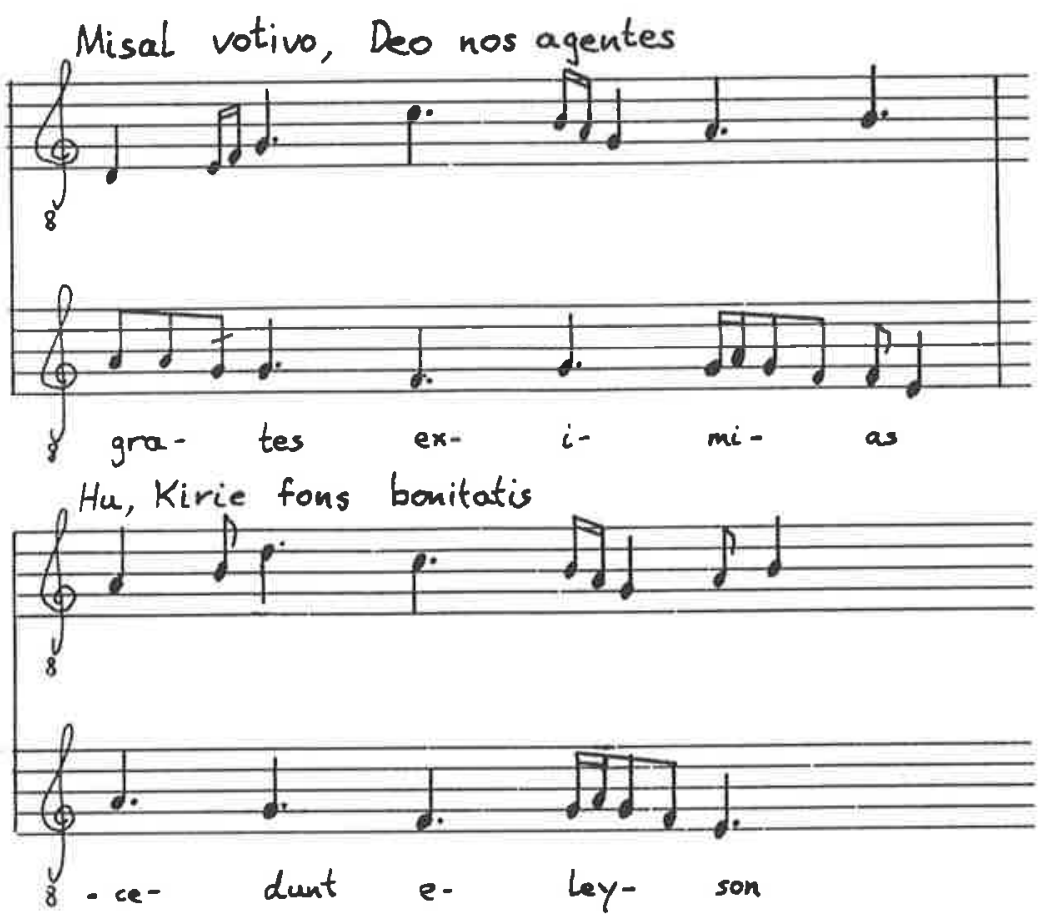

Another two-voice setting of Kyrie fons bonitatis very like Deo nos agentes is that of the 15th-century Munich 11764. This version uses largely the same pattern of movement between fifths and unisons as does the Misal votivo but is less ornamented. It also is restricted to the fifth as the widest interval occurring between the two voices. ${ }^{60}$

The transcription offered here may not be viewed as definitive because of problems arising from the notation. Two features appear at first sight to indicate a mensural notation; these are, firstly, the apparent use of longs and breves, and secondly, cum opposita proprietate ligatures. The identification of longs and breves based on the use of stems is problematic as the stems appear to have been used without consistency. This may be seen for example

\footnotetext{
${ }^{59}$ The transcription of the Hu work follows that of Anderson, Huelgas 1: 8.

${ }^{60}$ Transcription in Johannes Wolf, "Eine neue Quelle zur mehrstimmigen kirchlichen Praxis des 14.
} bis 15. Jahrhunderts", Festschrift Peter Wagner zum 60. Geburtstag, ed. Karl Weinmann (Leipzig: Breitkopf \& Hărtel, 1926), 229. 
over the word "inmensas", where three single notes with stems descending to the right occur in the duplum and three single notes without stems occur in the tenor. The use of vertical lines in the manuscript to mark the beginning and the end of "inmensas" indicates that the three notes in each voice belong to this one word. This inconsistency in the use of stems suggests that the unstemmed notes which elsewhere in the piece might be understood as breves should not always be transcribed in this manner. In conclusion, the presence or absence of stems cannot be seen as always significant. Having accepted this hypothesis, the transcription of the work becomes simpler, as may be illustrated by the following instance from the beginning of the work, involving the second apparently mensural feature, the cum opposita proprietate ligature. The four notes of the duplum placed above the second syllable of "Deo", if interpreted according to Franconian rules produce L SSB 16 , but as the tenor ligature is $\mathrm{BL}$, the voices are found not to match with regard to duration. The situation is not clarified by inclusion of the following and preceding notes, but if the apparent long is read as a breve, the problem recedes. Despite the seeming inconsistency with the finding in regard to stemmed and unstemmed notes, no reason has been found to suggest that the cum opposita proprietate ligatures are not used in a mensural fashion. They therefore have been interpreted in the usual manner and transcribed with semibreve pairs. Various forms occur in the manuscript, some written as one ligature for a single syllable, for example $\frac{1}{4}$ and 4 , while others are broken into two forms although still for only one syllable

An isosyllabic interpretation has been taken as the basis of the transcription. It has been chosen as appropriate given the problems already described, and because of the syllabic style of composition in which the tenor uses mainly single notes per syllable and the added voice uses from one to four notes per syllable with the majority being single 
notes. The isosyllabic basis establishes constraints for the interpretation of the problematic notation, while not being inconsistent with the apparent durational significance of many of the signs. Nevertheless, it needs to be remembered that unusual signs suggestive of mensural notation occurring occasionally throughout the 14th-century section of the Misal votivo indicate the need to question the apparent mensuralism of Deo nos agentes. ${ }^{61}$ The greater frequency of possibly mensural signs and the appearance of forms not seen elsewhere in the manuscript encourages the interpretation proposed here.

The interpretation of the notation of $\mathrm{Z} 184$ and the Misal votivo remains open to question. That of the former certainly appears mensural, but is not without ambiguities especially with regard to conjuncturae and alteration, while that of the latter source raises different problems as have been discussed. A pseudo-mensural concept in which the "decorative surface" of mensural notation has been adopted without its durational significance seems to be applicable in differing degrees in the two works of the Misal votivo; it applies especially to the stemmed isolated notes which are in meaning no different from unstemmed ones. For the transcription of Deo nos agentes, the apparent cum opposita proprietate ligatures have been accepted as mensurally significant and the notation of the work has as a result been described as semi-mensural; however, the possibility that they are decorative and without such mensural meaning is suggested by the fact that this type of ligature is found elsewhere with questionable durational meaning (for example, in the manuscripts of the Cantigas de Santa Maria ${ }^{63}$ and in the chant notation of the Misal votivo itself). Further study of cum opposita proprietate ligatures in Spanish and other sources may be of use in resolving this problem.

The transcriptions given here are made provisionally as starting points in the study of these two previously unknown sources. Definite answers continue to be unavailable at the

${ }^{61}$ See the discussion on pseudo-mensural notation in Chapter 4.

${ }^{62}$ Leo Treitler, "Cantus planus binatim in Italy and the Question of Oral and Written Tradition in General", in Le polifonie primitive in Friuli e in Europa (Rome: Edizioni Torre d'Orfeo, 1989), 154.

${ }^{63} \mathrm{Hendrik}$ van der Werf discusses the problem of the notation of the cantigas and the use of cum opposita proprietate ligatures in "Accentuation and Duration in the Music of the Cantigas de Santa Maria", in Studies on the Cantigas de Santa Maria: Art, Music and Poetry, ed. Israel J. Katz and John E. Keller (Madison, Wisconsin: The Hispanic Seminary of Medieval Studies, 1987), 222-34. 
present time to such problems of notation, and the area still awaits further musicological enquiry. The generally accepted modally-based paradigm for the transcription of discant such as is found in the first part of $\mathrm{Hu}$ and in Z 184 may need to be revised. This revision might apply particularly to sources in which the notation diverges notably from mensural forms and which can be described as semi-mensural or pseudo-mensural. Differing transcription methods which could be employed as alternatives need to receive further consideration and evaluation. Two possibilities already favoured by some musicologists and which give increased responsibility to performers are the use of firstly, rhythmically undifferentiated note-heads, and secondly, diplomatic transcription. Transcription with rhythm derived from text accent is a further possibility as is the use of an isochronic interpretation applied to syllables. Further explorations of the possible mensural significations of semi-mensural and pseudo-mensural notations may be fruitful and may perhaps be made in the contexts of text accent and broad comparative studies. Robert J. Snow's suggestion that the Aquitanian school of polyphony may be interpreted in the light of Vollaert's findings on duration in chant notation is an interesting one which could be developed further. ${ }^{64}$

The 14th-century treatises concerned with polyphonic practices from Spain provide no assistance with the particular problems of notation of the Zamoran works as they elaborate only on mensural notation in its well known and largely more advanced forms. ${ }^{65}$ They serve to highlight, rather, the old-fashioned notation of the two works from the 14th-century section of the Misal votivo. The 13th-century music treatise of Juan Gil de Zamora does not treat polyphony or notation. Also with regard to aspects of part-writing, the 14th-century treatises of Spanish provenance offer little relevant information.

Contrary motion is prominent in all works, although Deo nos agentes and to a lesser extent Benedicta. Virgo dei genitrix noticeably use parallel motion as well. Such employment of contrary motion is in accord with the emphasis in organum treatises from as early as c.

\footnotetext{
${ }^{64}$ Robert J. Snow, personal communication, and "The History of Medieval Music: Are All Our Premises Correct?", publication pending.

${ }^{65}$ For studies and transcriptions of these treatises see Higinio Anglès "De cantu organico" and María del Carmen Gómez, "De arte cantus".
} 
1100 and the 12th century such as the De Musica by Johannes Afflighemensis. ${ }^{66}$ On the other hand, parallel perfect consonsances such as the parallel fifths of Deo nos agentes are a feature which came to be forbidden by discant treatises. ${ }^{67}$ The usually higher pitch of the tenor in comparison to the added voice in Deo nos agentes and Gloria. Spiritus et alme reflects the practices evident in earlier organum treatises and the underlying view that the voice carrying the chant melody was the most important one. In general, among the works in the Zamoran sources octaves, fifths, and unisons are the preferred intervals between the voices on strong beats and at beginnings or ends of phrases. Fourths, like thirds, tend to be limited to use in voice-leading movement to a fifth or a unison. Such use of intervals reflects the strand of 13th-century theoretical teaching which saw the fourth as less consonant than the unison, fifth, and octave, ${ }^{68}$ a radical departure from early organum which had preferred separation of the voices by a fourth. Conlaudemus omnes pie makes more free use of the intervals of fourth, third, and sixth, even to the extent of using the first two at the beginning and end of a versicle; the octave, unison and fifth nevertheless still predominate in strong positions. Johannes de Garlandia's work describes the association of consonance and strong beat, which had also been referred to in the earlier Discantus positio vulgaris. ${ }^{69}$ All the Zamoran works reflect the general predilection for discant which emerged during the 13th century and which resulted in the dropping of the florid organum characteristic of the 12 th century. ${ }^{70}$ A clearer perspective on the contrapuntal techniques of the works

${ }^{66}$ For an English translation see Warren Babb and Claude V. Palisca, Hucbald, Guido, and John on Music: Three Medieval Treatises (New Haven: Yale University Press, 1978), 159-61. For another discussion of Johannes Afflighemensis' treatise and a translation of a section on contrary motion, see Sarah Fuller, "Early Polyphony", in The Early Middle Ages 10 1300, edited by Richard L. Crocker and David Hiley (Oxford: Oxford University Press, 1990), 523-24.

${ }^{67}$ This occurs for example in the 14th-century Berkeley treatise, University of California Music Library, MS. 744 (olim Phillipps 4450). See Oliver B. Ellsworth, The Berkeley Manuscript (Lincoln: University of Nebraska Press, 1984), 115. As is observed by Fuller, in Aquitanian polyphony of the 11th and 12th centuries, limited parallel movement of perfect consonances may be observed with some regularity although it may be obscured by ornamental motion (Fuller, "Aquitanian Polyphony", 306-7).

${ }^{60}$ The Discantus positio vulgaris exemplifies this teaching. For an English translation, see Janet Knapp, "Two Thirteenth Century Treatises on Modal Rhythm and the Discant", Journal of Music Theory 6 (1962): 203. Johannes de Garlandia and Franco of Cologne, on the other hand, placed the fourth together with the fifth as an intermediate consonance, less consonant than the unison and octave, more consonant than the thirds.

80.

${ }^{69}$ Sarah Fuller, “Theoretical Foundations of Early Organum Theory”, Acta Musicologica 53 (1981):

${ }^{70}$ Discant had already been distinguished from organum in the 12th-century treatise known as the Schneider anonymous, London, British Library, Egerton 2888 (Fuller, "Early Polyphony”, 526). 
discussed here might be gained from closer comparison with those of $\mathrm{Hu}$. A large study of contrapuntal techniques in the liturgical discant works in Hu along the lines of Sarah Fuller's study of Aquitanian polyphony ${ }^{71}$ would very probably provide valuable material against which the Zamoran works could be fruitfully compared.

Despite the apparently retrospective characteristics of voice-leading discussed in the previous paragraph, the works should perhaps not be viewed as old-fashioned or as remnants of an earlier practice. Instead, they may well be representative of a tradition of polyphonic performance living at the time in which the manuscripts were written and which incorporated varying styles, some already in use over a long period of time. This tradition may well have included improvisatory practices and little actual notation of music.

All the works examined in this chapter show connections with the polyphonic repertories of other parts of Spain and especially that of the monastery of Las Huelgas near Burgos. ${ }^{72}$ As other fragmentary sources from eastern Spain have been demonstrated to be related to Las Huelgas, ${ }^{73}$ its traditions can be seen to have been widespread, although it can be asked whether or not the monastery formed a true centre of diffusion. The five polyphonic works in the Zamoran sources suggest that the tradition employed slightly varied tenor melodies and some constant texts, but that the polyphonic settings were not fixed, and might substantially change from time to time and place to place, an observation probably in keeping with oral transmission. Anderson thought that in a wider European context "polyphony for the Mass Ordinary was composed for local use, and although there is an obvious contact of styles evident between some of the sources, there are differences too, and each community must have seen to its own local needs." in Spanish works. If more sources of polyphony from the Middle Ages are found in the

\footnotetext{
${ }^{71}$ Fuller, "Aquitanian Polyphony", particularly 259-309.
}

${ }^{72}$ Polyphony appears to have been sung in Cistercian monasteries in the early 13 th century. For a summary of the research on this area and the likelihood of the Lafage Anonymous treatise being of Cistercian origin with its chapters on organum and discant, see Sarah Fuller, "An Anonymous Treatise dictus de Sancto Martiale", Musica Disciplina 31 (1977): 5-30.

${ }^{73}$ For example Barc 1, Tortosa 133, and a recently discovered fragment from Vallbona. On the latter see Maricarmen Gómez "Deux nouveaux fragments polyphoniques antérieurs à l'Ars nova dans un manuscrit du monastère de Santa María de Vallbona", in Aspects de la Musique Liturgique au Moyen Age (Paris: Créaphis, 1991), 177-90.

${ }^{74}$ Gordon A. Anderson in his review of Lütolf, Die Mehrstimmigen in Musical Quarterly 57 (1971): 666. 
region of Zamora, it will be interesting to search for local characteristics in repertory choice, compositional style, and notational techniques, in addition to allowing the further broadening of the modern view of Spanish traditions of polyphony in general. 


\section{CONCLUSION}

The first impression gained from viewing the Zamoran sources, and especially from the Pergaminos musicales, is of the great diversity of their appearance. The difference in notation styles and in sizes (both of notation, script, and parchment) is outstanding. Close examination confirms the initial impressions and a full appreciation of the notational variety becomes a very large and fascinating task. Study of the notation of the sources leads to the conclusion that substantially more knowledge awaits discovery in relation to the manner of writing the various neume forms and the direct, as well as preference of staff type, throughout the Middle Ages on the Iberian Peninsula and the different parts of Europe in which the same general types of notation were used.

The wide period of time represented in the sources is one of the factors responsible for the notational diversity and provides the investigator with the opportunity for interesting comparative studies. Other reasons for the diversity are more difficult to establish beyond general hypotheses. Many questions can be proposed concerning the reasons for the concurrent use of square notation and Aquitanian notation, and the concurrent use of different classes of each of these two, to name only two of the problematic issues. Do the answers lie, for example, in the training of notators, the movement of manuscripts or people (or both) from one place to another, personal preference, "house styles" of scriptoria, or a lack of concern for uniformity?

The diversity in notation styles has necessitated the identification of ways in which the notation might be classified and the subsequent grouping of sources into different classes of notation, together with the establishment of features of each class. It is hoped that this classification may be of assistance in further research into both Aquitanian and square chant notations.

One of the interesting features to emerge from the notation study is the presence of variation from the forms of the notations used in other regions. For example, it is noteworthy that despite the proximity of Zamora to Portugal, the Portuguese style of Aquitanian notation identified by Solange Corbin, in which the lozenge is employed to indicate semitones, has not emerged in any of the Zamoran sources. Also, the semicircular virga with its usage as 
the top note of a major second is of particular interest because of the variation of this usage from that found elsewhere.

In the area of late Aquitanian notation, the apparent change in the meaning of the cephalicus from a liquescent sign to a note of double duration, is a surprising and possibly significant discovery which it is hoped may be further examined from the point of view of other late medieval sources of Aquitanian notation on the peninsula. In fact, Aquitanian notation as it was used from the late 13 th century through to the late 15 th or early 16 th centuries is a topic which in general remains in need of much further investigation.

Square notation sources have shown change in the form of the pes and other note forms, as well as the Spanish preference for the five-line staff. The variation in the meaning of the plica is a topic with important ramifications for performance. Although it is not possible to make general rules from the findings of this study, the suggestion has been made here that the 14th-century chant sources should receive a liquescent style of performance of the plica while in 15 th- to early 16 th-century sources the plica should be performed as a note of double duration. The 15th-century Ritual of Zamora presents important evidence for the performance of the plica as a long note, through the remarkable association of text accent and plica. In late chant sources written in the signs of mensural notation, the plica should receive two or even three notes as has been discussed.

Sources of both polyphony and chant have been found to demonstrate the use of mensurally influenced notations in which mensural signs may be with or without durational significance and which are mixed with the classic signs of chant notation to which no durational significance seems to be attached. While certain mensural note forms have occurred repeatedly in semi-mensural or pseudo-mensural contexts in sources of chant and other types of music in and out of Spain, a full understanding of their usage has not yet been achieved. This topic seems to be one that is of particular importance for Spanish sources in which such notation appears to have been relatively frequent and was employed for a variety of music. The music of the Cantigas de Santa María, for example, may come to be further illuminated by greater understanding of semi-mensural and pseudo-mensural notations. 
It is hoped that future investigation along lines such as those employed here, making use of the same or similar classifications, will be pursued into sources of Aquitanian and square notation from other regions and various monastic orders ranging through the earlier to later Middle Ages. This writer believes that as a result of further research, patterns will emerge enabling the establishment of more identifiable notational features associated with particular times, places, and traditions than has previously been possible in both Aquitanian and square chant notations. These features are likely to show local and regional forms or perhaps features associated with particular monastic traditions, and in addition, changes over time would be more accurately recognized.

The difficulty of identification for the fragments of place of origin and intended liturgical employment, as well as date of copying the sources, has presented difficulties and limited the conclusions which could be reached in this dissertation. Thus, it is largely only information gleaned from the Ritual and the Misal votivo which may be viewed with certainty as belonging to Zamora. A second major difficulty encountered was the paucity of studies of Spanish chant sources of the Middle Ages. This lack has restricted comparison in both the areas of notation and repertory but because of the considerable opportunity for study of notation within the range of Zamoran sources, the lack of other studies presented a lesser problem in this area than for repertory comparison. Fortunately, it has been possible to compensate for this lack to some extent by the employment of catalogues of chants from a wide range of European manuscripts as well as published material such as that of Paléographie Musicale and Analecta Hymnica. It is, nevertheless, to be hoped that catalogues of chants similar to those available for other regions will be produced for Iberian sources, and the present study is seen as offering a contribution to the fulfilment of this need.

In order to present substantial conclusions upon the repertories of the genres studied it would have been necessary to have had amongst the Zamoran sources complete (or reasonably complete) graduals, antiphoners, kyriales, or prosers. Nevertheless, the results of the search for texts and melodies in other sources and the subsequent comparisons have provided some useful results. These must contribute to future studies of Ordinary of Mass chants, prosae, responsory prosae, hymns, prefaces and Pater noster, and especially to the building of a broad view of their repertories as they existed on the Iberian Peninsula. 
Perhaps the most interesting discovery in this area is the identification of five hymn melodies unknown to Bruno Stäblein's study, Hymnen, and also of one unknown hymn text. A study of hymns in Iberian sources would seem on the strength of this result to be a particularly interesting one which may bring to light an interesting repertory of local melodies and texts. The early history of such a repertory may show connections with Old-Hispanic liturgical traditions and with particular monasteries (perhaps Cluniac) in southern France, while the late history is likely to represent new, locally composed hymns of which Iesus ab ore, found in a late Zamoran fragment, may well be an example. The findings concerning the usage of the two Pater noster tones, although both known elsewhere, may also prove to be significant and to be indicative of local or regional usage. On the other hand, amongst the four Ordinary of Mass chants for which catalogues are available (Kyrie, Gloria, Sanctus, and Agnus Dei), only one Kyrie melody was unidentifiable, whilst all prosae melodies were found in sources from outside the peninsula as were the melodies of the prefaces and Pater noster.

Variants in text and melody found in comparison with sources from inside and outside of the peninsula have been noted and in some cases appear to be of particular interest. The findings of frequent use of liquescent neumes and bistrophae in prosae and opening liquescence in hymns are noteworthy features worthy of further investigation; these may represent a local or regional melodic style characterized by a liking for liquescence and simple ornamentation. Another type of melodic variant is that exemplified in the first phrase of the Kyrie Clemens rector. This variant has already been found to be shared with two other Spanish sources and one southern French source. Again, one may postulate a regional tradition expressed in the Zamoran melody, the example suggesting the interconnectedness between southern French and Iberian sources which in this and other studies has appeared on a number of occasions. Furthermore, from the example of Clemens rector, arises the question of melodic types preferred in a region. Could the opening step-wise rise of a third ( $F$ to a) common to the Zamoran and other sources instead of the opening step-wise ascent of a fourth ( $F$ to $b$-flat) found elsewhere represent a larger phenomenon of melodic preference? Such a postulation would have to be carefully tested with a wide representation of sources and melodies available for comparison. 
Although not a principal focus of this study, efforts have been made throughout to identify connections between Zamoran sources and the practices of various traditions. Despite the fact that the task is fraught with difficulty and to be conclusive it is a very large task, some pointers have been found. Firstly, the role of the Cluniac monks from southern France was great in the 12th-century establishment of the episcopacy in Zamora and some evidence has been found suggesting their imprint upon the liturgical practice of the diocese. The results of the work of Pedro Romano Rocha on liturgical comparison and the likeness of chants in a few of the fragments (especially 13th-century ones) to those in Cluniac sources, combined with Cluny's important 11th- and 12th-century presence in the region (not limited to the episcopacy) indicate that the extent of the Cluniac influence on chant in the Zamoran sources would be a topic well worth pursuing in depth. Secondly, and more generally, the transmission of chant and Aquitanian notation from southern France remains a topic needing further attention; throughout the present study, a connection between southern or south-western French sources has arisen repeatedly. While associations with Cluny and southern France are likely to be particularly prevalent in the early sources with their traces continuing through late medieval practices, later sources might be expected to reflect the practices of the Cistercian, Dominican, and Franciscan orders as these came to be prominent in the region. A Cistercian presence may be suggested by the polyphonic source Z 184 with its three works which are found in $\mathrm{Hu}$, a source belonging to the Cistercian convent of Las Huelgas, while a Dominican presence is suggested at least by the office for St. Peter Martyr in the fragment $Z$ 226. The wealth and importance of Cistercian and Dominican monasteries in the region of Zamora makes the representation of their presence likely amongst the sources.

Surprising and indicative of a potentially important direction of future study is the finding of a Catalan connection for some texts found in sources of Zamora. This has been enabled by the broad-ranging comparative studies of Spanish sources made by Jane Morlet Hardie in which groups of chants for Holy Week have been isolated from sources of different regions. One of these groups comprises the Kyries tenebrarum, part of which are found in Z 269. Comparison of the two verses found in Z 269 with Morlet Hardie's findings shows that the material is likely to have been part of the office for Maundy 
Thursday. Morlet Hardie was able to show that these two verses were characteristic of a number of Catalonian chant sources from Barcelona and Vich dating from the 14th to 16th centuries, with the only non-Catalonian source to use the two verses being from mid 16th-century Santiago de Compostela; sources from other centres including Gerona and Toledo do not use the two verses. ${ }^{1}$ Morlet Hardie concluded that a Catalonian tradition of Kyries tenebrarum appears to have existed in which the texts differed substantially from those usually employed outside of Spain and also in other parts of Spain. ${ }^{2}$ Furthermore, study of the 14th-century Breviario of Zamora shows that the same two verses are given there for Maundy Thursday. ${ }^{3}$ The Zamoran practice may therefore be added to the pattern demonstrated by Morlet Hardie, the texts in use in Zamora belonging to the tradition connected with sources of Cataluña and Santiago de Compostela. Comparison of another fragment, Z 218, with Morlet Hardie's findings on Lamentation texts and associated responsories and their verses in Spanish sources shows again a connection with Catalonian practice. ${ }^{4}$ Future studies of chant in Zamoran sources with a concentration on the earliest sources might be undertaken to attempt the finding of other connections with Catalan practices. Such a study would meet with the usual difficulty of lack of studies from other parts of Spain; nevertheless, the historical connection with Cluny and Catalan clergy in the nearby area known as the Campi Gothicorum brings to this topic an intriguing potential.

Some evidence for Zamoran links with the traditions of Braga and Santiago de Compostela is also available. For Braga, evidence is at the present stage of research limited to the findings of Rocha. For Santiago de Compostela there is the evidence of the Kyries tenebrarum verses, the two for Maundy Thursday already mentioned being found in Catalonian sources and one from Santiago de Compostela. The third verse for Maundy Thursday and those for the following two days given in the Breviario ${ }^{5}$ are, with the exception of one small change, the same as those found in the Santiago de Compostela

${ }^{1}$ Jane Morlet Hardie, "Kyries tenebrarum in Sixteenth-Century Spain”, Nassarre 4 (1988): 174-75.

${ }^{2}$ Morlet Hardie, "Kyries tenebrarum", 173-74.

${ }^{3}$ Breviario, fol. 99.

${ }^{4}$ Personal communication from Dr. Jane Morlet Hardie.

${ }^{5}$ Fols. $99^{\nu}-103^{\nu}$. The same nine verses are also to be found in the mid 16th-century Zamoran breviary, Ma R 25990, fols. $169^{\prime}-175^{\circ}$. 
source. ${ }^{6}$ This then suggests a close link between Santiago de Compostela and Zamora. Zamora was, of course, part of the ecclesiastical province of Santiago de Compostela by the beginning of the 13th century; could similarities in the practices of Zamora and Santiago de Compostela be partially explained by this fact? Furthermore, at about the same time that Zamora had Cluniac bishops, Cluniacs were also present in this capacity in both Santiago de Compostela and Braga, and their presence may offer another source of the similarities between the practices of Zamora and these other two centres.

The picture of connections with other traditions which emerges is thus a complex one. From the studies of Ordinary of Mass chants, prosae, hymns, as well as preface and Pater noster chants in the Zamoran sources, no clear pattern of relation other than a repeated association with Spanish or French, usually southern French, sources is found, whilst the study of the polyphonic works shows connections with other Spanish regions. The notation studies reveal commonly found Spanish practices but in general the notation employed is very much a part of the wider tradition of usage of both Aquitanian and square notations. The results of this study suggest that for research into Spanish medieval liturgical sources, southern French practices should be taken increasingly into consideration.

The view of relations with the Zamoran practices as represented in the material studied here must in some cases be tempered by the fact that the AHPZa sources are without clear evidence of provenance and thus cannot be said with certainty to have been originally used or copied in the region of Zamora. As has been discussed, however, it seems likely that the manuscripts employed in binding would have formerly been in liturgical use not very distant from the binder's place of work and therefore probably in a church or monastery of the region of Zamora. Comparison of the feasts represented in the fragments with the calendar of the Church of Zamora shows two that are not included in the latter. These are the Visitation and Continentium; the first, however, is added to the end of the Breviario $^{7}$ and the second has been found in the mid 16th-century breviary of Zamora held in Madrid. ${ }^{8}$ The local feasts of Zamora, such as the Invention of St. Ildefonsus do

\footnotetext{
'Morlet Hardie, “Kyries tenebrarum”, 175.

${ }^{7} J a n i n i$, Manuscritos, 327. Breviario, fol. $466^{\text {F }}$.

${ }^{8}$ Ma R 25990, fols. $263^{\mathrm{v}}-264^{\text {? }}$.
} 
not appear amongst the fragments. Unfortunately, a full comparison of the liturgical content of the fragments with the Breviario and the Ritual, in order to determine their coincidence with the liturgy of the Church of Zamora, could not lie within the scope of this dissertation.

The name of the 13th-century scholar Juan Gil de Zamora is one known to students of medieval music and may draw the medievalists attention to the town after which he is named. His musical treatise while valuable in other ways, does not assist in the study of the Zamoran sources studied here; however, it is interesting to speculate on a possible role which he may have played in bringing repertory and advanced musical techniques into the region. He appears to have been a well equipped scholar who moved in influential circles and had a period of study in Paris. Could he, following his experience in Paris or at the court of Alfonso X, have encouraged the singing of polyphonic liturgical music in the churches of Zamora? There is no evidence that this was the case but the idea presents an interesting answer to the question of how a manuscript probably dating from the second half of the 13 th century or beginning of the 14 th century and containing polyphonic works also in $\mathrm{Hu}$, a manuscript of the wealthy Burgos monastery of Las Huelgas, came to be in Toro in the region of Zamora. Some evidence for Gil's involvement in the Church of Zamora in addition to his monastery in the town may exist in the list chantres of the cathedral. It seems that a man by the name of Gil held this post in the mid 13th century. Might this have been the same person as the scholar and writer of the Ars musica? Future research may be able to answer this question.

The fact that five polyphonic works were discovered amongst the Zamoran sources is interesting in itself as their discovery immediately suggests that more unknown sources of medieval polyphony may exist in the smaller Spanish centres. Furthermore, their existence in Zamoran sources gives evidence of a more widely practised polyphonic tradition in Spain than it has previously been possible to demonstrate. Many questions arise from these works which further research may answer. These concern issues such as the importance of oral transmission of polyphonic works, the variation found between the Zamoran examples and their concordances in other Spanish sources, the places where the works were performed, and the frequency and liturgical contexts of employment of polyphony in the region of 
Zamora. The fact that all the works are related to others with or without the same text in Spanish sources has intriguing implications concerning the nature of the polyphonic tradition in medieval Spain. One may postulate a tradition of discant singing in two or three parts spread across at least the northern half of the peninsula from Cataluña to western Castilla-León during the second half of the 13th century and the 14th century, perhaps existing as an oral tradition but one which was occasionally recorded in notation. A noteworthy feature of both the Zamoran sources with polyphony is their practicality. The earlier, Z 184 , is exceptional for a source of liturgical polyphony in that it included the monophonic chant to be interspersed with the polyphonically set sections of the works and also in its unusually large size which suggests its employment by more than one person at a time. The two works of the Misal votivo are given together with the full masses in which they are sung so that their liturgical contexts are clear. While efforts exerted by the writer in Zamora have failed to produce any further examples of medieval polyphony, the possibility continues to exist that more may come to light there and in others of the smaller Spanish centres. This is yet another area of Spanish medieval music which is still to be illuminated by future research and which holds some exciting possibilities for discovery and knowledge. 


\section{APPENDIX 1 : SOURCE DESCRIPTIONS}

The Pergaminos musicales of the AHPZa are treated first, followed by the Ritual and the Misal votivo. Explanatory notes are given below for each of the categories employed in the descriptions. The descriptions of the Pergaminos musicales reflect their nature as fragments and their employment as binding material. To take one example, this means that prior to their being cut down to a size suitable for binding, foliation may have been used more frequently than is now evident. Question marks indicate uncertainty in a description which may be due to problems such as poor legibility or reduced size of a fragment.

In the process of studying the fragments, it was found possible to sort many into the Books and Groups identified here. Under the name Book are fragments which are so alike in copying style and other factors as to suggest their likely provenance from a single manuscript. A Group contains fragments which while similar, are not sufficiently alike to warrant the name Book. On the other hand, Groups may in fact have been part of one manuscript and simply represent some variable such as changing scribes. The classification into Books and Groups is that of this writer and is not employed by the AHPZa. Fragments which are not placed into Books or Groups are named individually using the numbers assigned to them by the archive. Most of the factors upon which the groupings have been made are shown in the descriptions; it has not been possible to give others which include, for example, further notational details. Books and Groups with Aquitanian notation are identified by letters, while those in square and mensurally influenced notations are identified by numbers.

\section{Explanatory Notes}

Fragments: Each fragment with notation in a Book or Group is named.

Dating: Broad datings are given. None of the sources show a date of copying.

Notaries: These are the names of the notaries responsible for the protocol books on which the Pergaminos musicales were used as binding. (In order to avoid inconsistency acute accents are not used in these names; some records in the archive employ them, while others do not, undoubtedly a reflection of changing practices in usage of 
accents.)

Page size: Width is given first, followed by height. This is usually that of the largest folio in a Book or Group. (The full measurements of bifolios are not given.)

Page layout: First is given the number of columns per page. Secondly is given the number of staffs per column, but if a source contains no full column of staffs (i.e. all columns of the source contain text not set to music) the number of lines in a column is given; such lines are those usually ruled during manuscript preparation and upon which were placed text or notation by the scribes. Thirdly, for Aquitanian notation sources, is given the distance between staffs. This is not identified for square notation and mensurally influenced notation sources, instead for these the height of staffs is given as part of the description of the staff. Lastly and mainly for the earliest sources, "above top line" scribal practice is identified when visible, this term referring to the placement of the first line of writing above the topmost ruled line.

Foliation: Placing of foliation described if present. Foliation is only very rarely found in all fragments of a group or book.

Script: All use gothic script unless otherwise specified. Details of the scripts are included only for the fragments of classes $1 \mathrm{a}$ and $1 \mathrm{~b}$, as these date from the 12th and 13th centuries. For that period, the developments in gothic script may be more readily identified chronologically than is generally possible for later periods of its use. ${ }^{1}$ The descriptions largely apply to scripts of texts such as lessons which are not underlaid to notation. This is because the underlay style is sometimes quite different from the main text style and may diverge from formal gothic techniques.

Initials: These are described hierarchically when relevant, beginning with the most important. Variation in size is not identified if the same type of initials are used for readings and chants.

Notation: The class numbers established in Chapter 4 are used here.

Staff: The number and colour of staff lines are given, as well as the height of four and five red line staffs .

${ }^{1}$ On details of the changing features of early gothic script as used in Spain, see Millares Carlo, Tratado de paleografla española 1: 184-91. 
Virgules: Indication of the usage of single virgules is given. In those fragments where virgules principally separate words, it is usual that not all monosyllabic words receive a virgule. This practice has not been identified as it is common and may be taken as implied when virgules are described as separating words.

Liturgical placement: First identified here is use in Office or Mass. Details of day and hour are given as far as practical. It has not been possible to identify the liturgical placement for all fragments or all parts of fragments; therefore, for some, the description of liturgical placement is only partial or is stated as "unidentified". ${ }^{2}$ The often problematic identification means that entries under this heading for the fragments should generally be viewed as a guide which may be confirmed or altered in future as a result of further information. On the other hand, some feasts are indicated by rubrics and these are underlined (hours are not underlined even when indicated by rubrics). Feasts which have no notated chants are only named exceptionally.

Additional comments: Further information which is judged to be of particular interest or importance.

\section{PERGAMINOS MUSICALES, ZAMORA, ARCHIVO HISTÓRICO PROVINCIAL}

\section{Aquitanian Notation}

\section{Book A}

Fragments: Z 196, Z 199, Z 200.

Dating: 2nd half 12 th century.

Notary: Antonio de Sotomayor, Toro.

Page size: $275 \mathrm{~mm} \times 400 \mathrm{~mm}$.

Page layout: 2 columns, 38 or 39 lines, $16-18 \mathrm{~mm}$ between staffs, above top line.

Foliation: none.

Script: late carolingian/early gothic style with rounded forms; uncial $d$ at word ends and occasonally within, upright $d$ more common within and used initially; ligature $r$

${ }^{2}$ Identification has been made with the assistance of a variety of sources including: $P M 9, P M 12$, $P M 13$, Antiphonale Sarisburiense, Graduale Sarisburiense, SCRIBE database, $C A O$ 1, $A H$, and Bryden and Hughes. 
sometimes used after $o$, not after $b$ or $p$; upright $s$ at word ends, rare use of looped $s$ at word ends especially in abbreviations (for example $d s$ ); no fusion of bows; ampersand and tironian $e t$, ampersand also used as part of words; final $m$ sometimes written with the first and second minims in the form of an $o$ and the third minim curved in towards the $o$-shape.

Initials: 1 . black with red decoration; 2 . plain red or black.

Notation: class 1a.

Staff: 1 dry-point line.

Virgules: a few strokes apparent which may be virgules.

Liturgical placement: Office. After Epiphany Sunday? - matins, feria 4 - vespers, feria 5 matins (Z 196). Octave of Epiphany - lauds; Sunday? after Epiphany; after Epiphany feria 5 - matins, lauds, vespers; after Epiphany feria 6 - matins (Z 199). Christmas octave - matins, lauds; Epiphany - Epiphany and octave - sext, none, matins (Z 200).

Additional comments: Red ink is occasionally used for notation in Book A but its significance is not evident. Another unusual feature is the decoration given to the rubric abbreviations $a$ for antiphon and $v$ for verse. The decoration is most noticeable on the $a$ and consists of as many as eleven dots or dashes placed in an almost vertical line above the letter (see Plate 1 on page 108). Could this ornamentation have been carried over from the traditions of abbreviation used in manuscripts of the Old-Hispanic rite? A horizontal dash with or without a dot above it was the most common sign of abbreviation in the Visigothic script and could indicate a variety of abbreviations. ${ }^{3}$ Similar signs are found above the letter $a$ indicating antiphon in $\mathrm{Z} 15$ which uses Visigothic script and in the Antiphonal of León ${ }^{4}$ also written in Visigothic script but with Mozarabic neumes. Another source to use similar ornamentation above $a$ is a fragment in Santiago de Compostela (Archivo de la Catedral, frag. 3). It has Visigothic script and Aquitanian notation, and it is believed not to have originated in Santiago de

${ }^{3}$ Millares Carlo, Tratado de paleografla española 1: 89.

${ }^{4}$ Louis Brou, and José Vives, eds., Antifonario visigótico mozárabe de la Catedral de León, Monumenta Hispania Sacra, Serie Litúrgica 5 (Barcelona: Consejo Superior de Investigaciones Ciéntificas, 1959), fol. $127^{\vee}$ (and other folios). 


\section{Compostela..$^{5}$}

\section{Book B}

Fragments: Z 1, Z 3

Dating: 13th century (1st half?).

Notary: Francisco Gonzalez de Valderas, Toro.

Page size: $510 \mathrm{~mm}$ x $370 \mathrm{~mm}$.

Page layout: 2 columns, 40 lines, $20 \mathrm{~mm}$ between staffs, above top line.

Foliation: none.

Script: upright $d$ preferred, uncial $d$ at word ends; ligature $r$ after $o, p$, and $b$; looped $s$ at word ends; little fusion of bows; tironian $e t$.

Initials: 1 . one large decorated initial in yellow and blue with animal-like heads; 2 . ornately flourished in varying sizes with four colours - blue, orange, green, purple; 3 . plain black.

Notation: class $1 b$.

Staff: 1 yellow line.

Virgules: none.

Liturgical placement: Office. St. Thomas of Canterbury - vespers, lauds (Z 1); $\underline{\text { St. James }}$ apostle (Z 1 - text only). Apostle, vespers and matins $(Z 3)$.

Additional comments: $\mathrm{Z} 1$ appears to contain the closing portion of a rhymed office for St. Thomas of Canterbury. Of the five chants, three are found in volume 17 of $A H$ as part of a rhymed office in the saint's honour uniquely in Spanish sources. ${ }^{6}$ Only two sources are named, both from the 1540s: a breviary of Calahorra and another of an Hieronymite monastery. ${ }^{7}$ As St. Thomas was canonized in 1173, the probably 13th-century Z 1 reflects the rapid spread of his commemoration throughout Europe. ${ }^{8}$ The first four chants belong to lauds but the final one is a Magnificat antiphon. The

5Manuel C. Díaz y Díaz, Códices visigóticos en la monarquía leonesa (León: Centro de Estudios e Investigación "San Isidoro", 1983), 466 and plate 63.

${ }^{6} \mathrm{AH}$ 1: 179-81.

${ }^{7} A H$ 1: $181 ; A H 16: 12$ and 16 , for more complete references to the sources.

${ }^{8}$ David Hugh Farmer, The Oxford Dictionary of Saints (Oxford: Clarendon Press, 1979), 377. 
incipits of the texts are given below; the hymn and the Magnificat antiphon are those not found in $A H$.

[Antiphon] - (Laudemus Dominum quod doctrina)

Antiphon - Condignus thomas (ca)ntuarie recipitur

Hymn - Laudis ergo preconium

[Antiphon] - Honorabilis Angliae (closing Lauds antiphon)

Magnificat Antiphon - $O$ beata thoma martir

\section{Book C}

Fragments: Z 52, Z 53, Z 57, Z 67, Z 68.

Dating: 1st half/mid 13th century.

Notary: Francisco de Benavides, Toro.

Page size: $220 \mathrm{~mm} \times 300 \mathrm{~mm}$.

Page layout: 1 column, 12 staffs, $19-22 \mathrm{~mm}$ between staffs, above top line.

Foliation: none.

Script: upright $d$ more frequent than uncial $d$, upright $d$ used initially and internally, uncial $d$ used finally and internally; ligature $r$ after $o, p$, and $b$, looped $s$ used finally, used singly with an abbreviation mark; little fusion of bows; tironian $e t$.

Initials: 1 . red flourished with blue, blue flourished with red; 2 . as the previous but smaller, also black flourished with black; 3. plain black or red.

Notation: class $1 \mathrm{~b}$.

Staff: 1 yellow line in all but Z 52. The staff line appears to have been drawn over alternate dry-point lines, although in some places the yellow line has faded so that it is barely visible, and in one chant (Clemens rector omnium) the yellow line appears never to have been inserted. Z 52 makes use only of alternating dry-point lines for the staff.

Virgules: few.

Liturgical placement: Mass. Christmas Day (Z 52, Z 67). 9th Sunday? after Pentecost (Z 53). 2nd Sunday of Lent, 2nd week of Lent feria 2, 3rd Sunday of Lent, 3rd week of Lent feria 2 (Z 57). Mass of the Dead?; Kyrie, Gloria (Z 68). Gloria (Z 67). 
Additional comments: $\mathrm{Z} 68$ and $\mathrm{Z} 67$ are consecutive folios with the final chant of $\mathrm{Z} 68$ completed at the top of the recto of $\mathrm{Z} 67$. Six additional fragments to those listed above (Z 49, Z 50, Z 51, Z 55, Z 56, Z 66) should be placed with Book C. The six contain no music, although in $\mathrm{Z} 55$ and Z 56, space has been left for the insertion of notation of chants for the celebration of the Dedication of the Church.

\section{Book D}

Fragments: Z 99, Z 107, Z 191, Z 194.

Dating: late 13th/14th century.

Notaries: Baltasar de Mansilla, Vezdemarbán; Manuel Simon, Vezdemarbán.

Page size: $355 \mathrm{~mm}$ x $496 \mathrm{~mm}$.

Page layout: 2 columns, 20 staffs, $15-20 \mathrm{~mm}$ between staff, above top line?.

Foliation: none.

Initials: 1 . red flourished with blue, blue flourished with red; 2 . sepia and red with jagged and barred decoration; 3. sepia or red decorated or plain.

Notation: class 2.

Staff: 1 red line.

Virgules: few.

Liturgical placement: Office. St. Saturninus - matins, lauds (Z 107, Z 194). St. Andrew vespers, matins, lauds (Z 194, Z 99, Z 191). St. Nicholas - vespers, matins (Z 191). Additional comments: Staff line appears freely drawn and is rarely straight.

\section{Book E}

Fragments: Z 222, Z 224, Z 225 .

Dating: late 13 th/14th century.

Notary: Alonso de Salamanca, Zamora.

Page size: $320 \mathrm{~mm}$ x $445 \mathrm{~mm}$.

Page layout: 2 columns, 16 staffs, $20 \mathrm{~mm}$ between staffs.

Foliation: none.

Initials: 1 . red flourished with blue, blue flourished with red; 2 . sepia with jagged decoration. 
Notation: class 2.

Staff: 1 red line.

Virgules: separating words or phrases.

Liturgical placement: Office. Trinity - matins, lauds; Sunday in Pentecost - matins (Z 222). St. Katherine - matins ( $\mathrm{Z} 224, \mathrm{Z} 225)$.

\section{Group F}

Fragments: Z 217, Z 228, Z 229, Z 230, Z 233.

Dating: late 13th/14th century.

Notaries: Alonso de Salamanca, Zamora; Diego de Medina, Zamora; Juan Tabuyo, Zamora.

Page size: $388 \mathrm{~mm} \times 570 \mathrm{~mm}$.

Page layout: 2 columns, 20 staffs, $20-24$ mm between staffs.

Foliation: none.

Initials: 1 . red flourished with blue, blue flourished with red; 2 . sepia with red filler; 3. plain alternating red and blue.

Notation: class 2 .

Staff: 1 red line.

Virgules: separating words, occasionally phrases.

Liturgical placement: Office. Christmas Day - matins, lauds, vespers (Z 217). Christmas? (Z 230). 3rd Sunday in Lent - matins (Z 229). Passion Sunday? - matins (Z 228). Historia of Judith (Z 233).

Additional comments: Z 233 has a varying notation from the remainder of the group suggestive of a different perhaps later notator whose style was closer to square notation.

\section{Book G}

Fragments: Z 25, Z 26.

Dating: 14 th/15th century.

Notary: Alonso Meleno, Toro.

Page size: $240 \mathrm{~mm}$ x $365 \mathrm{~mm}$. 
Page layout: 2 columns, 16 staffs, $17-19$ mm between staffs.

Foliation: none.

Initials: 1 . red flourished with red; 2 . red and sepia.

Notation: class 2.

Staff: 1 red line.

Virgules: few.

Liturgical placement: Office. Sunday in Septuagesima - matins, lauds.

\section{Group H}

Fragments: Z 64, Z 204.

Dating: 14 th/15th century.

Notaries: Francisco de Benavides, Toro; Francisco Garcia de León?, Toro.

Page size: $270 \mathrm{~mm} \times 409 \mathrm{~mm}$.

Page layout: 2 columns, 24 lines (variable), $32-33 \mathrm{~mm}$ between staffs.

Foliation: none.

Initials: 1. red, plain or with red flourishing; 2 . sepia and red with jagged decoration, sepia with jagged decoration, plain red.

Notation: class 2.

Staff: 1 red line.

Virgules: irregular, tending to separate words when melismatic, otherwise tending to separate phrases.

Liturgical placement: Mass. St. Katherine, Conception BVM (Z 64). Unidentified (Z 204).

\section{Book I}

Fragments: Z 215, Z 216.

Dating: 15 th century.

Notary: Fernando de Cabañas, Zamora.

Page sizes: $220 \mathrm{~mm} \times 510 \mathrm{~mm}$ (cut vertically).

Page layout: 1 column, 8 staffs, $46 \mathrm{~mm}$ between staffs. 
Foliation: none.

Initials: red with flourished with blue, blue flourished with red.

Notation: class 2.

Staff: 1 red line. It appears that the red line was drawn between two faintly drawn text lines and the latter used as guides allowing one note per space, the larger spaces above and below these taking more notes.

Virgules: separating words.

Liturgical placement: Mass. Lent (Z 216). Quinquagesima (Z 215, Z 216).

\section{Z 9}

Dating: 13th century (1st half?).

Notary: Francisco Gonzalez de Valderas, Toro.

Page size: $305 \mathrm{~mm} \times 380 \mathrm{~mm}$.

Page layout: 2 columns, 20 staffs, $14 \mathrm{~mm}$ between staffs, above top line?.

Foliation: none.

Script: upright $d$ and uncial $d$; ligature $r$ after $o$ and $b$; looped $s$ at word ends; no fusion of bows; tironian $e t$.

Initials: 1 one large uncoloured initial with interweaving vine-like pattern; 2 . blue with flourished with red, red flourished with sepia; 3. plain sepia.

Notation: class $1 \mathrm{~b}$.

Staff: 1 dry-point line.

Virgules: few.

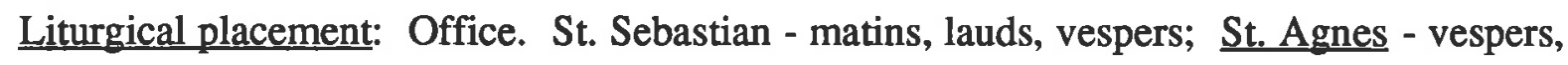
matins.

\section{$\mathbf{Z} 15$}

Dating: 1 st half 12 th century.

Notary: Francisco de Andujar, Toro.

Page size: $163 \mathrm{~mm} \times 280 \mathrm{~mm}$.

Page layout: 1 column, 36 lines, $13 \mathrm{~mm}$ between staffs, above top line. 
Foliation: none.

Script: Visigothic. Certain aspects suggest a transitional style showing Carolingian influence, as for example in the use of the abbreviation of pro consisting of a $p$ with an $o$ placed above. ${ }^{9}$

Initials: 1 . plain red with black outline; 2 . plain red.

Notation: class $1 \mathrm{a}$.

Staff: 1 dry-point line.

Virgules: none.

Liturgical placement: Office. Saturday after Epiphany - lauds, vespers.

Additional comments: Contains antiphon series for these two hours; these are the same as found in the Breviario of Zamora (fol. 50v) but not identical to lists given in CAO. The lists are very similar to those of a fragment located in Guimarães (Arquivo Alfredo Pimenta) in Portugal. The source, which is numbered B12-4-9, is very likely to be later than Z 15; it employs Aquitanian notation and gothic script. ${ }^{10}$

\section{Z 58}

Dating: 13th century (1st half?).

Notary: Francisco de Benavides, Toro.

Page size: $188 \mathrm{~mm}$ x $218 \mathrm{~mm}$.

Page layout: 1 column, 30 lines, 13-15 mm between staff lines, above top line?.

Foliation: none.

Script: uncial $d$ and upright $d$ used initially and internally, uncial $d$ used finally; ligature $r$ after $o$ and $p$; looped $s$ used finally; partial fusion of bows; ampersand and tironian et.

Initials: 1. red flourished with blue, blue flourished with red; 2. black flourished with black; 3. plain black.

9The formation of abbreviations by the placing of a letter above another was only used in the transitional Visigothic script, see Millares Carlo, Tratado de paleografia española 1: 89. The combination of Visigothic script and Aquitanian notation was discussed in Chapters 1 and 4.

${ }^{10}$ Discussion of the fragment and listing of its contents in Wesley D. Jordan, "A Collection of Early Antiphoner Fragments", 426-40. 
Notation: class $1 \mathrm{~b}$.

Staff: 1 grey line

Virgules: few.

Liturgical placement: Office. Trinity Sunday - matins.

Additional comments: The staff line appears to have been added after the notation as spaces can be seen in many places on either side of the notes. The colour may have faded from a light sepia or a yellow. (As both rubrics and lines between the words of the underlaid text remain vividly red, it is unlikely that the grey line was originally red.)

\section{Z 59}

Dating: 13th century (1st half?).

Notary: Francisco de Benavides, Toro.

Page size: 305 wide $\times 220 \mathrm{~mm}$ high (lower portion of folio only remains).

Page layout: 2 columns, 16 lines, 18-21 mm between staffs.

Foliation: none.

Script: upright $d$ more frequent than uncial $d$; ligature $r$ after $o$, not after $b$; looped $s$ at word ends; little fusion of bows; no abbreviation of $e t$.

Initials: 1. one pictorial initial with a seated figure (St. Agatha?) in sepia, blue-green, and yellow; 2. green flourished with red, red flourished with red; 3. plain black.

Notation: class $1 \mathrm{~b}$.

Staff: 1 dry-point line.

Virgules: none?

Liturgical placement: Office. St. Agatha - matins

\section{Z 90}

Dating: 15 th century.

Notary: Gaspar Hernandez Vaca, Toro.

Page size: $370 \mathrm{~mm}$ x $435 \mathrm{~mm}$.

Page layout: 1 column, 5 staffs, $75 \mathrm{~mm}$ between staffs. 
Foliation: none.

Initials: red flourished with blue, blue flourished with red.

Notation: class 2 .

Staff: 1 red line. Also uses fine sepia-coloured lines drawn perhaps for text, two above and two below the red line; the lines are used as for square notation.

Virgules: none

Liturgical placement: Office. Unidentified - matins, lauds.

\section{$\mathbf{Z} 100$}

Dating: 15th century.

Notary: Antonio Gomez, Toro.

Page size: $380 \mathrm{~mm} \times 480 \mathrm{~mm}$.

Page layout: 2 columns, 7 staffs, $50 \mathrm{~mm}$ between staffs.

Foliation: none.

Initials: 1 . red flourished with blue, blue flourished with red; 2 . sepia and red with jagged and barred decoration.

Notation: class 2.

Staff: 1 red line. Variable use of text lines between staffs so that either one or two notes is observable in the spaces between lines.

Virgules: separating words?

Liturgical placement: Office. St. Saturninus - matins?

\section{$\mathrm{Z} 123$}

Dating: 13th century (1st half?).

Notary: Antonio Catalan, Toro.

Page size: $362 \mathrm{~mm}$ x $510 \mathrm{~mm}$.

Page layout: 2 columns, 20 staffs, $20 \mathrm{~mm}$ between staffs, above top line?.

Foliation: verso, top centre.

Script: upright $d$ preferred; ligature $r$ after $o$ and $p$; looped $s$ at word ends; facing bows not fused; tironian $e t$. 
Initials: 1 . red or blue flourished and coloured with blue, red, purple, and green; 2. plain red or black.

Notation: class $1 \mathrm{~b}$

Staff: 1 yellow line, more or less drawn over alternate text lines.

Virgules: very few.

Liturgical placement: Office. Purification BVM - matins, lauds.

\section{Z 149}

Dating: 14 th/15th century.

Notary: Tirso Hernandez, Vezdemarbán.

Page size: $275 \mathrm{~mm} \times 407 \mathrm{~mm}$ (double folio).

Page layout: 2 columns, 9 staffs, $32 \mathrm{~mm}$ between staffs.

Foliation: recto, top centre.

Initials: 1. red flourished with blue, blue flourished with red; 2 . sepia with jagged decoration and red highlighting.

Notation: class 2 .

Staff: 1 red line drawn between two text lines. The latter two lines are used as guides, one note per space between the text and red lines with the larger spaces above and below these lines taking two notes.

Virgules: separating words.

Liturgical placement: Mass. 2nd week of Lent, ferias 2, 3 and 4.

Additional comments: bifolio with consecutive foliation.

\section{Z 171}

Dating: 2nd half 12 th century.

Notary: Alonso Martin, Pinilla de Toro.

Page size: $320 \mathrm{~mm}$ x $300 \mathrm{~mm}$ (top cut off).

Page layout: 2 columns, 25 lines, $18 \mathrm{~mm}$ between staffs.

Foliation: none.

Script: upright $d$ preferred, uncial $d$ at word ends only; ligature $r$ after $o$, not after $p$; 
upright $s$ at word ends occasionally, usually looped $s$; facing bows not fused; no ampersand or tironian $e t$.

Initials: 1 . simple blue, red or sepia (one colour only); 2. plain sepia.

Notation: class $1 \mathrm{~b}$.

Staff: none visible, may have used alternate dry-point text line as a guide.

Virgules: none.

Liturgical placement: Office. Feria 2 - sext, vespers.

\section{Z 197}

Dating: 2nd half 12 th century.

Notary: Pedro de Hoyos, Toro.

Page size: $361 \mathrm{~mm} \times 510 \mathrm{~mm}$.

Page layout: 2 columns, 40 lines, $18 \mathrm{~mm}$ between staffs, above top line.

Foliation: none.

Script: uncial $d$ at word ends, upright $d$ preferred; ligature $r$ used inconsistently after $o$, not used after $p$ or $b$; looped and upright $s$ at word ends, also $s$ descending below line $(c)$ used finally; facing bows not fused; tironian $e t$.

Initials: 1 . blue or red flourished and coloured with blue, red, and green; 2. black flourished with black; 2. red and blue; black with yellow or gold filler; plain red or black.

Notation: class $1 \mathrm{~b}$.

Staff: 1 yellow line.

Virgules: none.

Liturgical placement: Office. Quadragesima?, Sunday and ferial? - lauds, sext, none, vespers, compline; feria 3 - matins.

Additional comments: Another fragment, Z 198, appears to have been taken from the same manuscript. It contains no music.

\section{Z 201}

Dating: 14th century.

Notary: Pedro de Hoyos, Toro. 
Page size: $270 \mathrm{~mm}$ x $395 \mathrm{~mm}$.

Page layout: 2 columns, 14 or 15 staffs, 20 mm between staffs.

Foliation: none.

Initials: 1 . blue with flourished red, red flourished with sepia, sepia with red lines; 2. sepia.

Notation: class 2.

Staff: 1 red line.

Virgules: separating words.

Liturgical placement: Office. 2nd week? of Advent - lauds, vespers; 3rd Sunday of Advent - matins, lauds.

\section{Z 202}

Dating: 1st half 12 th century.

Notary: Francisco Gonzalez de Valderas, Toro.

Page size: $164 \mathrm{~mm} \times 265 \mathrm{~mm}$.

Page layout: 1 column, 25 lines, $17 \mathrm{~mm}$ between staffs, above top line.

Foliation: none.

Script: Visigothic; transitional features as in Z 15 .

Initials: 1 . simple red; 2 . plain sepia.

Notation: class 1a.

Staff: 1 dry-point line.

Virgules: few.

Liturgical placement: Mass. Sunday of Sexagesima.

Additional comments: The chants (gradual verse, tract, and offertory) found in the fragment are the usual ones for this mass.

\section{Z 218}

Dating: 2nd half/late 12th century.

Notary: Diego de Medina, Zamora.

Size: $158 \mathrm{~mm}$ x $320 \mathrm{~mm}$.

Page layout: 2 columns, 35 lines, 18-19mm between staffs, above top line. 
Foliation: none.

Script: upright $d$ used initially and medially more frequently than uncial $d$, uncial $d$ used finally; ligature $r$ after $o$; looped $s$ at word ends; little fusion of bows; tironian $e t$.

Initials: 1 . blue flourished with red; 2 . red flourished with red, sepia flourished with sepia; 3. plain black or red.

Notation: class 1a.

Staff: one dry-point? line.

Virgules: few, most numerous in melismatic chants.

Liturgical placement: Office. Maundy Thursday - matins, lauds; Good Friday - matins.

Additional comments: On one side of the fragment the end of a word can be seen in the left margin, this may be a gloss or a correction and seems unlikely to be a third column. A verse given here for Good Friday is one characteristic of Catalan sources; ${ }^{11}$ it is also found in the Breviario of Zamora. ${ }^{12}$

\section{Z 219}

Dating: 14th century.

Notary: Antonio de Salamanca, Zamora.

Page size: $310 \mathrm{~mm}$ x $480 \mathrm{~mm}$.

Page layout: 1 column, 13 staffs, $25-27$ mm between staffs, above top line?.

Foliation: none.

Initials: 1 . blue flourished with red, red flourished with red; 2. plain black.

Notation: class 2 .

Staff: 1 yellow line.

Virgules: irregular, perhaps to clarify word and neume relationship.

Liturgical placement: Office. Historie of Job and Ezechiel.

\footnotetext{
${ }^{11}$ Personal communication from Dr. Jane Morlet Hardie.

${ }^{12}$ Breviario, fol. 100 .
} 


\section{Z 226}

Dating: late 13 th/14th century.

Notary: Pedro Trebino, Zamora.

Page size: $310 \mathrm{~mm}$ x $456 \mathrm{~mm}$.

Page layout: 2 columns, 15 staffs, $21 \mathrm{~mm}$ between staffs.

Initials: 1. red flourished with blue, blue flourished with red; 2 . sepia with red decoration.

Foliation: none.

Notation: class 2.

Staff: 1 red line.

Virgules: separating most words.

Liturgical placement: Office. St. Peter Martyr - vespers; St. Anne - lauds.

\section{Z 239}

Dating: 2nd half 12th century.

Notary: Alonso de Salamanca, Zamora.

Page size: $315 \mathrm{~mm}$ x $465 \mathrm{~mm}$.

Page layout: 2 columns, 39 or 40 lines, $17 \mathrm{~mm}$ between staffs, above top line.

Foliation: none.

Script: uncial $d$ usually at word ends only, upright $d$ preferred; ligature $r$ after $o$, not after $b$; upright or looped $s$ at word ends; $e$ with cedilla; facing bows not fused; ampersand and occasionally tironian sign for $e t$.

Initials: 1 . red flourished with blue, blue flourished with red; 2. plain red, blue, or sepia.

Notation: class $1 b$.

Staff: 1 red line.

Virgules: none.

Liturgical placement: Office. Purification - lauds; Annunciation - matins, lauds.

Additional comments: This comprises three pieces sewn together, one piece being only about half a folio which has been cut vertically so that only one column remains. 


\section{Z 268}

Dating: 12 th century (2nd half?).

Notary: Diego de Medina, Zamora.

Page size: $135 \mathrm{~mm} \times 244 \mathrm{~mm}$.

Page layout: 1 column?, 24 lines, $16 \mathrm{~mm}$ between staffs, above top line?.

Foliation: none.

Script: both upright and uncial $d$, uncial $d$ preferred; ligature $r$ after $o$; both upright and looped $s$ at word ends; facing bows not fused; tironian $e t$.

Initials: 1 . simple red; 2. sepia or red.

Notation: class $1 b$.

Staff: 1 yellow line.

Virgules: few.

Liturgical placement: Mass. Trinity.

\section{Z 269}

Dating: 14 th/15th century.

Notary: Agustin de Torres, Benavente.

Page size: $205 \mathrm{~mm}$ x $283 \mathrm{~mm}$.

Page layout: 1 column, 5 staffs, $49 \mathrm{~mm}$ between staffs.

Foliation: none.

Initials: 1 . blue with red flourish; 2 . sepia with yellow filler.

Notation: class 2.

Staff: 1 red line.

Virgules: few.

Liturgical placement: Office. Maundy Thursday - lauds (tenebrae).

Additional comments: Part of the Kyries tenebrarum are found here. Two verses are those found in the Breviario of Zamora. These are characteristic of the practices of Catalonia and Santiago de Compostela. ${ }^{13}$

\footnotetext{
${ }^{13}$ Jane Morlet Hardie, “Kyries tenebrarum”, 173-75.
} 


\section{Z 272}

Dating: 14 th/15th century.

Notary: Francisco de Valderrabano, Zamora.

Page size: $215 \mathrm{~mm}$ x $310 \mathrm{~mm}$.

Page layout: 2 columns, 16 staffs, $17 \mathrm{~mm}$ between staffs.

Foliation: none.

Initials: 1 red flourished with blue, blue flourished with red; 2. sepia.

Notation: class 2.

Staff: 1 red line.

Virgules: irregular, usually separating one or two words.

Liturgical placement: Office. Corpus Christi - matins, vespers.

\section{Square and Mensurally Influenced Notations}

\section{Book 1}

Fragments: Z 62, Z 63, Z 110, Z 112, Z 113, Z 114, Z 117, Z 118, Z 124, Z 125, Z 137, Z 141, Z 155, Z 156, Z 157, Z 169.

Dating: 14th century.

Notaries: Francisco de Benavides, Toro; Sancho de Barreda, Toro; Juan de Villalobos, Toro; Jeronimo de Montalegre, Toro; Cristobal Martin, Toro; Hernando Arias de Yedra, Toro; Francisco Garcia de Leon, Toro; Bartolome Sanchez de Arcilla, Toro.

Page size: $300 \mathrm{~mm} \times 440 \mathrm{~mm}$.

Page layout: 1 column, 7 staffs.

Foliation: verso, top left corner.

Initials: 1 . red flourished with blue, blue flourished with red; 2 . black with jagged and barred decoration.

Notation: class 3.

Staff: 4 red lines, $21 \mathrm{~mm}$ high.

Virgules: separating phrases especially in syllabic chants; in melismatic chants, separating phrases or words, breaking melismas.

Liturgical placement: Office. 2nd Sunday of Advent - matins, lauds (Z 110). 4th week of 
Advent feria 5, ferias before Christmas - vespers $O$ antiphons ( $Z$ 155). 4th week of Advent feria 5 - lauds (Z 141). Christmas Eve - matins, compline (Z 141, Z 125). Christmas Day - matins, lauds (Z 125, Z 169). Circumcision - matins, lauds, vespers (Z 62, Z 63, Z 124). Epiphany (and octave) - compline, matins (Z 63). After Epiphany feria 2 - matins (Z 137). 3rd Sunday and 4th Sunday after Epiphany lauds and vespers (Z 157). Easter - matins (Z 156). St. Mary Magdalene - vespers,

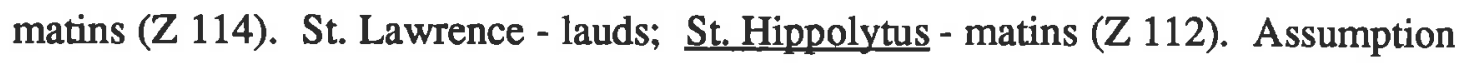
- matins; St. Bartholomew - matins (Z 118). St. Augustine - vespers, matins (Z 113, Z 117).

Additional comments: The similarity of all these fragments makes it very likely that all were taken from a single manuscript book. Some of the fragments evidently have been taken from consecutive or closely placed parts of the original book as has been revealed by a study of the chants and the foliation. The relationship of $Z 141$ and $Z$ 155 is shown below. Missing folios to fit between these two fragments are also indicated. (The numbers underlined are those found on the fragments.)

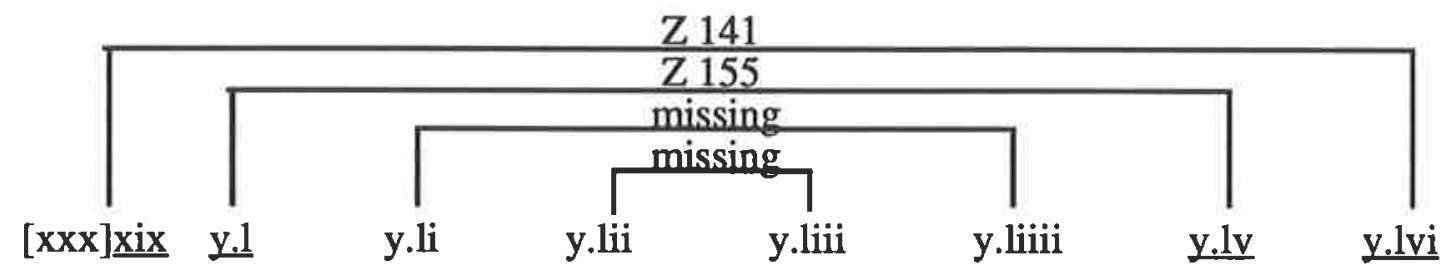

\section{Group 2}

Fragments: Z 85, Z 105, Z 145.

Dating: 15 th century.

Notaries: Cristobal Gomez, Toro; Jeronimo de Montalegre, Toro; Antonio Catalan, Toro.

Page size: $420 \mathrm{~mm}$ x $580 \mathrm{~mm}$.

Page layout: 1 column, 7 staffs.

Foliation: recto, top centre.

Initials: 1. one pictorial initial with a human figure (St. Lawrence?) in colours including red, purple, green, and yellow; 2. red flourished with blue, blue flourished with red; 3. decorated black with yellow filler. 
Notation: pseudo-mensural.

Staff: 5 red lines, $42-44 \mathrm{~mm}$ high.

Virgules: separating words, separating syllables in melismatic passages.

Liturgical placement: Office. Nativity BVM - vespers, matins (Z 105). St. Lawrence matins ( $\mathrm{Z}$ 145). Unidentified (Z 85).

\section{Group 3}

Dating: late 15 th/early 16 th century.

Fragments: Z 158, Z 159, 160, Z 161, Z 166, Z 167[3], Z 173.

Notaries: Bernardo de Montoya, Vezdemarbán; Domingo de Coca, Vezdemarbán.

Page size: $346 \mathrm{~mm} \times 500 \mathrm{~mm}$ (some are approximately half a folio).

Page layout: 1 column, 8 staffs.

Foliation: recto, top right corner.

Initials: 1 . red flourished with blue, blue flourished with red; 2 . decorative black.

Notation: class 4.

Staff: 5 red lines, $30 \mathrm{~mm}$ high.

Virgules: separating words.

Liturgical placement: Office. St. Paul (or Conversion of Paul) (Z 159, Z 160, Z 173).

Octave of St. Peter and St. Paul - vespers; Visitation BVM - vespers (Z 173). St. Peter - vespers? (Z 167[3]). All Saints - vespers (Z 166). Unidentified (Z 158, Z 161).

Additional comments: consecutive folios lxxii and lxxiii.

\section{Group 3a}

Fragments: Z 119, Z 120, Z 122, Z 131, Z 132.

Dating: late 15 th/early 16 th century.

Notaries: Pedro de Campelo, Toro; Juan de Villalobos, Toro.

Page size: $370 \mathrm{~mm}$ x $520 \mathrm{~mm}$ (some are approximately half a folio).

Page layout: 1 column, 8 staffs.

Foliation: recto, top right corner. 
Initials: 1 red flourished with blue, blue flourished with red; 2 . decorative black.

Notation: class 4.

Staff: 5 red lines, 30 and $34 \mathrm{~mm}$ high.

Virgules: separating words.

Liturgical placement: Office. 1st Sunday of Advent - vespers; 3rd Sunday of Advent vespers ( $Z$ 119). Advent - compline, 2nd vespers; 2nd Sunday of Advent - vespers (Z 120). Apostles - vespers (Z 122). Pentecost feria 4? - lauds? (Z 131). Corpus Christi - vespers? (Z 132).

\section{Book 4}

Fragments: Z 162, Z 163, Z 164, Z 176, Z 177, Z 189, Z 190, Z 192.

Dating: late 15th/early 16th century.

Notaries: Bernardo de Montoya, Vezdemarbán; Domingo de Coca, Vezdemarbán; Felipe Ramos, Vezdemarbán; Manuel Simon, Vezdemarbán.

Page size: $390 \mathrm{~mm}$ x $580 \mathrm{~mm}$ (some approximately half folios).

Page layout: 1 column, 8 staffs.

Foliation: recto, top right corner.

Initials: 1. red flourished with blue, blue flourished with red; 2 . decorative black.

Notation: class 4 .

Staff: 5 red lines, $35 \mathrm{~mm}$ high.

Virgules: separating words.

Liturgical placement: Mass. Easter Day (Z 192). Octave of Easter, 2nd Sunday after Easter ( $Z$ 162). 2nd Sunday and 3rd Sunday after Easter ( $Z$ 164). 3rd Sunday and 4th Sunday after Easter (Z 163). After Pentecost (Z 176-177, Z 189-190).

Additional comments: Z 189-190 are two pieces of one folio cut horizontally. Z 176-177 are similarly two pieces of one folio. Two consecutive folios are: $\mathrm{x} . \mathrm{iii}$ and $\mathrm{x} . \mathrm{iiii}$.

\section{Book 5}

Fragments: Z 185, Z 186, Z 187, Z 188, Z 193.

Dating: late 15 th/early 16 th century. 
Notaries: Felipe Ramos, Vezdemarbán; Bernardo de Montoya, Vezdemarbán; Manuel Simon, Vezdemarbán.

Page size: $350 \mathrm{~mm}$ x $495 \mathrm{~mm}$ (some approximately half folios).

Page layout: 1 column, 6 staffs.

Foliation: verso, top right corner.

Initials: 1 . plain red or blue; 2 . decorative black.

Notation: class 4.

Staff: 5 red lines, $40 \mathrm{~mm}$ high.

Virgules: separating words.

Liturgical placement: Mass. 3rd Sunday in Advent (Z 193). 3rd week of Lent ( $\mathrm{Z} 185$ ). 1st week of Lent feria 4, 2nd week of Lent (Z 186-Z 188).

\section{Book 5a}

Fragments: Z 167[1-2], Z 174, Z 175.

Dating: late 15 th/early 16 th century

Notaries: Bernardo de Montoya, Vezdemarbán; Domingo de Coca, Vezdemarbán.

Page size: $375 \mathrm{~mm} \times 525 \mathrm{~mm}$ (two half folios).

Page layout: 1 column, 6 staffs.

Foliation: none.

Initials: 1. plain red; 2. decorative red and decorative black.

Notation: semi-mensural (Z 167[1-2], Z 174); class 4 (Z 174, Z 175).

Staff: 5 red lines, $40 \mathrm{~mm}$ high.

Virgules: separating words.

Liturgical placement: Office. Good Friday - matins (Z 174, Z 175). Holy Saturday matins (Z 167[1-2]).

Additional comments: Z 167[1-2] is one folio which has been cut in half. Some underlaid text written in red instead of the usual black. 


\section{Book 6}

Fragments: Z 151, Z 153.

Dating: 15 th/early 16 th century.

Notary: Cristobal Gonzalez, Vezdemarbán.

Page size: $305 \mathrm{~mm}$ x $448 \mathrm{~mm}$.

Page layout: 1 column, 7 staffs.

Foliation: none.

Initials: 1 . red flourished with blue; 2 . decorative black.

Notation: mensural (Z 151); class 4 (Z 153).

Staff: 5 red lines, $34 \mathrm{~mm}$ high.

Virgules: separating words.

Liturgical placement: Mass. Gloria (Z 153). Credo (Z 151).

Additional comments: $\mathrm{Z} 151$ is cut into two parts.

\section{Book 7}

Fragments: Z 79, Z 129.

Dating: 15 th century.

Notaries: Juan de Villalobos, Toro; Antonio de Castro, Toro.

Page size: $255 \mathrm{~mm}$ x $388 \mathrm{~mm}$.

Page layout: 1 column, 30 lines?

Foliation: none.

Initials: 1 . red flourished with blue, blue flourished with red; 2 . sepia with barred and jagged decoration and yellow filler.

Notation: class 4 .

Staff: 5 red lines, $17 \mathrm{~mm}$ high.

Virgules: separating words.

Liturgical placement: Office. After Epiphany feria 2? (Z 79). After Epiphany Sunday? lauds (Z 129). 


\section{Book 8}

Fragments: Z 92, Z 93, Z 95, Z 97, Z 98, Z 106, Z 108, Z 195.

Dating: 15 th century.

Notaries: Baltasar de Mansilla, Vezdemarbán; Manuel Simon, Vezdemarbán.

Page size: $390 \mathrm{~mm}$ x $527 \mathrm{~mm}$.

Page layout: 2 columns, 10 staffs.

Foliation: none.

Initials: 1. red flourished with blue, blue fourished with red (some with yellow filler); 2 . black with jagged decoration, green and yellow fillers.

Notation: class 4.

Staff: 5 red lines, $22 \mathrm{~mm}$ high.

Virgules: separating words; separating syllables or neumes in melismatic chants or sections. Liturgical placement: Office. Assumption BVM - matins ( Z 97). Assumption BVM? matins, vespers (Z 93, Z 92, Z 95). Commemoration of St. Paul - lauds (Z 108). St.

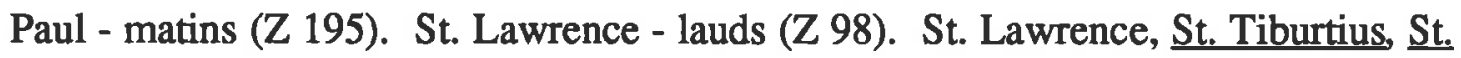
Hippolytus - vespers (Z 106).

Additional comments: Blank staffs occur in some fragments with text written below.

\section{Book 9}

Fragments: Z 209, Z 210, Z 211, Z 212.

Dating: 15 th century.

Notaries: Antonio Montesinos, Zamora; Fernando de Cabañas, Zamora; Diego de Ledesma, Zamora.

Page size: $365 \mathrm{~mm} \times 510 \mathrm{~mm}$.

Page layout: 1 column, 7 staffs.

Foliation: none.

Initials: 1 red flourished with blue, blue flourished with red; 2. sepia with jagged decoration. Notation: class 3.

Staff: 5 red lines, $32 \mathrm{~mm}$ high.

Virgules: infrequent, separating phrases. 
Liturgical placement: Office. Mary Magdalene? - lauds (Z 211). St. James (Z 212). Unidentified (Z 209, Z 210).

\section{Book 10}

Fragments: Z 205, Z 206, Z 207, Z 208.

Dating: 15 th/early 16 th century.

Notary: Alonso Orejon, Zamora.

Page size: $345 \mathrm{~mm}$ x $480 \mathrm{~mm}$.

Page layout: 1 column, 8 staffs.

Foliation: none.

Initials: 1 . red flourished with blue, blue flourished with red; 2 . decorative black with yellow touches.

Notation: class 4.

Staff: 5 red lines, $28-31 \mathrm{~mm}$ high.

Virgules: separating words.

Liturgical placement: Office. Sunday after Epiphany - vespers (Z 205). Continentium vespers ( $Z$ 206, Z 207). Confessor - vespers ( $Z$ 208).

Additional comments: Z 206 and Z 207 are consecutive folios.

\section{Z 10}

Dating: late 14 th/ 15 th century.

Notary: Juan de Toro, Toro.

Page size: $278 \mathrm{~mm} \times 240 \mathrm{~mm}$ (lower part of folio is cut off).

Page layout: 1 column, 5 staffs.

Foliation: none.

Initials: 1 . red flourished with blue, blue flourished with red; 2 . sepia with red decoration.

Notation: class 5 .

Staff: 5 red lines, $27 \mathrm{~mm}$ high.

Virgules: separating words, breaking melismas.

Liturgical placement: Office and Mass. St. Stephen. 


\section{Z 35}

Dating: 14 th/15th century.

Notary: Jeronimo Lopez, Toro.

Page size: $300 \mathrm{~mm} \times 415 \mathrm{~mm}$.

Page layout: 1 column, 7 staffs.

Foliation: recto, top right corner.

Initials: 1 . red flourished with blue, blue flourished with red; 2 . sepia.

Notation: class 3 .

Staff: 5 red lines, $32 \mathrm{~mm}$ high.

Virgules: separating words, breaking melismas.

Liturgical placement: Office. Apostles? - matins.

\section{Z 83-Z 84}

Dating: 15 th/early 16 th century.

Notary: Cristobal Gomez, Toro.

Page size: $360 \mathrm{~mm} \times 460 \mathrm{~mm}$ (measurement for the two pieces placed together).

Page layout: 1 column, 6 staffs.

Foliation: verso?, top right corner.

Initials: blue flourished with red.

Notation: class 4.

Staff: 5 red lines, $40 \mathrm{~mm}$ high.

Virgules: separating words.

Liturgical placement: Office. Purification BVM - vespers (Z 83, Z 84).

Additional comments: The two fragments are the two halves of a single folio which have been cut apart. 


\section{Z 101}

Dating: 15 th century.

Notary: Antonio Gomez, Toro

Page size: $330 \mathrm{~mm} \times 480 \mathrm{~mm}$.

Page layout: 1 column, 7 staffs.

Foliation: none.

Initials: 1 . thick red flourished with blue, thick blue flourished with red; 2 . sepia with yellow decoration.

Notation: class 5.

Staff: 5 red lines, $28 \mathrm{~mm}$ high.

Virgules: separating most words.

Liturgical placement: Office. Lent.

\section{Z 104}

Dating: 15th century.

Notary: Antonio Gomez, Toro.

Page size: $355 \mathrm{~mm}$ x $505 \mathrm{~mm}$.

Page layout: 1 column, 8 staffs.

Foliation: recto, top centre.

Initials: 1 red flourished with blue; 2. sepia with yellow decoration.

Notation: class 5 .

Staff: 5 red lines, 28-31 mm high.

Virgules: separating words, breaking melismas.

Liturgical placement: Mass. Lent.

\section{Z 111}

Dating: 15 th century.

Notary: Sancho de Barreda, Toro.

Page size: $280 \mathrm{~mm}$ x $393 \mathrm{~mm}$.

Page layout: 1 column, 9 staffs. 
Foliation: none.

Initials: 1 red flourished with blue, blue flourished with red; 2 . black with jagged and barred decoration.

Notation: class 4.

Staff: 5 red lines, $20 \mathrm{~mm}$ high.

Virgules: separating words.

Liturgical placement: Mass and Office. Nativity BVM - vespers.

\section{Z 115}

Dating: 15 th century.

Notary: Sancho de Barreda, Toro.

Page size: $390 \mathrm{~mm} \times 530 \mathrm{~mm}$.

Page layout: 1 column, 9 staffs.

Foliation: none.

Initials: 1 . red flourished with blue, blue flourished with red; 2 . decorated black with yellow inner colouring.

Notation: semi-mensural.

Staff: 5 red lines, $31-34 \mathrm{~mm}$ high.

Virgules: separating words, breaking long melismas.

Liturgical placement: Mass. Ember Saturday of Lent. SS. Peter and Paul.

\section{Z 116}

Dating: 15th century.

Notary: Sancho de Barreda, Toro.

Page size: $360 \mathrm{~mm}$ x $450 \mathrm{~mm}$.

Page layout: 1 column, 7 staffs.

Foliation: recto, top centre.

Initials: 1 . blue flourished with red lines; 2 . sepia/black with barred and jagged decoration.

Notation: class 5.

Staff: 5 red lines, $30 \mathrm{~mm}$ high. 
Virgules: separating words or phrases.

Liturgical placement: Office. St. Lucy - vespers.

\section{Z 148}

Dating: 15th century.

Notary: Jeronimo de Montalegre, Toro.

Page size: $255 \mathrm{~mm} \times 300 \mathrm{~mm}$ (top half of top staff cut off).

Page layout: 1 column, 6 staffs?.

Foliation: none.

Initials: 1 . blue flourished with red; 2 . black with simple decoration.

Notation: class 3.

Staff: 5 red lines, $26 \mathrm{~mm}$ high.

Virgules: separating phrases.

Liturgical placement: Office. St. Vincent - matins.

\section{Z 154}

Dating: 15th century.

Notary: Cristobal Cornejo, Toro.

Page size: $340 \mathrm{~mm}$ x $440 \mathrm{~mm}$.

Page layout: 1 column, 7 staffs.

Foliation: none.

Initials: 1. red flourished with blue, blue flourished with red; 2 . black with yellow filler.

Notation: class 3.

Staff: 5 red lines, $31 \mathrm{~mm}$ high.

Virgules: separating phrases.

Liturgical placement: Office? BVM.

\section{Z 165}

Dating: late 15 th/early 16 th century.

Notary: Bernardo de Montoya, Vezdemarbán. 
Page size: $320 \mathrm{~mm} \times 510 \mathrm{~mm}$.

Page layout: 1 column, 8 staffs.

Foliation: none.

Initials: 1. plain red; 2. decorative black.

Notation: class 4.

Staff: 5 red lines, $31 \mathrm{~mm}$ high.

Virgules: separating words (omitted occasionally).

Liturgical placement: Office. Holy saturday? - vespers.

\section{Z 168}

Dating: 15th century.

Notary: Bartolome Sanchez de Arcilla, Toro.

Page size: $360 \mathrm{~mm} \times 485 \mathrm{~mm}$.

Page layout: 1 column, 8 staffs.

Foliation: none.

Initials: 1 . red flourished with blue, blue flourished with red, yellow filler; 2 . black with jagged decoration and yellow filler.

Notation: class 4.

Staff: 5 red lines, $30 \mathrm{~mm}$ high.

Virgules: separating words, breaking melismas.

Liturgical placement: Mass. Martyr?

\section{Z 184}

Dating: mid 13th/beginning of 14th century.

Notary: Bernardo Sanchez, Toro.

Page size: 122 (bottom) -142 (top) $\mathrm{mm} \times 298 \mathrm{~mm}$ (top and sides cut off).

Page layout: 1 column, 6-7 staffs.

Foliation: none.

Initials: tall blue flourished with red, tall red unflourished.

Notation: Franconian-like mensural (polyphony); class 3 (monophony). 
Staff: 5 red lines.

Virgules: separating words or phrases.

Liturgical placement: Mass. BVM.

Additional comments: contains 3 polyphonic works.

\section{Z 203}

Dating: late 14th century.

Notary: Alonso Orejon, Zamora.

Page size: $294 \mathrm{~mm}$ x $450 \mathrm{~mm}$.

Page layout: 1 column, 9 staffs.

Foliation: verso, top centre.

Initials: 1. red flourished with blue; 2. black with barred and jagged decoration, yellow filler.

Notation: class 5 .

Staff: 4 red lines, $21 \mathrm{~mm}$ high.

Virgules: separating phrases (very short lines).

Liturgical placement: Mass. Cathedra of St. Peter.

\section{Z 234}

Dating: 14 th/15th century.

Notary: Alonso de Salamanca, Zamora.

Page size: $173 \mathrm{~mm} \times 230 \mathrm{~mm}$.

Page layout: 1 column, 10 staffs.

Foliation: none.

Initials: 1 . red flourished with blue; 2 . blue flourished with red, red flourished with blue (smaller and simpler than 1).

Notation: class 3 .

Staff: 5 red lines, 22-24 mm high.

Virgules: variable; separating words, phrases, or breaking melismas.

Liturgical placement: Office. Apostles - matins. 


\section{Z 240}

Dating: 14th century.

Notary: Juan Montero de Cabañas, Zamora.

Page size: $285 \mathrm{~mm}$ x $440 \mathrm{~mm}$.

Page layout: 1 column, 7 staffs.

Foliation: recto? top centre.

Initials: 1. red flourished with blue, blue flourished with red; 2 . sepia with red lining.

Notation: class 3.

Staff: 5 red lines, $32 \mathrm{~mm}$ high.

Virgules: separating phrases.

Liturgical placement: Mass. Ember Saturday in September.

\section{Z 243}

Dating: late 14 th to 15 th century.

Notary: Francisco Vivas, Zamora.

Page size: $301 \mathrm{~mm} \times 116 \mathrm{~mm}$ (top and bottom parts of folio cut off).

Page layout: 2 columns, 4 staffs.

Foliation: none.

Initials: sepia with simple decoration.

Notation: class 3.

Staff: 5 red lines, $22 \mathrm{~mm}$ high.

Virgules: separating words.

Liturgical placement: Mass? - unidentified.

\section{Z 245}

Dating: late 15 th/early 16 th century.

Notary: Antonio Montesinos, Zamora.

Page size: $394 \mathrm{~mm}$ x $510 \mathrm{~mm}$.

Page layout: 1 column, 5 staffs.

Foliation: none. 
Initials: 1 . plain red; 2 . decorative black.

Notation: class 4.

Staff: 5 red lines, $466 \mathrm{~mm}$ high.

Virgules: separating words or phrases.

Liturgical placement: Mass - Sanctus, Agnus Dei.

\section{Z 246}

Dating: 15th century.

Notary: Alonso de Carrion, Zamora.

Page size: $334 \mathrm{~mm}$ x $402 \mathrm{~mm}$.

Page layout: 1 column, 7 staffs.

Foliation: none.

Initials: green, yellow, and sepia with jagged and floral-like decoration.

Notation: class 3.

Staff: 5 red lines, $33 \mathrm{~mm}$ high.

Virgules: separating phrases.

Liturgical placement: Office. Lent? - matins.

\section{Z 260}

Dating: 15 th century.

Notary: Antonio Rodriguez de Aranjo, Zamora.

Page size: $228 \mathrm{~mm} \times 330 \mathrm{~mm}$.

Page layout: 1 column, 7 staffs.

Foliation: none.

Initials: 1 red flourished with blue; 2 . black with yellow filler.

Notation: class 4.

Staff: 5 red lines, $25 \mathrm{~mm}$ high.

Virgules: separating most words.

Liturgical placement: Office. Christmas Day.

Additional comments: Contains "Verbum patris hodie". 
RITUAL DE SACRAMENTOS Y MISAL PROPIO DE LA IGLESIA DE ZAMORA, ZAMORA, ARCHIVO CATEDRALICIO, CÓDICE 105

Dating: 15 th century. ${ }^{14}$

Page Size: $160 \mathrm{~mm} \times 220 \mathrm{~mm}$.

Page layout: 1 column, 6 staffs until fol. 74 from which there are 5 staffs (this change occurs towards the middle of a single gathering which comprises fols. $71^{\mathrm{r}}-787$.

Foliation: modern foliation only.

Initials: 1. red flourished with blue, blue flourished with red; 2. sepia with jagged, barred, and occasionaly floral-like decoration.

Notation: class 3 .

Staff: five red lines, $18 \mathrm{~mm}$ until fol. 74 and $22 \mathrm{~mm}$ for remainder.

Virgules: separating words or phrases; separating syllables in melismatic sections.

Liturgical placement: Mass. Notated contents are as follows. Wedding Mass (fols. $22^{\mathrm{v}}-28^{\mathrm{r}}$, includes preface). In agenda mortuorum (fols. $51^{\mathrm{v}}-58^{\mathrm{\gamma}}$ ). Festive common preface (fols. $74^{\mathrm{r}}-\mathrm{76}^{\mathrm{f}}$ ). Ferial common preface (fols. $76^{\mathrm{r}}-\mathrm{78}^{\mathrm{f}}$ ). Festive Pater noster

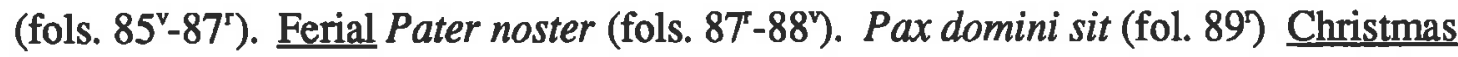
preface (fols. $91^{v}-92^{2}$ ). Epiphany preface (fols $92^{v}-93^{2}$ ). Quadragesima preface (fol. 93). Holy Cross preface (93-94). Resurrection preface (fols. 94r $-95^{r}$ ). Ascension preface (fol. 95). Pentecost preface (fols. 95 $-96^{v}$ ). Holy Trinity preface (fols. $\left.97^{\mathrm{r}}-98^{v}\right)$. Assumption preface (fol. 98 $)$. Preface for Nativity, Conception, Purification. and Annunciation of the BVM (fols. 98 -100 ). Apostles preface (fols $100^{\mathrm{r}}-101^{\mathrm{v}}$ ).

Additional comments: 234 folios. Bound in leather covered wood. Begins with the calendar. The chants for the Wedding Mass are those commonly used for Holy Trinity.

${ }^{14}$ Dating given by the archive. It is also the dating of a missal mentioned as lost by Janini; see Janini, Manuscritos, 327. The former archivist of the Cathedral of Zamora, Don Ramón Fita Revert, kindly informed me of his discovery of the Ritual in a cupboard, and of his certainty that it is the one previously thought lost and referred to by Janini. 


\section{Booklet}

This probably 15th-century booklet is kept (unattached) at the rear of the Ritual because of its likeness to the latter book. (It was found separate from the Ritual in the archives of the Cathedral of Zamora.) The booklet consists of two bifolios but must originally have had at least one more as is indicated by two chants, one lacking completion and the other lacking beginning. The foliation is a continuation of that of the Ritual. Comparison with the Ritual shows the following differences: the folios are a few millimetres wider and higher; initials show the same two general types but are different in details of design style; five staffs are employed but they are red one-line staffs approximately $30 \mathrm{~mm}$ apart; notation is class 2 Aquitanian. The contents are entirely notated and are "simplex" prefaces for the following: Christmas (fol. 235); Epiphany (fol. 236'); Resurrection (fol. 236 ${ }^{\vee}$, incomplete); Apostles (fol. $237^{\mathrm{r}}$, incomplete); and one for all feasts of the BVM (fols. $237^{\mathrm{r}}-238^{\mathrm{f}}$ ).

\section{MISAL VOTIVO PARA USO DE ZAMORA, MADRID, BIBLIOTECA LÁZARO} GALDIANO, MS. 662

\section{Folios $2^{r}-14^{v}$}

Dating: 15 th century ${ }^{15}$ (before 1450 ?) ${ }^{16}$

Size: $224 \mathrm{~mm} \times 302$.

Page layout: 1 column, 6 staffs.

Foliation: modern foliation only.

Initials: 1 red flourished with blue, blue flourished with red, decorative black with yellow filler; 2. red flourished with blue, blue flourished with red (smaller than 1), black with yellow filler.

Notation: class 4.

Staff: 5 red lines, $21 \mathrm{~mm}$ high.

Virgules: separating most words.

Liturgical placement: Mass and Office. Notated contents are as follows. Gloria and Credo

${ }^{15}$ The datings of the sections of this source are those of Janini, Manuscritos, 198-99.

${ }^{16}$ In Chapter 2 it was suggested that the absence of St. Bernardine of Siena from the calendar might indicate a date of copying prior to 1450 . 
incipits (fol. $2^{2}$ ). Festive common preface (fols. $2^{r}-3^{r}$ ). Ferial common preface $\left(\right.$ fol. $3^{\mathrm{r}}-4^{\mathrm{r}}$ ). Sanctus incipit (fol. 4). Festive Pater noster (fol. 7). Ferial Pater noster (fol. $7^{\vee}-8^{\vee}$ ). Pax domini sit (fol. 9). Office Pro defunctis (fols. $10^{\mathrm{y}}-13^{\mathrm{r}}$, invitatory only).

\section{Folios $\mathbf{1 5}^{\mathrm{r}}-\mathbf{5 3}^{\mathrm{v}}$}

Dating: 14th century.

Size: $224 \mathrm{~mm} \times 302 \mathrm{~mm}$.

Page layout: 1 column, 7 staffs.

Foliation: original foliation on recto, lower right corner. The modern foliation continuous with that of the previous section is referred to in this dissertation for convenience.

Initials: 1. red flourished with blue, blue flourished with red; 2 . red flourished with blue, blue flourished with red (smaller than 1).

Notation: class 3 (monophony); non-mensural (with pseudo-mensural elements) and semimensural (polyphony).

Staff: 5 red lines, $20-21 \mathrm{~mm}$ high, with the exception of fol. $53^{\mathrm{v}}$ on which the staff height is $14 \mathrm{~mm}$.

Virgules: separating phrases or occasionally words; breaking melismas in melismatic sections.

Liturgical placement: Office and Mass. Office In agenda mortuorum - vespers, matins, lauds (fols. $15^{\mathrm{r}}-35^{v}$ ). Mass of the Dead (fols. $36^{v}-41^{v}$ ). Mass for St. Ildefonsus, 2 January (fols. $46^{r}-51^{r}$ ). Mass for Invention of St. Ildefonsus, 26 May (fols. $51^{v}-53^{r}$ ).

\section{Folios 53'-55}

These folios appear to have been left blank on completion of the copying of the previous section, although they may have been ruled at the same time as those preceding fol. $53^{\mathrm{v}}$; fols. 53 and 54 are part of the final gathering which begins with fol. 45 . Differences are found in comparison with the first two sections of the book. The notation is late Aquitanian (class 2), written on one red line, with single lightly ruled text lines on both sides of the red line used as guides. There are between 6 and 8 staffs per page. Initials are in red and sepia, the secondary initials having jagged and barred decoration. The single chant is for the 
Office of the Dead and is Libera me domine de morte with 12 verses.

Additional comments: 2 polyphonic works are found in the 14th-century section (fols. 49 and 53). The book is bound attractively in leather covered wood with Mudejar decoration; the binding dates from the 15 th century. ${ }^{17}$

${ }^{17}$ Janini, Manuscritos, 198. 


\section{APPENDIX 2 : NUMERICAL TABLE OF PERGAMINOS MUSICALES}

Here the Pergaminos musicales are listed in fully numerical order according to the numbering of each, rather than according to book or group and broad notation type as is done in Appendix 1. The contents of each column of the table are as follows: in the first column the identifying number of each is given but without the prefix " $Z$ "; in the second, grouping into book or group as relevant; in the third, liturgical context of notated chants; in the fourth, use in office or mass; in the fifth, broad notation type; and in the sixth, the place of origin of the protocol book onto which the fragment was bound.

Key

Column 4: $\mathrm{O}=$ office; $M=$ mass.

Column 5: $\mathrm{A}=$ Aquitanian notation; $\mathrm{S}=$ square notation; $\mathrm{M}=$ mensurally influenced notation.

\section{Number Grouping Content}

1

3

9

10

15

25

26

35

52

53

57

58

59

62

63

B

B
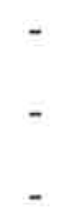

G

G

Apostles

Lent
St. Thomas of Canterbury

St. Sebastian, St. Agnes

St. Stephen

after Epiphany

Septuagesima

Septuagesima

Apostles?

Christmas Day

after Pentecost

Trinity Sunday

St. Agatha

Circumcision

Circumcision, Epiphany
Context Notation Protocol

O A Toro

O

A Toro

o

A

Toro

$\mathrm{O}, \mathrm{M}$

$S$

Toro

O

A Toro

o

A

Toro

O

A

Toro

o

S

Toro

M

A Toro

M

A Toro

M

A

Toro

o

A

Toro

0

A

Toro

o

S

Toro

o

S

Toro 
St. Katherine,

M

A

Toro

Conception BVM

67

Christmas Day, Ordinary

M

A

Toro

$68 \mathrm{C}$

the Dead?, Ordinary

M

A

Toro

$\begin{array}{ll}79 & 7\end{array}$

after Epiphany

$\mathrm{O}$

S

Toro

83

Purification BVM

O

S

Toro

84

Purification BVM

O

S

Toro

$85 \quad 2$

?

O

M

Toro

90

?

O

A

Toro

$92 \quad 8$

Assumption BVM?

O

$\mathrm{S}$

Vezdemarbán

$93 \quad 8$

Assumption BVM?

$\mathrm{O}$

S

Vezdemarbán

$95 \quad 8$

Assumption BVM?

O

S

Vezdemarbán

$97 \quad 8$

Assumption BVM

O

S

Vezdemarbán

$98 \quad 8$

St. Lawrence

O

S

Vezdemarbán

99 D

St. Andrew

O

A

Vezdemarbán

St. Saturninus

O
A
Toro

101

Lent

O

$\mathrm{S}$

Toro

104

Lent

M

S

Toro

$105 \quad 2$

Nativity BVM

O

M

Toro

$106 \quad 8$

St. Lawrence, St. Tiburtius, O

$\mathbf{S}$

Vezdemarbán

St. Hippolytus

107

St. Saturninus

O

A

Vezdemarbán

$108 \quad 8$

St. Paul

O

S

Vezdemarbán

$110 \quad 1$

Advent

o

S

Toro

Nativity BVM

M, O S

Toro

$112 \quad 1$

St. Lawrence,

O

S

Toro

St. Hippolytus

$113 \quad 1$

St. Augustine

O

S

Toro

$114 \quad 1$

St. Mary Magdalene

o

S

Toro

Toro 


\begin{tabular}{|c|c|c|c|c|c|}
\hline 116 & - & St. Lucy & $\mathrm{O}$ & $\mathrm{S}$ & Toro \\
\hline 117 & 1 & St. Augustine & $\mathrm{O}$ & S & Toro \\
\hline 118 & 1 & Assumption, St. Bartolomew & $\mathrm{O}$ & $\mathrm{S}$ & Toro \\
\hline 119 & $3 a$ & Advent & $\mathrm{O}$ & $\mathrm{S}$ & Toro \\
\hline 120 & $3 a$ & Advent & $\mathrm{O}$ & S & Toro \\
\hline 122 & $3 a$ & Apostles & $\mathrm{O}$ & S & Toro \\
\hline 123 & - & Purification BVM & $\mathrm{O}$ & A & Toro \\
\hline 124 & 1 & Circumcision & $\mathrm{O}$ & $S$ & Toro \\
\hline 125 & 1 & Christmas Eve, Christmas Day & 0 & S & Toro \\
\hline 129 & 7 & after Epiphany? & 0 & S & Toro \\
\hline 131 & $3 a$ & Pentecost? & $\mathrm{O}$ & S & Toro \\
\hline 132 & $3 a$ & Corpus Christi & 0 & S & Toro \\
\hline 137 & 1 & after Epiphany & $\mathrm{O}$ & $\mathrm{S}$ & Toro \\
\hline 141 & 1 & Advent, Christmas Eve & $\mathrm{O}$ & $\mathrm{S}$ & Toro \\
\hline 145 & 2 & St. Lawrence & 0 & M & Toro \\
\hline 148 & - & St. Vincent & 0 & $S$ & Toro \\
\hline 149 & - & Lent & $\mathbf{M}$ & A & Vezdemarbán \\
\hline 151 & 6 & Mass Ordinary & $\mathbf{M}$ & M & Vezdemarbán \\
\hline 153 & 6 & Mass Ordinary & $\mathbf{M}$ & $\mathrm{S}$ & Vezdemarbán \\
\hline 154 & - & BVM & $\mathrm{O} ?$ & $\mathrm{~S}$ & Toro \\
\hline 155 & 1 & Advent & $\mathrm{O}$ & $\mathrm{S}$ & Toro \\
\hline 156 & 1 & Easter & $\mathrm{O}$ & $\mathrm{S}$ & Toro \\
\hline 157 & 1 & after Epiphany & $\mathrm{O}$ & $S$ & Toro \\
\hline 158 & 3 & $?$ & $\mathrm{O} ?$ & $\mathrm{~S}$ & Vezdemarbán \\
\hline 159 & 3 & St. Paul & $\mathrm{O}$ & $S$ & Vezdemarbán \\
\hline 160 & 3 & St. Paul & 0 & $\mathrm{~S}$ & Vezdemarbán \\
\hline 161 & 3 & $?$ & 0 & $\mathrm{~S}$ & Vezdemarbán \\
\hline 162 & 4 & Easter & $\mathbf{M}$ & $\mathrm{S}$ & Vezdemarbán \\
\hline 163 & 4 & Easter & $\mathbf{M}$ & $\mathrm{S}$ & Vezdemarbán \\
\hline 164 & 4 & Easter & $\mathbf{M}$ & $\mathrm{S}$ & Vezdemarbán \\
\hline
\end{tabular}




\begin{tabular}{|c|c|c|c|c|c|}
\hline 165 & - & Holy Saturday? & $\mathrm{O}$ & $S$ & Vezdemarbán \\
\hline 166 & 3 & $?$ & $\mathrm{O}$ & $\mathbf{S}$ & Vezdemarbán \\
\hline $167[1-2]$ & $5 \mathrm{a}$ & Holy Saturday & $\mathrm{O}$ & $\mathbf{M}$ & Vezdemarbán \\
\hline $167[3]$ & 3 & St. Peter & 0 & $\mathbf{S}$ & Vezdemarbán \\
\hline 168 & - & Martyr? & $\mathbf{M}$ & $S$ & Toro \\
\hline 169 & 1 & Christmas Day & $\mathrm{O}$ & $\mathbf{S}$ & Toro \\
\hline 171 & - & Feria 2 & 0 & A & Pinilla de Toro \\
\hline 173 & 3 & $\begin{array}{l}\text { Oct. of SS. Peter \& Paul, } \\
\text { Visitation }\end{array}$ & 0 & $\mathbf{S}$ & Vezdemarbán \\
\hline 174 & $5 \mathrm{a}$ & Good Friday & 0 & $\mathrm{M}, \mathrm{S}$ & Vezdemarbán \\
\hline 175 & $5 a$ & Good Friday & $\mathrm{O}$ & $\mathbf{S}$ & Vezdemarbán \\
\hline 176 & 4 & after Pentecost & $\mathbf{M}$ & $\mathbf{S}$ & Vezdemarbán \\
\hline 177 & 4 & after Pentecost & $\mathbf{M}$ & $\mathbf{S}$ & Vezdemarbán \\
\hline 184 & - & BVM & $\mathbf{M}$ & $\mathbf{M}$ & Toro \\
\hline 185 & 5 & Lent & $\mathbf{M}$ & $\mathbf{S}$ & Vezdemarbán \\
\hline 186 & 5 & Lent & $\mathbf{M}$ & $\mathbf{S}$ & Vezdemarbán \\
\hline 187 & 5 & Lent & $\mathbf{M}$ & $\mathrm{S}$ & Vezdemarbán \\
\hline 188 & 5 & Lent & $\mathbf{M}$ & $\mathbf{S}$ & Vezdemarbán \\
\hline 189 & 4 & after Pentecost & $\mathbf{M}$ & $S$ & Vezdemarbán \\
\hline 190 & 4 & after Pentecost & $\mathbf{M}$ & $\mathbf{S}$ & Vezdemarbán \\
\hline 191 & $\mathrm{D}$ & St. Andrew, St. Nicholas & $\mathrm{O}$ & A & Vezdemarbán \\
\hline 192 & 4 & Easter Day & $\mathbf{M}$ & $\mathrm{S}$ & Vezdemarbán \\
\hline 193 & 5 & Advent & $\mathbf{M}$ & $\mathbf{S}$ & Vezdemarbán \\
\hline 194 & $\mathrm{D}$ & St. Saturninus, St. Andrew & $\mathrm{O}$ & A & Vezdemarbán \\
\hline 195 & 8 & St. Paul & $\mathrm{O}$ & $S$ & Vezdemarbán \\
\hline 196 & A & after Epiphany & $\mathrm{O}$ & A & Toro \\
\hline 197 & - & Quadragesima? & $\mathrm{O}$ & A & Toro \\
\hline 199 & A & after Epiphany & $\mathrm{O}$ & A & Toro \\
\hline 200 & A & Christmas Octave, Epiphany & $\mathrm{O}$ & A & Toro \\
\hline 201 & - & Advent & $\mathbf{O}$ & A & Toro \\
\hline
\end{tabular}




\begin{tabular}{|c|c|c|c|c|c|}
\hline 202 & - & Sexagesima & $\mathbf{M}$ & A & Toro \\
\hline 203 & - & Cathedra of St. Peter & $\mathbf{M}$ & $\mathrm{S}$ & Zamora \\
\hline 204 & $\mathrm{H}$ & $?$ & $\mathbf{M}$ & A & Toro \\
\hline 205 & 10 & after Epiphany & 0 & $S$ & Zamora \\
\hline 206 & 10 & Continentium & $\mathrm{O}$ & $\mathrm{S}$ & Zamora \\
\hline 207 & 10 & Continentium & $\mathrm{O}$ & $\mathrm{S}$ & Zamora \\
\hline 208 & 10 & Confessor & $\mathrm{O}$ & $\mathrm{S}$ & Zamora \\
\hline 209 & 9 & $?$ & $\mathrm{O}$ & $S$ & Zamora \\
\hline 210 & 9 & $?$ & $\mathrm{O}$ & $\mathrm{S}$ & Zamora \\
\hline 211 & 9 & Mary Magdalene? & 0 & $\mathrm{~S}$ & Zamora \\
\hline 212 & 9 & St. James & $\mathrm{O}$ & $\mathrm{S}$ & Zamora \\
\hline 215 & $\mathrm{I}$ & Quinquagesima & $\mathbf{M}$ & A & Zamora \\
\hline 216 & I & Lent, Quinquagesima & $\mathbf{M}$ & A & Zamora \\
\hline 217 & $\mathrm{~F}$ & Christmas Day & 0 & A & Zamora \\
\hline 218 & - & Holy Week & 0 & A & Zamora \\
\hline 219 & - & Historie of Job and Ezechiel & $\mathrm{O}$ & A & Zamora \\
\hline 222 & $\mathrm{E}$ & Trinity, Pentecost & $\mathrm{O}$ & A & Zamora \\
\hline 224 & $\mathrm{E}$ & St. Katherine & 0 & A & Zamora \\
\hline 225 & $\mathrm{E}$ & St. Katherine & $\mathrm{O}$ & A & Zamora \\
\hline 226 & - & St. Peter Martyr, St. Anne & $\mathrm{O}$ & A & Zamora \\
\hline 228 & $\mathrm{~F}$ & Passion Sunday? & $\mathbf{O}$ & A & Zamora \\
\hline 229 & $\mathrm{~F}$ & Lent & $\mathrm{O}$ & A & Zamora \\
\hline 230 & $\mathrm{~F}$ & Christmas? & O & A & Zamora \\
\hline 233 & $\mathrm{~F}$ & Historia of Judith & $\mathrm{O}$ & A & Zamora \\
\hline 234 & - & Apostles & 0 & $\mathrm{~S}$ & Zamora \\
\hline 239 & - & Purification, Annunciation & $\mathrm{O}$ & A & Zamora \\
\hline 240 & - & Ember Saturday - September & $\mathbf{M}$ & $S$ & Zamora \\
\hline 243 & - & $?$ & M? & $\mathrm{S}$ & Zamora \\
\hline 245 & - & Mass Ordinary & $\mathbf{M}$ & $\mathrm{S}$ & Zamora \\
\hline 246 & - & Lent? & $\mathrm{O}$ & $\mathrm{S}$ & Zamora \\
\hline
\end{tabular}




$\begin{array}{llllll}260 & - & \text { Christmas Day } & \text { O } & \text { S } & \text { Zamora } \\ 268 & - & \text { Trinity } & \text { M } & \text { A } & \text { Zamora } \\ 269 & - & \text { Holy Week } & \text { O } & \text { A } & \text { Benavente } \\ 272 & - & \text { Corpus Christi } & \text { O } & \text { A } & \text { Zamora }\end{array}$




\section{APPENDIX 3 : TRANSCRIPTIONS}

Two major problems encountered during the transcription of the melodies are firstly, the occasional illegibility or partial illegibility of the fragments, and secondly, the difficulty of establishing the pitch of Aquitanian notation written on a single staff-line without clef. The second of these problems has been discussed in Chapter 4. Those points at which poor legibility makes it impossible to read the notation or the text, or makes the reading doubtful, are marked in the transcriptions. Round brackets enclosing notes indicate that the enclosed notes are doubtful; round brackets enclosing text indicate that such text has been supplied from another source, usually $A H$. A short single slanted line / crossing part of the staff indicates that it has been impossible to read the notes of the Zamoran source at that point and that they may not be supplied from elsewhere within the same source. Two or more long slanted lines $/$ crossing through full staffs indicate larger portions of a chant missing due to a fragment having been cut or otherwise damaged. Square brackets indicate expanded text abbreviations but are only shown if some doubt exists as to whether or not the correct interpretation has been made.

The music has been transcribed in tail-less notes, with the exception of two chants in mensural or semi-mensural notation and the polyphonic pieces which are presented in modern measured notation. The epiphonus and the cephalicus of Aquitanian notation, and the plica of square notation likely to indicate liquescence, are notated as two notes joined by a crossed curved tie $九$. For those chants written in square notation in which the plica is used and is likely to indicate a note of double duration, the plica has been transcribed as a hollow note-head 0 . Plicas in the polyphonic transcriptions are transcribed in the conventional manner with two tied pitches, the stem of the second being crossed. Neumes transcribed in tail-less notes and comprising more than one pitch in both Aquitanian and square notation are signalled by curved ties. (It was decided to use curved ties rather than square ligature brackets for all neumes, without distinguishing between those with discrete elements and those which are ligated, for the sake of simplicity and clarity given the employment of both Aquitanian and square notation amongst the sources and the frequency of neumes with discrete elements in the former notation.) In transcriptions in modern 
measured notation the conventional square ligature brackets are employed to indicate ligatures and conjuncturae are indicated by curved ties. Virgules found in the chants have not been indicated. On the other hand, virgules are shown in the transcriptions of polyphonic pieces: those of $\mathrm{Z} 184$ reproduce the length of the virgule in the fragment and its position on the staff, while those of the Misal votivo are reproduced in standardized lengths as it seems certain that specific length is without significance in this source. Editorial accidentals in general have not been added as this aspect has not been studied in detail in this dissertation. B-flats have, however, been added to the Gloria. Spiritus et alme as these are found in the close concordance in $\mathrm{Hu}$ and one has been added to the hymn $O$ lux beata as it is suggested by the presence of a quilisma.

Occasional neumes have been indicated above the staffs in the transcriptions. These neumes fall mainly into two categories: 1 . those which it has not been possible to study in this dissertation and the interpretation of which is uncertain; and 2. those which have been considered here but remain problematic or are of interest. The semicircular virga is shown in the single chant of the transcriptions in which it occurs. All instances of the quilisma are marked by the letter $Q$ above the note. (This method of signalling the presence of a quilisma has been chosen because of the large variety of forms of the quilisma group which occur in the sources.)

The spelling of the sources is retained without normalization, however, all original punctuation has not been retained. The full texts given for hymns in the sources are included with their melodies. Few of the fragments, however, present entire hymns as most are missing strophes due to the size of the fragments or because only part of a hymn was included in the copying of a mansucript. Hymn melodies in the sources are with few exceptions given for no more than the first strophe, a few not even including the entire first strophe. In Conlaudemus omnes pie the music for each pair of versicles is only written out once; this method has been followed in the transcription.

The order of the transcriptions follows that of the chapters of Part C. (Preface and Pater noster chants are not transcribed.) The catalogue of openings of the Ordinary of Mass chants is placed first, followed by the few Ordinary chants which are transcribed in full. 


\section{CHANTS FOR THE ORDINARY OF MASS}

\section{Catalogue}

Chants of the Kyrie

1. Z 68[a]": Clemens rector eterne

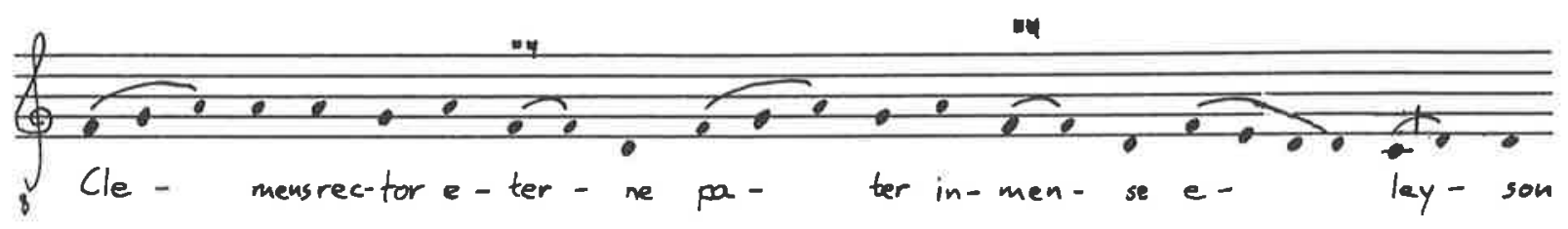

2. Misal votivo, fol. $36^{v}$

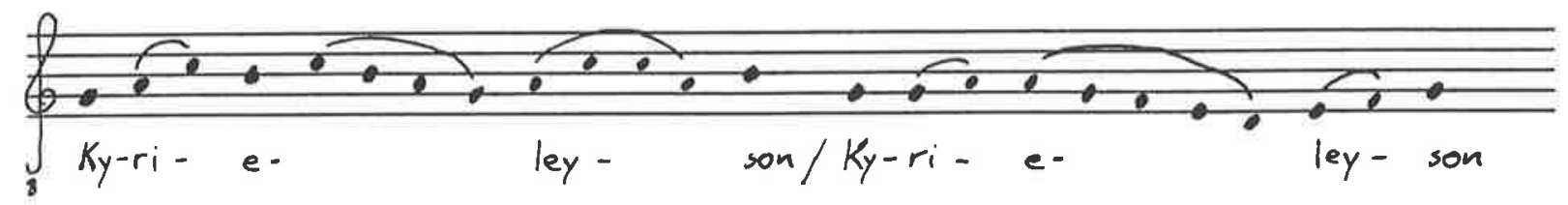

3. Misal votivo, fol. 46: Conditor kyrie omnium

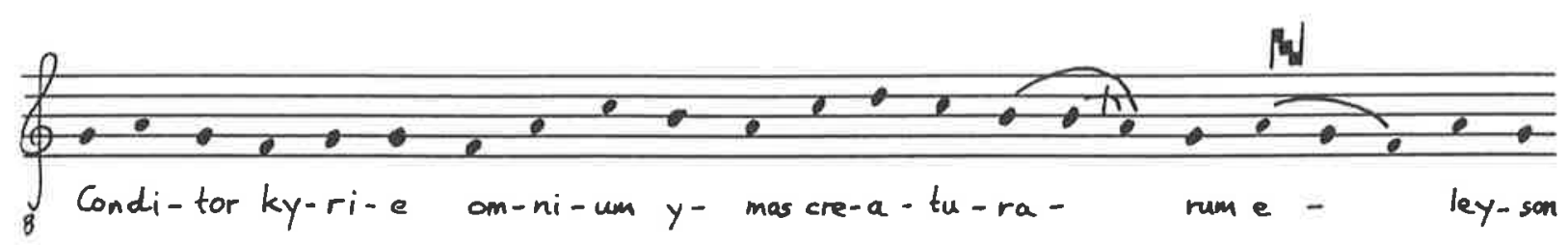




\section{Chants of the Gloria}

\section{Z 68[b]}
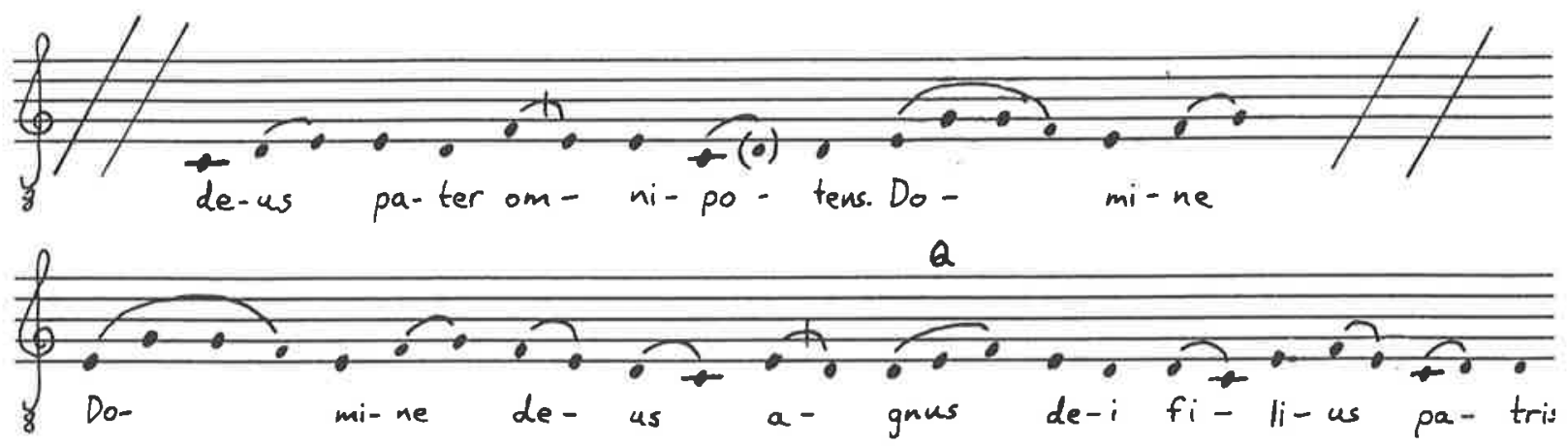

\section{Z 68[b]}

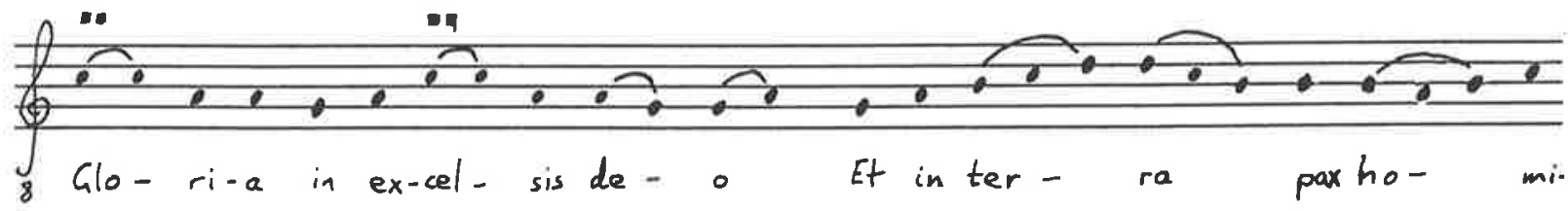

\section{3. $\mathrm{Z} 68[\mathrm{~b}]^{\mathrm{v}}-\mathrm{Z} 67^{\mathrm{r}}$}

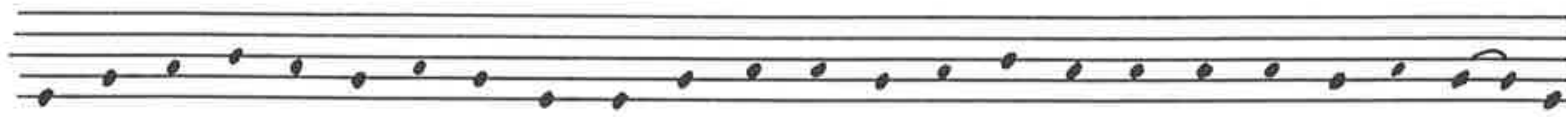

Glo-ri-a in ex-cel-sis de-o Et in ter-ra pax ho-mi-ni-bus bo-ne uo-lun-ta-tis

4. $\mathrm{Z} 67^{\mathrm{r}}$

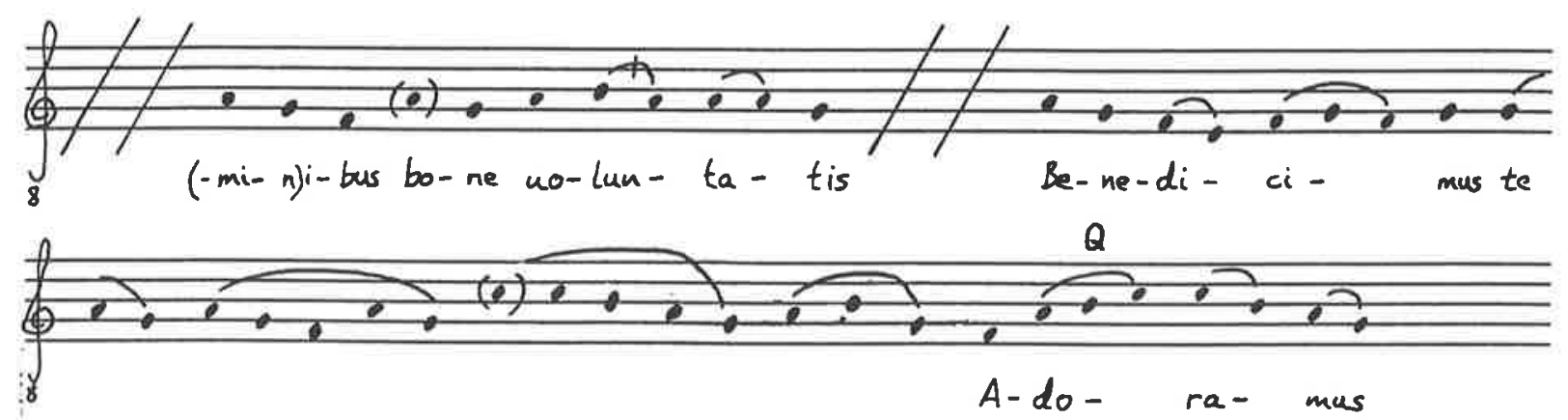


5. Misal votivo, fols. $46^{v}-47^{v}$

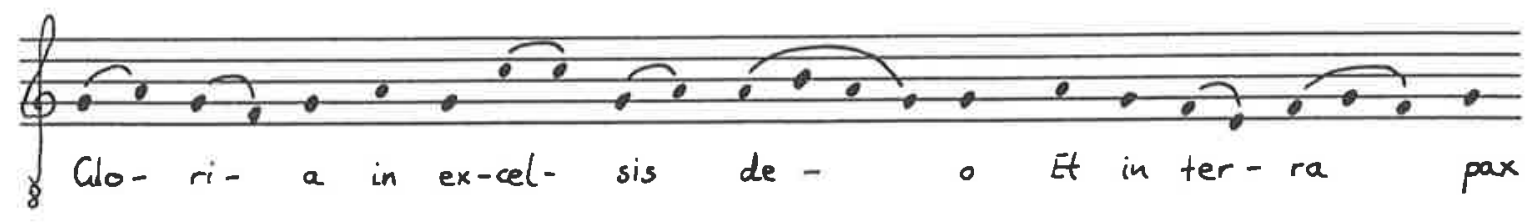

\section{Misal votivo, fol. $2^{r}$}

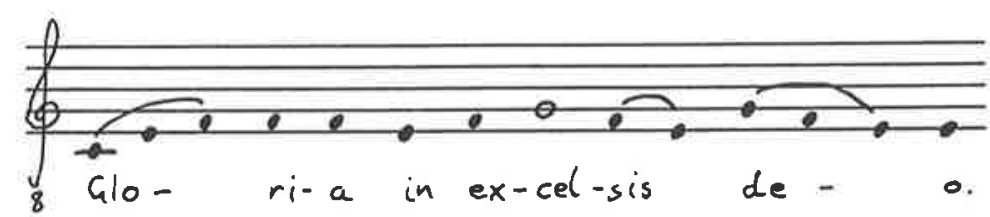

7. $\mathrm{Z} \mathrm{153}$

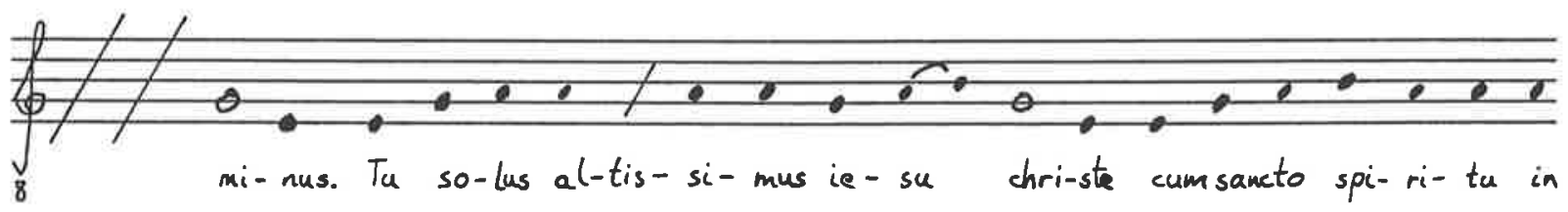

\section{Z 153}

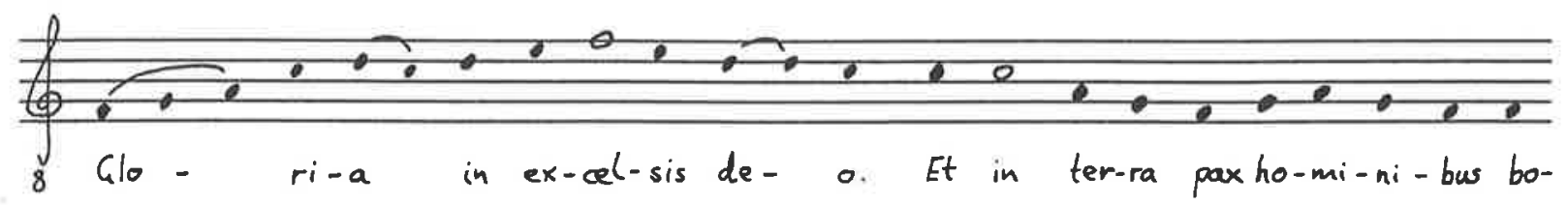




\section{Chants of the Credo}

1. Misal votivo, fol. $2^{r}$

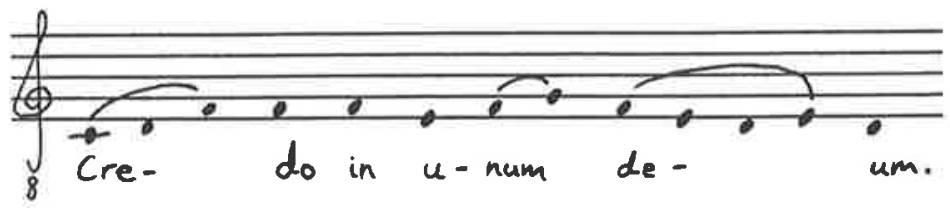

\section{Z 151}

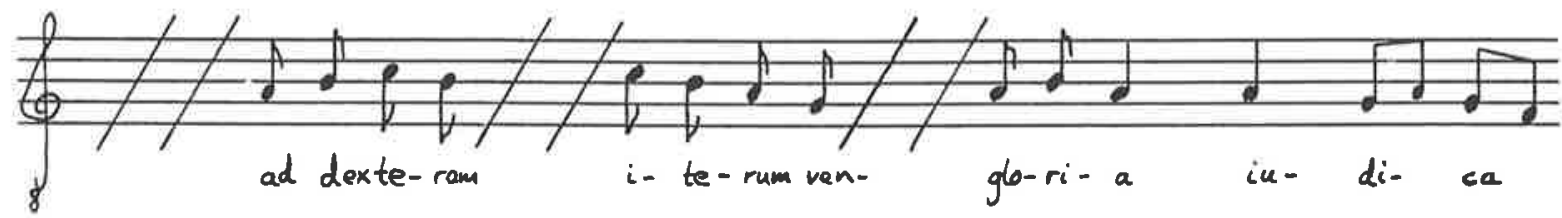


Chants of the Sanctus

1. Misal votivo, fol. 41

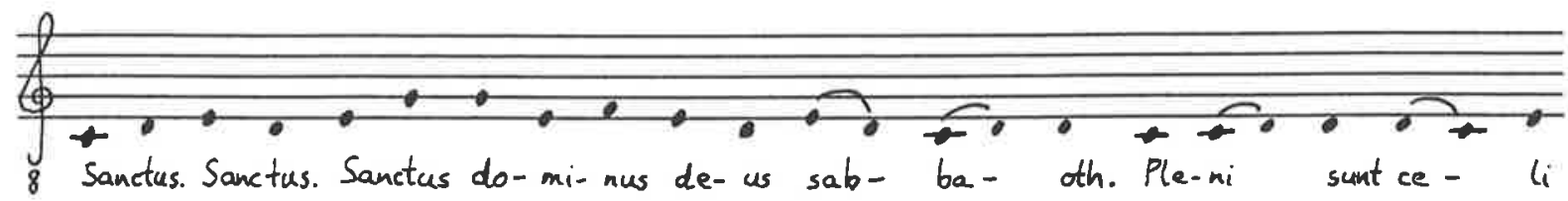

2. Misal votivo, fol. $50^{\circ}$

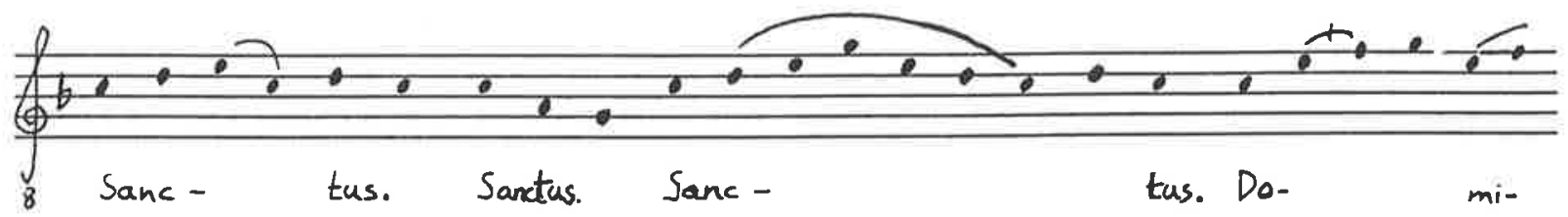

3. Misal votivo, fol. $4^{r}$

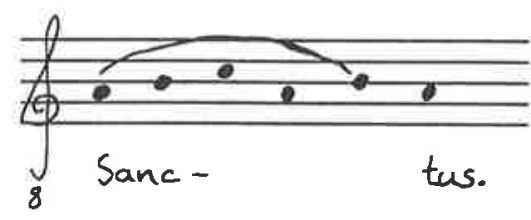

\section{Z 245[a]}
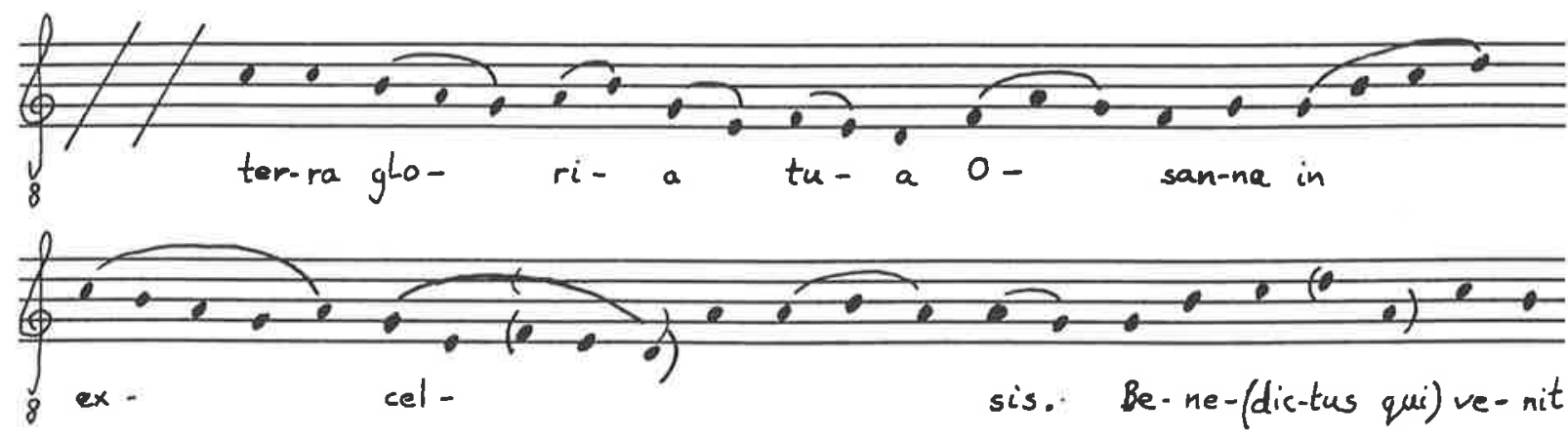
340

5. Z 245[b]

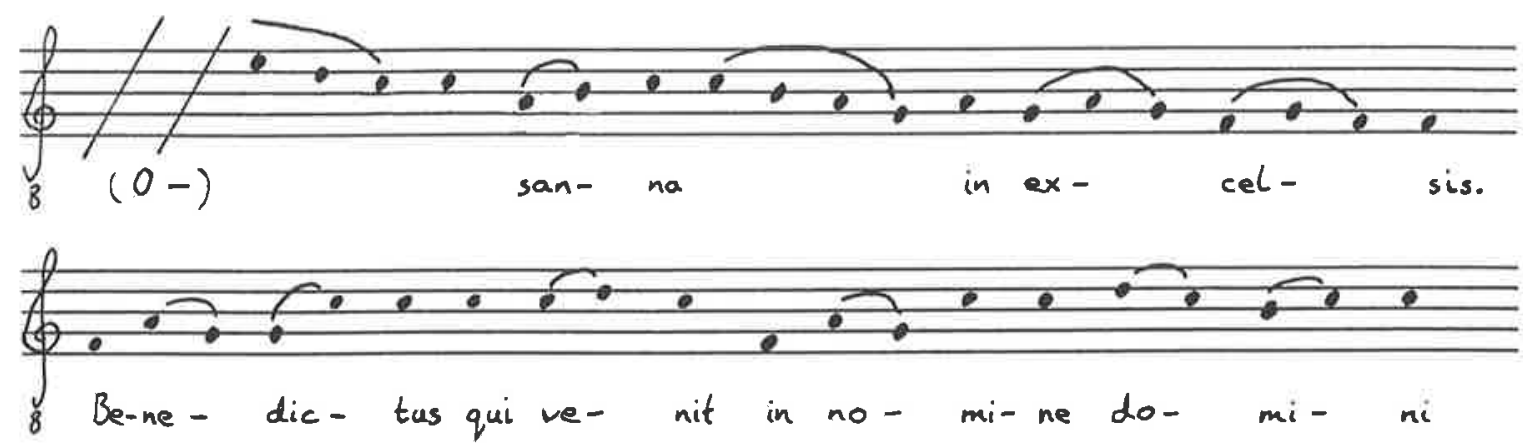




\section{Chants of the Agnus Dei}

1. Misal votivo, fol. $41^{v}$

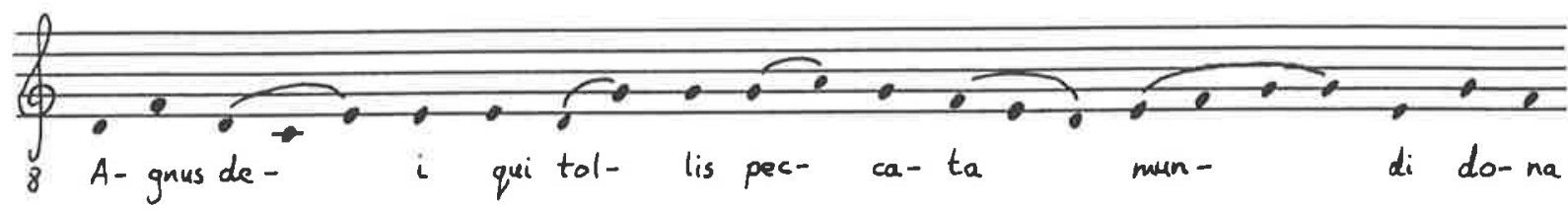

\section{Misal votivo, fols. $50^{\mathrm{v}}-\mathbf{5 1} 1^{\mathrm{r}}$}

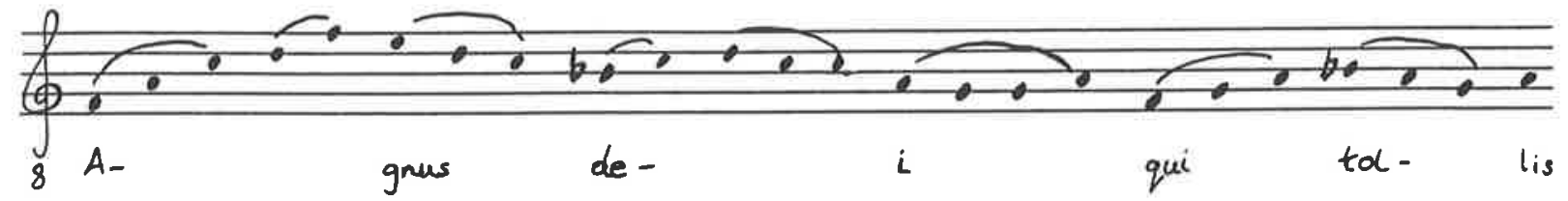

\section{Z 245[a]}

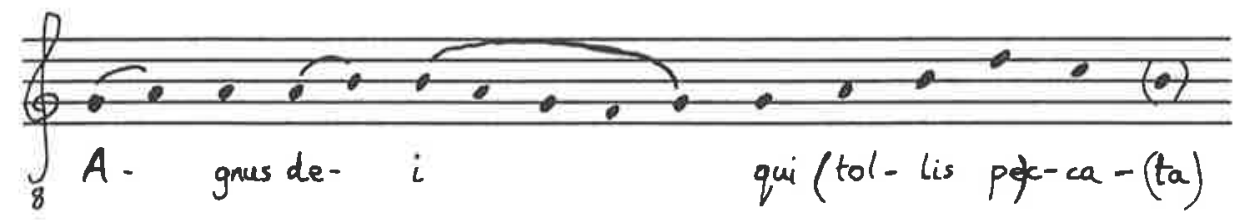

\section{Z 245[b]}

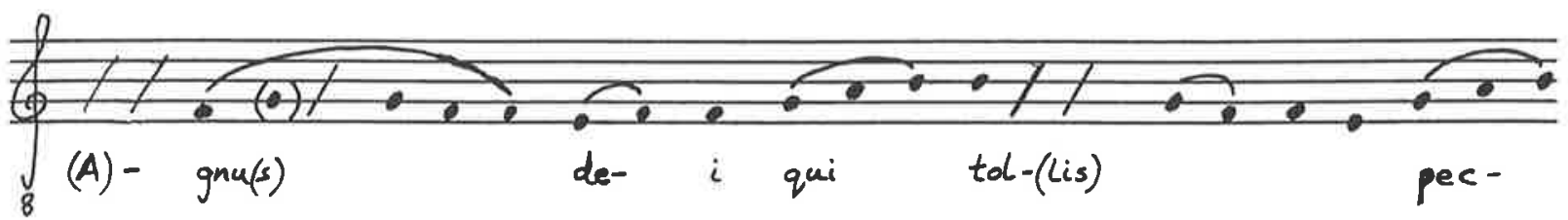




\section{FULL TRANSCRIPTIONS}

Kyrie no. 1. : Z 68[a]": Clemens rector eterne
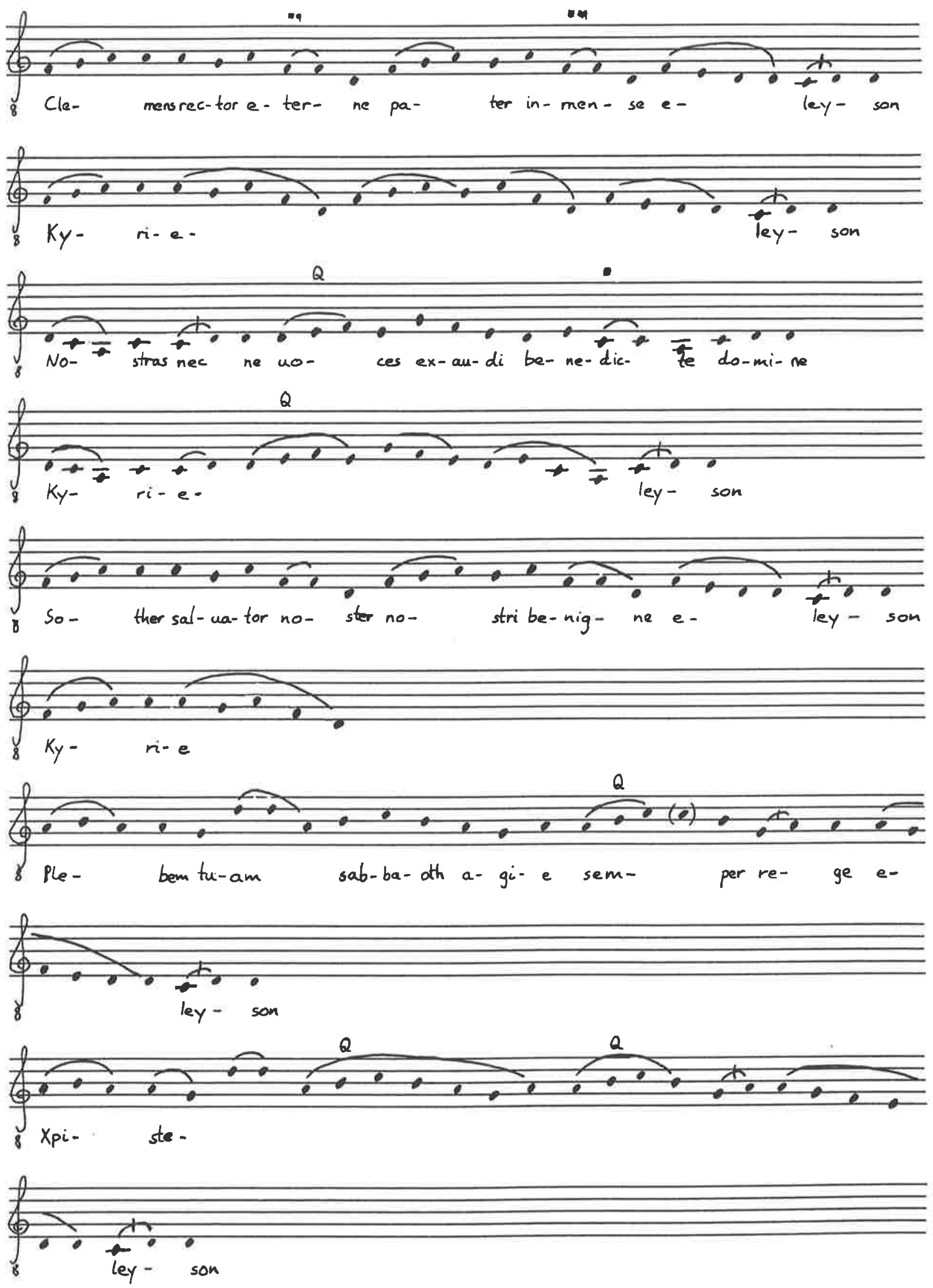
Kyrie no. 1. continued

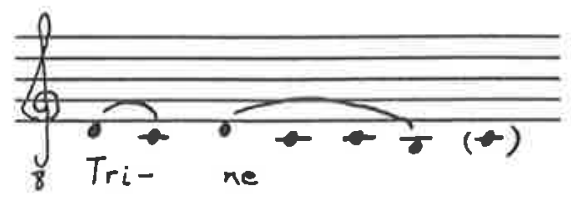

Credo no. 2. : Z 151

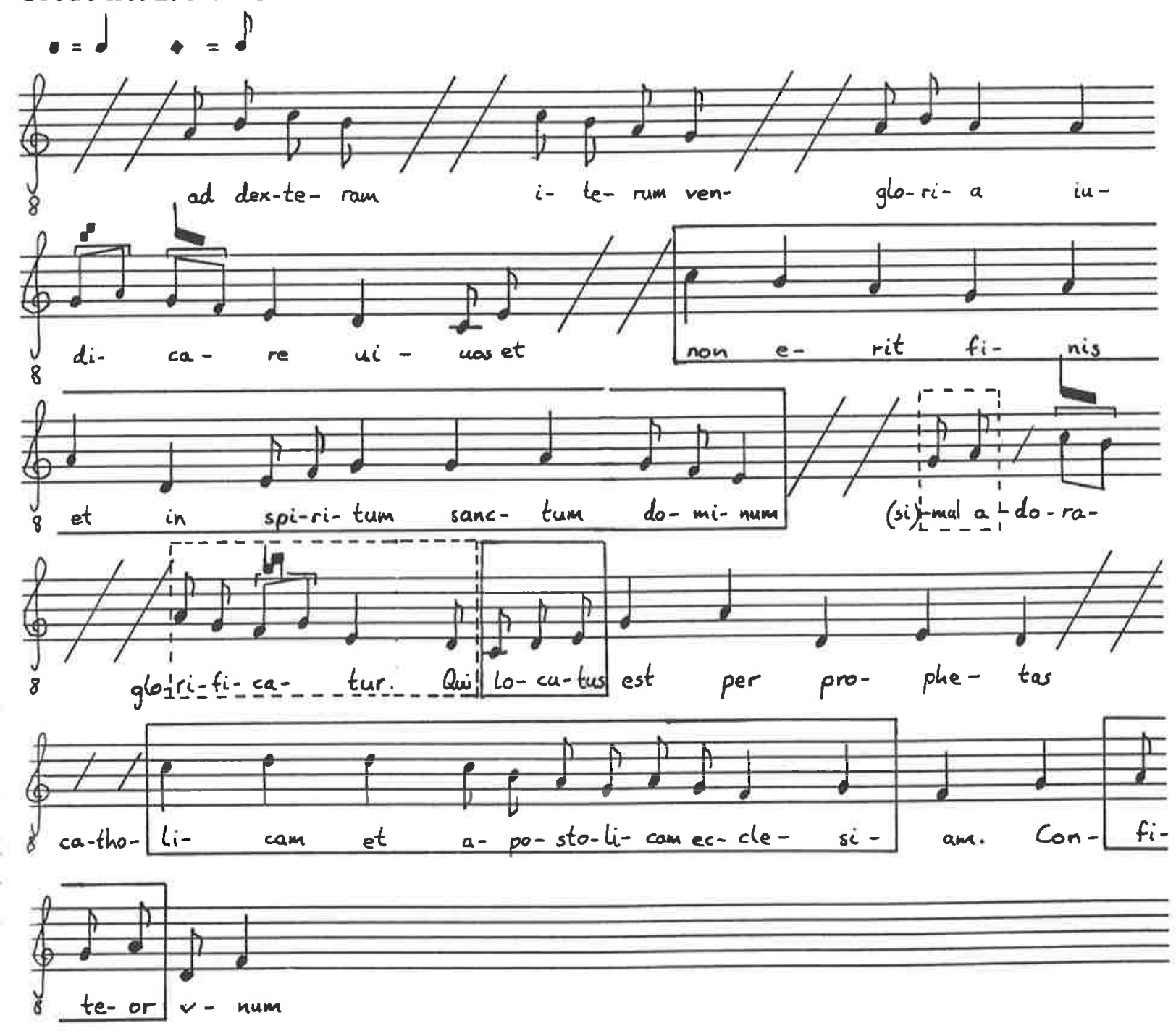


Sanctus no. 2. : Misal votivo, fol. 50"
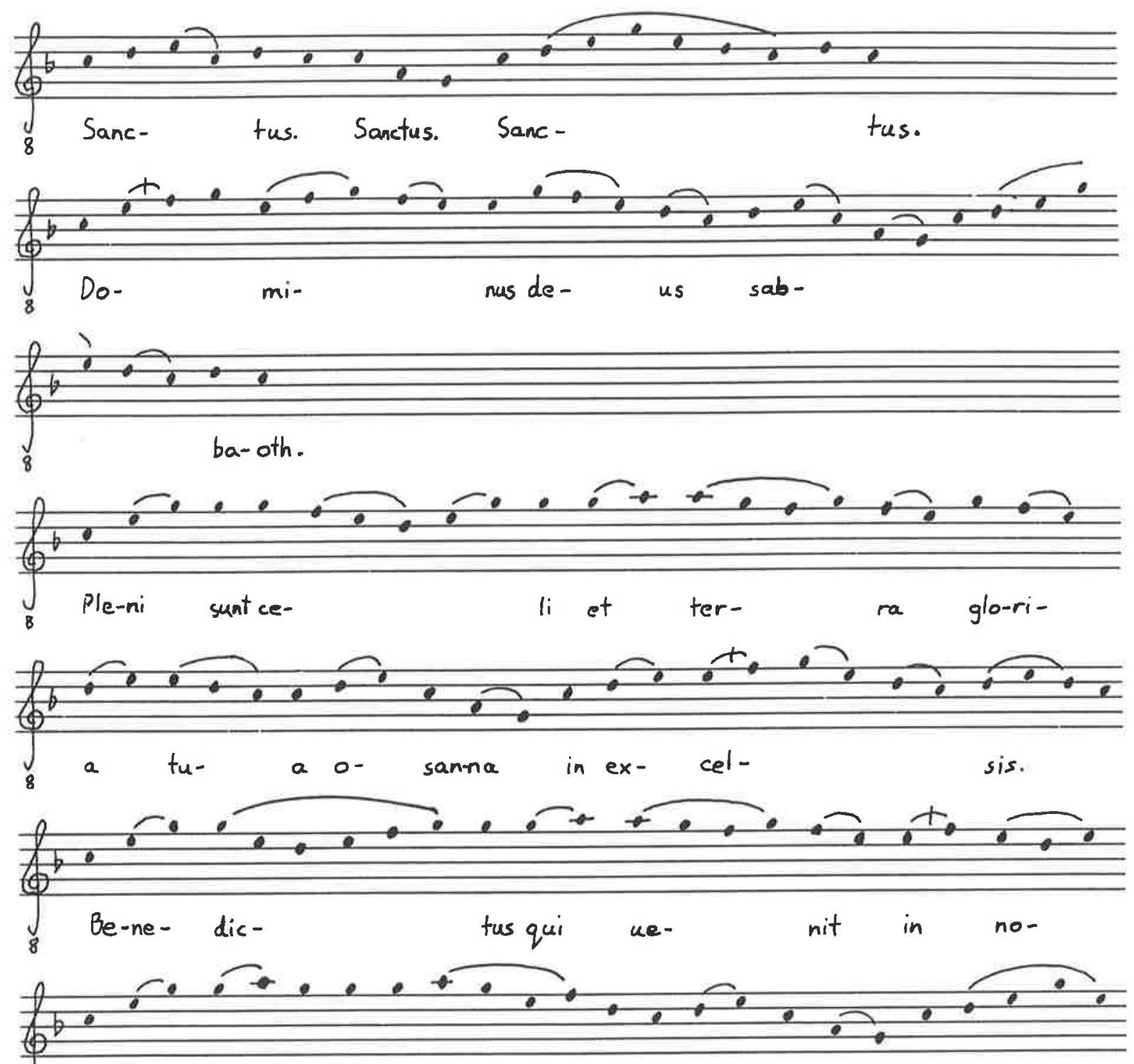
mi-ne do- mi-ni. Os-san- na.In ex-cel

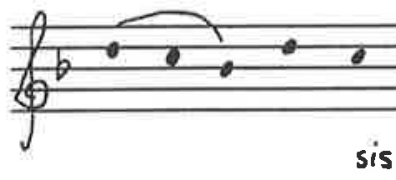


Agnus Dei no. 1. : Misal votivo, fol. 41
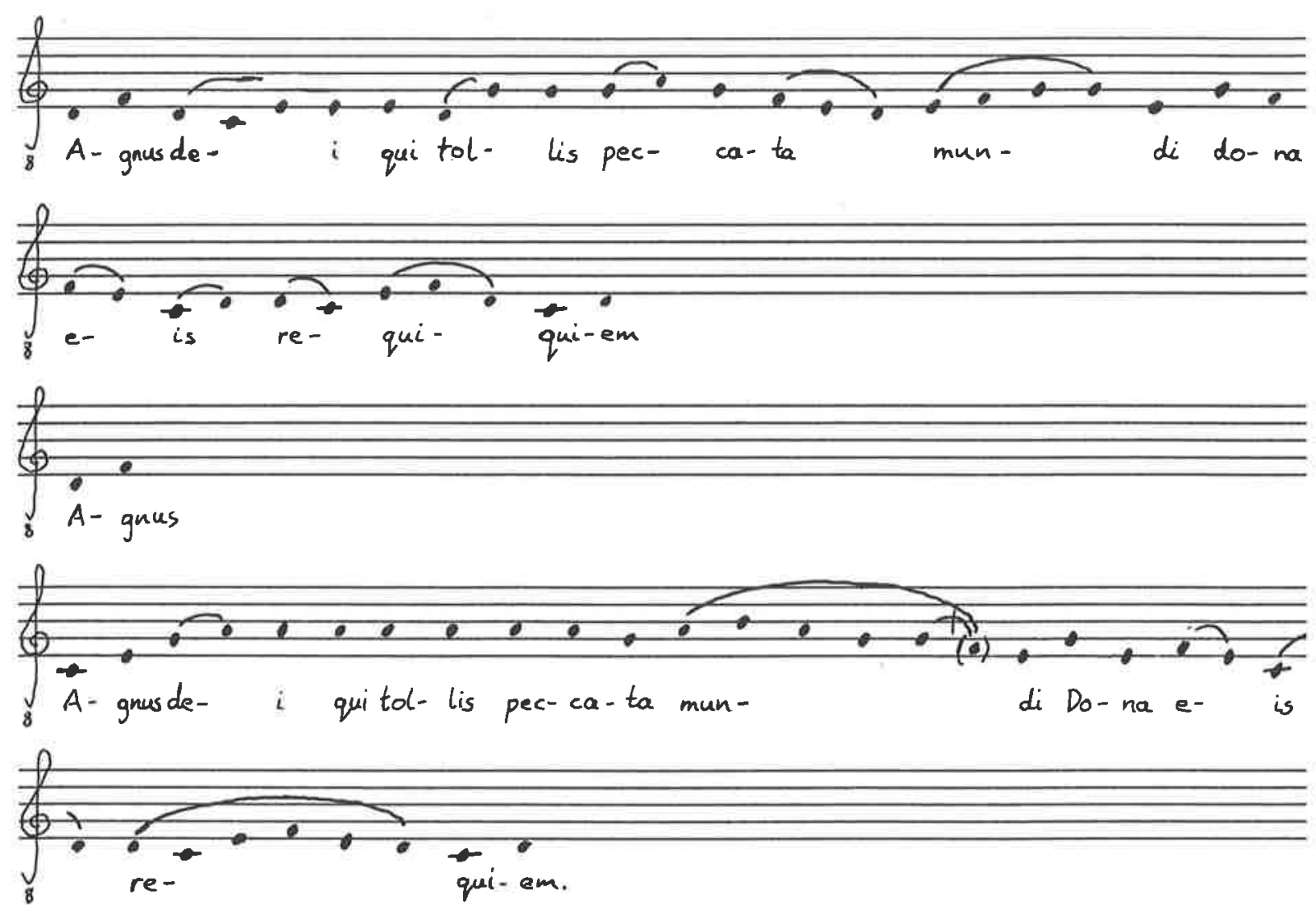


\section{PROSAE AND RESPONSORY PROSAE}

\section{Prosae}

\section{Nato canunt (Z 67)}
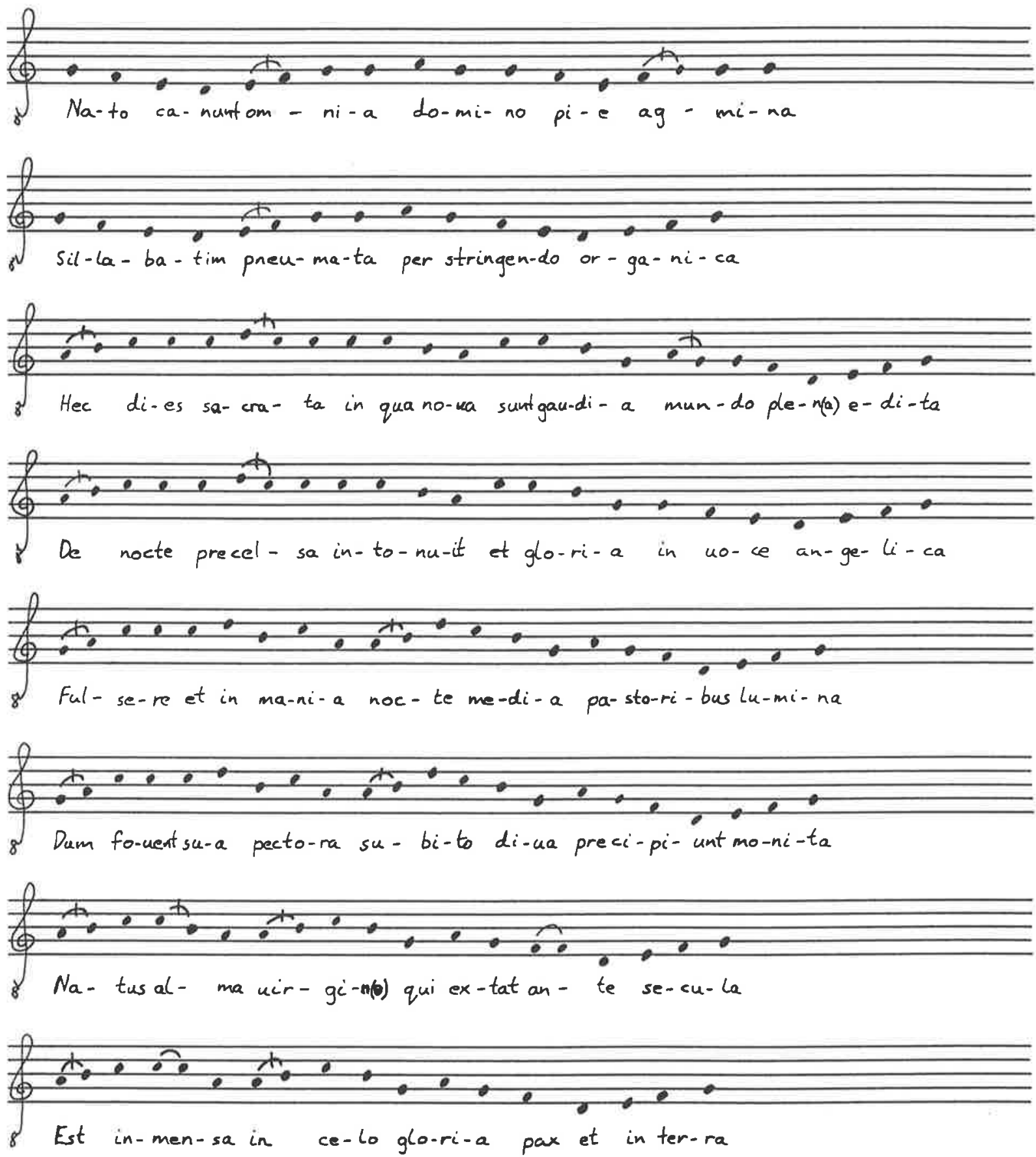
347

Nato canunt $\left(\mathrm{Z} 67^{\vee}\right)$ continued

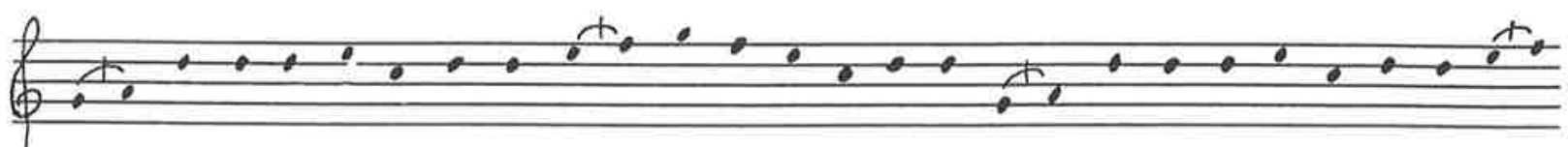

Sic er-goce-li ca-therua al- tis.si-mo iu-bi-lat ut tanto ca-no-re tre-matal-

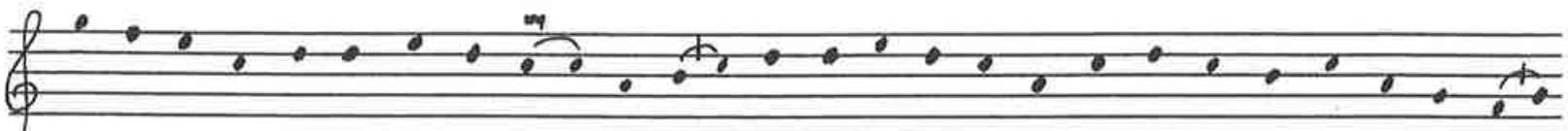

tapo-li ma-chi-na so-net et per om- ni-a hac in di-e glo-ri-a uo-ce cla-ra red-
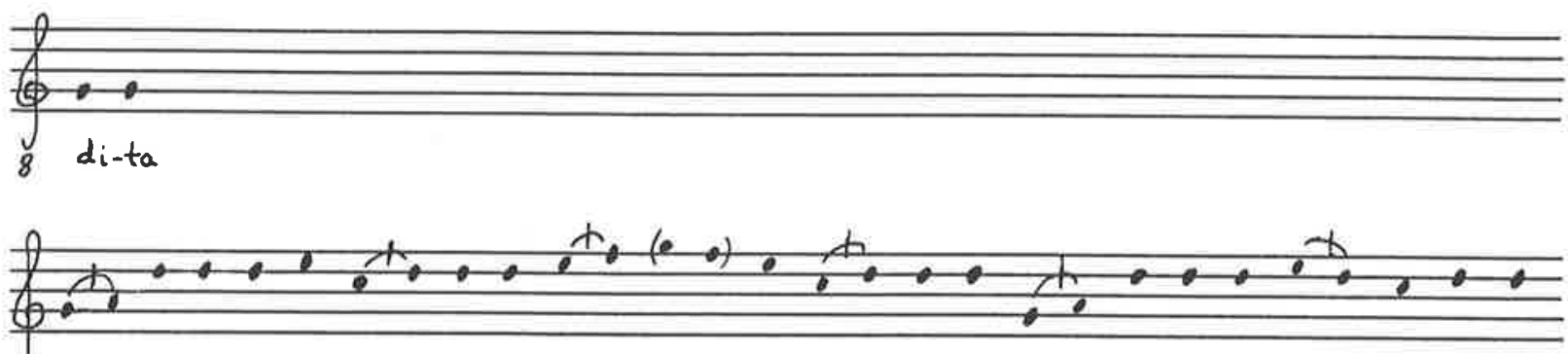

Hu- ma-na concropent curcta de - um na-tumin ter-ra con frocta surtim- pe-ri-a

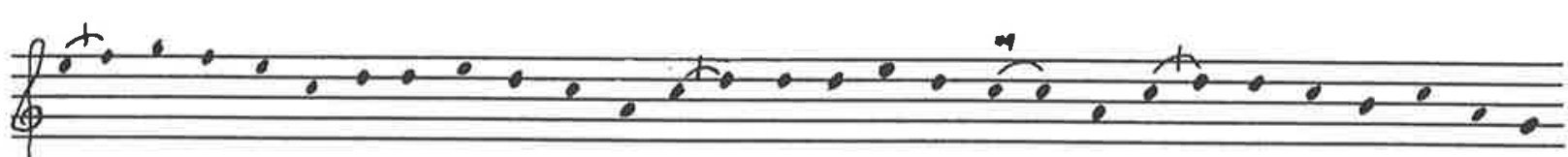

8 ho- stis crudel-lis-si-ma pax in ter-ra red- di-ta nuncle-ten- tur om- ni- a na-ti per exe

or- di-a

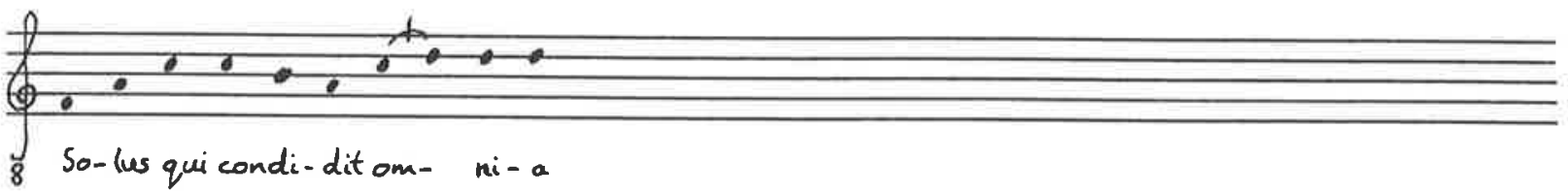

So-lus qui condi-dit om- mi- a 
2. [Adest precelsa] (Z 52')
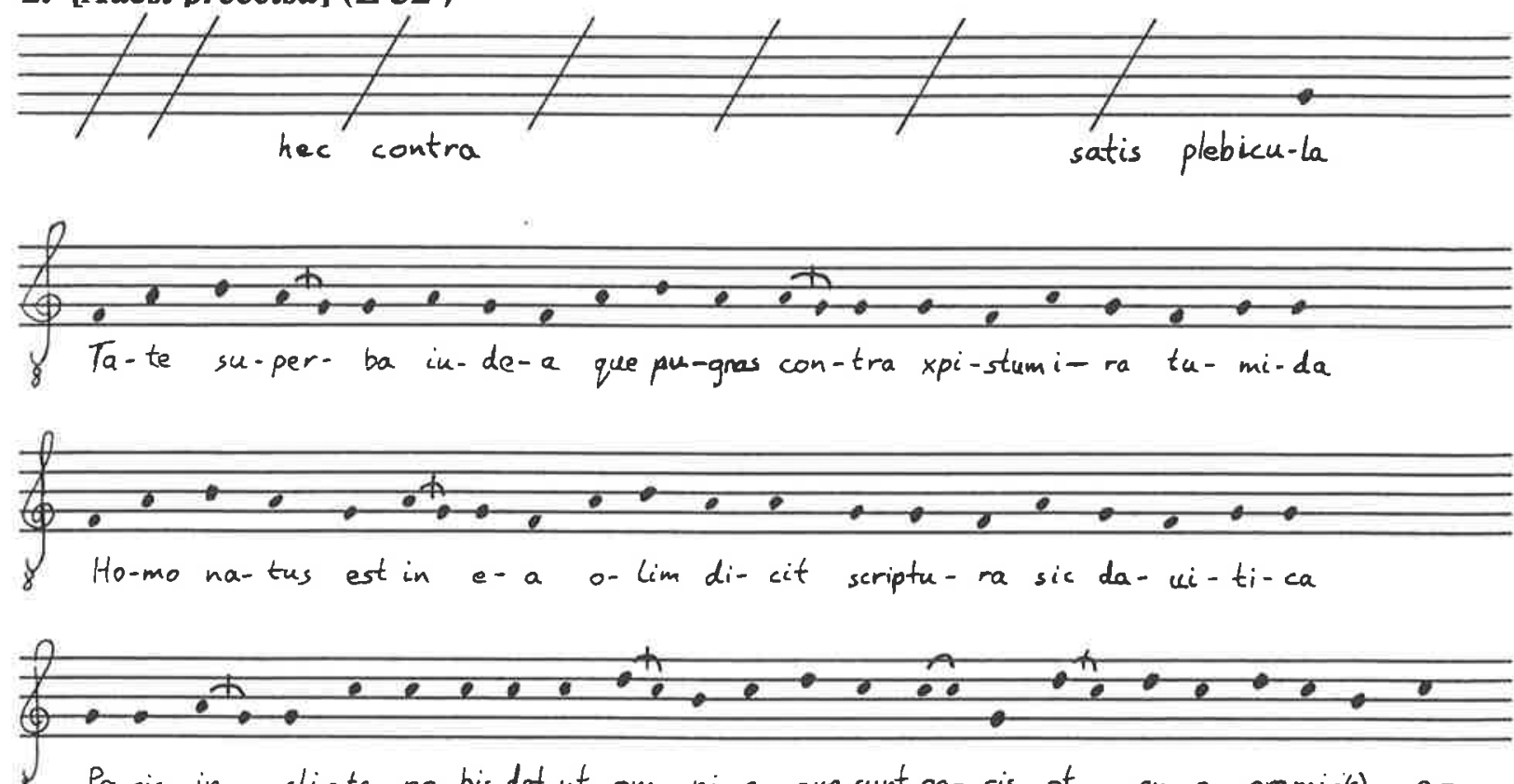

Pa-cis in - cli-ta no-bis det ut om-ni-a que sunt pa-cis et su-a premi-ja) e-
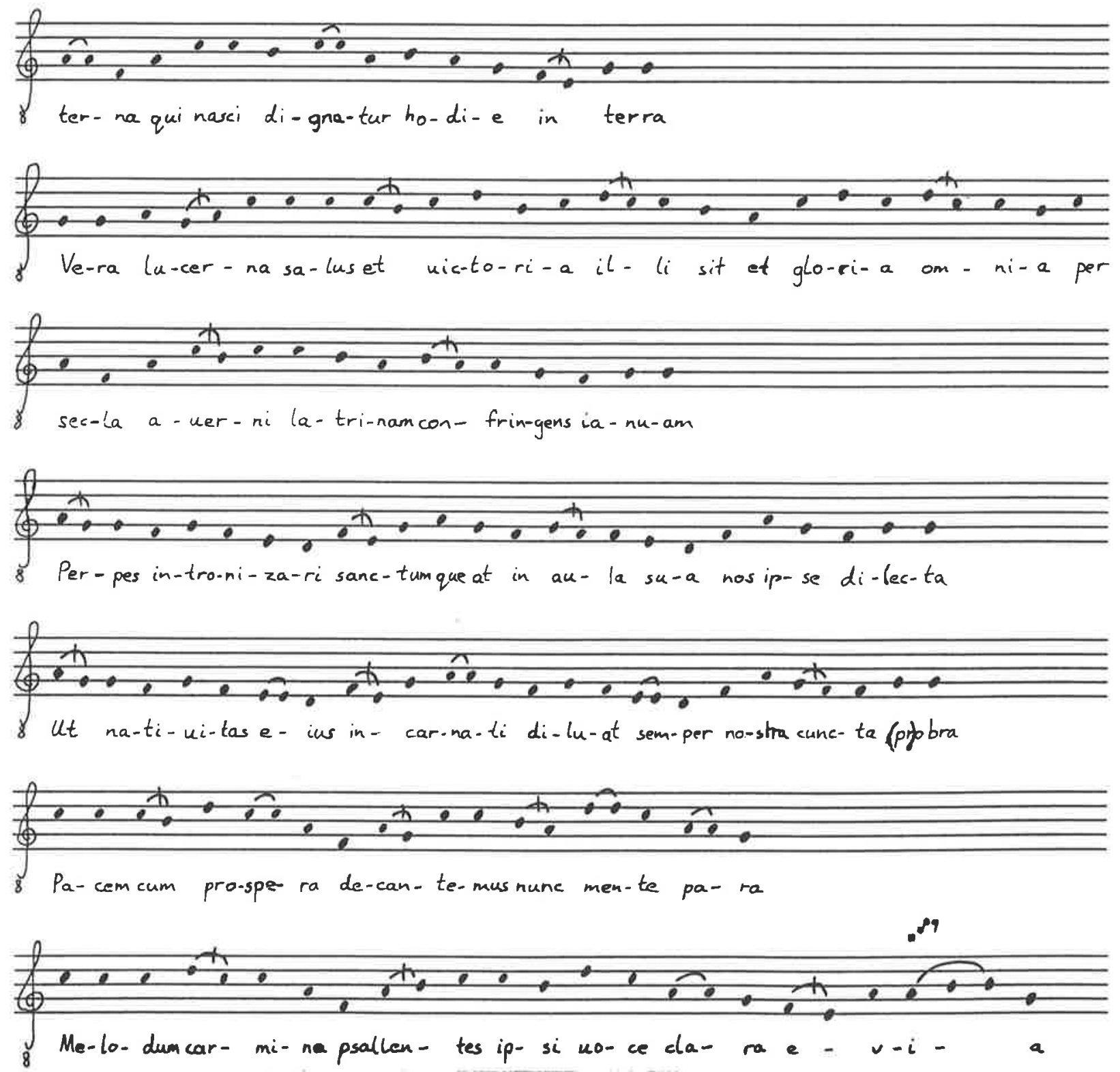


\section{Celeste organum (Z 52)}
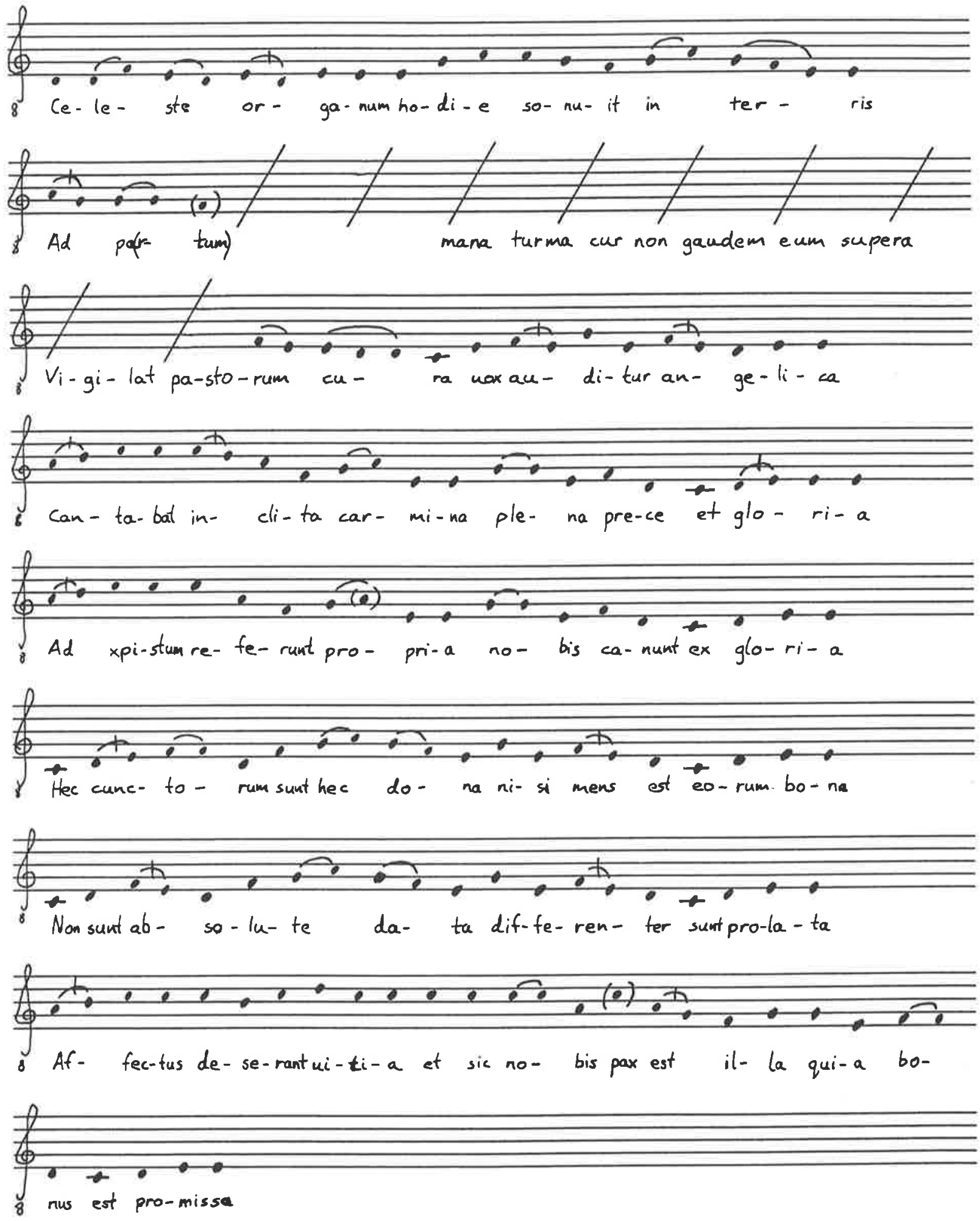
Celeste organum (Z 52) continued
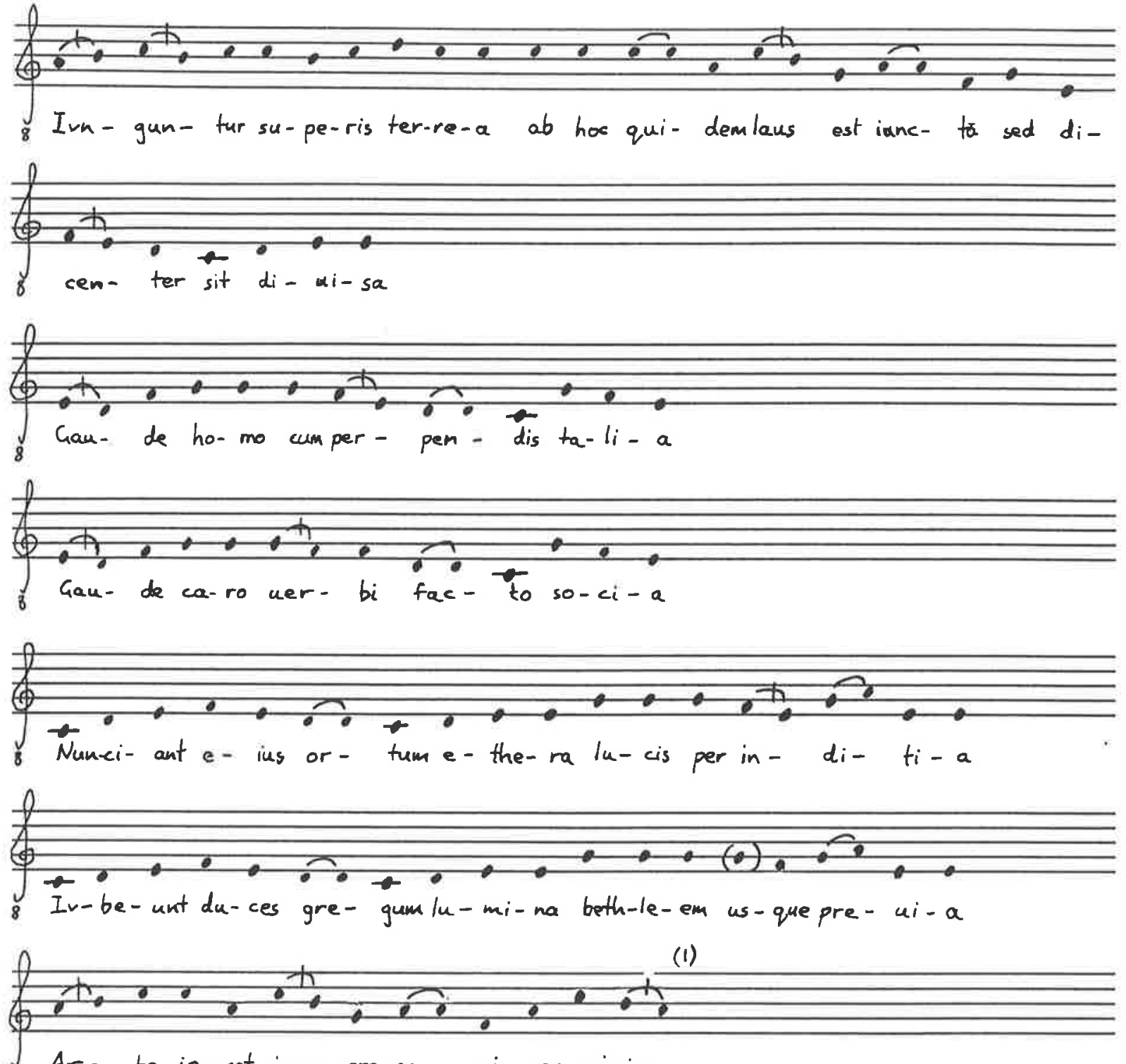

Ar- to ia-cet im- pre-se- pi rex quicin-

'Diastematy in this incomplete versicle is not precise and the reading from "Arto" is therefore uncertain. 


\section{Gaude roma $(\mathrm{Z} 203$ '}
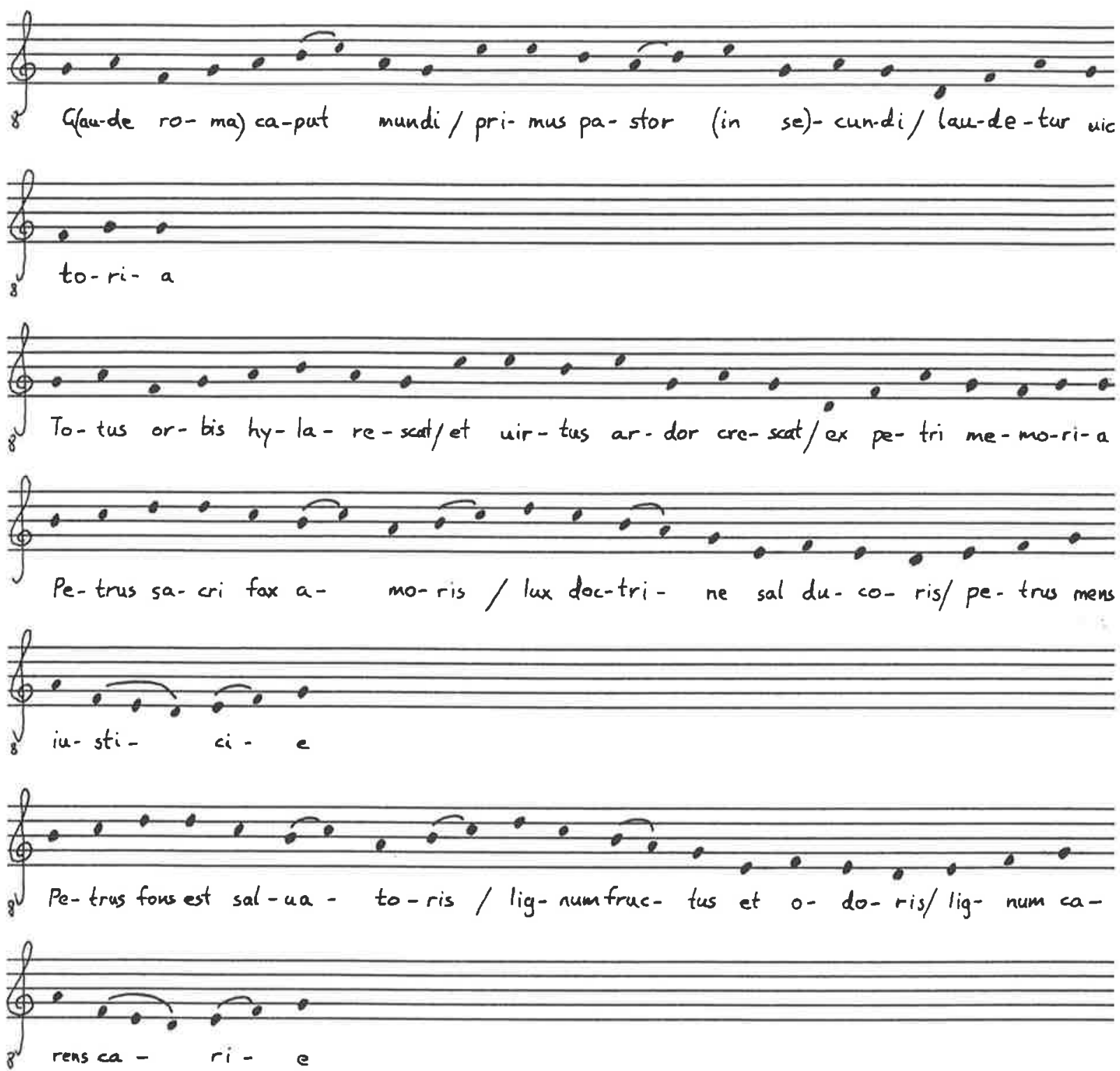

$\int_{8}^{0} \frac{(2)}{0.0(0)}$ 
352

5. Petre summe (Z 115[b])
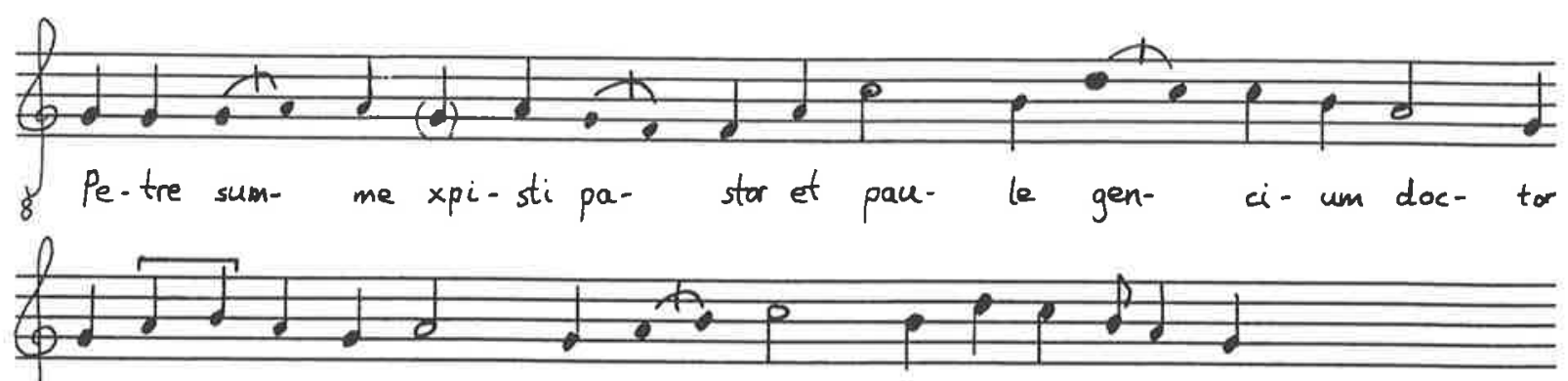

Ec-cle- si- am xpi- sti doc- tri- nis il- lu- mi-na-tam
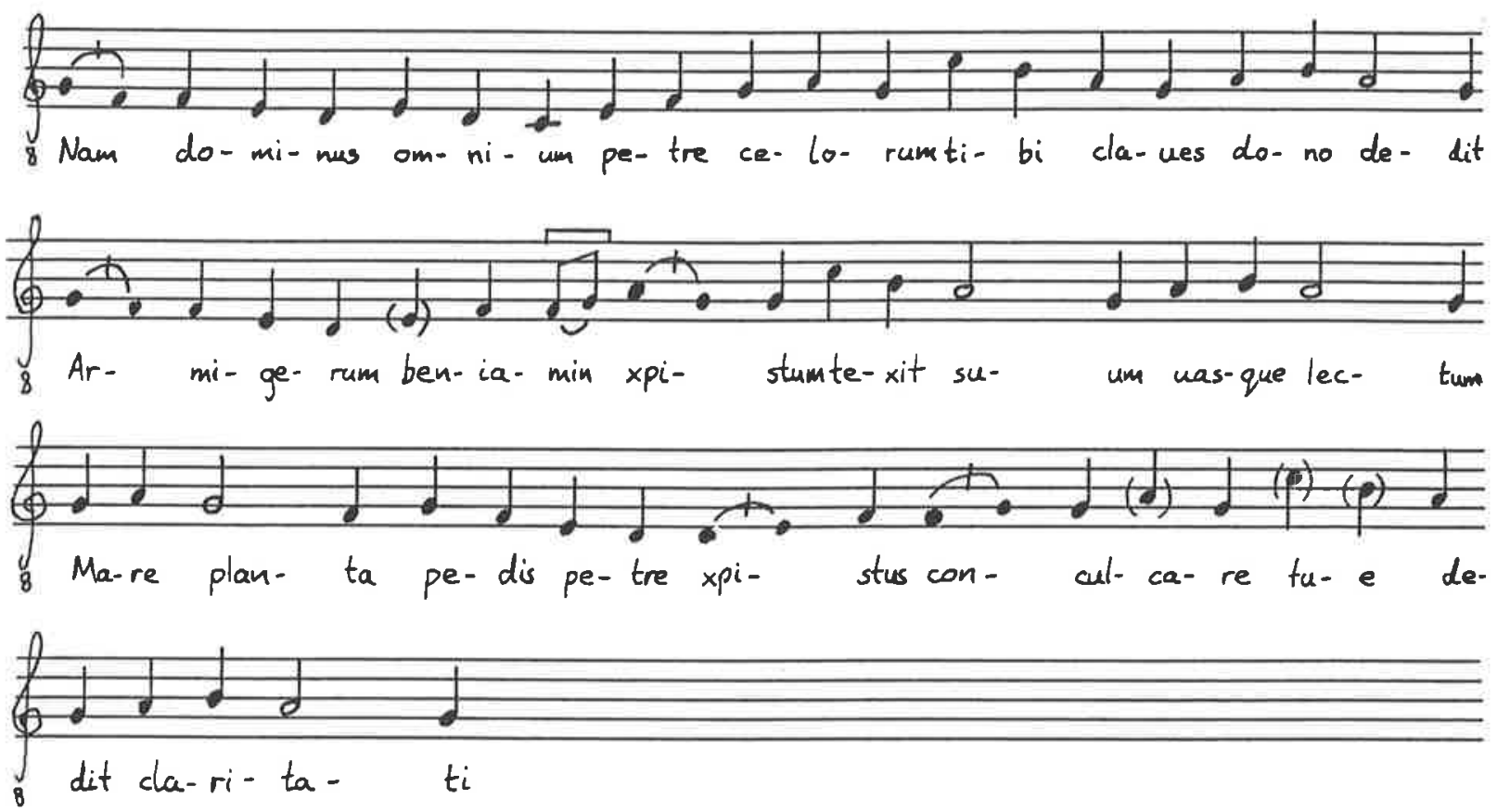


\section{Responsory Prosae}

\section{Inviolata maria intacta (Z 123)}
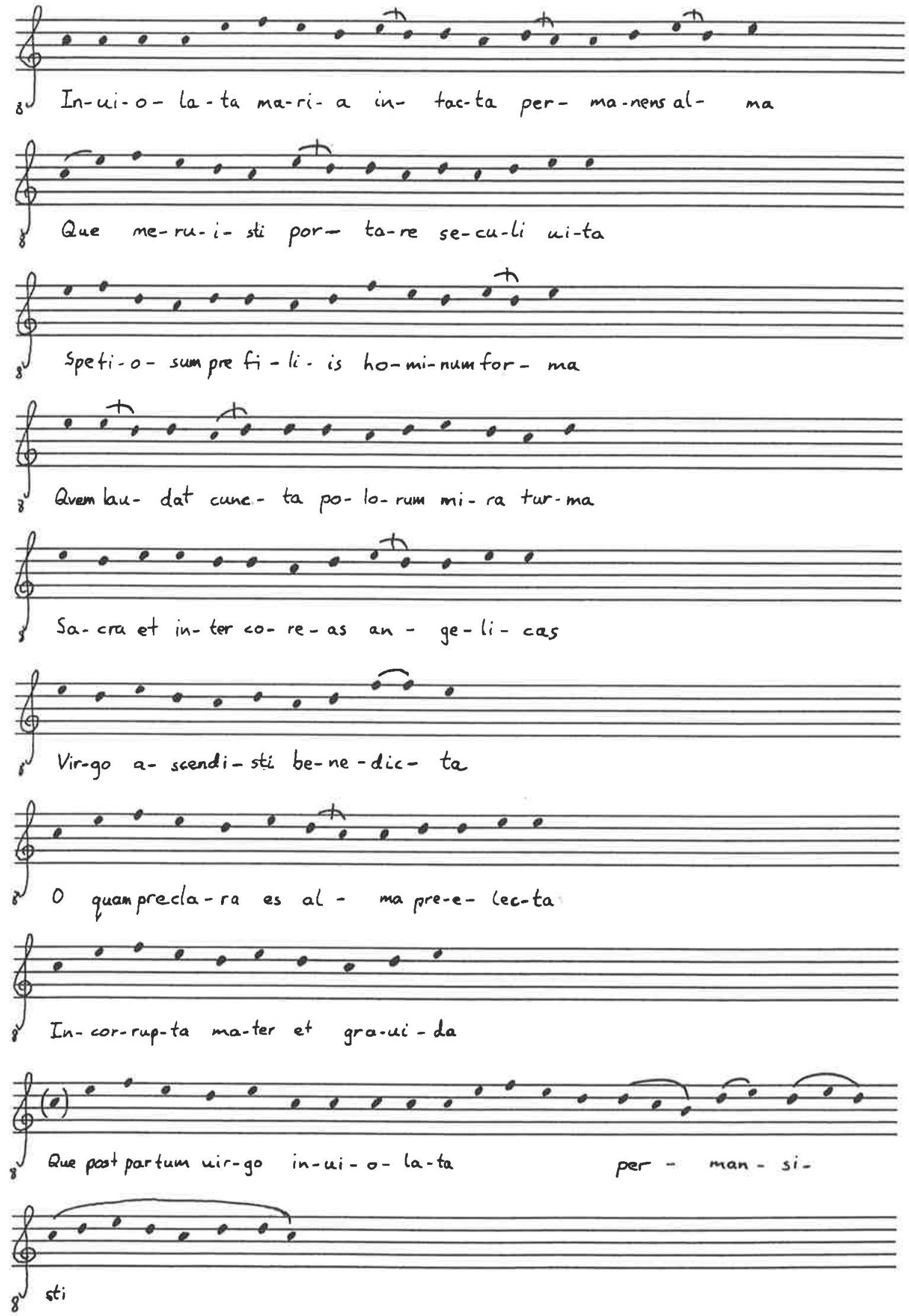
354

2. Velut in (Z 224)

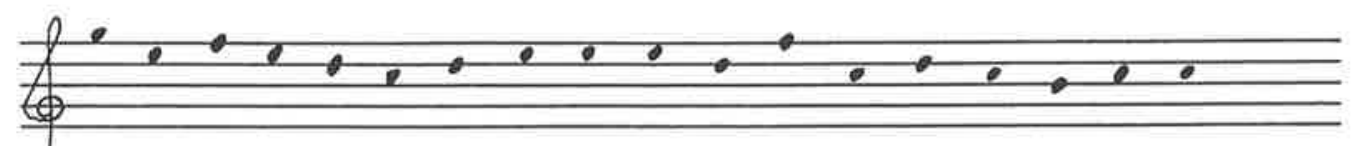

${ }_{8}$ Ue-lut in ca-la-mo ru-ti-lat fu-nenshinc do-na ui-ni-fi-ca

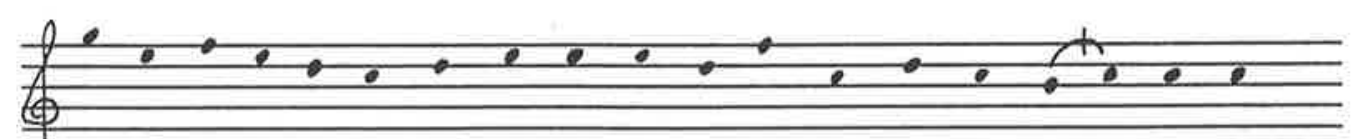

In-cor-rupti-o-ne plendi-da que ki-uit et mor-tis in um-bra

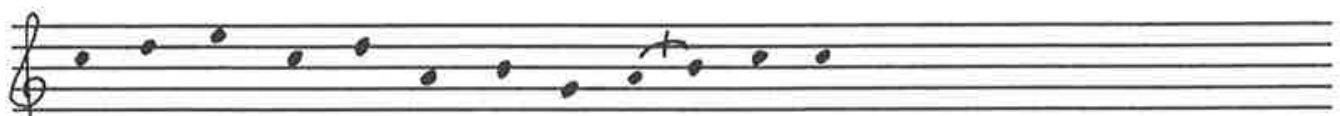

${ }_{8}$ Quambe-a- te ce- 10 re-grat om - ni- a
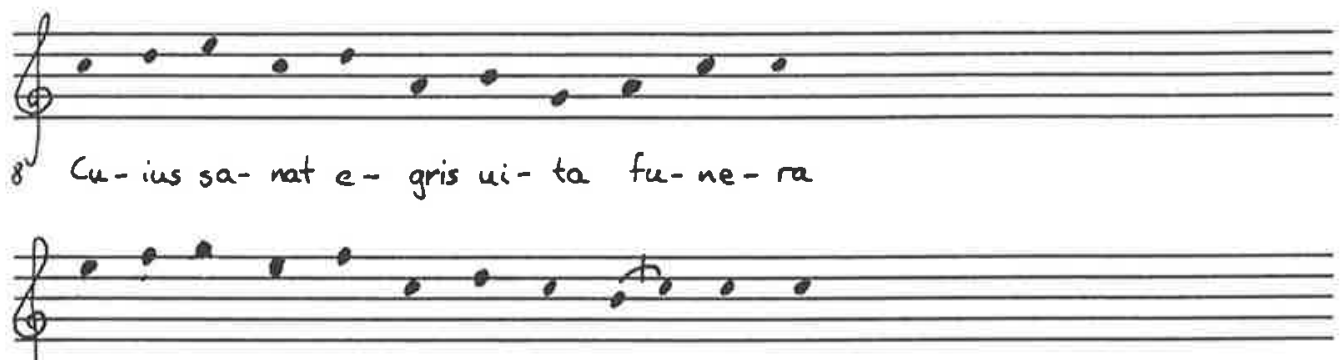

Quamde-co-re re-ful-get in glo- ri- a

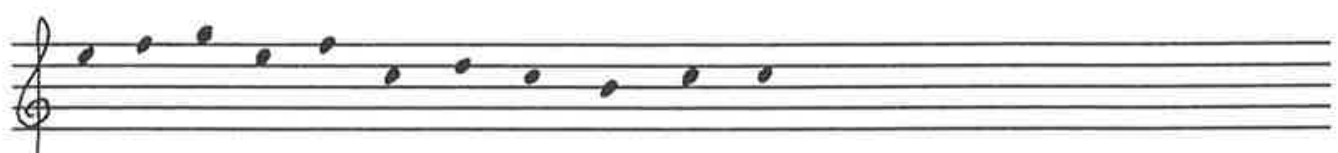

Cu-ius tumba largat uer-nat gra-ci- a 


\section{HYMNS}

1. A solis ortu cardine (Z 217[a])
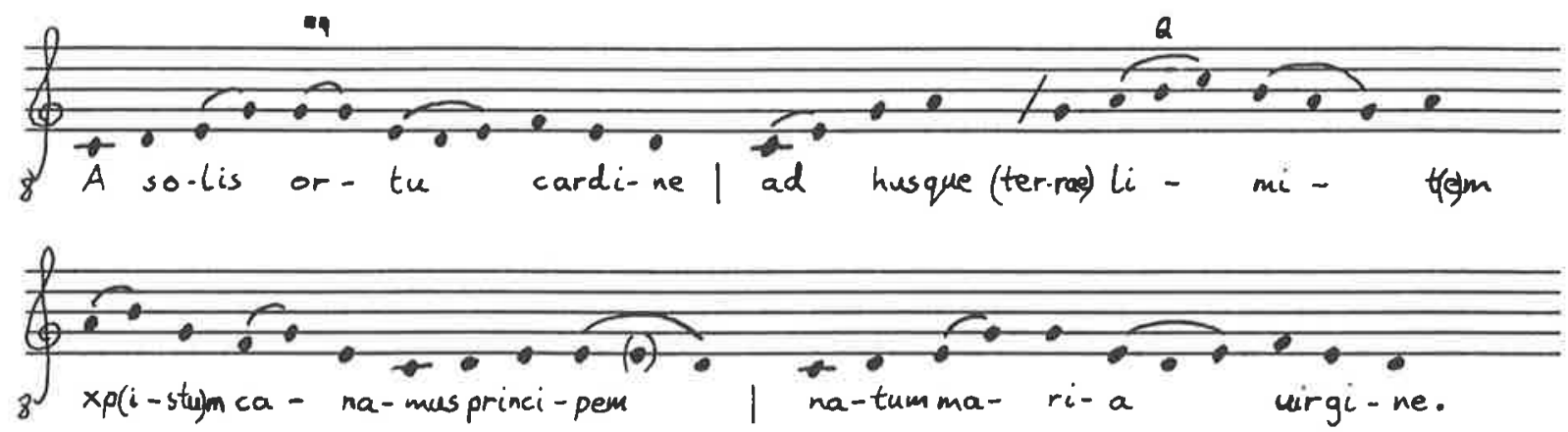

2. Beatus auctor seculi seruile corpus induit ut carne carnem liberans ne perderet quos condidit.

3. Caste parentis uiscera celestis intrat gratia uenter puelle baiulat secreta que non nouerat.

4. Domus pudici pectoris templum repente fit deo intacta nesciens uirum uerbo concepit filium.
5. Enixa est puerpera quem gabriel predixerat quem matris aluo gestiens clausus iohannes senserat.

6.(Feno iacere pertulit) presepe non aborruit paruoque lacte pastus est per quem nec ales esurit.

7. Gaudet chorus celestium et angeli canunt deo palamque fit pastoribus pastor creator omnium.

8. Gloria tibi domine. 
2. Conditor alme siderum (Z 119[a]")
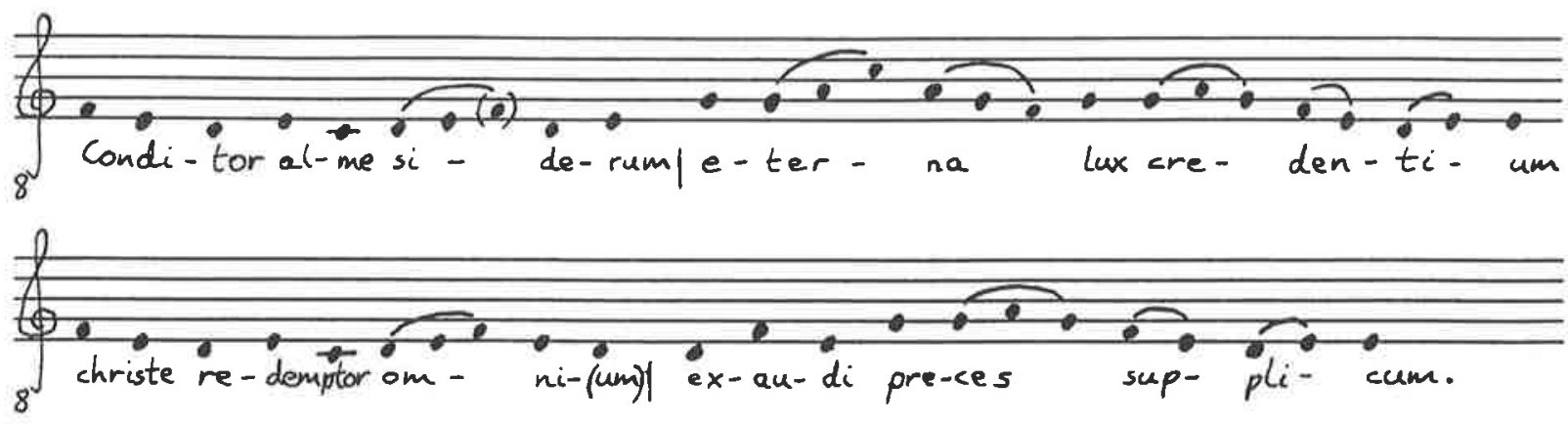

2. Qui condolen(s in)teritu (mortis pe)rire seculum (salvasti mundum lan)guidum dona(ns reis remedium.)

3. Vergente mundi ves(pere uti sponsus) de thala(m)o egressus (honestissi)ma virginis matris clausula.

4. Cuius forti potentie genu flectuntur omnia celestia terrestria nutu fatentur subdita.
5. Te deprecamur agie venture iudex seculi conserua nos in tempore hostis a telo perfidi.

6. Laus honor virtus gloria deo patri et filio sancto simul 
3. Eterna xpisti munera / apostolorum (Z 3)

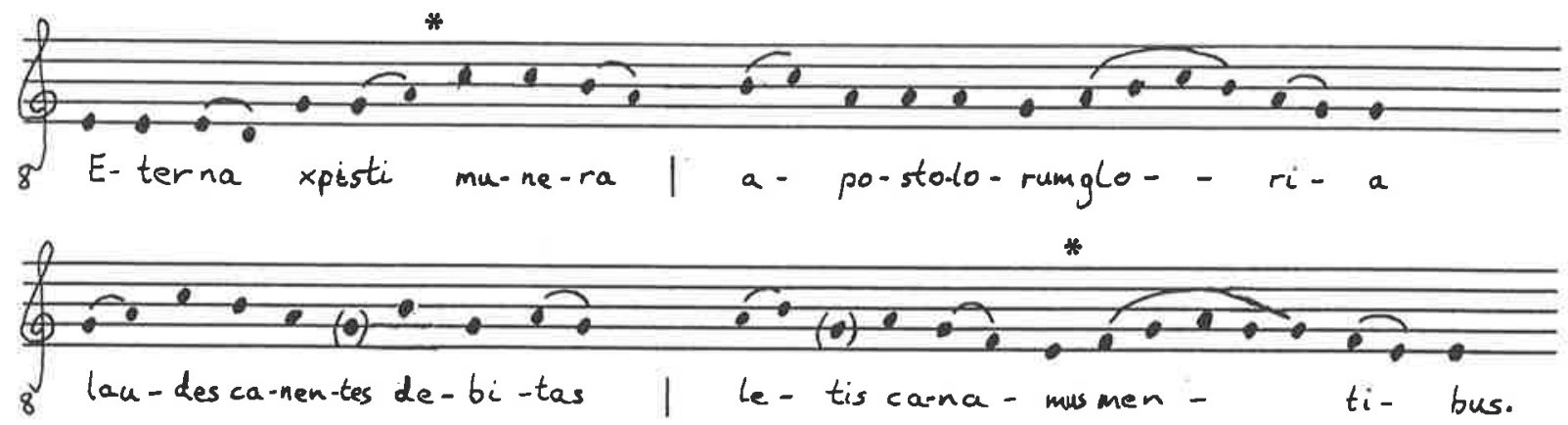

2. Ecclesiarum pri(nci)pes belli triumphales duces celestis (a)ule milites (et) uera mundi lumina.

3. Deuota sanctorum fides inuicta spes credenti(um) perfecta (xpisti) caritas mundi triumph(at) (prin)cipem
4. (I)n his pat[er]na gloria in his uoluntas sp[iritu]s exultat in his filius celum repletur gaudiis.

5. Te nunc redemptor $\mathrm{q}[$ uaesumu]s ut istorum consorcia iungas precantes seruulos in sempiterna seculorum. Amen. 
4. Exultet celum laudibus (Z 122)

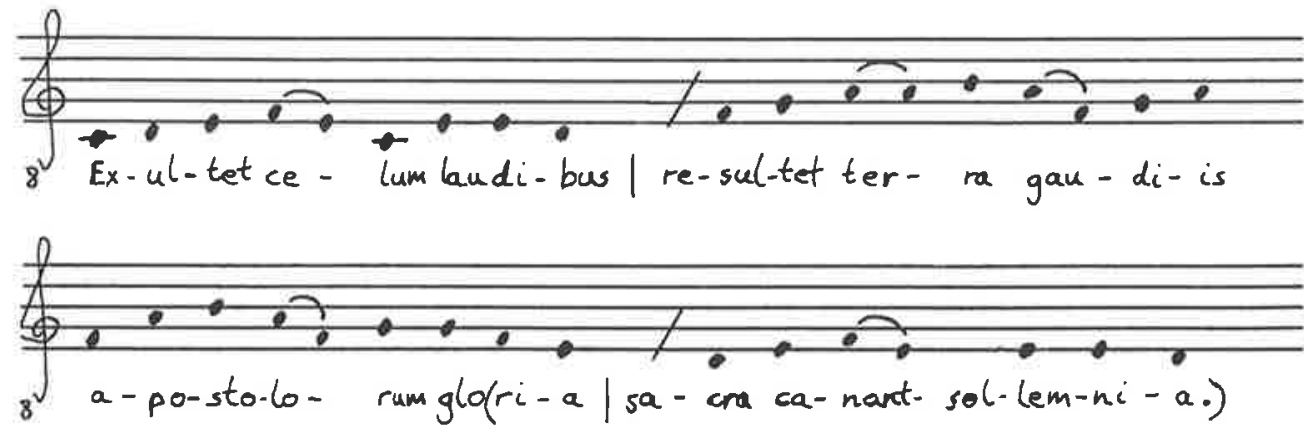

\section{Huius obtentu (Z 114[a])}

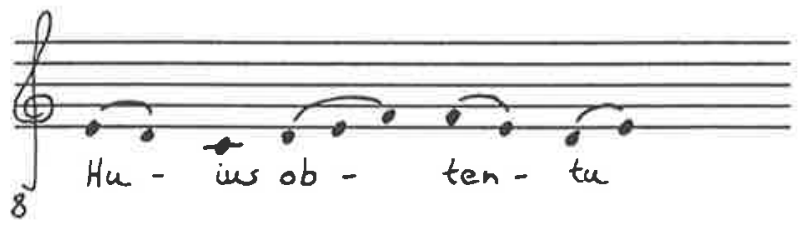


6. Iam xpiste sol (Z 197[a])

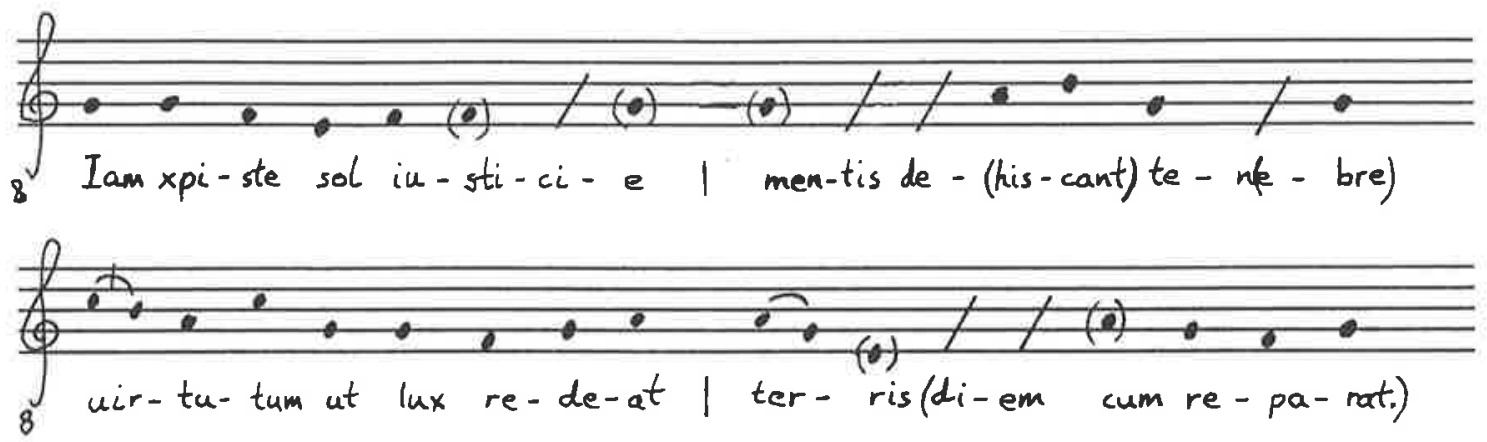

2. Da tempus accepta(bile)

(et) penitens cor tribue co(nver)tat ut be(nigni)tas quos longa suffert pietas.

3. Qu[iddamque] pen(it)entie da fer(re) licet grandium (ma)iori tuo munere quo demptio (sit) cr(imi)num.
4. Dies uenit dies tua in qua (reflo)re(nt) omnia letemur in hac ut tue per hanc reducti gratie.

5. Te rerum uni(uersitas) Clemens adoret trinitas et nos noui (per ve)niam nouum canamus (can)ticum.

6. $\mathrm{P}($ resta) beata trinitas. 
7. Iesus ab ore ( $\left(\mathrm{Z} \mathrm{206}^{\mathrm{v}}-207^{\mathrm{r}}\right)$

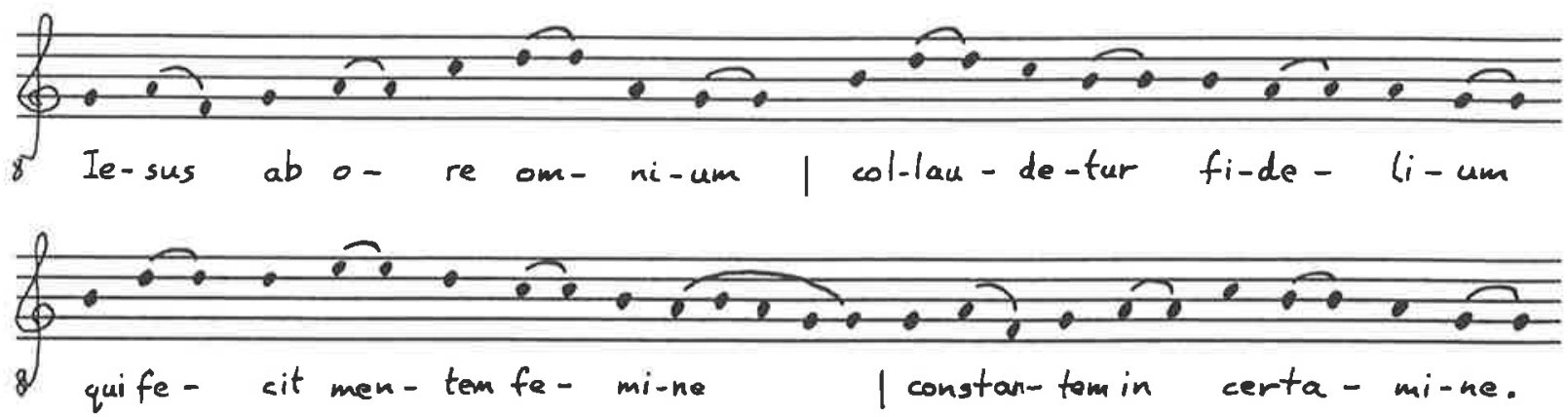

2. Honorauit miraculis eam nam a periculis multis saluauit dominus huius beate pretibus.

3. Hac oremus suppliciter vt nos iubet salubriter ne damnemur cum impiis in ad ventu iudicis.
4. Presta pater ingenite iesu cum sancto neumate vt eius sanctis meritis celi fruamur gaudiis. Amen 
8. Inmense celi conditor ( $\left.\mathrm{Z} 171[\mathrm{~b}]^{\mathrm{r}}\right)$

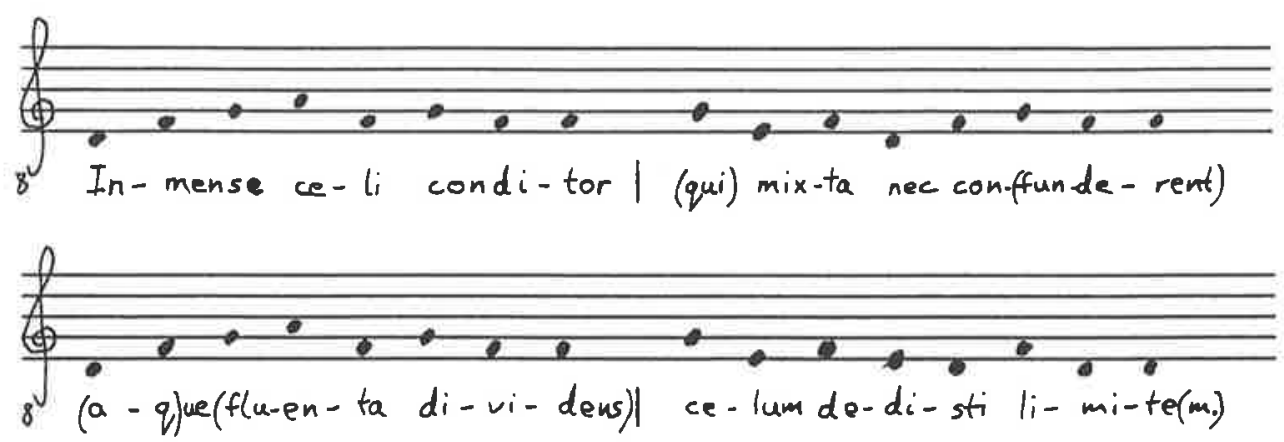

2. Firmans locum cel(est)ibus simulque terre

[no continuation] 


\section{Laudis ergo preconium (Z 1')}
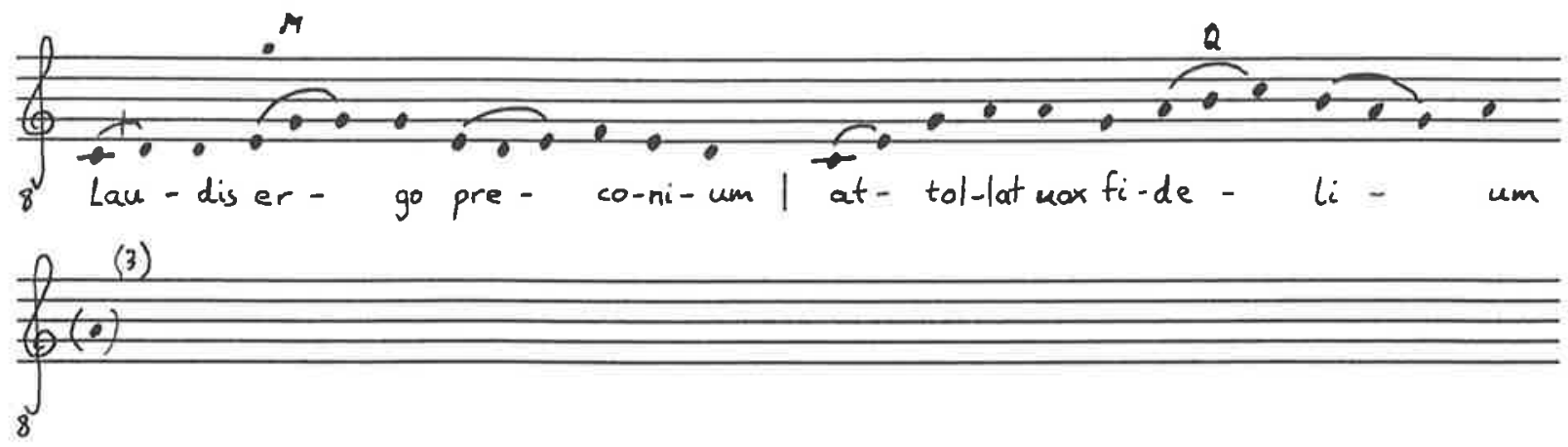

[1. continued]

nam miles per $\mathrm{m}$ [arti]rium

sequ[utus] est regem pium.

2. Ille natus de uirgine

hic renatus in sanguine

in ihesu namque nomine

est translatus in lumine.

3. Post stephanum enseruit prothomartir qui floruit sed festum propter statuit quod ualde nobis placuit.

4. Quinta die officium post $\mathrm{d}[\mathrm{e}] \mathrm{i}$ nathalicium celebrat plebs fidelium quod est bonum inicium.
5. In regis nathalicio angelorum cantacio pastorum ad miracio summa fuit deuocio.

6. In milite mirabile quod nempe est credibile per multos est probabile sacramentum uisibile.

7. Per angelos ostenditur ter clericis incipitur iussus fuit letabitur sic requies dimitatur.

8. Gloria tibi domine qui cuius superno mu[nere] sancti thome per $\mathrm{m}[\mathrm{er}] \mathrm{ita}$ cuncta fulgent per secula. Amen 
10. Magne dies leticie (Z 226[a]")
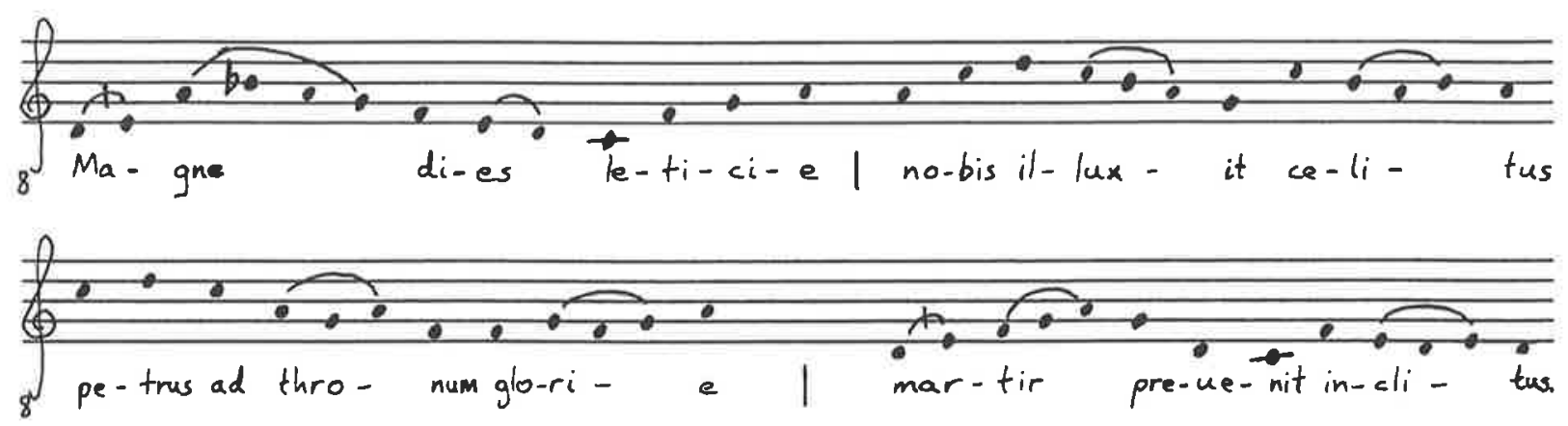

2. Puer in fide claruit

parentum carens nebula

deo s[er]uire studuit

sub paupertatis regula

3. Carnem aflixit iugiter

in labore multiplici

uiam sequens humiliter

patris sui dominici.
4. Vita mors signa uaria celum frequenti lumine dant petro testimonia de sanctitatis (culmine.)

5. Q[uaesumu $] \mathrm{s}$ auctor o[mniu]m in hoc paschali gaudio per ipsius suffragium cres 
11. O gloriosa domina (Z 239)
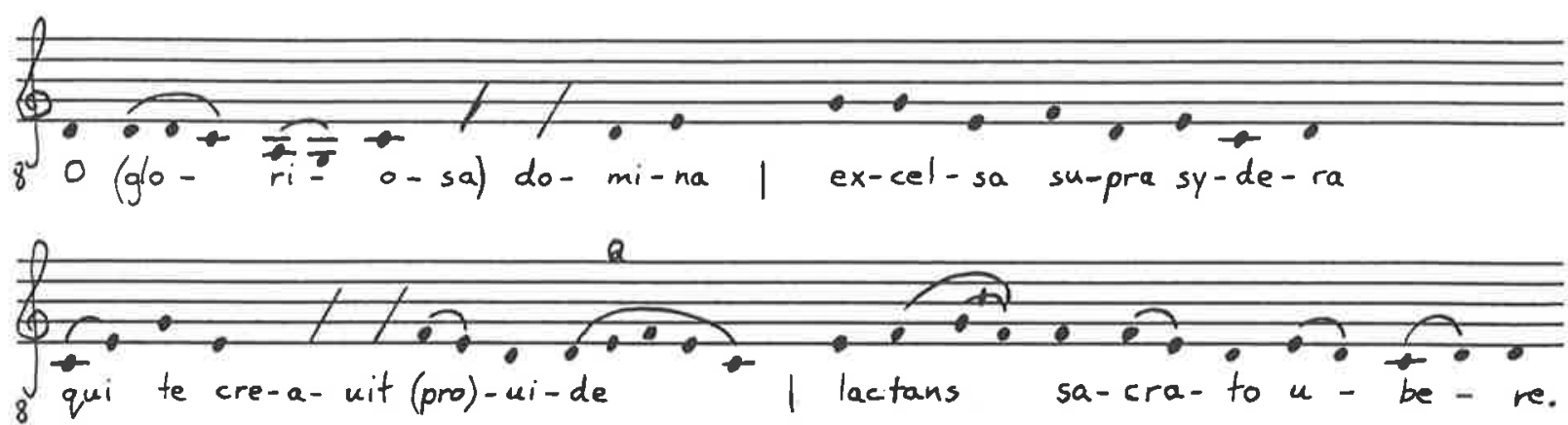

$\int_{8} \frac{}{\text { Quod }}$

2. Qvod eua tristis abstulit tu reddis almo germine (intre)nt ut astra flebiles celi fenestra facta es.

3. Tv regis ala ianua et porta lucis fulgida uitam datam per uirginem gen(tes) redempte plaudite. 
12. O lux beata (Z 199[a]")
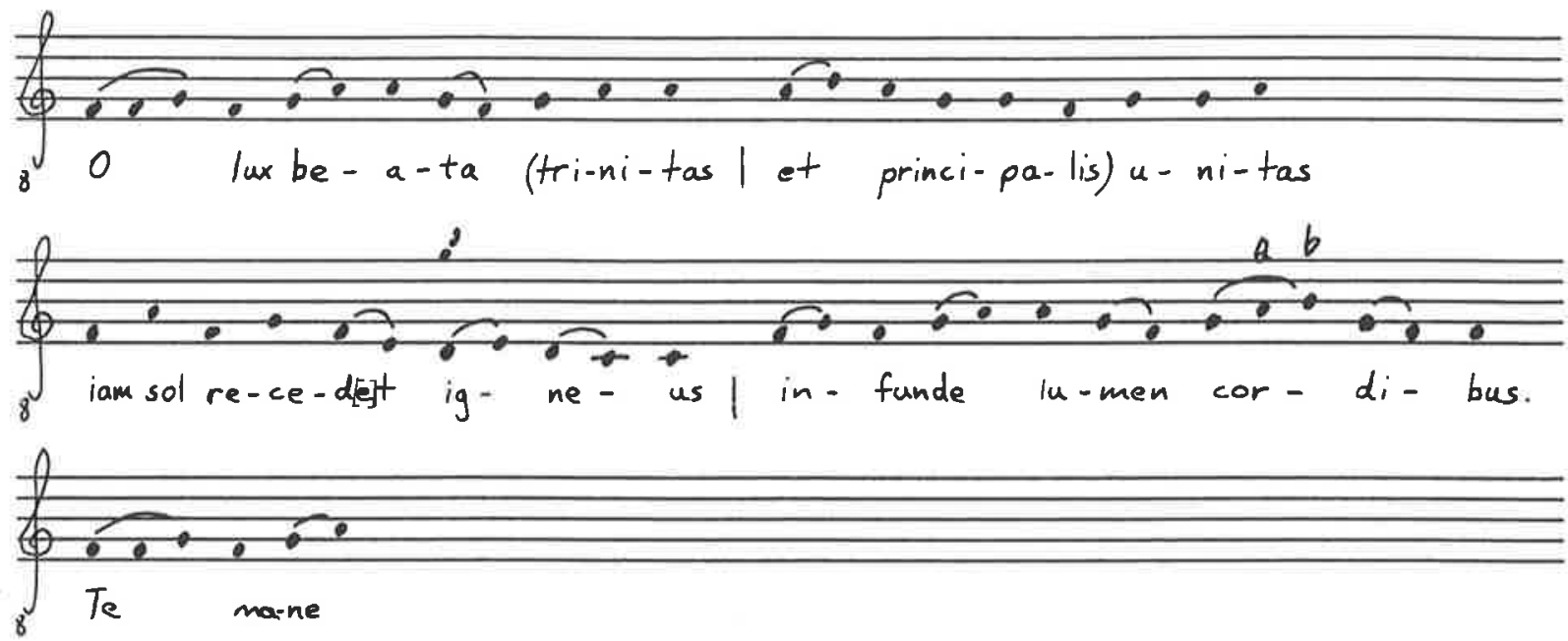

2. Te mane laudum (carmine)

te deprecemur uesperi

nostra supplex gloria

(per) cuncta laudet secula.

3. Deo patri (sit) gloria 
13. Pange lingua gloriosi / corporis misterium ( $\mathrm{Z}$ 272)
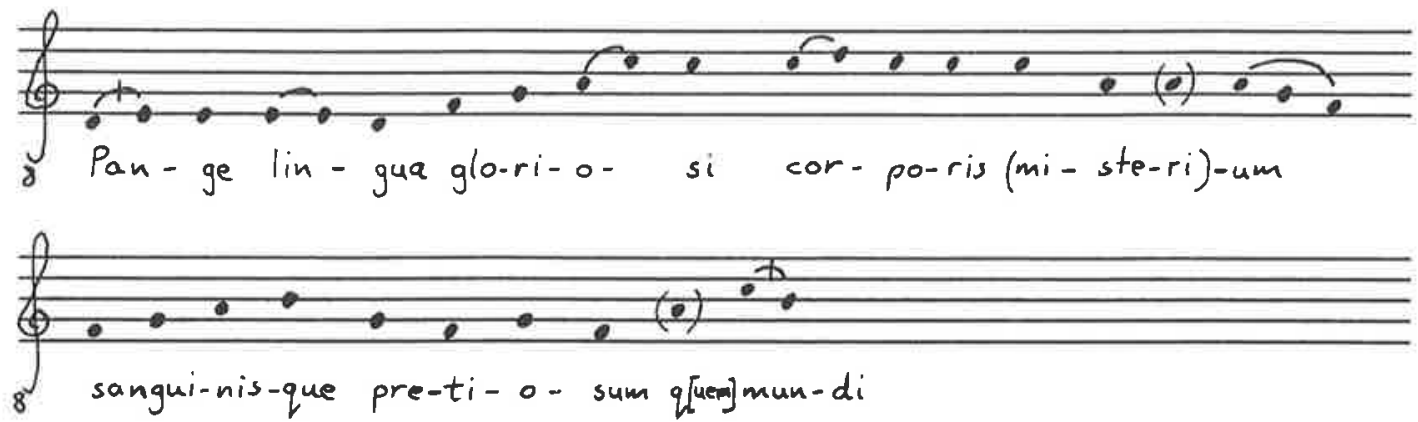

[1. continued]

effudit gentium.

${ }^{4}$ This section of text is not legible 
14. Sacris sollempniis iuncta ( $\mathrm{Z}$ 272)
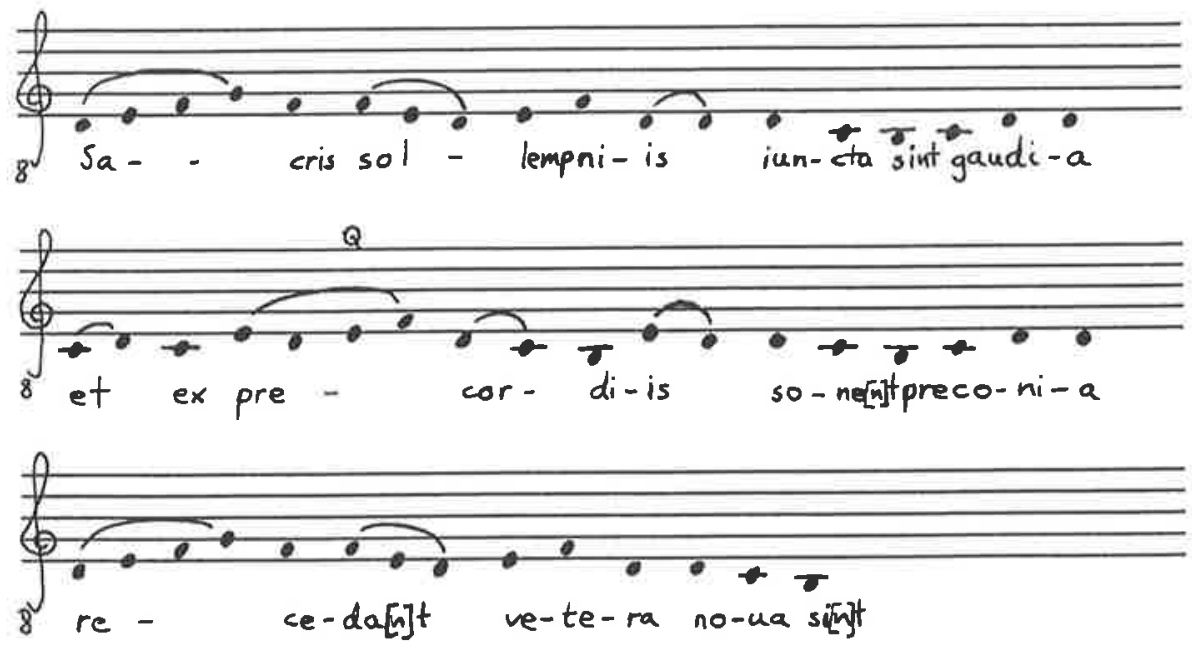

[1. continued]

omnia

corda uoces et opera. 
15. Te lucis ante terminum (Z 120[a] $\left.]^{\mathrm{r}}\right)$
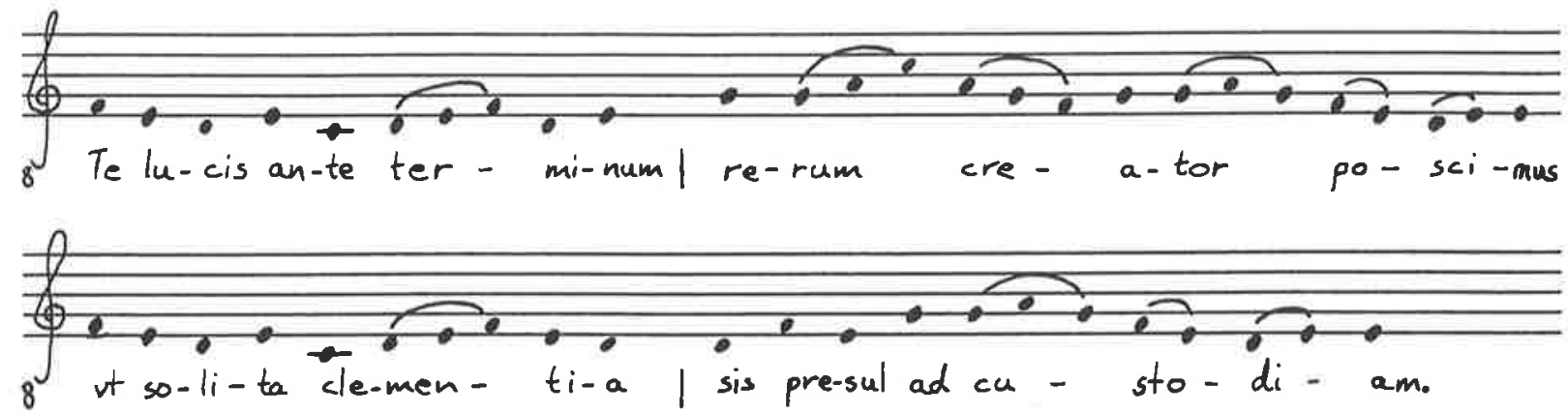

2. Procul recedant somnia

et (noctium) phantasmata

hostemque nos(tr)um comprime

ne (po)lluantur corpo(ra.)

3. Presta pater omnipotens

per iesum christum dominum

qui tecum perpetuum

regnat cum sancto spi(ri)tu. Amen. 
16. Ternis ter horis (Z 197[b])
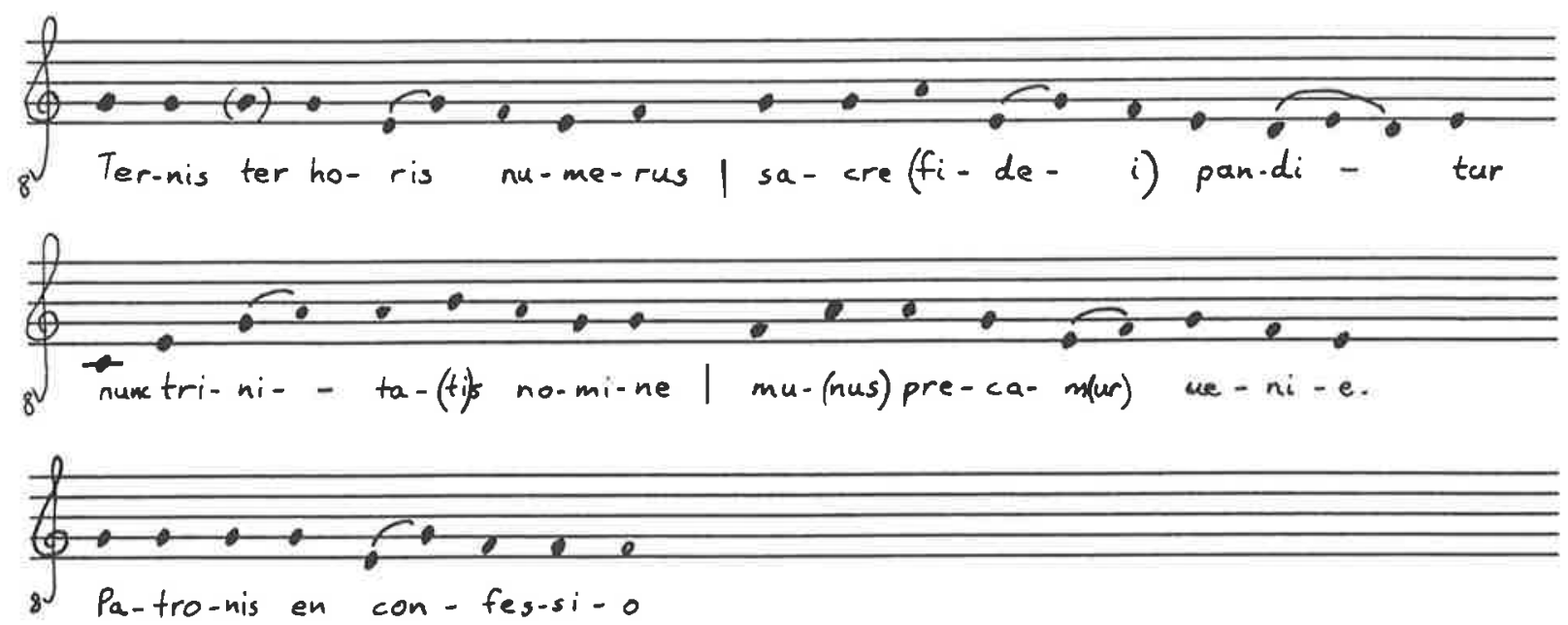

2. Patronis en confessio

xpisti me(ret)ur gra[ti]a

laus nostra uel deuocio

(meretur) ind(u)lg(entiam).

3. Mors per crucem nu(nc) interiit.

et post tenebras lux rediit

orror deiscat criminum

splendor nitescat (men)tium.

4. Gloria tibi trinitas. 
17. Xpiste qui lux (Z 197[b]')
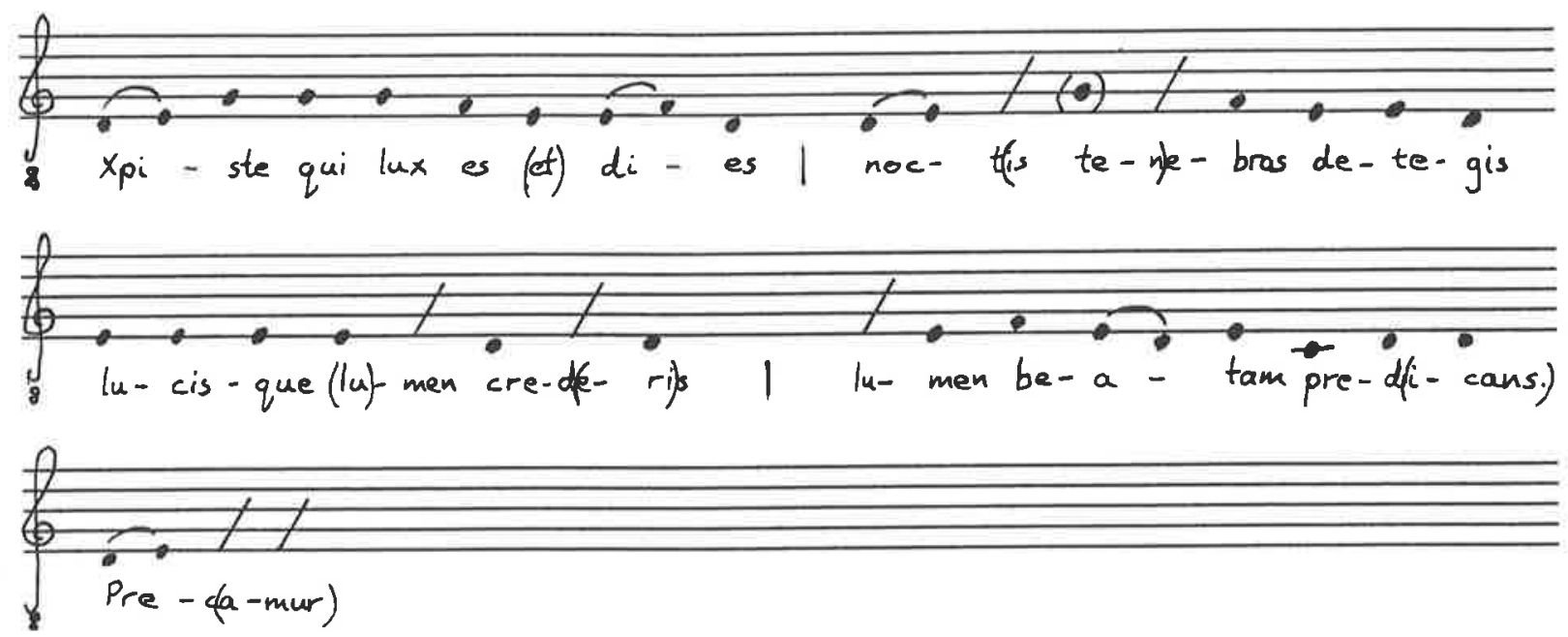

2. Prec(amur sancte) domine defende nos (in hac) noct(e sit nobis in) te requies qui(etam) noct(em tribue.)

3. Ne grauis sonus (irruat) nec hostis nos subripiat ne ca(ro illi) conse(ntiat) nos tibi reos statuat.

4. Oculi som(num) capia(nt) cor ad te semper vi(gile)t dextera tua $\mathrm{p}$ (ro)tegat famulos (qui) te diligunt.
5. De(fen)sor noster aspice in(sidi)antem repri(me) gub(er)na tuos famulos (quos sa)nguine me(r)catus es.

6. Mem(ento) nostri domine in graui isto corpore qui (es) defensor an(ime) adesto nobis domine.

7. $\mathrm{P}$ (resta pater)omnipotens per ihesum xpistum dominum qui (tecum in perpetuum regnat) cum sancto spiritu. 


\section{POLYPHONY}

\section{Gloria. Spiritus et alme (Z 184 ')}
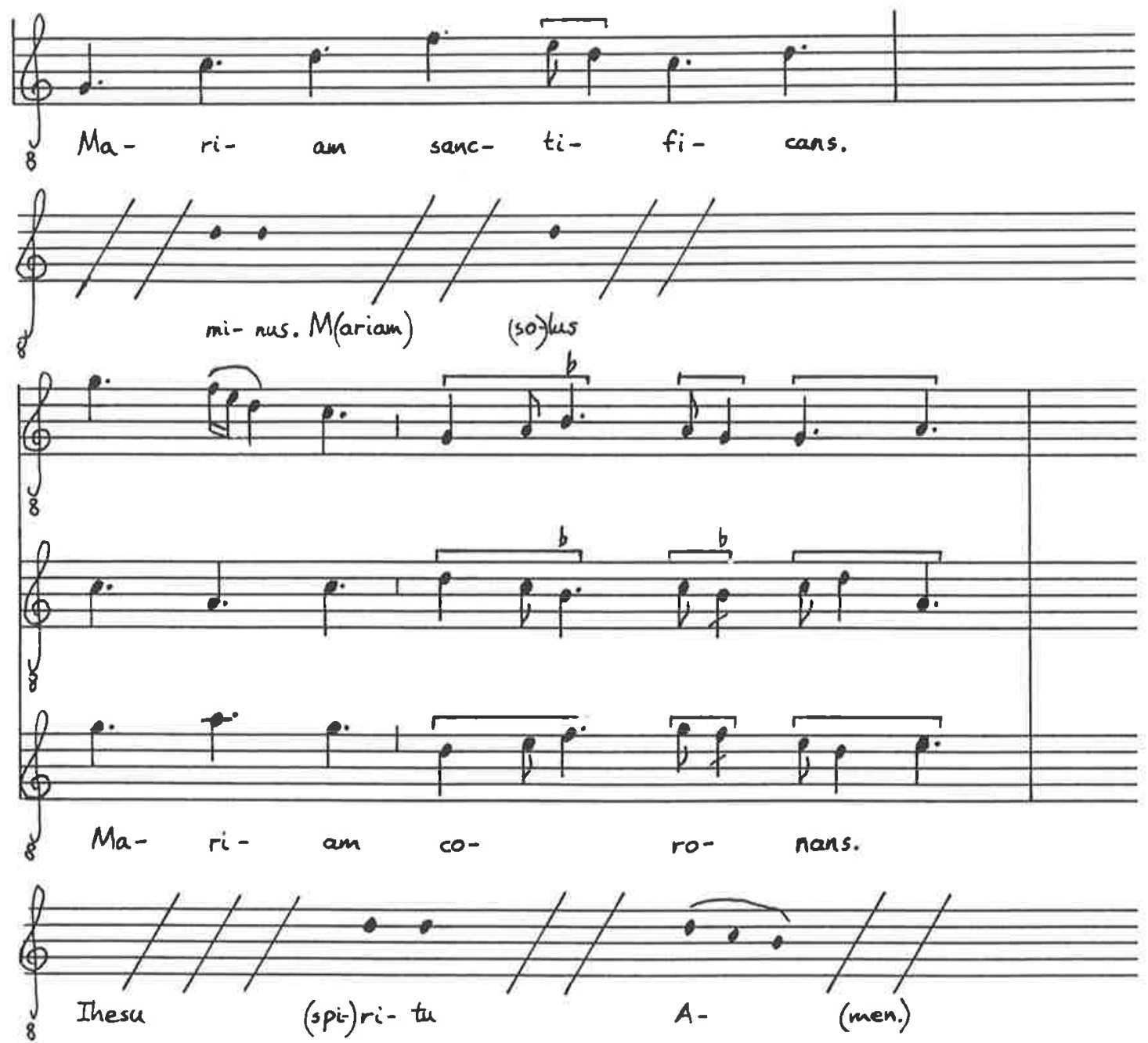
2. Benedicta. Virgo dei genitrix (Z 184 )
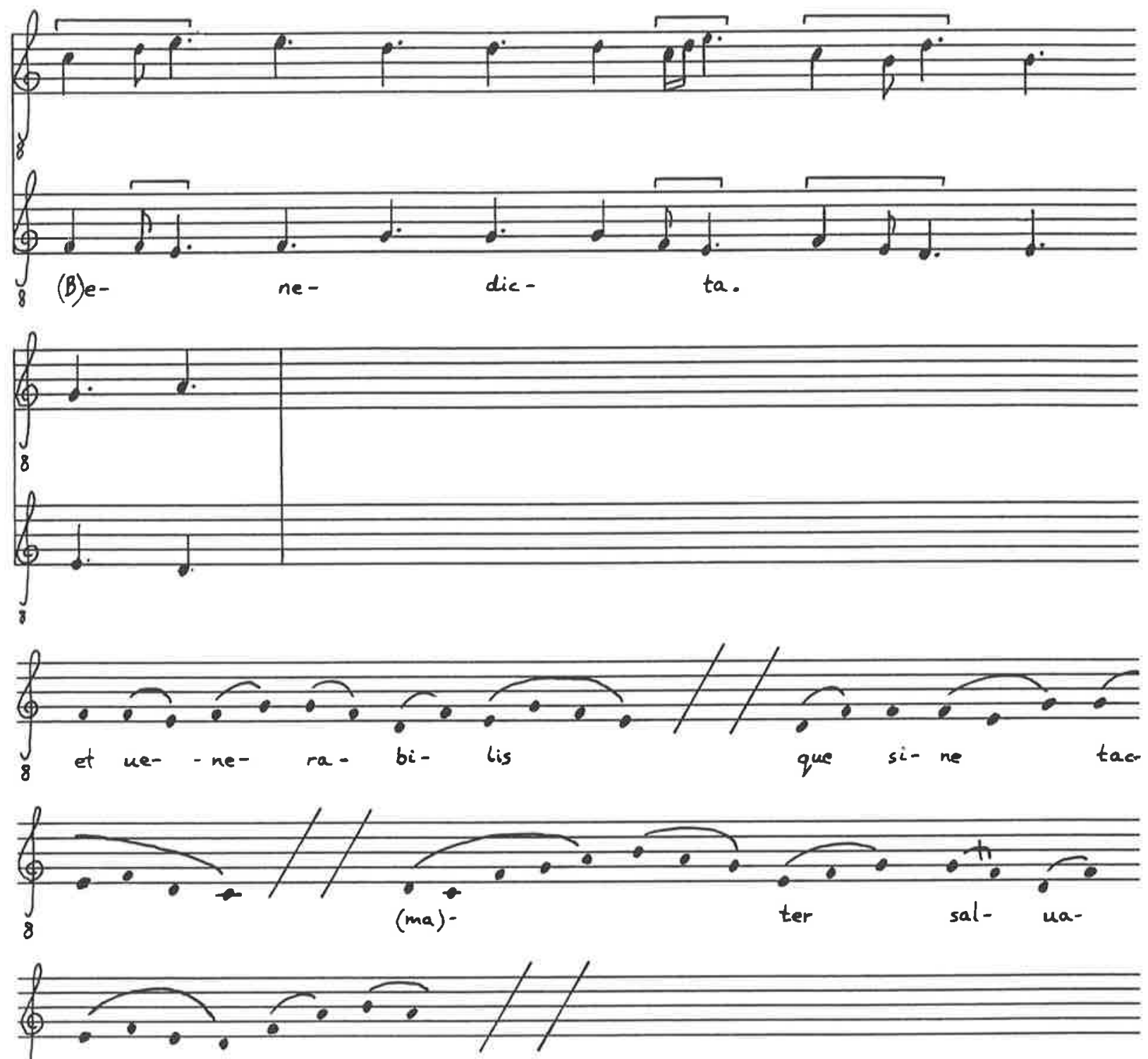

(to) -

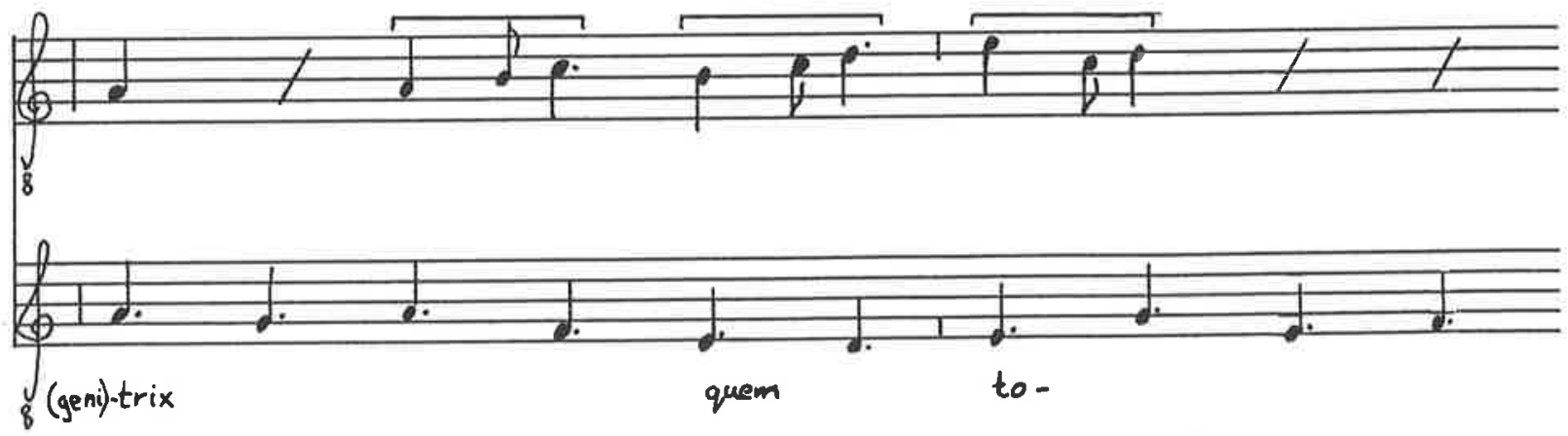


Benedicta. Virgo dei genitrix (Z 184 ) continued
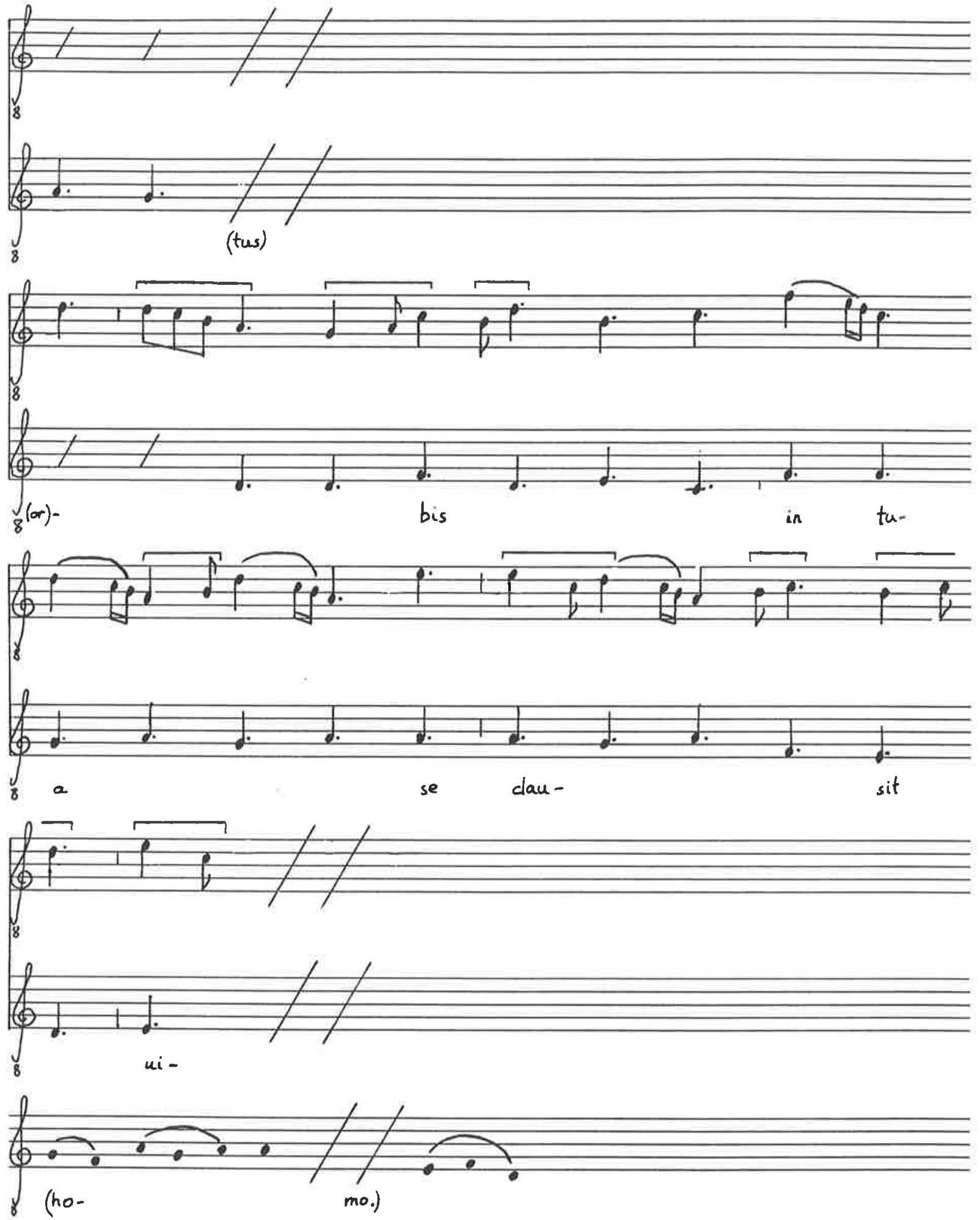
3. Alleluya. [Que est ista tam formosa] $\left(\mathrm{Z} \mathbf{1 8 4}^{v}\right)$

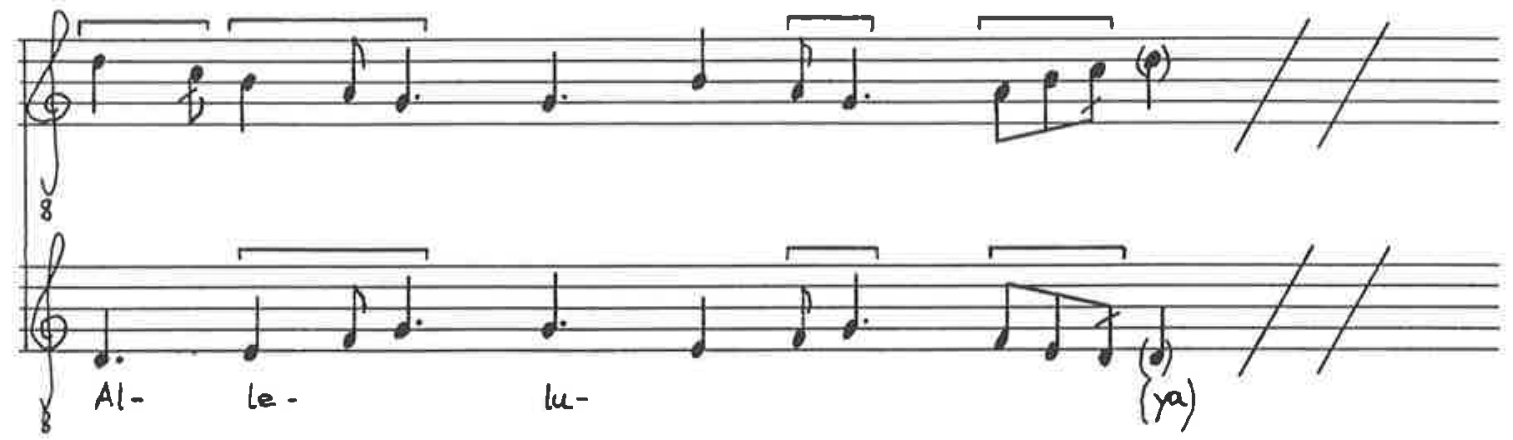




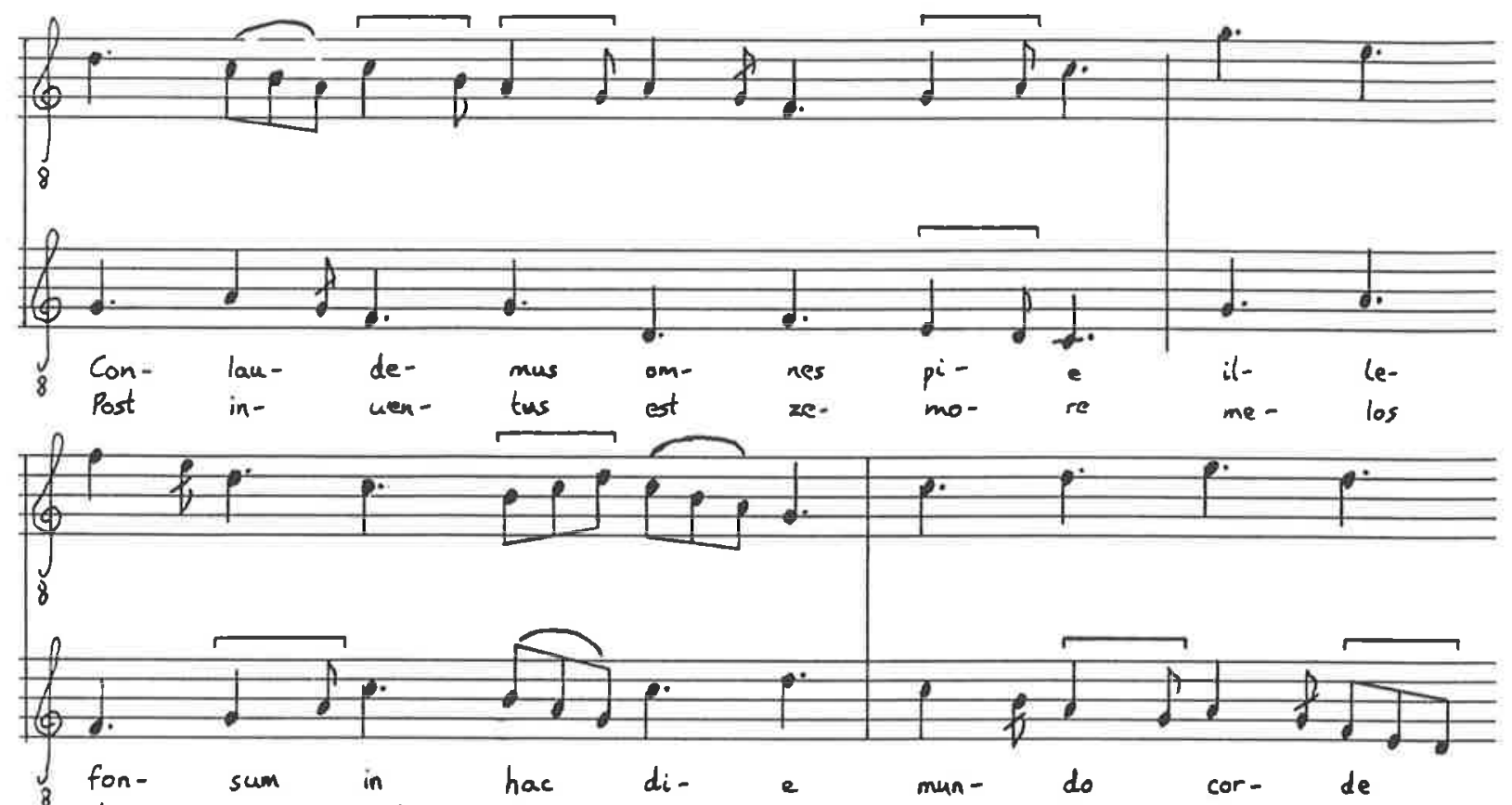

de- m[us] dul- ci o- re par tri at- que
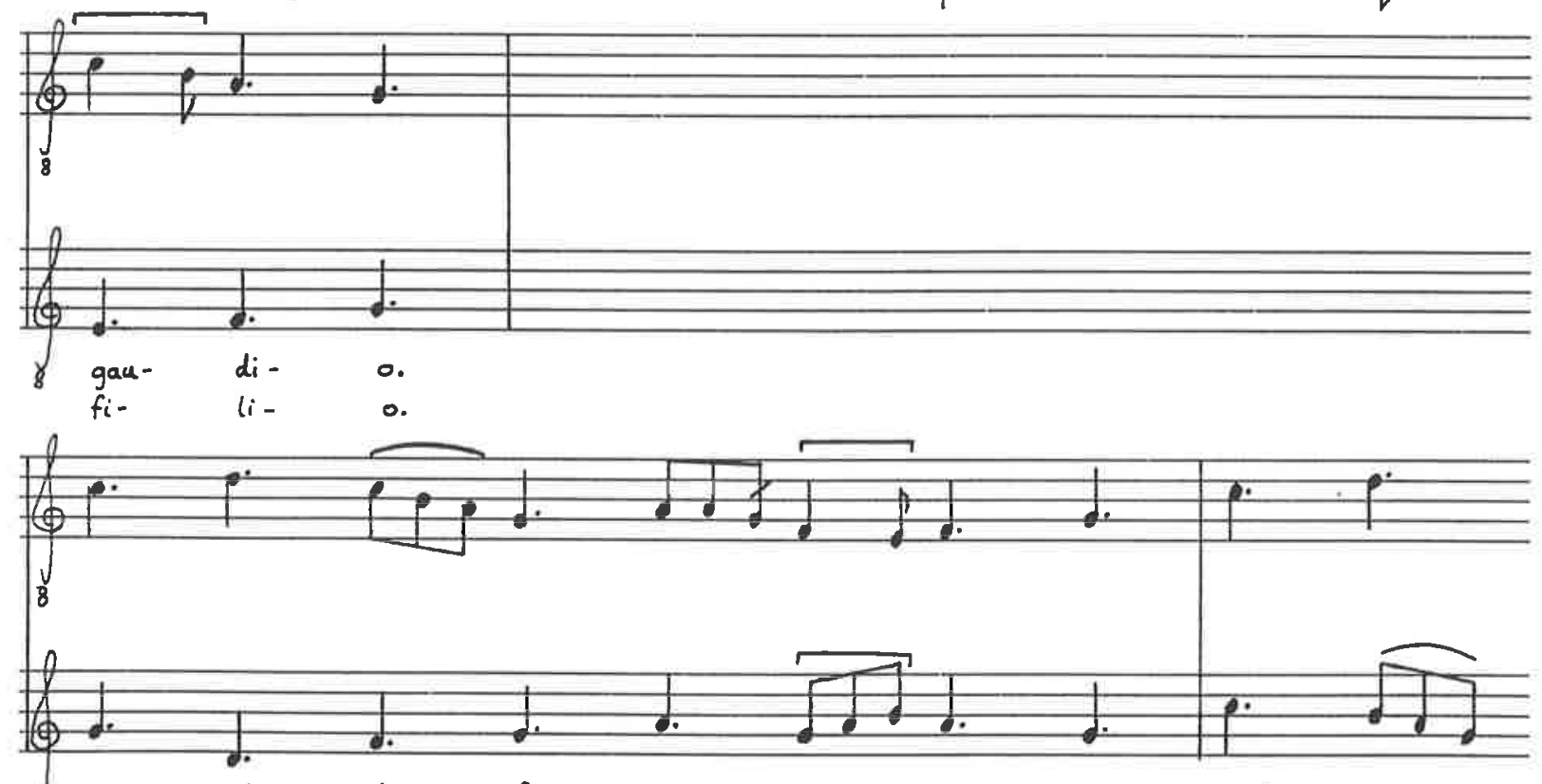

8 Ian il- le- fon- sus flo- ru- it qui pre-

Pre- di- ca- uit tri- ni- ta- tem il- le

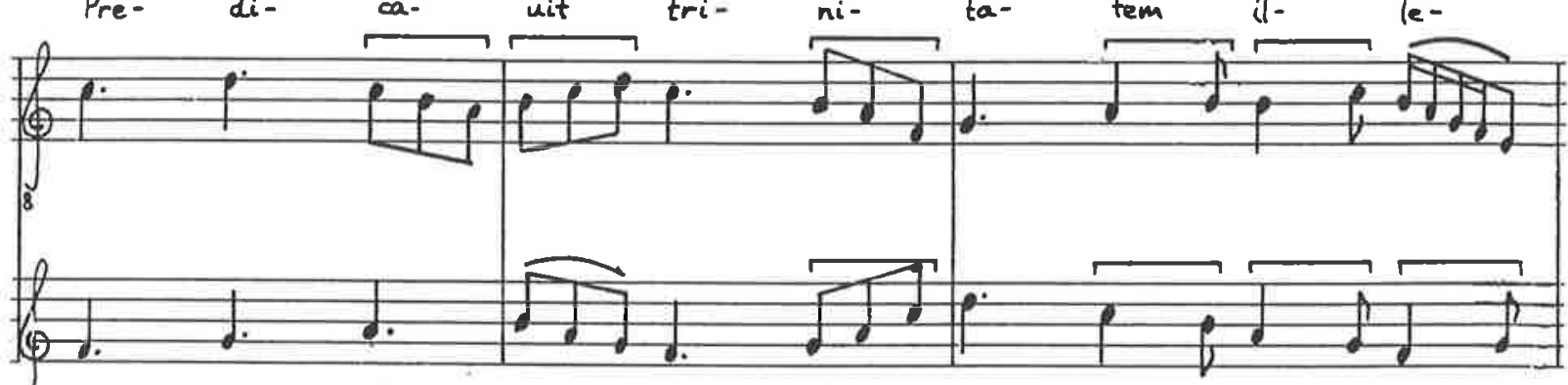

di- can- do do- cu- it ue- re par- tum
fon- sus u- ni- ta. tem de- um 
Conlaudemus omnes pie (Misal votivo, fol. 49) continued
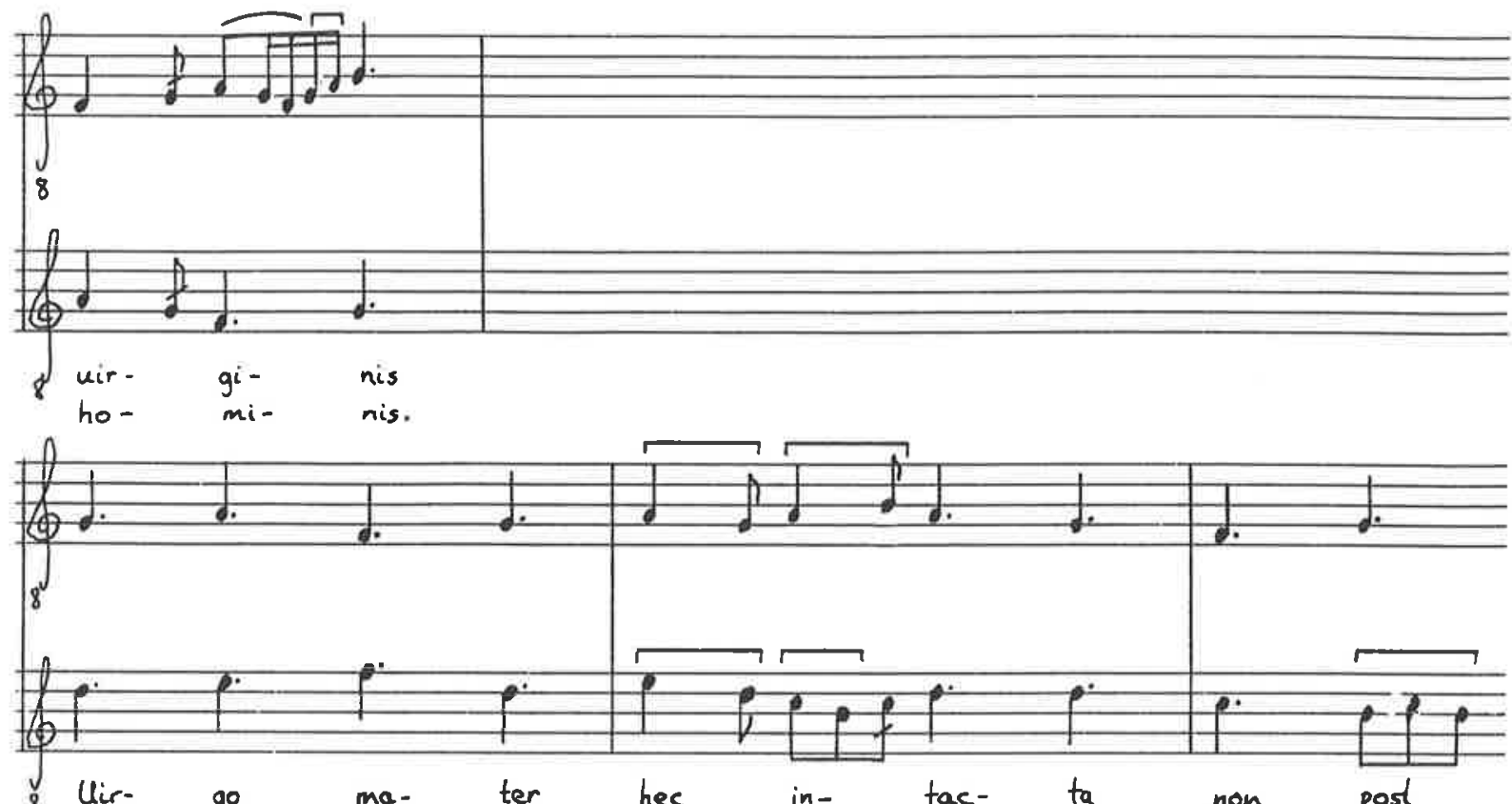

ce- le- sti uir- go so- li- 0 e- non ter-

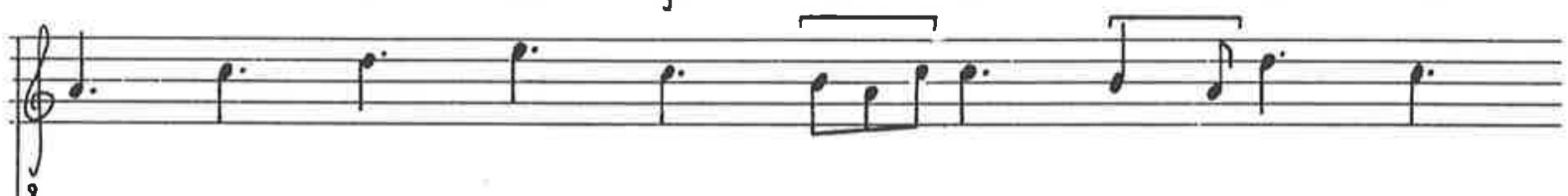

\#

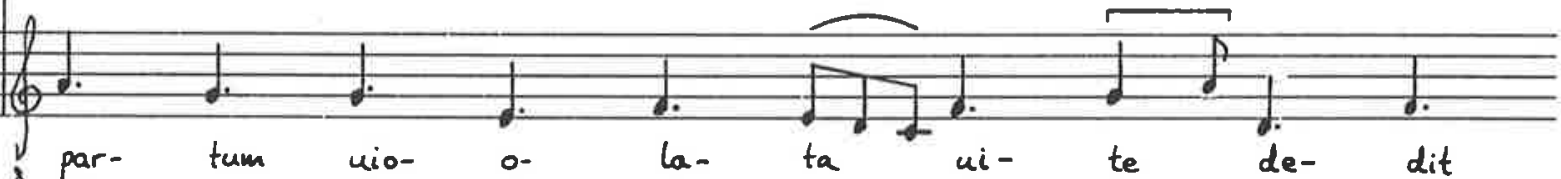

8 par- tum vio- o- la- ta ui- te de- dit

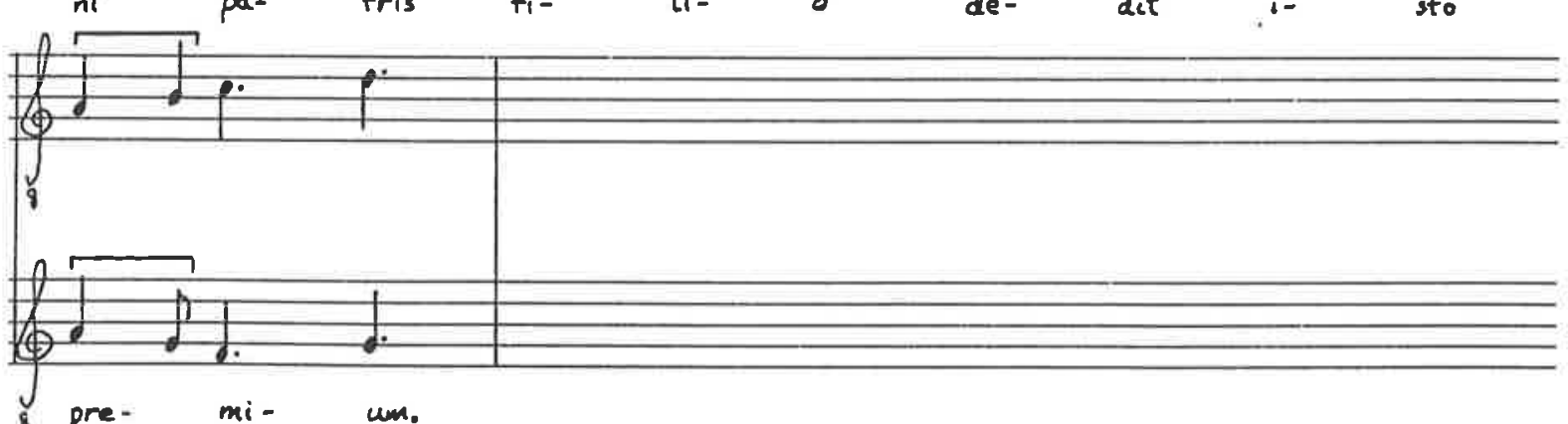

pre- mi- um.
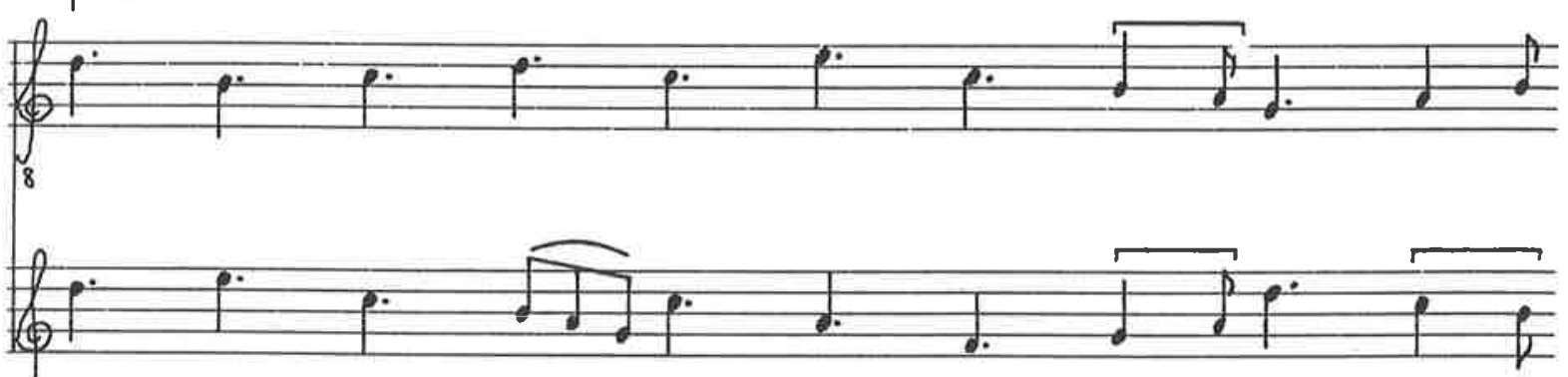

$\begin{array}{llllllll}\text { Ro- } & \text { gat de- um il- le- fon- sus ut det } \\ \text { The- } & \text { su bo- ne nos di- gna- } & \text { re it pos- }\end{array}$ 
Conlaudemus omnes pie (Misal votivo, fol. 49) continued

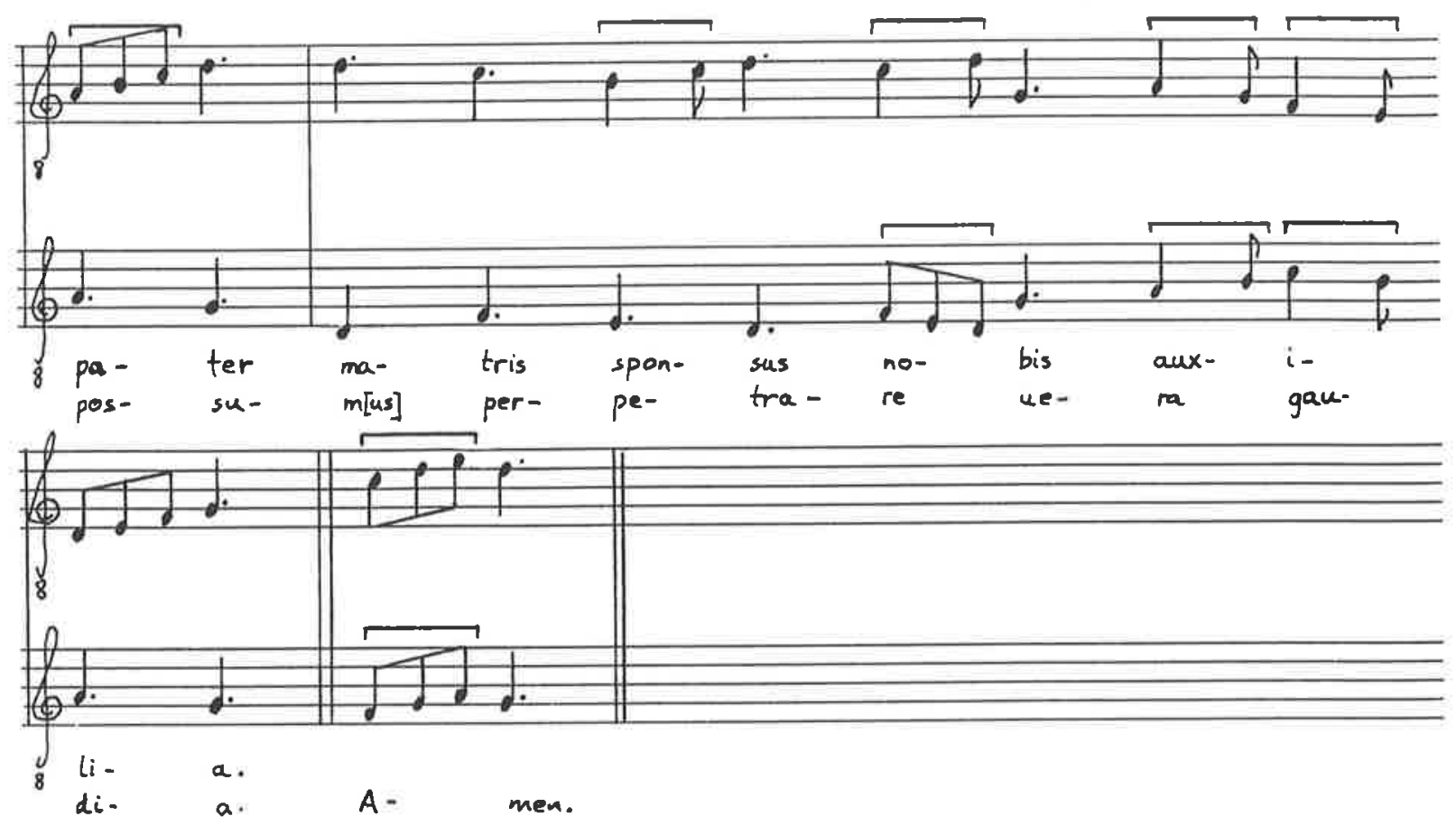


378

5. Deo nos agentes (Misal votivo, fol. 53')

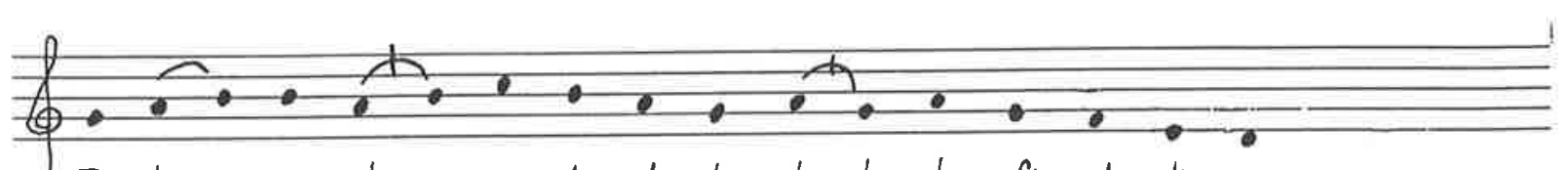

II- te uos de- um lau-dan-tes tur-be be fi- de-li- um
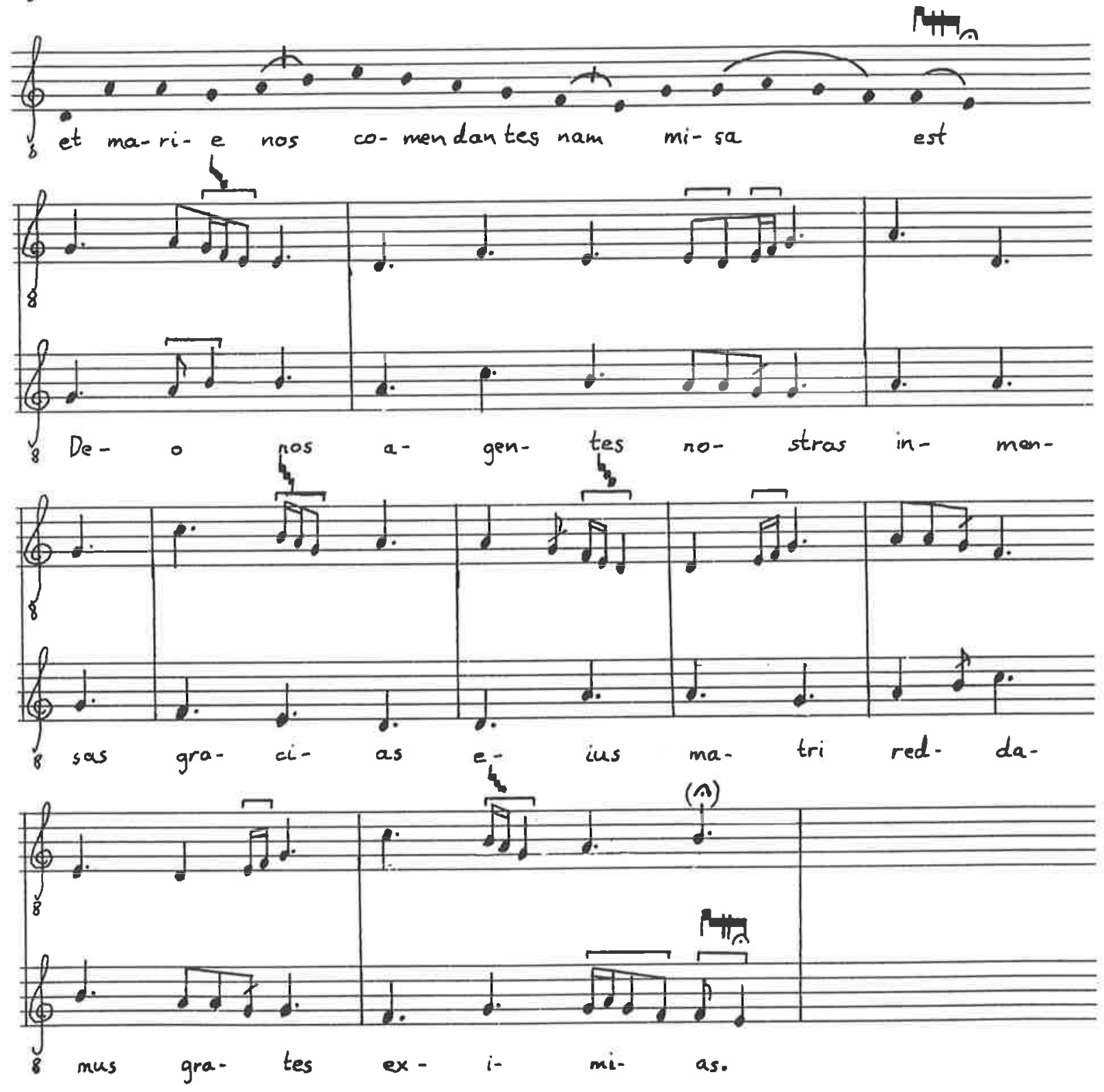
Nelson, K. E. (1990). Unknown Polyphony in a 14th Century Spanish Misal Votivo. Miscellanea Musicologica : Adelaide Sudies in Musicology, 17, 1-12.

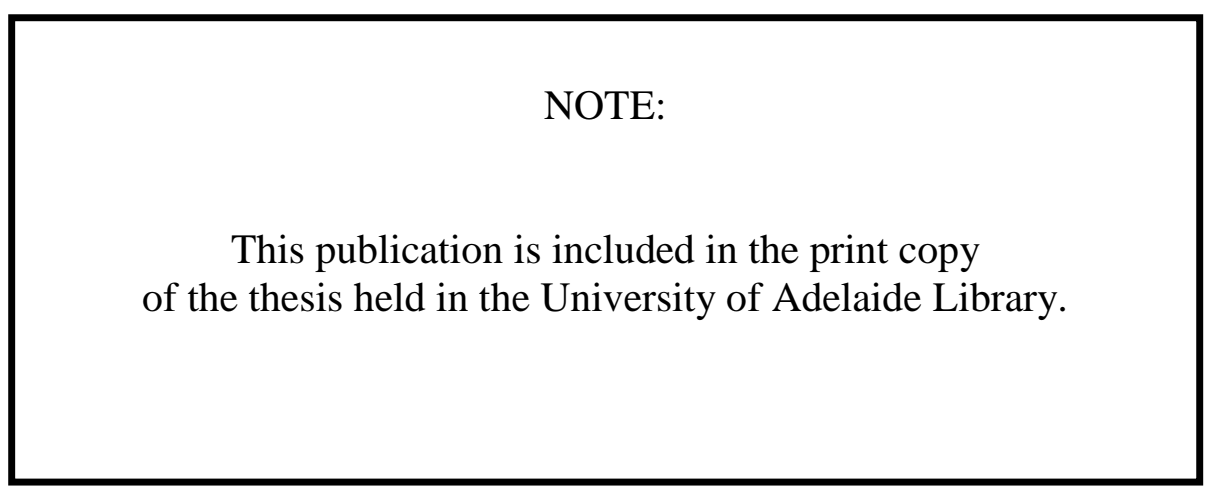




\section{BIBLIOGRAPHY}

\section{Manuscript Sources}

Arouca, Arquivo do Mosteiro de Santa Maria, s.n. [13th century antiphoner].

Barcelona, Archivo de la Catedral, Ms. 116.

Barcelona, Orfeó Catala, Ms. 1.

Besançon, Bibliotheque municipale, Ms. 76.

Burgos, Archivo de la Catedral, Ms. 61/2.

Gerona, Museo Diocesano, Ms. 4.

Huesca, Archivo de la Catedral, cód. 20 (3).

London, British Library, Add. 23935.

Madrid, Archivo Histórico Nacional, Códices, Carpeta 1455.

Madrid, Biblioteca de la Real Academia de la Historia, Aemil., cód. 18.

Madrid, Biblioteca de la Real Academia de la Historia, Aemil., cód. 51.

Madrid, Biblioteca Lázaro Galdiano, Ms. 662.

Madrid, Biblioteca Nacional, M. 4404.

Madrid, Biblioteca Nacional, Ms. M. 1361.

Madrid, Biblioteca Nacional, Mss. 136.

Madrid, Biblioteca Nacional, Mss. 270.

Madrid, Biblioteca Nacional, Mss. 289.

Madrid, Biblioteca Nacional, Mss. 931.

Madrid, Biblioteca Nacional, Mss. 1566.

Madrid, Biblioteca Nacional, Mss. 19421.

Madrid, Biblioteca Nacional, Mss. 20324.

Madrid, Biblioteca Nacional, Mss. Va19-7.

Montserrat, Biblioteca del Monasterio, Ms. 73.

Montserrat, Biblioteca del Monasterio, Ms. 759.

Montserrat, Biblioteca del Monasterio, Ms. 820.

Montserrat, Biblioteca del Monasterio, Ms. 1042 no. 25.

Paris, Bibliothèque nationale, lat. 1139. 
Paris, Bibliothèque nationale, n. a. lat. 495.

Paris, Bibliothèque nationale, n. a. lat. 1177.

Paris, Bibliothèque nationale, n. a. lat. 3126.

Rouen, Bibliothèque municipale, Ms. 260 y.1.

Santiago de Compostela, Archivo de la Catedral, frag. 9.

Villalobos, Convento de Santa Clara, s.n. [14th/15th century antiphoner].

Zamora, Archivo Catedralicio, cód. 104.

Zamora, Archivo Catedralicio, cód. 105.

Zamora, Archivo Histórico Provincial, Pergaminos musicales.

\section{Other Sources: Primary and Secondary}

Abrontes, Ricardo. "Arquitectura medieval". In Zamora en la edad media, 26-31. Zamora: Caja de Zamora, 1988.

Aguilar, Gaspar de. Arte de principios de canto llano. Viejos Libros de Música 11. Madrid: Joyas Bibliográficas, 1977. Facsimile edition.

Alfonso, Isabel. "El monacato". In Zamora en la edad media, 20-25. Zamora: Caja de Zamora, 1988.

Alonso, Miguel. Cuatro tratados de principios de canto llano: los de Espinosa, Aguilar, Escobar y el Anónimo. Viejos Libros de Música J/M. Madrid: Joyas Bibliográficas, 1983.

Alvarez-Coca González, María Jesús. "La fe pública en España. Registros y notarías". Boletín de la ANABAD 37, no. 1-2 (1987): 7-67.

Alvarez Martínez, Ursicino. Historia general civil y eclesiástica de la provincia de Zamora. 1899. Reprint. Madrid: Editorial Revista de Derecho Privado, 1965.

Anderson, Gordon A. Review of Die mehrstimmigen Ordinarium Missae-Sätze vom ausgehenden 11. bis zur Wende des 13. zum 14. Jahrhundert., by Max Lütolf. Musical Quarterly 57 (1971): 665-71.

—. "The Notation of the Bamberg and Las Huelgas Manuscripts". Musica Disciplina 32 (1978): 19-67. 
- The Las Huelgas Manuscript. Corpus Mensurabilis Musicae 79. 2 vols. NeuhausenStuttgart: American Institute of Musicology, 1982.

Anglès, Higini. El Còdex Musical de Las Huelgas. 3 vols. Barcelona: Institut d'Estudis Catalans, 1931.

—. "Hispanic Musical Culture from the 6th to the 14th Century". Musical Quarterly 26 (1940): 494-528.

—_ "La notación musical española de la segunda mitad del siglo XV". Anuario Musical 2 (1947): 151-73.

— . "De cantu organico. Tratado de un autor catalán del siglo XIV". Anuario Musical 13 (1958): 3-24.

—. "Die Bedeutung der Plika in der mittelalterlichen Musik". In Festschrift Karl Gustav Fellerer zum 60. Geburtstag, edited by Heinrich Hüschen, 28-39. Regensburg: Bosse, 1962.

- La música de las cantigas de Santa María del Rey Alfonso el Sabio. 3 vols. Barcelona: Diputación Provincial de Barcelona, 1943-64.

—_. "Early Spanish Music Culture and Cardinal Cisneros's Hymnal of 1515". In Aspects of Medieval and Renaissance Music, edited by Jan LaRue, 3-16. London: Oxford University Press, 1967.

Anglés, Higinio, and José Subirá. Catálogo Musical de la Biblioteca Nacional de Madrid. Vol. 1. Barcelona: Consejo Superior de Investigaciones Cientifícas, 1946.

Antiphonale Monasticum. Paris: Desclée, 1963.

Apel, Willi. Gregorian Chant. Bloomington: Indiana University Press, 1958.

-The Notation of Polyphonic Music 900-1600. 5th ed. Cambridge Mass.: The Medieval Academy of America, 1961.

Araiz, Andrés. Historia de la música religiosa en España. Barcelona: Editorial Labor, 1942.

Arlt, Wulf. “À propos de notations pragmatiques: le cas du codex Las Huelgas”. Revista de Musicología 13 (1990): 401-19. 
Babb, Warren, and Claude V. Palisca. Hucbald, Guido, and John on Music: Three Medieval Treatises. New Haven: Yale University Press, 1978.

Bécares Botas, Vicente. Los patronos de Zamora. San Ildefonso y San Atilano. Zamora: Archivo Histórico Diocesano, 1990.

Bent, Margaret. "New and Little-Known Fragments of English Medieval Polyphony”. Journal of the American Musicological Society 21 (1968): 137-56.

—_. "Notation, §III, 3". NG 13: 362-73.

—. "The Definition of Simple Polyphony. Some Questions". In Le polifonie primitive in Friuli e in Europa, edited by Cesare Corsi and Pierluigi Petrobelli, 33-42. Rome: Edizioni Torre d'Orfeo, 1989.

Berger, Karol. Musica Ficta: Theories of Accidental Inflections in Vocal Poyphony from Marchetto da Padova to Gioseffo Zarlino. Cambridge: Cambridge University Press, 1987.

Bermudo, Fray Juan. Declaración de instrumentos musicales. Edited by Macario Santiago Kastner. Documenta Musicologica, vol. 11. Kassel: Bärenreiter, 1957. Facsimile edition.

—_. "Exposition of Musical Instruments". Translated by Gordon J. Kinney. Lexington: M. I. King Library, University of Kentucky, 1976. Microform.

Bernard6, M. "Sobre el origen y la procedencia de la tradición himnódica hispánica a fines de la Edad Media". Paper delivered at the 15th Congress of the International Musicological Society, Madrid, 1992.

Bernhard, Michael. "Das musikalische Fachschrifttum im lateinischen Mittelalter". In Rezeption des antiken Fachs im Mittelalter, Geschichte der Musiktheorie, vol. 3. Darmstadt: Wissenschaftliche Buchgesellschaft, 1990.

Bishko, Charles Julian. Studies in Medieval Spanish Frontier History. London: Variorum Reprints, 1980.

- Spanish and Portuguese Monastic History 600-1300. London: Variorum Reprints, 1984. 
Bjork, David A. "Early Repertories of the Kyrie eleison". Kirchenmusikalisches Jahrbuch 63 (1979): 9-43.

—. "The Kyrie trope". Journal of the American Musicological Society 33 (1980): $1-41$.

Björkvall, Gunilla, ed. Corpus Troporum V: Les deux tropaires d'Apt, mss. 17 et 18. Stockholm: Almquist \& Wiksell, 1986.

Blezzard, Judith. "Merbecke, John”. NG 12: 168-70.

Bodington, Oliver E. Romance Churches of France. London: Grant Richards, 1925.

Boe, John, ed. Beneventanum Troporum Corpus II. Ordinary Chants and Tropes for the Mass from Southern Italy, A.D. 1000-1250. Parts 1 and 2. Recent Researches in the Music of the Middle Ages and Early Renaissance, vols. 19-24. Madison: A-R Editions, 1989.

Bonge, Dale. "Gaffurius on Pulse and Tempo: A Reinterpretation". Musica Disciplina 36 (1982): $167-74$.

Bosse, Detlev. Untersuchung einstimmiger mittelalterlicher Melodien zum "Gloria in excelsis deo". Forschungsbeiträge zur Musikwissenschaft, vol. 2. Regensburg: Gustav Bosse Verlag, 1955.

Breviarium secundum morem et consuetudinem Zamoranae ecclesiae. n.d. [Madrid, Biblioteca Nacional, R 25990].

Brockett, Clyde Waring. Antiphons, Responsories and other Chants of the Mozarabic Rite. Musicological Studies, vol. 15. New York: Institute of Mediaeval Music, 1968.

Brou, Louis, and José Vives, eds. Antifonario visigótico mozárabe de la Catedral de León Monumenta Hispania Sacra, Serie Litúrgica, vol. 5. Barcelona: Consejo Superior de Investigaciones Ciéntificas, 1959.

Brown, Howard Mayer. “Tactus”. NG 18: 518.

Brunner, Lance W. "The Sequences of Verona, Biblioteca Capitolare CVII and the Italian Sequence Tradition". Ph.D. diss., University of North Carolina at Chapel Hill, 1977.

Bryden, John R., and David G. Hughes. An Index of Gregorian Chant. Cambridge, Mass.: Harvard University Press, 1969. 
Bueno Domínguez, María Luisa. El monasterio de Santa María de Moreruela (1143-1300). Zamora: Caja de Ahorros Provincial de Zamora, 1975.

- Historia de Zamora: Zamora de los siglos XI-XIII. Zamora: Fundación Ramos de Castro, 1988.

Caldwell, John. Editing Early Music. Oxford: Clarendon Press, 1987.

Cappelli, Adriano. Dizionario di abbreviatura: latine ed italiane. 6th ed. Milan: Editore Ulrico Hoepli, 1979.

Cardine, Eugène. Gregorian Semiology. Translated by Robert M. Fowels. Sable-sur-Sarthe: Solesmes, 1982.

Carpenter, Nan Cooke. Music in the Medieval and Renaissance Universities. Norman: University of Oklahoma Press, 1958.

Castro, Manuel de. “Gil de Zamora, Juan”. DHEE 2: 1022.

- La provincia franciscana de Santiago. Ocho siglos de historia. Santiago de Compostela: Ediciones Monte Casino, 1984.

Cattin, Giulio. Music of the Middle Ages I. Cambridge: Cambridge University Press, 1984.

Cerone, Pedro. El Melopeo y Maestro. Tractado de musica theorica y practica. 1613. Reprint. Bologna: Forni, 1969.

Chevalier, Ulysse. Repertorium Hymnologicum. Catalogue des chants, hymnes, proses, séquences, tropes en usage dans l'église latine depuis les origines jusqu'à nos jours. 6 vols. Louvain, 1892-1921.

Collamore, Lila, and Joseph P. Metzinger, eds. Frere's Index to the Antiphons of the Sarum Antiphoner. London: The Plainsong and Medieval Music Society, 1990.

Collet, Henri. "Contribution à l'étude des théoriciens espagnols de la musique au XVI" siècle”. L'Année Musicale (1912): 1-63.

Conde, Javier Fernández. "La renovación de los estudios eclesiásticos". In Historia de la Iglesia en España, edited by Javier Fernández Conde, vol. 2, pt. 2. Madrid: Biblioteca de Autores Cristianos, 1982.

Corbin, Solange. Essai sur la musique religieuse portugaise au moyen âge (1100-1385). Paris: Société D’Édition «Les Belles Lettres», 1952. 
Coussemaker, E. de. Scriptorum de Musica Medii Aevi. 4 vols. 1864-76. Reprint. Hildesheim: Georg Olms, 1963.

Crocker, Richard L. "The Repertory of Proses at Saint Martial de Limoges in the 10th Century". Journal of the American Musicological Society 11 (1958): 149-64.

—.The Early Medieval Sequence. Berkeley: University of California Press, 1977.

—. "Medieval Chant". In The Early Middle Ages to 1300, edited by Richard L. Crocker and David Hiley. The New Oxford History of Music, vol. 2, 2nd ed. Oxford: Oxford University Press, 1990.

Curtius, E. A. European Literature and the Latin Middle Ages. London: Routledge \& Kegan Paul, 1979.

Díaz y Díaz, Manuel C. Códices visigóticos en la monarquía leonesa. León: Centro de Estudios e Investigacion "San Isidoro", 1983.

Diccionario de historia eclesiástica de España. 4 vols. Edited by Q. Aldea Vaquero, T. Marin Martinez, and J. Vives Gatell. Madrid: Instituto Enrique Flórez, 1972-75.

Dix, Gregory. The Shape of the Liturgy. Westminster: Dacre Press, 1945.

Dreves, Guido Maria, Clemens Blume, and H. M. Bannister, eds. Analecta Hymnica Medii Aevi. 55 vols., 1886-1922. Reprint. New York: Johnson Reprint Corporation, 1961.

Droste, Dianne Lynne. "The Musical Notation and Transmission of the Music of the Sarum Use, 1225-1500". Ph.D. diss., University of Toronto, 1983.

Duncan, Mary Elizabeth. "A Sixteenth-Century Mexican Chant Book: Pedro Ocharte's Psalterium, an[t]iphonarium sanctorale cum psalmis \& hymnis". Ph.D. diss., University of Washington, 1975.

Durán, Domingo Marcos. Lux bella. Viejos Libros de Música 1. Madrid: Joyas Bibliográficas, 1976. Facsimile edition.

- Comento sobre Lux bella. Viejos Libros de Música 2. Madrid: Joyas Bibliograficas, 1976. Facsimile edition.

- Súmula de canto de órgano, contrapunto y composición vocal y instrumental, práctica y especulativa. Viejos Libros de Música 3. Madrid: Joyas Bibliográficas, 1976. Facsimile edition. 
Durán Gudiol, Antonio, Ramón Moragas, and Juan Villareal, eds. Hymnarium Oscense. 2 vols. Zaragoza: Institución Fernando el Católico, 1987.

Ellsworth, Oliver B. The Berkeley Manuscript. Lincoln: University of Nebraska Press, 1984.

Emerson, John A. “Sources, MS, §II, Western plainchant”. NG 17: 609-34.

Equipo Jupiter 81-82. “Ordenanzas de la ciudad de Zamora, siglos XV-XVI”. Studia Zamorensis 3 (1982): 9-24.

Espías Sánchez, Manuel. Monasterios de clausura en Zamora. Zamora: Ediciones Monte Casino, 1980.

Estevan, Fernand. Reglas de canto plano è de contrapunto è de canto de organo. Edited by M $^{\mathrm{a}}$ Pilar Escudero García. Madrid: Editorial Alpuerto, 1984. Transcription and facsimile edition.

Farmer, David Hugh. The Oxford Dictionary of Saints. Oxford: Clarendon Press, 1979.

Fassler, Margot. "Who Was Adam of St. Victor? The Evidence of the Sequence Manuscripts". Journal of the American Musicological Society 37 (1984): 233-69.

Fernández de la Cuesta, Ismael. Los tratados de canto llano de Spañon, Martinez de Bizcargui y Molina. Viejos Libros de Música G/I. Madrid: Joyas Bibliográficas, 1978.

-. Manuscritos y fuentes musicales en España. Edad media. Madrid: Editorial Alpuerto, 1980.

—, ed. Antiphonale Silense, British Library Mss. Add. 30.850, Madrid: Sociedad Española de Musicología, 1985.

—. "La irrupción del canto gregoriano en España". Revista de Musicología 9 (1985): 239-48.

—. Historia de la música española. 1. Desde los origenes hasta el "ars nova". 2nd ed. Madrid: Alianza Editorial, 1988.

Fernández Duro, Cesáreo. Colección Bibliográfica-Biográfica de noticias referentes a la provincia de Zamora. Madrid: Imprenta Manuel Tello, 1891.

Fernández Prieto, E. “Zamora, Diócesis de”. DHEE 4: 2792-2800. 
Fernández Salmador, Ana Isabel. "Escultura medieval". In Zamora en la edad media, 32-35. Zamora: Caja de Zamora, 1988.

Ferrero Ferrero, Florián. El imperial monasterio de Nuestra Señora de Valparaiso. Zamora: Archivo Histórico Provincial de Zamora and Caja de Zamora, 1986.

Ferretti, Dom Paolo. Esthétique grégorienne. Translated by Dom A. Agaësse. Vol. 1. Solesmes, 1938.

Fischer, Kurt von, ed. Handschriften mit mehrstimmiger Musik des 14., 15. und 16. Jahrhunderts. RISM BIV ${ }^{3}$ - BIV ${ }^{4}$. Munich-Duisburg: G. Henle Verlag, 1972.

— . "The Sacred Polyphony of the Italian Trecento". Proceedings of the Royal Musical Association 100 (1973-74): 143-57.

Frere, Walter Howard. Graduale Sarisburiense. 1894. Reprint. Farnborough: Gregg, 1966. Antiphonale Sarisburiense. 6 vols. 1901-24. Reprint. Farnborough: Gregg, 1966.

Fuller, Sarah. "Aquitanian Polyphony of the Eleventh and Twelfth Centuries". 3 vols. Ph.D. diss., University of California, Berkeley, 1969.

—. "An Anonymous Treatise dictus de Sancto Martiale". Musica Disciplina 31 (1977): $5-30$.

—. "Theoretical Foundations of Early Organum Theory". Acta Musicologica 53 (1981): $52-84$.

—. "Early Polyphony". In The Early Middle Ages to 1300, edited by Richard L. Crocker and David Hiley. The New Oxford History of Music, vol. 2, 2nd ed., 485-556. Oxford: Oxford University Press, 1990.

Gallo, F. Alberto. "The Practice of Cantus Planus Binatim in Italy from the Beginning of the 14th Century to the Beginning of the 16th Century". In Le polifonie primitive in Friuli $e$ in Europa, edited by Cesare Corsi and Pierluigi Petrobelli, 13-30. Rome: Edizioni Torre d'Orfeo, 1989.

García Rodríguez, Carmen. El culto de los santos en la España romana y visigoda. Madrid: Consejo Superior de Investigaciones Científicas, 1966.

Gerbert, Martin. Scriptores ecclesiastici de musica sacra potissimum. Vol. 3. 1784. Reprint. Hildesheim: Georg Olms, 1963. 
Hildesheim: Georg Olms, 1963.

Gillingham, Bryan. "Atavism and Innovation in a Late Medieval Proser". Studies in Music from the University of Western Ontario 10 (1985): 79-103.

Glare, P. G. W. Oxford Latin Dictionary. Oxford: Clarendon Press, 1982.

Gómez Muntané, María Carmen. "De arte cantus de Johannes Pipudi, sus Regulae contrapunctus y los Apuntes de teoría de un estudiante catalán del siglo XIV”. Anuario Musical 31-32 (1976-77): 37-49.

—_."El Ars Antiqua en Cataluña", Revista de Musicología 2 (1979): 197-255.

——. "Quelques remarques sur le répertoire polyphonique antérieur à l'Ars nova provenant de l'ancien royaume d'Aragon" Cahiers de Civilisation Médiévale 31 (1988): 101-10.

. "Prehistoria de la enseñanza musical en las universidades españolas". In De Musica Hispana et Aliis. Miscelánea en honor al Prof. Dr. José López-Calo, S. J., coordinated by Emilio Casares and Carlos Villanueva, vol. 1, 77-89. Santiago de Compostela: Universidade de Santiago de Compostela, 1990.

—_. "Deux nouveaux fragments polyphoniques antérieurs à l'Ars nova dans un manuscrit du monastère de Santa María de Vallbona”. In Aspects de la Musique Liturgique au Moyen Age, 177-90. Paris: Créaphis, 1991.

González Barrionuevo, Herminio. 'Dos grafías especiales del "scándicus" en la notación “Mozárabe” del norte de España'. Revista de musicología 13 (1990): 11-79.

González Blanco, Antonino. "La cristianización de Zamora”. In Primer Congreso de historia de Zamora, vol. 2, 267-99. Zamora: Instituto de Estudios Zamoranos "Florián de Ocampo", 1990.

Graduale Triplex. Solesmes: Desclée, 1979.

Le Graduel Romain. II Les Sources. Solesmes: Abbaye Saint-Pierre de Solesmes, 1957.

Granja Alonso, Manuel de la. Estudio histórico, artístico, religioso, agrícola y humano del Real Monasterio de Santa Maria de Moreruela de la Orden Cisterciense. Zamora: Diputación de Zamora, 1990. 
Grier, James. "Scribal Practices in the Aquitanian Versaria of the Twelfth Century: Towards a Typology of Error and Variant". Journal of the American Musicological Society 45 (1992): 373-427.

Gros I Pujol, Miguel S. "Las tradiciones litúrgicos medievales en el noroeste de la península". In IX Centenário de Dedicaçao da Sé de Braga. Congresso Internacional Actas, vol. 3, 103-15. Braga: Universidade Católica Portuguesa, 1990.

Guadalupe, $\mathbf{M}^{2}$ Luisa. "El tesoro del cabildo zamorano: aproximación a una biblioteca del siglo XIII". Studia Historica 1, no. 2 (1983): 167-80.

Gümpel, Karl-Werner. "Zur Frühgeschichte der vulgärsprachlichen spanischen und katalonischen Musiktheorie". Gesammelte Aufsätze zur Kulturgeschichte Spaniens 24 (1968): 258-336.

— "Das Enchiridion de principiis musice discipline des Guillermus de Podio", Gesammelte Aufsätze zur Kulturgeschichte Spaniens 27 (first series) (1973): 359-96. . "Musica cum Rhetorica: MS Ripoll 42". In Essays on the Music of J. S. Bach and Other Divers Subjects: A Tribute to Gerhard Herz, edited by R. L. Weaver, 117-44. Louisville: University of Louisville Press, 1981.

—_. "Gregorian Chant and Musica Ficta: New Observations from Spanish Theory of the Renaissance”. Recerca Musicològica 6-7 (1986-87): 5-27.

—. "El canto melódico de Toledo: algunas reflexiones sobre su origen y estilo". Recerca Musicològica 8 (1988): 38-45.

Gutiérrez, Carmen Julia. "El Himnario de Huesca: nueva aproximación". Anuario Musical 44 (1989): 23-60.

Haller, Robert B. "Early Dominican Mass Chants: A Witness to Thirteeenth Century Chant Style". Ph.D. diss., Catholic University of America, 1986.

Harrán, Don. Word-Tone Relations in Musical Thought. Musicological Studies and Documents, vol. 40. Neuhausen-Stuttgart: American Institute of Musicology, 1986. Hastings, Alan D., ed. Text and Concordances of the Tratado de la música MS. ç.III.23, Biblioteca del Escorial. Madison: The Hispanic Seminary of Medieval Studies, 1989. 
Hesbert, René-Jean, ed. Le prosaire de la Sainte-Chapelle, Monumenta Musicae Sacrae, vol. 1. Macon: Protat Frères, 1952.

. ed. Corpus Antiphonalium Officii. 6 vols. Rome: Casa Editrice Herder, 1963-79.

Hiley, David. “Notation, §III, 1, 2”. NG 13: 344-62.

—. "Plica". NG 15: 12-13.

—. "The Liturgical Music of Norman Sicily: a Study Centred on Manuscripts 288, 289, 19421 and Vitrina 20-4 of the Biblioteca Nacional, Madrid”. Ph.D. diss., University of London, 1981.

—. "The Normandy chant traditions - Normandy, Britain, Sicily". Proceedings of the Royal Musical Association 107 (1980-81): 1-33.

—. 'The Plica and Liquescence". In Gordon Athol Anderson (1929-1981) In Memoriam, Musicological Studies, vol. 49, 379-91. Henryville: Institute of Medieval Music, 1984.

—_. "Ordinary of Mass Chants in English, North French and Sicilian manuscripts". Journal of the Plainsong and Medieval Music Society 9 (1986).

—. "Chant". In Performance Practice. Music before 1600, edited by Howard Mayer Brown and Stanley Sadie, 37-54. London: Macmillan, 1989.

—. "Rouen, Bibliothèque Municipale, MS 249 (A.280) and the Early Paris Repertory of Ordinary of Mass Chants and Sequences". Music and Letters 70 (1989): 467-82. Hillgarth, J. N. The Spanish Kingdoms 1250-1516. 2 vols. Oxford: Clarendon Press, 1976. Hofmann-Brandt, Helma. Die Tropen zu den Responsorien des Officiums. 2 vols. Kassel: Bärenreiter, 1973.

Hourlier, Jacques. La notation musicale des chants liturgiques latins. Cenomani: Solesmes, 1960.

Hughes, Andrew. "Medieval Liturgical Books in Twenty-Three Spanish Libraries: Provisional Inventories". Traditio 38 (1982): 365-94.

- Medieval Manuscripts for Mass and Office: A Guide to Their Organizaton and Terminology. Toronto: University of Toronto Press, 1982. 
Hughes, Anselm. Anglo-French Sequelae. Nashdom Abbey: The Plainsong and Mediaeval Music Society, 1934.

Huglo, Michel. "Règlement du XII' siècle pour la transcription des livres notés". In Festschrift Bruno Stäblein zum 70. Geburtstag, edited by Martin Ruhnke, 121-33. Kassel: Bärenreiter, 1967.

- Les tonaires: inventaire, analyse, comparaison. Paris: Société Française de Musicologie, 1971.

—_."La pénétration des manuscrits aquitains en Espagne". Revista de Musicología 9 (1985): 249-56.

Les livres de chant liturgique. Turnhout: Brepols, 1988.

Husmann, Heinrich. “Alleluia, Sequenz und Prosa im altspanischen Choral”. In Miscelánea en homenaje a Monseñor Higinio Anglés, vol. 1, 407-15. Barcelona: Consejo Superior de Investigaciones Científicas, 1958-61.

—. "Notre-Dame und Saint-Victor". Acta Musicologica 36 (1964): 98-123, 191-221.

—., ed. Tropen- und Sequenzhandschriften. RISM BV. Munich-Duisburg: G. Henle Verlag, 1964.

Intonarium Toletanum. Alcalá, 1515.

Iradiel, Paulino, Salustiano Moreta, and Esteban Sarasa. Historia medieval de la España cristiana. Madrid: Ediciones Cátedra, 1989.

Jacobs, Charles. Tempo Notation in Renaissance Spain. New York: Institute of Mediaeval Music, 1964.

Janini, José. "Liturgia Romana”. DHEE 2: 1320-1324.

—. Manuscritos litürgicos de las bibliotecas de España. Vol. 1 Castilla y Navarra. Burgos: Aldecoa, 1977.

Johannes de Grocheo. Concerning Music (De Musica). Translated by Albert Seay. Colorado Springs: Colorado College Music Press, 1974. 
Jordan, Wesley D. “A Collection of Early Antiphoner Fragments from Portugal (Lisboa, Viseu, Ponte de Lima, and Guimarães): A Miscellany of Historical and Technical Observations". In Gordon Athol Anderson (1929-1981) In Memoriam. Musicological Studies, vol. 49, 403-73. Henryville: Institute of Mediaeval Music, 1984.

Julian, John. A Dictionary of Hymnology. 1907. Reprint. New York: Dover Publications, 1957.

Kelly, Thomas Forrest. “Responsory Tropes”. Ph.D. diss., Harvard University, 1973.

- "New Music from Old: The Structuring of Responsory Prosas". Journal of the American Musicological Society 30 (1977): 366-90.

Ker, N. R. 'From "Above Top Line" to "Below Top Line": a Change in Scribal Practice'. Celtica 5 (1960): 13-16.

King, Archdale A. Liturgies of the Religious Orders. London: Longmans, Green and Co., 1955.

—. Liturgies of the Primatial Sees. London: Longmans, Green and Co., 1957.

- Liturgy of the Roman Church. London: Longmans, Green and Co., 1957.

Klauser, Theodor. A Short History of the Western Liturgy. London: Oxford University Press, 1969.

Knapp, Janet. "Two Thirteenth-Century Treatises on Modal Rhythm and the Discant". Journal of Music Theory 6 (1962): 201-15.

León Tello, Francisco José. Estudios de historia de la teoría musical. 2nd ed. Madrid: Consejo Superior de Investigaciones Científicas, 1991.

- La teoría española de la música en los siglos XVII y XVIII. Madrid: Consejo Superior de Investigaciones Científicas, 1974.

—. "Durán, Domingo Marcos". NG 5: 738.

—. "Ferrer, Pedro". NG 6: 496.

—. "Martínez de Bizcargui, Gonzalo". NG 11: 722.

—. "Podio [Puig], Guillermo de". NG 15: 17. 
Lera Maillo, José Carlos de. "La documentación medieval del Archivo Catedral de Zamora: fuentes para la historia de Zamora". In Fuentes y métodos de la historia local. Actas, 69-80. Zamora: Instituto de Estudios Zamoranos, Diputación de Zamora, 1991.

Leroquais, Victor. Les Bréviaires Manuscrits des Bibliothèques Publiques de France. Vol. 1. Paris: Lefever, 1934.

Levy, Kenneth. "Old-Hispanic Chant in its European Context”. In España en la Música de Occidente, edited by Emilio Casares Rodicio, Ismael Fernández de la Cuesta, and José López-Calo, vol. 1, 3-14. Madrid: Instituto Nacional de las Artes Escénicas y de la Música, 1987.

The Liber Usualis with Introduction and Rubrics in English. Tournai: Desclée, 1963.

Linage Conde, Antonio. Review of Synodicum hispanum, edited by Antonio García y García. Scriptorium 42 (1988): 239.

Linehan, Peter. The Spanish Church and the Papacy in the Thirteenth Century. Cambridge: Cambridge University Press, 1971.

- Spanish Church and Society 1150-1300. London: Variorum Reprints, 1983.

López-Calo, José. La música medieval en Galicia. La Coruña: Fundación "Pedro Barrie de la Maza, Conde Fenosa", 1982.

—. La música en la catedral de Zamora. Vol. I. Catálogo del archivo de Música. Zamora: Diputación de Zamora, 1985.

—. "Encuadratura del panorama global de la música en Braga". In IX Centenário de Dedicaçao da Sé de Braga. Congresso Internacional Actas, vol. 3, 127-42. Braga: Universidade Católica Portuguesa, 1990.

Lütolf, Max. Die mehrstimmigen Ordinarium Missae-Sätze vom ausgehenden 11. bis zur Wende des 13. zum 14. Jahrhundert. 2 vols. Bern: Kommissionsverlag Paul Haupt, 1970.

—. "Fünf Punkte zur Mehrstimmigkeit in Spanien vor 1320/1330". In Symposium Alfonso X el Sabio y la música, 53-63. Madrid: Sociedad Española de Musicología, 1987. 
MacClintock, Carol. Readings in the History of Music in Performance. Bloomington: Indiana University Press, 1979.

MacKay, Angus. Spain in the Middle Ages: From Frontier to Empire, 1000-1500. London: Macmillan, 1977.

Madrazo, Pedro de. "La Colegiata de Toro". Boletín de la Real Academia de la Historia 20 (1892): 433-42.

Marcusson, Olof, ed. Corpus Troporum II: Prosules de la messe I: Tropes de l'alleluia. Stockholm: Almquist \& Wiksell, 1976.

Martín, José-Luis. Documentos Zamoranos I. Documentos del Archivo Catedralicio del Zamora. Primera parte (1182-1261). Salamanca: Ediciones Universidad de Salamanca, 1982.

Martín, José-Luis and Antonio Linage Conde. Religión y sociedad medieval. El catecismo de Pedro de Cuéllar. Salamanca: Junta de Castilla y León, 1987.

Martínez de Bizcargui, Gonzalo. Arte de canto llano y contrapunto y canto de órgano con proporciones y modos. Viejos Libros de Música 8. Madrid: Joyas Bibliográficas, 1976. Facsimile edition.

—. Arte de canto llano y contrapunto y canto de organo con proporciones y modos. Burgos, 1515.

- Arte de canto llano y contrapunto y canto de organo con proporciones y modos. Burgos, 1528.

- Arte de canto llano. Edited by Albert Seay. Colorado Springs: Colorado College Music Press, 1979.

—. Intonaciones nuevamente corregidas según uso de los modernos que hoy cantan y entonan en la Iglesia Romana. Viejos Libros de Música 15. Madrid: Joyas Bibliográficas, 1980. Facsimile edition.

Mas, Josiane. “La notation catalane”. Revista de musicología 11 (1988): 11-30.

Matilla Tascón, Antonio. Guia-inventario de los archivos de Zamora y su provincia. Madrid: Dirección General de Archivos y Bibliotecas y Diputación Provincial de Zamora, 1964. 
Melnicki, Margareta. Das einstimmige Kyrie des lateinischen Mittelalters, Forschungsbeiträge zur Musikwissenschaft, vol. 1. Regensburg: Gustav Bosse Verlag, 1955.

Menéndez Pelayo, Marcelino. Obras completas. Antología de poetas liricos castellanos. Vol. 1. Madrid: Consejo Superior de Investigaciones Científicas, 1944.

Millares Carlo, Agustín. Manuscritos visigóticos. Madrid: Instituto Enrique Flórez, 1963.

—.Tratado de paleografla española. 3rd ed. 3 vols. Madrid: Espasa-Calpe, 1983.

Miller, Clement A. “Gaffurius's Practica Musicae: Origin and Contents”. Musica Disciplina 22 (1968): 105-28.

Missale Giennense. Seville, 1499.

Missale mixtum alme ecclesie toletane. Toledo, 1499.

Missale romanum. 1572. [Jaén, Catedral].

Mocquereau, Dom André. Le nombre musical grégorienne. Rome-Tournai: Desclée, 1908-27. Molina, Bartolomé. Arte de canto llano llamado Lux videntis. Viejos Libros de Música 9. Madrid: Joyas Bibliográficas, 1977. Facsimile edition.

Moreta Velayos, Salustiano. "Repoblación”. In Zamora en la edad media, 10-15. Zamora: Caja de Zamora, 1988.

Morlet Hardie, Jane. “Kyries tenebrarum in Sixteenth-Century Spain”. Nassarre 4 (1988): 161-94.

Mota Murillo, Rafael. "El Ars musica de Juan Gil de Zamora. El ms. H/29 del Archivio Capitolare Vaticano". Archivo Ibero-Americano 42 (1982): 651-701.

Mundó, Anscari. “El proser-troper Montserrat 73”. Liturgia 3 (1966): 101-42.

Die Musik in Geschichte und Gegenwart. 17 vols. Edited by Friedrich Blume. Kassel: Bärenreiter, 1949-86.

Nassarre, Pablo. Escuela Música según la práctica moderna. Introduction by Lothar Siemens. Zaragoza: Institución "Fernando el Católico", 1980. Facsimile edition.

Navarro Talegón, José. Catálogo monumental de Toro y su alfoz. Zamora: Caja de Ahorros Provincial de Zamora, 1980.

Nebrija, Antonio de. Gramatica Castellana. Edited by Pascual Galindo Romeo and Luis Ortiz Muñoz. Madrid: Silvero Aquirre, 1946. 
The New Grove Dictionary of Music and Musicians. 20 vols. Edited by Stanley Sadie. London: Macmillan, 1980.

O'Callaghan, Joseph F. A History of Medieval Spain. Ithaca: Cornell University Press, 1975.

Odelman, Eva, ed. Corpus Troporum VI: Prosules de la messe 2: Les prosules limousines de Wolfenbüttel. Stockholm: Almquist \& Wiksell, 1986.

Odriozola, A. “Liturgia. D. Libros Litúrgicos Impresos”. DHEE 2: 1326-1330.

Olexy, Ronald T. "The Responsories in the 11th Century Aquitanian Antiphonal Toledo, Bibl. Cap. 44.2". Ph.D. diss. Catholic University of America, 1980.

Olivar, Alexandre. Els manuscrits litúrgics de la Biblioteca de Montserrat. Scripta et Documenta, vol. 18. Monestir de Montserrat, 1969.

- Cataleg dels manuscrits de la biblioteca del Monestir de Montserrat. Scripta et Documenta, vol. 25. Monestir de Montserrat, 1977.

Pacetti, D. “Bernardine of Siena, St.”. New Catholic Encyclopedia. Vol. 2. New York: McGraw-Hill, 1967. 345-47.

Paléographie musicale. Vols. 2-3. Le répons-graduel Justus ut palma, reproduit en fac-similé d'après plus de deux cents antiphonaires manuscrits d'origines diverses du IXe au XVIIe siecle. 1891-92. Reprint. Berne: Herbert Lang, 1974.

- Vol. 9. Antiphonaire monastique XIIe siecle codex 601 de la bibliothèque capitulaire de Lucques. 1906. Reprint. Berne: Herbert Lang, 1974.

- Vol. 12. Antiphonaire monastique XIIIe siècle codex F. 160 de la bibliotheque de la cathédrale de Worcester. 1922. Reprint. Berne: Herbert Lang, 1971.

- Vol. 13. Le codex 903 de la Bibliothèque Nationale de Paris (XIe siècle): Graduel de Saint-Yrieix. 1925. Reprint. Berne: Herbert Lang, 1971.

Parrish, Carl. The Notation of Medieval Music. 1959. Reprint. New York: Pendragon Press, 1978.

Pérez de Urbel, J. “Monacato”. DHEE 3: 1502-1508.

Pérez-Embid Wamba, Javier. El Cister en Castilla y León: Monacato y dominios rurales (Siglos XII-XV). Salamanca: Junta de Castilla y León, 1986. 
Planchart, Alejandro Enrique. “St Martial. I, II”. NG 16: 396-98.

Plummer, John. "Use" and "Beyond Use"'. In The Book of Hours in Medieval Art and Life, edited by Roger S. Wieck. London: Sotheby's Publications, 1988.

Podio, Guillermo de. Ars musicorum. Viejos Libros de Música 4. Madrid: Joyas Bibliográficas, 1976. Facsimile edition.

The Practica musicae of Franchinus Gafurius. Edited and translated by Irwin Young. Madison: University of Wisconsin Press, 1969.

Practica Musice Franchini Gafori Laudensis. 1496. Reprirt New York: Broude Bros., 1979.

Prado, R. P. Germanus. Cantus lamentationum pro ultimo triduo hebdomadae majoris juxta hispanos codices. Tournai: Desclée, 1934.

Rahlves, Friedrich. Cathedrals and Monasteries of Spain. London: Nicholas Kaye, 1966.

Ramis de Pareja, Bartolomeo. Musica Practica. Bologna: Forni, 1969.

Ramos de Castro, Guadalupe. La Catedral de Zamora. Zamora: Fundación Ramos de Castro, 1982.

Randel, Don M. The Responsorial Psalm Tones for the Mozarabic Office. Princeton: Princeton University Press, 1969.

——. "La teoría musical en la época de Alfonso X el Sabio". In Symposium Alfonso X el Sabio y la música, 39-51. Madrid: Sociedad Española de Musicología, 1987.

Reaney, Gilbert, ed. Manuscripts of Polyphonic Music. 11th - Early 14th Century. RISM BIV'. Munich-Duisburg: G. Henle Verlag, 1966.

—. Manuscripts of Polyphonic Music (c. 1320-1400). RISM BIV ${ }^{2}$. Munich-Duisburg: G. Henle Verlag, 1969.

Reilly, Bernard F. 'On Getting to Be a Bishop in Leon-Castile: The "Emperor" Alfonso VII and the Post-Gregorian Church'. Studies in Medieval and Renaissance History 1 (1978): 35-68.

-The Kingdom of León-Castilla under Queen Urraca 1109-1126. Princeton: Princeton University Press, 1982.

- The Kingdom of León-Castilla under King Alfonso VI, 1065-1109. Princeton: Princeton University Press, 1988. 
Riesco Terrero, Angel. Diccionario de abreviaturas hispanas de los siglos XIII al XVIII. Salamanca: Imprime Varon, 1983.

Ripresa, Amando. "Genesis y evolución urbana de la Zamora medieval". Hispania 122 (1972): 525-45.

Rivera Recio, Juan Francisco. La iglesia de Toledo en el siglo XII (1068-1208). Vol. 1. Rome: Instituto Español de Historia Eclesiástica, 1966.

Robertson, Anne Walters. "Benedicamus Domino: the Unwritten Tradition", Journal of the American Musicological Society 41 (1988): 1-62.

Robert-Tissot, Michel, ed. Johannes Aegidius de Zamora. Ars musica, Corpus Scriptorum de Musica, vol. 20. American Institute of Musicology, 1974.

Rocha, Pedro Romano. L'office divin au moyen âge dans l'église de Braga. Paris: Fundaçao Calouste Gulbenkian, 1980.

Rodríguez de Diego, José Luis. El tumbo del monasterio cisterciense de la Espina. Valladolid: Universidad de Valladolid, 1982.

—. "Documentación medieval del Archivo Histórico Provincial de Zamora". Studia Historica 1, no. 2 (1983): 181-202.

Roederer, Charlotte. Festive Troped Masses from the Eleventh Century: Christmas and Easter in the Aquitaine. Madison: A-R Editions, 1989.

Rubio, Samuel. "Los jerónimos de El Escorial, el canto gregoriano y la liturgia". La Ciudad de Dios 182 (1969): 225-31.

—. "Las melodias de los «libros corales» del Escorial". La Ciudad de Dios 182 (1969): 343-72.

—. Libro de música práctica de Francisco Tovar. Viejos Libros de Música F. Madrid: Joyas Bibliográficas, 1978.

—. Historia de la música española 2. Desde el "ars nova" hasta 1600. Madrid: Alianza Música, 1983.

Rueda Fernández, José Carlos. "Introducción al estudio de la economía zamorana a mediados del siglo XVI: su estructura socio-profesional en 1561". Studia Historica 2, no. 3 (1984): 113-50. 
Sánchez Herrero, José. Las Diócesis del reino de León. Siglos XIV y XV. León: Centro de Estudios e Investigación "San Isidoro", 1978.

Sánchez Rodríguez, Marciano. "La Diócesis de Zamora en la segunda mitad del siglo XIII". In Primer congreso de historia de Zamora, vol. 3, 147-71. Zamora: Instituto de Estudios Zamoranos “Florián de Ocampo", 1991.

Sanders, Emest H. "Sources, MS, §V. Early motet”, NG 17: 655-57.

Schildbach, Martin. "Das einstimmige Agnus Dei und seine handschriftliche Überlieferung vom 10. bis zum 16. Jahrhundert”. Ph.D. diss. Friedrich-Alexander-Universität, Erlangen-Nürnberg, 1967.

Schlager, Karlheinz. Alleluia-Melodien I ab 1100. Monumenta Monodica Medii Aevi, vol. 7. Kassel: Bärenreiter, 1968.

—. "Regionaltradition und Modalität in der liturgischen Monodie des Mittelalters". Studia Musicologica 27 (1985): 117-22.

—. Schlager. Alleluia-Melodien II ab 1100. Monumenta Monodica Medii Aevi, vol. 8. Kassel: Bärenreiter, 1987.

Schmid, Bernhold. Der Gloria-Tropus Spiritus et alme bis zur Mitte des 15. Jahrhunderts, Münchener Veröffentlichungen zur Musikgeschichte, vol. 46. Tutzing: Hans Schneider, 1988.

SCRIBE. Computer database. Bundoora, Victoria: Scribe Software Associates, La Trobe University, 1988.

Serrano Velasco, Ana, Ma Pilar Sauco Escudero, Juan D. Martín Sanz, and Celso Abad Amor. Estudios sobre los teóricos españoles de canto gregoriano de los siglos XV al XVIII. Madrid: Sociedad Española de Musicología, 1980.

Shiloah, Barbara A. "The Scriptorium of San Sahagún: a Period of Transition". In Santiago, Saint-Denis, and Saint Peter, edited by Bernard F. Reilly, 41-61. New York: Fordham University Press, 1985.

Snow, Robert J. “The History of Medieval Music: Are All Our Premises Correct?”. Publication pending.

Snyder, James. Medieval Art. New York: Henry N. Adams, 1989. 
Spañon, Alfonso. Introduccion de canto llano. Viejos Libros de Música 7. Madrid: Joyas Bibliográficas, 1976. Facsimile edition.

Stäblein, Bruno. Hymnen (1). Die mittelalterlichen Hymnenmelodien des Abendlandes. Monumenta Monodica Medii Aevi, vol. 1. Kassel: Bärenreiter, 1956.

—. "Hymnus, B. Der lateinische Hymnus". MGG 6: 993-1018.

—. "Pater noster". MGG 10: 943-50.

—. "Präfation". MGG 10: 1535-1537.

—. "Die Sequenzmelodie «Concordia» und ihr geschichtlicher Hintergrund". In Festschrift Hans Engel zum siebzigsten Geburtstag, edited Horst Heussner, 364-92. Kassel: Bärenreiter, 1964.

- Schriftbild der einstimmigen Musik. Musikgeschichte in Bildern, vol. 3, pt. 4. Leipzig: VEB Deutscher Verlag für Musik, 1975.

Steiner, Ruth. "Hymn, §II: Monophonic Latin”. NG 8: 838-41.

—. "Lord's Prayer". NG 11: 229-30.

Stevens, Denis. "Music in Honor of St. Thomas of Canterbury”. Musical Quarterly 56 (1970): 311-48.

Stevens, John. Words and Music in the Middle Ages. Cambridge: Cambridge University Press, 1986.

Stevenson, Robert. Juan Bermudo. The Hague: Martinus Nijhoff, 1960.

- Spanish Music in the Age of Columbus. 1960. Reprint. The Hague: Martinus Nijhoff, 1964.

—. "Bermudo, Juan". NG 2: 611-12.

—. "Spanish Musical Impact beyond the Pyrenees (1250-1500)". In España en la Música de Occidente, edited by Emilio Casares Rodicio, Ismael Fernández de la Cuesta, and José López-Calo, vol. 1, 115-64. Madrid: Instituto Nacional de las Artes Escénicas y de la Música, 1987.

Subirá, José. Los tres tratados de Domingo Marcos Durán. Viejos Libros de Música A/C. Madrid: Joyas Bibliográficas, 1977. 
Suñol, Dom Grégoire M. Introduction a la Paléographie Musicale Grégorienne. Paris: Desclée, 1935.

Tack, Franz. Gregorian Chant. Cologne: Arno Volk Gerlag, 1960.

Talegón, José Navarro. Catálogo monumental de Toro y su alfoz. Zamora: Caja de Ahorros Provincial de Zamora, 1980.

Thannabaur, Peter Josef. Das einstimmige Sanctus der römischen Messe in der handschriftlichen Überlieferung des 11. bis 16. Jahrhunderts. Erlanger Arbeiten zur Musikwissenschaft, vol. 1. Munich: Walter Ricke, 1962.

Thesaurus Musicarum Latinarum. Computer database. Directed by Thomas J. Mathiesen. Indiana University, Bloomington.

Thomson, S. Harrison. Latin Bookhands of the Later Middle Ages 1100-1500. Cambridge: Cambridge University Press, 1969.

Tischler, Hans. "Ligatures, plicae and vertical bars in premensural notation". Revue belge de musicologie 11 (1957): 83-92.

Torres, Joseph de. Arte de Canto Llano. Madrid, 1734.

Treitler, Leo. "The Aquitanian Repertories of Sacred Monody in the Eleventh and Twelfth Centuries". 3 vols. Ph.D. diss., Princeton University, 1967.

—. "Reading and Singing: On the Genesis of Occidental Music-Writing". Early Music History 4 (1984): 135-208.

—. "Cantus planus binatim in Italy and the Question of Oral and Written Tradition in General". In Le polifonie primitive in Friuli e in Europa, edited by Cesare Corsi and Pierluigi Petrobelli, 145-61. Rome: Edizioni Torre d'Orfeo, 1989.

Turco, Alberto. Il canto gregoriano. Vol. 1. Rome: Edizioni Torre D'Orfeo, 1987.

Utley, Francis Lee. “The Choristers' Lament”. Speculum 16 (1946): 195-202.

Utterback, Kristine T. “Cum multimodi curiositatis”: A Musical Treatise from EleventhCentury Catalonia'. Speculum 54 (1979): 283-96.

van der Werf, Hendrik. The Emergence of Gregorian Chant. 2 vols. Rochester, New York: published by the author, 1983. 
—. "Accentuation and Duration in the Music of the Cantigas de Santa Maria". In Studies on the Cantigas de Santa Maria: Art, Music and Poetry, edited by Israel J. Katz and John E. Keller, 223-234. Madison, Wisconsin: The Hispanic Seminary of Medieval Studies, 1987.

Van Deusen, Nancy. "Music at Nevers Cathedral". 2 vols. Musicological Studies, vol. 30. Henryville: Institute of Mediaeval Music, 1980.

—. "The Sequence Repertory of Nevers Cathedral". Forum Musicologicum 2 (1980) 44-59.

—. "Style, Nationality and the Sequence in the Middle Ages". Journal of the Plainsong and Mediaeval Music Society 5 (1982): 44-55.

Van Dijk, S. J. P. "An Advertisement Sheet of an Early Fourteenth-Century Writing Master at Oxford". Scriptorium 10 (1956): 47-64.

—. Sources of the Modern Roman Liturgy. 2 vols. Leiden: E. J. Brill, 1963.

Van Dijk, S. J. P., and J. Hazelden Walker. The Origins of the Modern Roman Liturgy. London: Darton, Longman \& Todd, 1960.

Vollaerts, Jan. Rhythmic Proportions in Early Medieval Ecclesiastical Chant. 2nd ed. Leiden: E. J. Brill, 1960.

Wagner, Peter. Einführung in die gregorianischen Melodien. 3 vols. 1911-21. Reprint. Hildesheim: Georg Olms, 1962.

Walpole, A. S. Early Latin Hymns. 1922. Reprint. Hildesheim: Georg Olms, 1966.

Watson, Rowan. "Medieval Manuscript Fragments”. Archives 13 (1977): 61-73.

Wolf, Johannes. "Eine neue Quelle zur mehrstimmigen kirchlichen Praxis des 14. bis 15. Jahrhunderts". In Festschrift Peter Wagner zum 60. Geburtstag, edited by Karl Weinmann, 222-37. Leipzig: Breitkopf \& Härtel, 1926.

Wright, Craig. Music and Ceremony at Notre Dame at Paris, 500-1550. Cambridge: Cambridge University Press, 1982.

Zaragoza Pascual, Ernesto. "Los cantorales de la abadía de Silos". Tesoro Sacro Musical 60 , no. 2 (1977): $46-57$. 
Zarlino, Gioseffo. On the Modes, Part Four of Le Istitutioni harmoniche, 1558. Translated by Vered Cohen, edited by Claude V. Palisca. New Haven: Yale University Press, 1983. 